\title{
Fire-cracked Rock Use and Reuse in the Hueco Bolson, Fort Bliss, Jexas
}

Cynthia L. Jennis, Johanna M. Hunziker, and Jeff D. Leach with a contribution by Wulf gose

Archaeological Survey Report, No. 257 Center for Archaeological Research The University of Jexas at San Antonio
Archaeological Jechnical Reports, Mo. 12 Anthropology Research Center The University of Jexas at $\&$ I Paso 



\title{
Fire-cracked Rock Use and Reuse in the Hueco Bolson, Fort Bliss, Texas
}

\author{
Cynthia L. Tennis, Johanna M. Hunziker, and Jeff D. Leach \\ with a contribution by Wulf Gose
}

\author{
Robert J. Hard and C. Britt Bousman \\ Principal Investigators
}

\author{
prepared for the \\ Department of the Army \\ Directorate of the Environment \\ Cultural Resource Branch \\ Fort Bliss, Texas
}

contract number DABT51-95-D-0029

Archaeological Survey Report, No. 257

Center for Archaeological Research

The University of Texas at San Antonio
Archaeological Technical Reports, No. 12 Anthropology Research Center The University of Texas at El Paso 
The following information is provided in accordance with the General Rules of Practice and Procedure, Chapter 41.11 (Investigative Reports), Texas Antiquities Committee:

1. Type of investigation: Artifact analysis

2. Project name: Fort Bliss Fire-cracked Rock

3. County: El Paso

4. Principal investigators: Robert J. Hard and C. Britt Bousman

5. Name and location of sponsoring agency: U.S. Army, Fort Bliss, Texas

6. Texas Antiquities Committee Permit No.: n/a

7. Published by the Center for Archaeological Research, The University of Texas at San Antonio, $6900 \mathrm{~N}$. Loop 1604 W., San Antonio, Texas 78249-0658, 1997

A list of publications offered by the Center for Archaeological Research is available. Call (210) 458-4378; write to the Center for Archaeological Research, The University of Texas at San Antonio, 6900 N. Loop 1604 W., San Antonio, Texas 78249-0658; e-mail to car@lonestar.utsa.edu; or visit CAR's Web site at http://www.csbs.utsa.edu/research/car/index.htm. 
Public reporting burden for this collection of information is estumated to average 1 hour per response, including the time for reviewing instructions, searching existing data sources gathering and maintaining the data needed, and completing and reviewing the collection of information. Send comments regarding this burden estimate or any other aspect of this collection of information, including suggestions for reducing this burden. to Washington Headquarters Services, Directorate for intormation Operations and Reports, 1215 jefferson Davis Highway, Suite 1204, Arlington, VA 22202-4302. and to the Office of Management and Budget. Paperwork Reduction Project (0704-0188), Washington, DC 20503.

\begin{tabular}{|c|c|c|}
\hline 1. AGENCY USE ONLY (Leave blank) & 2. REPORT DATE & $\begin{array}{l}\text { 3. REPORT TYPE AND DATES COVERED } \\
\text { Burned rock analysis, 1996-1997 }\end{array}$ \\
\hline
\end{tabular}

\section{TITLE AND SUBTITLE}

Fire-cracked Rock Use and Reuse in the Hueco

Bolson, Fort Bliss, Texas

6. AUTHOR(S)

Cynthia L. Tennis, Johanna M. Hunziker, and Jeff D. Leach
5. FUNDING NUMBERS

DABT51-95-D-0029

7. PERFORMING ORGANIZATION NAME(S) AND ADDRESS(ES)

Center for Archaeological Research, UTSA

6900 N. Loop 1604 W.

San Antonio; Texas 78249

9. SPONSORING/MONITORING AGENCY NAME(S) AND ADDRESS(ES)

Department of the Army

Directorate of the Environment

Cultural Resource Branch

Fort Bliss, Texas

\section{SUPPLEMENTARY NOTES}

Published jointly with The University of Texas at El Paso, Anthropology Research Center

Archaeological Technical Reports, No. 12

12b. DISTRIBUTION CODE

\section{ABSTRACT (Maximum 200 words)}

The Center for Archaeological Research of The University of Texas at San Antonio conducted an analysis of 29,058 pieces of fire-cracked rock and burned caliche selected from a sample of hundreds of features tested as part of the Hueco Mountain Archaeological Project at Fort Bliss, Texas. Feature and non-feature material included in this analysis were collected from site FB 13237 located on the proximal fan, FB 12719 within the basin area, and FB 12412 situated in the transitional zone between the two.

The goal of the analysis was to identify patterns of attribute variability in burned rock that could be used to infer function of the various features and sites in the sample. Specific burned rock attributes used in the study were material type, size, weight, and the presence or absence of fracturing, cortex, and discoloration. These attributes were recorded and compared in various combinations at course- and fine-grained levels of intensity to address issues of reuse, recycling, feature function, thermally induced morphological variability, and how these variables might relate to specific land forms through time.

Through these comparisons, patterns relating to expedient material selection, feature type, reuse and feature function were identified.

\begin{tabular}{|c|c|c|c|}
\hline & $\begin{array}{l}\text { 15. NUMBER OF PAGES } \\
156\end{array}$ \\
\hline \multicolumn{3}{|l|}{ 14. SUBJECT TERMS } & 16. PRICE CODE \\
\hline $\begin{array}{l}\text { 17. SECURITY CLASSIFICATION } \\
\text { OF REPORT } \\
\text { Unclassified }\end{array}$ & $\begin{array}{l}\text { 18. SECURITY CLASSIFICATION } \\
\text { OF THIS PAGE } \\
\text { Unclassified }\end{array}$ & $\begin{array}{l}\text { 19. SECURITY CLASSIFICATION } \\
\text { OF ABSTRACT } \\
\text { Unclassified }\end{array}$ & $\begin{array}{l}\text { 20. LIMITATION OF ABSTRACT } \\
\text { UL }\end{array}$ \\
\hline
\end{tabular}




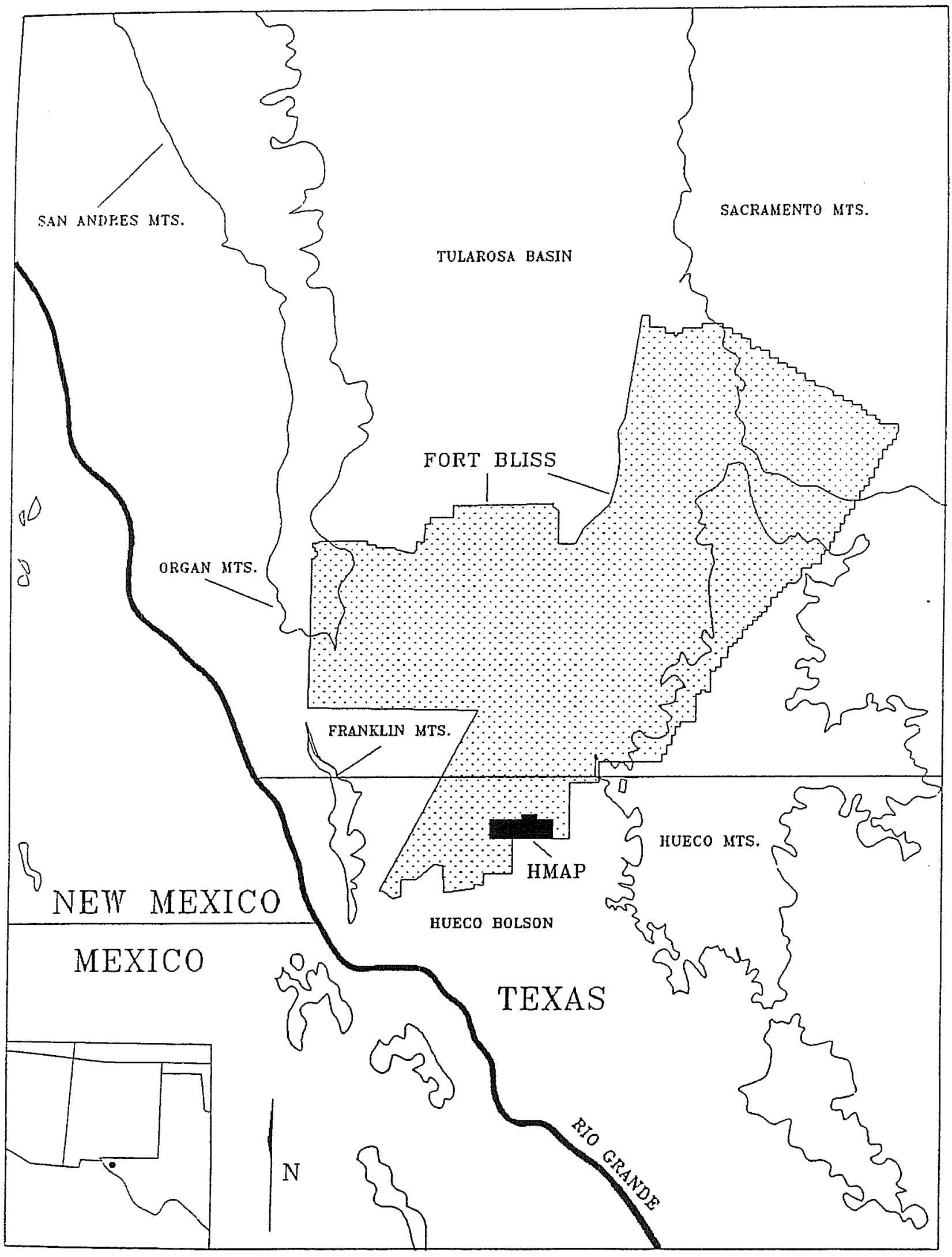

Hueco Mountain Archaeological Project Study Area 


\section{Abstract}

The Center for Archaeological Research of The University of Texas at San Antonio conducted an analysis of 29,058 pieces of fire-cracked rock and burned caliche selected from a sample of hundreds of features tested as part of the Hueco Mountain Archaeological Project at Fort Bliss, Texas. Feature and non-feature material included in this analysis were collected from site FB 13237 located on the proximal fan, FB 12719 within the basin area, and FB 12412 situated in the transitional zone between the two.

The goal of the analysis was to identify patterns of attribute variability in burned rock that could be used to infer function of the various features and sites in the sample. Specific burned rock attributes used in the study were material type, size, weight, and the presence or absence of fracturing, cortex, and discoloration. These attributes were recorded and compared in various combinations at course- and fine-grained levels of intensity to address issues of reuse, recycling, feature function, thermally induced morphological variability, and how these variables might relate to specific land forms through time.

Through these comparisons, patterns relating to expedient material selection, feature type, reuse and feature function were identified. 


\section{Contents}

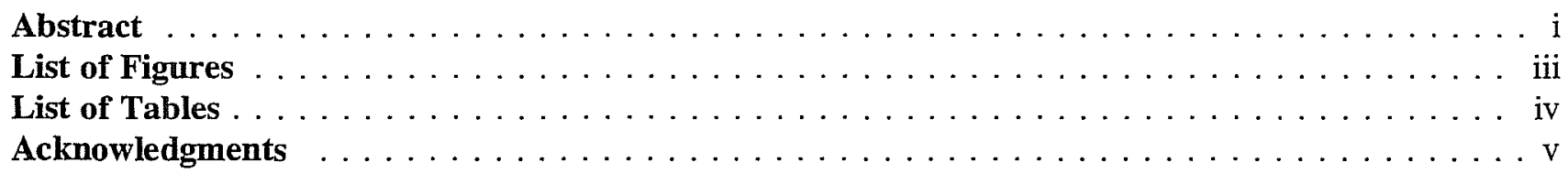

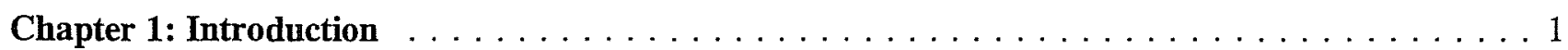

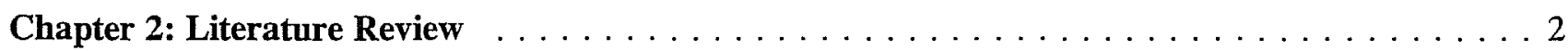

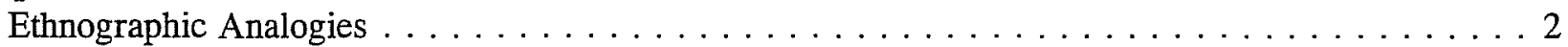

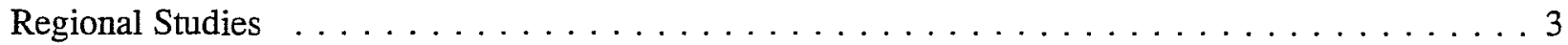

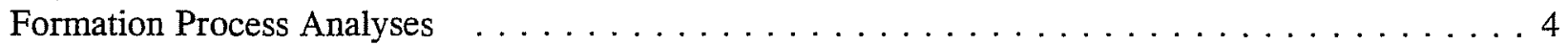

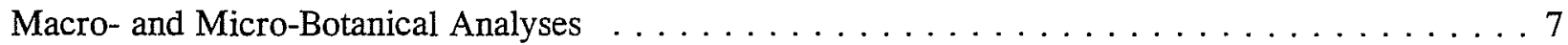

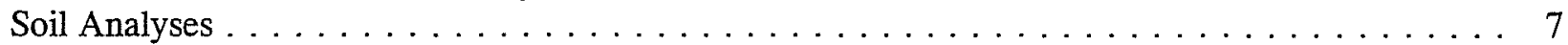

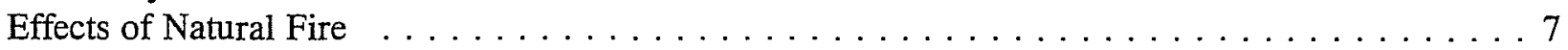

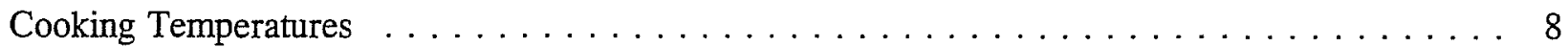

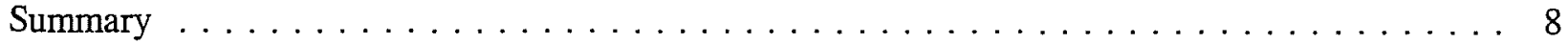

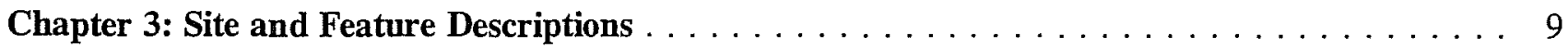

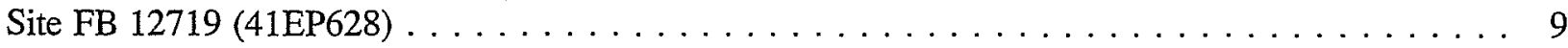

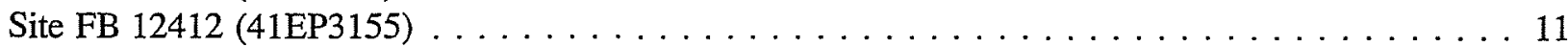

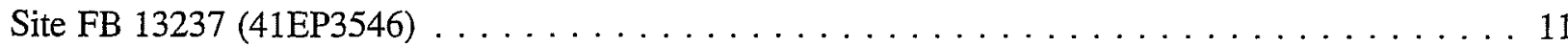

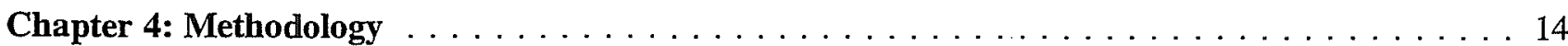

Material Type . . . . . . . . . . . . . . . . . . . . . . . . . 14

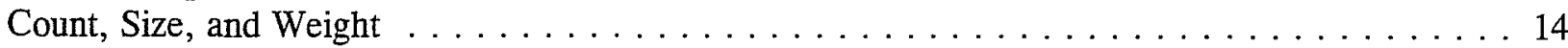

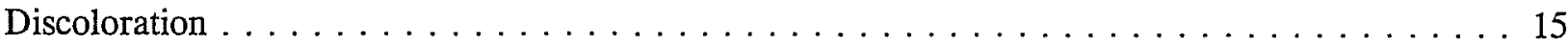

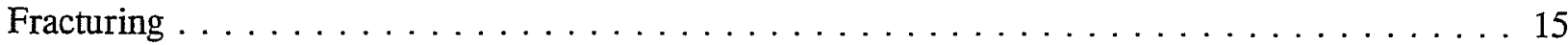

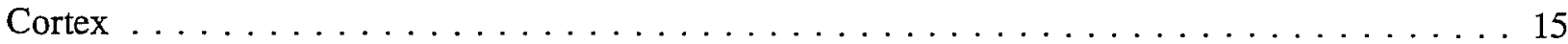

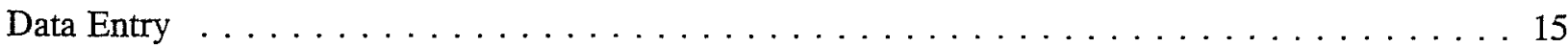

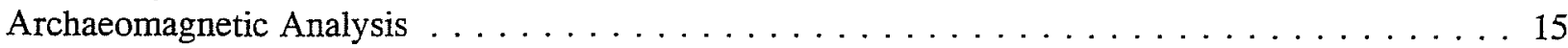

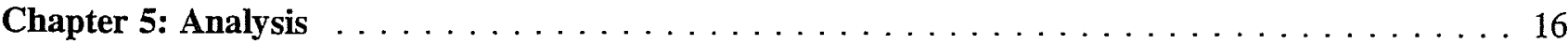

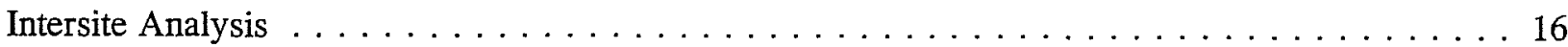

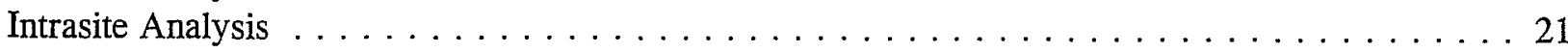

Block-level Analysis . . . . . . . . . . . . . . . . . . . . 26

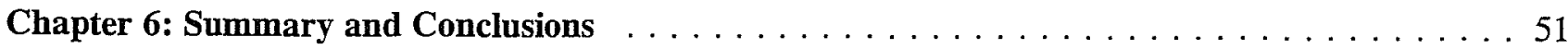

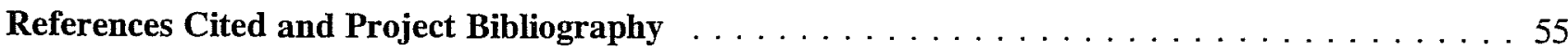

Appendix A: Burned Rock Data by Site $\ldots \ldots \ldots \ldots \ldots$

Appendix B: Archaeomagnetic Analysis of Burned Rocks from Fort Bliss, Wulf Gose . . . . . . 123 


\section{Figures}

Frontispiece: Hueco Mountain Archaeological Project Study Area

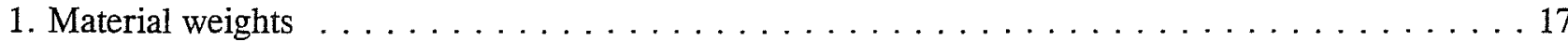

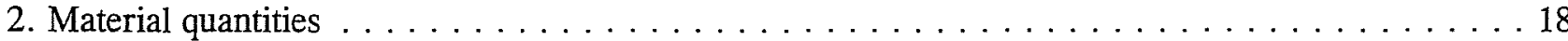

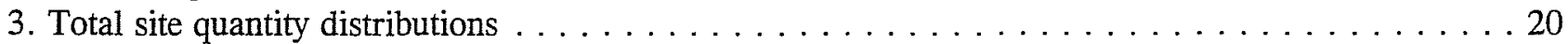

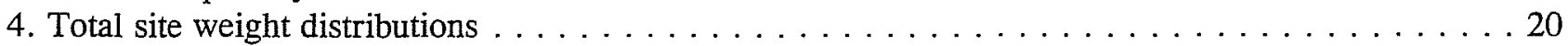

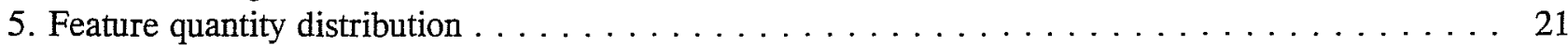

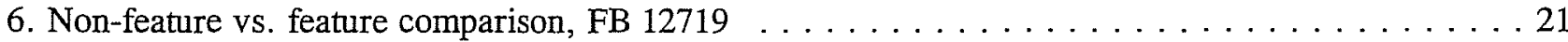

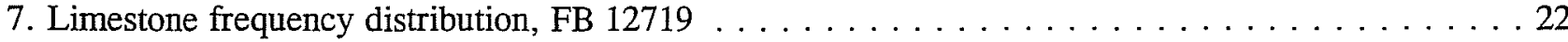

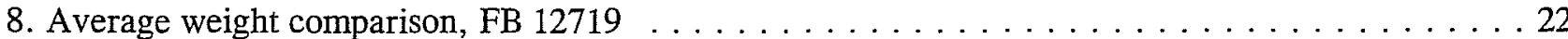

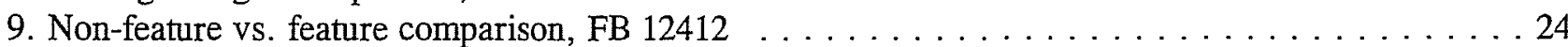

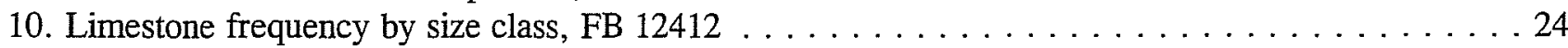

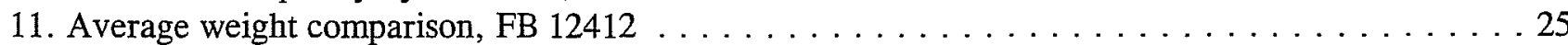

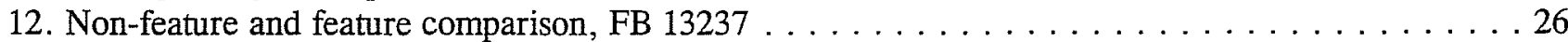

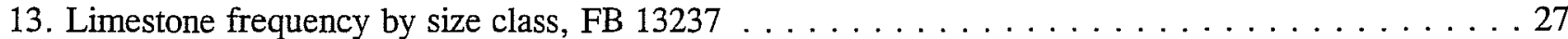

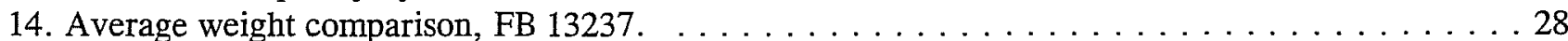

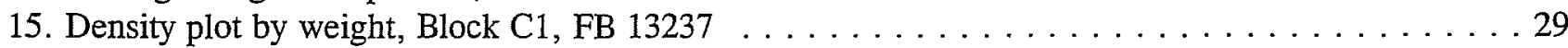

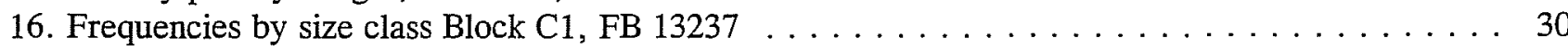

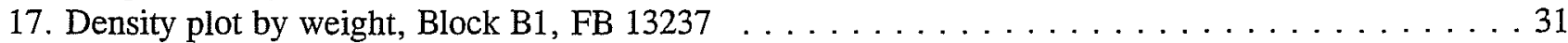

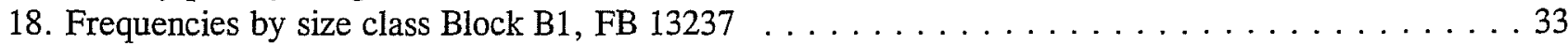

19. Density plot by weight, Block A1, FB $13237 \ldots \ldots \ldots \ldots \ldots \ldots \ldots \ldots \ldots \ldots \ldots \ldots$

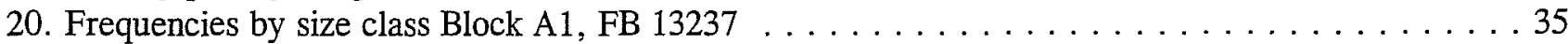

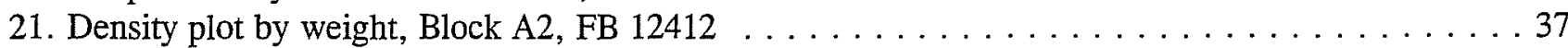

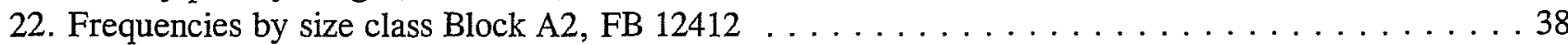

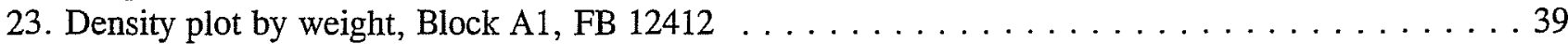

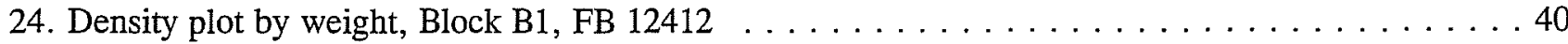

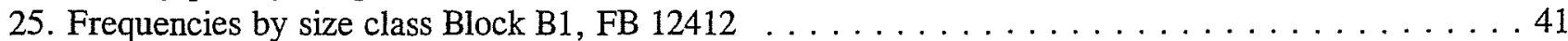

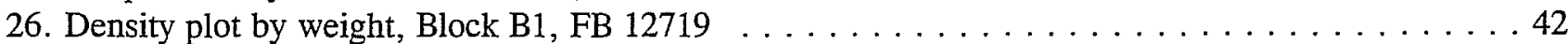

27. Frequencies by size class Block B1, FB $12719 \ldots \ldots \ldots \ldots \ldots \ldots \ldots \ldots \ldots \ldots$

28. Density plot by weight, Block A1, FB $12719 \ldots \ldots \ldots \ldots \ldots \ldots \ldots \ldots \ldots \ldots$

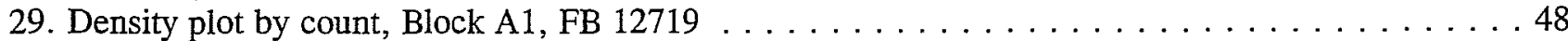

30. Three-dimensional surface contour map, Block A1, FB $12719 \ldots \ldots \ldots \ldots$. . . . . . . . . . . 49

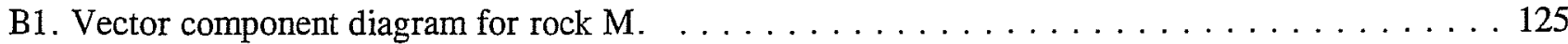

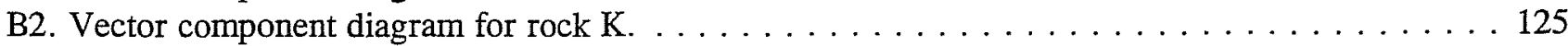

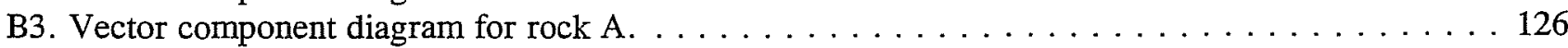

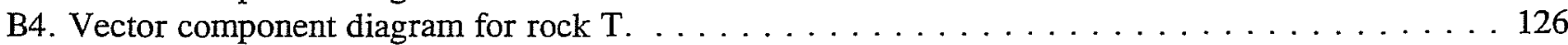

B5. Histogram of magnetically estimated temperatures of heating of burned rocks from Fort Bliss . . 127 


\section{Tables}

1. Archaeobotanical Remains Recovered from Flotation Samples . . . . . . . . . . . . . . 10

2. Faunal Remains Recovered from Sites FB 12412 and FB $12719 \ldots \ldots \ldots \ldots$. . . . . . . . . . . 10

3. Size Class Categories . . . . . . . . . . . . . . . . . . . . . . . . . . . 14

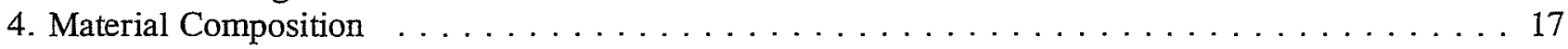

5. Feature Descriptions . . . . . . . . . . . . . . . . . . . . . . . . . 19

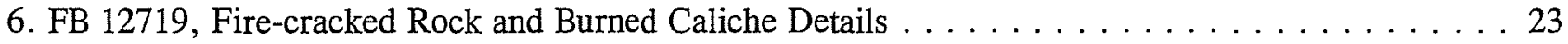

7. FB 12412, Fire-cracked Rock and Burned Caliche Details . . . . . . . . . . . . . . . . . . 25

8. FB 13237, Fire-cracked Rock Details . . . . . . . . . . . . . . . . . . . 26

9. FB 13237, Fracture and Cortex Percentages . . . . . . . . . . . . . . . . . . . 36

10. FB 12412, Fracture and Cortex Percentages (Limestone Only) . . . . . . . . . . . . . . . 41

11. Weight and Quantity of Non-feature Burned Rock in Block B1 by Material Type . . . . . . . . . 44

12. Percent of Burned Rock in Each Size Range . . . . . . . . . . . . . . . . . . . . . . . . 44

13. Burned Rock Weight by Material from Select Feature Proveniences in Block B1 . . . . . . . . . . 45

14. FB 12719, Fracture and Cortex Percentages (Limestone Only) . . . . . . . . . . . . . . 45

15. Total Weight and Quantity of Burned Rock from Block A1 . . . . . . . . . . . . . . . . 47

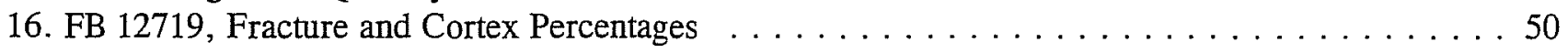

B1. Fire-cracked Rock from Fort Bliss . . . . . . . . . . . . . . . . . . . . . . . . . . . . . . . 124 


\section{Acknowledgments}

The staff at the Center for Archaeological Research wishes to acknowledge Jim Bowman, Galen Burgett, and Kelly Poche from the Directorate of Environment, Conservation Division at Fort Bliss, and Dr. John Peterson from The University of Texas at El Paso for their assistance in coordinating this joint research effort. We would also like to thank Dr. Ray Mauldin and the rest of the staff at the Anthropology Research Center at The University of Texas at El Paso for sharing their knowledge of the region. The authors would like to personally thank Robert J. Hard, CAR director, for his leadership in this analysis and Marcie Renner, CAR editor, for her patience and expertise in preparing the manuscript. 



\section{Chapter 1. Introduction}

This report is an outgrowth of the Heuco Mountain Archaeological Project (HMAP), part of a long-term management strategy designed to manage and, when necessary, to mitigate the impact or potential impact of military maneuvering to cultural resources on Fort Bliss, Texas. The HMAP study area is located on the eastern edge of the Heuco Bolson, part of the Tularosa Valley which extends from south-central New Mexico, through extreme west Texas, and into northern Chihuahua, Mexico. The Hueco Bolson is situated between the Franklin-Organ mountains to the west and the Hueco-Sacramento Mountains to the east.

Fieldwork for the HMAP consisted of an initial (Phase I) survey of a $26-\mathrm{km}^{2}$ strip at the western edge of the Hueco Mountains. Subsequently, the southern $14 \mathrm{~km}^{2}$ of the study area were subjected to a 100-percent, point provenienced surface collection (Phase IIA), subsurface testing (Phase IIB), and data collection (Phase III). These last three phases of investigation resulted in the identification and recording of 533 sites, 172 of which received subsurface testing and data collection.

Three of the 172 tested sites-FB 12412, FB 12419 , and FB 13237-were selected for burned rock analysis. Site selections were made in consultation with Fort Bliss archaeologists based on the completeness of the sites' burned-rock collections and their topographic locations. The analysis of 100 percent of the burned rock from the three sites was undertaken to address issues of function, recycling, and reuse of fire-cracked features. 


\section{Chapter 2. Literature Review}

In preparation for the Fort Bliss fire-cracked and burned caliche analysis, a bibliography was complied of recent research dealing with experimentation, analytical methodologies, and formational and functional interpretations of thermally altered caliche and burned rock from around the world. This bibliography is included with the cited references. The following review is a synthesis of regionally applicable data.

Rocks were used prehistorically in association with fire because of their ability to contain, absorb, retain, and transfer heat for bathing, warmth, and cooking. Remnants of these activities appear on the global scale in the archaeological record in a wide range of forms, from small hearths with lightly burned stones and slabs to large accumulations or mounds of fire-cracked rocks. In the last 10 years, new interest in the behavioral implications of the variations in form and function of these accumulations has led to a renewed interest in their analysis. New methods of investigating and interpreting the functions of these abundant remnants of past lifeways are being developed. This paper reviews the analytical methods used in these developing approaches.

\section{Ethnographic Analogies}

Although not a new approach, ethnographic accounts of the use of heated stones in food preparation are at the base of most of the recent archaeological work (e.g. Binford 1983; Goode 1991; Hester 1991; House and Smith 1975; Thoms 1989). These accounts offer insight into prehistoric behavioral practices that may account for some of the burned-rock features analyzed by archaeologists today.

In their ethnographic synthesis of North American Indians, Driver and Massey (1957) document various techniques involving the use of stones in cooking. Stone boiling was the dominant method of food preparation in the Sub-Arctic, the Northwest Coast, the West Coast, the Plains, and the Great Basin geographical areas where pottery was absent and mobility high. Rocks were heated directly in the fire, then removed with sticks or wooden tongs and placed in animal skin, bark, or woven containers of liquid. Cabeza de Vaca recorded the use of barrel cactus as containers in his description of stone boiling techniques by "unidentified" tribes on the Texas Coast (Driver and Massey 1957). Heated rocks were renewed frequently to maintain the desired amount of boiling, and a sufficient supply of stones made the process faster. Wet stones were apparently not immediately reused, as the moisture content slowed the reheating time. Stone boiling was used in the preparation of most foods, as well as in acorn-processing and grease-rendering activities.

The use of rock in earth ovens, "a kind of Indian fireless cooker," is also documented along the western coast of North America, in the desert Southwest, and across all of Mesoamerica (Driver and Massey 1957). Earth ovens are described as holes in the ground into which hot stones and food were placed. Meat and plant foods, frequently premoistened and wrapped in leaves or bark, were placed in the pits, then covered with dirt and allowed to cook overnight. Fires were sometimes built on top of the pits to add additional heat, and water was occasionally added to increase the amount of steam. 
Pits filled with fire and heated rocks were also used in desert regions to cook agave buds. "Often a number of families or a whole community cooked their agave in a single huge pit, which might be used year after year" (Driver and Massey 1957).

In areas where stone boiling was common, meat was most frequently broiled on stakes or horizontal frames suspended over the fire or roasted directly on heated stones beside the fire. Hot stones were also used as direct sources of heat for baking acorn bread in California (Driver and Massey 1957).

Direct ethnographic analogies for behaviors associated with the uses of heated stones have also been drawn from studies of extant groups of huntergatherers. Studies of the Alyawara (Binford 1986; O'Connell 1987), the Efe (Fisher and Strickland 1989), the Dobe Bushmen (Yellen 1977), and the !Kung Bushmen in Africa (Binford 1983), and the Nunamuit of Alaska (Binford 1983) supplied models of intra-site distribution of fire-cracked features that are applicable for archaeological interpretations of group size, site structure, and site function. These studies documented the variety of tasks that take place around nuclear family hearths (Yellen 1977) and the distributional patterning of artifacts that result from activities around these hearths (Binford 1983, 1986). Fisher and Strickland (1989) documented the distributional relationship between exterior hearths and structure opening in Efe villages as well as the varying distances between hearths. These site-structure studies (Binford 1983; O'Connell 1987; Yellen 1977) also show that large, communal cooking activities involving earth ovens and roasting pits take place away from the main camp, information that provides behavioral implications regarding the occupational history of site formation in archaeological interpretations.

Results of regional surveys in Sweden illustrate spatial relationship similar to ethnographically observed patterns between the prehistoric Skärvstenshögar (burnt mounds) and settlements recorded there. Swedish mounds characteristically contain a mix of stone, ash, pottery, daub, grinding stones, and hammer stones and are defined as refuse dumps. They are consistently located $10-30 \mathrm{~m}$ away from settlements (Larsson 1990).

Descriptions of active and abandoned sotol distilleries in Mexico provide comparative information for archaeological burned rock features (Tunnell and Madrid 1990). The authors report that the sotol ovens in Chihuahua used for sotol distillation are approximately $3 \mathrm{~m}$ across and $2.5 \mathrm{~m}$ deep. These measurements are similar to those from ovens at Casas Grandes. The ovens are completely lined with rock and have a domed firing box filling the lower half of the oven, also made of rock. Between 300-400 sotol heads are placed on top of the firing box and the whole oven is covered by a $30-\mathrm{cm}$-thick layer of soil and baked for 24-28 hours. Water is added to the oven from a hole in the top to produce steam, which keeps the sotol moist and prevents scorching. The rocks that make up the firing box are replaced after 10-14 firings as they become too broken, and are discarded down slope from the ovens forming mounded accumulations of burned rock (Tunnell and Madrid 1990).

\section{Regional Studies}

Region-wide investigations of small fire-cracked features have also been conducted recently. The results of a distributional comparison of radiocarbon and obsidian hydration dates from hearth features and artifacts in the central basin area near El Paso have been used to suggest a significant change in land-use patterns in that area (Mauldin 1994). Mauldin argues that the distribution of 114 radiocarbon dates from fire-cracked hearth features, hearth stains, and a few pit features established a pattern suggesting that small sites with features were utilized during a limited time span in the basin. The small hearth sites in the basin are earlier than the larger sites concentrated along the alluvial fans and rivers near the mountains. Further comparisons between the dates from hearths and obsidian hydration dates and diagnostic artifacts from sites not associated with hearths in the basin indicate that while use of the basin area continued through the prehistoric, later use of the basin did not involve the use of hearths (Mauldin 1994). 
The large quantities of burned rock characteristic of fulacht fiadh (burnt mounds) in Scotland have been attributed to frequent use or repeated use over long periods of time (Barfield and Hodder 1987, as cited by Barber 1990). To examine this interpretation, Barber (1990) applied three analytical methods to interpret the use of burnt mounds across Scotland. Citing previously conducted experiments which produced $0.5 \mathrm{~m}^{3}$ of broken stone per boiling, he argues that the volume of stone typically found on fulacht fiadh in Scotland represents from 40 to 400 "boilings" (Barber 1990). At the rate of 10 cookings per year, the largest site's deposit would accumulate in as little as 40 years. The absence of turf regeneration horizons in excavations indicates that no long periods of abandonment occurred, and a review of multiple radiocarbon samples revealed closely grouped dates. The correlation of these three indications of short-term use is suggestive of relatively rapid mound accumulation (Barber 1990).

\section{Formation Process Analyses}

Investigations into the actual formation processes involved in burned-rock feature accumulation are undertaken to provide a better understanding of the functional differences these features represent. Methods of identifying these processes focus on the direct thermodynamic effects of cultural activities reflected by morphological changes in fire-cracked rocks and results of experiments designed to replicate these activities.

\section{Volumetric Comparisons}

In a study of camas-roasting pits in the Calispell Valley in northeastern Washington State, simple artifact and feature frequency and density data were used to identify the archaeological signature of camas-processing sites and to argue that they were temporally and functionally related to nearby residential sites (Thoms 1989). Relative oven size was used as a measure of camas intensification, and the increase of oven frequency was used to infer increased intensification through time. Ethnographic accounts from that area indicate that rocks
$10-15 \mathrm{~cm}$ in diameter were consistently selected for use in earth ovens. Because heat loss is directly related to the amount of surface area relative to rock volume, Thoms (1989) also suggests that the average rock size in archaeological features should be a relative indicator of feature use.

Estimates of the total density of burned rock occurring in mounds and middens are obtained by Larsson (1990) through calculations of cubic area and extrapolation based on sample counts and weights (Hines 1995). Both authors suggest that analysis of volumetric variables may provide comparative data for inferring socio-economic and population density differences between features.

At the Head-Smashed-In Buffalo Jump site in Alberta, Canada, all fire-cracked rocks larger than five centimeters in diameter were counted, measured, weighed, and mapped (Brink and Dawe 1989). Although sandstone is the local rock type, over 80 percent of the burned rock at the site was quartzite and other stones imported from deposits 2-4 $\mathrm{km}$ away. The selection of non-sandstone material is seen as an indication of stone-boiling activities, as sandstone had proved unsatisfactory in stone boiling during previous experiments (Brink et al. 1986, cited by Brink and Dawe 1989). The authors argue that the masses of burned rock at the site did not result from grease-extracting activities, based on the observation that the total weight of burned rock recovered from the largest pit at the site $(153.6 \mathrm{~kg}$ ), is substantially smaller than the $700 \mathrm{~kg}$ of burned stone from a single degreasing feature reported by Binford (1978, as cited by Brink and Dawe 1989). They propose that the rock accumulation is the result of meat boiling to feed the large group during butchering activities (Brink and Dawe 1989).

Statistical analysis of the variation in rock shape and density was conducted on fire-cracked rock from four known feature types in the Calispell Valley (Sanders et al. 1991). Their analytical process defined material type and fracture shape, and compared these characteristics between and within data subsets from residential, camas-processing, and special-purpose sites to identify the relationship 
between fire-cracked rock morphology and functionally distinct features. They found that blocky and curvilinear fracturing occurred in the same densities in oven features, possibly as the result of moisture intentionally added for steaming, while a low frequency (6.4 percent) of blocky fracturing was present in boiling pits. The authors conclude that the proportion of blocky to linear densities is not indicative of functional differences. There is too much variation within the singlefunction classes they examine to allow for functional classifications to be developed based only on firecracked rock.

Mauldin et al. (1994) explored the topic of reuse of features by comparing the sizes of burned caliche nodules recovered from 165 features in the central Heuco Bolson with experimentally fired caliche. The experimental firing showed that the largest nodule size class decreased with subsequent firings. The experimental size distribution, however, was different from the archaeologically observed size distribution, which was dominated by small items. They propose that the disproportionately large percentage of small sizes could be a function of exposure and modern disturbance (Mauldin et al. 1994). The authors also found a correlation between increased frequency, of artifacts and decrease in burned rock size, supporting the use of size frequency as a measure of feature reuse.

\section{Archeomagnetic Analysis}

Archeomagnetic analysis applies the principles of paleomagnetism to archaeological phenomena (Collins et al. 1990). Magnetic minerals in rocks produce a record of thermoremanent magnetization, moving from their original position during heating and realigning to north as they cool. These remanent directions were originally correlated with known pole positions to address chronological questions, but recently, vector patterns have been used to infer prehistoric cultural behaviors and post-depositional processes reflected in burned rock in the archaeological record (Takac 1995). Comparison of magnetic alignments from multiple in situ samples from burned features have been used to infer function based on whether rocks were moved after they cooled and represent rake-out or dump activities or were allowed to cool in place in an undisturbed hearth (Collins et al. 1990).

Controlled experiments measuring the degree of realignment and declination that occurs at different temperatures have produced results that can be used to estimate the amount of heat produced by archaeological features and to infer the length of the heating episode (Collins et al. 1990). Additional ongoing experimentation is attempting to identify magnetic signatures resulting from stone boiling (Takac 1995).

\section{Thin-Section Analysis}

Thin sections of reddened gritstone from burnt mounds in the south Cumbrian area in England contain fractured grains of quartz, indicating the rock has been subjected to thermal shock. These internal fractures and rough-sided, re-entrant exterior angles are classified as characteristic of the effect of sudden cooling rather than direct heat which produces smoother, plain or curved fractures (Nixon 1990).

\section{Experimental Replication}

Experimental boiling studies have been conducted in southwest Wales where burnt mound formation processes are visible in excavation (Williams 1990). Here, Iron Age mounds are associated with a succession of pits dug into the underlying clay. Mounds accumulate as cracked boiling stones are removed from the pits. In some cases, separate dump sequences have been identified. A number of experiments were carried out based on the results of excavations at one site. Local surface boulders were used to boil water, producing cracked-rock debris of the type seen in the mounds. A pit was then dug based on excavated pit dimensions (not given in report). The pit was filled with water and a leg of lamb was successfully cooked using heated stones. Based on the $70 \mathrm{~kg}$ of cracked rock produced during this cooking experiment, it was estimated that one of the mounds at this site represented between 20 and 60 pit uses (Williams 1990). 
A controlled stone-boiling experiment was conducted to compare the effect of repeated heating/ dowsing episodes on seven naturally occurring rock types in Ireland (Buckley 1990). For this experiment a wooden trough was constructed based on the average dimensions of troughs excavated in association with fulacht fiadh in that country $(l=1.9$ $\mathrm{m}, \mathrm{w}=0.9 \mathrm{~m}, \mathrm{~d}=0.9 \mathrm{~m})$. An average beginning rock size of $15 \mathrm{~cm}$ was selected based on ease of transport and rapid heating time. Stones were heated for 15 minutes in an open hearth next to the trough and placed in water preheated to a temperature of $28^{\circ} \mathrm{C}$. The number of heating/dowsing episodes necessary to reduce the different rocks to less than five centimeters produced the following results: micaceous sandstones (5), limestone (6), agglomerate (10), akrose (12), basalt (20), and vesiculated basalt and gabbro $(>25)$. The author uses these results to suggest that perceived distributional differences of burnt mounds in Ireland might actually be the result of differential properties of naturally available rocks (Buckley 1990).

Numerous controlled experiments have been conducted to identify specific morphological responses resulting from thermodynamic differences created by slow cooling in hearths and earth ovens versus rapid cooling from submersion during stone boiling (Draper and Stanfield 1987; Duncan and Doleman 1991; House and Smith 1975; Jackson 1995; Mauldin et al. 1994; Sanders et al. 1991; Thoms 1989; Whitkind 1977). These attempts to experimentally replicate the various fracture patterns found archaeologically in fire-cracked rock and burned caliche have thus far produced ambiguous results.

Schalk and Maette (1988) identified two basic morphological responses to heat stress in rock: curvilinear fractures where the angle at the spall edge and the rock surface is less than $45^{\circ}$, and blocky/angular fractures where angles are almost $90^{\circ}$. They hypothesize that curvilinear fractures result from uneven temperature gradients within the rock during heating, while blocky fractures result from rapid cooling of heated rock. While Thoms (1986), Draper and Stanfield (1987), and Duncan and Doleman (1991) have recreated blocky fractures from stone-boiling experiments, similar experiments by House and Smith (1975), Jackson (1996), and Witkind (1977) have proven unsuccessful. Stones left in the ashes to cool to simulate hearth stones showed evidence of discoloration but did not develop fractures (Duncan and Doleman 1991; Mauldin et al. 1994). Statistical analysis of the frequency of blocky vs. curvilinear fracturing in oven features and boiling pits in archaeological sites in the Calispell Valley did not support the relationship of blocky fractures and boiling activities (Sanders et al. 1991). They propose that material type, size of rock, and the rate, duration, and intensity of the firing episode rather than the cooling method produce the variations recorded in archaeologically fire-cracked rock (House and Smith 1975; Sanders et al. 1991; Witkind 1977).

Similar ambiguity has resulted from experiments on thermal conductivity of caliche. Experiments conducted by Lintz (1989) and Duncan and Doleman (1991) found that caliche discolors at temperatures of $300-700^{\circ} \mathrm{C}$, temperatures hotter than natural grass fires. The experiments conducted by Lintz (1989) indicate that caliche holds together well and is effective in transferring heat for stone boiling, while similar experiments by Duncan and Doleman (1991) found that after two boilings, caliche samples were reduced to fine sediment and no longer held or transferred heat. Experiments by Mauldin et. al (1994) indicate that features containing rock (caliche) maintained temperatures over $300^{\circ} \mathrm{C}$ for up to nine hours, while wood fire temperatures dropped to below $150^{\circ} \mathrm{C}$ in this same time period, indicating that the addition of rock to features substantially extends the heating period. Lintz (1989) also found that metaquartzite and chert had better heat conductivity than sandstone, while House and Smith (1975) report that sandstone fragmented less readily than chert or quartzite and seemed to maintain the boil longer. It appears these differences may also depend upon regional variability in raw materials and differences in heating temperatures. 


\section{Macro- and Microbotanical Analyses}

\section{Pollen Analysis}

In the synthesis of 225 central Texas middens, Howard (1991) examined the amount of botanical information obtained from these excavations. While a functional hypothesis of vegetal preparation is supported by the presence of milling stones in association with 83 percent of the middens, the botanical samples from 19 of these middens failed to provide a recognizable pattern of plant use (Howard 1991). Out of 13 samples analyzed for macrobotanical remains, only oak, hackberry, and walnut were found in more than one midden (oak $=5$, hackberry $=5$, walnut $=2$ ). Six attempts have been made to collect microbotanical samples, two of which yielded interpretable quantities of pollen. These pollen, however, represent taxa still present in the modern environment and are therefore not clearly indicative of prehistoric economic use (Howard 1991).

\section{Organic Residue Analysis}

Organic residue analysis involves testing for different identifiable lipids that have adhered to or been absorbed into artifacts-burned rocks as well as chipped-stone tools (Collins et al. 1990). Fatty acid lipids provide a chemically based, general taxonomic classification of plant residues. Sterols are another type of lipid that can be used to identify plant vs. animal organic residue remains. Sterol analysis provides a more precise differentiation between plant and animal residue as there are very few sterols that are present in both. In the study of the Camp Pearl Wheat site, samples of stone tools, burned hearth stones, and unmodified limestone rocks were tested. The burned rock analysis revealed a predominance of faunal residue reflective of either a higher frequency of meat in the diet or a cooking technology where more meat was in direct contact with the heated stones (Collin et al. 1990). Residue analysis of burned rocks from Mustang Branch and the Barton site in central Texas produced evidence of cooking and drying meat (Ricklis and Collins 1994). Analysis of multiple sides of the rocks were conducted to differentiate between boiling stones where residue would be expected on all sides, and hearth stones where residue should appear predominately on only one side. In this analysis, sufficient variation on the sides was present to allow the author to rule out boiling (Ricklis and Collins 1994).

\section{Soil Analyses}

Routine soil analyses of matrix in burnt mounds in Scotland reveals that phosphate levels in burnt mound deposits are higher than those found in the local top soils and subsoils. Also, higher-thannormal quantities of organic material in burnt mounds are revealed through 'Loss On Ignition' (LOI) tests (Russell-White 1990a). High phosphate levels normally indicate decayed bone, but may also be due to the presence of burned ash in the mounds. High LOI values generally mean that organic material has been added to the soil, but could also be the result of decayed, unburned fuel. These ambiguities render soil analyses inconclusive methods of identifying burnt mound function (Russell-White 1990a). Phosphate analyses from hearth features in central Texas have also produced inconclusive results (Collins et al. 1990).

\section{Effects of Natural Fire}

Bellomo (1993) and Connor et al. (1989) conducted investigations into the characteristics and effects of naturally occurring fire. Their reserach has applications for the study of burned rock. Bellomo (1993) employed a methodological approach to identifying humanly controlled fire. His method involves microscopic and magnetometer examinations of soil in the field and archeomagnetic examinations in the lab. He compared information from controlled grass fires, controlled tree-stump burns, and experimental campfires. He found that campfires generate mean temperatures of $600^{\circ} \mathrm{C}$ and maintain mean temperatures of $400^{\circ} \mathrm{C}$ for $1.5-3$ hours. Grass fires generate a mean temperature of $225^{\circ} \mathrm{C}$ and maintain a temperature in excess of $100^{\circ} \mathrm{C}$ for only two minutes. The author also found 
that multiburn campfires (three to four experimental uses) produced basin-shaped features which extend approximately $15 \mathrm{~cm}$ below the surface and exhibit a high degree of oxidation and changes in magnetic characteristics (Bellomo 1993).

In their investigations, Connor et al. (1989) evaluated the effects of forest fires on archaeological contents. They identified four important effects that may be noted on archaeological sites: 1) mosaic burn patterns with sharply defined boundaries; 2) morphological changes to stone and bone is limited to the level of the burn or within several centimeters below the burn surface; 3) specific oxidized soil features are present; and 4) layers of fluffy, white ash are present. Thermal damage to surface rock, found in basins of treefalls, varies with rock material: sandstone reddened but did not crack; quartzite occasionally exhibits a blackened surface; and obsidian showed signs of feathering, shattering, and surficial weathering (Connor et al. 1989).

\section{Cooking Temperatures}

In a study of hunter-gatherer pottery, Reid (1989) presents information on cooking temperatures from Lundberg and Kotschevar (1965). The temperatures have a direct bearing on functional interpretations of burned caliche and fire-cracked rock cooking features. The nutritional value and caloric accessibility of protein, fat, and carbohydrates from plant and animal food sources is increased by the use of controlled heating to specific temperatures required to produce palatable effects. The author identified two basic methods of cooking: dry and moist. Dry cooking includes broiling, roasting, baking, and parching. These techniques require temperatures in the coals and embers ranging from $150^{\circ} \mathrm{C}$ (where meat begins to broil) to $550-625^{\circ} \mathrm{C}$. Moist cooking includes simmering, boiling, and steaming, which require lower temperatures, from $85^{\circ} \mathrm{C}$ (where simmering begins) to $100^{\circ} \mathrm{C}+$ needed for steaming.

Pressure cooking with steam in capped cooking pits with alternating layers of hot rocks and moist vegetation gelatinizes the plant carbohydrates so the finished product can be pressed in compact form for easier transport or storage (Reid 1989). The author reports that simmering at $85-88^{\circ} \mathrm{C}$, where bubbles form below but do not break the surface, is most suitable for stewing meats and for oil and grease rendering from seeds and fractured bones. Higher temperatures that produce a rolling boil are not suitable for these purposes, as boiling makes meat tough and prevents skimming of released oils and fats. Boiling only becomes adaptive for cooking starchy cereal grains and roots which do not completely gelatinize below a temperature of $93^{\circ} \mathrm{C}$. He suggests that a covariant relationship should exist between the exploitation of carbohydrate seeds and boiling (Reid 1989).

\section{Summary}

This review of analytical methodologies available for investigating and interpreting burned-rock features presents archaeologists with a new set of research design decisions. As early as 1980 , archaeologists began to call for consistent recording of variables within burned-rock clusters as they realized that these variations could be used to explain differences in function, differences in site types, and differential availability or preferential collection of resources (White 1980). Since not all sites offer equal amounts of information and not all projects afford equal opportunities for data retrieval, choices must be carefully examined as some methods have proved more productive than others. Well-designed field and analytical programs, along with experimental results and inferences from interdisciplinary studies, provide avenues to increase our understanding of the function of burned-rock features. Such an understanding is a prerequisite for a broad range of behavioral interpretation including subsistence, seasonality, population fluctuations, and social organization. 


\section{Chapter 3. Site and Feature Descriptions}

Of the 172 sites tested during the HMAP, the following were chosen for the burned rock study: FB 12719 (41EP628), FB 12412 (41EP3155), and FB 13237 (41EP3546). Each of the three sites is located in a different environmental zone. Site FB 12719 is located in the central basin (elevation 1,230 to $1,240 \mathrm{~m}$ above mean sea level [amsl]), FB 12412 is located in the transitional zone (elevation 1,240 to $1,250 \mathrm{~m}$ amsl), and FB 13237 is on the proximal fan of the Hueco Mountains (elevation $1270 \mathrm{~m}$ amsl). The following descriptions were obtained from field summaries provided by Fort Bliss archaeologists.

\section{Site FB 12719 (41EP628)}

Site FB 12719 covers an area of $5,364 \mathrm{~m}^{2}$. The local environment is characterized by mesquitestabilized dunes, interdunal deflational depressions, recurrent sheet sands, and isolated patches of local forbs and grasses. The site was identified during the Phase I collection as a surface scatter of burned rock and artifacts. Six features were recorded on the surface: $30,31,32,33,34$, and 37 . A total of $448 \mathrm{~m}^{2}$ was excavated within two excavation blocks: $\mathrm{A} 1$ and $\mathrm{B} 1$.

\section{Block A1}

A large excavation block was established over Features 32,33 , and 34. Feature 32 is described as a light-bulb-shaped pit structure measuring $3.95 \times$ $2.80 \times 0.25 \mathrm{~m}$. Artifacts recovered from the feature fill include chipped stone, ground stone, unspecified brownware ceramics, burned rock, and burned bone. The following three radiocarbon dates were obtained from Feature 32: $1060 \pm 50$ B.P., $1140 \pm 70$ B.P., and $1240 \pm 60$ B.P. (all dates adjusted).

Within Feature 32, Features 78 and 85 were recorded on the structure floor. Feature 78 was a basinshaped hearth measuring $0.37 \times 0.47 \times 0.10 \mathrm{~m}$. Feature 85 was a possible posthole measuring 0.25 $\mathrm{m}$ in diameter and $0.05 \mathrm{~m}$ in depth.

Feature 33, also a pit structure, is described as being semi-circular in shape and measuring $2.65 \mathrm{x}$ $3.60 \times 0.20 \mathrm{~m}$. Artifacts recovered from the feature fill include chipped stone, unspecified brownware ceramics, ground stone, and burned rock. Two radiocarbon dates, $1040 \pm 80$ B.P. and $1500 \pm 110$ B.P., were obtained from Feature 33. A flotation sample from Feature 33 contained pieces of Fabaceae and Atriplex/Sarcobatus charcoal in addition to Chenopodium seed and charred bone (Table 1).

Feature 34 is described as a large, roughly circular pit structure measuring $4.15 \times 2.95 \times 0.15 \mathrm{~m}$. Artifacts recovered from the feature fill include unspecified brownware ceramics, El Paso brownware ceramics, chipped stone, ground stone, a ceramic spindle whorl, burned bone, and burned rock. Two circular, basin-shaped hearths with carbonaceous ash fill, Features 80 and 89 , were identified on the structure floor. Feature 80 measured $0.35 \mathrm{~m}$ in diameter and $0.10 \mathrm{~m}$ in depth. Feature 89 measured $0.62 \times 0.80 \times 0.18 \mathrm{~m}$. Radiocarbon dates of $1360 \pm 70$ B.P. and $1200 \pm 110$ B.P. were obtained for Feature 34 and Feature 80 respectively. 
Table 1. Archaeobotanical Remains Recovered From Flotation Samples

\begin{tabular}{|c|c|c|c|c|c|c|c|}
\hline \multirow{2}{*}{ Taxon } & \multirow[b]{2}{*}{ Common } & \multicolumn{2}{|c|}{ Site FB 13237} & \multicolumn{2}{|c|}{ Site FB 12719} & \multicolumn{2}{|c|}{ Site FB 12412} \\
\hline & & Ftr. 40 & Ftr.46 & Ftr. 33 & Ftr. 32 & Ftr. 12 & Ftr. 16 \\
\hline Bahia absinthifolia & hairy seed bahia & & 2 & & & & \\
\hline Caryophyllaceae & pink family & 3 & & & & & \\
\hline Euphorbia cf. serrula & spurge & 25 & 1 & & & & \\
\hline Solanum eleagnifolium & purple nightshade & 1 & & & & & \\
\hline Chenopodium & seed & & & $\mathrm{x}$ & & & \\
\hline Prosopis & charcoal & $\mathrm{x}$ (cf.) & & & & $\mathrm{x}$ (cf.) & $\mathrm{x}$ \\
\hline Fabaceae & charcoal & $\mathrm{x}$ & & $\mathrm{x}$ & $\mathrm{x}$ & & \\
\hline Atriplex/Sarcobatus & charcoal & & & $\mathrm{x}$ & & & \\
\hline
\end{tabular}

$\mathrm{x}=$ presence $\quad$ cf. = compares favorably

\section{Block B1}

A second excavation block was established over Feature 30 . Feature 30 is described as a small, dishshaped hearth with an ash stain and burned rock, measuring $0.50 \times 0.40 \times 0.04 \mathrm{~m}$. Excavation of the block exposed Feature 77, a semi-circular dishshaped hearth with carbonaceous ash measuring $0.60 \times 0.50 \times 0.10 \mathrm{~m}$. A single flake and burned caliche were recovered from feature fill. Artifacts recovered from non-feature contexts include chipped stone, ground stone, unspecified brownware ceramics, and burned rock.
A large amount of animal bone was recovered from site FB 12719, mostly from the pit structures (Table 2). Feature 32 contained 601 pieces of bone consisting of mainly black-tailed jackrabbit (Lepus californicus), unidentified Lagomorph, and unidentified small and medium mammal. Feature 33 contained 343 pieces of bone consisting of blacktailed jackrabbit, cottontail (Sylvilagus sp.), unidentified Lagomorph, squirrel (Sciuridae), unidentified Artiodactyla, and unidentified small and medium mammal. Pieces of unidentified small/ medium mammal were recovered from Features 78 and 85 .

Table 2. Faunal Remains Recovered From Sites FB 12412 and FB 12719

\begin{tabular}{|c|c|c|c|c|}
\hline \multirow{2}{*}{ Site } & $\begin{array}{c}\text { Feature } \\
\text { Number }\end{array}$ & $\begin{array}{c}\text { Total Bone } \\
\text { Count }\end{array}$ & $\begin{array}{c}\text { MNI } \\
\text { Lepus }\end{array}$ & $\begin{array}{c}\text { MN } \\
\text { Sylvilagus }\end{array}$ \\
\hline FB 12412 & - & 1 (modern) & - & - \\
\hline FB 12719 & - & 7 (modern) & - & 1 \\
\cline { 2 - 5 } & - & 252 & 2 & 1 \\
\cline { 2 - 5 } & 32 & 601 & 6 & - \\
\cline { 2 - 5 } & 33 & 343 & 4 & 1 \\
\cline { 2 - 5 } & 34 & 32 & 1 & - \\
\cline { 2 - 5 } & 78 & 7 & - & - \\
\hline
\end{tabular}


Site FB 12719 was determined to be a residential site associated with the Late to Middle Formative period. It is not clear whether the structures represent two or more contemporaneous occupations or a series of single occupations.

\section{Site FB 12412 (41EP3155)}

Site FB 12412 is $44,463.36 \mathrm{~m}^{2}$ in size and is located within the transitional zone between the rocky fan of the Hueco Mountains and the basin. The local environment is dominated by creosote bush (Larrea tridentata) and tarbush (Flourensia cernua). Mesquite (Prosopsis glandulosa), and broom snakeweed (Xanthocephlam sarothrae), along with various succulents, forbs, and grasses, are also present.

Twenty features were identified on the surface. Features 1-19 and 24 are described as discrete concentrations of burned rock ranging from 1-8 m in diameter. Only Features $3,9,12$, and 16 were tested. Features 3 and 9 are described as discrete concentrations of burned caliche measuring $8 \times 4 \mathrm{~m}$ and $3 \times 2 \mathrm{~m}$ respectively. Feature 12 is described as a discrete concentration of burned caliche with carbonaceous stain measuring two meters in diameter. Feature 16 is described as a discrete concentration of burned rock measuring three meters in diameter. A total of $199 \mathrm{~m}^{2}$ was excavated within three excavation blocks: A1, A2, and B1.

\section{Block A1}

A $10-\mathrm{x}-10-\mathrm{m}$ block was established to encompass Feature 12. Testing revealed that Feature 12 was a circular, basin-shaped hearth with charcoal and ash fill measuring $0.77 \times 0.64 \times 0.15 \mathrm{~m}$. A single piece of burned unspecified brownware ceramic was recovered from the feature fill. Artifacts recovered from non-feature areas within the block include unspecified brownware ceramics, chipped stone, burned rock, and a single projectile point. A radiocarbon date of $1070 \pm 60$ B.P. was obtained from Feature 12.

\section{Block A2}

A second $10-\mathrm{x}-10-\mathrm{m}$ block was established to encompass Features 3 and 9 . Testing revealed that for both features the concentrations of burned caliche were confined to the surface. No staining or subsurface concentrations of burned rock or caliche were encountered. Two discrete concentrations of chipped stone artifacts were identified subsurface, one in the area of Feature 3, the other just west of Feature 9.

\section{Block B1}

An 8-x-8-m excavation block was established to encompass Feature 16. After subsurface testing, Feature 16 was described as a circular, rock-lined hearth with charcoal, carbonaceous ash, and burned rock fill, measuring $2.0 \mathrm{~m}$ in diameter and $0.14 \mathrm{~m}$ in depth. Artifacts recovered from the feature fill include chipped stone, flake tools, and burned caliche. Flotation samples contained charred bone and Prosopis charcoal. A single specimen of small/ medium mammal bone was recovered from nonfeature context: This specimen was described as being of probable modern origin. The following three radiocarbon dates were obtained from Feature 16: $1060 \pm 70$ B.P., $870 \pm 50$ B.P., and $790 \pm 60$ B.P.

Site FB 12412 is a multicomponent site with at least two separate occupational episodes indicated from the radiocarbon dates. Site function is not known, but the discrete concentrations of lithic artifacts indicate special activity areas within the site.

\section{Site FB 13237 (41EP3546)}

Site FB 13237 is located on the alluvial fan on the western base of the Hueco Mountains and is $5,524.60 \mathrm{~m}^{2}$ in size. The local environment is dominated by creosote bush, tarbush, mesquite, and broom snakeweed on the distal portion of the fan. The proximal portion is dominated by creosote bush and tarbush with some mesquite, prickly pear (Opuntia phaeacantha), lechuguilla (Agave 
lechuguilla), and various other succulents. Various forbs and grasses are sparsely distributed over both the proximal and distal portions of the fan.

Fourteen features-Features $39-51$ and $77-$ were identified on the surface. All surface features other than Features 51 and 77 were described as concentrations of burned limestone. Feature 51 was a concentration of burned limestone with a carbonaceous stain, and Feature 77 was a discrete cluster of ceramic sherds. Three excavation blocks-Blocks A1, B1, and C1-were established and a total of $48 \mathrm{~m}^{2}$ was excavated.

\section{Block A1}

A 4-x-4-m excavation block was established over Feature 48. Feature 48 is described as a surficial concentration of burned limestone, measuring $13 \mathrm{x}$ $9 \mathrm{~m}$. Subsurface testing revealed an increase in burned rock density and number of large rocks, but no stains were noted. Artifacts recovered from Feature 48 (which encompasses all of Block A1) include unspecified brownware ceramics, chipped stone, flake tools, burned rock, and one bone bead.

\section{Block B1}

A second 4-x-4-m block was established over a concentration of burned rock. The latter, measuring $6 \times 4 \mathrm{~m}$, was designated Feature 46 on the surface. Subsurface testing revealed that Feature 46 was a rock-lined, basin-shaped hearth pit with carbonaceous ash, charcoal, and burned rock fill. The hearth pit measured an estimated $1.15 \mathrm{~m}$ in diameter and $0.25 \mathrm{~m}$ deep. Feature 46 extended beyond the limits of the test area for an unknown distance. A single radiocarbon date of $4120 \pm 80$ B.P. was obtained from Feature 46. Flotation samples yielded bahia (Bahia absinthifolia), spurge (Euphorbia cf. serrula), and unidentified charcoal fragments.

Testing within the block also exposed a small, ovalshaped carbonaceous stain designated Feature 98. Further testing revealed that Feature 98 was a shallow, irregular, basin-shaped pit measuring 0.70 $\mathrm{x} 0.95 \times 0.09 \mathrm{~m}$, with a light carbonaceous ash fill. Artifacts recovered from the feature fill include chipped stone and burned limestone. A large number of burned limestone pieces was recovered from throughout the block.

\section{Block C1}

A third 4-x-4-m test block was established over Feature 40 , which was defined by a 7-x-5-m concentration of burned rock on the surface. Subsurface testing revealed that Feature 40 was a conical-shaped, cobble-lined hearth pit with carbonaceous ash and charcoal fill. The pit hearth measured $0.80 \times 0.70 \times 0.18 \mathrm{~m}$. Artifacts recovered from the feature fill include chipped stone, unspecified brownware ceramics, and burned limestone. A single radiocarbon date of $670 \pm 60$ B.P. was obtained from Feature 40. Flotation samples yielded Caryophyllaceae, spurge, purple nightshade (Solanum eleagnifolium), and Fabaceae and Prosopis charcoal.

Subsurface testing also revealed two additional features, 102 and 103, not evident on the surface. Feature 102 was a semicircular, basin-shaped, rockringed hearth with carbonaceous ash and rock fill. This hearth measured $0.83 \times 0.56 \times 0.24 \mathrm{~m}$. Artifacts recovered from Feature 102 fill include chipped stone, unspecified brownware ceramics, and burned limestone. A single radiocarbon date of $1660 \pm 70$ B.P. was obtained from Feature 102 . Flotation samples yielded only unidentified charcoal fragments.

Feature 103 was also a semicircular, basin-shaped, rock-ringed hearth with carbonaceous ash fill. Only half of Feature 103 was investigated because it extended beyond the test block. The extrapolated measurements for this feature are $0.80 \times 0.56 \times$ $0.15 \mathrm{~m}$. No artifacts were recovered from the feature fill.

Non-feature artifacts recovered from the site, surface and subsurface, include El Paso Brownware, 
El Paso Bichrome, El Paso Polychrome, and unspecified brownware ceramics, chipped stone, retouched flakes, a single core, and burned limestone.

Site FB 13237 is a multicomponent site with at least three temporally discrete episodes of occupation as indicated by the radiocarbon dates. Periods of occupation range from the Late Archaic to the Early and Late Formative. 


\section{Chapter 4. Methodology}

The analysis of 100 percent of the burned rock from three of the 172 sites excavated during the HMAP was undertaken to address issues of function, recycling, and reuse of fire-cracked features. Sites, FB 12412, FB 12419, and FB 13237 were selected in consultation with Fort Bliss archaeologists based on their topographic location and the completeness of their burned-rock collection. Attributes chosen with these specific research questions in mind include material type, size, weight, and presence or absence of fracturing, cortex, and discoloration. These attributes were recorded for all feature and non-feature burned rocks collected.

\section{Material Type}

The rocks from each provenience were first sorted by material. Material types were coded as 1 through 15: 1 =chert, 2 =Rancheria chert, 3 =quartzite, 4 =limestone, $\quad 5=$ rhyolite, $\quad 6=$ sandstone, 7 =granitic,$\quad 8$ =basalt, 9 =vesicular basalt, $14=$ caliche, $15=$ other. (These codes had already been established for earlier projects; code numbers 10 through 13 were not encountered during this analysis.) Material selection has been viewed in other studies as both a reflection of material availability (Mauldin et al. 1994; O'Laughlin 1980) and as an indication of feature function (Duncan and Doleman 1991; Oakes 1981). The geographical distribution of the sites in this study may supply additional information to this discussion.

\section{Count, Size, and Weight}

Each material type was sorted by size (maximum diameter). Size categories were coded as 1 through 12: size 1 being less than $1.5 \mathrm{~cm}$, categories 2 through 4 increased sequentially by $1.5-\mathrm{cm}$ increments, and categories 5 and above increased sequentially by $2.5-\mathrm{cm}$ increments (Table 3 ). The number of rocks in each size category was recorded and weighed on an electronic balance. We hoped that by comparing size to average weight in each category, differences in fracturing patterns would be seen between features with different functions. Experimental work (Burkley 1990; Duncan and Doleman 1991; Schalk and Maette 1988; etc.) indicates that stones used for boiling fracture in a

Table 3. Size/Class Categories

\begin{tabular}{|c|c|c|}
\hline Size Class & Range in cm & Midpoint \\
\hline 1 & $<1.5$ & .75 \\
\hline 2 & $1.5-2.5$ & 2 \\
\hline 3 & $2.5-4$ & 3.25 \\
\hline 4 & $4-5.5$ & 4.75 \\
\hline 5 & $5.5-8$ & 6.75 \\
\hline 6 & $8-10.5$ & 9.25 \\
\hline
\end{tabular}

\begin{tabular}{|c|c|c|}
\hline Size Class & Range in cm & Midpoint \\
\hline 7 & $10.5-13$ & 11.75 \\
\hline 8 & $13-15.5$ & 14.25 \\
\hline 9 & $15.5-18$ & 16.75 \\
\hline 10 & $18-20.5$ & 19.25 \\
\hline 11 & $20.5-23$ & 21.75 \\
\hline 12 & $23-25.5$ & 24.25 \\
\hline
\end{tabular}


blocky pattern due to thermal shock. Stones used in pit features for baking, parching, etc. are heated and cooled more slowly and therefore fracture in a curvilinear pattern. These different fracturing patterns should be reflected in a size-to-weight ratio comparison.

\section{Discoloration}

Interior alterations in material color were to identify burned stone and caliche. For each size category within each material type, the number of burned rocks exhibiting thermal discoloration was recorded. To make this assessment, small pieces were broken off from each rock specimen. When discoloration was found to exist only on the surface, this change, in the case of limestone, was attributed to weathering and the specimen was removed from the collection. Caliche specimens with only surface discoloration were also removed from the sample.

\section{Fracturing}

The burned rocks within each size category and material type other than caliche were observed for fracturing. Fracturing was recorded as present or absent. Any breaks that appeared to be a result of post-excavation damage were not recorded. If rocks with fresh breaks could be refit with another piece, they were recorded as a single specimen. With caliche, distinguishing between fragmentation caused by thermal alteration and that resulting from natural causes is difficult; therefore, fragmentation was not recorded for caliche.

The degree of fracturing can be a result of amount and type of use. As rocks are exposed to repeated episodes of heating and cooling, they fracture into smaller and smaller pieces. The degree of fracturing can be used to address questions of reuse and recycling of rock. Repeated use of a feature should result in a greater amount of fractured versus nonfractured rock. A greater degree of fracturing may also be a result of feature function in that certain activities-such as stone boiling-tend to fracture rock at a faster rate.

\section{Cortex}

The presence of cortex on material other than caliche was noted, although amount of cortex remaining was not determined due to the large sample size and time constraints. The presence of cortex on fractured material may help in identifying patterns of reuse. With the continued fracturing and reduction in size of stone, the number of specimens with cortex present should decrease. The amount of stone with no cortex present should reflect a higher degree of fracturing.

\section{Data Entry}

All attribute data were entered into a spreadsheet program (QuattroPro ${ }^{\circ}$ ) containing provenience information. Complete data tables are given in Appendix A. Collection numbers on each bag were used to tie the attribute information with provenience information. Density distributions of rock at the level of excavation block, 1-x-1-m unit, feature, and level were constructed using a mapping program (Surfer').

\section{Archaeomagnetic Analysis}

In addition to the recording of attributes, several samples of limestone from eight features were selected for archeomagnetic analysis by Wulf Gose of The University of Texas at Austin (Appendix B). It was hoped that the archaeomagnetic analysis would identify subsequent firing episodes in a single feature and the temperature at which the rock was fired. 


\section{Chapter 5. Analysis}

Analysis of the thermally altered caliche and burned rock was undertaken to investigate patterns that might address the following research issues: 1) evidence of reuse/recycling, 2) feature function, 3) chronological relationships, 4) evidence of postdepositional site formation processes, and 5) morphological variability in the rock due to temperature variation. Investigation of the data from the three sites was approached on three levels. Coarsegrained comparisons of burned rock raw material and feature types on an intersite basis were conducted to identify variations in temporal, functional, and topographic land use in the study area. Intrasite variation between non-feature and feature burned rock by weight, quantity, and rock sizes was examined for patterns that could be attributed to different feature function(s) and use. Fine-grained variations in burned rock size, weight, and percent of fracture of non-feature and feature burned rocks within selected provenances were analyzed to identify patterns of reuse and discard. Rock core samples from selected features were submitted for archeomagnetic testing for evidence of function and reuse through variations in firing temperatures and heating episodes.

\section{Intersite Analysis}

The assemblage used for this analysis consisted of 29,058 pieces of fire-cracked rock and burned caliche weighing $554,511.2 \mathrm{~g}(1,223 \mathrm{lbs})$. As shown in Table 4, limestone accounted for 96 percent of the total weight and 68 percent of the total quantity, while burned caliche comprised four percent of the weight and 31 percent of the quantity. Other material types, which contributed less than one percent to the total weight and one percent to the total quantity, include chert, Rancheria chert, rhyolite, sandstone, granitic, basalt, vesicular basalt, and unknown other.

Eighty-eight percent $(n=489,487.63 \mathrm{~g})$ of the total sample weight and 52 percent of the quantity $(n=15,248)$ was recovered from site FB 13237 , located on the proximal fan of the Hueco Mountains. Four percent of the sample weight $(n=20,268.69 \mathrm{~g})$ and 18 percent of the quantity $(n=5,272)$ was collected from site FB 12412 in the transitional zone. Burned rock and caliche from the basin site, FB 12719, accounts for eight percent $(\mathrm{n}=44,754.88 \mathrm{~g})$ of the sample weight and 29 percent $(n=8,538)$ of the total burned rock.

\section{Material Types}

As illustrated in Figures 1 and 2, material composition varies between sites. The contribution of total caliche weight and count increases from $<1$ percent on the proximal fan (FB 13237) to 61 and 75 percent respectively at the basin site (FB 12719). A similar pattern of increasing frequencies of burned caliche is seen in feature composition from these sites. While no burned caliche was recovered from the features on the proximal fan site (FB 13237), burned caliche makes up 37 percent of feature material and 44 percent of feature weight from the site in the transitional zone (FB 12412) and 77 percent of the feature material and 40 percent of the feature weight in the basin site (FB 12719). These findings follow the general pattern established in the El Paso area of caliche utilization in basin and lowland areas and use of non-caliche rock in the Piedmont areas. This pattern is traditionally viewed as a reflection of the availability of materials (Mauldin et al. 1994; O'Laughlin 1980). In his survey of prehistoric sites on the alluvial fans of the 
Table 4. Material Composition

\begin{tabular}{|c|c|c|c|c|c|c|c|c|c|c|c|c|c|}
\hline \multirow[t]{2}{*}{ Site } & \multirow[t]{2}{*}{ Material } & \multicolumn{2}{|l|}{$\begin{array}{l}\text { Total } \\
\text { Weight }\end{array}$} & \multicolumn{2}{|c|}{$\begin{array}{c}\text { Total } \\
\text { Quantity }\end{array}$} & \multicolumn{2}{|c|}{$\begin{array}{c}\text { Non-feature } \\
\text { Weight }\end{array}$} & \multicolumn{2}{|c|}{$\begin{array}{c}\text { Non-feature } \\
\text { Quantity }\end{array}$} & \multicolumn{2}{|l|}{$\begin{array}{l}\text { Feature } \\
\text { Weight }\end{array}$} & \multicolumn{2}{|c|}{$\begin{array}{l}\text { Feature } \\
\text { Quantity }\end{array}$} \\
\hline & & $\mathrm{g}$ & $\%$ & $\#$ & $\%$ & $\mathrm{~g}$ & $\%$ & $\#$ & $\%$ & $\mathrm{~g}$ & $\%$ & $\#$ & $\%$ \\
\hline \multirow{3}{*}{12719} & caliche & 16276.28 & 36 & 6418 & 75 & 10717.45 & 35 & 5004 & 75 & 5558.83 & 40 & 1414 & 77 \\
\hline & limestone & 27216.12 & 61 & 1935 & 23 & 19113.92 & 62 & 1553 & 23 & 8102.2 & 59 & 385 & 21 \\
\hline & other & 1262.48 & 3 & 185 & 2 & 1109.14 & 4 & 144 & 2 & 153.34 & 1 & 41 & 2 \\
\hline & Site Total & 44754.88 & & 8538 & & 30940.51 & & 6698 & & 13814.37 & & 1840 & \\
\hline \multirow{3}{*}{12412} & caliche & 5796.88 & 29 & 2690 & 51 & 4024.4 & 25 & 2082 & 52 & 1772.5 & 44 & 473 & 37 \\
\hline & limestone & 14381.64 & 71 & 2556 & 48 & 12169.92 & 75 & 1892 & 47 & 2211.72 & 55 & 798 & 63 \\
\hline & other & 90.17 & 0 & 26 & 1 & 34.23 & 0 & 22 & 1 & 55.94 & 1 & 5 & 0 \\
\hline & Site Total & 20268.69 & & 5272 & & 16228.55 & . & 3996 & & 4040.16 & & 1276 & \\
\hline \multirow{3}{*}{13237} & caliche & 203.64 & 0 & 6 & 0 & 203.64 & 0 & 6 & 0 & 0 & 0 & 0 & 0 \\
\hline & limestone & 488567.65 & 100 & 15219 & 100 & 254433.7 & 1 & 10927 & 1 & 234143.7 & 1 & 4292 & 100 \\
\hline & other & 716.34 & 0 & 23 & 0 & 695.97 & 0 & 20 & 0 & 10.67 & 0 & 3 & 0 \\
\hline & Site Total & 489487.63 & & 15248 & & 255333.3 & & 10953 & & 234154.4 & & 4295 & \\
\hline \multirow{3}{*}{$\begin{array}{l}\text { All } \\
\text { sites }\end{array}$} & caliche & 22276.8 & 4 & 9114 & 31 & & & & & & & & \\
\hline & limestone & 530165.41 & 96 & 19710 & 68 & & & & & & & & \\
\hline & other & 2068.99 & 0 & 234 & 1 & & & & & & & & \\
\hline & Total & 554511.2 & & 29058 & & & & & & & & & \\
\hline
\end{tabular}

Franklin Mountains northwest of El Paso, O'Laughlin (1980) found no fire-cracked rock features containing burned caliche, while Mauldin's study of 790 features within the Hueco Bolson found that over 80 percent of the features contained caliche (Mauldin et al. 1994).

Studies from the Tularosa Basin north of El Paso, however, produced a different pattern of material selection. Oakes (1981) found the fire-cracked rock assemblage on the western side of the basin is dominated by limestone even though the nearest source of this material is $6.5 \mathrm{~km}$ away. Duncan and Doleman (1991) report that although the nearest source of non-caliche rock is $3-5 \mathrm{~km}$ away from their portion of the study area and caliche is readily available, burned caliche accounted for only 13 percent of the total fire-cracked rock quantity and 2.5 percent of the total assemblage weight. Duncan and Doleman (1991) suggests the predominance of imported rock from substantial distances indicates this material was selected for functional reasons, most probably stone boiling, while burned caliche may represent impromptu or incidental fires.

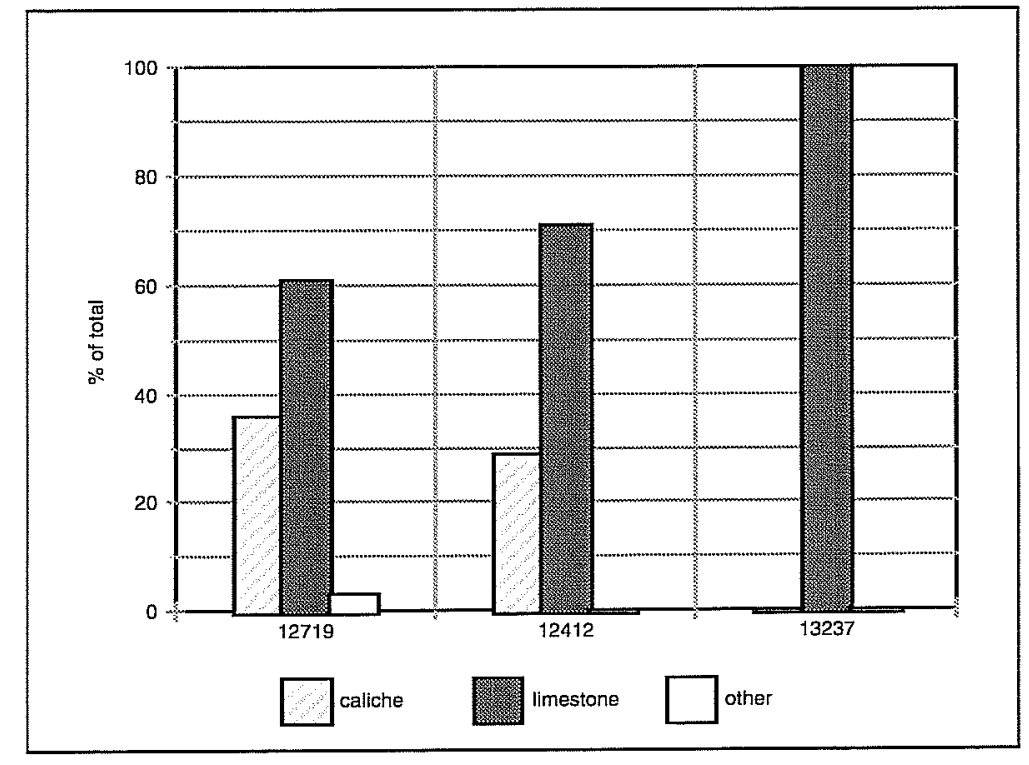

Figure 1. Material weights. 


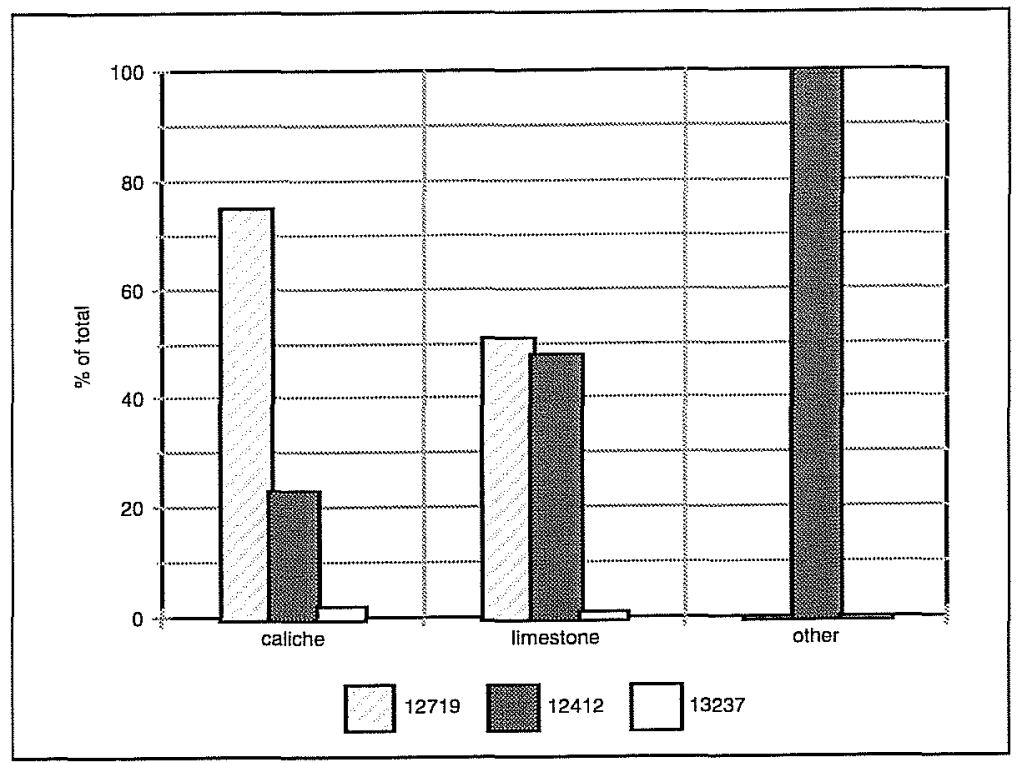

Figure 2. Material quantities.

Availability rather than function appears to have been a factor in material selection in our study area. Although the three sites are located in different environmental zones, no more than $1.5 \mathrm{~km}$ separates the basin site, FB 12719 , from the nearest source of limestone. Therefore, if limestone was of functional importance, it would have been reasonably accessible, especially to site FB 12412 located in the transitional zone at the base of the alluvial fan. The increasing frequency of burned caliche as one moves into the basin suggests expedient use of available materials for generalpurpose activities not requiring large quantities of limestone, as proposed by Carmichael (1985), Hard (1983), and Whalen (1977).

\section{Feature Type}

Feature type classifications are assigned in this report based on the morphological categories of firecracked rock features defined at the Goberadora site by Miller $(1989,1990)$. The four categories are:

1) Rock-lined pits: shallow basin pits averaging one meter in diameter with walls and base lined completely with unbroken cobbles averaging $20-30 \mathrm{~cm}$ in diameter. Spaces between the cobbles are often filled with smaller, sometimes fractured, rocks.

2) Fire-cracked rock discard scatters: dispersals of highly fractured rock with no evidence of underlying basins or pits. Discard scatters are generally found in direct association with rock-lined pits.

3) Fire-cracked rock middens: dense accumulations of fire-cracked rock not directly associated with rocklined pits

4) Hearths: small, shallow basins or pits with fill composed of darkly stained soil and a small number of burned rocks.

This analysis includes burned rock from 18 features identified during excavation (Table 5). Features from site FB 13237, located on the distal fan, include two rock-lined pits, three hearth features, and one burned-rock discard scatter. Features excavated at site FB 12412, located in the transitional zone, include one rock-lined pit, one hearth, and two burned rock scatters. Aside from the burned caliche and fire-cracked rock associated with the fill of the three pit structures on site FB 12719 in the basin, all excavated features from this site are identified as hearths.

The three rock-lined pits have diameters ranging in size from $0.8-2 \mathrm{~m}$, and are between $.18-.14 \mathrm{~m}$ deep. Feature 16 from site FB 12412 and Feature 46 form site FB 13237 are similar in size, but Feature 46 , while not fully excavated, contained almost twice as many burned rocks. Eight basin-shaped hearth features were identified. These hearths have an average area of $.39 \mathrm{~m}$ (std $.15 \mathrm{~m}$ ) and range in area from $.17-.67 \mathrm{~m}$.

\section{Radiocarbon Dates}

Radiocarbon dates were recovered from 10 of the excavated features (Table 5). With the exception of the date from Feature 85, features at site FB 12719 and FB 12412 fall within the range established for the Mesilla phase (A.D. 300-1100) in the El Paso 
Table 5. Feature Descriptions

\begin{tabular}{|c|c|c|c|c|c|c|c|}
\hline \multirow{2}{*}{ Site } & \multirow{2}{*}{ Blk. } & \multirow{2}{*}{ Ftr. } & \multirow{2}{*}{ Description } & \multirow{2}{*}{$\begin{array}{l}\text { Dimensions } \\
\text { (meters) }\end{array}$} & \multicolumn{2}{|c|}{ Burned Rock } & \multirow{2}{*}{${ }^{14} \mathrm{C}$ Date } \\
\hline & & & & & Quantity & Wgt. (g) & \\
\hline \multirow{8}{*}{$\begin{array}{c}12719 \\
\text { Central Basin } \\
\text { UTM } 8728\end{array}$} & $\mathrm{~B} 1$ & 30 & dish-shaped hearth & $.50 \times .40 \times .04$ & 325 & 2000.86 & \\
\hline & \multirow[t]{7}{*}{ Al } & 32 & bulb-shaped pit structure & $3.95 \times 2.80$ & 328 & 5501.16 & $\begin{array}{l}1060 \pm 50 \\
1140 \pm 60 \\
1240 \pm 60\end{array}$ \\
\hline & & 78 & .hearth inside Ft 32 & $37 \times .47 \times .10$ & 10 & 12.19 & \\
\hline & & 33 & pit structure & $2.65 \times 3.60$ & 718 & 3667.75 & $\begin{array}{c}1040 \pm 80 \\
1500 \pm 110 \\
\end{array}$ \\
\hline & & 34 & pit structure & $4.15 \times 2.95$ & 361 & 2390.37 & $1360 \pm 70$ \\
\hline & & 80 & hearth feature inside $\mathrm{Ft} 34$ & .35 diam $x .10$ & 2 & .51 & $1200 \pm 110$ \\
\hline & & 89 & basin-shaped hearth inside Ft. 34 & $.35 \times .10$ circular & 33 & 68.89 & \\
\hline & & 85 & possible post hole inside Ft. 32 & $.25 \times .05$ & 20 & 18.65 & $1710 \pm 150$ \\
\hline \multirow{4}{*}{$\begin{array}{c}12412 \\
\text { Transitional } \\
\text { UTM } 8928\end{array}$} & Al & 12 & $\begin{array}{l}\text { basin-shaped hearth pit; } \\
\text { brownware, flakes }\end{array}$ & $\begin{array}{l}.77 \times .64 \times .15 \\
\text { circular }\end{array}$ & 119 & 163.33 & $1070 \pm 60$ \\
\hline & $\mathrm{B} 2$ & 16 & deep rock-lined hearth & 2.0 diam. $\times 1.4$ & 270 & 894.70 & $\begin{array}{c}870 \pm 50 \\
790 \pm 60 \\
1060 \pm 70 \\
\end{array}$ \\
\hline & \multirow[t]{2}{*}{$\mathrm{A} 2$} & 3 & $\begin{array}{l}\text { concentration of burned caliche and } \\
\text { rock }\end{array}$ & $8 \times 4$ & 673 & 1792.58 & \\
\hline & & 9 & $\begin{array}{l}\text { concentration of burned caliche and } \\
\text { rock }\end{array}$ & $3 \times 2$ & 209 & 1138.65 & \\
\hline \multirow{6}{*}{$\begin{array}{c}13237 \\
\text { Proximal Fan } \\
\text { UTM } 9029\end{array}$} & \multirow[t]{3}{*}{$\mathrm{Cl}$} & 40 & cobble-lined hearth & $.80 \times .70 \times .18$ & 346 & 88170.09 & $670 \pm 60$ \\
\hline & & 102 & basin-shaped, FCR-ringed hearth & $\begin{array}{l}.83 \times .56 \times .24 \\
\text { semi-circular }\end{array}$ & 165 & 49206.50 & $1660 \pm 70$ \\
\hline & & 103 & $\begin{array}{l}\text { FCR-ringed, semi-circular, basin- } \\
\text { shaped hearth; } 1 / 2 \text { excavated }\end{array}$ & $.80 \times .56 \times .15$ & 55 & 12690.00 & \\
\hline & \multirow[t]{2}{*}{ B1 } & 46 & $\begin{array}{l}\text { deep rock-lined, steep-sided, basin- } \\
\text { shaped hearth; not fully excavated }\end{array}$ & 1.5 diam $x .25$ & 508 & 44352.72 & $4120 \pm 80$ \\
\hline & & 98 & basin-shaped stain & $.70 \times .95 \times .09$ & & & \\
\hline & A1 & 48 & FCR concentration w/o pit outline & & 3209 & 39859.25 & \\
\hline
\end{tabular}

area. This phase is characterized by a substantial amount of residential mobility, the use of huts and pithouses, and a subsistence economy based primarily on hunting and gathering (Hard 1983; Hard et al. 1994; Whalen 1981). Dates from features on site FB 13237 range from the Archaic period to the El Paso phase when residential sites appear to cluster at the toes of the alluvial fans (Hard et al. 1994; Mauldin 1994). 


\section{Rock Size-Class Comparison}

Frequency of total weight and quantity of nonfeature and feature burned caliche and fire-cracked rock from the three sites were compared by size class to search for patterns associated with function (Figures 3 and 4). The small size-classes dominate all contexts, creating the skewed distributions in Figure 3. Burned rocks smaller than $2.5 \mathrm{~cm}$ in diameter make up over 60 percent of the rock recovered from each of the three sites: FB 12719 (90 percent, $n=7,655$ ), FB 12412 ( 90 percent, $\mathrm{n}=4765$ ), and FB 13237 (63 percent, $\mathrm{n}=9744)$. The percent of total site weight contributed by rocks in the different size classes presents a different pattern (Figure 4). A normal distribution pattern is present at site FB 13237. Weights at site FB 12719 show a bimodal distribution with rocks in size-class 3 $(2.4-4 \mathrm{~cm})$ and size-class $5(5.5-8 \mathrm{~cm})$ contributing a slightly disproportionate amount to the total. At site FB 12412, a slightly skewed unimodal distribution is seen. The skewed and bimodal rock weight patterns at FB 12719 and FB 12412 are most probably the result of the mix of caliche and limestone at these sites. Figure 5 illustrates that features from the three sites are also dominated by burned rocks four centimeters or less in diameter.

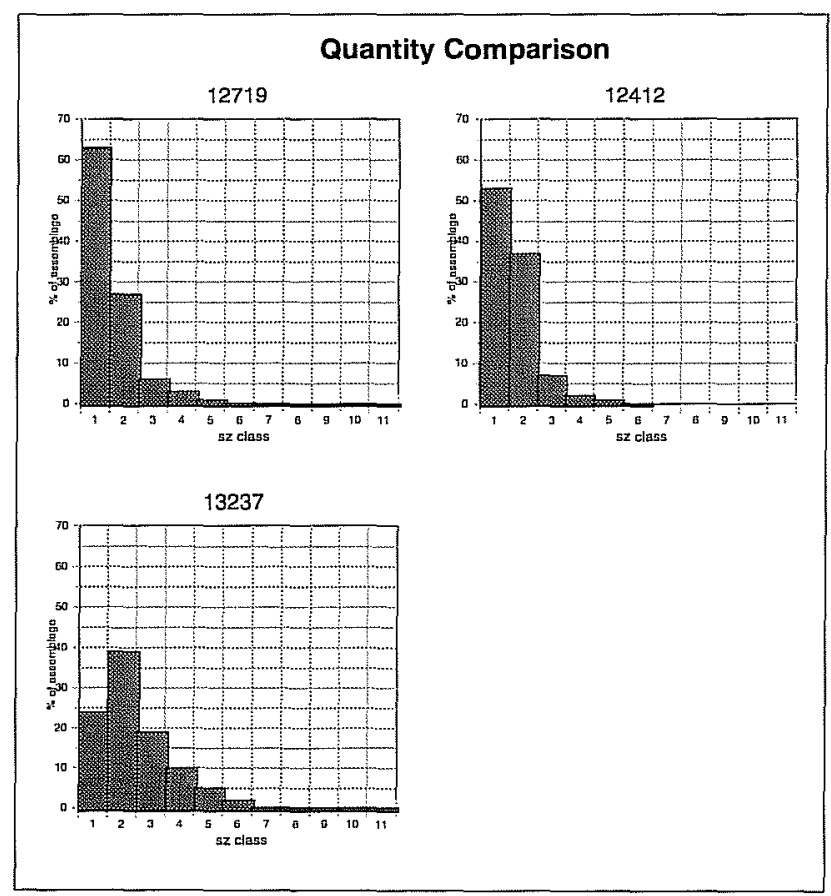

Figure 3. Total site quantity distributions.

\section{Archaeomagnetic Comparisons}

Archeomagnetic analyses to identify firing temperatures and multiple-firing episodes were conducted on a small sample of burned limestone from each of the three sites. Results from these tests, presented in detail in Appendix B, produced patterned differences between firing temperatures at these sites. With the exception of one sample, rocks from FB12412 and FB12719 displayed evidence of maximum heating temperatures between $300^{\circ}-375^{\circ} \mathrm{C}$ while heating temperatures from FB13237 ranged from $350^{\circ}-500^{\circ} \mathrm{C}$. Gose (Appendix B) suggests these differences may reflect a difference in food being processed at these sites, with the hotter rocks at FB13237 used for processing meat and the cooler rocks at FB12412 and FB12719 used in plant processing. Cooking information from Reid (1989) and Lundberg and Kotschevar (1965) indicate that temperatures within both these ranges are required for dry cooking techniques such as roasting, broiling, baking, and parching.

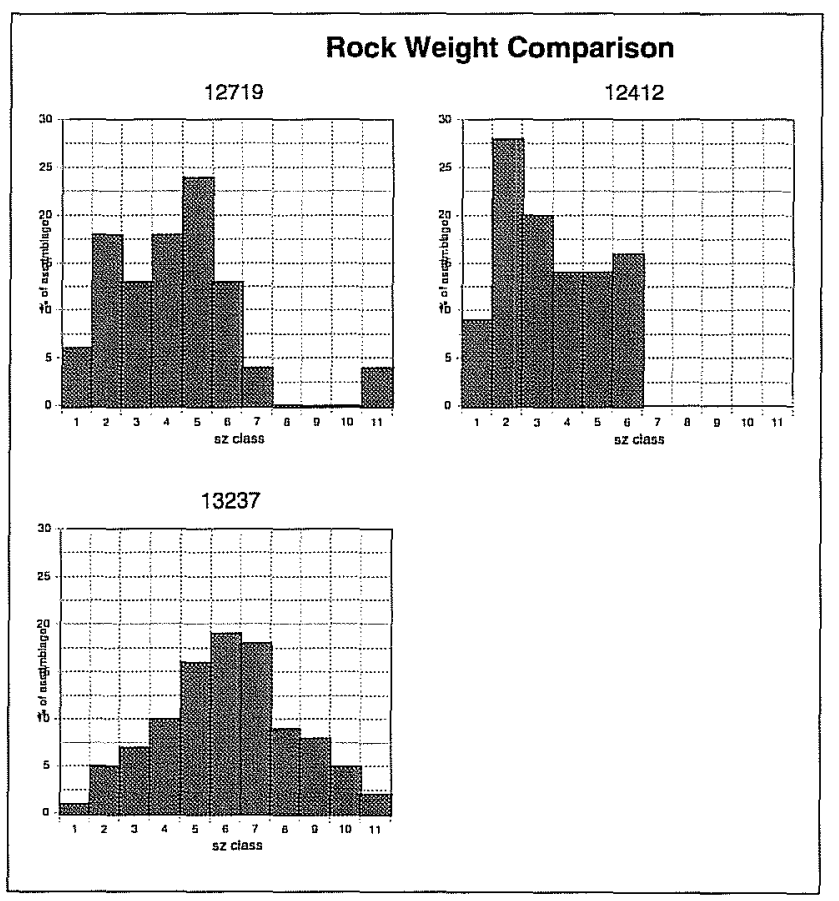

Figure 4. Total site weight distributions. 


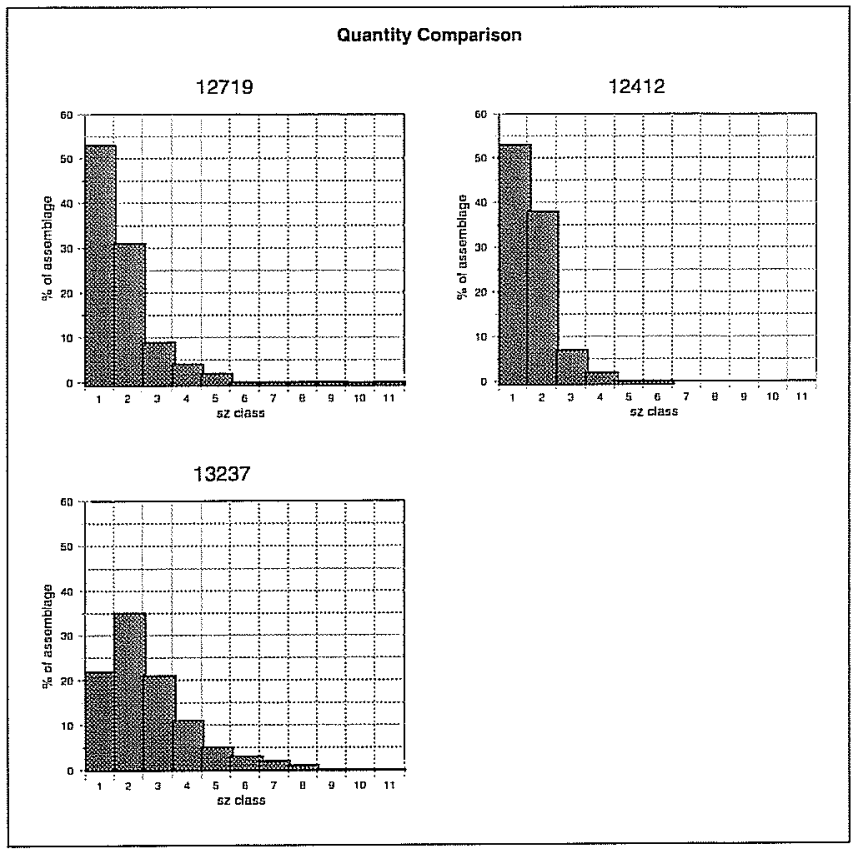

Figure 5. Feature quantity distribution.

\section{Intrasite Analysis}

Intrasite analysis was conducted to search for patterns of discard and reuse. Attributes included in this fine-grain analysis include comparisons of non-feature vs. feature weight and quantity, and mean, standard deviation, and frequency of size class for non-feature and feature rock.

\section{Site FB 12719}

Feature and non-feature weight and quantity of rocks from FB12719 were compared by frequency in size class. If the nonfeature rocks represent discarded stone that had become too fractured to effectively hold/transfer heat, these rocks should be consistently smaller than the rocks identified as part of the feature. Figure 6 illustrates that non-feature burned rocks (all material types) are smaller than feature burned rocks with the frequency of size-class $1(<1.5 \mathrm{~cm})$ in the non-feature assemblage accounting for 64 percent $(n=4,296)$, as opposed to the feature assemblage of 57 percent $(n=1,055)$. The histogram of weight by size class in the nonfeature assemblage shows a distribution skewed toward the larger sizes, unlike the normal distribution displayed by the feature rock weights. While all the burned rock and caliche on this site is small, both of these patterns suggest the overall non-feature rocks do represent discards.

Quantity distributions by size class for rocks from individual features and non-feature rock was investigated to consider differences or similarities that may relate to function. However, because of the friable nature of caliche, only size classes of burned limestone are included. These finding are illustrated in Figure 7. A pattern of dominance of smaller burned rocks is again present. It is, however, interesting that the

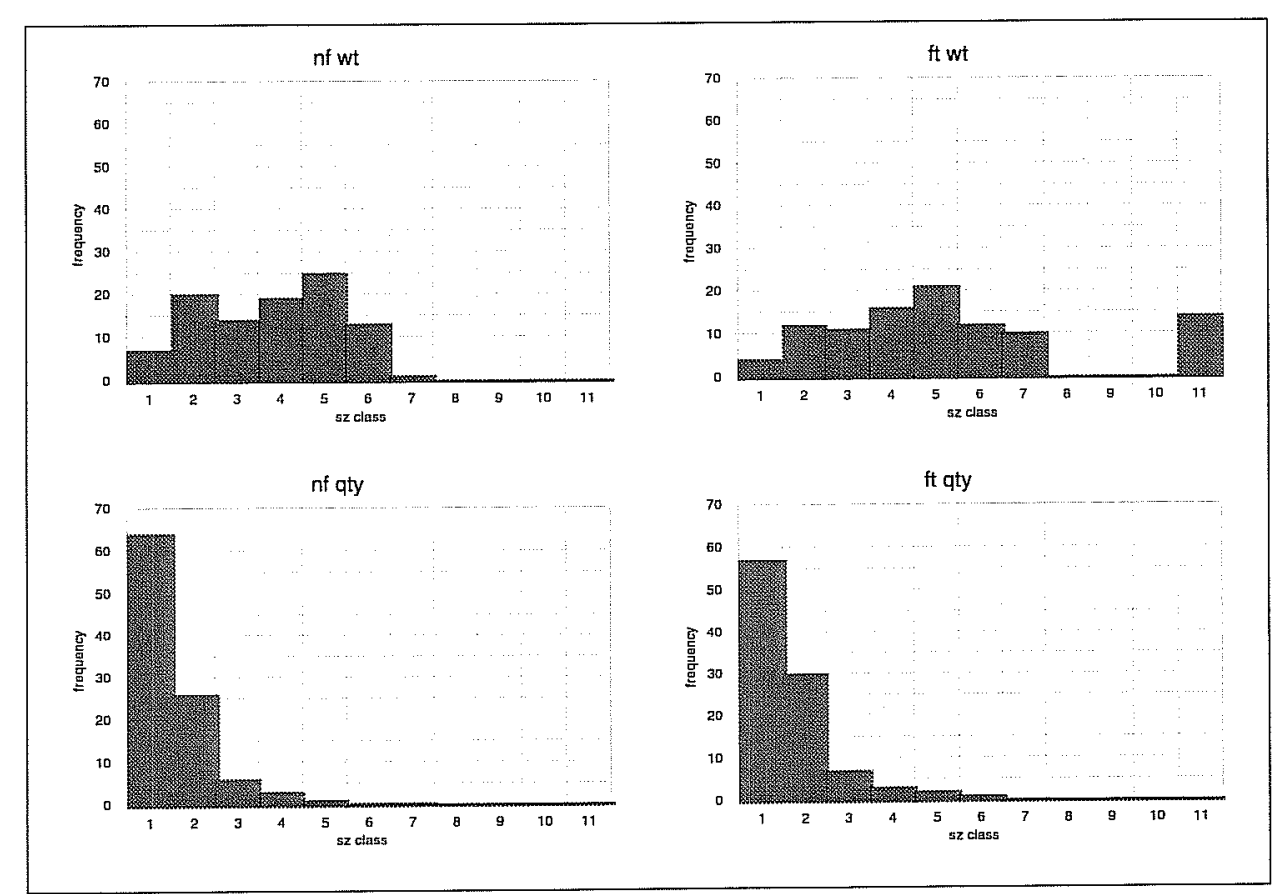

Figure 6. Non-feature vs. feature comparison, FB 12719. 


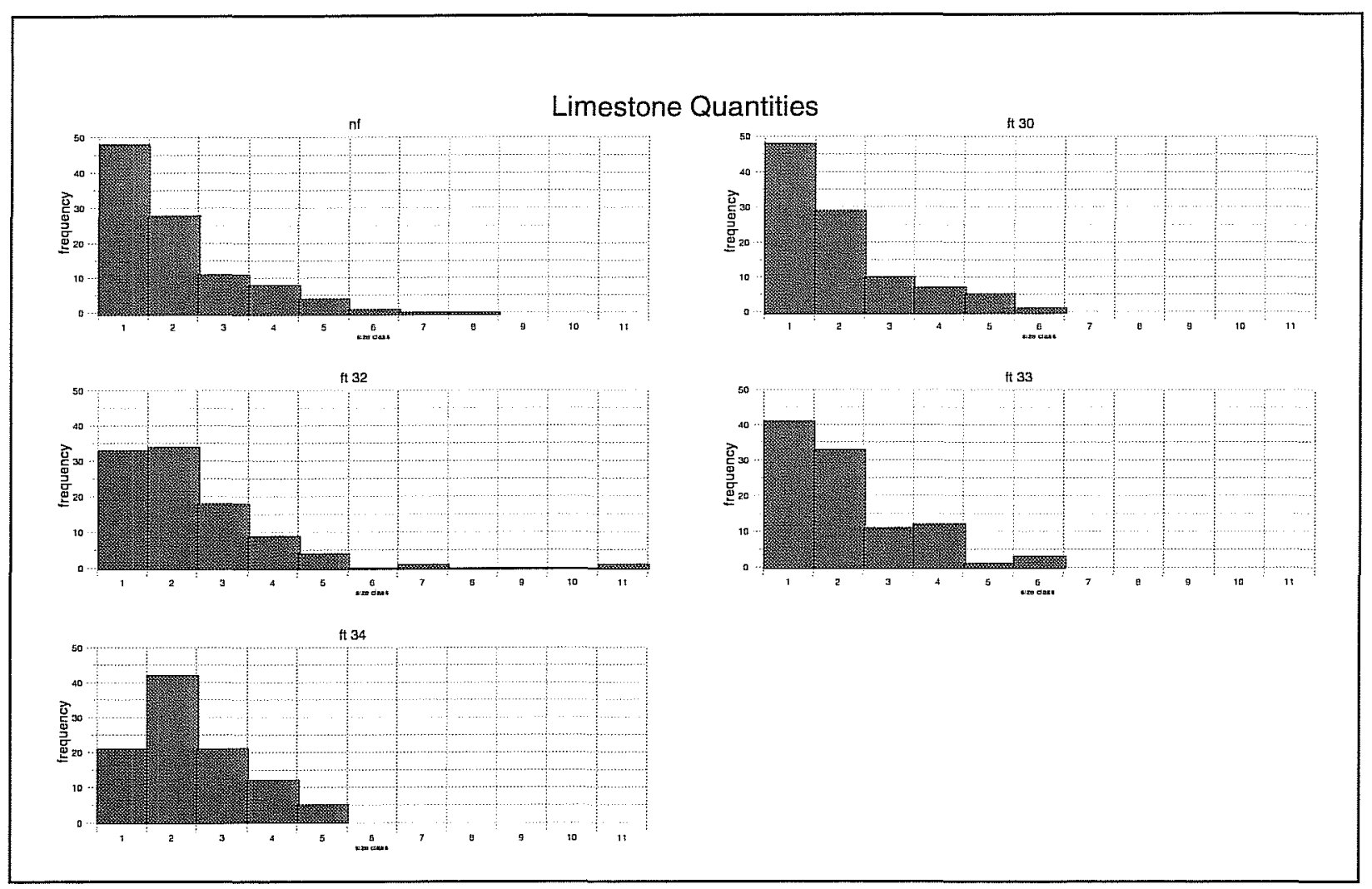

Figure 7. Limestone frequency distribution, FB12719.

size frequencies of the non-feature limestone most closely resembles those of Feature 30, the one dishshaped hearth not associated with a pit structure on this site, suggesting that the non-feature limestone could represent disarticulated hearth features. heavier average weight of size 5 and 6 rocks in Feature 32 suggests these rocks are less fractured and possibly blockier than the same sized rock from other portions of the site. The inverse is seen in the
Mean size of burned limestone recovered from the entire site ranges from $2.02-2.61 \mathrm{~cm}$, while the burned caliche ranges from 1.09-1.46 in mean size (Table 6). Duncan and Doleman (1991) suggest that differences between blocky fracture patterns associated with stone-boiling activities and curvilinear fracturing associated with dry-cooking activities should be evident in comparisons of rock size and average weight. The variations in the average weights by size class for the burned limestone at site FB 12719 is illustrated in Figure 8. Aside from the expected observation that as rocks get bigger they get heavier, the

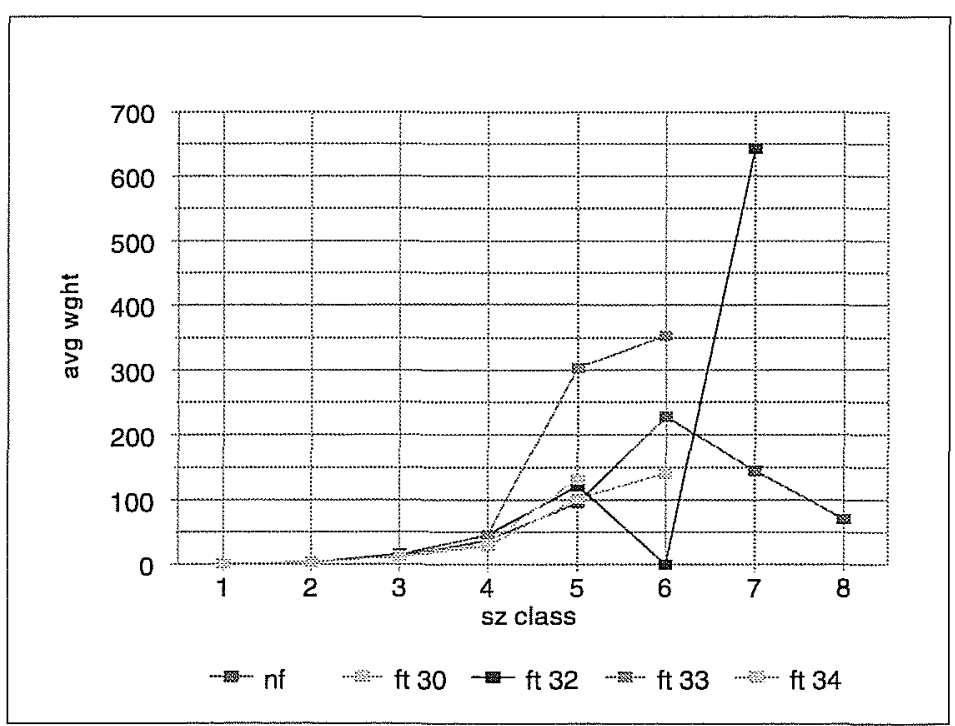

Figure 8. Average weight comparison, FB12719. 
Table 6. FB 12719, Fire-cracked Rock and Burned Caliche Details

\begin{tabular}{|c|c|c|c|c|c|c|c|}
\hline Site & Feature & Material & Qty & Weight (g) & $\begin{array}{c}\text { Rock Size } \\
\text { Range (cm) }\end{array}$ & $\begin{array}{c}\text { Mean Size (cm) } \\
\text { (std) }\end{array}$ & ${ }^{14} \mathrm{C}$ Date (B.P.) \\
\hline \multirow[t]{16}{*}{12719} & \multirow[t]{2}{*}{30} & limestone & 114 & 1285.6 & $<1.5-10.5$ & $2.02(1.76)$ & \\
\hline & & caliche & 211 & 715.26 & $<1.5-8$ & $1.09(.99)$ & \\
\hline & \multirow[t]{2}{*}{32} & limestone & 79 & 3603.27 & $<1.5-23$ & $2.61(2.86)$ & \multirow{2}{*}{$\begin{array}{l}1060 \pm 50 \\
1140 \pm 60 \\
1240 \pm 60\end{array}$} \\
\hline & & caliche & 736 & 3622.32 & $<1.5-15.5$ & $1.49(1.16)$ & \\
\hline & \multirow[t]{2}{*}{78} & limestone & 0 & & & & \\
\hline & & caliche & 10 & 11.79 & $<1.5-2.5$ & $2(1)$ & \\
\hline & \multirow[t]{2}{*}{33} & limestone & 76 & 1671.29 & $<1.5-10.5$ & $2.2(1.84)$ & \multirow{2}{*}{$\begin{array}{c}1040 \pm 80 \\
1500 \pm 110\end{array}$} \\
\hline & & caliche & 1319 & 8116.92 & $<1.5-10.5$ & $1.63(1.42)$ & \\
\hline & \multirow[t]{2}{*}{34} & limestone & 110 & 1540.63 & $<1.5-8$ & $2.54(1.52)$ & \multirow[t]{2}{*}{$1360 \pm 70$} \\
\hline & & caliche & 1520 & 14399.54 & $<1.5-18$ & $1.83(1.6)$ & \\
\hline & \multirow[t]{2}{*}{80} & limestone & 2 & .51 & 1.5 only & & \multirow[t]{2}{*}{$1200 \pm 110$} \\
\hline & & caliche & 0 & & & & \\
\hline & \multirow[t]{2}{*}{89} & limestone & 0 & & & & \\
\hline & & caliche & 33 & 68.89 & $<1.5-5.5$ & & \\
\hline & \multirow[t]{2}{*}{85} & limestone & 0 & & & & \multirow[t]{2}{*}{$1710 \pm 150$} \\
\hline & & caliche & 18 & 18.44 & $<1.5-2.5$ & & \\
\hline
\end{tabular}

larger non-feature rocks where the decreased average weight in size 7 and 8 rocks suggests the fractures in these rocks are less blocky, more curvilinear. While much of the burned rock from this site was recovered from fill within structures (Features 32, 33, and 34), these two fracture patterns suggest burned limestone served multiple functions at FB 12719.

\section{Site FB 12412}

Feature and non-feature weight and quantity comparisons by size class of rocks from FB 12412 are shown in Figure 9. No difference is seen between feature and non-feature size class frequency distribution; both assemblages are heavily skewed to the right, reflecting the dominance of rock sizes smaller than $2.5 \mathrm{~cm}$ in diameter. The weight distribution diagrams illustrate that although over 50 percent of both feature and non-feature weight comes from rocks smaller than four centimeters in diameter, 56 percent of the weight $(n=2258.97 \mathrm{~g})$ in the features is concentrated in size classes 2 and 3.

As at site FB 12719, over 75 percent of the burned limestone assemblage at FB 12412 is dominated by smaller rocks (Figure 10). A similar distribution pattern is seen between the of rock from Features 3 and 9 , the two burned rock scatters. Size class 2 $(1.5-2.5 \mathrm{~cm})$ is the most frequent and no rocks larger than size $5(5.5-8 \mathrm{~cm})$ are present. The size distribution of burned rocks in Feature 16 (a rocklined pit) most closely resembles the distribution of the non-feature rocks with rocks $<1.5 \mathrm{~cm}$ being the most frequent. No clear pattern between discarded non-feature burned rock and feature burned rock could be identified in these two analyses.

Mean size of burned limestone from FB 12412 ranges from $1.37-2.06 \mathrm{~cm}$, while burned caliche mean sizes are between $1.12-1.57 \mathrm{~cm}$ (Table 7). These mean limestone sizes are smaller than those from FB 12719 (Table 6), although FB 12412 is 


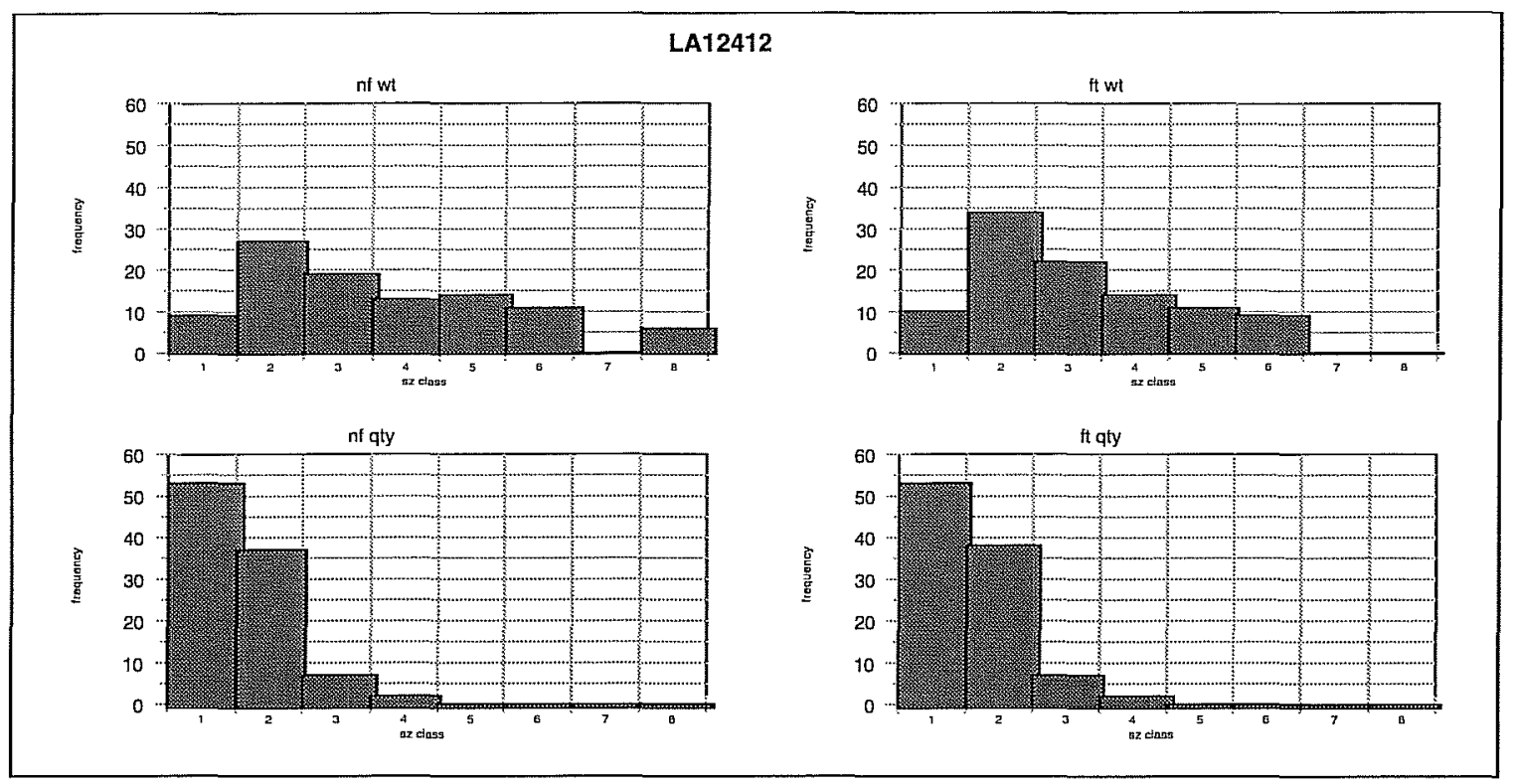

Figure 9. Non-feature vs. feature comparison, $F B 12412$.

located closer to a limestone source. These smaller sizes may result from functional differences at FB 12412 or from more intense use of the features.

Comparison of average weights in size classes for the limestone recovered from FB 12412 is illustrated in Figure 11. Size 2 rocks $(1.5-2.5 \mathrm{~cm})$ in the nonfeature assemblage have a greater average weight than size 2 rocks from the features. This is also true for size 5 rocks $(5.5-8 \mathrm{~cm})$ from Feature 9. The heavier average weights suggest these rocks are more angular/blocky in shape, but no clear functionally related pattern of fracturing is evident.

\section{Site FB 13237}

Feature and non-feature weight and quantity comparisons by size class for rocks from FB 13237 are shown in Figure 12. Both the non-feature and feature weight frequencies approach a normal distribution. Non-feature weights are skewed slightly toward the larger sizes while feature weights are skewed slightly toward the smaller sizes, reflecting the influence of the large rocks in the rock-lined pit features. The quantity histograms, however, are sharply skewed to the right, graphically illustrating that 84 percent of nonfeature rock $(n=9,285)$ and 78 percent of the feature rock $(n=3,355)$ are smaller than four centimeters in diameter.

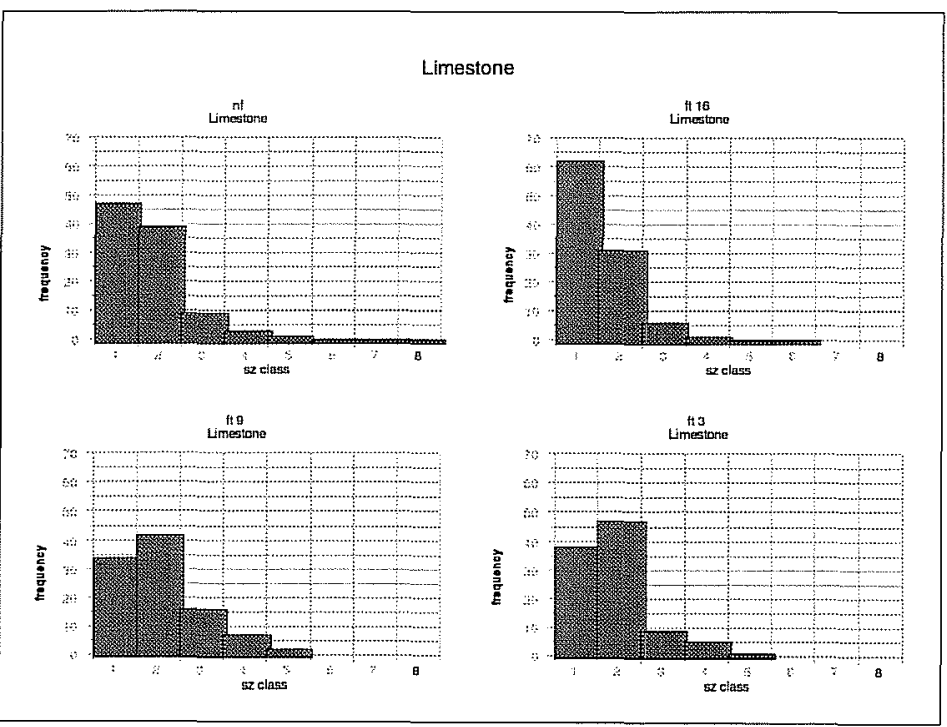

Figure 10. Limestone frequency by size class, FB12412. 
Table 7. FB 12412, Fire-cracked Rock and Burned Caliche Details

\begin{tabular}{|c|c|c|c|c|c|c|}
\hline Feature & Material & Quantity & Weight (g) & $\begin{array}{c}\text { Rock Size } \\
\text { Range (cm) }\end{array}$ & $\begin{array}{c}\text { Mean size (cm) } \\
\text { (std) }\end{array}$ & $\begin{array}{l}{ }^{14} \text { C Date } \\
\text { B.P. }\end{array}$ \\
\hline \multirow[t]{2}{*}{ non-feature } & limestone & 2083 & 12169.92 & $<1.5-15.5$ & $1.7(1.25)$ & \\
\hline & caliche & 1892 & 4024.38 & $<1.5-10.5$ & $1.34(.82)$ & \\
\hline \multirow[t]{2}{*}{12} & limestone & 6 & 34.04 & $<1.5-4$ & $2(1.02)$ & \multirow[t]{2}{*}{$1070 \pm 60$} \\
\hline & caliche & 113 & 129.32 & $<1.5-2.5$ & $1.12(.57)$ & \\
\hline \multirow[t]{2}{*}{16} & limestone & 250 & 872.81 & $<1.5-10.5$ & $1.37(1.01)$ & \multirow{2}{*}{$\begin{array}{c}870 \pm 50 \\
790 \pm 60 \\
1060 \pm 70\end{array}$} \\
\hline & caliche & 20 & 21.89 & $<1.5-2.5$ & $1.13(.59)$ & \\
\hline \multirow[t]{2}{*}{3} & limestone & 116 & 593.61 & $<1.5-8$ & $1.83(1.14)$ & \\
\hline & caliche & 557 & 1196.56 & $<1.5-5.5$ & $1.44(83)$ & \\
\hline \multirow[t]{2}{*}{9} & limestone & 101 & 711.29 & $<1.5-8$ & $2.06(1.33)$ & \\
\hline & caliche & 20 & 108 & $<1.5-10.5$ & $1.57(1.17)$ & \\
\hline
\end{tabular}

Size distribution patterns of nonfeature rocks and rocks in individual features, illustrated in Figure 13, show considerable variability which is also reflected in differences in mean size and standard deviations given in Table 8. Similarities are present between Feature 48 , the burned-rock concentration, and the non-feature rocks from other parts of the sites.

Eighty-six percent of the Feature 48 assemblages $(n=2,489)$ and 84 percent of the non-feature assemblage $(n=9,249)$ are $s 4 \mathrm{~cm}$ in diameter with mean sizes of $2.41 \mathrm{~cm}$ (std= $1.54)$ and $2.54 \mathrm{~cm} \quad(\mathrm{std}=1.94)$ respectively. The higher frequency of smaller rocks and the overall smaller rock size make these accumulations distinguishable as discard assemblages when compared to the other designated features.

Mean sizes of fire-cracked rock from the hearth and rock-lined pit features at FB 13237 range from $3.66-7.15 \mathrm{~cm}$ (Table 8). The largest means, $7.15 \mathrm{~cm}$ and $6.23 \mathrm{~cm}$, are from Features 102 and 103

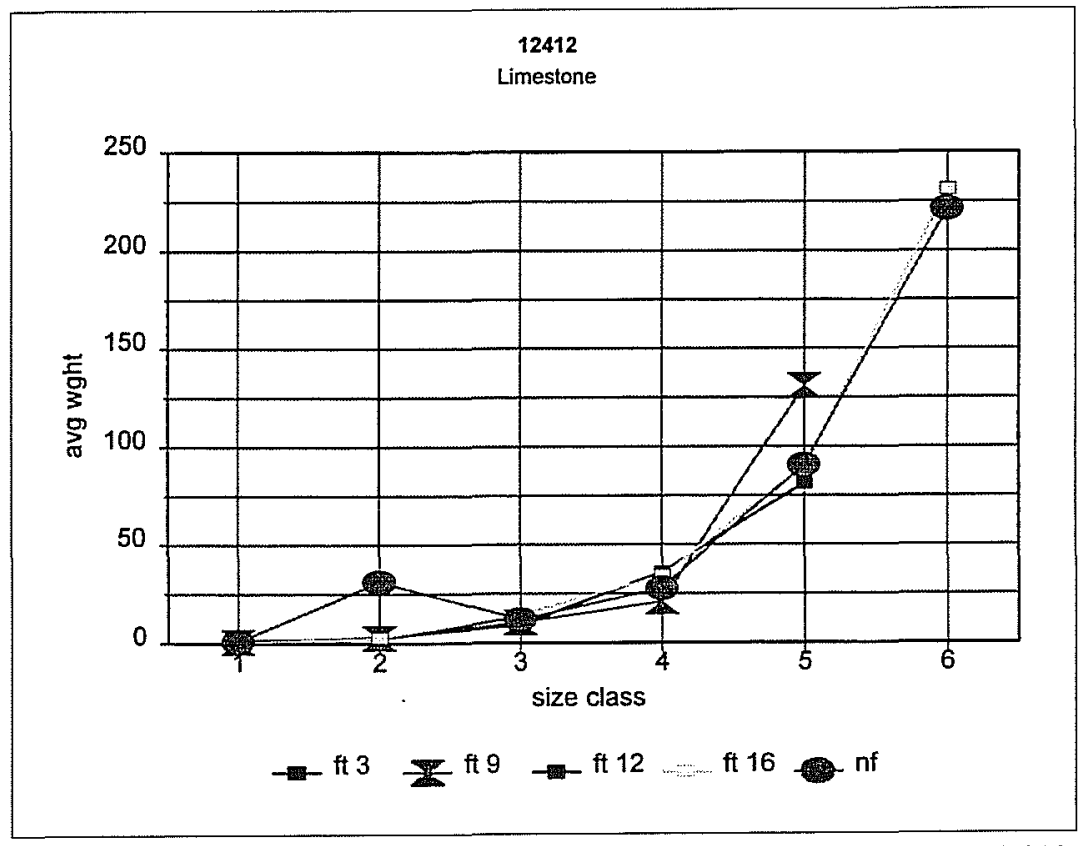

Figure 11. Average weight comparison, FB 12412.

respectively, the two features described as basinshaped, ringed hearths. Variations between these two may be a result of partial excavation of Feature 103. While Features 40 and 46 , the two rock-lined pits, contain rocks of up to $20.5 \mathrm{~cm}$ and $13 \mathrm{~cm}$ respectively, the lower means may result from smaller rock used as fill between larger cobbles in 


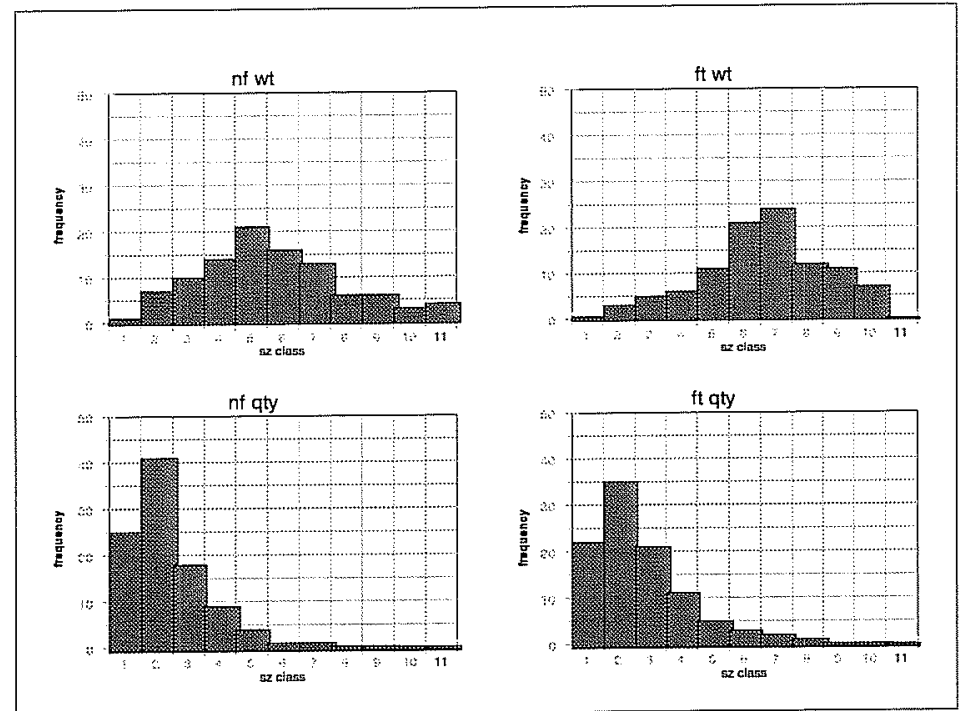

Figure 12. Non-feature and feature comparison, FB 13237.

\section{Block-Level Analysis}

A fine-grained analysis was conducted to compare attributes of burned rocks from features with those from the surrounding non-feature excavation block. Pattern recognition analyses were performed by generating gridbased density contour maps in Surfer ${ }^{\circ}$. The total weight and counts of burned rock from selected areas were summed by excavation units $(1 \times 1 \mathrm{~m})$ and plotted by levels for a given block. The density patterns created by the contour program are enhanced by adding grid lines for individual units and boundary information for features within the lining as described by Miller $(1989,1990)$. The smaller rocks could also represent discarded rocks that accumulated in the fill and were not identified separately during excavated. Comparison of average rock weights (Figure 14) revealed no patterns suggestive of functionally differentiated fracturing at FB 13237.

Table 8. FB 13237 Fire-cracked Rock Details

\begin{tabular}{|c|c|c|c|c|c|c|}
\hline Feature & Material & Quantity & Weight (g) & $\begin{array}{c}\text { Rock Size } \\
\text { Range (cm) }\end{array}$ & $\begin{array}{c}\text { Mean Size (cm) } \\
\text { (std) }\end{array}$ & $\begin{array}{c}{ }^{14} \mathrm{C} \text { Date } \\
\text { B.P. }\end{array}$ \\
\hline non-feature & limestone & 10953 & $255,333.3$ & $<1.5-23$ & $2.54(1.94)$ & \\
\hline 40 & limestone & 346 & 88170.09 & $<1.5-20.5$ & $5.66(4.4)$ & $670 \pm 60$ \\
\hline 102 & limestone & 165 & 49206.50 & $<1.5-20.5$ & $7.15(4.25)$ & $1660 \pm 70$ \\
\hline 103 & limestone & 55 & 12690.00 & $<1.5-13$ & $6.23(3.5)$ & \\
\hline 46 & limestone & 508 & 44352.72 & $<1.5-13$ & $3.9(2.97)$ & $4120 \pm 80$ \\
\hline 48 & limestone & 3209 & 39859.25 & $<1.5-18$ & $2.41(1.54)$ & \\
\hline 98 & limestone & 11 & 138.09 & $<1.5-8$ & $3.66(1.6)$ & \\
\hline
\end{tabular}




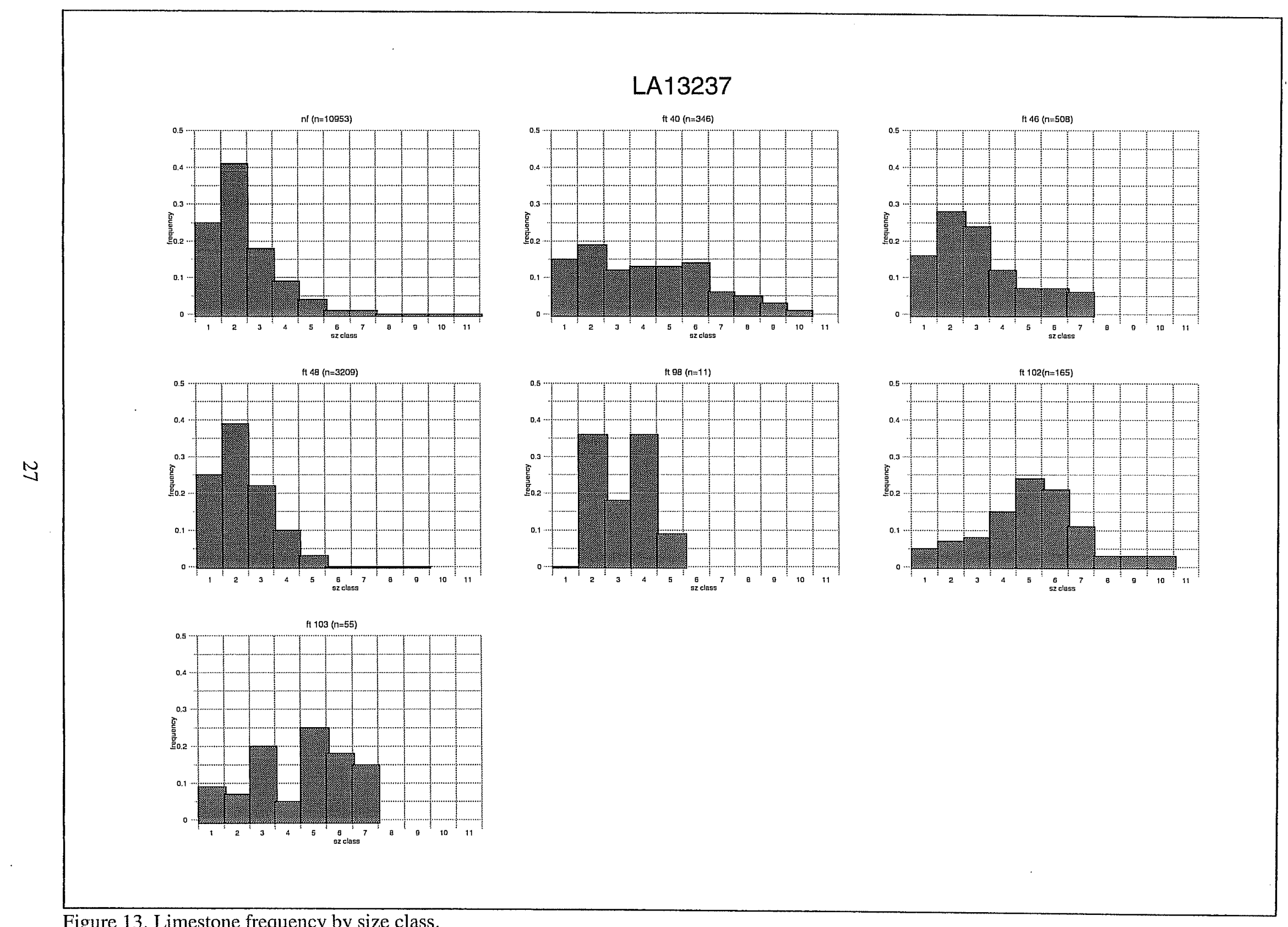

Figure 13. Limestone frequency by size class. 


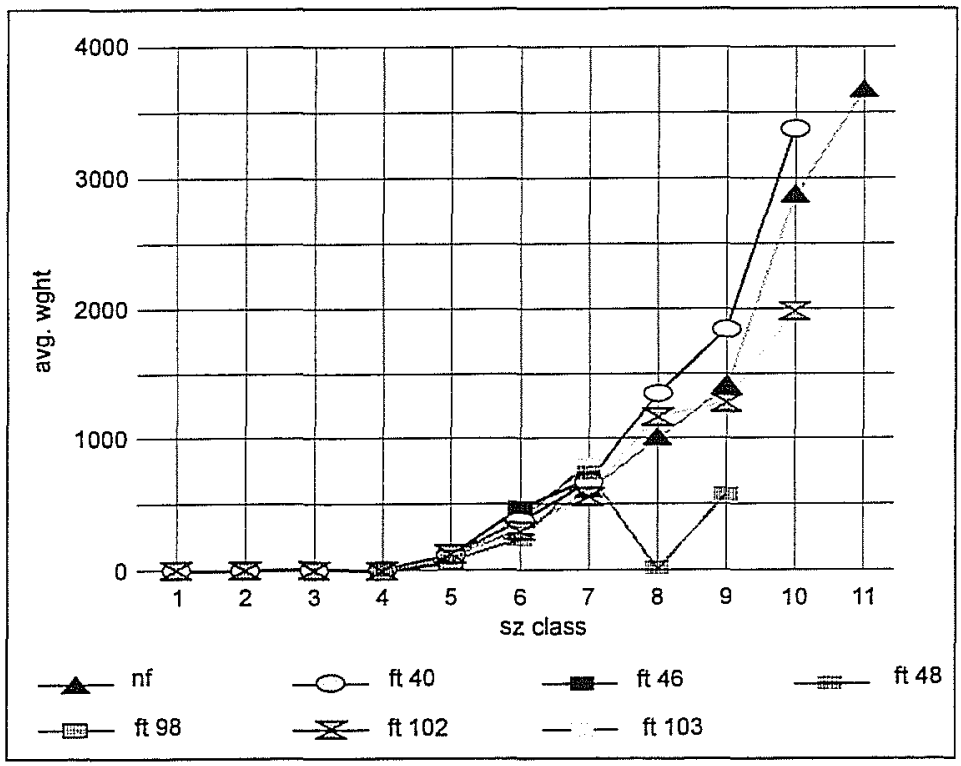

Figure 14. Average weight comparison, FB 13237.
In Level 4, Features 102 and 103 become defined based on the density of rock in their respective units, whereas, Feature 40 is not completely defined. None of the feature locations identified in this block was directly discernable from surface densities (Level 3) of burned rock. Also of interest in Level 4 is the relatively high density of burned rock in the extreme northeast corner (Unit E167/190) of the block. This area of the block within Level 4 has the highest density of burned rock. The excavators did not note this area on any of the excavation forms and it was not assigned a feature number in the field.

Density contour plots of the burned rock in Level 5 (Figure 15) demonstrate a decreasing distribution of burned rock when compared to the overlying Level 4 . Burned rocks associated with Features 102 and 103 remain evident, suggesting that both features continue into this level. Feature 102 appears to have more burned rock in this level than does Feature 103. The upper portion of Feature 40 is identified by the highdensity of burned rock in Unit E166/N189. The high-density of burned rock noted in the extreme northeast corner of the block in Level 3, however, has all but disappeared. The density of non-feature burned rock is beginning to decline at this level as well.

Examination of Level 6, which includes only Unit E166/N189, reveals a large quantity of burned rock within the Feature 40 limits (see Figure 15). This level defines the bottom of that feature and the vertical extent of burned rock in this excavation block. Level 6 was not excavated in units containing Features 102 and 103 as the bottom of each features was reached in Level 5.

To compare patterns in burned rock size between features and non-feature areas in this block, the percentage of rock in each size category was plotted for a number of proveniences (Figure 16). In Level 3 , which is composed of non-feature burned rock, 50 percent of the rock was in the 1-2 size range, 38 percent was in the $3-4$ size range, 11 percent in the 5-6 size range, and 1 percent was in the 7-8 size 

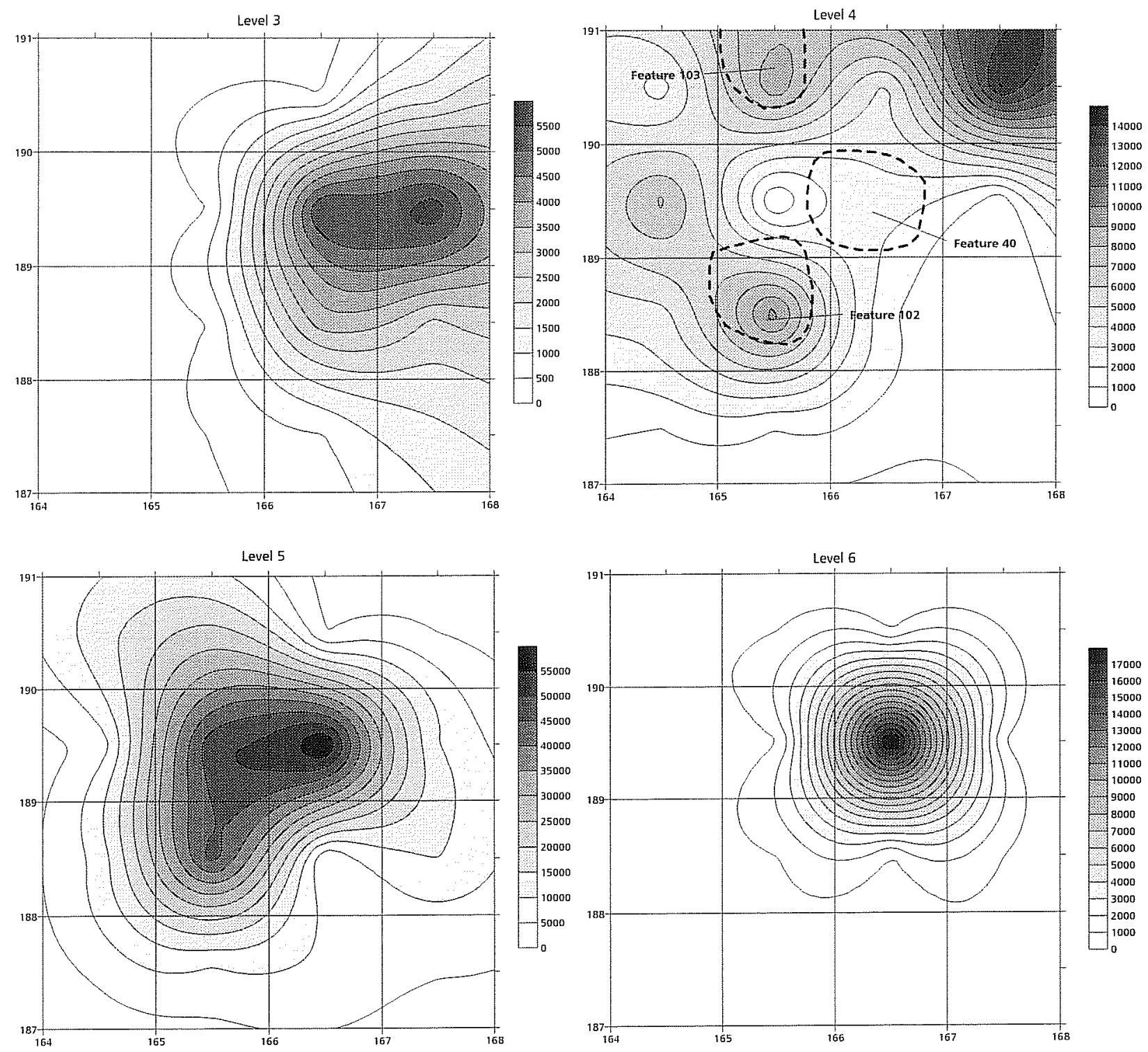

Figure 15. Density plot by weight, Block CI, FB 13237.

range. The small size of these non-feature rocks is graphically illustrated in the skewed histogram in Figure 16.

In Level 4 the high density area of non-feature rocks identified in Unit E167/N190 in the northeast corner of the block was plotted separately (Figure 16). Again over 85 percent of the burned rock falls within the 1-4 size category.
To compare feature rock to the non-feature rock discussed above, the bottoms of the features were identified to isolated the burned rock that constitutes the heating elements. The goal is to determine if "intact" heating elements are present within these features, as the excavations notes indicate. If present, we would expect the heating elements to contain a higher frequency of larger rocks than nonfeature burned rock. 


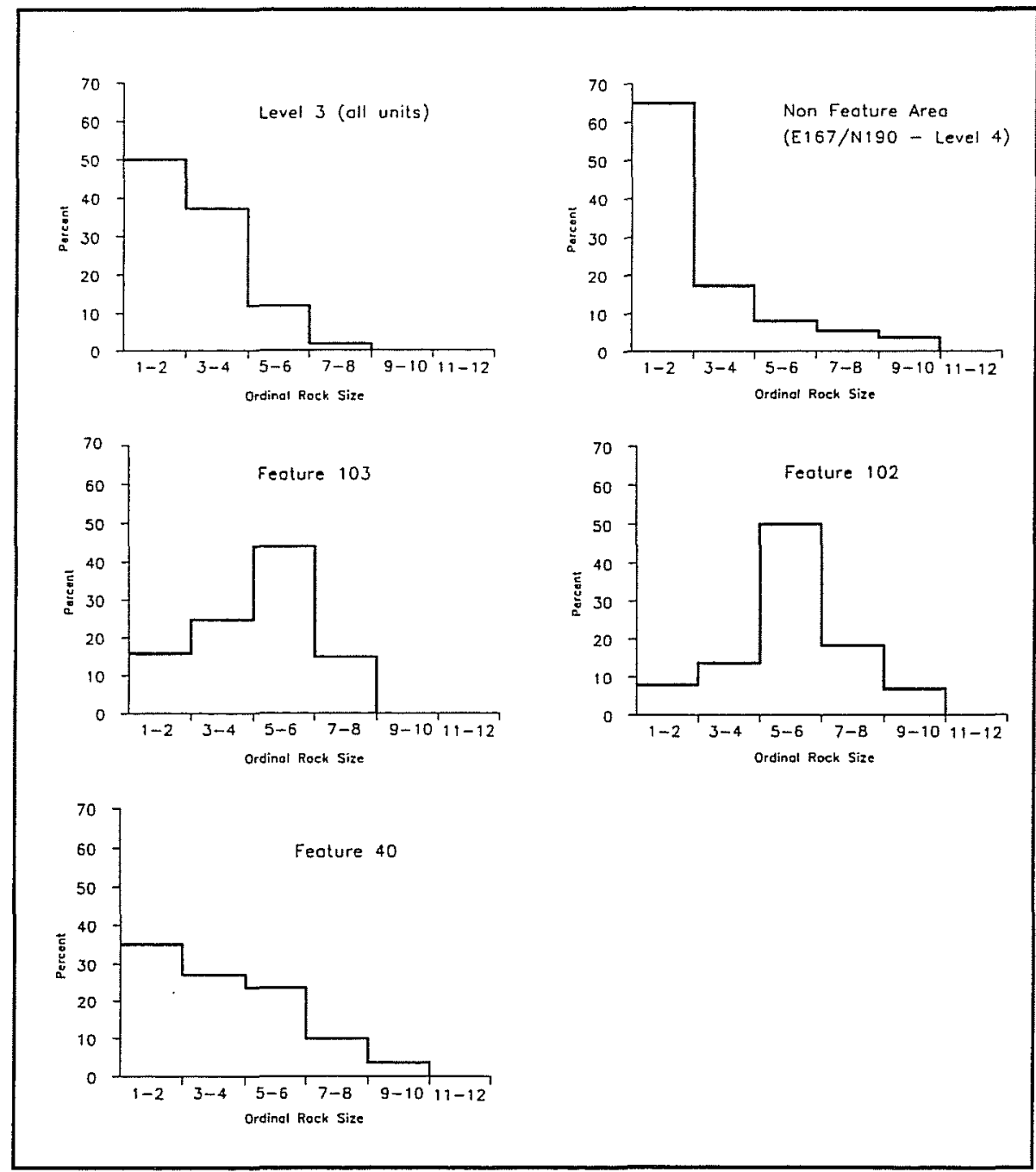

Figure 16. Frequencies by size class, Block C1, FB 13237.

3-4 size range, 24 percent in the 5-6 size range, 10 percent in the $7-8$ size range, and 3 percent is in the 9-10 size range (Figure 16).

When we compare the differences in the size of burned rock recovered from feature and non-feature areas in Block $\mathrm{C} 1$, we see a distinctive pattern. The majority of the burned rock recovered from non-feature areas is small, burned rock from Features 102 and 103 is dominated by the larger size classes. Feature 40, however, is not dominated by the larger burned rock classes, but, as illustrated in Figure 16, has an almost unimodal distribution only slightly skewed to the right. The differences between size frequencies in Feature 40 and Features 102 and 103 may indicate a different function or use history. Feature 40 is described as an intact cobblelined pit without a specific heating element, while Features 102 and 103 are

Feature 103, which is best defined by a high-density of burned rock in Level 4, has 16 percent of its burned rock in the 1-2 size range, 25 percent in the 3-4 size range, 44 percent in the 5-6 size range, and 15 percent in the $7-8$ size range (Figure 16).

For Feature 102 only the burned rock recovered from Level 5 of Unit E165/N188, the area identified as the feature bottom during excavation, is included in this analysis (Figure 16). Here, 77 percent of the burned rock is size 5 or larger.

For Feature 40 , the burned rock recovered from Unit E166/N189 Levels 5 and 6, the bottom (heating element) is considered. Of that rock 36 percent is in the 1-2 size range, 27 percent in the identified as rock-ringed stains with burned rock in the feature fill which probably represent heating elements. This difference may also be a function of excavation techniques or of our arbitrary assignment of heating elements.

The differences in size-frequency distributions between feature and non-feature burned rock is evident. The smaller size of the non-feature burned rocks recovered from above the features and from the extreme northeastern corner of Level 4 (E167/N190) suggests this rock has been discarded after repeated use has reduced them to a size no longer efficient for retaining or transferring heat. Since there is no indication in the excavation notes that other features lie just outside of the area 
investigated, we suggest that the discarded rocks in Level 3 and in the northeastern corner of the excavation block are associated with the identified features in this block.

Estimates of maximum firing temperatures for sample rocks in Block $\mathrm{C} 1$ indicate the non-feature rocks were subjected to uniformly higher degrees of heat than those remaining within the feature boundaries. It is possible that these non-feature rocks represent discarded remnants of heating elements from Features 40,102 , or 103 . At the same time however, the lack of multiple magnetic vectors for the majority of these samples seems to point away from reuse (see Appendix B).

\section{Block B1}

The density contour maps for Block B1 were plotted using total weight of rock recovered from each of the $161-x-1-m$ excavation unit levels (Figure 17). Burned rock was recovered from all three excavation levels (Levels 2, 3, and 4). This
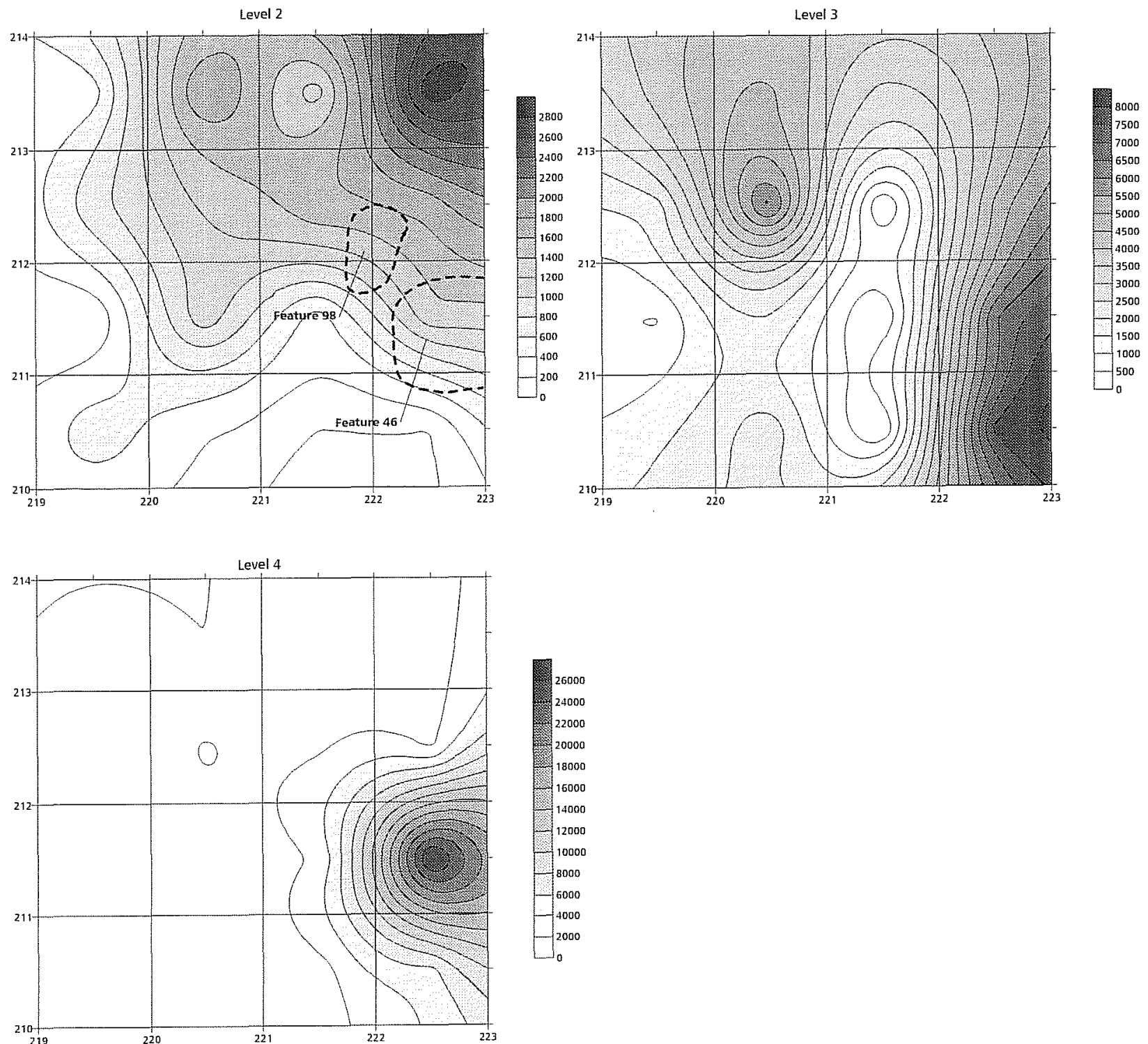

Figure 17. Density plot by weight, Block B1, FB 13237. 
block was established to investigate a concentration of burned rock on the surface originally designated Feature 46.

Within Level 2, burned rock is scattered throughout the block with a distinct concentration in the extreme northeastern corner (Unit E222/N213) (Figure 17). The horizontal limits of Features 46 and 98 are depicted in this level for comparison with the lower levels, although Feature 46 extends into Level 4, and Feature 98 continues into Level 3.

The pattern revealed in Level 3 shows burned rock scattered throughout the block with areas of higher burned rock density evident in Unit E220/N212 and in the southeastern corner of the block (Figure 17). Interestingly, the area outlined in Level 2 as containing Feature 98 shows a low-density of burned rock in Level 3. This is as expected as Feature 98 was described a shallow pit with ash fill. This plot illustrates that any burned rock associated with Feature 98 is confined to Level 2 although the stain from this feature extends into Level 3.

The density plot for Level 4 clearly defines the bottom, or heating element, of the rock-lined hearth designated Feature 46, in Units E222/N210 and E222/N211. The higher density of burned rock in this area was evident in the Level 3 plot, but does not become defined until Level 4 .

To compare patterns in the feature and non-feature burned rock areas within the block were isolated. To look more closely size distribution of burned rock from the high-density area revealed in Level 2 in Unit E222/N213 the rock from this unit was plotted separately. The frequencies by size class for this provenience are as follows: 51 percent of the burned rock is in the 1-2 size range, 41 percent is in the 3-4 size range, 7 percent is in the 5-6 size range, and 1 percent is in the 7-8 size range (Figure 18). When we look at the node identified in Level 3 in Unit E220/N212 we see a similar pattern. In this area, 81 percent of the burned rock is in the 1-2 size range, 18 percent is in the 3-4 size range, and 1 percent is in the 5-6 size range (Figure 18). Clearly, both of these non-feature concentrations are characterized by a high frequency of small burned rock.
To construct the burned rock size distributions for features in this block, the heating elements, or bottoms of the features, were isolated. Feature 98 was not considered in this comparison since it was an ash stain with very little associated burned rock, and the density contour plots reveal no distinct clustering of burned rock in the units containing this feature. Feature 46, however, was a rock-lined pit that is well-defined in the density contour plots (Figure 17). As mentioned above, Feature 46 is present in Levels 2 and 3, but is most clearly defined in Unit E222/N211 in Level 4. A plot of the size distribution within Unit E222/N211 in Level 4 reveals that 25 percent of the burned rock is in the 1-2 size range, 32 percent is in the 3-4 size range, 30 percent is in the 5-6 size range, and 14 percent is in the 7-8 size range (Figure 18). This plot shows that the burned rock recovered from the bottom of Feature 46, which represents the heating element, has a greater frequency of larger burned rocks than the burned rock recovered from the non-feature areas.

The density contour plots and burned rock size frequency histograms reveal interesting patterns. The area with a high-density of non-feature burned rock identified in Level 2 (Unit E222/N213) has a burned-rock size distribution similar to that identified for the discard areas in Block C1 (see discussion above). In addition, the high-density area identified in Level 3 in Unit E220/N212 also appears to be representative of a discard area. Interestingly, the high density area in Level 3 was not distinguishable in the overlying level and is therefore stratigraphically lower than the discard area in Level 2. This suggests that the two discard events are stratigraphically and chronologically separate. However, this vertical difference seen on the density plots may be a function of assigning arbitrary collection levels in the field rather than a real difference in vertical position. Nevertheless, we can not rule out that the vertical separation between the two is real, and thus represents reuse with some unknown time passing between the two events. The horizontal association of these discard scatters to the rock-lined pit Feature 46 suggests these clusters are related to Feature 46 which produced a single radiocarbon date of $4120-80$ B.P., the oldest date from site FB 13237. 

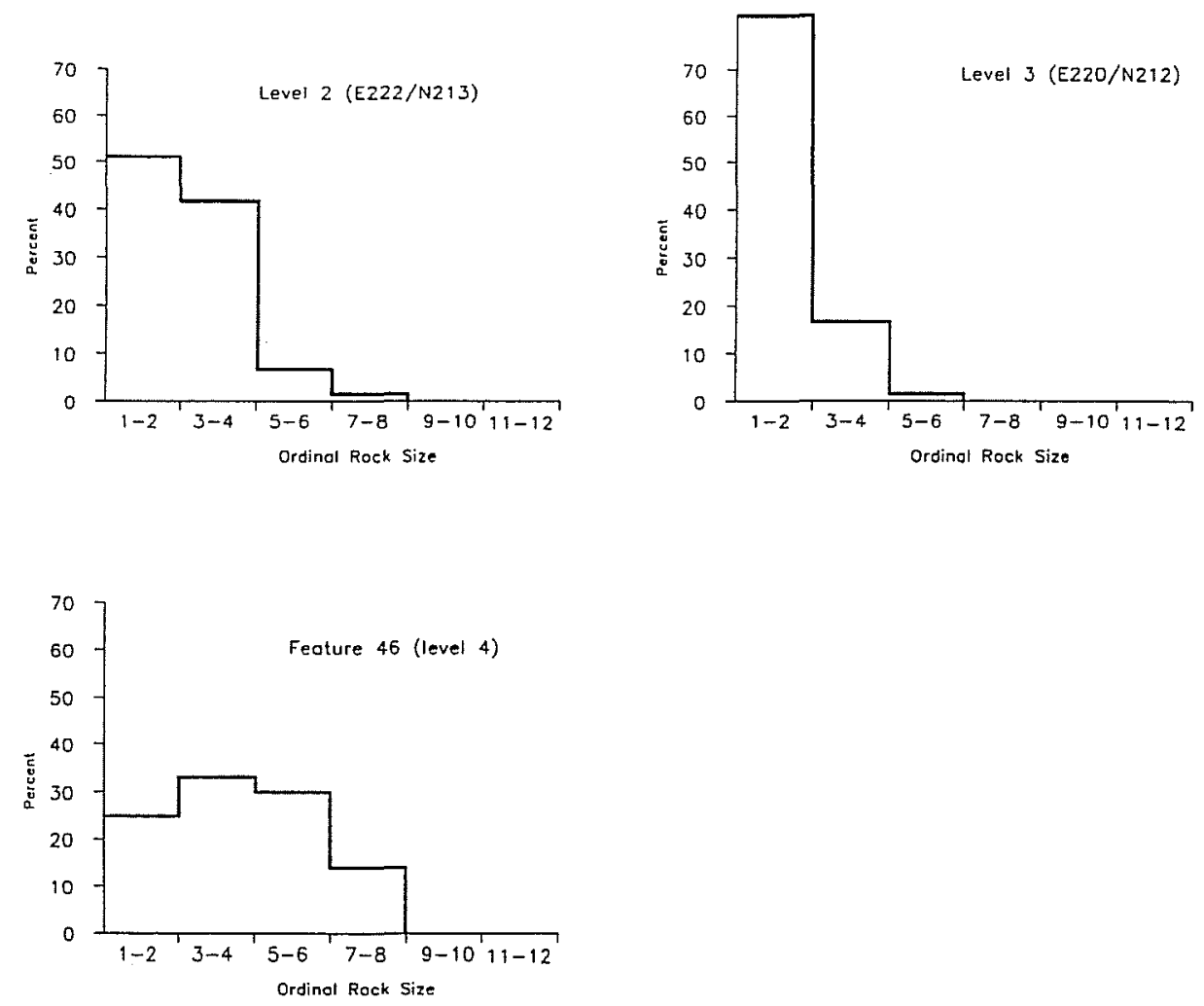

Figure 18. Frequencies by size class, Block B1, FB 13237.

Additional evidence of reuse of Feature 46 is present in the multiple magnetic vectors identified in the archaeomagnetic analysis (Appendix B).

\section{Block A1}

The entire $16 \mathrm{~m}^{2}$ of Block A1 was designated Feature 48 , so when constructing the density plots the limits of the excavation area served as the limits of the feature. Like the other blocks on the site, the total weight of burned rock by unit was summed and plotted in a series of density contour plots by excavation level (Levels 1 and 2) (Figure 19).

The density plot of Level 1 reveals a scatter of burned rock over the southern and eastern portion of the block, with a high density area in Unit E254/N188 (Figure 19). However, several units in the northern and western portion of the block were not excavated as part of Level 1 because these units lie stratigraphically lower on the surface and were excavated as part of Level 2 . In Level 2, a highdensity of burned rock is evident in Unit $\mathrm{E} 253 / \mathrm{N} 188$, and a high-density area is visible along the western edge of the block.

According to the excavation notes, there was no evidence of pits or charcoal staining in either level of the block, so a comparison between feature and non-feature rock is not possible. Therefore, we compared the distribution of burned rock from the high density areas to that of the entire level.

The size distribution plot of high-density area in Level 1 (Unit E254/N188) revealed that 69 percent of the burned rock is in the 1-2 size range, 27 percent is in the 3-4 size range, and 3 percent is in the 5-6 size range (Figure 20). When we plot all the Level 1 rock, 60 percent is in the 1-2 size range, 37 percent is in the $3-4$ size range, 6 percent is in the 
5-6 size range, and 1 percent is in the 7-8 size range (Figure 20).

The second high-density area, Unit E253/N188 in Level 2, has the following distribution: 68 percent of the burned rock is in the 1-2 size range, 27 percent is in the 3-4 size range, 3 percent is in the 5-6 size range, and 1 percent is in the 7-8 size range (Figure 20). The distribution for all of the burned rock in Level 2 is, 70 percent in the 1-2 size range, 29 percent is in the 3-4 size range, and 2 percent is in the 5-6 size range (Figure 20). At a block level, all of Levels 1 and 2, 68 percent of the burned rock is in the 1-2 size range, 30 percent is in the $3-4$ size range, 2 percent is in the 5-6 size range, and 1 percent is in the 7-8 size range (Figure 20).

From the size range comparisons discussed above, it is clear that the burned rock in Block $\mathrm{Al}$ is predominately small pieces. While several areas of higher densities of burned rock are identified in the density plots, these areas have similar distribution patterns on the accompanying histograms. The size distributions for the high density areas and the entire block are similar to the ones noted for the discard areas in Blocks $\mathrm{C} 1$ and $\mathrm{B} 1$. More importantly, no distributions that look like the feature elements identified in Blocks $\mathrm{C} 1$ and $\mathrm{B} 1$ are evident for Feature 48 (Block A1). This suggests that this block either 1) represents heavily used feature(s) that have since deflated, which would explain the absence of discernable pits and ash/charcoal staining; or 2) it represents the remains of a discard area from pit features that were missed by the placement of the excavation block. Either of these explanations is plausible, but we suggest the latter is more plausible due to the low frequency of large rocks. In order for the size distribution seen in Block A1 to be a result of deflated, heavily used feature, the use must have been extensive. Given the availability of limestone
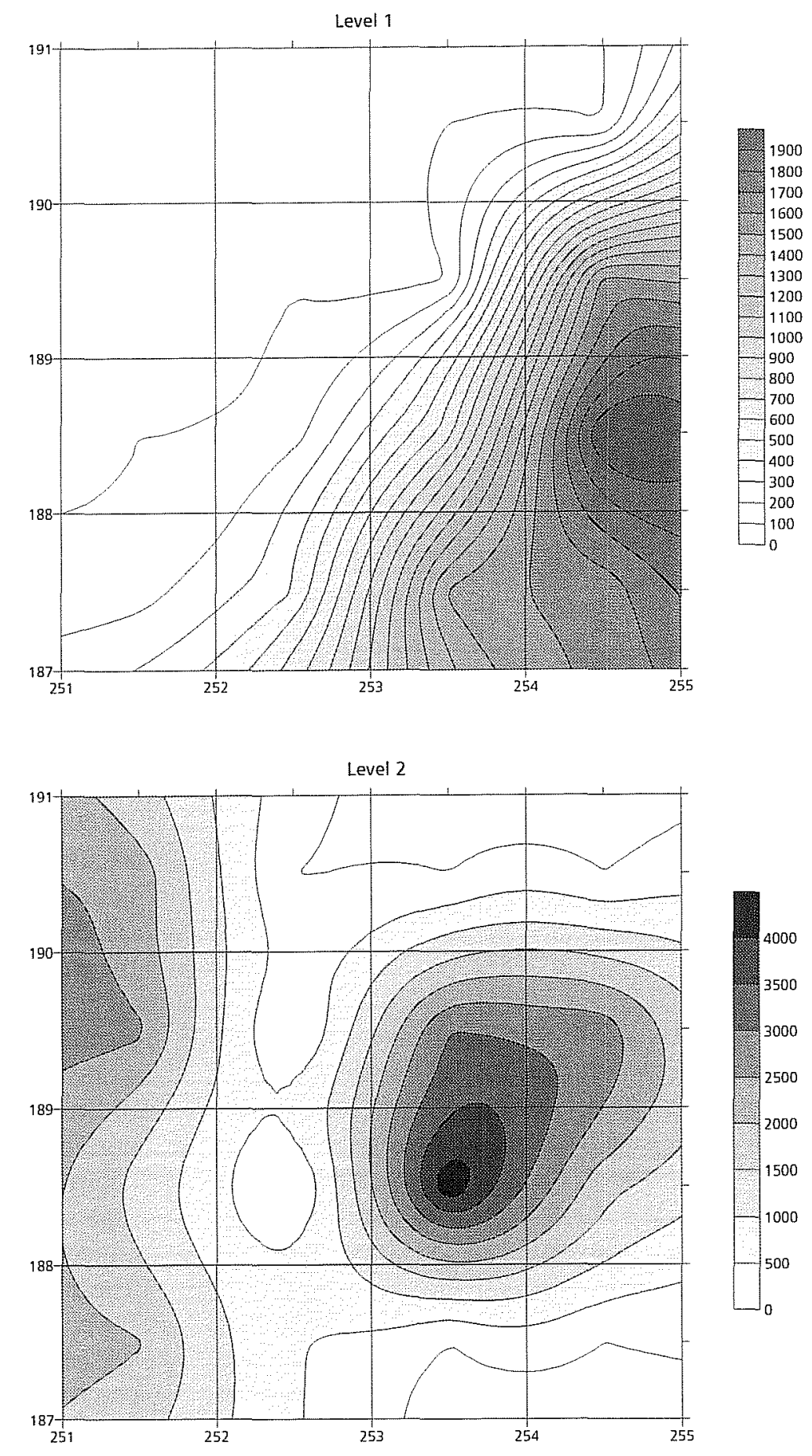

Figure 19. Density plot by weight, Block A1, FB 13237. 

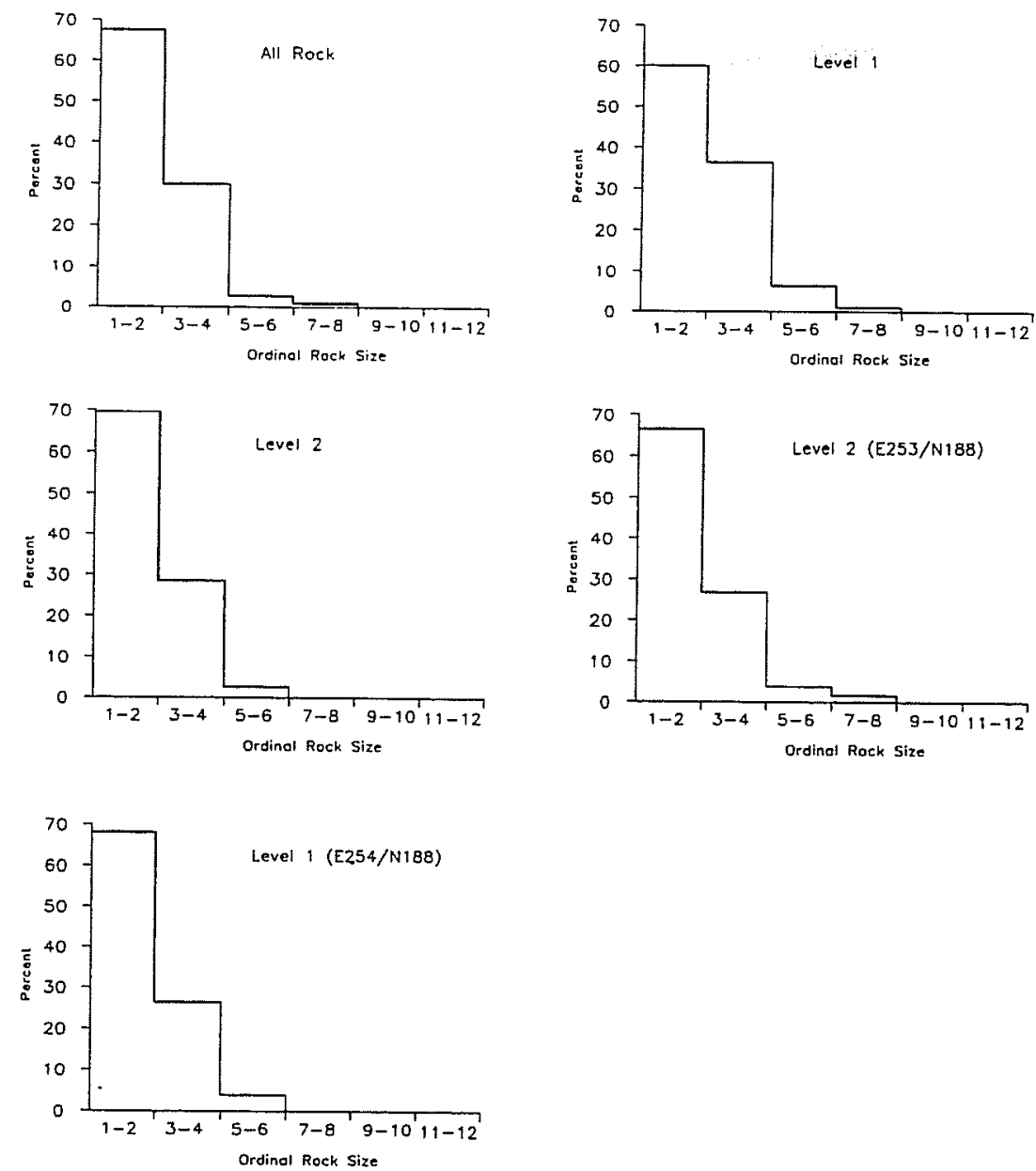

Figure 20. Frequencies by size class, Block A1, FB 13237.

at the site it seems unlikely that all of the rocks would have been reused to the extent indicated without being replaced by larger pieces.

In addition to the density and size distribution pattern analysis, frequency of fracturing and frequency of cortex within each size range was

examined. As discussed earlier, with repeated use, rock will fracture into smaller and smaller pieces eventually becoming void of cortex. We have used a high frequency of small rocks within a limited area as an argument for discard events or extensive use of features. If this is indeed the case, a higher frequency of the smaller rocks in heavily used features and discard areas should be fractured and void of cortex. The frequency of fracturing present and cortex absence within each size range was calculated for each of the features and for all of the non-feature rock from the three excavation blocks at site FB 13237 (Table 9).

Features 40 and 46 do exhibit a high percentage of fracturing and lack of cortex in the small size ranges, indicating the small rocks in these features have been reused. Feature 102 and 103, the two hearth features, have the lowest frequency of overall fracturing and lack of cortex, suggesting a more limited use history for these features. Feature 48 , the shallow scatter, and the nonfeature rock have similar patterns with less fracturing and more cortex present in the smaller size ranges than the other features.

The deviation of fracturing and cortex patterns from what we had expected in the nonfeature and scatter features could be the result of several factors. It is possible that limestone discolored due to weathering was collected from the excavation blocks and included in the analysis of the Feature 48 and non-feature rock. Because the analysts had to rely strictly on the field notes in order to determine the context of all rock recovered, any rock that exhibited discoloration beyond just a thin weathering layer was considered to be thermally altered. An additional source of non-fractured rock contributing to the analysis is the presence of rock throughout the site that was thermally altered by natural events. 
Table 9. FB 13237, Fracture and Cortex Percentages

\begin{tabular}{|c|c|c|c|c|c|c|c|c|c|c|c|c|c|c|}
\hline \multirow{2}{*}{$\begin{array}{l}\text { Size } \\
\text { Range }\end{array}$} & \multicolumn{2}{|c|}{$\begin{array}{c}\text { Feature } 40 \\
n=346\end{array}$} & \multicolumn{2}{|c|}{$\begin{array}{c}\text { Feature } 46 \\
n=508\end{array}$} & \multicolumn{2}{|c|}{$\begin{array}{c}\text { Feature } 48 \\
n=3209\end{array}$} & \multicolumn{2}{|c|}{$\begin{array}{c}\text { Feature } 98 \\
n=11\end{array}$} & \multicolumn{2}{|c|}{$\begin{array}{c}\text { Feature } 102 \\
\mathrm{n}=165\end{array}$} & \multicolumn{2}{|c|}{$\begin{array}{c}\text { Feature } 103 \\
n=55\end{array}$} & \multicolumn{2}{|c|}{$\begin{array}{c}\text { Non- } \mathrm{ft} \\
\mathrm{n}=11178\end{array}$} \\
\hline & $\begin{array}{c}\% \\
\text { frac } \\
\text { present }\end{array}$ & $\begin{array}{c}\% \\
\text { cortex } \\
\text { absent }\end{array}$ & $\begin{array}{c}\% \\
\text { frac } \\
\text { present }\end{array}$ & $\begin{array}{c}\% \\
\text { cortex } \\
\text { absent }\end{array}$ & $\begin{array}{c}\% \\
\text { frac } \\
\text { present }\end{array}$ & $\begin{array}{c}\% \\
\text { cortex } \\
\text { absent }\end{array}$ & $\begin{array}{c}\% \\
\text { frac } \\
\text { present }\end{array}$ & $\begin{array}{c}\% \\
\text { cortex } \\
\text { absent }\end{array}$ & $\begin{array}{c}\% \\
\text { frac } \\
\text { present }\end{array}$ & $\begin{array}{c}\% \\
\text { cortex } \\
\text { absent }\end{array}$ & $\begin{array}{c}\% \\
\text { frac } \\
\text { present }\end{array}$ & $\begin{array}{c}\% \\
\text { cortex } \\
\text { absent }\end{array}$ & $\begin{array}{c}\% \\
\text { frac } \\
\text { present }\end{array}$ & $\begin{array}{c}\% \\
\text { cortex } \\
\text { absent }\end{array}$ \\
\hline $1-2$ & 81 & 84 & 90 & 86 & 47 & 72 & $0^{*}$ & 0 & 87 & 56 & 13 & 0 & 70 & 54 \\
\hline $3-4$ & 80 & 50 & 81 & 56 & 40 & 52 & 25 & 30 & 73 & 35 & 70 & 35 & 68 & 49 \\
\hline $5-6$ & 67 & 12 & 71 & 7 & 75 & 21 & $0^{* *}$ & 0 & 53 & 8 & 21 & 0 & 68 & 46 \\
\hline $7-8$ & 63 & 0 & $57 * * *$ & 0 & 75 & 0 & - & - & 44 & 0 & $63^{* * *}$ & 0 & 33 & 12 \\
\hline $9-10$ & 42 & 0 & - & - & - & - & - & - & 10 & 0 & - & - & 31 & 8 \\
\hline 11 & - & - & - & - & - & - & - & - & - & 0 & - & - & 0 & \\
\hline Total \% & 74 & 44 & 81 & 57 & 61 & 63 & 25 & 30 & 91 & 18 & 38 & 9 & 68 & 36 \\
\hline
\end{tabular}

*no size $1 \quad * *$ no size $6 \quad * * *$ no size 8

\section{FB 12412}

\section{Block A2}

A total of $100 \mathrm{~m}^{2}$ was excavated in this block. Firecracked rock and burned caliche were recovered from five levels (6-10) and from two features (3 and 9). Features 3 and 9 consisted of surface scatters of burned caliche with no staining or subsurface presence.

For each unit, density contour plots were generated using the total weight of burned rock in Levels 6 and 7, and Levels 8-10 combined (Figure 21). Caliche and limestone were combined due to small sample size. In Level 6 several high density areas of burned rock are evident. The boundaries for Features 3 and 9 identified on the surface correspond to two of the highest density areas seen on the contour plot. The other high density areas in the northeastern portion of the block appear to be related to these features.

In Level 7, the number of units containing burned rock and the amount of burned rock decreases considerably. There is one area of high density in the northwestern portion of the block that appears to be associated with Feature 3, while the high density of rock weight corresponding to Feature 9 is no longer evident. This suggests that the burned rock concentration associated with Feature 3 extends into Level 7 , but Feature 9 terminates at a shallower depth.

Only a small amount of burned rock was recovered from Levels 8, 9, and 10 (levels were combined due to low weight totals). The limited amount of burned rock recovered from these lower levels suggests that the Feature 3 does not continue into the lower levels.

To explore size patterns in the burned rock in the feature and non-feature areas, percentages were plotted in several histograms (Figure 22). Limestone and caliche were combined for this analysis. Of all the burned rock recovered, 90 percent is in the 1-2 size range, 9 percent is in the 3-4 size range, and 1 percent is in the 5-6 size range.

To consider what appears to be the lowest portion (possible heating element) in Feature 3, we plotted the burned rock recovered from Unit E527/N562 in Level 7. At that provenience 89 percent of the burned rock is in the 1-2 size range and 11 percent is in the 3-4 size range. Much like the block totals, the majority of rock from Feature 3 is small in size. 
For Feature 9 we consider the burned rock recovered from two units: E532/N562 and E532/N563 in Level 6. The pattern in rock size is very similar to Feature 3 , with 87 percent of the rock falling in the $1-2$ size range, 11 percent in the 3-4 size range, and 1 percent in the 5-6 size range.

The pattern for feature and non-feature areas in Block A2 is very similar. Nearly all of the burned rock is small. Attempts to isolate other areas (e.g., Unit E529/N561, Level 6) within the block for comparison reveals much the same pattern, as do patterns between limestone and caliche. Based on the density contour plots, the boundaries for Feature 3 assigned in the field may be too large. It may be more appropriate to consider the high density of burned rock in the north central portion of the block, the area that encompasses all of Feature 9 and the eastern portion of Feature 3, as a single feature. Even then, the rock in this newly defined feature area would be characterized by small burned rocks.

\section{Block A1}

A total of $90 \mathrm{~m}^{2}$ was excavated in this block. As with the other blocks, total weight of burned rock for each unit was summed by level and plotted in a series of density contour plots (Figure 23). Due to small sample size, caliche and limestone were combined. Four levels (13-16) were excavated, all of which contained burned rock. A single feature, Feature 12, was identified in this block.

Due to the limited number of units excavated as part of Level 13, burned rock weights for this level were combined with those from Level 14. As can be seen from the density contour plot (Figure 23), very little burned rock is present in the upper two levels. Since Feature 12 was identified in the field by staining in these levels, it does not appear on the density contour plot. However, one unit (E505/N511) does show a higher density of burned rock than the surrounding units.

In Level 15, Feature 12, which is described as a basin-shaped hearth pit compose of 95 percent burned caliche, becomes defined by a discrete, high density area of burned rock with very little
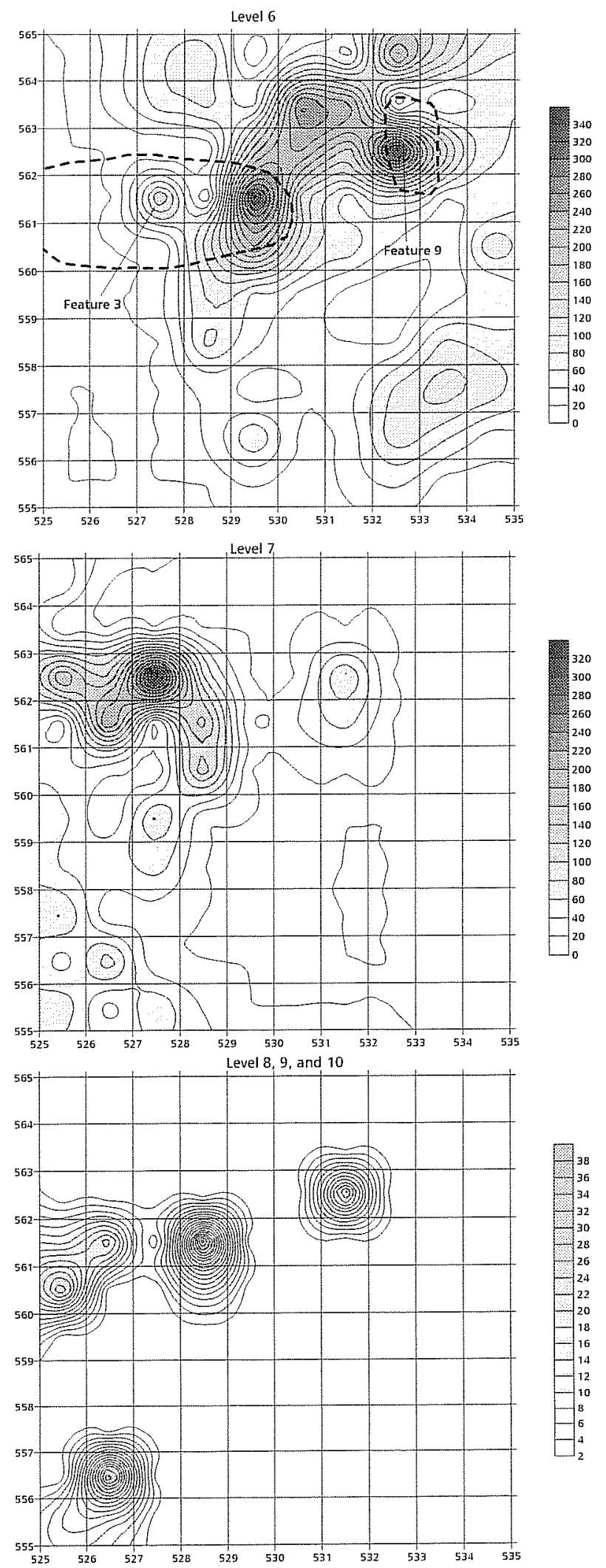

Figure 21. Density plot by weight, Block $A 2$, FB 12412. 

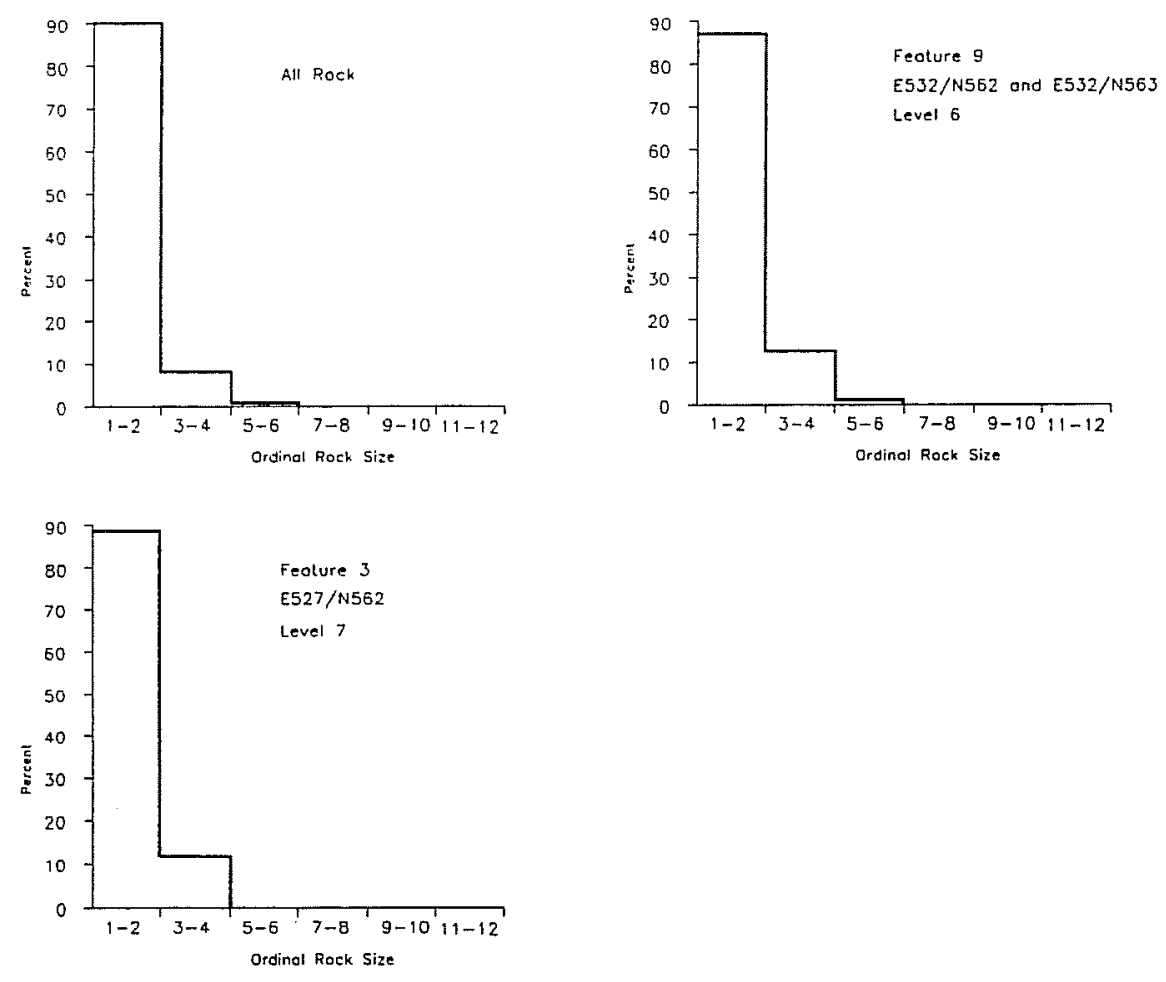

Figure 22. Frequencies by size class, Block A2, FB 12412.

the majority of the burned rock, regardless of its provenience, is small in size.

The pattern in burnedrock size and distribution identified here is very similar to the pattern identified for feature and non-feature areas in Block A2. Features in Block A2 were defined on the basis of burned rock distributions, with no evidence of charcoal staining or pits. Features in Block A1 were defined by burned rock distributions and charcoal staining. Both blocks have few highdensity patterns associated with features and nodes of burned rock present between and around the feature(s). It is interesting to note that

burned rock in any of the adjacent units. Limited amounts of burned rock, however, are clearly evident in several areas on the southern side of the block.

In Level 16 , Feature 12 is no longer evident. The only burned rock recovered from this level is from Unit E504/N510 in the extreme southern edge of the block. This unit also exhibited burned rock in the level just above. Although this was the only unit to exhibit burned rock concentrations in the same area across multiple levels, it was not assigned a feature number in the field.

To explore differences between Feature 12 and the non-feature densities identified in the density contour plots, size comparisons by provenience were examined. At the block level (all excavation levels combined), 97 percent of the burned rock was in the 1-2 size range. Ninety-nine percent of the Feature 12 rock and caliche was in the 1-2 size range. Further comparisons were unlikely to provide any additional insight beyond the fact that charcoal staining is present in Block A1 in Feature 12 and that this feature has a relatively high-density of burned caliche within the block. However, the size range of burned rock within the feature is almost identical (all small) to the size ranges for the burned rocks throughout the remainder of the block. Without the visible charcoal stained area seen in Feature 12, the block is almost identical in burned rock weight and size patterns for the block containing Features 3 and 9, which are described as amorphous concentrations of burned rock and caliche. This suggests that Features 3 and 9 represent hearth pits, similar to Feature 12, that have since been deflated or disarticulated.

\section{Block B1}

A total of $32 \mathrm{~m}^{2}$ was excavated in this block. Three levels (4-6) were excavated and one feature (Feature 16) was identified. For pattern recognition analysis, the total weight of burned caliche and limestone was summed by unit and plotted by level as density contour plots (Figure 24). 

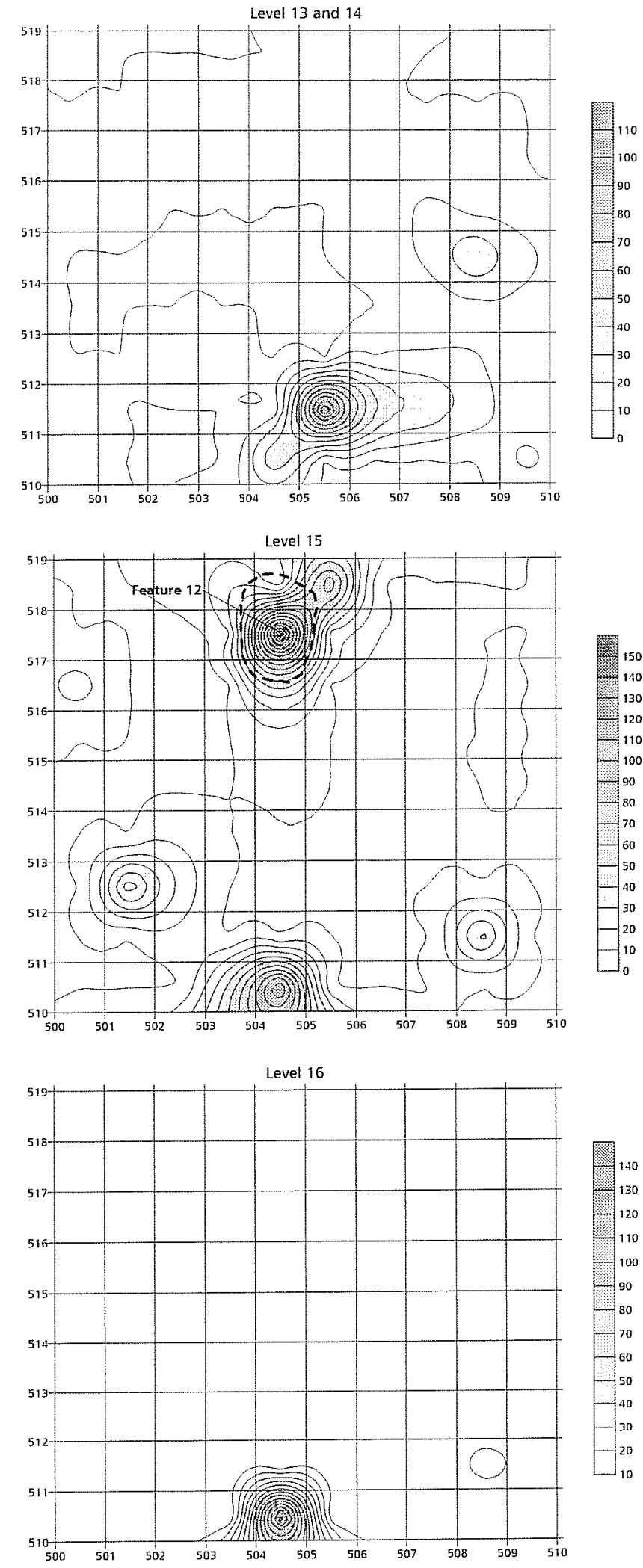

Level 4 is characterized by a low density of burned rock scattered over a limited number of units within the level. Two higher density concentrations of burned rock are clearly evident in Units E654/N502 and E657/N504. In Level 5, burned rock was also confined to a small number of units, but Feature 16 becomes evident in Unit E657/N503. In addition, a concentration of burned caliche is apparent in the southern edge of the block in Unit E655/N501. Feature 16 was identified on the surface in the field only by a carbonaceous stain, but after excavation was defined as a rock-lined hearth. In Level 6, any evidence of Feature 16 has begun to disappear and a small amount of burned rock is scattered along the north/northeastern edge of the excavation block.

To explore any patterns in the distribution of burned rock size in feature and non-feature areas, the percentages of burned rock by sizeclass and provenience was plotted (Figure 25). We first consider the relatively higher density of burned rock evident in two units in Level 4. In the first area (Unit E657/N504), 66 percent of the burned rock is in the 1-2 size range, 25 percent is in the 3-4 size range, and 9 percent is in the 5-6 size range. In the second area in Level 4 (Unit E654/N502), 72 percent of the burned rock is in the 1-2 size range, 14 percent is in the 3-4 size range, and 14 percent is in the 5-6 size range.

For Feature 16, the burned rock recovered from Unit E657/N503 in Level 5 was examined (Figure 25). According to the field notes this level contained the bottom of the feature. At this provenience, 77 percent of the burned rock is in the $1-2$ size range, 16 percent is in the $3-4$ size range, and 6 percent is in the 5-6 size range. Overall, the pattern in burned-rock size for feature and non-features areas in this block is consistently small. We see no demonstrable differences regarding feature or non-feature proveniences.

Figure 23. Density plot by weight, Block A1, FB 12412. 

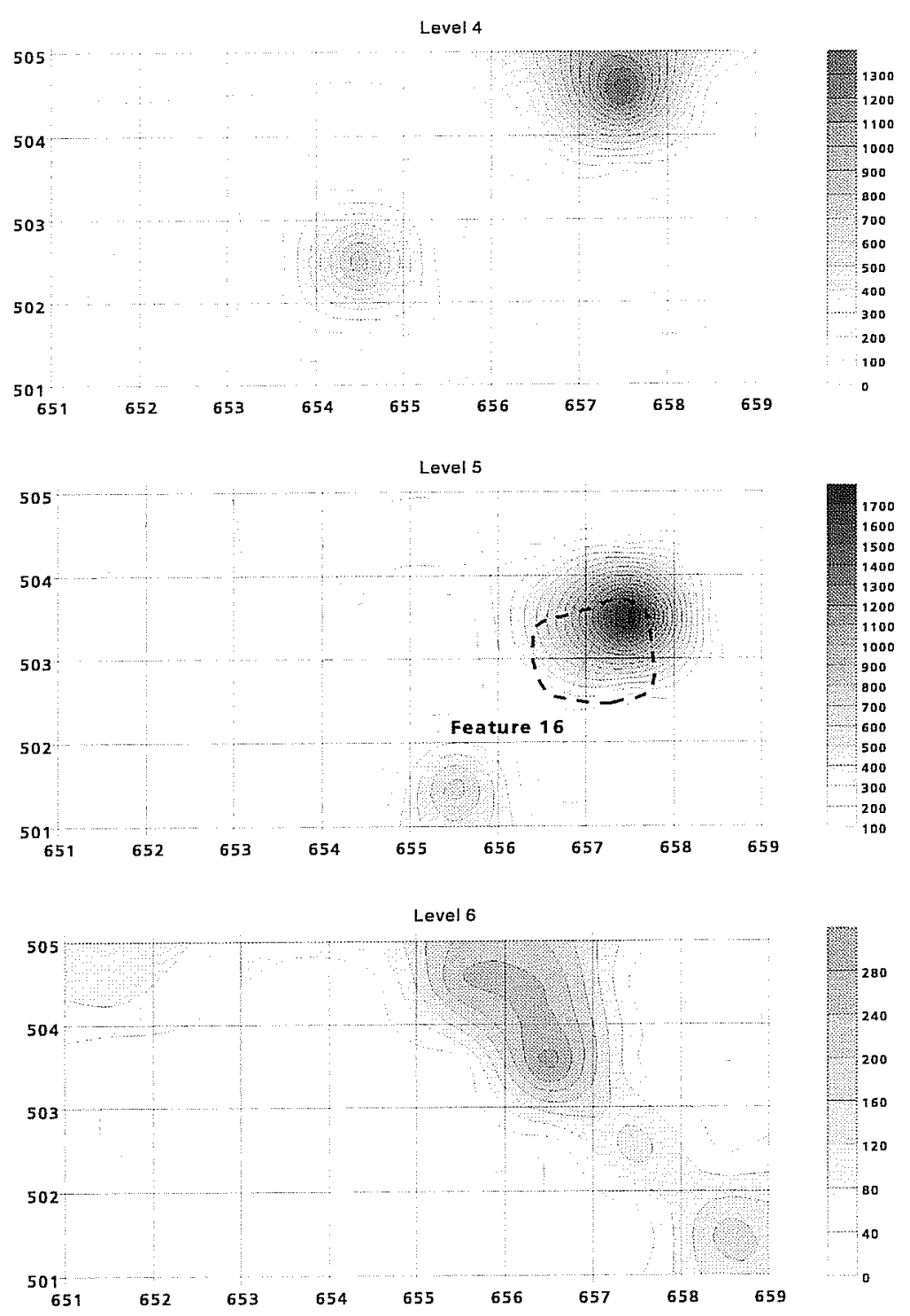

Figure 24. Density plot by weight, Block B1, FB 12412.

As with the other blocks on this site, we consistently identify areas that are defined as features based either on the presence of charcoal staining and clusters of burned rock and/or caliche, as with Features 12 and 16, or based entirely on clusters of burned rock, as with Features 3 and 9. In both cases, there are no discernable differences in the size distributions of burned rock from the features and that from the non-feature areas. The intact features (12 and 16) have the same size distributions as the "deflated" features ( 3 and 6). Comparison of rock size distribution does not enable us to attempt to determine if high-density areas are discard events, intact features, or deflated features. This pattern of deflated versus non-deflated, though beyond the scope of this analysis, may hint at the dynamic nature of the deposition and erosion in the Transitional Zone. 
An alternative method of approaching this problem is to consider the frequency of fractures and cortex remaining on the limestone within the feature and non-feature areas. Seventy-one percent of the total quantity of burned rock on the site was limestone. The percentage of fracturing and rocks without cortex was calculated by size range for each feature and non-feature area (Table 10). All of the non-feature and feature rocks from FB 12412 have high frequencies of fracturing. A higher frequency of the rocks from Features 3 and 9 and the non-feature areas however, still retain some of their cortex suggesting that the small size of the rocks on this site are a reflection of smaller original size as opposed to exhaustive use.

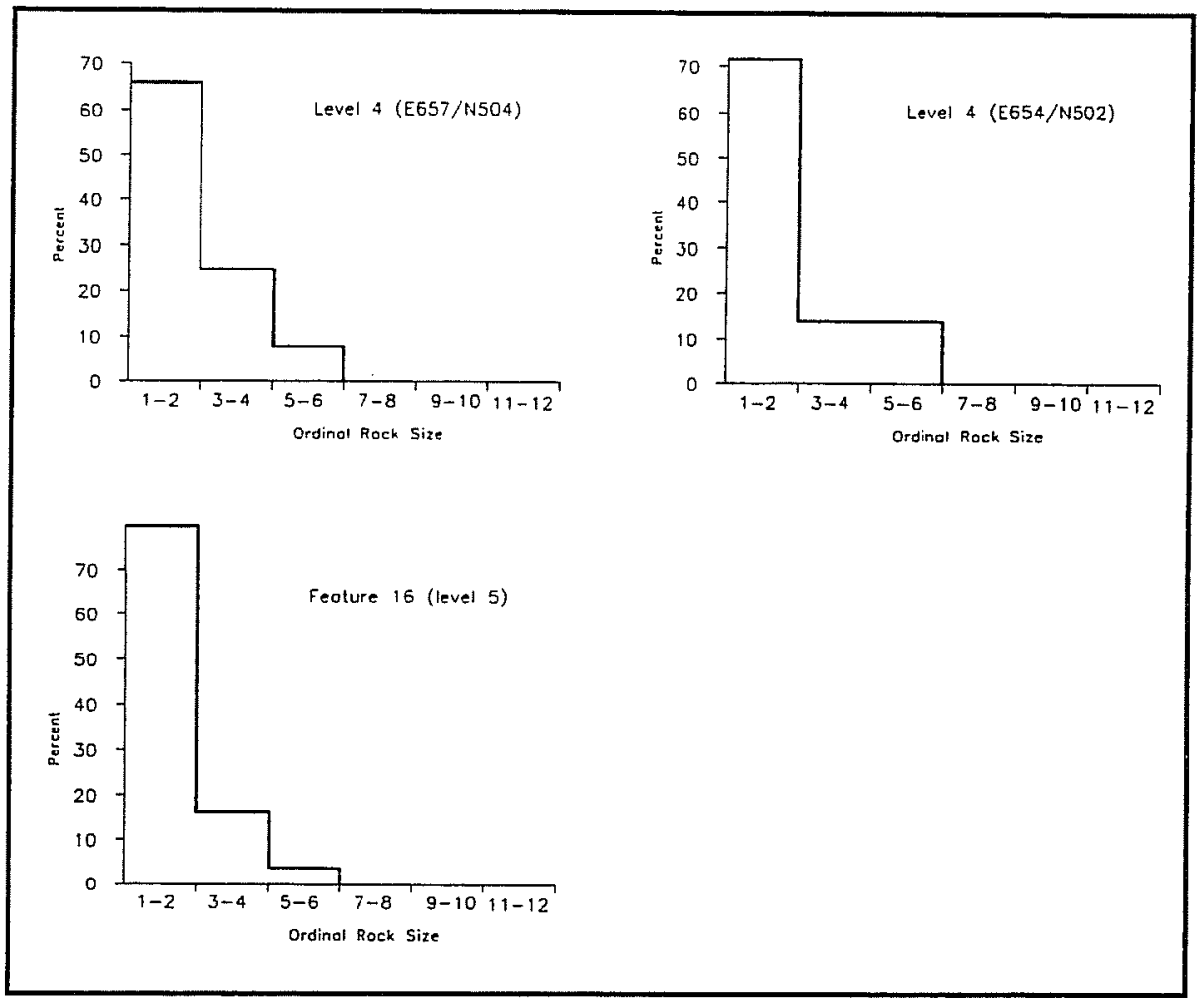

Figure 25. Frequencies by size class, Block B1, FB 12412.

Table 10. FB 12412, Fracture and Cortex Percentages (Limestone Only)

\begin{tabular}{|c|c|c|c|c|c|c|c|c|c|c|}
\hline \multirow{2}{*}{$\begin{array}{l}\text { Size } \\
\text { Range }\end{array}$} & \multicolumn{2}{|c|}{$\begin{array}{c}\text { Feature } 3 \\
n=116\end{array}$} & \multicolumn{2}{|c|}{$\begin{array}{c}\text { Feature } 9 \\
\mathbf{n}=101\end{array}$} & \multicolumn{2}{|c|}{$\begin{array}{l}\text { Feature } 12 \\
n=6\end{array}$} & \multicolumn{2}{|c|}{$\begin{array}{l}\text { Feature } 16 \\
n=250\end{array}$} & \multicolumn{2}{|c|}{$\begin{array}{c}\text { Non-Feature } \\
n=250\end{array}$} \\
\hline & $\begin{array}{c}\% \\
\text { Fracture } \\
\text { Present }\end{array}$ & $\begin{array}{c}\% \\
\text { Cortex } \\
\text { Absent }\end{array}$ & $\begin{array}{c}\% \\
\text { Fracture } \\
\text { Present }\end{array}$ & $\begin{array}{c}\% \\
\text { Cortex } \\
\text { Absent }\end{array}$ & $\begin{array}{c}\% \\
\text { Fracture } \\
\text { Present }\end{array}$ & $\begin{array}{c}\% \\
\text { Cortex } \\
\text { Absent }\end{array}$ & $\begin{array}{c}\% \\
\text { Fracture } \\
\text { Present }\end{array}$ & $\begin{array}{c}\% \\
\text { Cortex } \\
\text { Absent }\end{array}$ & $\begin{array}{c}\text { \% } \\
\text { Fracture } \\
\text { Present }\end{array}$ & $\begin{array}{c}\% \\
\text { Cortex } \\
\text { Absent }\end{array}$ \\
\hline $1-2$ & 97 & 74 & 98 & 74 & 75 & 75 & 100 & 94 & 97 & 89 \\
\hline $3-4$ & 92 & 44 & 100 & 58 & 100 & 100 & 100 & 82 & 89 & 55 \\
\hline $5-6$ & 0 & 0 & 100 & 50 & - & - & 100 & 50 & 96 & 34 \\
\hline $7-8$ & - & - & - & - & - & - & - & - & $\begin{array}{c}100 \\
\text { (no } 7 \mathrm{~s})\end{array}$ & $\begin{array}{c}100 \\
\text { (no } 7 \mathrm{~s})\end{array}$ \\
\hline Totals & 75 & 47 & 99 & 62 & 83 & 83 & 100 & 75 & 95 & 65 \\
\hline
\end{tabular}




\section{Block B1}

A total of $78 \mathrm{~m}^{2}$ within five levels $(3-7)$ was excavated in Block B1 to investigate two features (30 and 77). Density contour plots of the burned rock recovered during excavation were constructed using total burned rock weight summed by unit and level (Figure 26). The burned rock recovered from this block included limestone, caliche, and sandstone, all of which were included in the density plots. Due to the low density of burned rock in Level 6, it is combined with Level 7. The horizontal boundaries of Features 30 and 77 are depicted at the level in which they were best defined during excavation.
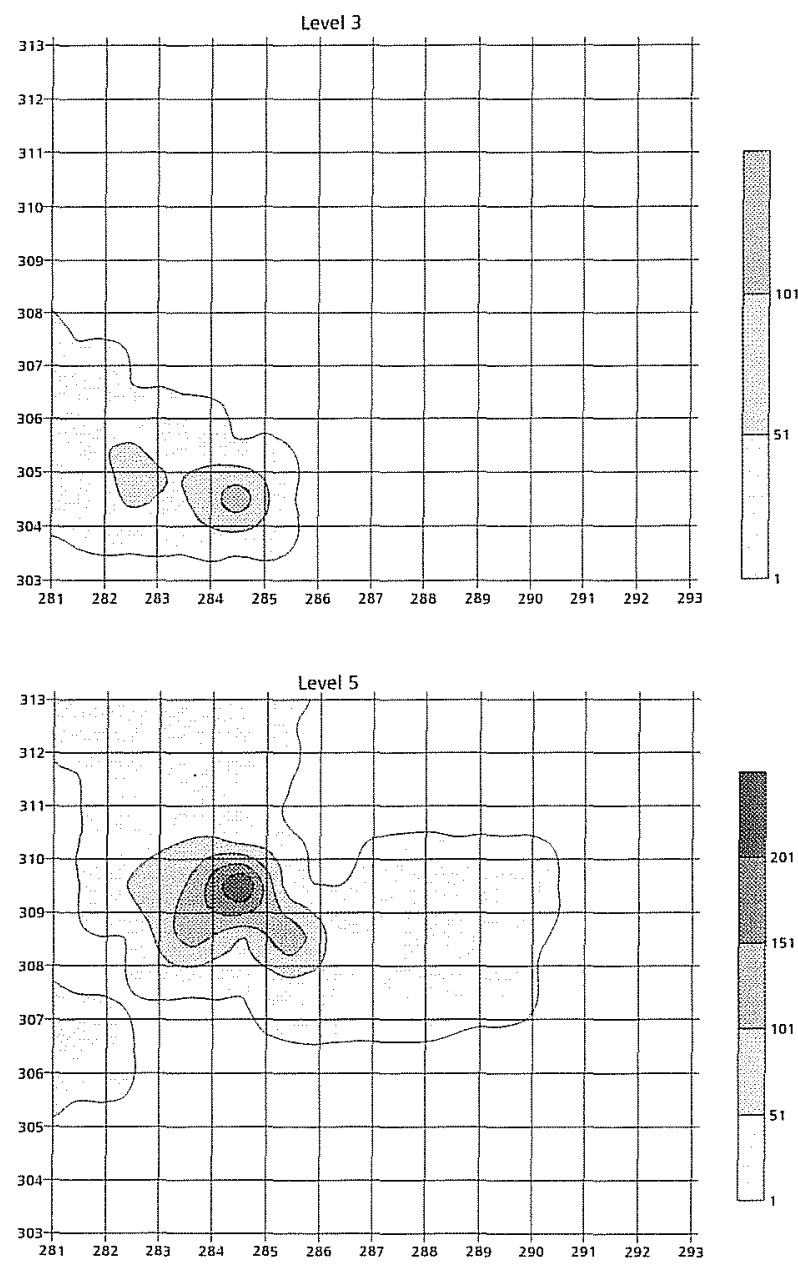

In Level 3 very little burned rock is present except in the southwestern corner of the block where there is a slight increase in density evident in Unit E284/N304. The southeastern corner and the northernmost row of units were not excavated at this level. In Level 4, the same burned rock density is evident and Feature 77 appears as a small, very dense node. In Level 5 the dense area that was associated with Feature 77 is no longer well defined, and the high-density area to the southeast of Feature 77, evident in Levels 3 and 4, has all but disappeared. In Level 5, a node of higher density of burned rock is evident in Unit E284/N309, but disappears in the underlying level. The high-density area in Unit E284/N309, which appears to be associated with Feature 30, becomes a well-defined node of high-density in Levels 6 and 7.
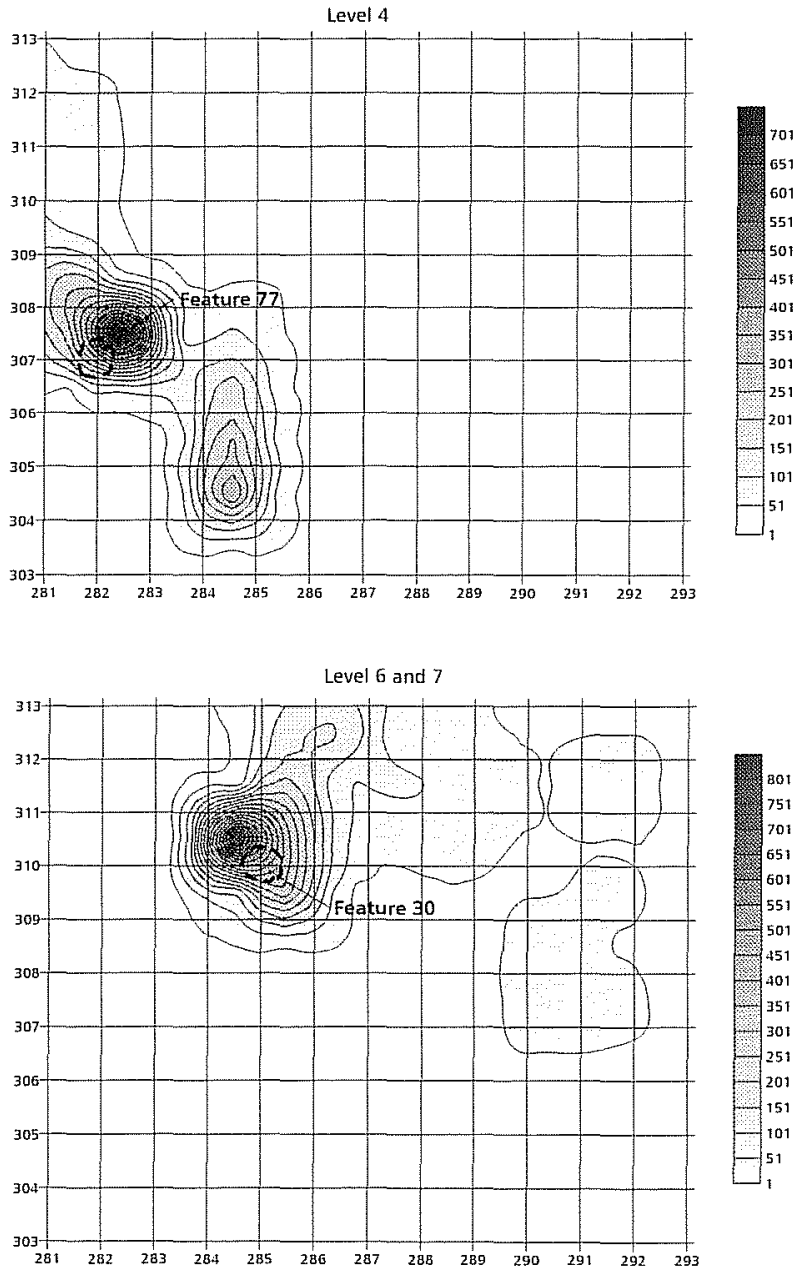

Figure 26. Density plot by weight, Block B1, FB 12719. 
The density contour plots of burned-rock weight by excavation levels reveal that feature areas identified in the field are well defined by the presence of highdensity nodes, and several areas of high-density not identified as features during excavation are evident between these feature nodes. These areas may be the upper portions of eroded features, or may represent discard events from the use of Features 30 and 77 .

To explore patterns identified in the density contour maps discussed above, burned-rock size frequencies in features and non-feature areas were contrasted in a series of histograms (Figure 27). We first consider all burned rock recovered from the block by material type. For limestone, 88 percent of the burned rock recovered is in the 1-2 size range, 9 percent is in the 3-4 size range, and 3 percent in the 5-6 size range. For caliche, 96 percent is in the 1-2 size range, 4 percent is in the $3-4$ size range, and less than 1 percent is in the 5-6 size range. At the block level, all recovered burned rock is characterized by small items, regardless of material type.

For Feature 77 , we use the burned rock recovered from Level 4 of Unit E282/N307. In this unit and level, where Feature 77 is best defined, 80 percent of the limestone is in the 1-2 size range, 9 percent is in the 3-4 size range, and 11 percent is in the 5-6 size range. For caliche in Feature 77, 100 percent is in the 1-2 size range.

For Feature 30, we use the burned rock recovered from Level 6 of Unit 284/N310. In this provenience, 50 percent of the limestone is in the 1-2 size range, 40 percent is in the $3-4$ size range, and 10 percent is in the 5-6 size range. For the caliche recovered from this provenience, 95 percent is in the 1-2 size range, 3 percent is in the $3-4$ size range, and 2 percent is in the 5-6 size range. Like Feature 77 , the majority of the burned caliche recovered from Feature 30 is less than $2.5 \mathrm{~cm}$ in diameter. However, the histograms for Features 30 and 77 show quite different patterns of limestone-size distribution. Eighty percent of the burned limestone in Feature 77 is $2.5 \mathrm{~cm}$ or less in diameter, while 40 percent of the burned limestone in Feature 30 is between $2.5-4 \mathrm{~cm}$ in diameter and 10 percent is between $5.5-10.5 \mathrm{~cm}$ in diameter. This may suggest different use-life or functions for the two features.
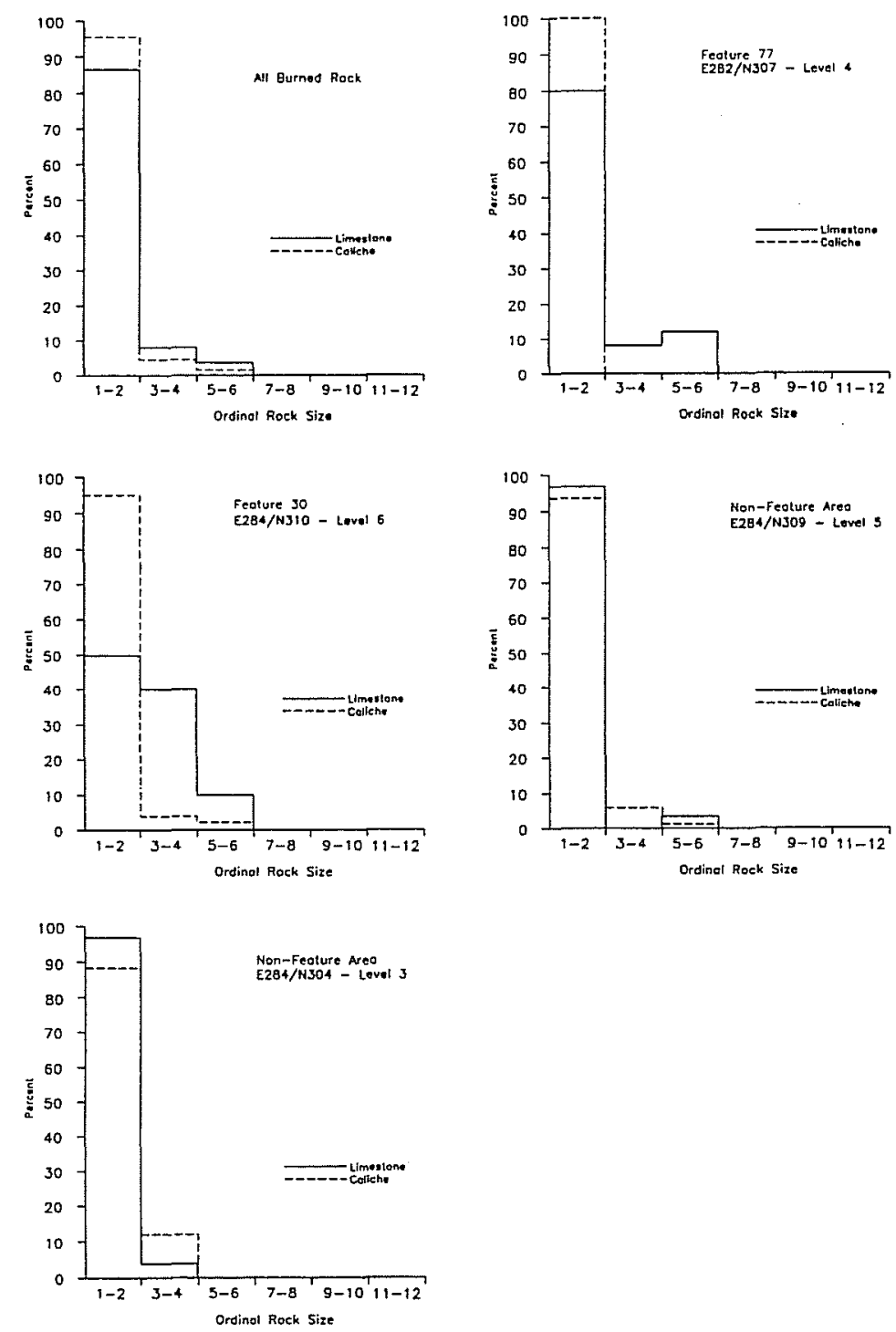

Figure 27. Frequencies by size class, Block B1, FB 12719. 
We also consider burned-rock size distributions for two non-feature areas. The first is located in Unit E284/N304 in Level 3. Eighty-eight pieces of limestone and caliche weighing $141.64 \mathrm{~g}$ were recovered (Table 11). At this provenience, 97 percent of the limestone recovered is in the 1-2 size range and 3 percent is in the 3-4 size range. For the caliche, 89 percent is in the 1-2 size range and 11 percent is in the 3-4 size range. Interestingly, no burned rock larger than the 3-4 size range was recovered from this provenience. The second area is in Unit E284/N309 in Level 5. In this provenience, 99 pieces of limestone and caliche weighing $280.92 \mathrm{~g}$ were recovered. For the limestone, 97 percent was in the 1-2 size range, none was in the 3-4 size range, and 3 percent was in the 5-6 size range. For caliche, 93 percent was in the 1-2 size range, 6 percent was in the 3-4 size range, and 1 percent was in the 5-6 size range (Table 12).
It appears that both non-feature areas identified by weight-density contour maps are characterized by small burned rock, similar to the feature areas. The non-feature areas, however, have a greater frequency of burned limestone smaller than $2.5 \mathrm{~cm}$ in diameter. This suggests that the non-feature areas are indeed discard from previous use of Features 30 and/or 77 . The percentage of small burned caliche is high in all four proveniences.

The comparison of material types between features reveals that Feature 30 has a much higher percentage of caliche than Feature 77. From Table 13 we see that of the $957.84 \mathrm{~g}$ of burned rock recovered from Feature 30,34 percent $(321.74 \mathrm{~g})$ is caliche. In Feature 77 (see Table 13), only 2 percent $(21.10 \mathrm{~g})$ of the $944.23 \mathrm{~g}$ of burned rock is caliche.

Table 11. Weight and Quantity of Non-feature Burned Rock in Block B1 by Material Type

\begin{tabular}{|c|c|c|c|}
\hline Provenience & $\begin{array}{c}\text { Limestone } \\
\text { (g / qty.) }\end{array}$ & $\begin{array}{c}\text { Caliche } \\
\text { (g/ qty.) }\end{array}$ & Total \\
\hline E284/N309 - Level 5 & $93.03 / 29$ & $187.89 / 70$ & $\mathbf{2 8 0 . 9 2 / 9 9}$ \\
\hline E284/N304 - Level 3 & $97.75 / 79$ & $43.89 / 9$ & $\mathbf{1 4 1 . 6 4 / 8 8}$ \\
\hline & $\mathbf{1 9 0 . 7 8 / 1 0 8}$ & $\mathbf{2 3 1 . 7 8 / 7 9}$ & \\
\hline
\end{tabular}

Table 12. Percent of Burned Rock in Each Size Range

\begin{tabular}{|c|c|c|c|c|c|c|c|c|}
\hline & \multicolumn{2}{|c|}{ Feature 30 } & \multicolumn{2}{c|}{ Feature 77 } & \multicolumn{2}{c|}{$\begin{array}{c}\text { Unit } \\
\text { E284/N304 } \\
\text { Level 3 }\end{array}$} & \multicolumn{2}{c|}{$\begin{array}{c}\text { Unit } \\
\text { E284/N309 } \\
\text { Level 5 }\end{array}$} \\
\hline $\begin{array}{c}\text { Size } \\
\text { Range }\end{array}$ & limestone & caliche & limestone & caliche & limestone & caliche & limestone & caliche \\
\hline $1-2$ & 50 & 95 & 80 & 100 & 97 & 89 & 97 & 93 \\
\hline $3-4$ & 40 & 3 & 9 & - & 3 & 11 & - & 6 \\
\hline $5-6$ & 10 & 2 & 11 & - & - & - & 3 & 1 \\
\hline
\end{tabular}


Table 13. Burned Rock Weight by Material from Select Feature Proveniences in Block B1

\begin{tabular}{|c|c|c|c|}
\hline Feature & Limestone $(\mathrm{g})$ & Caliche $(\mathrm{g})$ & Total \\
\hline Feature $30^{\mathrm{a}}$ & 636.1 & 321.74 & $\mathbf{9 5 7 . 8 4}$ \\
\hline Feature $77^{\mathrm{b}}$ & 923.13 & 21.10 & $\mathbf{9 4 4 . 2 3}$ \\
\hline & $\mathbf{1 5 5 9 . 2 3}$ & $\mathbf{3 4 2 . 8 4}$ & \\
\hline
\end{tabular}

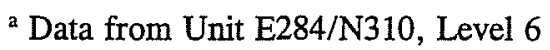

${ }^{\mathrm{b}}$ Data from Unit E282/N307, Level 4.

The high density area in Unit E284/N304, Level 3, consists of 31 percent caliche compared to 67 percent from Unit E284/N309, Level 5 (Table 11). This indicates that the high density node in Unit E284/N303, Level 3, is most likely associated with Feature 77.

Fracture and cortex frequencies are compared for burned limestone only in Table 14. Rocks from Feature 77 are not included in this table as they were not collected or labeled separately and could not be differentiated from surrounding non-feature rock during attribute analysis. In Feature 30, the one limestone hearth feature on FB 12719, 100 percent of the rocks in all size classes are fractured and over 50 percent of the rocks are void of cortex. The fracture and cortex frequencies of rocks from the structures features compares more favorably with the non-feature surface rock, suggesting the burned rock within the structures represents structure fill and not discrete features within the structures.

Table 14. FB 12719, Fracture and Cortex Percentages (Limestone Only)

\begin{tabular}{|c|c|c|c|c|c|c|c|c|c|c|}
\hline \multirow{2}{*}{$\begin{array}{l}\text { Size } \\
\text { Range }\end{array}$} & \multicolumn{2}{|c|}{$\begin{array}{c}\text { Feature } 30 \\
n=114\end{array}$} & \multicolumn{2}{|c|}{$\begin{array}{c}\text { Feature } 32 \\
n=79\end{array}$} & \multicolumn{2}{|c|}{$\begin{array}{c}\text { Feature } 33 \\
n=76\end{array}$} & \multicolumn{2}{|c|}{$\begin{array}{c}\text { Feature } 34 \\
n=110\end{array}$} & \multicolumn{2}{|c|}{$\begin{array}{c}\text { Non-Feature } \\
n=1551\end{array}$} \\
\hline & $\begin{array}{c}\% \text { Fracture } \\
\text { Present }\end{array}$ & $\begin{array}{c}\% \text { Cortex } \\
\text { Absent }\end{array}$ & $\begin{array}{c}\% \text { Fracture } \\
\text { Present }\end{array}$ & $\begin{array}{c}\% \text { Cortex } \\
\text { Absent }\end{array}$ & $\begin{array}{c}\text { \% Fracture } \\
\text { Present }\end{array}$ & $\begin{array}{c}\% \text { Cortex } \\
\text { Absent }\end{array}$ & $\begin{array}{c}\text { \% Fracture } \\
\text { Present }\end{array}$ & $\begin{array}{c}\% \text { Cortex } \\
\text { Absent }\end{array}$ & $\begin{array}{c}\% \text { Fracture } \\
\text { Present }\end{array}$ & $\begin{array}{c}\% \text { Cortex } \\
\text { Absent }\end{array}$ \\
\hline $1-2$ & 100 & 95 & 85 & 65 & 100 & 92 & 89 & 56 & 94 & 89 \\
\hline $3-4$ & 100 & 51 & 83 & 62 & 89 & 39 & 100 & 45 & 95 & 55 \\
\hline $5-6$ & 100 & 67 & $\begin{array}{c}50 \\
\text { (no 6s) }\end{array}$ & 17 & 100 & 100 & $\begin{array}{c}80 \\
\text { (no 6s) }\end{array}$ & 40 & 98 & 34 \\
\hline $7-8$ & - & - & $\begin{array}{c}50 \\
\text { (no 8s) }\end{array}$ & 50 & - & - & - & - & 100 & 100 \\
\hline $9-11$ & - & - & $\begin{array}{c}100 \\
\text { (11s only) }\end{array}$ & 100 & - & - & - & - & - & - \\
\hline Totals & 100 & 71 & 91 & 69 & 96 & 72 & 92 & 48 & 87 & 82 \\
\hline
\end{tabular}




\section{Block A1}

Field investigations in Block $\mathrm{A} 1$ involved the excavation of nearly $3001-x-1-m$ units. This included the excavation of several pit structures (Features 32, 33, and 34) and large, open areas around the structures. In addition, several features (Features 78, 80, 85, and 89) located on or near the floors of several of the structures were documented. No "true" burned rock features similar to those recorded in Block B1 were noted although a considerable amount of burned rock was recovered from the excavation area. In general, the burned rock recovered from Block $\mathrm{A} 1$ was scattered about the surface or within pit structure fill and floors. To explore patterns in rock across the site, density plots of burned rock by material type, weight, and count for excavation units and levels were constructed.

Figure $28 \mathrm{~A}$ is a density contour plot of the weight of all burned rock from Block $A 1$ summed by unit. Inspection of Figure 28A reveals a continuous scatter of burned rock throughout the excavation area, with noticeable nodes of burned rock in several units. When the structure locations are superimposed onto the density contour plot (Figure 28B) it appears that the three most dense areas of burned rock spatially correspond to the locations of the structures.

Table 15 provides the weight and quantity of burned rock by material type for Block A1. Burned limestone accounts for 60 percent of the total weight of burned rock recovered from this excavation area, burned caliche constitutes about 38 percent, and other materials account for two percent. However, while limestone accounts for 60 percent of the total rock weight, it makes up only 18 percent of the total number of burned rock specimens, while caliche accounts for 79 percent of the total burned rock count. Other material types comprise approximately three percent of the burned rock count.
A
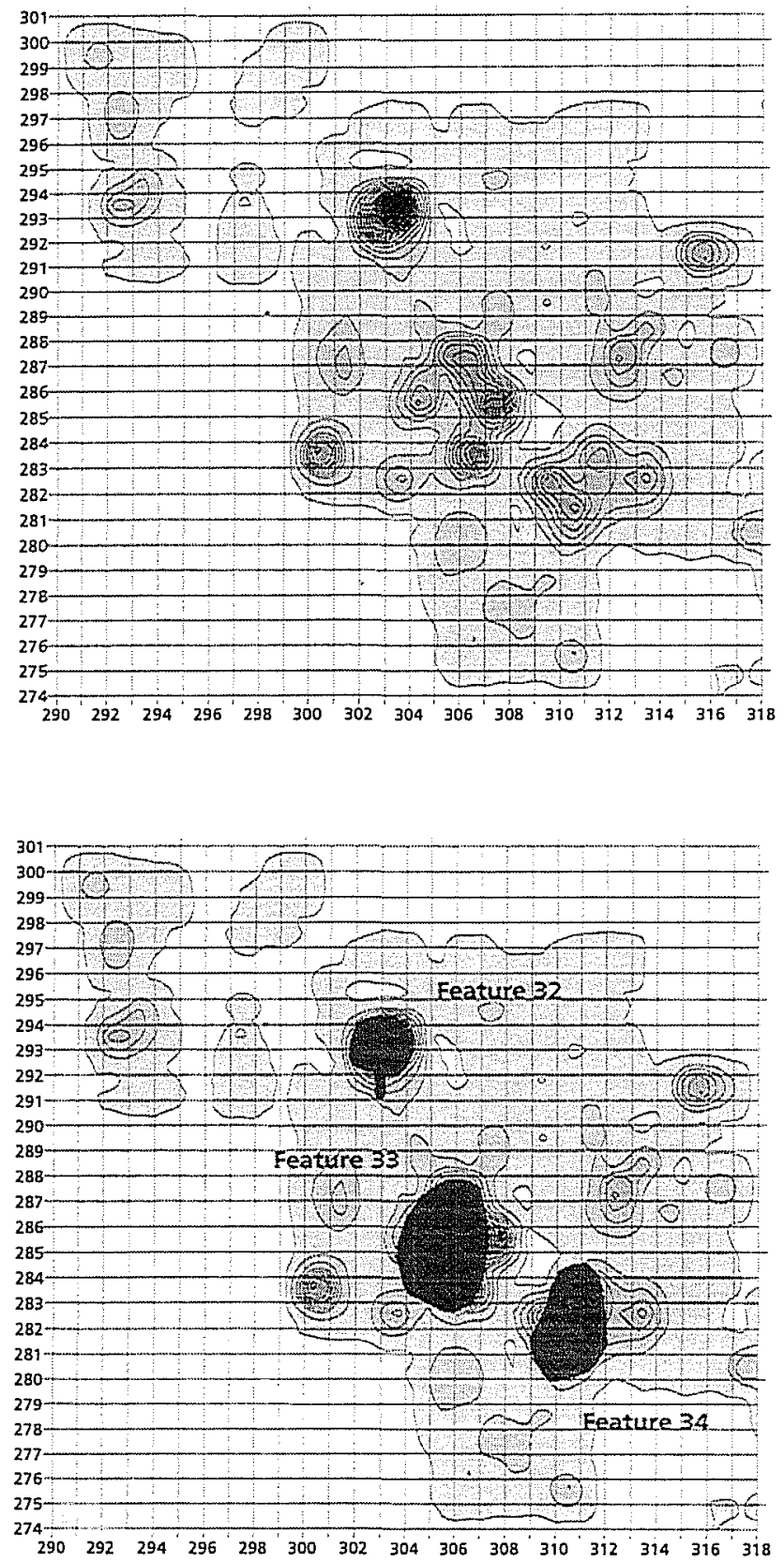

Figure 28. Density plot by weight, Block A1, FB 12719. 
Table 15. Total Weight and Quantity of Burned Rock for Block A1

\begin{tabular}{|l|l|l|}
\hline \multicolumn{1}{|c|}{ Material Type } & \multicolumn{1}{c|}{ Total Weight (g) } & Quantity \\
\hline Limestone & $21,711.30$ & 1143 \\
\hline Caliche & $13,803.95$ & 4938 \\
\hline Other $^{\mathrm{a}}$ & 679.29 & 168 \\
\hline & $\mathbf{3 6 1 9 4 . 5 4}$ & $\mathbf{6 2 4 9}$ \\
\hline
\end{tabular}

${ }^{a}$ Other material type includes chert, Rancheria chert, quartzite, rhyolite, sandstone, and granite.

As mentioned above, limestone dominates the block in overall weight, but caliche accounts for more of the total count. This suggests that different patterns than those identified by looking at total weights summed by unit and material type might be expected if we plotted total counts summed by unit and material type. Figure 29 is a plot of the quantity of caliche and limestone summed by unit for Level 1. Not surprisingly, different patterns than those identified by total weight emerge. The limestone plot exhibits less clustering than was evidenced by the total weight of rock summed by unit for the same data set. The pattern produced by looking at counts suggests that limestone is widely and evenly dispersed in low numbers throughout the excavation area. Conversely, the plot for caliche illustrates several high-density areas not evident in the plot based on weight (Figure 28). This suggests that the high-density patterns identified in the weight plot are the result of a small number of rocks.

The patterns in limestone and caliche weight and count reveal that burned caliche occurs as small pieces in a greater number of proveniences across the block (burned caliche occurs in 259 of the nearly 300 units excavated and limestone in only 205), whereas limestone is more spatially restricted and larger in overall rock size. Nevertheless, the overall pattern is a relatively continuous scatter of both burned limestone and caliche throughout the excavation area.

No formal features-discrete locations of burned rock with possible charcoal staining-were identified in Block A1. While several of the features noted in the floor of the structures had small amounts of burned rock in the fill, the excavators did not note these as burned rock features. The patterns identified in the density contour plots suggest that density and/or count of burned rock might be used to argue for the presence of a burned rock feature not identified in the field.

Figure 30 illustrates the possible remnant features for examples of our two data sets. In the top portion of the figure, the areas of the excavation block containing the highest density of burned limestone by weight is easily distinguished from the surrounding lower-density areas by the peaks in the surface plot. Likewise, the relatively high density areas of burned caliche by total counts (Figure 30b) is also well delineated.

When we consider the actual size of the burned caliche that constitutes the high density areas depicted in Figure 30, most are heavily skewed towards small size categories. For example, of the burned caliche recovered from the high density area in Unit E308/N277, 98 percent of the burned rock is in the 1-2 size range. In other high density areas, such as Units E311/N283 and E292/N296, 97 percent and 98 percent of the burned rock respectively, is in the 1-2 size range. Burned limestone, though characterized by a small percentage of larger size classes, follows much the same pattern.

It is difficult to determine if the high density areas of burned rock identified in the weight and quantity plots are feature locations, as the low density of burned rock in this block guarantees that even a 
Limestone
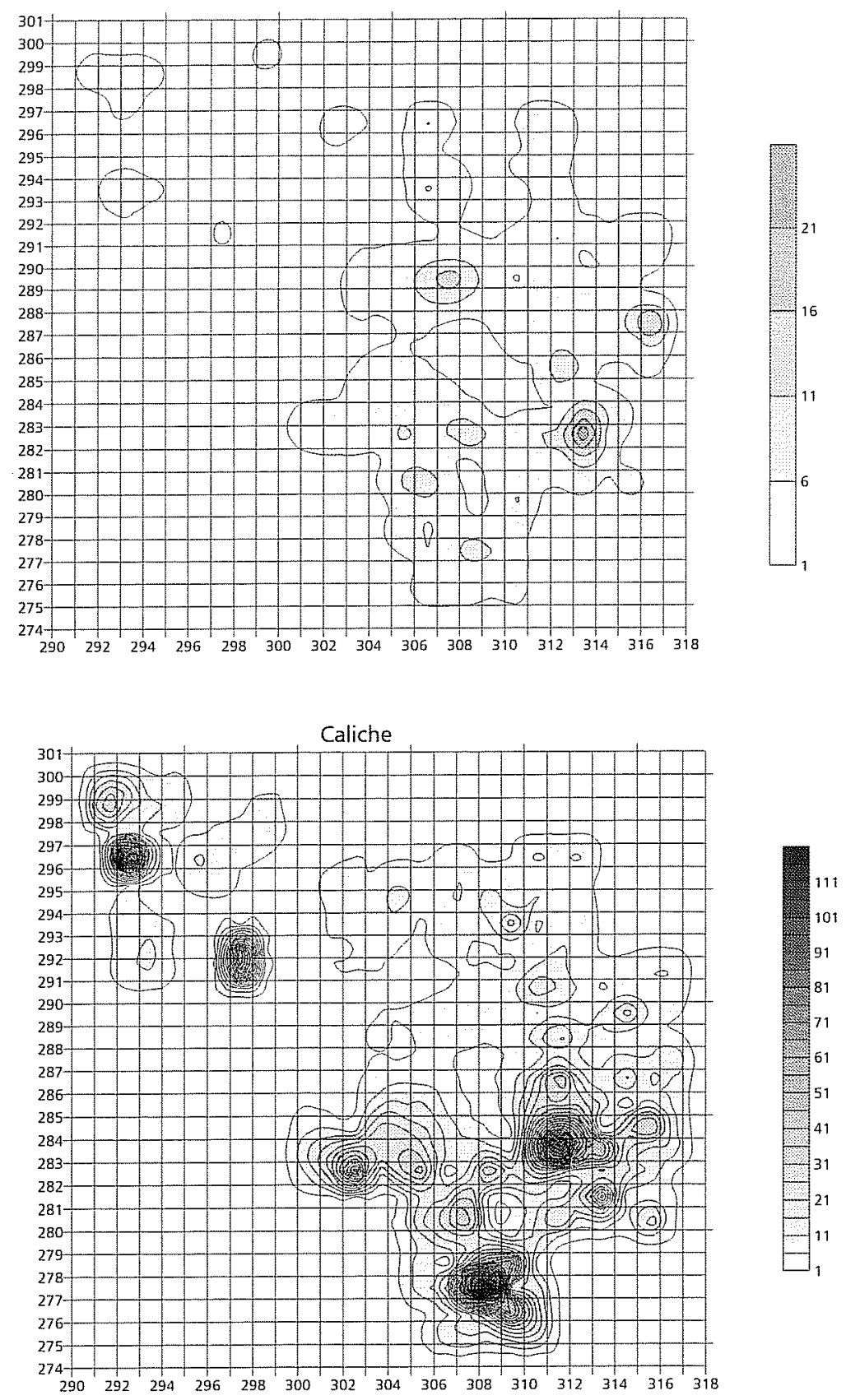

Figure 29. Density plot by count, Block A1, FB 12719.

limited amount of clustering of burned rock will result in the patterns suggestive of features. The lack of charcoal staining with any of the burned rock nodes complicates matters further. However, the excavators noted in their field notes that the upper portion of the site (Level 1) appears to have been slightly deflated, resulting in a condensation of materials. This possible deflation may account for the lack of charcoal staining.

The frequency of fracturing present and cortex absent for feature and non-feature limestone within each size group is given in Table 16. While frequencies of fracturing from all proveniences are 


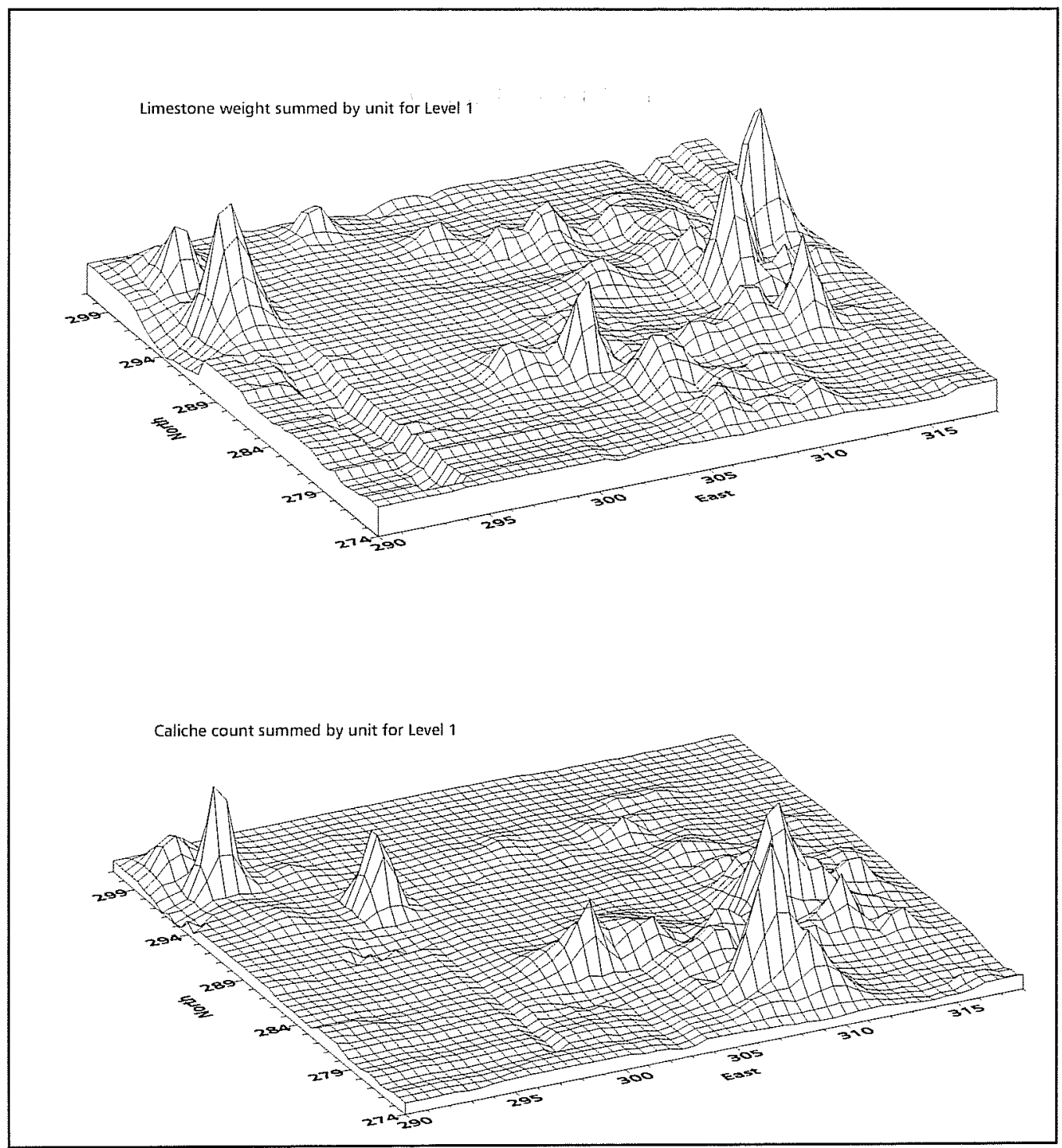

Figure 30. Three-dimensional surface contour map, Block A1, FB 12719. a. limestone weight; b. caliche count.

high, 100 percent of the burned limestone from Feature 30-the only articulated cooking feature at FB 12719-is fractured. Seventy to 80 percent of the feature and non-feature rocks are also void of cortex, indicating an extensive amount of reuse. This supports the importance of curated limestone suggested earlier in the analysis. 
Table 16. FB 12719, Fracture and Cortex Percentages

\begin{tabular}{|c|c|c|c|c|c|c|c|c|c|c|}
\hline \multirow{2}{*}{$\begin{array}{c}\text { Size } \\
\text { Range }\end{array}$} & \multicolumn{2}{|c|}{$\begin{array}{c}\text { Feature } 30 \\
n=114\end{array}$} & \multicolumn{2}{|c|}{$\begin{array}{c}\text { Feature } 32 \\
n=79\end{array}$} & \multicolumn{2}{|c|}{$\begin{array}{c}\text { Feature } 33 \\
n=76\end{array}$} & \multicolumn{2}{|c|}{$\begin{array}{c}\text { Feature } 34 \\
n=110\end{array}$} & \multicolumn{2}{|c|}{$\begin{array}{c}\text { Non-feature } \\
n=1551\end{array}$} \\
\hline & $\begin{array}{c}\% \\
\text { fracture } \\
\text { present }\end{array}$ & $\begin{array}{c}\% \\
\text { cortex } \\
\text { absent }\end{array}$ & $\begin{array}{c}\% \\
\text { fracture } \\
\text { present }\end{array}$ & $\begin{array}{c}\% \\
\text { cortex } \\
\text { absent }\end{array}$ & $\begin{array}{c}\% \\
\text { fracture } \\
\text { present }\end{array}$ & $\begin{array}{c}\% \\
\text { cortex } \\
\text { absent }\end{array}$ & $\begin{array}{c}\% \\
\text { fracture } \\
\text { present }\end{array}$ & $\begin{array}{c}\% \\
\text { cortex } \\
\text { absent }\end{array}$ & $\begin{array}{c}\% \\
\text { fracture } \\
\text { present }\end{array}$ & $\begin{array}{c}\% \\
\text { cortex } \\
\text { absent }\end{array}$ \\
\hline $1-2$ & 100 & 95 & 85 & 65 & 100 & 92 & 89 & 56 & 94 & 60 \\
\hline $3-4$ & 100 & 51 & 83 & 62 & 89 & 39 & 100 & 45 & 95 & 72 \\
\hline $5-6$ & 100 & 67 & 100 & 33 & 100 & 100 & $80^{*}$ & $40^{*}$ & 98 & 95 \\
\hline $7-8$ & - & - & $100 * *$ & $100 * *$ & - & - & - & - & 100 & 100 \\
\hline $9-10$ & - & - & - & - & - & - & - & - & - & - \\
\hline 11 & - & - & 100 & 100 & - & - & - & - & - & - \\
\hline Total \% & 100 & 71 & 94 & 72 & 96 & 77 & 90 & 47 & 97 & 82 \\
\hline
\end{tabular}

*No size 6

**No size 8 


\section{Chapter 6. Summary and Conclusions}

This study included the analysis of 29,058 pieces of fire-cracked rock and burned caliche selected from a sample of hundreds of features tested as part of the Hueco Mountain Archaeological Project. Feature and non-feature material included in this analysis were collected from FB 13237 located, on the proximal fan, FB 12719 within the basin area, and FB 12412 situated in the transitional zone between the two. These three sites were selected to allow potential variability in burned rock features in these differing land forms to be observed.

The goal of the analysis was to identify patterns of attribute variability in burned rock that could be used to gauge the amount of reuse and to infer functions of the various features and sites in the sample. Specific burned rock attributes including material type, size, weight, and the presence or absence of fracturing, cortex, and discoloration were recorded and compared in various combinations at course- and fine-grained levels of intensity to address issues of reuse, recycling, feature function, thermally induced morphological variability, and how these variables might relate to specific land forms through time.

From intersite comparisons, a pattern of expedient material selection was identified based on the increasing frequencies of burned caliche utilization at site FB 12412 in the transitional zone and FB 12719 in the basin, despite the accessibility of limestone located no more than $1.5 \mathrm{~km}$ away. This suggests that limestone itself had no district functional role in the fire-cracked features in this study area. Comparisons of rock size and weight for the total assemblage from each site indicate that over 60 percent of the rocks recovered from each of the three sites is smaller than $2.5 \mathrm{~cm}$ in diameter. Burned rock from features at the three sites are predominately smaller than four centimeters in diameter.

Patterning in feature type was also recognized. Burned-rock features from site FB 13237, located on the rocky proximal fan, include rock-lined hearths, rock-ringed hearths, basin-shaped hearth pits, and burned-rock scatters without discernable pits. Similarly, a basin-shaped hearth pit, a rocklined hearth, and two burned-rock scatters were identified at site FB 12412 in the transitional zone. Aside from the fire-cracked rock and burned caliche associated with pit-structure fill at site FB 12719 in the basin, actual burned-rock feature types are limited to several small hearth features within the structures and one dished-shaped hearth away from the structures.

The rock-lined pit features identified at FB 13237 and FB 12412 are similar to the roasting and/or steaming ovens described ethnographically by Driver and Massey (1957) and historically by Honea (1962) and Tunnell and Madrid (1990) for processing sotol and other bulbous plant materials. As Reid (1989) and Lundberg and Kotschevar (1965) indicate, steaming in layers of hot rock and moist vegetation gelatinizes plant carbohydrates for increased nutritional value and accessibility. Further replicative experimentation is needed to determine whether the variations in amount and size of the rocks in the features from this study resulted in variations in temperature, overall heating efficiency, and/or cooking time or are a function of the quantity of food being processed.

Patterns relating to the issues of reuse and feature function were identified during intrasite and block level comparisons of feature and non-feature burned rock attributes. Through comparisons of non-feature 
and feature size frequencies, weight density plots, and fracture and cortex frequencies areas of extensively reused and subsequently discarded burned rock were identified associated with Features 40 and 46 , the rock-lined hearth pits at site FB 13237. These areas are created as larger rocks lining the bottom of the pits become fractured through use and are subsequently removed from the pit and replaced with larger, more energy efficient stones. Thus, the discard areas demonstrate reuse of these cooking apparatus. Again, detailed experimental work to replicate the context and morphology of the features in question is required before estimates of frequency and duration of reuse can be made. Radiocarbon dates from this site reveal several occupational episodes beginning about 4,100 years ago and ending around 700 years before present (note that these dates only include the excavated features and may not be representative of the occupational history of this site as numerous other features on the site were not tested). No functional differences between features was suggested by size/weight comparisons.

The other site along the Piedmont zone is FB 12412 . This site is situated topographically lower on the Piedmont than FB 13237, in the Transitional zone between the Piedmont and the basin. Unlike the rocky matrix of the upland portions of the Piedmont where FB 13237 is located, the Transitional zone where FB 12412 is found is almost void of rock.

With the exception of Feature 16, a rock-lined pit, the features at FB 12412 are quite different from those noted for FB 13237. Feature 12 is described as a basin-shaped pit and Features 3 and 9 are concentrations of burned caliche and lime-stone. The burned-rock features at the site do not appear to be the result of deflation, as charcoal staining was noted in numerous area. One variable that may be contributing to this pattern is the presence of caliche in the burned rock assemblage at FB 12412. However, if the features at FB 12412 were intended to function in a manner similar to those at FB 13237, we would expect them to be dominated by limestone, as the latter would have been a better medium for heat transfer than caliche (e.g., Duncan and Doleman 1991).
This apparently is not the case at FB 12412. The small size and limited amount of burned limestone recovered suggest that the larger, still usable stone may have been scavenged from these features, or they represent very different feature types than those documented at FB 13237. The former is impossible to determine, but given that mass quantities of unaltered limestone lie within $100 \mathrm{~m}$ of the site, this seems unlikely. The latter is more likely. The lack of rock-lined pits at FB 12412 may indicate a different range of activities for this site and its features. The radiocarbon dates (see sections above) recovered from Features 12 and 16 are within the range of the later feature dates at FB 13237. The exception to this is the Late Archaic date from Feature 46 at site FB 13237.

Non-feature and feature rocks at FB 12412 have the smallest mean size of the three sites in the study although the source of larger limestone rocks is less than $100 \mathrm{~m}$ away. The rocks at FB 12412 also have the highest frequency of fracturing yet retain some of their cortex, suggesting that the small size of the rocks on this site is a reflection of smaller original size as opposed to exhaustive reuse. This suggests that smaller rocks were selected from the source, perhaps for ease of transport or for functional reasons. There is some indication of blocky fracturing from the size/weight comparisons of the rocks at this site. These attributes suggests features at FB 12412 may have functioned as open hearths for a range of tasks (see O'Laughlin 1980; Whalen 1980 ) or may have been associated with stoneboiling activities. Driver and Massey (1957) report that ethnographically stone boiling was the dominant method of food preparation in many areas of North America were pottery was absent and mobility high. Boiling may be a misnomer, however, for as Reid (1989) suggests, simmering is most suitable for stewing meat and rendering oil and grease from seeds and bones. Actual boiling at temperatures above $93^{\circ} \mathrm{C}$ is only adaptive for exploitation of carbohydrate seeds and roots.

The final site considered in this analysis is FB 12719. This site consists of a number of pit structures and floor and non-floor features. Unlike sites FB 13237 and 12412, this site is situated over one kilometer west of the Piedmont area in the 
sandy zone of the central basin. The area is characterized by mesquite stabilized dunes and sheet sands. Other than the occasional small $(<2 \mathrm{~cm})$ gravel, no rock source is present in the basin. The only material available for thermal features is the underlying carbonate zone (caliche).

Features from this site consist of one well-defined hearth (Feature 30), three pit structures (Features 32,33 , and 34), and several small, poorly defined hearths within the structures. Much like the highdensity nodes identified for the sites along the Piedmont, high-density areas adjacent to the bounded features were apparent. While the features and non-feature nodes are clearly distinguishable from the remainder of the excavation block on the bases of burned rock density, they do not display significantly different patterns in rock size. Comparisons of burned rock size (both caliche and limestone) from the bottoms of features with rock from other areas in the block reveals no significant increase in rock size in the features.

By looking at all the burned rock, regardless of material type, we found that the densest burned rock areas by weight are spatially correlated with the location of the pit structures. Analysis of the burned caliche and limestone patterns generated by summing the total weight of burned rock by unit and level reveals that very different patterns could be achieved by performing the same analysis using total counts instead of weights. The patterns generated by total numbers revealed very little patterning in burned limestone and considerable clustering of burned caliche. It also appears that much of the patterning generated by looking at burned rock weights is a result of a small number of rocks as a single piece of burned limestone weighing 500 plus grams can heavily skew a plot. Likewise, large numbers of burned caliche, which appear to be heavily dominated by small pieces at this site, can significantly skew a plot. This is further compounded by the fact that burned rock densities are very low across the site. Just the slightest clustering of burned rock will be manifested as a node in our analysis. As mentioned, the majority of burned rock at this site is small and scattered over a large excavation area.
The presence of burned limestone and other burned non-caliche materials (e.g., quartzite) at the site suggests that non-caliche material may have served a specific functional purpose as they were obviously transported to the site (see Duncan and Doleman 1991). These materials may also have been brought to the site for other purposes (i.e. sandstone for ground-stone tools, quartzite for hammer stones) and eventually recycled as hearth stones. Nonfeature rocks consistently weigh less than feature rocks, repeating the pattern established at the other sites for discard rocks; however, the size distribution of these non-feature rocks more closely resembles the distribution from the hearth feature (Feature 30). Size-to-weight comparisons suggests that some of the rock have blocky fracture patterns while others are curvilinear, indicating a variety of functions. The fracture and cortex frequencies of rocks from the structures features compares more favorably with the non-feature surface rock suggesting the burned rock within the structures represents post-abandonment fill and not discrete features within the structures.

In conclusion, the results of the burned analysis has provided insight to the multiple roles that rock may have played in the systems operating in the Jornada. The presence of rock-lined pits in Piedmont zone are evidence that pit baking was taking place along the toes of the Hueco Mountains. Though the ethnobotanical material recovered from these features was limited, the size of the features and the technology suggests that succulents may have been processed, which is indirectly supported by the presence of succulents growing on the Piedmont and adjacent uplands of the Hueco Mountains (see O'Laughlin 1980 for a further discussion of this relationship).

The Transitional and Basin zone features have a more enigmatic function. The absence of rock-lined bases argues against there use as pit-ovens, or earth ovens. Clearly, until we have experimental data on the cooking requirements of certain foods, and more specifically, what one can cook/bake with just a few hundred grams of rock, their function will remain problematic. 
The presence of relatively large quantities of limestone at the basin site (FB 12719) attests to the importance of this material in the activities conducted at this site. The importance of limestone as a curated item is further supported by the small size of the limestone recovered from the site; presumably due to reuse. The absence of rock-lined pits at the basin site is also of interest. The presence of pit structures and significant amounts of other artifacts and faunal material suggest some level of sedentism and reuse of this location, yet no rocklined earth ovens are present at the site (see Whalen 1994). This suggests that if foodstuffs requiring extended cooking times were exploited, these activities took place off site.

The results of this study are a clear step forward in understanding the variability in burned rock features in the Jornada. As more and more data on burned rock features are amassed in the region, variations in feature morphology and burned-rock attributes through time and space may shed light on the role these features played in the prehistoric cultural systems of the region. However, to fully understand much of the variation in burned rock features, it will be necessary to refine excavation techniques and to conduct well controlled experiments to understand the processes that result in this most abundant of archaeological features.

\section{Comments}

In this analysis we have attempted to investigate the function and reuse of fire-cracked rock and burned caliche features from three sites in the Hueco Bolson through attribute analysis of the burned rock themselves. The set of attributes selected for this analysis were based on experimental results and examples used successfully in other studies of this kind (Duncan and Doleman 1991; Lintz 1989; Mauldin et al. 1994; etc.). Some of these proved useful in pattern recognition from a sample of this size while others were only practical after modifications. Time and budgetary constraints made recording attributes such as number of fractures and percent of cortex remaining for individual rocks impractical in a sample of this size. Instead, the presence/absence of fracturing and the presence/ absence of cortex was recorded for individual rocks within each size class. Although these modifications somewhat limited the degree of information, the resulting percentages did provide useful comparative data that enabled us to recognize patterns of increased intensities of reuse. Similarly, attempts to record blocky/curvilinear fracturing proved too subjective even though all attribute recording was performed only by the authors. The weight-to-size graphs produce patterns at site FB 12412 that indicate a more angular fracture pattern. The attributes used in this study, however, were not appropriate for the analysis of burned caliche. The friable nature of caliche negates size comparisons unless these observations are made in the field before the pieces are subjected to breakage through transport. Likewise, the fracturing and cortex attributes are not applicable to burned caliche.

While successful in identifying patterned variations between firing temperatures used at the study sites, the analysis of the archaeomagnetic data proved less than successful in identifying patterns of feature reuse. Two factors possibly contributed to the unexpected lack of evidence of multiple reuse of burned rock on our sites. 1) The sample size sent for analysis was too small to produce meaningful patterns. This problem is, at least in part, due to the limited number of large rocks available for testing at FB 12412 and FB 12719. 2) Subsequent firings at higher temperatures will erase any record of previous firing at a lower temperature.

This study was successful in identifying patterns of reuse, an issue relevant to understanding formation processes and land-use histories. And, because the collection and analysis did not focus solely on feature rock, the spatial and attribute analyses were able to identifying discard accumulations from density areas not noted during excavation. However, before burned-rock and caliche analyses can be successfully used to infer functional histories of features, comparative, replicable data from experimental studies on local materials must be available. These data should incorporate temperature controls that can be correlated with cooking techniques. Special attributes designed specifically for caliche are also needed. 


\section{References Cited and Project Bibliography}

Abbott, J. T., and C. D. Frederick

1990 Proton Magnetometer Investigations of Burned Rock Middens in West-Central Texas: Clues to Formation Process. Journal of Archaeological Science 17:535-545.

Akins, N.

1985 Fire-cracked Rock. In The Excavation of the Cortez $\mathrm{CO}_{2}$ Pipeline Project Sites, 1982-1983, edited by M. P. Marshall, pp 173-177. Office of Contract Archeology, University of New Mexico, Albuquerque.

Barber, J.

1990 Scottish Burnt Mounds: Variations on a Theme. In Burnt Offerings: International Contributions to Burnt Mound Archaeology, compiled by V. Buckley, pp. 98-104. Wordwell, Academic, Dublin, Ireland.

Barfield, L., and M. Hodder

1987 Burnt Mounds as Saunas and the Prehistory of Bathing. Antiquity 61:370-379.

Bearden, S. E., and J. G. Gallagher

1980 Experimental Thermal Alteration of Dolomite and Limestone. In Evaluation of Cultural Resources at Brantley Reservoir, Eddy County, New Mexico, pp. 444-452. Archeology Research Program, Research Report No. 120, Department of Anthropology, Southern Methodist University, Dallas.

Bellomo, R. V.

1993 A Methodological Approach for Identifying Archaeological Evidence of Fire Resulting from Human Activities. Journal of Archaeological Science 20:525-553.

Binford, L. R.

1978 Nunamiut Ethnoarchaeology. Academic Press, New York.

1983 In Pursuit of the Past: Decoding the Archaeological Record. Thames and Hudson, New York.

1986 An Alyawara Day: Making Men's Knives and Beyond. American Antiquity 51:547-562.

Black, S.

1995 Turning Up the Heat on the Archeology of Hot-Rock Features. Paper presented at Workshop on Hot-Rock Features, Council of Texas Archeologists Meeting, Austin.

Black, S. L., L. W. Ellis, D. G. Creel, and G. T. Goode

1996 Hot Rock Cooking on the Greater Edwards Plateau: Four Burned Rock Midden Sites in West Central Texas. Studies in Archeology, Texas Archeological Research Laboratory, The University of Texas at Austin, review draft.

Blackwelder, E.

1927 Fire as an Agent in Rock Weathering. Journal of Geology 35:134-140. 
1933 The Isolation Hypothesis of Rock Weathering. American Journal of Science, 5th Series 26(152):97-113.

Brink, J. and B. Dawe

1989 Final Report of the 1985 and 1986 Field Seasons at Head-Smashed-In Buffalo Jump, Alberta. Archaeological Survey of Alberta Manuscript Series No. 16, Alberta Culture and Multiculturalism Historical Resources Division, Edmomton, Alberta, Canada.

Brink, J., M. Wright, B. Dawe, and D. Glau

1986 Final Report of the 1984 Season at Head-Smashed-In Buffalo Jump, Alberta. Archaeological Survey of Alberta Manuscript Series No. 9, Alberta Culture and Multiculturalism Historical Resources Division, Edmomton, Alberta, Canada.

Buckley, V. M.

1990 Experiments Using a Reconstructed Fulacht with a Variety of Rock Types: Implications for the Petromorphology of Fulachta Fiadh. In Burnt Offerings: International Contributions to Burnt Mound Archaeology, compiled by V. Buckley, pp.170-172. Wordwell, Academic Publishers, Dublin, Ireland.

1991 Irish Fulachta Fiadh: An Overview. In Burnt Mounds and Hot Stone Technology, edited by M. A. Hodder and L. H. Barfield, pp. 3-9. Sandwell Metropolitan Borough Council, West Midlands, England.

Cain, P. J., S. S. Peng, and E. R. Podnieks

1975 Rock Fragmentation by High-Frequency Fatigue. Report of Investigations 8020, United States Department of the Interior, Bureau of Mines, Washington D.C.

Carmichael, D. C.

1985 Archeological Excavations at Two Prehistoric Campsites near Keystone Dam, El Paso, Texas. University Museum Occasional Papers No. 14. New Mexico State University, Las Cruces.

Cavallo, J.

1984 Fish, Fires, and Foresight: Middle Woodland Economic Adaptations in the Abbott Farm National Landmark, New Jersey. North American Archaeologist 5:111-138.

Collins, M. B., B. Ellis, and C. Dodt-Ellis

1990 Excavations at the Camp Pearl Wheat Site (41KR243): An Early Archaic Campsite on Town Creek, Kerr County, Texas. Studies in Archeology 6. Texas Archeological Research Laboratory, The University of Texas, Austin.

Connor, M. A., K. P. Cannon, and D. C. Carlevato

1989 The Mountains Burnt: Forest Fires and Site Formation Processes. North American Archaeologist, Vol. $10(4): 293-310$.

Creel, D. G.

1991 Assessing the Relationship Between Burned Rock Midden Distribution and Archaic Subsistence in West Central Texas. In The Burned Rock Middens of Texas: An Archeological Symposium, edited by T. R. Hester, pp. 33-43. Studies in Archeology 13, Texas Archeological Research Laboratory, The University of Texas, Austin. 
1986 A Study of Prehistoric Burned Rock Middens in West Central Texas. Ph.D. dissertation, University of Arizona, Tucson.

Dockrill, S. J.

1991 Geophysical Survey of Burnt Mounds in the Northern Isles: The Magnetic Response. In Burnt Mounds and Hot Stone Technology, edited by M. A. Hodder and L. H. Barfield, pp. 35-39. Sandwell Metropolitan Borough Council, West Midlands, England.

Draper, J., and A. Stanfield

1987 The Cultural Significance of Fire-cracked Rock at the Ozette Site: A Preliminary Study. Ms. on file, Department of Anthropology, Washington State University, Pullman.

Driver, H. E., and W. C. Massey

1957 Comparative Studies of North American Indians. Transactions of the American Philosophical Society, Vol. 47, The American Philosophical Society, Philadelphia.

Duncan, R. B., and W. H. Doleman

1991 Fire-Cracked Rock Studies. In Landscape Archeology in the Southern Tularosa Basin, Volume 2, Testing, Excavation, and Analysis. edited by W. H. Doleman, R. C. Chapman, J. A. Schutt, M. K. Swift, and K. D. Morrison, pp. 317-344. Report No. 185-324E, Office of Contract Archeology, University of New Mexico, Albuquerque.

Fisher, J. W., and H. C. Strickland

1989 Ethnoarchaeology Among the Efe Pygmies, Zaire: Spatial Organization of Campsites. American Journal of Physical Anthropology 78:473-484.

Frederick C. D., and J. T. Abbott

1992 Magnetic Prospection of Prehistoric Sites in an Alluvial Environment: Examples From NW and West-central Texas. Journal of Field Archaeology 19:139-153.

Frison, G. C.

1983 Stone Circles, Stone-Filled Fire Pits, Grinding Stones and High Plains Archaeology. Memoir 19, Plains Anthropologist 28(2):81-91.

Griggs, D. T.

1936 The Factor of Fatigue in Rock Exfoliation. Journal of Geology 44:781-796.

Goode, G. T.

1991 Late Prehistoric Burned Rock Middens in Central Texas. In The Burned Rock Middens of Texas: An Archeological Symposium, edited by T. R. Hester, pp. 71-93. Studies in Archeology 13, Texas Archeological Research Laboratory, The University of Texas, Austin.

Hard, R. J.

1983 Excavations in the Caster Range Archeological District in El Paso, Texas. El Paso Centennial Museum Publications in Anthropology No. 11. The University of Texas at El Paso. 
Hard, R. J. , P. Graeber, J. Manasco, C. Tennis, and K. Thuesen

1994 Doña Ana Phase Ceramics and Cultural Evolution in the Southern Jornada Mogollon. Bulletin of the Texas Archeological Society 62/1991:267-283.

Hester, T. R.

1991 Preface. In The Burned Rock Middens of Texas: An Archeological Symposium, edited by T. R. Hester, pp. v-vii. Studies in Archeology 13, Texas Archeological Research Laboratory, The University of Texas, Austin.

Hines, M. H.

1995 Burned Rock Feature Analysis at the Wind Canyon Site, 41HZ119. Paper presented at Workshop on Hot-Rock Features, Council of Texas Archeologists Meeting, Austin.

Hodder, M. A.

1990 Burnt Mounds in the English West Midlands. In Burnt Offerings: International Contributions to Burnt Mound Archaeology, compiled by V. Buckley, pp.106-111. Wordwell, Academic, Dublin, Ireland.

Honea, K. H.

1962 The Rammadyat of Northwest Africa and the Burned Rock Middens of Texas, Bulletin of the Texas Archeological Society 32:317-320.

Hough, W.

1926 Fire as an Agent of Human Culture. Smithsonian Institution, Washington, D.C.

House, J. H., and J. W. Smith

1975 Experiments in Replication of Fire-Cracked Rock. In The Cache River Archeological Project, assembled by M. B. Schiffer and J. H. House, pp. 75-80. Research Series No. 8. Arkansas Archeological Survey, Fayetteville.

Howard, M. A.

1991 Burned Rock Midden Excavations, Hearths and Botanical Remains. In The Burned Rock Middens of Texas: An Archeological Symposium, edited by T. R. Hester, pp. 45-69. Studies in Archeology 13. Texas Archeological Research Laboratory, The University of Texas, Austin.

Hunter, J. R., and S. J. Dockrill

1990 Recent Research into Burnt Mounds on Fair Isle, Shetland, and Sanday, Orkney. In Burnt Offerings: International Contributions to Burnt Mound Archaeology, compiled by V. Buckley, pp. 62-68. Wordwell, Academic, Dublin, Ireland.

Ingbar, E. E.

1985 Analysis of Fire-Cracked Rock and Chipped Stone Assemblages. In Archeological Testing at the Fairchild Site (LA 45732), Otero County, New Mexico, edited by R. Anyon, pp. 44-48. Office of Contract Archeology, University of New Mexico, Albuquerque. 
Jackson, M. A.

1995 A Morphological Analysis of Fire-cracked Rocks from the Northern Rocky Mountain Field School, Kootenai National Forest, Montana. Paper presented at Workshop on Hot-Rock Features, Council of Texas Archeologists Meeting, Austin.

Johnson, L., Jr.

1986 A Plague of Phases. Bulletin of the Texas Archeological Association 57:1-26.

1991 Early Archaic Life at the Sleeper Archaeological Site 41BC65 of the Texas Hill Country, Blanco County, Texas. Report No. 39. Texas State Department of Highways and Public Transportation, Publications in Archeology, Austin.

Johnson, L., and G. T. Goode

1994 A New Try at Dating and Characterizing Holocene Climates, as well as Archeological Periods, on the Eastern Edwards Plateau. Bulletin of the Texas Archeological Association 65:1-51.

Jones, A. E.

1991 The Geophysical Survey of Burnt Mounds: A Study from Acocks Green, Birmingham. In Burnt Mounds and Hot Stone Technology, edited by M. A. Hodder and L. H. Barfield, pp. 31-39. Sandwell Metropolitan Borough Council, West Midlands, England.

Knepper, D., and M. Petraglia

1996 Prehistoric Occupation at the Connoquenessing Site, An Upland Setting in the Upper Ohio River Valley. Archaeology of Eastern North America, [in press].

Latas, T. W.

1992 An Analysis of Fire Cracked Rock: A Sedimentological Approach. In Deciphering a Shell Midden, edited by J. K. Stein, pp. 211-237. Academic, New York.

Larsson, T. B.

1990 Skärvstenshögar - The Burnt Mounds of Sweden. In Burnt Offerings: International Contributions to Burnt Mound Archaeology, compiled by V. Buckley, pp. 142-152. Wordwell, Academic, Dublin, Ireland.

Leach, J. D.

1993 Hot Rocks in the Sand. In Prehistoric and Historic Research Along the Border: Proceedings of the 7th and 8th Jornada-Mogollon Conference, edited by M. Duran. Human Systems Research. In press.

Lintz, C.

1989 Experimental Thermal Discoloration and Heat Conductivity Studies of Caliche from Eastern New Mexico. Geoarchaeology 4(4):319-346.

Lovick, S. K.

1983 Fire-Cracked Rock as Tools: Wear Pattern Analysis. Plains Anthropologist 28(99):41-52.

Lundberg, D. E., and L. H. Kotschevar

1965 Understanding Cooking. The University Store, University of Massachusetts, Amherst. 
McCourt, W. E.

1906 Fire Tests of Some New York Building Stones. Bulletin 100, Economics and Geology 14. New York State Education Department, Albany.

McDowell-Loudan, E. E.

1983 Fire-cracked Rock: Preliminary Experiments to Determine Its Nature and Significance in Archeological Contexts. The Chesopiean 21(1):20-20.

McParland, P.

1977 Experiments in the Firing and Breaking of Rocks. Calgary Archaeologist 5:31-33.

Mauldin, R.

1994 Small Sites in Western Texas and Southern New Mexico. Bulletin of the Texas Archeological Association 65:185-206.

Mauldin, R., T. Graves, and M. Bentley

1994 Small Sites in the Central Hueco Bolson: A Final Report on Project 90-11. Manuscript on file, Directorate of the Environment, Ft. Bliss, Texas. Draft.

Miller, M. R.

1989 Archaeological Excavations at the Gobernadora and Ojasen Sites: Doña Ana Phase Settlement in the Western Hueco Bolson, El Paso County, Texas. Center for Anthropological Research Report No. 673. New Mexico State University, Las Cruces.

1990 Archaeological Investigations in the Northern Hills Subdivision: Late Mesilla and Doña Ana Phase Settlement in Northeast El Paso, El Paso County, Texas. Draft final report submitted to Batcho \& Kaufman Associates. Cultural Resources Report Number 100, El Paso, Texas.

Nixon, M. J.

1990 Some South Cumbrian Burnt Mounds-An Initial Survey. In Burnt Offerings: International Contributions to Burnt Mound Archaeology, compiled by V. Buckley, pp. 112-114. Wordwell, Academic, Dublin, Ireland.

Oakes, Y. R.

1981 Prehistoric Subsistence Adaptations on the White Sands Missile Range. Laboratory of Anthropology Note 277, Museum of New Mexico, Santa Fe.

O’Connell, J. F.

1987 Alyawara Site Structure and Its Archaeological Implications. American Antiquity 52:74-108.

O'Laughlin, T. C.

1980 The Keystone Dam Site and Other Archaic and Formative Sites in Northwest El Paso, Texas. Publications in Anthropology No. 8. The University of Texas at El Paso.

Olive, M., and Y. Taborin

1989 Nature et Fonction des Foyers Préhistoriques. Mémoires du Musée de Préhistoire de France, $\mathrm{n}^{\circ} 2$, Nemours, France. 
Purdy, B. A.

1975 Fractures for the Archeologists. In Lithic Technology, edited by E. Swanson, pp. 133-141. Mouton, The Hague.

Prewitt, E. R.

1991 Burned Rock Middens: A Summary of Previous Investigations and Interpretations. In The Burned Rock Middens of Texas: An Archeological Symposium, edited by T. R. Hester, pp. 25-32. Studies in Archeology 13. Texas Archeological Research Laboratory, The University of Texas, Austin.

Reid, K. C.

1989 A Material Science Perspective on Hunter-Gatherer Pottery. In Pottery Technology: Ideas and Approaches, edited by G. Bronitsky, pp. 167-180. Westview, Boulder.

Ricklis, R. A., and M. B. Collins

1994 Archaic and Late Prehistoric Human Ecology in the Middle Onion Creek Valley, Hays County, Texas. Studies in Archeology No. 19. Texas Archeological Research Laboratory, The University of Texas at Austin.

Russell-White, C. J.

1990a The East Rhins of Galloway. In Burnt Offerings: International Contributions to Burnt Mound Archaeology, compiled by V. Buckley, pp. 70-76. Wordwell, Academic, Dublin, Ireland.

1990b Synthesis. In Burnt Offerings: International Contributions to Burnt Mound Archaeology, compiled by V. Buckley, pp. 87-91. Wordwell, Academic, Dublin, Ireland.

Sanders, P. H., W. Andrefsky, Jr., and S. R. Samuels

1991 The Calispell Valley Archaeological Project Final Report Volume 2. Project Report Number 16. Center for Northwest Anthropology, Washington State University, Pullman.

Schutt, J. A., M. R. Binford, R. B. Duncan, and M. K. Swift

1991 Methods of Lithic and Fire-Cracked Rock Analysis. In Landscape Archeology in the Southern Tularosa Basin, Volume 2, Testing, Excavation, and Analysis. edited by W. H. Doleman, R. C. Chapman, J. A. Schutt, M. K. Swift, and K. D. Morrison, pp. 299-313. Report No. 185-324E, Office of Contract Archeology, University of New Mexico, Albuquerque.

Shiner, J. L., and M. V. Shiner

1977 Structure and Organization of a Burned Rock Midden: The Indian Creek Site, Real County, Texas. Plains Anthropologist 22(2):263-282.

Takac, P.

1995 Vectors of Change: Archaeomagnetic Analysis of the Context, Formation, and Function of Limestone Burned Rock Features in Central Texas. Paper presented at Workshop on Hot-Rock Features, Council of Texas Archeologists Meeting, Austin. 
Thoms, A. V.

1986 Hot Rocks: The Short-Term Storage of Energy in the Calispell Valley. In Calispell Archaeological Project Interim Report for 1984 and 1985 Field Seasons, edited by A. V. Thoms and G. C. Burtchard, pp 447-477. Contributions in Cultural Resource Management No. 10. Center for Northwest Anthropology, Washington State University, Pullman.

1989 The Northern Roots of Hunter-Gatherer Intensification: Camas and the Pacific Northwest. Ph.D. dissertation, Washington State University, Pullman.

Tunnell, C., and E. Madrid

1990 Making and Taking Sotol in Chihuahua and Texas. In Papers from the Third Symposium on Resources of the Chihuahuan Desert Region, edited by A. M. Powell, R. R. Hollander, J. C. Barlow, W. B. McGillivray, and D. J. Schmidly, pp. 145-162. Chihuahuan Desert Research Institute, Sul Ross State University, Alpine, Texas.

Weir, F. A.

1976 The Central Texas Archaic. Ph.D. dissertation, Washington State University, Pullman.

Whalen, M. E.

1977 Settlement Patterns of the Eastern Hueco Bolson. Anthropological Paper No. 4, El Paso Centennial Museum. The University of Texas at El Paso.

1981 Special Studies in the Archaeology of the Hueco Bolson. Publications in Anthropology No. 9. El Paso Centennial Museum. The University of Texas at El Paso.

1994 Turquoise Ridge and the Late Prehistoric Residential Mobility in the Desert Mogollon Region. University of Utah Anthropological Papers, No. 118, Salt Lake City.

White, E. M., and L. A. Hannus

1983 Weathering and Disintegration of Rocks at Oakwood Lake, South Dakota (39BK7). Plains Anthropologist 28(99):53-57.

White, J. R.

1980 A Closer Look at Clusters. American Antiquity 45:66-74.

Williams, G.

1990 Burnt Mounds in South-West Wales. In Burnt Offerings: International Contributions to Burnt Mound Archaeology, compiled by V. Buckley, pp. 129-140. Wordwell, Academic, Dublin, Ireland.

Witkind, W. M.

1977 An Experiment in Stone Boiling. In Hop Hill: Culture and Climatic Change in Central Texas, by J. Gunn and R. Mahula, pp. 205-208. Special Report, No. 5. Center for Archaeological Research, The University of Texas at San Antonio.

Yellen, J. E.

1977 Archaeological Approaches to the Present: Models for Reconstructing the Past. Academic, New York. 


\section{Appendix A: Burned Rock Data by Site}

Key to Codes:

Mat(erial)
$\begin{aligned} & 1 \text { chert } \\ & 2 \text { Rancheria chert } \\ & 3 \text { quartzite } \\ & 4 \text { limestone } \\ & 5 \text { rhyolite } \\ & 6 \text { sandstone } \\ & 7 \text { granitic } \\ & 8 \text { basalt } \\ & 9 \text { vesicular basalt } \\ & 14 \text { caliche } \\ & 15 \text { other } \\ &(10-13 \text { not encountered) }\end{aligned}$

Size (cm)

$\begin{array}{cc}1 & <1.5 \\ 2 & 1.5-2.5 \\ 3 & 2.5-4 \\ 4 & 4-5.5 \\ 5 & 5.5-8 \\ 6 & 8-10.5 \\ 7 & 10.5-13 \\ 8 & 13-15.5 \\ 9 & 15.5-18 \\ 10 & 18-20.5 \\ 11 & 20.5-23 \\ 12 & 23-25.5\end{array}$

Fr: fractured

NF: non-fractured

Disc P: discoloration present

Disc A: discoloration absent

Cort P: cortex present

Cort A: cortex absent

Comm: comments 


\begin{tabular}{|c|c|c|c|c|c|c|c|c|c|c|c|c|c|c|c|}
\hline Site & Coll\# & Feature & LV & Blk & Mat & Size & Grams & Qty & $\mathrm{Fr}$ & $\mathrm{NF}$ & Disc P & Disc A & Cort $P$ & Cort A & Comm \\
\hline 12412 & 100 & & 6 & OA2 & 14 & 2 & 32.19 & 7 & & & 7 & & & & \\
\hline \begin{tabular}{|l|}
12412 \\
\end{tabular} & 100 & & 6 & OA2 & 14 & 1 & 0.4 & 1 & & & 1 & & & & \\
\hline \begin{tabular}{|l|}
12412 \\
\end{tabular} & 100 & & 6 & OA2 & 14 & 3 & 22.24 & 2 & & & 2 & & & & \\
\hline 12412 & 101 & & 6 & OA2 & 14 & 1 & 3.88 & 6 & & & 6 & & & & \\
\hline \begin{tabular}{|l|}
12412 \\
\end{tabular} & 101 & & 6 & OA2 & 14 & 2 & 6.94 & 4 & & & 4 & & & & \\
\hline 12412 & 101 & & 6 & OA2 & 4 & 1 & 1.63 & 1 & 1 & & 1 & & 1 & & \\
\hline 12412 & 101 & & 6 & OA2 & 14 & 3 & 8.2 & 1 & & & 1 & & & & \\
\hline 12412 & 101 & & 6 & OA2 & 4 & 2 & 13.1 & 3 & 3 & & 3 & & 3 & & \\
\hline 12412 & 102 & & 6 & OA2 & 4 & 4 & 15.72 & 1 & & & & & & & \\
\hline 12412 & 102 & & 6 & OA2 & 4 & 2 & \begin{tabular}{|l|l}
100.01 \\
\end{tabular} & 29 & & & 29 & & & & \\
\hline 12412 & 102 & & 6 & OA2 & 14 & 1 & 40.36 & 43 & & & 43 & & & & \\
\hline 12412 & 102 & & 6 & OA2 & 4 & 3 & 66.86 & 6 & & & 6 & & & & \\
\hline 12412 & 103 & & 6 & OA2 & \begin{tabular}{|l|}
14 \\
\end{tabular} & 2 & 20.82 & 5 & & & 5 & & & & \\
\hline 12412 & 103 & & 6 & OA2 & \begin{tabular}{|l|}
14 \\
\end{tabular} & 3 & 6.58 & 1 & & & 1 & & & & \\
\hline 12412 & 103 & & 6 & OA2 & 1 & 1 & 0.7 & 1 & 1 & & 1 & & & 1 & \\
\hline \begin{tabular}{|l|}
12412 \\
\end{tabular} & 103 & & 6 & OA2 & \begin{tabular}{|l|}
14 \\
\end{tabular} & 1 & 1.14 & 2 & & & 2 & & & & \\
\hline 12412 & 103 & & 6 & OA2 & 4 & 1 & 4.62 & 3 & 1 & $\overline{2}$ & 3 & & 3 & & \\
\hline \begin{tabular}{|l|}
12412 \\
\end{tabular} & 103 & & 6 & OA2 & 4 & 2 & 11.99 & 4 & 2 & 2 & 4 & & 4 & & \\
\hline 12412 & 104 & & 6 & OA2 & 4 & 1 & 2.82 & 2 & & 2 & 2 & & 2 & & \\
\hline 12412 & 104 & & 6 & $O A 2$ & 14 & 2 & 16.59 & 6 & & & 6 & & & & \\
\hline 12412 & 104 & & 6 & OA2 & 1 & 1 & 0.31 & 1 & 1 & & 1 & & 1 & & \\
\hline 12412 & 104 & & 6 & OA2 & 4 & 4 & 28.59 & 1 & & 1 & 1 & & 1 & & \\
\hline \begin{tabular}{|l|}
12412 \\
\end{tabular} & 104 & & 6 & OA2 & 4 & 3 & 29.35 & 2 & 1 & 1 & 2 & & 2 & & \\
\hline 12412 & 104 & & 6 & OA2 & 14 & 1 & 6.06 & 9 & & & 9 & & & & \\
\hline 12412 & 104 & & 6 & OA2 & 4 & 2 & 4.88 & 4 & 4 & & 4 & & 4 & & \\
\hline 12412 & 105 & & 6 & $O A 2$ & 14 & 1 & 0.79 & 2 & & & 2 & & & & \\
\hline 12412 & 105 & & 6 & OA2 & 4 & 1 & 0.7 & 2 & 2 & & 2 & & & 2 & \\
\hline 12412 & 105 & & 6 & OA2 & 4 & 2 & 7.54 & 3 & 3 & & 3 & & 2 & 1 & \\
\hline 12412 & 105 & & 6 & OA2 & 14 & 2 & 3.62 & 1 & & & 1 & & & & \\
\hline 12412 & 105 & & 6 & OA2 & 4 & 3 & 17 & 1 & 1 & & 1 & & & 1 & \\
\hline 12412 & 106 & & 6 & $O A 2$ & 14 & 1 & 10.05 & 17 & & & 17 & & & & \\
\hline 12412 & 106 & & 6 & OA2 & 14 & 2 & 49.72 & 26 & & & 26 & & & & \\
\hline 12412 & 106 & & 6 & OA2 & 4 & 3 & 41.21 & 3 & 2 & 1 & 3 & & 3 & & \\
\hline 12412 & 106 & & 6 & OA2 & 14 & 3 & 98.08 & 7 & & & 7 & & & & \\
\hline 12412 & 106 & & 6 & OA2 & 4 & 1 & 6.28 & 7 & 7 & & 7 & & 1 & 6 & \\
\hline 12412 & 106 & & 6 & OA2 & 14 & 4 & 41.52 & 1 & & & 1 & & & & \\
\hline 12412 & 106 & & 6 & OA2 & 4 & 4 & 88.07 & 1 & & 1 & 1 & & 1 & & \\
\hline 12412 & 106 & & 6 & OA2 & 4 & 2 & 21.72 & 7 & 7 & & 7 & & 4 & 3 & \\
\hline 12412 & 107 & & 6 & OA2 & 14 & 2 & 22.89 & 8 & & & 8 & & & & \\
\hline 12412 & 107 & & 6 & OA2 & 14 & 1 & 2.27 & 6 & & & 6 & & & & \\
\hline 12412 & 108 & & 6 & OA2 & 4 & 4 & 71.24 & 2 & 2 & & 2 & & 1 & 1 & \\
\hline 12412 & 108 & & 6 & OA2 & 14 & 2 & 37.27 & 10 & & & 10 & & & & \\
\hline 12412 & 108 & & 6 & OA2 & 4 & 1 & 0.68 & 2 & 2 & & 2 & & & 2 & \\
\hline 12412 & 108 & & 6 & OA2 & 4 & 3 & 9.23 & 1 & 1 & & 1 & & 1 & & \\
\hline 12412 & 108 & & 6 & OA2 & 4 & 2 & 3.22 & 3 & 3 & & 3 & & 1 & 2 & \\
\hline 12412 & 108 & & 6 & OA2 & 14 & 3 & 13.66 & 2 & & & 2 & & & & \\
\hline 12412 & 108 & & 6 & OA2 & 14 & 4 & 33.15 & 1 & & & 1 & & & & \\
\hline 12412 & 108 & & 6 & OA2 & 14 & 1 & 4.97 & 7 & & & 7 & & & & \\
\hline \begin{tabular}{|l|}
12412 \\
\end{tabular} & 109 & & 6 & OA2 & 14 & 4 & 24.81 & 1 & & & 1 & & & & \\
\hline 12412 & 109 & & 6 & OA2 & 14 & 2 & 42.18 & 14 & & & 14 & & & & \\
\hline 12412 & 109 & & 6 & OA2 & 14 & 3 & 39.58 & 14 & & & 14 & & & & \\
\hline 12412 & 109 & & 6 & OA2 & 14 & 1 & 5.36 & 6 & & & 6 & & & & \\
\hline 12412 & 112 & & 6 & OA2 & 4 & 2 & 1.14 & 1 & & & & 1 & & 1 & \\
\hline 12412 & 112 & & 6 & OA2 & 4 & 1 & 0.92 & 1 & 1 & & 1 & & & 1 & \\
\hline 12412 & 112 & & 6 & OA2 & 14 & 1 & 3.34 & 6 & & & 6 & & & & \\
\hline 12412 & 112 & & 6 & OA2 & 14 & 2 & 14.56 & 6 & & & 6 & & & & \\
\hline 12412 & 113 & & 6 & OA2 & 4 & 2 & 2.34 & 1 & 1 & & 1 & & 1 & & \\
\hline 12412 & 113 & & 6 & OA2 & 14 & 1 & 7.19 & 5 & & & 5 & & & & \\
\hline 12412 & 113 & & 6 & OA2 & 4 & 1 & 2.9 & 5 & 5 & & 5 & & 5 & & \\
\hline 12412 & 114 & & 7 & $O A 2$ & 14 & 2 & 20.53 & 8 & & & 8 & & & & \\
\hline 12412 & 114 & & 7 & OA2 & 4 & 2 & 22.7 & 6 & 6 & & 6 & & 3 & 3 & \\
\hline 12412 & 114 & & 7 & OA2 & 14 & 1 & 5.46 & 8 & & & 8 & & & & \\
\hline 12412 & 114 & & 7 & OA2 & 4 & 1 & 0.96 & 4 & 4 & & 4 & & 2 & 2 & \\
\hline 12412 & 114 & & 7 & OA2 & 14 & 3 & 18.25 & 2 & & & 2 & & & & \\
\hline 12412 & 114 & & 7 & OA2 & 4 & 3 & 10.36 & 1 & 1 & & 1 & & 1 & & \\
\hline
\end{tabular}




\begin{tabular}{|c|c|c|c|c|c|c|c|c|c|c|c|c|c|c|c|}
\hline Site & Coll \# & Feature & LV & Blk & Mat & Size & Grams & Qty & $\mathrm{Fr}$ & $\mathrm{NF}$ & Disc $\mathrm{P}$ & Disc A & Cort $P$ & Cort A & Comm \\
\hline 12412 & 115 & & 6 & OA2 & 4 & 3 & 20.75 & 1 & 1 & & 1 & & 1 & & \\
\hline 12412 & 115 & & 6 & OA2 & 4 & 1 & 0.74 & 2 & 2 & & 2 & & & 2 & \\
\hline 12412 & 115 & & 6 & OA2 & 14 & 1 & 2.71 & 4 & & & 4 & & & & \\
\hline 12412 & 115 & & 6 & OA2 & 14 & 2 & 10.59 & 5 & & & 5 & & & & \\
\hline 12412 & 115 & & 6 & OA2 & 4 & 2 & 16.8 & 5 & 5 & & 5 & & 2 & 3 & \\
\hline 12412 & 116 & & 6 & OA2 & 4 & 1 & 8.79 & 12 & 12 & & 12 & & 2 & 10 & \\
\hline 12412 & 116 & & 6 & OA2 & 4 & 2 & 11.03 & 3 & 3 & & 3 & & 3 & & \\
\hline 12412 & 116 & & 6 & OA2 & 14 & 1 & 0.59 & 1 & & & 1 & & & & \\
\hline 12412 & 117 & & 6 & OA2 & 1 & 1 & 0.41 & 1 & 1 & & & & & 1 & \\
\hline 12412 & 117 & & 6 & OA2 & 4 & 3 & 11.55 & 1 & 1 & & 1 & & 1 & & \\
\hline 12412 & 117 & & 6 & OA2 & 14 & 2 & 16.59 & 8 & & & 8 & & & & \\
\hline 12412 & 117 & & 6 & OA2 & 14 & 1 & 7.29 & 9 & 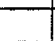 & & 9 & & & & \\
\hline 12412 & 117 & & 6 & OA2 & 4 & 4 & 26.46 & 1 & & 1 & 1 & & 1 & & \\
\hline 12412 & 117 & & 6 & OA2 & 1 & 1 & 2.62 & 1 & 1 & & 1 & & 1 & & \\
\hline 12412 & 117 & & 6 & OA2 & 4 & 2 & 18.85 & 7 & 7 & & 7 & & 2 & 5 & \\
\hline 12412 & 119 & & 6 & OA2 & 4 & 2 & 6.56 & 4 & 4 & & 4 & & 2 & 2 & \\
\hline 12412 & 119 & & 6 & OA2 & 14 & 1 & 2.89 & 3 & & & 3 & & & & \\
\hline 12412 & 119 & & 6 & OA2 & 4 & 1 & 8.55 & 12 & 11 & 1 & 12 & & 2 & 10 & \\
\hline 12412 & 119 & & 6 & OA2 & 14 & 2 & 21.29 & 6 & & & 6 & & & & \\
\hline 12412 & 119 & & 6 & OA2 & 14 & 3 & 36.65 & 2 & & & 2 & & & & \\
\hline 12412 & 119 & & 6 & OA2 & 4 & 3 & 12.21 & 1 & 1 & & 1 & & & 1 & \\
\hline 12412 & 120 & & 6 & OA2 & 4 & 3 & 6.55 & 1 & 1 & & 1 & & 1 & & \\
\hline 12412 & 120 & & 6 & OA2 & 4 & 1 & 1.72 & 1 & 1 & & 1 & & & 1 & \\
\hline 12412 & 120 & & 6 & OA2 & 4 & 2 & 16.56 & 3 & 3 & & 3 & & 1 & 2 & \\
\hline 12412 & 120 & & 6 & OA2 & 14 & 2 & 6.95 & 1 & & & 1 & & & & \\
\hline 12412 & 120 & & 6 & OA2 & 14 & 1 & 1.32 & 1 & & & 1 & & & & \\
\hline 12412 & 121 & & 6 & OA2 & 14 & 1 & 0.76 & 1 & & & 1 & & & & \\
\hline 12412 & 121 & & 6 & OA2 & 4 & 2 & 5.05 & 1 & 1 & & 1 & & 1 & & \\
\hline 12412 & 121 & & 6 & OA2 & 14 & 2 & \begin{tabular}{l|l}
3.9 \\
\end{tabular} & 2 & & & 2 & & & & \\
\hline 12412 & 121 & & 6 & OA2 & 14 & 3 & 5.5 & 1 & & & 1 & & & & \\
\hline 12412 & 122 & & 6 & OA2 & 4 & 2 & 64.93 & 25 & 25 & & 25 & & 6 & 19 & \\
\hline 12412 & 122 & & 6 & OA2 & 4 & 1 & 11.5 & 15 & 15 & & 15 & & 7 & 8 & \\
\hline 12412 & 122 & & 6 & OA2 & 1 & 1 & 0.24 & 1 & 1 & & 1 & & & 1 & \\
\hline 12412 & 122 & & 6 & OA2 & 14 & 1 & 0.97 & 2 & & & 2 & & & & \\
\hline 12412 & 122 & & 6 & OA2 & 4 & 3 & 55.51 & 3 & 3 & & 3 & & 2 & 1 & \\
\hline 12412 & 122 & & 6 & OA2 & 14 & 2 & 3.19 & 2 & 2 & & 2 & & & & \\
\hline 12412 & 123 & & 6 & OA2 & 4 & 1 & 2.78 & 7 & 7 & & 7 & & & 7 & \\
\hline 12412 & 123 & & 6 & OA2 & 14 & 1 & 6.02 & 6 & & & 6 & & & & \\
\hline 12412 & 123 & & 6 & OA2 & 4 & 2 & 43.53 & 15 & 14 & 1 & 15 & & 3 & 12 & \\
\hline 12412 & 123 & & 6 & OA2 & 14 & 2 & 16.35 & 3 & & & 3 & & & & \\
\hline 12412 & 123 & & 6 & OA2 & 4 & 3 & 15.45 & 2 & 1 & 1 & 2 & & 1 & 1 & \\
\hline 12412 & 124 & & 6 & OA2 & 14 & 2 & 20.56 & 4 & & & 4 & & & & \\
\hline 12412 & 124 & & 6 & OA2 & 4 & 1 & 2.54 & 3 & 3 & & 3 & & 1 & 2 & \\
\hline 12412 & 124 & & 6 & OA2 & 14 & 1 & 2.57 & 3 & & & 3 & & & & \\
\hline 12412 & 125 & & 6 & OA2 & 4 & 1 & 5.23 & 7 & 7 & & 7 & & 2 & 5 & \\
\hline 12412 & 125 & & 6 & OA2 & 14 & 5 & 46.4 & 1 & & & 1 & & & & \\
\hline 12412 & 125 & & 6 & $\overline{O A 2}$ & 4 & 2 & 11.25 & 1 & 1 & & 1 & & & 1 & \\
\hline 12412 & 125 & & 6 & $\overline{O A 2}$ & 14 & 2 & 29.65 & 5 & & & 5 & & & & \\
\hline 12412 & 125 & & 6 & OA2 & 14 & 1 & 5.45 & 8 & & & 8 & & & & \\
\hline 12412 & 126 & & 6 & OA2 & 14 & 1 & 6.63 & 8 & & & 8 & & & & \\
\hline 12412 & 126 & & 6 & OA2 & 14 & 2 & 16.26 & 4 & & & 4 & & & & \\
\hline 12412 & 126 & & 6 & OA2 & 4 & 1 & 3.82 & 3 & 3 & & 3 & & & 3 & \\
\hline 12412 & \begin{tabular}{l|l}
126 \\
\end{tabular} & & 6 & OA2 & 4 & 2 & 5.75 & 3 & 3 & & 3 & & & 3 & \\
\hline 12412 & 126 & & 6 & OA2 & 4 & 3 & 29.91 & 1 & & 1 & 1 & & 1 & & \\
\hline 12412 & 126 & & 6 & $O A 2$ & 14 & 3 & 14.23 & 1 & & & 1 & & & & \\
\hline 12412 & 127 & & 6 & OA2 & 14 & 1 & 1.2 & 2 & & & 2 & & & & \\
\hline 12412 & 127 & & 6 & OA2 & 4 & 2 & 4.64 & 2 & 2 & & 2 & & 1 & 1 & \\
\hline 12412 & \begin{tabular}{|l|}
127 \\
\end{tabular} & & 6 & OA2 & 14 & 4 & 52.12 & 1 & & & 1 & & & & \\
\hline 12412 & 127 & & 6 & OA2 & 4 & 3 & \begin{tabular}{|c|}
7.97 \\
\end{tabular} & 1 & 1 & & 1 & & 1 & & \\
\hline 12412 & \begin{tabular}{|l|}
127 \\
\end{tabular} & & 6 & OA2 & 4 & 1 & 1.85 & 2 & 2 & & 2 & & & 2 & \\
\hline 12412 & 127 & & 6 & $\overline{O A 2}$ & 14 & 2 & 29.09 & 7 & & & 7 & & & & \\
\hline 12412 & 128 & & 6 & OA2 & 14 & 4 & 46.17 & 1 & & & 1 & & & & \\
\hline 12412 & 128 & & 6 & $\overline{O A 2}$ & 14 & 2 & 23.13 & 6 & & & 6 & & & & \\
\hline 12412 & 128 & & 6 & OA2 & 14 & 1 & 2.18 & 5 & & & 5 & & & & \\
\hline 12412 & 129 & & 6 & $\mathrm{OA2}$ & 4 & 2 & 14.1 & 6 & 6 & & 6 & & 2 & 4 & \\
\hline
\end{tabular}




\begin{tabular}{|c|c|c|c|c|c|c|c|c|c|c|c|c|c|c|c|}
\hline Site & Coll \# & Feature & $\mathrm{LV}$ & Blk & Mat & Size & Grams & Qty & $\mathrm{Fr}$ & $\mathrm{NF}$ & Disc P & Disc A & Cort $\mathrm{P}$ & Cort A & Comm \\
\hline 12412 & 129 & & 6 & OA2 & 4 & 3 & 44.62 & 5 & 3 & 2 & 5 & & 4 & 1 & \\
\hline 12412 & 129 & & 6 & OA2 & 4 & 1 & 0.7 & 1 & 1 & & 1 & & & 1 & \\
\hline 12412 & 129 & & 6 & OA2 & 1 & 2 & 2.23 & 1 & 1 & & 1 & & & 1 & \\
\hline 12412 & 130 & & 6 & OA2 & 14 & 1 & 4.45 & 5 & & & 5 & & & & \\
\hline 12412 & 130 & & 6 & OA2 & 14 & 2 & 15.18 & 5 & & & 5 & & & & \\
\hline 12412 & 130 & & 6 & OA2 & 14 & 3 & 6.71 & 1 & & & 1 & & & & +1 flake \\
\hline 12412 & 131 & & 6 & OA2 & 14 & 1 & 4.02 & 2 & & & 2 & & & & \\
\hline 12412 & 131 & & 6 & OA2 & 4 & 2 & 10.95 & 5 & 5 & & 5 & & 1 & 4 & \\
\hline 12412 & 131 & & 6 & OA2 & 4 & 3 & 24.77 & 3 & 3 & & 3 & & 1 & 2 & \\
\hline 12412 & 131 & & 6 & OA2 & 4 & 4 & 15.82 & 1 & 1 & & 1 & & 1 & & \\
\hline 12412 & 131 & & 6 & OA2 & 4 & 1 & 9.22 & 10 & 10 & & 10 & & & 10 & \\
\hline 12412 & 131 & & 6 & OA2 & 1 & 2 & 0.95 & 1 & & & 1 & & & & \\
\hline 12412 & 132 & & 6 & OA2 & 14 & 2 & 16.98 & 6 & & & 6 & & & & \\
\hline 12412 & 132 & & 6 & OA2 & 4 & 1 & 0.57 & 2 & 2 & & 2 & & & 2 & \\
\hline 12412 & 132 & & 6 & OA2 & 4 & 2 & 8.69 & 3 & 2 & 1 & 3 & & 2 & 1 & \\
\hline 12412 & 132 & & 6 & OA2 & 14 & 1 & 2.68 & 6 & & & 6 & & & & \\
\hline 12412 & 133 & & 6 & OA2 & 14 & 1 & 7.94 & 11 & & & 11 & & & & \\
\hline 12412 & 133 & & 6 & OA2 & 4 & 3 & 65.32 & 6 & 6 & & 6 & & 4 & 2 & \\
\hline 12412 & 133 & & 6 & OA2 & 4 & 4 & 57.53 & 2 & 2 & & 2 & & 2 & & \\
\hline 12412 & 133 & & 6 & OA2 & 14 & 2 & 19.42 & 5 & & & 5 & & & & \\
\hline 12412 & 133 & & 6 & OA2 & 1 & 2 & \begin{tabular}{|l|}
3.79 \\
\end{tabular} & 2 & 2 & & 2 & & & 2 & \\
\hline 12412 & 133 & & 6 & OA2 & 4 & 2 & 64.04 & 22 & 22 & & 22 & & 8 & 12 & \\
\hline 12412 & 133 & & 6 & OA2 & 4 & 1 & 14.75 & 28 & 28 & & 28 & & 4 & 24 & \\
\hline 12412 & 133 & & 6 & OA2 & 1 & 1 & 0.47 & 1 & 1 & & 1 & & & 1 & \\
\hline 12412 & 134 & & 6 & OA2 & 4 & 2 & 9.34 & 3 & 3 & & 3 & & 2 & 1 & \\
\hline 12412 & 134 & & 6 & OA2 & 4 & 1 & 2.66 & 7 & 7 & & 7 & & 2 & 5 & \\
\hline 12412 & 135 & & 6 & OA2 & 4 & 4 & 26.78 & 1 & & 1 & 1 & & 1 & & \\
\hline 12412 & 135 & & 6 & OA2 & 14 & 2 & 2.16 & 1 & & & 1 & & & & \\
\hline 12412 & \begin{tabular}{l|l|}
135 \\
\end{tabular} & & 6 & OA2 & 14 & 1 & 1.57 & 2 & & & 2 & & & & \\
\hline 12412 & 135 & & 6 & OA2 & 4 & 2 & 1.27 & 1 & 1 & & 1 & & 1 & & \\
\hline 12412 & $\begin{array}{l}136 \\
\end{array}$ & & 6 & OA2 & 4 & 2 & 13.53 & 5 & 5 & & 5 & & 2 & 3 & \\
\hline 12412 & 136 & & 6 & \begin{tabular}{|l|} 
OA2 \\
\end{tabular} & 4 & 4 & 20.66 & 1 & 1 & & 1 & & 1 & & \\
\hline 12412 & 136 & & 6 & OA2 & 14 & 2 & 6.91 & 3 & & & 3 & & & & \\
\hline 12412 & 136 & & 6 & OA2 & 4 & 3 & 19.55 & 1 & & 1 & 1 & & 1 & & \\
\hline 12412 & 136 & & 6 & $\overline{O A 2}$ & 4 & 1 & 3.54 & 7 & 7 & & 7 & & 2 & 5 & \\
\hline 12412 & 136 & & 6 & $\mathrm{OA2}$ & 14 & 1 & 1.93 & 4 & & & 4 & & & & \\
\hline 12412 & 137 & & 6 & $\overline{O A 2}$ & 4 & 1 & 4.75 & 10 & 9 & 1 & 10 & & 1 & 9 & \\
\hline 12412 & 137 & & 6 & OA2 & 4 & 3 & 4.22 & 1 & 1 & & 1 & & & 1 & \\
\hline 12412 & 137 & & 6 & OA2 & 4 & 2 & 8.11 & 3 & 2 & 1 & 3 & & 2 & 1 & \\
\hline 12412 & 138 & & 6 & $\overline{O A 2}$ & 14 & 2 & \begin{tabular}{l|l|}
6.74 \\
\end{tabular} & 2 & & & 2 & & & & \\
\hline 12412 & 138 & & 6 & $\overline{O A 2}$ & 14 & 1 & 4.97 & 4 & & & 4 & & & & \\
\hline 12412 & 139 & & 6 & OA2 & 4 & 1 & \begin{tabular}{|l|l|}
7.18 \\
\end{tabular} & 10 & 10 & & 10 & & 4 & 6 & \\
\hline 12412 & 139 & & 6 & OA2 & 14 & 4 & \begin{tabular}{|l|}
17.13 \\
\end{tabular} & 1 & & & 1 & & & & \\
\hline 12412 & 139 & & 6 & $\overline{O A 2}$ & 14 & 2 & 11.31 & 4 & & & 4 & & & & \\
\hline 12412 & 139 & & 6 & OA2 & 4 & 3 & 27.51 & 3 & 3 & & 3 & & 3 & & \\
\hline 12412 & 139 & & 6 & OA2 & 14 & 1 & 4.94 & 4 & & & 4 & & & & \\
\hline 12412 & 139 & & 6 & OA2 & 4 & 2 & \begin{tabular}{l|l|}
6.87 \\
\end{tabular} & 2 & 1 & 1 & 2 & & 1 & 1 & \\
\hline 12412 & 140 & & 6 & OA2 & 4 & 3 & 8.69 & 1 & 1 & & 1 & & & 1 & \\
\hline 12412 & 140 & & 6 & OA2 & 4 & 1 & \begin{tabular}{l|l|}
0.62 \\
\end{tabular} & 1 & 1 & & 1 & & & 1 & \\
\hline 12412 & 140 & & 6 & OA2 & 14 & 2 & \begin{tabular}{|l|}
8.35 \\
\end{tabular} & 5 & & & 5 & & & & \\
\hline 12412 & 140 & & 6 & OA2 & 4 & 2 & 11 & 3 & 3 & & 3 & & 2 & 1 & \\
\hline 12412 & 140 & & 6 & \begin{tabular}{|l|}
$\mathrm{OA} 2$ \\
\end{tabular} & 14 & 1 & 9.51 & 17 & & & 17 & & & & \\
\hline 12412 & 142 & 9 & 6 & OA2 & 4 & 2 & \begin{tabular}{|l|l|}
5.75 \\
\end{tabular} & 3 & 3 & & 3 & & 3 & & \\
\hline 12412 & 142 & 9 & 6 & OA2 & 4 & 1 & 3.19 & 6 & 6 & & 6 & & 2 & 4 & \\
\hline 12412 & 142 & 9 & 6 & OA2 & 14 & 2 & 12.03 & 5 & & & 5 & & & & \\
\hline 12412 & 142 & 9 & 6 & $\overline{O A 2}$ & 14 & 1 & 3.15 & 3 & & & 3 & & & & \\
\hline 12412 & 142 & 9 & 6 & $\overline{\mathrm{OA} 2}$ & 4 & 4 & 10.32 & 1 & 1 & & 1 & & & 1 & \\
\hline 12412 & 143 & & 6 & \begin{tabular}{|l|} 
OA2 \\
\end{tabular} & 4 & 2 & 4.16 & 2 & 2 & & 2 & & & 2 & \\
\hline 12412 & 143 & & 6 & OA2 & 14 & 1 & 1.29 & 2 & & & 2 & & & & \\
\hline 12412 & 143 & & 6 & $\overline{\mathrm{OA} 2}$ & 14 & 2 & 5.82 & 4 & & & 4 & & & & \\
\hline$\frac{\mid 2412}{12412}$ & 144 & & 6 & OA2 & 4 & 3 & 32.36 & 2 & 2 & & 2 & & 1 & 1 & \\
\hline 12412 & 144 & & 6 & OA2 & 4 & 3 & 32.36 & 2 & 2 & & 2 & & 1 & 1 & \\
\hline 12412 & 144 & & 6 & OA2 & 14 & 1 & 6.03 & 10 & & & 10 & & & & \\
\hline 12412 & 144 & & 6 & $\overline{\mathrm{OA} 2}$ & 4 & 5 & 129.72 & 2 & 1 & 1 & 2 & & 2 & & \\
\hline 12412 & 144 & & 6 & $\overline{O A 2}$ & 4 & 1 & $\begin{array}{l}6.69 \\
\end{array}$ & 11 & 11 & & 11 & & 2 & 8 & \\
\hline
\end{tabular}




\begin{tabular}{|c|c|c|c|c|c|c|c|c|c|c|c|c|c|c|c|}
\hline Site & Coll \# & Feature & Lv & Blk & Mat & Size & \begin{tabular}{|l|} 
Grams \\
\end{tabular} & Qty & $\mathrm{Fr}$ & $\mathrm{NF}$ & Disc P & Disc A & Cort P & Cort A & Comm \\
\hline 12412 & 144 & & 6 & OA2 & 4 & 4 & 19.1 & 1 & & 1 & 1 & & 1 & & \\
\hline \begin{tabular}{|l|l|}
12412 \\
\end{tabular} & 144 & & 6 & OA2 & 4 & 2 & 40.06 & 15 & 14 & 1 & 15 & & 4 & 11 & \\
\hline 12412 & 144 & & 6 & $O A 2$ & 14 & 2 & 4 & 2 & & & 2 & & & & \\
\hline \begin{tabular}{|l|}
12412 \\
\end{tabular} & 144 & & 6 & OA2 & 14 & 2 & 4 & 2 & & & 2 & & & & \\
\hline \begin{tabular}{|l|}
12412 \\
\end{tabular} & 144 & & 6 & $O A 2$ & 14 & 3 & 33.09 & 3 & & & 3 & & & & \\
\hline 12412 & 144 & & 6 & OA2 & 4 & 2 & 40.06 & 15 & 14 & 1 & 15 & & 4 & 11 & \\
\hline \begin{tabular}{|l|}
12412 \\
\end{tabular} & 144 & & 6 & OA2 & 4 & 4 & 19.1 & 1 & & 1 & 1 & & 1 & & \\
\hline \begin{tabular}{|l|}
12412 \\
\end{tabular} & 144 & & 6 & OA2 & 14 & 3 & 33.09 & 3 & & & 3 & & & & \\
\hline \begin{tabular}{|l|}
12412 \\
\end{tabular} & 144 & & 6 & OA2 & 4 & 5 & 129.72 & 2 & 1 & 1 & 2 & & 2 & & \\
\hline \begin{tabular}{|l|}
12412 \\
\end{tabular} & 144 & & 6 & OA2 & 14 & 1 & 6.03 & 10 & & & 10 & & & & \\
\hline \begin{tabular}{|l|}
12412 \\
\end{tabular} & 145 & & 6 & OA2 & 14 & 1 & 6.21 & 10 & & & 10 & & & & \\
\hline \begin{tabular}{|l|}
12412 \\
\end{tabular} & 145 & & 6 & OA2 & 14 & 2 & 10.19 & 4 & & & 4 & & & & \\
\hline \begin{tabular}{|l|}
12412 \\
\end{tabular} & 145 & & 6 & OA2 & 4 & 1 & 9.83 & 13 & 12 & 1 & 13 & & 4 & 9 & \\
\hline 12412 & 145 & & 6 & $\overline{0 A 2}$ & 4 & 2 & 24.01 & 9 & 8 & 1 & 9 & & 3 & 6 & \\
\hline \begin{tabular}{|l|}
12412 \\
\end{tabular} & 145 & & 6 & $0 A 2$ & 4 & 4 & 35.26 & 3 & 2 & 1 & 3 & & 3 & & \\
\hline \begin{tabular}{|l|}
12412 \\
\end{tabular} & 145 & & 6 & OA2 & 14 & 3 & 13.05 & 1 & & & 1 & & & & \\
\hline \begin{tabular}{|l|}
12412 \\
\end{tabular} & 146 & 9 & 6 & OA2 & 14 & 3 & 27 & 2 & & & 2 & & & & \\
\hline \begin{tabular}{|l|}
12412 \\
\end{tabular} & 147 & 9 & 6 & $0 A 2$ & 4 & 2 & 45.94 & 19 & 17 & 2 & 19 & & 5 & 14 & \\
\hline \begin{tabular}{|l|}
12412 \\
\end{tabular} & 147 & 9 & 6 & $0 A 2$ & 14 & 2 & 13.25 & 5 & & & 5 & & & & \\
\hline \begin{tabular}{|l|}
12412 \\
\end{tabular} & 147 & 9 & 6 & OA2 & 4 & 3 & 66.03 & 7 & 7 & & 7 & & 5 & 2 & \\
\hline \begin{tabular}{|l|}
12412 \\
\end{tabular} & 147 & 9 & 6 & $\overline{0 A 2}$ & 4 & 5 & 201.9 & 1 & 1 & & 1 & & 1 & & \\
\hline \begin{tabular}{|l|}
12412 \\
\end{tabular} & 147 & 9 & 6 & $0 \mathrm{~A} 2$ & 14 & 1 & 14.37 & 10 & & & 10 & & & & \\
\hline \begin{tabular}{|l|}
12412 \\
\end{tabular} & 147 & 9 & 6 & OA2 & 14 & 3 & 46.06 & 4 & & & 4 & & & & \\
\hline \begin{tabular}{|l|}
12412 \\
\end{tabular} & 147 & 9 & 6 & OA2 & 4 & 1 & 16.11 & 18 & 18 & & 18 & & 2 & 16 & \\
\hline \begin{tabular}{|l|}
12412 \\
\end{tabular} & 147 & 9 & 6 & OA2 & 4 & 4 & 39.35 & 3 & 3 & & 3 & & & 3 & \\
\hline \begin{tabular}{|l|}
12412 \\
\end{tabular} & 148 & & 6 & OA2 & 4 & 4 & 24.2 & 1 & 1 & 0 & 1 & & 1 & & \\
\hline \begin{tabular}{|l|}
12412 \\
\end{tabular} & 148 & & 6 & DA2 & 4 & 1 & 0.83 & 2 & 2 & 0 & 2 & & 0 & 2 & \\
\hline \begin{tabular}{|l|}
12412 \\
\end{tabular} & 148 & & 6 & OA2 & 4 & 2 & 19.67 & 6 & 5 & 1 & 6 & & 2 & 4 & \\
\hline \begin{tabular}{|l|}
12412 \\
\end{tabular} & 149 & & 6 & DA2 & 14 & 1 & 4.31 & 9 & & & 9 & & & & \\
\hline 12412 & 149 & & 6 & OA2 & 14 & 3 & 8.1 & 1 & & & 1 & & & & \\
\hline 12412 & 149 & & 6 & OA2 & 14 & 2 & 3.43 & 3 & & & 3 & & & & \\
\hline 12412 & 149 & & 6 & $\overline{O A} 2$ & 4 & 2 & 23.72 & 6 & 6 & & 6 & & & 6 & \\
\hline 12412 & 149 & & 6 & $0 A 2$ & 4 & 1 & 2.51 & 4 & 4 & & 4 & & 3 & 1 & \\
\hline 12412 & 149 & & 6 & IOA2 & 4 & 3 & 25.15 & 2 & 2 & & 2 & & 2 & & \\
\hline 12412 & 150 & & 6 & OA2 & 14 & 3 & 27 & 2 & & & 2 & & & & \\
\hline 12412 & 150 & & 6 & OA2 & 14 & 2 & 19.09 & 11 & & & 11 & & & & \\
\hline 12412 & 150 & & 6 & OA2 & 4 & 3 & 79.8 & 6 & 6 & & 6 & & 3 & 3 & \\
\hline 12412 & 150 & & 6 & OA2 & 4 & 1 & 3.23 & 5 & 5 & & 5 & & & 5 & \\
\hline \begin{tabular}{|l|}
12412 \\
\end{tabular} & 150 & & 6 & OA2 & 4 & 2 & 11.27 & 3 & 3 & & 3 & & & 3 & \\
\hline 12412 & 150 & & 6 & OA2 & 14 & 6 & 38.07 & 1 & & & 1 & & & & \\
\hline 12412 & 150 & & 6 & OA2 & 14 & 1 & 16.52 & 28 & & & 28 & & & & \\
\hline 12412 & 150 & & 6 & $\overline{0 A 2}$ & 14 & 4 & 26.52 & 1 & & & 1 & & & & \\
\hline \begin{tabular}{|c|}
12412 \\
\end{tabular} & 151 & & 6 & $\overline{\mathrm{A} 2}$ & 4 & 1 & 2.72 & 3 & 3 & & 3 & & & 3 & \\
\hline 12412 & 151 & & 6 & OA2 & 14 & 1 & 5.1 & 6 & & & 6 & & & & \\
\hline 12412 & 151 & & 6 & $\overline{O A 2}$ & 4 & 2 & 10.83 & 4 & 4 & & 4 & & & 4 & \\
\hline 12412 & 151 & & 6 & $0 \mathrm{~A} 2$ & 14 & 2 & 9.44 & 4 & & & 4 & & & & \\
\hline \begin{tabular}{|l|l|}
12412 \\
\end{tabular} & 152 & & 6 & OA2 & 4 & 1 & 0.62 & 1 & 1 & & 1 & & & 1 & \\
\hline \begin{tabular}{|l|l|}
12412 \\
\end{tabular} & 153 & & 6 & $0 \mathrm{OA2}$ & 4 & 4 & 30.75 & 2 & 2 & & 2 & & 2 & & \\
\hline 12412 & 153 & & 6 & OA2 & 14 & 2 & 30.27 & 10 & & & 10 & & & & \\
\hline 12412 & 153 & & 6 & $0 \mathrm{~A} 2$ & 4 & 2 & 14.06 & 6 & 6 & 0 & 4 & 2 & 1 & 5 & \\
\hline 12412 & 153 & & 6 & OA2 & 14 & 1 & 19.32 & 20 & & & 20 & & & & \\
\hline 12412 & 153 & & 6 & $\overline{O A 2}$ & 4 & 1 & 0.62 & 2 & 2 & & 2 & & & 2 & \\
\hline \begin{tabular}{|l|l|}
12412 \\
\end{tabular} & 154 & 9 & 6 & OA2 & 14 & 2 & 22.92 & 7 & & & 7 & & & & \\
\hline 12412 & 154 & 9 & 6 & OA2 & 4 & 1 & 2.16 & 4 & 4 & & 4 & & & 4 & \\
\hline 12412 & 154 & 9 & 6 & $0 A 2$ & 4 & 5 & 59.52 & 1 & 1 & & 1 & & & 1 & \\
\hline 12412 & 154 & 9 & 6 & OA2 & 4 & 2 & 27.09 & 9 & 9 & & 9 & & 4 & 5 & \\
\hline 12412 & 154 & 9 & 6 & OA2 & 14 & 1 & 7.96 & 12 & & & 12 & & & & \\
\hline 12412 & 154 & 9 & 6 & 10A2 & 4 & 3 & \begin{tabular}{|c|}
34.79 \\
\end{tabular} & 3 & 3 & & 3 & & 1 & 2 & \\
\hline 12412 & 156 & 3 & 6 & TA2 & 4 & 1 & 7.63 & 13 & 13 & & 13 & & 1 & 12 & \\
\hline 12412 & 156 & 3 & 6 & OA2 & 14 & 4 & 13.23 & 1 & & & 1 & & & & \\
\hline 12412 & 156 & 3 & 6 & OA2 & 14 & 1 & 11.04 & 16 & & & 16 & & & & \\
\hline 12412 & 156 & 3 & 6 & OA2 & 14 & 2 & 40.8 & 14 & & & 14 & & & & \\
\hline 12412 & 156 & 3 & 6 & OA2 & 14 & 3 & 8.54 & 1 & & & 1 & & & & \\
\hline 12412 & 156 & 3 & 6 & OA2 & 4 & 2 & 23.22 & 8 & 8 & & 8 & & 3 & 5 & \\
\hline
\end{tabular}




\begin{tabular}{|c|c|c|c|c|c|c|c|c|c|c|c|c|c|c|c|}
\hline \begin{tabular}{|l|} 
Site \\
\end{tabular} & Coll \# & Feature & LV & Blk & Mat & Size & Grams & Qty & $\mathrm{Fr}$ & $\mathrm{NF}$ & Disc $P$ & Disc A & Cort P & Cort A & Comm \\
\hline 12412 & 156 & 3 & 6 & OA2 & 4 & 3 & 4.29 & 1 & 1 & & 1 & & & 1 & \\
\hline 12412 & 157 & & 6 & OA2 & \begin{tabular}{|l|}
14 \\
\end{tabular} & 2 & 5.1 & 2 & & & 2 & & & & \\
\hline 12412 & 157 & & 6 & $0 A 2$ & 4 & 3 & 8.3 & 1 & 1 & & 1 & & 1 & & \\
\hline 12412 & 157 & & 6 & OA2 & \begin{tabular}{|l|}
14 \\
\end{tabular} & 1 & 1.06 & 2 & & & 2 & & & & \\
\hline 12412 & 158 & & 6 & 10A2 & 4 & 2 & 12.54 & 6 & 6 & & 6 & & 1 & 5 & \\
\hline 12412 & 158 & & 6 & OA2 & 4 & 3 & 24.68 & 2 & 2 & & 2 & & 2 & & \\
\hline 12412 & 158 & & 6 & OA2 & 14 & 1 & 15.65 & 17 & & & 17 & & & & \\
\hline 12412 & 158 & & 6 & OA2 & 4 & 4 & 28.89 & 1 & 1 & & 1 & & 1 & & \\
\hline 12412 & 158 & & 6 & OA2 & 14 & 2 & 13.91 & 4 & & & 4 & & & & \\
\hline $1 \overline{12412}$ & 158 & & 6 & OA2 & 14 & 3 & 9.71 & 1 & & & 1 & & & & \\
\hline \begin{tabular}{|l|}
12412 \\
\end{tabular} & 158 & & 6 & TA2 & 4 & 1 & 5.88 & 5 & 5 & & 5 & 0 & 2 & 3 & \\
\hline 12412 & 159 & 9 & 6 & OA2 & 14 & 1 & 17.24 & 21 & & & 21 & & & & \\
\hline \begin{tabular}{|l|}
12412 \\
\end{tabular} & 159 & 9 & 6 & OA2 & 15 & 2 & 27.6 & 1 & & 1 & & 1 & 1 & & quartz \\
\hline \begin{tabular}{|l|}
12412 \\
\end{tabular} & 159 & 9 & 6 & OA2 & 4 & 2 & 23.67 & 7 & 7 & & 7 & & 2 & 5 & \\
\hline 12412 & 159 & 9 & 6 & OA2 & 14 & 6 & 118.99 & 1 & & & 1 & & & & \\
\hline 12412 & 159 & 9 & 6 & OA2 & 14 & 4 & 41.82 & 1 & & & 1 & & & & \\
\hline 12412 & 159 & 9 & 6 & OA2 & 4 & 3 & 29.96 & 3 & 3 & & 3 & & 1 & 2 & \\
\hline \begin{tabular}{|l|}
12412 \\
\end{tabular} & 159 & 9 & 6 & OA2 & 14 & 3 & 10.86 & 1 & & & 1 & & & & \\
\hline 12412 & 159 & 9 & 6 & OA2 & 1 & 2 & 1.97 & 1 & 1 & & & 1 & 1 & & \\
\hline \begin{tabular}{|l|}
12412 \\
\end{tabular} & 159 & 9 & 6 & OA2 & 4 & 4 & 61.57 & 2 & 2 & & 2 & & 1 & 1 & \\
\hline \begin{tabular}{|l|}
12412 \\
\end{tabular} & 159 & 9 & 6 & OA2 & 4 & 1 & 3.46 & 4 & 4 & & 4 & & & 4 & \\
\hline 12412 & 159 & 9 & 6 & OA2 & 14 & 2 & 37.14 & 11 & & & 11 & & & & \\
\hline \begin{tabular}{|l|}
12412 \\
\end{tabular} & 160 & 3 & 6 & $\overline{\mathrm{AA} 2}$ & 4 & 4 & 18.02 & 1 & 1 & & 1 & & 1 & & \\
\hline \begin{tabular}{|l|}
12412 \\
\end{tabular} & 160 & 3 & 6 & OA2 & 14 & 2 & 43.13 & 13 & & & 13 & & & & \\
\hline \begin{tabular}{|l|}
12412 \\
\end{tabular} & 160 & 3 & 6 & $\overline{O A 2}$ & \begin{tabular}{|l|}
14 \\
\end{tabular} & 1 & 10.35 & 13 & & & 13 & & & & \\
\hline 12412 & 160 & 3 & 6 & OA2 & 4 & 1 & 1.08 & 1 & 1 & & 1 & & 1 & & \\
\hline \begin{tabular}{|l|}
12412 \\
\end{tabular} & 160 & 3 & 6 & OA2 & 4 & 2 & 11.1 & 4 & 4 & & 4 & & & 4 & \\
\hline 12412 & 160 & 3 & 6 & OA2 & 14 & 3 & 17.15 & 2 & & & 2 & & & & \\
\hline \begin{tabular}{|l|}
12412 \\
\end{tabular} & 161 & & 6 & OA2 & 4 & 3 & 10.67 & 1 & 1 & & 1 & & 1 & & \\
\hline 12412 & 161 & & 6 & OA2 & 4 & 2 & 15.45 & 5 & 5 & & 5 & & 2 & 3 & \\
\hline 12412 & 161 & & 6 & OA2 & 14 & 1 & 5.34 & 5 & & & 5 & & & & \\
\hline 12412 & 161 & & 6 & OA2 & 4 & 1 & 1.5 & 1 & 1 & & 1 & & & 1 & \\
\hline 12412 & 161 & & 6 & OA2 & 14 & 4 & 26.26 & 1 & & & 1 & & & & \\
\hline 12412 & 161 & & 6 & OA2 & 14 & 2 & 12.74 & 5 & & & 5 & & & & \\
\hline 12412 & 161 & & 6 & OA2 & 14 & 3 & 12.79 & 1 & & & 1 & & & & \\
\hline 12412 & 162 & & 6 & OA2 & 14 & 1 & 9.55 & 7 & & & 7 & & & & \\
\hline 12412 & 162 & & 6 & OA2 & 4 & 1 & 4.99 & 5 & 5 & & 5 & & 2 & 3 & \\
\hline 12412 & 162 & & 6 & OA2 & 14 & 2 & 47.44 & 10 & & & 10 & & & & \\
\hline 12412 & 162 & & 6 & $\mathrm{OA2}$ & 4 & 2 & 21.6 & 9 & 9 & & 9 & & 2 & 7 & \\
\hline 12412 & 163 & & 6 & OA2 & 14 & 1 & 1.24 & 1 & & & 1 & & & & \\
\hline 12412 & 163 & & 6 & OA2 & 4 & 2 & 10.81 & 4 & 4 & & 4 & & 3 & 1 & \\
\hline 12412 & 163 & & 6 & $\mathrm{OA2}$ & 14 & 2 & 2.26 & 1 & & & 1 & & & & \\
\hline 12412 & 163 & & 6 & OA2 & 4 & 1 & 3.29 & 5 & 5 & & 5 & & 2 & 3 & \\
\hline 12412 & 164 & & 6 & OA2 & 14 & 2 & 42.2 & 10 & & & 10 & & & & \\
\hline 12412 & 164 & & 6 & $\overline{A A 2}$ & 4 & 2 & 13 & 6 & 6 & & 6 & & 4 & 2 & \\
\hline 12412 & 164 & & 6 & OA2 & 14 & 1 & 11.22 & 15 & & & 15 & & & & \\
\hline 12412 & 164 & & 6 & OA2 & 14 & 3 & 9.19 & 1 & & & 1 & & & & \\
\hline 12412 & 165 & & 6 & OA2 & 4 & 1 & 6.92 & 1 & 1 & & 1 & & & 1 & \\
\hline 12412 & 165 & & 6 & OA2 & 4 & 2 & 3.11 & 1 & 1 & & 1 & & & 1 & \\
\hline 12412 & 165 & & 6 & OA2 & 14 & 2 & 15.84 & 6 & & & 6 & & & & \\
\hline 12412 & 165 & & 6 & $\overline{\mathrm{A} 2}$ & 14 & 1 & 3.83 & 8 & & & 8 & & & & \\
\hline 12412 & 166 & & 6 & OA2 & 14 & 2 & 5.22 & 1 & & & 1 & & & & \\
\hline 12412 & 166 & & 6 & $\mathrm{OA} 2$ & 4 & 3 & 6.52 & 1 & 1 & & 1 & & 1 & & \\
\hline 12412 & 166 & & 6 & $0 \mathrm{~A} 2$ & 4 & 2 & 21.39 & 5 & 5 & & 5 & & 3 & 2 & \\
\hline 12412 & 166 & & 6 & OA2 & 4 & 1 & 1.97 & 2 & 2 & & 2 & & 1 & 1 & \\
\hline 12412 & 166 & & 6 & OA2 & 14 & 1 & 3.92 & 3 & & & 3 & & & & \\
\hline 12412 & 167 & & 6 & OA2 & \begin{tabular}{|l|}
4 \\
\end{tabular} & 2 & 3.06 & 2 & 2 & & 2 & & 1 & 1 & \\
\hline 12412 & 167 & & 6 & $\mathrm{OA2}$ & 14 & 2 & 3.59 & 3 & & & 3 & & & & \\
\hline 12412 & 167 & & 6 & $0 \mathrm{~A} 2$ & 14 & 1 & 1.6 & 3 & & & 3 & & & & \\
\hline 12412 & 167 & & 6 & OA2 & 4 & 3 & 12.18 & 1 & 1 & & 1 & & & 1 & \\
\hline 12412 & 168 & 9 & 6 & $0 A 2$ & 4 & 3 & 10.15 & 1 & 1 & & 1 & & 1 & & \\
\hline 12412 & 168 & 9 & 6 & OA2 & 4 & 2 & 2.56 & 1 & 1 & & 1 & & 1 & & \\
\hline 12412 & 168 & 9 & 6 & OA2 & 14 & 2 & 21.49 & 7 & & & 7 & & & & \\
\hline 12412 & 168 & 9 & 6 & OA2 & 14 & 1 & 2.92 & 6 & & & 6 & & & & \\
\hline 12412 & \begin{tabular}{|c|}
168 \\
\end{tabular} & 9 & 6 & OA2 & 4 & 1 & 0.51 & 1 & 1 & & 1 & & & 1 & \\
\hline
\end{tabular}




\begin{tabular}{|c|c|c|c|c|c|c|c|c|c|c|c|c|c|c|c|}
\hline \begin{tabular}{|l} 
Site \\
\end{tabular} & Coll \# & Feature & LV & Blk & Mat & Size & Grams & Qty & $\mathrm{Fr}$ & $\mathrm{NF}$ & Disc $P$ & Disc $A$ & Cort P & \begin{tabular}{|l} 
Cort A \\
\end{tabular} & Comm \\
\hline \begin{tabular}{|l}
12412 \\
\end{tabular} & 169 & & 6 & OA2 & 4 & 1 & 0.49 & 1 & 1 & & 1 & & 1 & & \\
\hline \begin{tabular}{|l|}
12412 \\
\end{tabular} & 170 & & 6 & OA2 & 14 & 2 & 28.56 & 9 & & & 9 & & & & \\
\hline 12412 & 170 & & 6 & OA2 & 4 & 1 & 1 & 4 & 4 & & 4 & & & 4 & \\
\hline 12412 & 170 & & 6 & OA2 & 14 & 1 & 9.33 & 13 & & & 13 & & & & \\
\hline 12412 & 170 & & 6 & OA2 & 4 & 2 & 8.04 & 3 & 3 & & 3 & & 2 & 1 & \\
\hline \begin{tabular}{|l|}
12412 \\
\end{tabular} & 171 & 9 & 6 & OA2 & 4 & 1 & 1.57 & 1 & 1 & & 1 & & 1 & & \\
\hline \begin{tabular}{|l|}
12412 \\
\end{tabular} & 171 & 9 & 6 & OA2 & 14 & 1 & 1.49 & 2 & & & 2 & & & & \\
\hline 12412 & 171 & 9 & 6 & OA2 & 4 & 4 & 34.13 & 1 & 1 & & 1 & & 1 & & \\
\hline 12412 & 171 & 9 & 6 & OA2 & 14 & 3 & 13.04 & 1 & & & 1 & & & & \\
\hline 12412 & 171 & 9 & 6 & OA2 & \begin{tabular}{|l|}
14 \\
\end{tabular} & 2 & 8.53 & 3 & & & 3 & & & & \\
\hline \begin{tabular}{|l|}
12412 \\
\end{tabular} & 171 & 9 & 6 & $O A 2$ & 4 & 3 & 24.24 & 2 & 2 & & 2 & & 1 & 1 & \\
\hline 12412 & 171 & 9 & 6 & OA2 & 4 & 2 & 7.32 & 3 & 3 & & 3 & & 1 & 2 & \\
\hline \begin{tabular}{|l|}
12412 \\
\end{tabular} & 172 & & 6 & OA2 & 4 & 2 & 10.65 & 4 & 4 & & 4 & & & 4 & \\
\hline \begin{tabular}{|l|}
12412 \\
\end{tabular} & 172 & & 6 & OA2 & 14 & 2 & 11.62 & 5 & & & 5 & & & & \\
\hline \begin{tabular}{|l|}
12412 \\
\end{tabular} & 172 & & 6 & OA2 & 14 & 1 & 0.81 & 1 & & & 1 & & & & \\
\hline \begin{tabular}{|l|}
12412 \\
\end{tabular} & 172 & & 6 & OA2 & 14 & 3 & 25.82 & 3 & & & 3 & & & & \\
\hline 12412 & 173 & & 6 & OA2 & 14 & 2 & 1.99 & 2 & & & 2 & & & & \\
\hline 12412 & 173 & & 6 & OA2 & 4 & 1 & 1.05 & 3 & 3 & & 3 & & & 3 & \\
\hline \begin{tabular}{|l|}
12412 \\
\end{tabular} & 173 & & 6 & OA2 & 14 & 1 & 2.62 & 5 & & & 5 & & & & \\
\hline \begin{tabular}{|l|}
12412 \\
\end{tabular} & 173 & & 6 & OA2 & 14 & 3 & 10.41 & 1 & & & 1 & & & & \\
\hline 12412 & 173 & & 6 & OA2 & 4 & 3 & 18.95 & 2 & 2 & & 2 & & 2 & & \\
\hline 12412 & 173 & & 6 & 0A2 & 4 & 2 & 2.98 & 2 & 2 & & 2 & & 1 & 1 & \\
\hline 12412 & 174 & & 6 & $\overline{0 A 2}$ & 14 & 4 & 29.38 & 1 & $=$ & & 1 & & & & \\
\hline \begin{tabular}{|l|}
12412 \\
\end{tabular} & 174 & & 6 & OA2 & \begin{tabular}{|l|}
14 \\
\end{tabular} & 5 & 94.14 & 1 & & & 1 & & & & \\
\hline 12412 & 174 & & 6 & $0 A 2$ & 4 & 1 & 0.88 & 1 & 1 & & 1 & & & 1 & \\
\hline \begin{tabular}{|l|l|}
12412 \\
\end{tabular} & 174 & & 6 & OA2 & 4 & 3 & 12.82 & 1 & 1 & & 1 & & 1 & & \\
\hline \begin{tabular}{|l|}
12412 \\
\end{tabular} & 174 & & 6 & $0 A 2$ & 4 & 2 & 6.2 & 2 & 2 & & 2 & & & 2 & \\
\hline 12412 & 174 & & 6 & $0 A 2$ & 14 & 1 & 8.61 & 10 & & & 10 & & & & \\
\hline 12412 & 174 & & 6 & OA2 & \begin{tabular}{|l|}
14 \\
\end{tabular} & 3 & 48.15 & 5 & & & 5 & & & & \\
\hline 12412 & 174 & & 6 & OA2 & \begin{tabular}{|l|}
14 \\
\end{tabular} & 2 & 29.49 & 12 & & & 12 & & & & \\
\hline 12412 & 175 & & 6 & OA2 & 14 & 2 & 47.09 & 15 & & & 15 & & & & \\
\hline \begin{tabular}{|l|}
12412 \\
\end{tabular} & 175 & & 6 & $0 \mathrm{~A} 2$ & 4 & 1 & 4.21 & 4 & 4 & & 4 & & & 4 & \\
\hline 12412 & 175 & & 6 & OA2 & 4 & 4 & 26.23 & 1 & & & 1 & & 1 & & \\
\hline \begin{tabular}{|l|}
12412 \\
\end{tabular} & 175 & & 6 & OA2 & 14 & 3 & 28.6 & 2 & & & 2 & & & & \\
\hline 12412 & 175 & & 6 & $\overline{O A 2}$ & 14 & 1 & 6.72 & 11 & & & 11 & & & & \\
\hline \begin{tabular}{|l|}
12412 \\
\end{tabular} & 175 & & 6 & OA2 & 4 & 3 & 15.3 & 1 & 1 & & 1 & & & 1 & \\
\hline 12412 & 175 & & 6 & OA2 & 4 & 2 & 21.06 & 6 & 6 & & 6 & & 2 & 4 & \\
\hline 12412 & 176 & & 7 & OA2 & 4 & 1 & 2.14 & 2 & 2 & & 2 & & 1 & 1 & \\
\hline \begin{tabular}{|l|}
12412 \\
\end{tabular} & 176 & & 7 & OA2 & 14 & 3 & 13.76 & 2 & & & 2 & & & & \\
\hline 12412 & 176 & & 7 & $0 A 2$ & 14 & 2 & 14.21 & 6 & & & 6 & & & & \\
\hline \begin{tabular}{|l|}
12412 \\
\end{tabular} & 176 & & 7 & OA2 & 4 & 2 & 2.03 & 1 & 1 & & 1 & & & 1 & \\
\hline \begin{tabular}{|l|}
12412 \\
\end{tabular} & 176 & & 7 & OA2 & 14 & 1 & 4.44 & 5 & & & 5 & & & & \\
\hline 12412 & 176 & & 7 & $0 \mathrm{~A} 2$ & 3 & 1 & 0.56 & 1 & 1 & & & 1 & 1 & & \\
\hline 12412 & 178 & 3 & 7 & OA2 & 14 & 1 & $\begin{array}{l}10.37 \\
\end{array}$ & 15 & & & 15 & & & & \\
\hline \begin{tabular}{|l|}
12412 \\
\end{tabular} & 178 & 3 & 7 & $0 \mathrm{~A} 2$ & 14 & 2 & 24.36 & 11 & & & 11 & & & & \\
\hline 12412 & 178 & 3 & 7 & $\overline{0 A 2}$ & 14 & 3 & 12.49 & 1 & & & 1 & & & & \\
\hline \begin{tabular}{|l|}
12412 \\
\end{tabular} & 178 & 3 & 7 & OA2 & 4 & 3 & 5.2 & 1 & 1 & & 1 & & 1 & & \\
\hline \begin{tabular}{|l|}
12412 \\
\end{tabular} & 178 & 3 & 7 & OA2 & 4 & 2 & 5.99 & 2 & 2 & & 2 & & 1 & 1 & \\
\hline \begin{tabular}{|l|}
12412 \\
\end{tabular} & 179 & & 6 & OA2 & 4 & 1 & 2.9 & 2 & 2 & & 2 & & 1 & 1 & \\
\hline \begin{tabular}{|l|}
12412 \\
\end{tabular} & 179 & & 6 & OA2 & 4 & 2 & 6.46 & 2 & 2 & & 2 & & 2 & & \\
\hline \begin{tabular}{|l|}
12412 \\
\end{tabular} & 179 & & 6 & OA2 & 14 & 2 & 9.27 & 3 & & & 3 & & & & \\
\hline 12412 & 179 & & 6 & OA2 & 14 & 1 & 4.28 & 6 & & & 6 & & & & \\
\hline 12412 & 180 & & 7 & OA2 & 3 & 2 & 6.34 & 1 & 1 & & 1 & & 1 & & \\
\hline 12412 & 180 & & 7 & OA2 & \begin{tabular}{|l|}
14 \\
\end{tabular} & 2 & 21.12 & 8 & & & 8 & & & & \\
\hline 12412 & 180 & & 7 & OA2 & 14 & 1 & 11.42 & 17 & & & 17 & & & & \\
\hline 12412 & 180 & & 7 & OA2 & 14 & 3 & 11.81 & 1 & & & 1 & & & & \\
\hline 12412 & 180 & & 7 & OA2 & 4 & 2 & 1.11 & 1 & 1 & & 1 & & & 1 & \\
\hline 12412 & 180 & & 7 & OA2 & 4 & 1 & 2.29 & 3 & 3 & & 3 & & 1 & 2 & \\
\hline 12412 & 181 & 3 & 7 & OA2 & 4 & 2 & 5.43 & 2 & 1 & 1 & 1 & & 1 & 1 & \\
\hline 12412 & 181 & 3 & 7 & OA2 & 4 & 1 & 3.55 & 5 & 5 & & 5 & & 2 & 3 & \\
\hline 12412 & 181 & 3 & 7 & OA2 & 3 & 1 & $\begin{array}{l}0.44 \\
\end{array}$ & 1 & 1 & & 1 & & & 1 & \\
\hline 12412 & 181 & 3 & 7 & OA2 & 4 & 4 & 43 & 2 & 1 & 1 & 1 & & 1 & 1 & \\
\hline 12412 & 181 & 3 & 7 & $O A 2$ & 14 & 3 & 21.69 & 2 & & & 2 & & & & \\
\hline 12412 & 181 & 3 & 7 & OA2 & \begin{tabular}{|l|}
14 \\
\end{tabular} & 2 & \begin{tabular}{|l|l|}
43.87 \\
\end{tabular} & 21 & & & 21 & & & & \\
\hline 12412 & 181 & 3 & 7 & OA2 & \begin{tabular}{|l|}
14 \\
\end{tabular} & 1 & 18.26 & 27 & & & 27 & & & & \\
\hline
\end{tabular}




\begin{tabular}{|c|c|c|c|c|c|c|c|c|c|c|c|c|c|c|c|}
\hline \begin{tabular}{|l|} 
Site \\
\end{tabular} & \begin{tabular}{|l|} 
Coll \# \\
\end{tabular} & Feature & LV & Blk & \begin{tabular}{|l|} 
Mat \\
\end{tabular} & Size & Grams & Qty & $\mathrm{Fr}$ & $\mathrm{NF}$ & \begin{tabular}{|l} 
Disc $P$ \\
\end{tabular} & Disc A & \begin{tabular}{|l} 
Cort P \\
\end{tabular} & \begin{tabular}{|c|}
$\operatorname{Cort} A$ \\
\end{tabular} & Comm \\
\hline 12412 & 183 & & 6 & OA2 & 14 & 1 & 7.23 & 10 & & & 10 & & & & \\
\hline \begin{tabular}{|l|}
12412 \\
\end{tabular} & 183 & & 6 & OA2 & 4 & 2 & 4.29 & 3 & 3 & & 3 & & 1 & 2 & \\
\hline \begin{tabular}{|l}
12412 \\
\end{tabular} & 183 & & 6 & $O A 2$ & 14 & 3 & 18.11 & 1 & & & 1 & & & & \\
\hline \begin{tabular}{|l|}
12412 \\
\end{tabular} & 183 & & 6 & OA2 & 14 & 2 & 24.46 & 8 & & & 8 & & & & \\
\hline \begin{tabular}{|l|}
12412 \\
\end{tabular} & 183 & & 6 & OA2 & 3 & 2 & 2.98 & 1 & 1 & & 1 & & 1 & & \\
\hline \begin{tabular}{|l|}
12412 \\
\end{tabular} & 183 & & 6 & OA2 & 4 & 3 & 25.05 & 1 & 1 & & 1 & & 1 & & \\
\hline \begin{tabular}{|l|}
12412 \\
\end{tabular} & 183 & & 6 & OA2 & 4 & 1 & 3.45 & 5 & 5 & & 5 & & 2 & 3 & \\
\hline \begin{tabular}{|l|}
12412 \\
\end{tabular} & 184 & & 7 & OA2 & 4 & 1 & 0.51 & 2 & 2 & & 2 & & 1 & 1 & \\
\hline 12412 & 184 & & 7 & OA2 & 14 & 1 & 7.74 & 13 & & & 13 & & & & \\
\hline \begin{tabular}{|l|}
12412 \\
\end{tabular} & 184 & & 7 & OA2 & 14 & 2 & 10.78 & 7 & & & 7 & & & & \\
\hline \begin{tabular}{|l|}
12412 \\
\end{tabular} & 184 & & 7 & OA2 & 4 & 2 & 3.74 & 1 & 1 & & 1 & & 1 & & \\
\hline \begin{tabular}{|c|}
12412 \\
\end{tabular} & 184 & & 7 & OA2 & 4 & 3 & 5.23 & 1 & 1 & & 1 & & & 1 & \\
\hline \begin{tabular}{|l|}
12412 \\
\end{tabular} & 185 & & 7 & OA2 & 14 & 1 & 5.28 & 7 & & & 7 & & & & \\
\hline 12412 & 185 & & 7 & $\overline{O A 2}$ & 14 & 2 & 11.79 & 5 & & & 5 & & & & \\
\hline \begin{tabular}{|l|}
12412 \\
\end{tabular} & 185 & & 7 & OA2 & 4 & 1 & 1 & 2 & 2 & & 2 & & & 2 & 1 flake \\
\hline 12412 & 186 & 3 & 7 & OA2 & 1 & 2 & 0.7 & 1 & 1 & & 1 & & 1 & & \\
\hline \begin{tabular}{|l|}
12412 \\
\end{tabular} & 186 & 3 & 7 & OA2 & 4 & 2 & 19.38 & 3 & 1 & 2 & 3 & & 2 & 1 & \\
\hline 12412 & 186 & 3 & 7 & OA2 & 14 & 2 & 38.94 & 17 & & & 17 & & & & \\
\hline \begin{tabular}{|l|}
12412 \\
\end{tabular} & 186 & 3 & 7 & OA2 & 14 & 1 & 16.04 & 34 & & & 34 & & & & \\
\hline 12412 & 188 & & 7 & OA2 & 14 & 1 & 7.71 & 16 & & & 16 & & & & \\
\hline \begin{tabular}{|l|}
12412 \\
\end{tabular} & 188 & & 7 & OA2 & 14 & 3 & 19.06 & 3 & & & 3 & & & & \\
\hline 12412 & 188 & & 7 & OA2 & 4 & 2 & 19.02 & 5 & 5 & & 5 & & 2 & 3 & \\
\hline 12412 & 188 & & 7 & OA2 & 3 & 2 & 3.05 & 1 & 1 & & 1 & & 1 & & \\
\hline 12412 & 188 & & 7 & OA2 & 4 & 1 & 0.75 & 2 & 2 & & 2 & & & 2 & \\
\hline 12412 & 188 & & 7 & OA2 & 14 & 2 & 25.14 & 9 & & & 9 & & & & \\
\hline 12412 & 189 & & 7 & $\mathrm{OA2}$ & 4 & 2 & 14.21 & 3 & 3 & & 3 & & 1 & 2 & \\
\hline 12412 & 189 & & 7 & $0 A 2$ & 14 & 2 & 16.24 & 5 & & & 5 & & & & \\
\hline 12412 & 189 & & 7 & OA2 & 4 & 1 & 1.32 & 2 & 2 & & 2 & & & 2 & \\
\hline 12412 & 189 & & 7 & OA2 & 14 & 1 & \begin{tabular}{|l|}
5.73 \\
\end{tabular} & 8 & & & 8 & & & & \\
\hline 12412 & 190 & & 6 & $O A 2$ & 4 & 2 & 2.93 & 1 & 1 & & 1 & & & 1 & \\
\hline 12412 & 190 & & 6 & $0 A 2$ & 14 & 1 & 1.38 & 1 & & & 1 & & & & \\
\hline \begin{tabular}{|l|}
12412 \\
\end{tabular} & 190 & & 6 & $0 \mathrm{~A} 2$ & 14 & 1 & 1.38 & 1 & & & 1 & & & & \\
\hline \begin{tabular}{|l|}
12412 \\
\end{tabular} & 190 & & 6 & OA2 & 4 & 1 & 0.59 & 1 & 1 & & 1 & & & 1 & \\
\hline 12412 & 190 & & 6 & OA2 & 4 & 1 & 0.59 & 1 & 1 & & 1 & & & 1 & \\
\hline 12412 & 190 & & 6 & OA2 & 14 & 2 & 7.98 & 4 & & & 4 & & & & \\
\hline \begin{tabular}{|l|}
12412 \\
\end{tabular} & 190 & & 6 & $0 \mathrm{A2}$ & 14 & 2 & 7.98 & 4 & & & 4 & & & & \\
\hline \begin{tabular}{|l|}
12412 \\
\end{tabular} & 190 & & 6 & OA2 & 4 & 2 & 2.93 & 1 & 1 & & 1 & & & 1 & \\
\hline 12412 & 190 & & 6 & OA2 & 4 & 3 & 10.76 & 1 & 1 & & 1 & & & 1 & \\
\hline 12412 & 190 & & 6 & $\overline{O A 2}$ & 4 & 3 & 10.76 & 1 & 1 & & 1 & & & 1 & \\
\hline \begin{tabular}{|l|}
12412 \\
\end{tabular} & 191 & 3 & 7 & OA2 & 4 & 2 & 16.37 & 5 & 5 & & 5 & & 2 & 3 & \\
\hline \begin{tabular}{|l|}
12412 \\
\end{tabular} & 191 & 3 & 7 & OA2 & 14 & 3 & 31.98 & 4 & & & 4 & & & & \\
\hline 12412 & 191 & 3 & 7 & $O A 2$ & 14 & 4 & 13.98 & 1 & & & 1 & & & & \\
\hline 12412 & 191 & 3 & 7 & $0 A 2$ & 14 & 2 & 68.08 & 21 & & & 21 & & & & \\
\hline 12412 & 191 & 3 & 7 & OA2 & 4 & 3 & 14.14 & 1 & 1 & & 1 & & 1 & & \\
\hline \begin{tabular}{|l|}
12412 \\
\end{tabular} & 191 & 3 & 7 & OA2 & 14 & 1 & 27.49 & 45 & & & 45 & & & & \\
\hline \begin{tabular}{|l|}
12412 \\
\end{tabular} & 191 & 3 & 7 & $O A 2$ & 4 & 1 & 5.13 & 10 & 10 & & 10 & & 1 & 9 & \\
\hline \begin{tabular}{|l|}
12412 \\
\end{tabular} & 193 & & 7 & OA2 & 14 & 1 & 4.25 & 8 & & & 8 & & & & \\
\hline 12412 & 193 & & 7 & OA2 & 4 & 4 & \begin{tabular}{|c|}
11.17 \\
\end{tabular} & 1 & 1 & & 1 & & 1 & & \\
\hline 12412 & 193 & & 7 & OA2 & 4 & 3 & 24.31 & 1 & 1 & & 1 & & 1 & & \\
\hline 12412 & 193 & & 7 & OA2 & 4 & 1 & 1.17 & 3 & 3 & & 3 & & & 3 & \\
\hline 12412 & 193 & & 7 & $\overline{O A 2}$ & 4 & 2 & 3.06 & 2 & 2 & & 2 & & & 2 & \\
\hline 12412 & 193 & & 7 & $0 A 2$ & 14 & 2 & 14.03 & 5 & & & 5 & & & & \\
\hline 12412 & 194 & & 7 & OA2 & 4 & 2 & 5.65 & 3 & 3 & & 3 & & & 3 & \\
\hline 12412 & 194 & & 7 & OA2 & 4 & 3 & \begin{tabular}{|c|}
33.67 \\
\end{tabular} & 1 & 1 & & 1 & & 1 & & \\
\hline 12412 & 194 & & 7 & OA2 & 14 & 1 & 8.75 & 19 & & & 19 & & & & \\
\hline 12412 & 194 & & 7 & OA2 & 4 & 1 & 1.94 & 4 & 4 & & 4 & & 1 & 3 & \\
\hline 12412 & 194 & & 7 & OA2 & 14 & 3 & 11.93 & 1 & & & 1 & & & & \\
\hline 12412 & 194 & & 7 & OA2 & 14 & 2 & 34.56 & 16 & & & 16 & & & & \\
\hline 12412 & 195 & & 7 & OA2 & 14 & 3 & 9.96 & 1 & & & 1 & & & & \\
\hline 12412 & 195 & & 7 & OA2 & 14 & 1 & 1.13 & 3 & & & 3 & & & & \\
\hline 12412 & 195 & & 7 & $0 A 2$ & 14 & 2 & 14.87 & 6 & & & 6 & & & & \\
\hline 12412 & 195 & & 7 & $0 A 2$ & 4 & 1 & 2.27 & 3 & 3 & & 3 & & 2 & 1 & \\
\hline 12412 & 195 & & 7 & $0 \mathrm{~A} 2$ & 4 & 2 & 2.4 & 2 & 2 & & 2 & & 1 & 1 & \\
\hline 12412 & 196 & & 7 & OA2 & 14 & 2 & 14.1 & 7 & & & 7 & & & & \\
\hline 12412 & 196 & & 7 & OA2 & 4 & 1 & 2.2 & 2 & 2 & & 2 & & & 2 & \\
\hline
\end{tabular}




\begin{tabular}{|c|c|c|c|c|c|c|c|c|c|c|c|c|c|c|c|}
\hline Site & Coll \# & Feature & LV & Blk & Mat & Size & Grams & Qty & $\mathrm{Fr}$ & NF & Disc $P$ & Disc $\mathrm{A}$ & \begin{tabular}{|l|} 
Cort P \\
\end{tabular} & Cort $A$ & Comm \\
\hline 12412 & 196 & & 7 & OA2 & 14 & 3 & 9.24 & 2 & & & 2 & & & & \\
\hline \begin{tabular}{|l|}
12412 \\
\end{tabular} & 196 & & 7 & OA2 & 14 & 1 & 6.01 & 10 & & & 10 & & & & \\
\hline 12412 & 197 & & 7 & OA2 & 4 & 1 & 0.72 & 1 & 1 & & 1 & & & 1 & \\
\hline 12412 & 197 & & 7 & OA2 & 14 & 2 & 13.04 & 5 & & & 5 & & & & \\
\hline 12412 & 197 & & 7 & OA2 & 14 & 4 & 11.09 & 1 & & & 1 & & & & \\
\hline 12412 & 197 & & 7 & OA2 & 14 & 1 & 6.05 & 9 & & & 9 & & & & \\
\hline 12412 & 197 & & 7 & OA2 & 6 & 3 & 4.47 & 1 & 1 & & 1 & & 1 & & no prov. \\
\hline 12412 & 198 & 3 & 6 & OA2 & 14 & 4 & 27.94 & 1 & & & 1 & & & & \\
\hline 12412 & 198 & 3 & 6 & $0 A 2$ & 4 & 1 & 1.06 & 2 & 2 & & 2 & & & 2 & \\
\hline 12412 & 198 & 3 & 6 & OA2 & 4 & 2 & 5.64 & 2 & 2 & & 2 & & 1 & 1 & \\
\hline 12412 & 198 & 3 & 6 & OA2 & 14 & 2 & 59.09 & 20 & & & 20 & & & & \\
\hline 12412 & 198 & 3 & 6 & OA2 & 14 & 3 & 40.26 & 2 & & & 2 & & & & \\
\hline 12412 & 198 & 3 & 6 & OA2 & 14 & 1 & 17.73 & 31 & & & 31 & & & & \\
\hline 12412 & 199 & & 7 & OA2 & 4 & 2 & 2.63 & 1 & 1 & & 1 & & & 1 & \\
\hline \begin{tabular}{|l|}
12412 \\
\end{tabular} & 199 & & 7 & OA2 & 4 & 3 & 5.48 & 1 & 1 & & 1 & & & 1 & \\
\hline 12412 & 200 & & 7 & OA2 & 14 & 2 & 5.67 & 4 & & & 4 & & & & \\
\hline 12412 & 200 & & 7 & $0 A 2$ & 14 & 1 & 4.12 & 7 & & & 7 & & & & \\
\hline 12412 & 201 & 3 & 7 & OA2 & 14 & 1 & 10.03 & 19 & & & 19 & & & & \\
\hline 12412 & 201 & 3 & 7 & OA2 & 4 & 1 & 0.84 & 2 & 2 & & 2 & & 1 & 1 & \\
\hline 12412 & 201 & 3 & 7 & OA2 & 4 & 2 & 2.47 & 1 & 1 & & 1 & & & 1 & \\
\hline 12412 & 201 & 3 & 7 & OA2 & 14 & 3 & 2.3 & 1 & & & 1 & & & & \\
\hline 12412 & 201 & 3 & 7 & $0 A 2$ & 14 & 2 & 24.77 & 10 & & & 10 & & & & \\
\hline 12412 & 203 & & 7 & $0 A 2$ & 14 & 2 & 7.66 & 2 & & & 2 & & & & \\
\hline 12412 & 203 & & 7 & OA2 & 14 & 1 & 4.7 & 8 & & & 8 & & & & \\
\hline 12412 & 203 & & 7 & OA2 & 4 & 2 & 2.33 & 1 & 1 & & 1 & & 1 & & \\
\hline 12412 & 204 & & 7 & OA2 & 4 & 2 & 3.8 & 1 & 1 & & 1 & & 1 & & \\
\hline 12412 & 204 & & 7 & OA2 & 14 & 1 & 14.92 & 22 & & & 22 & & & & \\
\hline 12412 & 204 & & 7 & OA2 & 14 & 2 & 32.6 & 14 & & & 14 & & & & \\
\hline 12412 & 205 & 3 & 7 & OA2 & 14 & 2 & 47.93 & 13 & & & 13 & & & & \\
\hline 12412 & 205 & 3 & 7 & $\overline{0 A 2}$ & 14 & 1 & 12.17 & 16 & & & 16 & & & & \\
\hline 12412 & 205 & 3 & 7 & OA2 & 4 & 3 & 26.21 & 2 & 2 & & 2 & & 1 & 1 & \\
\hline 12412 & 205 & 3 & 7 & OA2 & 4 & 2 & 16.94 & 7 & 7 & & 7 & & 2 & 5 & \\
\hline 12412 & 205 & 3 & 7 & $0 A 2$ & 4 & 4 & 29.94 & 1 & 1 & & 1 & & 1 & & \\
\hline 12412 & 205 & 3 & 7 & OA2 & 14 & 4 & $\begin{array}{l}9.39 \\
\end{array}$ & 1 & & & 1 & & & & \\
\hline 12412 & 205 & 3 & 7 & OA2 & 4 & 1 & 3.58 & 4 & 4 & & 4 & & & 4 & \\
\hline 12412 & 205 & 3 & 7 & OA2 & 14 & 3 & 44.32 & 5 & & & 5 & & & & \\
\hline 12412 & 206 & & 7 & OA2 & 4 & 4 & 18.85 & 1 & 1 & & 1 & & 1 & & \\
\hline 12412 & 206 & & 7 & OA2 & 14 & 3 & 34.25 & 2 & & & 2 & & & & \\
\hline 12412 & 206 & & 7 & OA2 & 14 & 1 & 17.13 & 24 & & & 24 & & & & \\
\hline 12412 & 206 & & 7 & OA2 & 14 & 2 & 16.29 & 8 & & & 8 & & & & \\
\hline 12412 & 207 & & 7 & OA2 & 14 & 2 & 32.72 & 12 & & & 12 & & & & \\
\hline 12412 & 207 & & 7 & OA2 & 4 & 3 & 11.84 & 1 & 1 & & 1 & & 1 & & \\
\hline 12412 & 207 & & 7 & OA2 & 14 & 4 & 39.66 & 1 & & & 1 & & & & \\
\hline 12412 & 207 & & 7 & OA2 & 4 & 2 & 22.77 & 5 & 5 & & 5 & & 1 & 4 & \\
\hline 12412 & 207 & & 7 & OA2 & 4 & 5 & 68.81 & 1 & 1 & & 1 & & 1 & & \\
\hline 12412 & 207 & & 7 & OA2 & 14 & 1 & 12.6 & 16 & & & 16 & & & & \\
\hline 12412 & 207 & & 7 & OA2 & 4 & 1 & 0.49 & 1 & 1 & & 1 & & & 1 & \\
\hline 12412 & 209 & 3 & 7 & OA2 & 14 & 3 & 28.08 & 3 & & & 3 & & & & \\
\hline 12412 & 209 & 3 & 7 & OA2 & 14 & 1 & \begin{tabular}{|l|l|}
6.83 \\
\end{tabular} & 13 & & & 13 & & & & \\
\hline 12412 & 209 & 3 & 7 & $0 A 2$ & 14 & 4 & 27.93 & 2 & & & 2 & & & & \\
\hline 12412 & 209 & 3 & 7 & $\overline{O A 2}$ & 4 & 2 & 5.05 & 3 & 3 & & 3 & & 2 & 1 & \\
\hline 12412 & 209 & 3 & 7 & OA2 & 4 & 1 & 0.69 & 1 & 1 & & 1 & & & 1 & \\
\hline 12412 & 209 & 3 & 7 & OA2 & 14 & 2 & 48.74 & 17 & & & 17 & & & & \\
\hline 12412 & 210 & 3 & 8 & OA2 & 14 & 2 & 10.12 & 3 & & & 3 & & & & \\
\hline 12412 & 210 & 3 & 8 & $\overline{O A 2}$ & 14 & 1 & 1.11 & 2 & & & 2 & & & & \\
\hline 12412 & 211 & 3 & 7 & OA2 & 4 & 3 & 6.28 & 1 & 1 & & 1 & & & 1 & \\
\hline 12412 & 211 & 3 & 7 & OA2 & 14 & 1 & 4.22 & 6 & & & 6 & & & & \\
\hline 12412 & 211 & 3 & 7 & OA2 & 14 & 2 & 8.73 & 4 & & & 4 & & & & \\
\hline 12412 & 213 & 3 & 8 & OA2 & 14 & 2 & 18.82 & 5 & & & 5 & & & & \\
\hline 12412 & 213 & 3 & 8 & OA2 & 14 & 1 & 2.36 & 4 & & & 4 & & & & \\
\hline 12412 & 213 & 3 & 8 & OA2 & 14 & 3 & 7.92 & 1 & & & 1 & & & & \\
\hline 12412 & 214 & 3 & 7 & $\overline{O A 2}$ & 14 & 2 & 41.04 & 10 & & & 10 & & & & \\
\hline 12412 & 214 & 3 & 7 & OA2 & 14 & 3 & 58.27 & 6 & & & 6 & & & & \\
\hline 12412 & 214 & 3 & 7 & OA2 & 4 & 2 & 12.56 & 3 & 3 & & 3 & & 1 & 2 & \\
\hline 12412 & 214 & 3 & 7 & $O A 2$ & 14 & 1 & $\begin{array}{c}0.51 \\
\end{array}$ & 6 & & & 6 & & & & \\
\hline
\end{tabular}




\begin{tabular}{|c|c|c|c|c|c|c|c|c|c|c|c|c|c|c|c|}
\hline Site & Coll \# & Feature & LV & Blk & Mat & Size & Grams & Qty & $\mathrm{Fr}$ & $\mathrm{NF}$ & Disc P & Disc A & Cort P & Cort A & Comm \\
\hline 12412 & 214 & 3 & 7 & OA2 & \begin{tabular}{|l|}
4 \\
\end{tabular} & 4 & 39.17 & 1 & 1 & & 1 & & & 1 & \\
\hline 12412 & 215 & & 7 & OA2 & 14 & 1 & 2.72 & 4 & & & 4 & & & & \\
\hline 12412 & 215 & & 7 & OA2 & 4 & 2 & 9.13 & 3 & 3 & & 3 & & & 3 & \\
\hline 12412 & 215 & & 7 & OA2 & \begin{tabular}{|l|}
14 \\
\end{tabular} & 2 & 20.58 & 8 & & & 8 & & & & \\
\hline 12412 & 215 & & 7 & DA2 & 4 & 3 & 15.15 & 1 & & 1 & 1 & & 1 & & \\
\hline 12412 & 216 & 3 & 7 & OA2 & 4 & 1 & 0.51 & 1 & 1 & & 1 & & & 1 & \\
\hline 12412 & 216 & 3 & 7 & OA2 & 4 & 2 & 9.59 & 3 & 3 & & 3 & & 1 & 2 & \\
\hline 12412 & 216 & 3 & 7 & OA2 & 14 & 1 & 4.71 & 6 & & & 6 & & & & \\
\hline 12412 & 216 & 3 & 7 & OA2 & 4 & 3 & 22.64 & 2 & 2 & & 2 & & 1 & 1 & \\
\hline \begin{tabular}{|l|}
12412 \\
\end{tabular} & 216 & 3 & 7 & $\overline{O A 2}$ & 14 & 2 & 16.33 & 7 & & & 7 & & & & \\
\hline 12412 & 216 & 3 & 7 & OA2 & 4 & 4 & 84.16 & 1 & 1 & & 1 & & 1 & & \\
\hline 12412 & 217 & 3 & 7 & OA2 & 4 & 1 & 0.71 & 1 & 1 & & 1 & & & 1 & \\
\hline 12412 & 217 & 3 & 7 & OA2 & 14 & 2 & 3.38 & 3 & & & 1 & & & & \\
\hline 12412 & 217 & 3 & 7 & OA2 & 14 & 1 & 6.79 & 7 & & & 7 & & & & \\
\hline 12412 & 217 & 3 & 7 & OA2 & 1 & 1 & 1.27 & 1 & 1 & & 1 & & 1 & & \\
\hline 12412 & 217 & 3 & 7 & OA2 & 4 & 2 & 4.34 & 1 & 1 & & 1 & & & 1 & \\
\hline 12412 & 217 & 3 & 7 & OA2 & 4 & 3 & 4.88 & 1 & 1 & & 1 & & & 1 & \\
\hline 12412 & 219 & & 7 & OA2 & 14 & 1 & 14.39 & 18 & 18 & & 18 & & & & \\
\hline 12412 & 219 & & 7 & OA2 & \begin{tabular}{|l|}
14 \\
\end{tabular} & 3 & 12.14 & 1 & 1 & & 1 & & & & \\
\hline 12412 & 219 & & 7 & OA2 & 14 & 4 & 25.65 & 1 & & & 1 & & & & \\
\hline 12412 & 219 & & 7 & OA2 & 4 & 2 & 1.49 & 1 & 1 & & 1 & & 1 & & \\
\hline 12412 & 219 & & 7 & OA2 & 14 & 2 & 33.19 & 11 & 11 & & 11 & & & & \\
\hline 12412 & 220 & & 8 & OA2 & \begin{tabular}{|l|}
14 \\
\end{tabular} & 4 & 26.03 & 1 & & & 1 & & & & \\
\hline 12412 & 220 & & 8 & OA2 & 14 & 1 & 10.95 & 15 & & & 15 & & & & \\
\hline 12412 & 220 & & 8 & OA2 & 14 & 2 & 29.72 & 11 & & & 11 & & & & \\
\hline 12412 & 220 & & 8 & OA2 & 4 & 1 & 0.51 & 1 & 1 & & 1 & & & 1 & \\
\hline 12412 & 220 & & 8 & DA2 & 14 & 3 & 11.72 & 1 & & & 1 & & & & \\
\hline 12412 & 221 & & 9 & $\mathrm{OA2}$ & 14 & 1 & 1.81 & 3 & & & 3 & & & & \\
\hline 12412 & 221 & & 9 & OA2 & 14 & 2 & 6.93 & 3 & & & 3 & & & & \\
\hline 12412 & 222 & 3 & 8 & OA2 & 4 & 2 & 7.38 & 3 & 3 & & 3 & & 1 & 2 & \\
\hline 12412 & 222 & 3 & 8 & $O A 2$ & 14 & 2 & 15.89 & 11 & & & 11 & & & & \\
\hline 12412 & 222 & 3 & 8 & $0 A 2$ & 14 & 3 & 11.91 & 2 & & & 2 & & & & \\
\hline 12412 & 222 & 3 & 8 & $0 A 2$ & 14 & 1 & 1.98 & 3 & & & 3 & & & & \\
\hline 12412 & 222 & 3 & 8 & OA2 & 4 & 3 & 2.99 & 1 & 1 & & 1 & & & 1 & \\
\hline 12412 & 222 & 3 & 8 & OA2 & 4 & 1 & 1.13 & 1 & 1 & & 1 & & & 1 & \\
\hline 12412 & 223 & 3 & 8 & OA2 & 4 & 2 & 4.14 & 3 & 3 & & 3 & & 1 & 2 & \\
\hline 12412 & 223 & 3 & 8 & $O A 2$ & 14 & 2 & 9.76 & 5 & & & 5 & & & & \\
\hline 12412 & 223 & 3 & 8 & OA2 & 14 & 1 & 1.49 & 3 & 3 & & 3 & & 1 & 2 & \\
\hline 12412 & 223 & 3 & 8 & OA2 & 14 & 1 & 4.8 & 9 & & & 9 & & & & \\
\hline 12412 & 224 & 3 & 7 & OA2 & 4 & 1 & 1.6 & 3 & 3 & & 3 & & 2 & 1 & \\
\hline 12412 & 224 & 3 & 7 & OA2 & 14 & 1 & 13.54 & 19 & & & 19 & & & & \\
\hline 12412 & 224 & 3 & 7 & OA2 & 4 & 2 & 20.39 & 4 & 4 & & 4 & & 1 & 3 & \\
\hline 12412 & 224 & 3 & 7 & OA2 & 14 & 2 & 39.51 & 16 & & & 16 & & & & \\
\hline 12412 & 224 & 3 & 7 & OA2 & 4 & 5 & 81.33 & 1 & 1 & & 1 & & 1 & & \\
\hline 12412 & 224 & 3 & 7 & OA2 & 4 & 3 & 13.86 & 1 & 1 & & 1 & & 1 & & \\
\hline 12412 & 224 & 3 & 7 & OA2 & 14 & 3 & 22.38 & 1 & & & 1 & & & & \\
\hline 12412 & 225 & & 10 & OA2 & 4 & 1 & 1.11 & 1 & 1 & & 1 & & & 1 & \\
\hline 12412 & 225 & & 10 & OA2 & 14 & 1 & 0.88 & 2 & & & 2 & & & & \\
\hline 12412 & 225 & & 10 & OA2 & 14 & 2 & 1.21 & 1 & & & 1 & & & & \\
\hline 12412 & 226 & 3 & 8 & OA2 & 14 & 3 & 2.95 & 1 & & & 1 & & & & \\
\hline 12412 & 226 & 3 & 8 & $0 A 2$ & 14 & 1 & 1.28 & 2 & & & 2 & & & & \\
\hline 12412 & 226 & 3 & 8 & OA2 & 14 & 2 & 7.46 & 2 & & & 2 & & & & \\
\hline 12412 & 227 & & 8 & $\mathrm{OA2}$ & 14 & 2 & 6.84 & 2 & & & 2 & & & & \\
\hline 12412 & 227 & & 8 & OA2 & 14 & 1 & 2.94 & 4 & & & 4 & & & & \\
\hline 12412 & 227 & & 8 & OA2 & 4 & 2 & 0.93 & 1 & 1 & & & & & & \\
\hline 12412 & 228 & 9 & 8 & OA2 & 14 & 4 & 22.68 & 1 & & & 1 & & & & \\
\hline 12412 & 228 & 9 & 8 & OA2 & 14 & 2 & 4.96 & 3 & & & 3 & & & & \\
\hline 12412 & 228 & 9 & 8 & OA2 & 1 & 1 & 0.66 & 1 & 1 & & 1 & & & 1 & \\
\hline 12412 & 228 & 9 & 8 & \begin{tabular}{|l|}
$0 A 22$ \\
\end{tabular} & 14 & 1 & 0.13 & 1 & & & 1 & & & & \\
\hline 12412 & 229 & & 8 & OA2 & 14 & 2 & 16.85 & 6 & & & 6 & & & & \\
\hline 12412 & 229 & & 8 & OA2 & 14 & 1 & 20.19 & 22 & & & 22 & & & & \\
\hline 12412 & 230 & & 5 & $\mathrm{OB1}$ & 14 & 2 & 16.26 & 8 & & & 11 & & & & \\
\hline 12412 & 230 & & 5 & OB1 & 4 & 3 & 33.47 & 2 & 2 & & 2 & & 1 & 1 & \\
\hline 12412 & 230 & & 5 & $\mathrm{OB} 1$ & 14 & 3 & 8.74 & 1 & & & 1 & & & & \\
\hline 12412 & 230 & & 5 & $\overline{O B} 1$ & 14 & 1 & 30.02 & 61 & & & 61 & & & & \\
\hline
\end{tabular}




\begin{tabular}{|c|c|c|c|c|c|c|c|c|c|c|c|c|c|c|c|}
\hline Site & Coll \# & Feature & LV & Blk & Mat & Size & Grams & Qty & $\mathrm{Fr}$ & $\mathrm{NF}$ & Disc P & Disc A & Cort P & Cort A & Comm \\
\hline 12412 & 230 & & 5 & OB1 & 4 & 1 & 22.01 & 34 & 34 & & 17 & & 2 & 32 & \\
\hline 12412 & 230 & & 5 & OB1 & 4 & 2 & 64.17 & 21 & 21 & & 21 & & 4 & 17 & \\
\hline 12412 & 232 & & 4 & OB1 & 14 & 2 & 12.61 & 4 & & & 4 & & & & \\
\hline 12412 & 232 & & 4 & OB1 & 14 & 1 & 12.76 & 17 & & & 17 & & & & \\
\hline 12412 & 232 & & 4 & OB1 & 4 & 2 & 48.05 & 12 & 12 & & 12 & & 5 & 7 & \\
\hline 12412 & 232 & & 4 & OB1 & 4 & 1 & 11.57 & 11 & 11 & & 11 & & 3 & 8 & \\
\hline 12412 & 232 & & 4 & OB1 & 4 & 3 & 13.46 & 1 & 1 & & 1 & & & 1 & \\
\hline 12412 & 233 & & 5 & OB1 & 4 & 3 & 38.14 & 2 & 2 & & 2 & & 2 & & \\
\hline 12412 & 233 & & 5 & OB1 & 14 & 1 & 3.02 & 10 & & & 10 & & & & \\
\hline 12412 & 233 & & 5 & OB1 & 4 & 1 & 4.52 & 6 & 6 & & 6 & & & 6 & \\
\hline 12412 & 233 & & 5 & OB1 & 14 & 2 & 11.19 & 4 & & & 4 & & & & \\
\hline 12412 & 233 & & 5 & OB1 & 4 & 2 & 9.15 & 4 & 4 & & 3 & 1 & 1 & 3 & \\
\hline 12412 & 234 & & 6 & $\overline{O B 1}$ & 14 & 1 & 14.81 & 20 & & & 20 & & & & \\
\hline 12412 & 234 & & 6 & $\overline{0 B 1}$ & 14 & 2 & 14.94 & 6 & & & 6 & & & & \\
\hline 12412 & 234 & & 6 & OB1 & 4 & 4 & 22.01 & 1 & 1 & & 1 & & & & \\
\hline 12412 & 234 & & 6 & OB1 & 4 & 3 & 56.28 & 5 & 5 & & 5 & & 3 & 2 & \\
\hline 12412 & 234 & & 5 & OB1 & 4 & 2 & 136.53 & 32 & 32 & & 32 & & 5 & 27 & \\
\hline 12412 & 234 & & 5 & OB1 & 4 & 1 & 68.89 & 92 & 92 & & 92 & & 10 & 80 & \\
\hline 12412 & 235 & 16 & 5 & OB1 & 4 & 3 & 35.17 & 3 & 3 & & 3 & & & 3 & \\
\hline 12412 & 235 & 16 & 5 & OB1 & 4 & 2 & 83.67 & 27 & 27 & & 27 & & 3 & 24 & \\
\hline 12412 & 235 & 16 & 5 & $0 \mathrm{~B} 1$ & 4 & 1 & 37.92 & 66 & 66 & & 66 & & 3 & 63 & \\
\hline 12412 & 235 & 16 & 5 & OB1 & 14 & 1 & 1.92 & 2 & & & 2 & & & & \\
\hline 12412 & 236 & & 5 & $\overline{O B} 1$ & 4 & 1 & 9.65 & 25 & 25 & & 25 & & & 25 & \\
\hline 12412 & 236 & & 5 & $\mathrm{OB} 1$ & 14 & 1 & 3.62 & 5 & 5 & & 5 & & & & \\
\hline 12412 & 236 & & 5 & OB1 & 4 & 2 & 11.81 & 5 & 5 & & 5 & & 2 & 3 & \\
\hline 12412 & 237 & & 5 & OB1 & 4 & 1 & 1.43 & 1 & 1 & & 1 & & & 1 & \\
\hline 12412 & 238 & & 4 & OB1 & 4 & 3 & 14.45 & 1 & 1 & & 1 & & & 1 & \\
\hline 12412 & 238 & & 4 & OB1 & 4 & 2 & 27.86 & 11 & 11 & & 11 & & 1 & 10 & \\
\hline 12412 & 238 & & 4 & $\overline{\mathrm{OB} 1}$ & 14 & 1 & 3.07 & 6 & & & 6 & & & & \\
\hline 12412 & 238 & & 4 & OB1 & 14 & 2 & 1.35 & 1 & & & 1 & & & & \\
\hline 12412 & 238 & & 4 & OB1 & 4 & 1 & 5.78 & 12 & 12 & & 12 & & & 12 & \\
\hline 12412 & 239 & 16 & 5 & $\mathrm{OB} 1$ & 4 & 2 & 25.89 & 10 & 10 & & 10 & & & 10 & \\
\hline 12412 & 239 & 16 & 5 & $\mathrm{OB} 1$ & 4 & 1 & 6.47 & 11 & 11 & & 11 & & & 11 & \\
\hline 12412 & 239 & 16 & 5 & $\mathrm{OB} 1$ & 4 & 3 & 55.52 & 3 & 3 & & 3 & & 3 & & \\
\hline 12412 & 239 & 16 & 5 & OB1 & 14 & 2 & 7.59 & 2 & & & 2 & & & & \\
\hline 12412 & 240 & & 4 & OB1 & 4 & 6 & 480.3 & 1 & 1 & & 1 & & 1 & & \\
\hline 12412 & 240 & & 4 & OB1 & 4 & 2 & 81.18 & 18 & 18 & & 15 & 3 & 5 & 13 & \\
\hline 12412 & 240 & & 4 & OB1 & 14 & 1 & 8.98 & 10 & & & 10 & & & & \\
\hline 12412 & 240 & & 4 & OB1 & 4 & 4 & 123.28 & 2 & 2 & & 2 & & & 2 & \\
\hline 12412 & 240 & & 4 & OB1 & 4 & 1 & 11.47 & 13 & 13 & & & 13 & & 13 & \\
\hline 12412 & 240 & & 4 & $\mathrm{OB} 1$ & 4 & 5 & 172 & 2 & 2 & & 2 & & 1 & 1 & \\
\hline 12412 & 240 & & 4 & OB1 & 4 & 3 & 157.14 & 10 & 10 & & 7 & 3 & 1 & 9 & \\
\hline 12412 & 241 & & 4 & OB1 & 4 & 1 & 0.98 & 3 & 3 & & & 3 & & 3 & \\
\hline 12412 & 241 & & 4 & OB1 & 14 & 1 & 0.56 & 2 & & & 2 & & & & \\
\hline 12412 & 241 & & 4 & OB1 & 4 & 2 & 3.41 & 1 & 1 & & 1 & & 1 & & \\
\hline 12412 & 242 & & 5 & OB1 & 4 & 2 & 4.15 & 1 & 1 & & & 1 & & 1 & \\
\hline 12412 & 243 & & 5 & OB1 & 14 & 2 & 5.4 & 3 & & & 3 & & & & \\
\hline 12412 & 243 & & 5 & OB1 & 4 & 2 & 6.42 & 4 & 4 & & 4 & & 1 & 3 & \\
\hline 12412 & 243 & & 5 & OB1 & 14 & 1 & 2.43 & 10 & & & 10 & & & & \\
\hline 12412 & 243 & & 5 & OB1 & 4 & 1 & 10.14 & 18 & 18 & & & 18 & & 18 & \\
\hline 12412 & 244 & & 5 & OB1 & 4 & 4 & 17.87 & 1 & 1 & & & 1 & & 1 & \\
\hline 12412 & 246 & & 4 & OB1 & 4 & 4 & 37.19 & 1 & 1 & & 1 & & 1 & & \\
\hline 12412 & 246 & & 4 & OB1 & 4 & 1 & 0.47 & 1 & 1 & & & 1 & 1 & & \\
\hline 12412 & 246 & & 4 & OB1 & 4 & 3 & 40.95 & 3 & 3 & & 3 & & 1 & 2 & \\
\hline 12412 & 246 & & 4 & $\mathrm{OB} 1$ & 4 & 5 & 353.5 & 3 & 3 & & 3 & & 1 & 2 & \\
\hline 12412 & 247 & & 4 & OB1 & 4 & 3 & 110.87 & 9 & 9 & & 5 & 4 & 1 & 8 & \\
\hline 12412 & 247 & & 4 & OB1 & 4 & 2 & 47.46 & 9 & 9 & & 9 & & 1 & 8 & \\
\hline 12412 & 247 & & 4 & OB1 & 4 & 1 & 3.61 & 5 & 5 & & & 5 & & & \\
\hline 12412 & 247 & & 4 & OB1 & 4 & 4 & 162.75 & 6 & 6 & & 6 & & 2 & 4 & \\
\hline 12412 & 248 & & 5 & OB1 & 4 & 3 & 81.96 & 8 & 8 & & 8 & & & 8 & \\
\hline 12412 & 248 & & 5 & OB1 & 4 & 1 & 1.76 & 3 & 3 & & 3 & & & 3 & \\
\hline 12412 & 248 & & 5 & OB1 & 4 & 4 & 37.92 & 1 & 1 & & 1 & & 1 & & \\
\hline 12412 & 248 & & 5 & OB1 & 4 & 2 & 86.39 & 17 & 17 & & 17 & & 1 & 16 & \\
\hline 12412 & 249 & & 5 & OB1 & 4 & 2 & 68.06 & 17 & 17 & & 17 & & 2 & 15 & \\
\hline 12412 & 249 & & 5 & OB1 & 4 & 1 & 2.66 & 4 & 4 & & 4 & & & 4 & \\
\hline
\end{tabular}




\begin{tabular}{|c|c|c|c|c|c|c|c|c|c|c|c|c|c|c|c|}
\hline Site & Coll \# & Feature & LV & Blk & Mat & Size & Grams & Qty & $\mathrm{Fr}$ & $\mathrm{NF}$ & Disc P & Disc A & Cort P & Cort A & Comm \\
\hline \begin{tabular}{|l|}
12412 \\
\end{tabular} & 249 & & 5 & OB1 & 4 & 3 & 119.85 & 9 & 9 & & 9 & & 1 & 8 & \\
\hline 12412 & 249 & & 5 & OB1 & 4 & 4 & 19.04 & 1 & 1 & & 1 & & & 1 & \\
\hline \begin{tabular}{|l|}
12412 \\
\end{tabular} & 250 & & 5 & OB1 & 4 & 3 & 39.03 & 3 & 3 & & 3 & & & 3 & \\
\hline \begin{tabular}{|l|}
12412 \\
\end{tabular} & 250 & & 5 & OB1 & 4 & 2 & 115.37 & 27 & 27 & & 27 & & 3 & 24 & \\
\hline 12412 & 250 & & 5 & OB1 & 4 & 4 & 20.34 & 1 & 1 & & 1 & & & 1 & \\
\hline 12412 & 250 & & 5 & OB1 & 4 & 1 & 10.41 & 9 & 9 & & 9 & & 1 & 8 & \\
\hline \begin{tabular}{|l|}
12412 \\
\end{tabular} & 251 & & 6 & OB1 & 4 & 1 & 40.23 & 7 & 7 & & 7 & & & 7 & \\
\hline \begin{tabular}{|l|}
12412 \\
\end{tabular} & 251 & & 6 & OB1 & 4 & 3 & 17.63 & 2 & 1 & & 1 & & & 2 & \\
\hline \begin{tabular}{|l|}
12412 \\
\end{tabular} & 252 & & 5 & OB1 & 4 & 1 & 10.73 & 11 & 11 & & 11 & & 1 & 10 & \\
\hline \begin{tabular}{|l|}
12412 \\
\end{tabular} & 252 & & 5 & OB1 & 4 & 2 & 29.78 & 11 & 11 & & 11 & & 2 & 9 & \\
\hline 12412 & 252 & & 5 & OB1 & 4 & 4 & 32.83 & 2 & 2 & & 2 & & & 2 & \\
\hline \begin{tabular}{|l|}
12412 \\
\end{tabular} & 252 & & 5 & OB1 & 4 & 3 & 55.41 & 4 & 4 & & 4 & & & 4 & \\
\hline \begin{tabular}{|l|}
12412 \\
\end{tabular} & 253 & 16 & 5 & OB1 & 4 & 3 & 60.18 & 3 & 3 & & 3 & & 1 & 2 & \\
\hline \begin{tabular}{|l|}
12412 \\
\end{tabular} & 253 & 16 & 5 & OB1 & 4 & 2 & 54.05 & 21 & 21 & & 21 & & 2 & 19 & \\
\hline \begin{tabular}{|l|}
12412 \\
\end{tabular} & 253 & 16 & 5 & OB1 & 4 & 4 & 67.95 & 2 & 2 & & 2 & & & 2 & \\
\hline \begin{tabular}{|l|}
12412 \\
\end{tabular} & 253 & 16 & 5 & OB1 & 4 & 1 & 12.45 & 17 & 17 & & 17 & & & 17 & \\
\hline 12412 & 255 & & 5 & OB1 & 4 & 5 & 39.86 & 1 & 1 & & 1 & & 1 & & \\
\hline \begin{tabular}{|l|}
12412 \\
\end{tabular} & 255 & & 5 & OB1 & 4 & 6 & 258.4 & 1 & 1 & & 1 & & 1 & & \\
\hline 12412 & 255 & & 5 & OB1 & 4 & 3 & 28.69 & 2 & 2 & & 2 & & & 2 & \\
\hline \begin{tabular}{|l|}
12412 \\
\end{tabular} & 255 & & 5 & OB1 & 4 & 1 & 21.33 & 18 & 18 & & 18 & & & 18 & \\
\hline \begin{tabular}{|l|}
12412 \\
\end{tabular} & 255 & & 5 & OB1 & 4 & 4 & 158.3 & 5 & 5 & & 5 & & 1 & 4 & \\
\hline 12412 & 255 & & 5 & OB1 & 4 & 2 & 40.85 & 11 & 11 & & 11 & & 1 & 10 & \\
\hline 12412 & 256 & & 5 & OB1 & 4 & 8 & \begin{tabular}{|c|}
999.7 \\
\end{tabular} & 1 & 1 & & 1 & & 1 & & \\
\hline \begin{tabular}{|l|}
12412 \\
\end{tabular} & 256 & & 5 & OB1 & 4 & 4 & 112.17 & 3 & 3 & & 3 & & 2 & 1 & \\
\hline \begin{tabular}{|l|}
12412 \\
\end{tabular} & 256 & & 5 & OB1 & 4 & 2 & 36.91 & 8 & 8 & & 8 & & 2 & 6 & \\
\hline \begin{tabular}{|l|}
12412 \\
\end{tabular} & 256 & & 5 & OB1 & 4 & 6 & 378.3 & 2 & 2 & & 2 & & 1 & 1 & \\
\hline \begin{tabular}{|l|l|}
12412 \\
\end{tabular} & 256 & & 5 & OB1 & 4 & 3 & 31.98 & 3 & 3 & & 3 & & 2 & 1 & \\
\hline 12412 & 256 & & 5 & $\mathrm{OB} 1$ & 4 & 1 & 8.59 & 10 & 10 & & 10 & & & 10 & \\
\hline 12412 & 257 & & 5 & $\mathrm{OB} 1$ & 4 & 2 & 6 & 1 & 1 & & 1 & & 1 & & \\
\hline \begin{tabular}{|l|}
12412 \\
\end{tabular} & 257 & & 5 & $\mathrm{OB} 1$ & 14 & 1 & 1.28 & 1 & & & 1 & & & & \\
\hline \begin{tabular}{|l|}
12412 \\
\end{tabular} & 258 & & 5 & OB1 & 4 & 6 & \begin{tabular}{|l|}
126.97 \\
\end{tabular} & 1 & 1 & & 1 & & 1 & & \\
\hline 12412 & 258 & & 5 & $\mathrm{OB} 1$ & 4 & 3 & 8.08 & 1 & 1 & & 1 & & & 1 & \\
\hline \begin{tabular}{|l|}
12412 \\
\end{tabular} & 258 & & 5 & $\mathrm{OB} 1$ & 4 & 4 & 13.44 & 1 & 1 & & 1 & & & 1 & \\
\hline 12412 & 258 & & 5 & OB1 & 4 & 2 & 37.88 & 23 & 23 & & 23 & & 2 & 19 & \\
\hline 12412 & 261 & & 5 & OB1 & 4 & 4 & 18.34 & 1 & 1 & & 1 & & 1 & & \\
\hline \begin{tabular}{|l|}
12412 \\
\end{tabular} & 262 & 16 & 5 & OB1 & 4 & 5 & 89.11 & 1 & 1 & & 1 & & 1 & & \\
\hline 12412 & 262 & 16 & 5 & OB1 & 4 & 1 & 0.54 & 2 & 2 & & 2 & & & 2 & \\
\hline \begin{tabular}{|l|}
12412 \\
\end{tabular} & 264 & & 5 & $\mathrm{OB} 1$ & 4 & 1 & \begin{tabular}{|l|l|}
1.03 \\
\end{tabular} & 2 & 2 & & 2 & & 1 & 1 & \\
\hline 12412 & 265 & & 5 & $\mathrm{OB} 1$ & 4 & 2 & 47.49 & 18 & 18 & & 18 & & & 18 & \\
\hline 12412 & 265 & & 5 & OB1 & 14 & 1 & 1.09 & 1 & & & 1 & & & & \\
\hline 12412 & 265 & & 5 & OB1 & 4 & 3 & 36.87 & 4 & 4 & & 4 & & 1 & 3 & \\
\hline 12412 & 265 & & 5 & OB1 & 4 & 1 & 1.93 & 2 & 2 & & 2 & & & 2 & \\
\hline 12412 & 266 & & 5 & OB1 & 4 & 2 & 10.79 & 4 & 4 & & 4 & & & 4 & \\
\hline 12412 & 266 & & 5 & OB1 & 14 & 1 & 2.64 & 3 & & & 3 & & & & \\
\hline 12412 & 266 & & 5 & OB1 & 4 & 1 & 1.72 & 2 & 2 & & 2 & & & 2 & \\
\hline \begin{tabular}{|l|}
12412 \\
\end{tabular} & 267 & & 5 & OB1 & 4 & 2 & 74.56 & 25 & 25 & & 25 & & 3 & 22 & \\
\hline 12412 & 267 & & 5 & $\mathrm{OB1}$ & 4 & 4 & 58.93 & 2 & 2 & & 2 & & 1 & 1 & \\
\hline 12412 & 267 & & 5 & OB1 & 4 & 3 & 35.77 & 4 & 4 & & 4 & & 1 & 3 & \\
\hline \begin{tabular}{|l|}
12412 \\
\end{tabular} & 267 & & 5 & $\mathrm{OB} 1$ & 4 & 1 & 20.22 & 35 & 35 & & 35 & & & 35 & \\
\hline \begin{tabular}{|l|}
12412 \\
\end{tabular} & 268 & & 5 & OB1 & 4 & 4 & 15.14 & 1 & 1 & & 1 & & & 1 & \\
\hline \begin{tabular}{|l|}
12412 \\
\end{tabular} & 268 & & 5 & OB1 & 4 & 1 & 1.1 & 3 & 3 & & 3 & & & 3 & \\
\hline 12412 & 268 & & 5 & OB1 & 4 & 3 & 15.8 & 2 & 2 & & 2 & & 1 & 1 & \\
\hline 12412 & 269 & & 5 & OB1 & 4 & 1 & 14.06 & 14 & 14 & & 14 & & & 14 & \\
\hline \begin{tabular}{|l|}
12412 \\
\end{tabular} & 269 & & 5 & OB1 & 4 & 2 & $\begin{array}{l}17.17 \\
\end{array}$ & 7 & 7 & & 7 & & 1 & 6 & \\
\hline \begin{tabular}{|l|}
12412 \\
\end{tabular} & 269 & & 5 & OB1 & 14 & 1 & 2.39 & 4 & & & 4 & & & & \\
\hline \begin{tabular}{|l|}
12412 \\
\end{tabular} & 270 & & 5 & OB1 & 14 & 1 & \begin{tabular}{ll|}
1.32 \\
\end{tabular} & 2 & & & 2 & & & & \\
\hline \begin{tabular}{|l|}
12412 \\
\end{tabular} & 270 & & 5 & OB1 & 4 & 1 & 14.95 & 23 & 23 & & 23 & & 2 & 21 & \\
\hline \begin{tabular}{|l|}
12412 \\
\end{tabular} & 270 & & 5 & OB1 & 4 & 2 & 43.51 & 15 & 15 & & 15 & & 2 & 13 & \\
\hline \begin{tabular}{|l|}
12412 \\
\end{tabular} & 271 & & 5 & OB1 & 4 & 1 & 1.03 & 1 & 1 & & 1 & & & 1 & \\
\hline 12412 & 271 & & 5 & OB1 & 1 & 1 & \begin{tabular}{|l|}
1.32 \\
\end{tabular} & 1 & 1 & & 1 & & & 1 & \\
\hline \begin{tabular}{|l|}
12412 \\
\end{tabular} & 271 & & 5 & OB1 & 4 & 2 & \begin{tabular}{|l|}
3.87 \\
\end{tabular} & 1 & 1 & & 1 & & & 1 & \\
\hline \begin{tabular}{|l|}
12412 \\
\end{tabular} & 271 & & 5 & $\mathrm{OB} 1$ & 4 & 5 & 26.91 & 1 & 1 & & 1 & & 1 & & \\
\hline \begin{tabular}{|l|}
12412 \\
\end{tabular} & 272 & & 5 & $\mathrm{OB1}$ & 4 & 2 & 20.46 & 13 & 13 & & 13 & & & 13 & \\
\hline \begin{tabular}{|l|}
12412 \\
\end{tabular} & 272 & & 5 & OB1 & 14 & 1 & $\begin{array}{l}6.04 \\
\end{array}$ & 15 & & & 15 & & & & \\
\hline \begin{tabular}{|l|l|}
12412 \\
\end{tabular} & 272 & & 5 & $\mathrm{OB1}$ & 14 & 3 & 15.09 & 1 & & & 1 & & & & \\
\hline
\end{tabular}




\begin{tabular}{|c|c|c|c|c|c|c|c|c|c|c|c|c|c|c|c|}
\hline \begin{tabular}{|l|} 
Site \\
12412
\end{tabular} & \begin{tabular}{|r|} 
Coll \# \\
272 \\
\end{tabular} & Feature & $\frac{\mathrm{LV}}{5}$ & \begin{tabular}{|l|} 
Blk \\
OB1
\end{tabular} & Mat & \begin{tabular}{|c|} 
Size \\
1
\end{tabular} & \begin{tabular}{|c|} 
Grams \\
1784
\end{tabular} & Qty & $\mathrm{Fr}$ & $\mathrm{NF}$ & Disc $\mathrm{P}$ & Disc A & Cort $P$ & Cort A & Comm \\
\hline \begin{tabular}{|l|}
12412 \\
12412
\end{tabular} & $\begin{array}{l}272 \\
272\end{array}$ & & 5 & OB1 & 4 & 1 & 17.84 & 35 & 35 & & 35 & & & 35 & \\
\hline & $\frac{272}{272}$ & & 5 & $\mathrm{OB} 1$ & 14 & 2 & 8.44 & 4 & & & 4 & & & & \\
\hline \begin{tabular}{|l|}
12412 \\
\end{tabular} & $\frac{272}{273}$ & & 5 & OB1 & 1 & 1 & 0.22 & 1 & 1 & & 1 & & & 1 & \\
\hline 12412 & $\frac{273}{273}$ & & 5 & OB1 & 14 & 1 & 1.58 & 3 & & & 3 & & & & \\
\hline 12412 & $\frac{273}{273}$ & & 5 & OB1 & 4 & 2 & 1.19 & 1 & 1 & & 1 & & & 1 & \\
\hline 12412 & $\begin{array}{l}273 \\
274\end{array}$ & & 5 & OB1 & 4 & 1 & 2.16 & 3 & 3 & & 3 & & & 3 & \\
\hline \begin{tabular}{|l|}
12412 \\
\end{tabular} & $\frac{214}{274}$ & & 5 & OB1 & 14 & 1 & 2.86 & 7 & & & 7 & & & & \\
\hline \begin{tabular}{|l|l|}
12412 \\
\end{tabular} & 274 & & $\frac{5}{5}$ & \begin{tabular}{|l|} 
OB1 \\
BB1
\end{tabular} & $\frac{14}{4}$ & $\frac{2}{2}$ & $\begin{array}{r}2.58 \\
51.17\end{array}$ & $\frac{2}{17}$ & & & 2 & & & & \\
\hline 12412 & 274 & & 5 & OB1 & $\frac{7}{4}$ & $\frac{5}{4}$ & 12364 & 3 & $\frac{11}{3}$ & & $\frac{17}{3}$ & & & $\frac{17}{3}$ & \\
\hline \begin{tabular}{|l|}
12412 \\
\end{tabular} & 274 & & 5 & OB1 & 4 & 6 & 108.7 & 1 & 1 & & 1 & & 1 & & \\
\hline \begin{tabular}{|l|}
12412 \\
\end{tabular} & 274 & & 5 & OB1 & 4 & 3 & 32.53 & 5 & 5 & & 5 & & 1 & 4 & \\
\hline \begin{tabular}{|l|}
12412 \\
\end{tabular} & 274 & & 5 & $\mathrm{OB} 1$ & 1 & 1 & 0.35 & 1 & 1 & & 1 & & & 1 & \\
\hline 12412 & 274 & & 5 & OB1 & 4 & 1 & 28.24 & 48 & 48 & & 48 & & & 48 & \\
\hline 12412 & 274 & & 5 & OB1 & 4 & 5 & 69.23 & 1 & 1 & & 1 & & 1 & & \\
\hline \begin{tabular}{|l|}
12412 \\
\end{tabular} & 275 & & 5 & OB1 & 4 & 1 & 1.26 & 3 & 3 & & 3 & & & 3 & \\
\hline 12412 & 276 & & 5 & OB1 & 4 & 2 & 2.47 & 1 & 1 & & 1 & & & 1 & \\
\hline 12412 & 276 & & 5 & OB1 & 4 & 2 & 0.46 & 3 & 3 & & 3 & & & 3 & \\
\hline 12412 & 277 & & 6 & OB1 & 4 & 1 & 2.16 & 8 & 8 & & 8 & & & 8 & \\
\hline 12412 & 278 & & 6 & OB1 & 4 & 3 & 21.2 & 2 & 2 & & 2 & & 1 & 1 & \\
\hline 12412 & 278 & & 6 & OB1 & 4 & 2 & 1.67 & 1 & 1 & & & & & 1 & \\
\hline \begin{tabular}{|l|}
12412 \\
\end{tabular} & 278 & & 6 & OB1 & 4 & 1 & 2.58 & 4 & 4 & & 4 & & & 4 & \\
\hline 12412 & 279 & & 6 & OB1 & 4 & 1 & 1 & 1 & & & 1 & & & & \\
\hline 12412 & 279 & & 6 & OB1 & 4 & 1 & 1.09 & 4 & 4 & & 4 & & & 4 & \\
\hline 12412 & 279 & & 6 & OB1 & 4 & 2 & 1.05 & 1 & 1 & & 1 & & & 1 & \\
\hline 12412 & 279 & & 6 & OB1 & 4 & 3 & 12.31 & 1 & 1 & & 1 & & 1 & & \\
\hline \begin{tabular}{|l|}
12412 \\
\end{tabular} & 280 & & 6 & OB1 & 4 & 2 & 1.5 & 2 & 2 & & 2 & & & 2 & \\
\hline \begin{tabular}{|l|}
12412 \\
\end{tabular} & 281 & & 6 & OB1 & 4 & 2 & 1.93 & 1 & 1 & & 1 & & & 1 & \\
\hline 12412 & 282 & & 6 & $\mathrm{OB} 1$ & 4 & 2 & 16.78 & 6 & 6 & & 6 & & 3 & 3 & \\
\hline \begin{tabular}{|l|l}
12412 \\
\end{tabular} & 282 & & 6 & $\mathrm{OB} 1$ & 4 & 3 & 15.5 & 3 & 3 & & 3 & & & 3 & \\
\hline 12412 & 282 & & 6 & OB1 & 14 & 1 & 0.54 & 1 & & & 1 & & & & \\
\hline \begin{tabular}{|l|}
12412 \\
\end{tabular} & 282 & & 6 & $\mathrm{OB} 1$ & 4 & 1 & 3.5 & 4 & 4 & & 4 & & & 4 & \\
\hline 12412 & 283 & & 6 & OBB1 & 4 & 4 & 19.94 & 1 & 1 & & 1 & & 1 & & \\
\hline \begin{tabular}{|l|}
12412 \\
\end{tabular} & 284 & & 6 & OB1 & 4 & 1 & 1.68 & 6 & 6 & & 6 & & & 6 & \\
\hline \begin{tabular}{|l|}
12412 \\
\end{tabular} & 284 & & 6 & OB1 & 4 & 2 & 2.8 & 2 & 2 & & 2 & & & 2 & \\
\hline \begin{tabular}{|l|}
12412 \\
\end{tabular} & 284 & & 6 & OB1 & 4 & 3 & 17.18 & 2 & 2 & & 2 & & 1 & 1 & \\
\hline \begin{tabular}{|l|}
12412 \\
\end{tabular} & 284 & & 6 & OB1 & 14 & 1 & 0.66 & 1 & & & 1 & & & & \\
\hline 12412 & 285 & & 4 & OB1 & 4 & 5 & 350.6 & 3 & 3 & & 3 & & 2 & 1 & \\
\hline 12412 & 285 & & 4 & OB1 & 4 & 6 & 416.9 & 2 & 2 & & 2 & & 1 & 1 & \\
\hline 12412 & 285 & & 4 & OB1 & 4 & 3 & 40.03 & 5 & 5 & & 5 & & 1 & 4 & \\
\hline 12412 & 285 & & 4 & OB1 & 4 & 2 & 20.26 & 9 & 9 & & 9 & & & 9 & \\
\hline 12412 & 285 & & 4 & OBB1 & 4 & 1 & 9.61 & 17 & 17 & & 17 & & & 17 & \\
\hline \begin{tabular}{|l|}
12412 \\
\end{tabular} & 286 & & 6 & OB1 & 4 & 2 & 7.2 & 3 & 3 & & 3 & & 1 & 2 & \\
\hline 12412 & 286 & & 6 & OBB1 & 4 & 3 & 6.73 & 1 & 1 & & 1 & & & 1 & \\
\hline \begin{tabular}{|l|}
12412 \\
\end{tabular} & 286 & & 6 & $\mathrm{OB1}$ & 4 & 1 & 3.67 & 9 & 9 & & 9 & & & 9 & \\
\hline \begin{tabular}{|l|}
12412 \\
\end{tabular} & 287 & & 6 & $\mathrm{OB} 1$ & 4 & 1 & 10.39 & 21 & 21 & & 21 & & & 21 & \\
\hline 12412 & 287 & & 6 & OB1 & 14 & 3 & 13.61 & 1 & & & 1 & & & & \\
\hline 12412 & 287 & & 6 & OB1 & 14 & 2 & 3.2 & 2 & & & 2 & & & & \\
\hline 12412 & 287 & & 6 & $\mathrm{OB} 1$ & 4 & 2 & 12.7 & 5 & 5 & & 5 & & & 5 & \\
\hline 12412 & 289 & & 6 & OB1 & 1 & 1 & 0.31 & 1 & 1 & & & 1 & & 1 & \\
\hline \begin{tabular}{|l|}
12412 \\
\end{tabular} & 289 & & 6 & OB1 & 14 & 2 & 2.35 & 1 & & & 1 & & & & \\
\hline 12412 & 289 & & 6 & OB1 & 4 & 5 & 154.87 & 1 & 1 & & 1 & & & 1 & \\
\hline 12412 & 289 & & 6 & OB1 & 4 & 1 & 5.89 & 9 & 9 & & 9 & & & 9 & \\
\hline 12412 & 289 & & 6 & OB1 & 4 & 2 & 21.96 & 5 & 5 & & 5 & & & 5 & \\
\hline 12412 & 289 & & 6 & OB1 & 14 & 1 & 2.36 & 7 & & & 7 & & & & \\
\hline 12412 & 290 & & 6 & OB1 & 4 & 2 & 8.21 & 3 & 3 & & 3 & & 1 & 2 & \\
\hline 12412 & 290 & & 6 & OB1 & 4 & 3 & 15.06 & 1 & 1 & & 1 & & & 1 & \\
\hline \begin{tabular}{|l|}
12412 \\
\end{tabular} & 290 & & 6 & OB1 & 4 & 1 & 4.07 & 6 & 6 & & $\overline{6}$ & & & 6 & \\
\hline \begin{tabular}{|l|}
12412 \\
\end{tabular} & 291 & & 6 & OB1 & 4 & 2 & 10.73 & 7 & 7 & & 7 & & & 7 & \\
\hline \begin{tabular}{|l|}
12412 \\
\end{tabular} & 291 & & 6 & OB1 & 4 & 1 & 4.58 & 10 & 10 & & 10 & & & 10 & \\
\hline 12412 & 291 & & 6 & OB1 & 4 & 3 & 4.54 & 1 & 1 & & 1 & & & 1 & \\
\hline 12412 & 291 & & 6 & OB1 & 4 & 4 & 25.09 & 1 & 1 & & 1 & & & 1 & \\
\hline 12412 & 292 & 16 & 5 & OB1 & 4 & 2 & 10.32 & 4 & 4 & & 4 & & 1 & 3 & \\
\hline 12412 & 292 & 16 & 5 & OB1 & 4 & 1 & 4.22 & 18 & 18 & & 18 & & & 18 & \\
\hline 12412 & 292 & 16 & 5 & OB1 & 4 & 3 & 6.24 & 1 & 1 & & 1 & & & 1 & \\
\hline
\end{tabular}




\begin{tabular}{|c|c|c|c|c|c|c|c|c|c|c|c|c|c|c|c|}
\hline Site & Coll \# & Feature & LV & Blk & Mat & Size & Grams & Qty & $F_{T}$ & $\mathrm{NF}$ & Disc $P$ & Disc A & Cort P & Cort A & Cormm \\
\hline 12412 & 545 & & 15 & OA1 & \begin{tabular}{|l|}
14 \\
\end{tabular} & 2 & 4.7 & 4 & & & 4 & & & & \\
\hline 12412 & 545 & & 15 & OA1 & 4 & 2 & 1.4 & 1 & 1 & & 1 & & & 1 & \\
\hline 12412 & 545 & & 15 & OA1 & 14 & 1 & 3.27 & 4 & & & 4 & & & & \\
\hline 12412 & 546 & & 14 & OA1 & \begin{tabular}{|l|}
14 \\
\end{tabular} & 1 & 0.36 & 1 & & & 1 & & & & \\
\hline 12412 & 546 & & 14 & OA1 & 14 & 2 & 2.73 & 1 & & & 1 & & & & \\
\hline 12412 & 547 & & 14 & OA1 & 14 & 1 & 0.64 & 3 & & & 3 & & & & \\
\hline 12412 & 547 & & 14 & OA1 & 4 & 2 & 6.38 & 1 & 1 & & 1 & & & 1 & \\
\hline 12412 & 547 & & 14 & OA1 & 4 & 1 & 0.53 & 1 & 1 & & 1 & & & 1 & \\
\hline 12412 & 548 & & 15 & OA1 & 14 & 1 & 2.27 & 2 & & & 2 & & & & \\
\hline 12412 & 548 & & 15 & $0 A 1$ & 4 & 1 & 0.4 & 2 & 2 & & 2 & & & 2 & \\
\hline 12412 & 548 & & 15 & OA1 & 4 & 2 & 2.22 & 1 & 1 & & 1 & & 1 & & \\
\hline 12412 & 548 & & 15 & OA1 & 14 & 2 & 1.09 & 1 & & & 1 & & & & \\
\hline 12412 & 549 & & 16 & OA1 & 14 & 1 & 2 & 5 & & & 5 & & & & \\
\hline 12412 & 549 & & 16 & OA1 & 14 & 2 & 2.38 & 1 & & & 1 & & & & \\
\hline 12412 & 550 & & 15 & OA1 & 14 & 2 & 31.55 & 12 & & & 12 & & & & \\
\hline 12412 & 550 & & 15 & OA1 & 4 & 2 & 36.17 & 10 & 10 & & 10 & & 3 & 7 & \\
\hline 12412 & 550 & & 15 & OA1 & 14 & 1 & 18.22 & 21 & & & 21 & & & & \\
\hline 12412 & 550 & & 15 & OA1 & 4 & 1 & 28.77 & 33 & 33 & & 33 & & & 33 & \\
\hline 12412 & 552 & 12 & 15 & OA1 & 14 & 1 & 0.43 & 6 & & & 6 & & & & \\
\hline 12412 & 553 & 12 & 15 & OA1 & 14 & 1 & 0.5 & 2 & & & 2 & & & & \\
\hline 12412 & 554 & & 15 & OA1 & 14 & 1 & 0.98 & 2 & & & 2 & & & & \\
\hline 12412 & 555 & & 15 & OA1 & 14 & 3 & 24.17 & 3 & & & 3 & & & & \\
\hline 12412 & 555 & & 15 & OA1 & 14 & 2 & 16.51 & 5 & & & 5 & & & & \\
\hline 12412 & 555 & & 15 & OA1 & 14 & 1 & 5.49 & 6 & & & 6 & & & & \\
\hline 12412 & 556 & & 15 & $0 \mathrm{~A} 1$ & 4 & 3 & 34.4 & 2 & 2 & & 1 & 1 & & & \\
\hline 12412 & 556 & & 15 & OA1 & 14 & 3 & 12.34 & 2 & & & 2 & & & & \\
\hline 12412 & 556 & & 15 & OA1 & 14 & 2 & 9 & 3 & & & 3 & & & & \\
\hline 12412 & 556 & & 15 & OA1 & 14 & 1 & 3.02 & 3 & & & 3 & & & & \\
\hline 12412 & 557 & & 16 & OA1 & 14 & 2 & 7.87 & 4 & & & 4 & & & & \\
\hline 12412 & 557 & & 16 & OA1 & 14 & 1 & 6.82 & 6 & & & 6 & & & & \\
\hline 12412 & 558 & 12 & 15 & OA1 & 14 & 1 & 1.08 & 8 & & & 8 & & & & \\
\hline 12412 & 559 & & 16 & OA1 & 7 & 2 & 1.88 & 1 & 1 & & 1 & & 1 & & \\
\hline 12412 & 559 & & 16 & OA1 & 14 & 2 & 22.32 & 7 & & & 7 & & & & \\
\hline 12412 & 559 & & 16 & OA1 & 4 & 2 & 56.76 & 11 & 11 & & 11 & & 1 & 10 & \\
\hline 12412 & 559 & & 16 & OA1 & 4 & 3 & 24.66 & 2 & 2 & & & & & 2 & \\
\hline 12412 & 559 & & 16 & $\overline{0 A 1}$ & 14 & 1 & 18.67 & 24 & & & 24 & & & & \\
\hline 12412 & 559 & & 16 & OA1 & 6 & 1 & 1.03 & 2 & 2 & & 2 & & & 2 & \\
\hline 12412 & 559 & & 16 & OA1 & 4 & 1 & 28.67 & 33 & 33 & & 33 & & & 33 & \\
\hline 12412 & 560 & & 15 & OA1 & 14 & 1 & 12.13 & 21 & & & 21 & & & & \\
\hline 12412 & 560 & & 15 & OA1 & 14 & 3 & 41.28 & 2 & & & 2 & & & & \\
\hline 12412 & 560 & & 15 & OA1 & 4 & 1 & 0.44 & 1 & 1 & & 1 & & & 1 & \\
\hline 12412 & 560 & & 15 & OA1 & 14 & 2 & 25.76 & 8 & & & 8 & & & & \\
\hline 12412 & 561 & & 15 & OA1 & 4 & 1 & 1.38 & 3 & 3 & & 3 & & & 3 & \\
\hline 12412 & 561 & & 15 & OA1 & 14 & $\overline{1}$ & 0.98 & 4 & & & 4 & & & & \\
\hline 12412 & 561 & & 15 & OA1 & 4 & 3 & 5.18 & 1 & 1 & & 1 & & & 1 & \\
\hline$\frac{12412}{12}$ & 561 & & 15 & \begin{tabular}{|l|l} 
OA1 \\
\end{tabular} & 14 & 2 & 9.49 & 4 & & & 4 & & & & \\
\hline 12412 & 568 & & 15 & OA1 & 14 & 1 & 4.94 & 10 & & & 10 & & & & \\
\hline 12412 & 568 & & 15 & OA1 & 4 & 1 & 3.79 & 1 & 1 & & 1 & & & 1 & \\
\hline 12412 & 569 & 12 & 15 & OA1 & 4 & 1 & 1.3 & 1 & 1 & & 1 & & 1 & & \\
\hline 12412 & 569 & 12 & 15 & OA1 & 14 & 2 & 32.85 & 16 & & & 16 & & & & \\
\hline 12412 & 569 & 12 & 15 & OA1 & 4 & 1 & 1.3 & 1 & 1 & & 1 & & 1 & & \\
\hline 12412 & 569 & 12 & 15 & OA1 & 4 & 3 & 13.53 & 1 & 1 & & 1 & & 1 & & \\
\hline 12412 & 569 & 12 & 15 & OA1 & 14 & 1 & 6.47 & 9 & & & 9 & & & & \\
\hline 12412 & 569 & 12 & 15 & OA1 & 4 & 3 & 13.53 & 1 & 1 & & 1 & & 1 & & \\
\hline 12412 & 569 & 12 & 15 & OA1 & 14 & 2 & 32.85 & 16 & & & 16 & & & & \\
\hline 12412 & 569 & 12 & 15 & OA1 & 14 & 1 & 6.47 & 9 & & & 9 & & & & \\
\hline 12412 & 570 & & 15 & OA1 & 14 & 2 & 9.83 & 6 & & & 6 & & & & \\
\hline 12412 & 570 & & 15 & OA1 & 14 & 1 & 8.63 & 16 & & & 16 & & & & \\
\hline 12412 & 571 & 12 & 15 & OA1 & 14 & 2 & 19.3 & 7 & & & 7 & & & & \\
\hline 12412 & 571 & 12 & 15 & OA1 & 14 & 1 & 18.88 & 27 & & & 27 & & & & \\
\hline 12412 & 574 & 12 & 15 & OA1 & 14 & 2 & 2.13 & 2 & & & 2 & & & & \\
\hline 12412 & 574 & 12 & 15 & OA1 & 4 & 2 & 2.89 & 1 & & 1 & 1 & & 1 & & \\
\hline 12412 & 574 & 12 & 15 & OA1 & 14 & 1 & 3.4 & 6 & & & 6 & & & & \\
\hline 12412 & 575 & & 15 & OA1 & 14 & 1 & 5.4 & 7 & & & 7 & & & & \\
\hline 12412 & 575 & & 15 & OA1 & 14 & 2 & 13.76 & 4 & & & 4 & & & & \\
\hline
\end{tabular}




\begin{tabular}{|c|c|c|c|c|c|c|c|c|c|c|c|c|c|c|c|}
\hline Site & Coll\# & Feature & LV & Blk & Mat & Size & Grams & Qty & $\overline{\mathrm{Fr}}$ & NF & Disc P & Disc $A$ & Cort $P$ & Cort A & Comm \\
\hline 12412 & 576 & & 6 & $\overline{0 B 1}$ & 4 & 3 & 43.45 & 6 & 6 & & 6 & & & 6 & \\
\hline 12412 & 576 & & 6 & $0 B 1$ & 4 & 1 & 12.23 & 23 & 23 & & 23 & & 1 & 22 & \\
\hline 12412 & 576 & & 6 & $\overline{O B 1}$ & 4 & 5 & 55.56 & 1 & 1 & & & 1 & 1 & & \\
\hline 12412 & 576 & & 6 & OB1 & 4 & 2 & 28.72 & 14 & 14 & & 14 & 0 & 1 & 13 & \\
\hline 12412 & 576 & & 6 & OB1 & 4 & 4 & 69.42 & 4 & 4 & & 4 & & 2 & 2 & \\
\hline
\end{tabular}




\begin{tabular}{|c|c|c|c|c|c|c|c|c|c|c|c|c|c|c|c|c|}
\hline Site & \begin{tabular}{|l|} 
Coll \# \\
\end{tabular} & Feature & Lev & Blk & $A C$ & Mat & $\mathrm{Sz}$ & Grams & Qty & Frac & $\mathrm{NF}$ & Disc $\mathrm{P}$ & Disc $A$ & Cort $P$ & Cort A & Comments \\
\hline 12719 & 512 & & 0 & 0 & 281 & 6 & 4 & 11.4 & 1 & 1 & & & 1 & 1 & & \\
\hline 12719 & 541 & & 0 & A1 & 281 & 6 & 1 & 1.1 & 1 & 1 & & & 1 & 1 & & \\
\hline 12719 & 618 & & 0 & A1 & 281 & 6 & 3 & 11.3 & 1 & 1 & & & 1 & & 1 & \\
\hline 12719 & 684 & & 0 & A1 & 281 & 6 & 3 & 7.2 & 1 & 1 & & & 1 & 1 & & \\
\hline 12719 & 722 & & 0 & 0 & 281 & 6 & 4 & 14.1 & 1 & 1 & & & 1 & 1 & & \\
\hline 12719 & 729 & & 0 & 0 & 281 & 5 & 4 & 38.4 & 1 & 1 & & 1 & & 1 & & \\
\hline 12719 & 730 & & 0 & 0 & 281 & 5 & 3 & 12.1 & 1 & 1 & & 1 & & 1 & & \\
\hline 12719 & 731 & & 0 & 0 & 281 & 6 & 3 & 6.1 & 1 & 1 & & & 1 & 1 & & \\
\hline 12719 & 736 & & 0 & 0 & 281 & 6 & 2 & 1.67 & 1 & 1 & & & 1 & 1 & & \\
\hline 12719 & 738 & & 0 & 0 & 281 & 6 & 2 & 4.3 & 1 & 1 & & & 1 & 1 & & \\
\hline 12719 & 739 & & 0 & 0 & 281 & 6 & 3 & 9.7 & 1 & 1 & & 1 & & 1 & & \\
\hline 12719 & 828 & & 0 & 0 & 281 & 6 & 5 & 89.6 & 1 & 1 & & & 1 & 1 & & \\
\hline 12719 & 830 & & 0 & 0 & 281 & 6 & 4 & 22.8 & 1 & 1 & & & 1 & 1 & & \\
\hline 12719 & 832 & & 0 & 0 & 281 & 7 & 6 & 384 & 1 & 1 & & 1 & & 1 & & \\
\hline 12719 & 1000 & & 3 & $\mathrm{A1}$ & 283 & 14 & 3 & 48.56 & 2 & & & 1 & 1 & & & \\
\hline 12719 & 1000 & & 3 & A1 & 283 & 14 & 1 & 0.36 & 1 & & & 1 & & & & \\
\hline 12719 & \begin{tabular}{|c|}
1000 \\
\end{tabular} & & 3 & A1 & 281 & 4 & 3 & 40.19 & 3 & 3 & & 2 & 1 & & & \\
\hline 12719 & \begin{tabular}{|l|}
1000 \\
\end{tabular} & & 3 & A1 & 283 & 14 & 2 & 8.62 & 4 & & & & 4 & & & \\
\hline 12719 & 1000 & & 3 & A1 & 281 & 5 & 2 & 2.88 & 1 & 1 & & 1 & & 1 & & \\
\hline 12719 & \begin{tabular}{|l|}
1000 \\
\end{tabular} & & 3 & A1 & 281 & 4 & 1 & 0.8 & 1 & & 1 & & 1 & & & \\
\hline 12719 & 1000 & & 3 & A1 & 281 & 4 & 2 & 3.94 & 2 & & & & & & & \\
\hline 12719 & 1000 & & 3 & A1 & 281 & 4 & 4 & 25.42 & 1 & 1 & & 1 & & & & \\
\hline 12719 & \begin{tabular}{|l|}
1001 \\
\end{tabular} & & 3 & A1 & 281 & 4 & 1 & 0.34 & 1 & & 1 & & 1 & & & \\
\hline 12719 & 1001 & & 3 & A1 & 281 & 4 & 4 & 118.8 & 1 & 1 & & 1 & & & & \\
\hline 12719 & 1001 & & 3 & A1 & 281 & 4 & 2 & 0.91 & 1 & & 1 & & 1 & & & \\
\hline 12719 & \begin{tabular}{|l|}
1001 \\
\end{tabular} & & 3 & A1 & 281 & 4 & 5 & 101.68 & 1 & 1 & & 1 & & 1 & & \\
\hline 12719 & \begin{tabular}{|l|}
1001 \\
\end{tabular} & & 3 & A1 & 281 & 4 & 5 & 75.11 & 2 & & 2 & & 2 & & & \\
\hline 12719 & 1002 & & 3 & A1 & 281 & 4 & 2 & 2.49 & 1 & 1 & & 1 & & & 1 & \\
\hline 12719 & 1002 & & 3 & At & 281 & 4 & 2 & 2.52 & 1 & 1 & & 1 & & & & \\
\hline 12719 & 1002 & & 3 & A1 & 281 & 4 & 2 & 1.97 & 1 & 1 & & 1 & & 1 & & \\
\hline 12719 & 1002 & & 3 & $\overline{A 1}$ & 281 & 6 & 2 & 1.56 & 1 & 1 & & 1 & & & 1 & \\
\hline 12719 & 1002 & & 3 & $\mathrm{~A} 1$ & 281 & 4 & 2 & 2.88 & 1 & 1 & & & 1 & & & \\
\hline 12719 & 1002 & & 3 & A1 & 283 & 14 & 2 & 8.55 & 3 & & 3 & 3 & & & & \\
\hline 12719 & 1002 & & 3 & A1 & 281 & 4 & 5 & 64.98 & 1 & 1 & & 1 & & 1 & & \\
\hline 12719 & 1002 & & 3 & $\mathrm{~A} 1$ & 283 & 14 & 1 & 2.13 & 4 & & 4 & 4 & & & & \\
\hline 12719 & 1002 & & 3 & $\mathrm{~A} 1$ & 281 & 4 & 4 & 65.7 & 3 & 3 & & 3 & & & & \\
\hline 12719 & 1002 & & 3 & A1 & 281 & 4 & 3 & 20.4 & 1 & 1 & & & 1 & & & \\
\hline 12719 & 1002 & & 3 & A1 & 281 & 4 & 1 & 0.42 & 1 & & 1 & & 1 & & & \\
\hline 12719 & 1002 & & 3 & $\mathrm{~A} 1$ & 281 & 4 & 2 & 6.24 & 1 & 1 & & 1 & & 1 & & \\
\hline 12719 & 1002 & & 3 & A1 & 281 & 4 & 1 & 0.52 & 1 & 1 & & 1 & & & 1 & \\
\hline 12719 & 1002 & & 3 & $\mathrm{~A} 1$ & 281 & 6 & 2 & 1.43 & 1 & 1 & & 1 & & & 1 & \\
\hline 12719 & 1002 & & 3 & A1 & 281 & 4 & 2 & 0.95 & 1 & 1 & & 1 & & 1 & & \\
\hline 12719 & 1002 & & 3 & $\mathrm{~A} 1$ & 281 & 4 & 1 & 1.48 & 1 & 1 & & 1 & & & & \\
\hline 12719 & 1003 & & 3 & $\mathrm{~A} 1$ & 281 & 4 & 5 & 315.6 & 2 & 2 & & 2 & & & & \\
\hline 12719 & 1003 & & 3 & $\mathrm{~A} 1$ & 281 & 4 & 6 & 53.96 & 1 & 1 & & 1 & & & 1 & \\
\hline 12719 & 1003 & & 3 & A1 & 281 & 4 & 4 & 192 & 3 & 3 & & 3 & & & & \\
\hline 12719 & 1003 & & 3 & $\mathrm{~A} 1$ & 281 & 4 & 2 & 6.82 & 2 & & 2 & & 2 & & & \\
\hline 12719 & 1003 & & 3 & A1 & 281 & 4 & 2 & 20.07 & 3 & 3 & & 3 & & & & \\
\hline 12719 & 1003 & & 3 & A1 & 283 & 14 & 2 & 4.8 & 2 & & 2 & 1 & 1 & & & \\
\hline 12719 & 1003 & & 3 & A1 & 281 & 4 & 3 & \begin{tabular}{|l|l|}
17.79 \\
\end{tabular} & 2 & & 2 & & 2 & & & \\
\hline 12719 & 1003 & & 3 & A1 & 281 & 2 & 3 & 12.09 & 1 & 1 & & 1 & & 1 & & \\
\hline 12719 & 1003 & & 3 & A1 & 283 & 14 & 3 & \begin{tabular}{|l|}
37.3 \\
\end{tabular} & 3 & & 2 & & 2 & & & \\
\hline 12719 & 1003 & & 3 & $\mathrm{~A} 1$ & 283 & 14 & 1 & 0.8 & 2 & & 2 & & 2 & & & \\
\hline 12719 & 1004 & & 3 & $\overline{A 1}$ & 281 & 4 & 3 & 8.04 & 1 & 1 & & & 1 & & & \\
\hline 12719 & 1004 & & 3 & A1 & 281 & 4 & 4 & 25.55 & 1 & 1 & & & 1 & & & \\
\hline 12719 & 1004 & & 3 & A1 & 281 & 6 & 2 & 1.67 & 1 & & 1 & & 1 & & 1 & \\
\hline 12719 & 1004 & & 3 & A1 & 281 & 4 & 3 & 59.39 & 6 & 6 & & 6 & & & & \\
\hline 12719 & 1004 & & 3 & A1 & 283 & 14 & 2 & 7.2 & 4 & & 3 & 3 & & & & \\
\hline 12719 & 1004 & & 3 & A1 & 281 & 4 & 5 & 190.86 & 3 & 3 & & 3 & & & & \\
\hline 12719 & 1004 & & 3 & $\mathrm{~A} 1$ & 281 & 4 & 2 & 29.58 & 6 & 6 & & 6 & & & & \\
\hline 12719 & 1004 & & 3 & A1 & 281 & 4 & 4 & 11.59 & 1 & 1 & & 1 & & 1 & & \\
\hline 12719 & 1004 & & 3 & A1 & 281 & 4 & 5 & 78.56 & 1 & 1 & & & 1 & 1 & & \\
\hline 12719 & 1004 & & 3 & A1 & 281 & 4 & 4 & 34.89 & 1 & 1 & & 1 & & & & \\
\hline 12719 & 1004 & & 3 & A1 & 281 & 4 & 1 & 3.45 & 2 & 2 & & 2 & & & & \\
\hline 12719 & 1004 & & 3 & $\mathrm{~A} 1$ & 281 & 4 & 1 & 2.29 & 2 & & 2 & 2 & & & & \\
\hline 12719 & 1004 & & 3 & A1 & 281 & 4 & 6 & 282.05 & 2 & 2 & & 2 & & & 2 & \\
\hline 12719 & 1005 & & 3 & $\mathrm{~A} 1$ & 283 & 14 & 1 & 1.1 & 1 & & & 1 & & & & \\
\hline 12719 & 1005 & & 3 & $\mathrm{~A} 1$ & 283 & 14 & 2 & 7.8 & 1 & & & 1 & 1 & & & \\
\hline
\end{tabular}




\begin{tabular}{|c|c|c|c|c|c|c|c|c|c|c|c|c|c|c|c|c|}
\hline Site & Coll \# & Feature & Lev & Blk & $A C$ & \begin{tabular}{|l|} 
Mat \\
\end{tabular} & $S z$ & Grams & Qty & Frac & $\mathrm{NF}$ & Disc $P$ & Disc A & Cort P & Cort A & Comments \\
\hline 12719 & 1006 & & 2 & A1 & 283 & 14 & 2 & 1.22 & 1 & & & 1 & & & & \\
\hline 12719 & 1006 & & 2 & A1 & 283 & 14 & 3 & 14.67 & 1 & & & 1 & & & & \\
\hline 12719 & 1006 & & 2 & $\mathrm{A1}$ & 281 & 4 & 2 & 11.29 & 1 & 1 & & & 1 & & & \\
\hline 12719 & 1006 & & 2 & $\mathrm{~A} 1$ & 281 & 6 & 3 & 4.9 & 1 & 1 & & 1 & & & 1 & \\
\hline 12719 & 1007 & & 2 & $\mathrm{~A} 1$ & 281 & 4 & 3 & 10.43 & 2 & 2 & & 2 & & & & \\
\hline 12719 & 1007 & & 2 & $\mathrm{~A} 1$ & 283 & 14 & 1 & 0.48 & 1 & & & 1 & & & & \\
\hline 12719 & 1007 & & 2 & A1 & 283 & 14 & 2 & 2.04 & 1 & & & 1 & & & & \\
\hline 12719 & 1008 & & 2 & A1 & 281 & 4 & 3 & 24.28 & 2 & 2 & & 2 & & & & \\
\hline 12719 & 1008 & & 2 & A1 & 281 & 4 & 2 & 1.74 & 1 & 1 & & 1 & & 1 & & \\
\hline 12719 & 1008 & & 2 & A1 & 281 & 4 & 1 & 1.9 & 2 & 2 & & 2 & & & & \\
\hline 12719 & 1009 & & 2 & A1 & 283 & 14 & 2 & 2.11 & 1 & & & & 1 & & & \\
\hline 12719 & 1009 & & 2 & $A 1$ & 281 & 4 & 2 & 1.97 & 1 & 1 & & 1 & & 1 & & \\
\hline 12719 & 1009 & & 2 & A1 & 281 & 4 & 1 & 0.98 & 1 & 1 & & & 1 & & 1 & \\
\hline 12719 & 1009 & & 2 & A1 & 283 & 14 & 1 & 1.51 & 1 & & & 1 & & & & \\
\hline 12719 & 1009 & & 2 & A1 & 281 & 4 & 3 & 8.42 & 1 & 1 & & 1 & & 1 & & \\
\hline 12719 & 1009 & & 2 & A1 & 281 & 7 & 2 & 2.28 & 1 & 1 & & & 1 & & 1 & \\
\hline 12719 & 1009 & & 2 & A1 & 281 & 4 & 5 & 51.11 & 1 & 1 & & 1 & & & & \\
\hline 12719 & 1009 & & 2 & A1 & 281 & 4 & 1 & 0.6 & 1 & 1 & & 1 & & & 1 & \\
\hline 12719 & 1009 & & 2 & $\mathrm{~A} 1$ & 281 & 6 & 1 & 0.43 & 1 & 1 & & 1 & & & 1 & \\
\hline 12719 & 1009 & & 2 & A1 & 281 & 4 & 2 & 2.68 & 1 & 1 & & 1 & & & & 2 chert flakes \\
\hline 12719 & 1010 & & 2 & A1 & 283 & 14 & 1 & 0.33 & 1 & & & 1 & & & & \\
\hline 12719 & 1010 & & 2 & A1 & 281 & 4 & 2 & 4.35 & 2 & 2 & & 2 & & & & \\
\hline 12719 & 1010 & & 2 & A1 & 281 & 4 & 1 & 0.54 & 1 & 1 & & 1 & & & & \\
\hline 12719 & 1011 & & 3 & A1 & 281 & 4 & 2 & 1.12 & 1 & 1 & & 1 & & & 1 & \\
\hline 12719 & 1011 & & 3 & A1 & 283 & 14 & 1 & 4.46 & 10 & & & 10 & & & & \\
\hline 12719 & 1011 & & 3 & $\mathrm{~A} 1$ & 281 & 4 & 1 & 1.02 & 1 & 1 & & 1 & & & & 1 chert debi \\
\hline 12719 & 1011 & & 3 & $\mathrm{A1}_{1}$ & 283 & 14 & 3 & 9.68 & 1 & & & 1 & & & & \\
\hline 12719 & 1011 & & 3 & $\mathrm{~A} 1$ & 283 & 14 & 2 & 16.67 & 6 & & & 6 & & & & \\
\hline 12719 & 1012 & & 3 & $\mathrm{~A} 1$ & 283 & 14 & 1 & 0.58 & 1 & & & 1 & & & & \\
\hline 12719 & 1012 & & 3 & A1 & 283 & 14 & 3 & 34.68 & 1 & & & 1 & & & & \\
\hline 12719 & 1012 & & 3 & A1 & 283 & 14 & 2 & 4.34 & 2 & & & 2 & & & & \\
\hline 12719 & 1013 & & 3 & $\mathrm{~A} 1$ & 283 & 14 & 1 & 1.58 & 2 & & & 2 & & & & \\
\hline 12719 & 1014 & & 4 & $\overline{\mathrm{A} 1}$ & 281 & 4 & 1 & 0.36 & 1 & 1 & & 1 & & & & \\
\hline 12719 & 1016 & & 3 & A1 & 281 & 4 & 1 & 0.33 & 1 & 1 & & 1 & & & 1 & \\
\hline 12719 & 1017 & & 4 & A1 & 281 & 4 & 3 & 5.93 & 1 & 1 & & & 1 & & 1 & \\
\hline 12719 & 1018 & & 4 & A1 & 283 & 14 & 1 & 0.8 & 1 & & & 1 & & & & \\
\hline 12719 & 1018 & & 4 & $\mathrm{A1}$ & 281 & 7 & 2 & 2.44 & 1 & 1 & & & 1 & & 1 & \\
\hline 12719 & \begin{tabular}{|l|}
1018 \\
\end{tabular} & & 4 & $\mathrm{A1}$ & 283 & 14 & 2 & 3.46 & 1 & & & 1 & & & & 1 flake \\
\hline 12719 & 1022 & & 3 & A1 & 281 & 4 & 4 & 9.45 & 1 & 1 & & 1 & & & & \\
\hline 12719 & 1023 & & 3 & $\mathrm{~A} 1$ & 283 & 14 & 2 & 3.41 & 1 & & & 1 & & & & \\
\hline 12719 & \begin{tabular}{|l|}
1023 \\
\end{tabular} & & 3 & $\mathrm{~A} 1$ & 281 & 4 & 3 & $\begin{array}{l}19.39 \\
\end{array}$ & 2 & 2 & & 2 & & & & \\
\hline 12719 & 1023 & & 3 & A1 & 283 & 14 & 1 & 0.45 & 1 & & & 1 & & & & \\
\hline 12719 & 1023 & & 3 & A1 & 281 & 4 & 2 & 3.82 & 1 & 1 & & 1 & & & & \\
\hline 12719 & \begin{tabular}{|l|}
1023 \\
\end{tabular} & & 3 & A1 & 281 & 6 & 1 & 0.74 & 1 & 1 & & 1 & & 1 & & \\
\hline 12719 & 1024 & & 4 & A1 & 281 & 4 & 2 & 5.34 & 1 & 1 & & 1 & & & & \\
\hline 12719 & 1024 & & 4 & A1 & 281 & 4 & 4 & 25.89 & 1 & 1 & & 1 & & & & 1 flake \\
\hline 12719 & 1025 & & 1 & A1 & 281 & 4 & 2 & 5.88 & 2 & & 2 & 2 & & & & \\
\hline 12719 & 1025 & & 1 & A1 & 281 & 4 & 4 & 18.95 & 1 & & 1 & 1 & & & & \\
\hline 12719 & 1026 & & 1 & $\mathrm{~A} 1$ & 281 & 4 & 3 & 5.5 & 1 & & 1 & 1 & & & & \\
\hline 12719 & 1027 & & 1 & A1 & 283 & 14 & 1 & 0.76 & 1 & & & 1 & & & & \\
\hline 12719 & \begin{tabular}{|l|}
1027 \\
\end{tabular} & & 1 & A1 & 281 & 6 & 2 & 1.4 & 1 & 1 & & & 1 & 1 & & \\
\hline 12719 & 1028 & & 1 & A1 & 283 & 14 & 2 & 7.38 & 2 & & & 2 & & & & \\
\hline 12719 & 1029 & & 4 & A1 & 281 & 4 & 5 & 152.78 & 2 & 2 & & 2 & & & & 2 flakes \\
\hline 12719 & 1031 & & 3 & A1 & 283 & 14 & 1 & 0.36 & 1 & & & 1 & & & & \\
\hline 12719 & 1032 & & 1 & $\bar{A} 1$ & 283 & 14 & 1 & 0.99 & 1 & & & 1 & & & & \\
\hline 12719 & 1035 & & 2 & A1 & 281 & 4 & 2 & 1.82 & 1 & 1 & & 1 & & & 1 & \\
\hline 12719 & 1035 & & 2 & A1 & 281 & 4 & 5 & \begin{tabular}{|l|}
63.11 \\
\end{tabular} & 1 & 1 & & 1 & & & & \\
\hline 12719 & 1036 & & 2 & $\mathrm{~A} 1$ & 281 & 4 & 1 & 3.59 & 3 & 3 & & 3 & & 3 & & \\
\hline 12719 & 1036 & & 2 & $\mathrm{~A} 1$ & 283 & $\overline{14}$ & 2 & 8.71 & 2 & & & 2 & & & & \\
\hline 12719 & 1036 & & 2 & $\mathrm{~A} 1$ & 283 & 14 & 1 & 3.22 & 6 & & & 6 & & & & \\
\hline 12719 & 1037 & & 1 & $\mathrm{~A} 1$ & 281 & 4 & 2 & 14.54 & 7 & 7 & & 7 & & 3 & 4 & \\
\hline 12719 & 1037 & & 1 & $\mathrm{~A} 1$ & 281 & 4 & 5 & 55.57 & 1 & 1 & & 1 & & 1 & & \\
\hline 12719 & 1037 & & 1 & $\mathrm{~A} 1$ & 281 & 4 & 2 & 4.24 & 1 & 1 & & 1 & & 1 & & \\
\hline 12719 & 1037 & & 1 & A1 & 281 & 4 & 1 & 0.93 & 1 & & 1 & 1 & & 1 & & \\
\hline 12719 & 1037 & & 1 & A1 & 281 & 4 & 1 & 1.22 & 3 & 3 & & 3 & & 3 & & \\
\hline 12719 & 1037 & & 1 & $\mathrm{~A} 1$ & 281 & 4 & 3 & 39.91 & 3 & 3 & & 3 & & 2 & 1 & \\
\hline 12719 & 1037 & & 1 & A1 & 283 & 14 & 2 & 6.96 & 2 & & & 2 & & & 2 & \\
\hline 12719 & \begin{tabular}{|l|}
1037 \\
\end{tabular} & & 1 & $\bar{A} 1$ & 283 & 14 & 1 & 3.99 & 4 & & & 4 & & & & \\
\hline
\end{tabular}




\begin{tabular}{|c|c|c|c|c|c|c|c|c|c|c|c|c|c|c|c|c|}
\hline Site & Coll \# & Feature & Lev & Blk & $A C$ & Mat & $\mathrm{Sz}$ & Grams & Qty & Frac & $\mathrm{NF}$ & Disc $P$ & Disc A & Cort P & $\operatorname{Cort} A$ & Comments \\
\hline 12719 & 1038 & & 4 & $\mathrm{~A} 1$ & 281 & 4 & 2 & 12.64 & 6 & 6 & & 6 & & 3 & 3 & \\
\hline 12719 & 1038 & & 4 & A1 & 281 & 4 & 1 & 1.18 & 2 & 2 & & 2 & & & 2 & \\
\hline 12719 & 1038 & & 4 & A1 & 281 & 4 & 6 & 4.35 & 1 & 1 & & 1 & & & 1 & \\
\hline 12719 & 1038 & & 4 & $\mathrm{~A} 1$ & 283 & 14 & 3 & 7.04 & 1 & & & 1 & & & & \\
\hline 12719 & 1038 & & 4 & $\mathrm{~A} 1$ & 283 & 14 & 2 & 22.45 & 6 & & & 6 & & & & \\
\hline 12719 & 1038 & & 4 & $\mathrm{~A} 1$ & 283 & 14 & 1 & 0.73 & 1 & & & 1 & & & & \\
\hline 12719 & 1039 & & 4 & $\mathrm{~A} 1$ & 281 & 4 & 4 & 45.92 & 1 & 1 & & 1 & & 1 & & \\
\hline 12719 & 1039 & & 4 & $\mathrm{~A} 1$ & 281 & 4 & 2 & 8.53 & 2 & 2 & & 2 & & 2 & & \\
\hline 12719 & 1039 & & 4 & $\mathrm{~A} 1$ & 281 & 4 & 2 & 6.58 & 1 & & 1 & 1 & & 1 & & \\
\hline 12719 & 1040 & & 4 & $\mathrm{~A} 1$ & 281 & 5 & 2 & 1.54 & 1 & 1 & & 1 & & & 1 & \\
\hline 12719 & 1040 & & 4 & $\mathrm{~A} 1$ & 283 & 14 & 1 & 0.62 & 1 & & & 1 & & & & 1 debitage \\
\hline 12719 & 1041 & & 3 & $\mathrm{~A} 1$ & 281 & 4 & 2 & 8.29 & 2 & 2 & & 2 & & & 2 & \\
\hline 12719 & 1041 & & 4 & $\mathrm{~A} 1$ & 281 & 4 & 1 & 1.9 & 3 & 3 & & 3 & & 1 & 2 & \\
\hline 12719 & 1041 & & 3 & $\mathrm{~A} 1$ & 281 & 4 & 4 & 35.27| & 1 & 1 & & 1 & & & $\overline{1}$ & 1 flake \\
\hline 12719 & 1042 & & 3 & $\mathrm{~A} 1$ & 281 & 4 & 1 & 0.84 & 2 & 2 & & 2 & & 1 & 2 & 2 flakes \\
\hline 12719 & 1042 & & 3 & $\mathrm{~A} 1$ & 281 & 4 & 3 & 35.75 & 3 & 3 & & 3 & & 3 & & \\
\hline 12719 & 1042 & & 3 & $\mathrm{~A} 1$ & 281 & 4 & 4 & 46.73 & 1 & 1 & & 1 & & & 1 & \\
\hline 12719 & 1042 & & 3 & $\mathrm{~A} 1$ & 283 & 14 & 2 & 6.66 & 2 & & & 2 & & & & \\
\hline 12719 & 1042 & & 3 & $\mathrm{~A} 1$ & 281 & 1 & 3 & 20.74 & 1 & 1 & & & 1 & 1 & & \\
\hline 12719 & 1042 & & 3 & A1 & 281 & 4 & 2 & 13.81 & 5 & 5 & & 5 & & 1 & 4 & \\
\hline 12719 & 1043 & & 3 & $\mathrm{~A} 1$ & 283 & 14 & 1 & 2.06 & 7 & & & 7 & & & & \\
\hline 12719 & 1043 & & 3 & $\mathrm{~A} 1$ & 283 & 14 & 2 & 4.62 & 2 & & & 2 & & & & \\
\hline 12719 & 1044 & & 4 & $\mathrm{~A} 1$ & 283 & 14 & 3 & 10.18 & 4 & & & 4 & & & & \\
\hline 12719 & 1044 & & 4 & $\mathrm{~A} 1$ & 283 & 14 & 5 & 54.54 & 1 & & & 1 & & & & \\
\hline 12719 & 1045 & & 4 & $\mathrm{~A} 1$ & 281 & 4 & 4 & 78.33 & 1 & 1 & & 1 & & 1 & & \\
\hline 12719 & 1045 & & 4 & $\mathrm{~A} 1$ & 281 & 4 & 1 & 0.85 & 4 & & 4 & 4 & & 4 & & \\
\hline 12719 & 1045 & & 4 & $\mathrm{~A} 1$ & 281 & 4 & 2 & 1.81 & 1 & 1 & & 1 & & & 1 & \\
\hline 12719 & 1046 & & 4 & $\bar{A} 1$ & 281 & 4 & 4 & 30.14 & 1 & 1 & & 1 & & & 1 & 2 flakes \\
\hline 12719 & 1046 & & 4 & $\mathrm{~A} 1$ & 281 & 4 & 2 & 7.56 & 4 & 4 & & 4 & & 2 & 2 & \\
\hline 12719 & 1046 & & 4 & A1 & 281 & 4 & 1 & 1 & 2 & 2 & & 2 & & & 2 & \\
\hline 12719 & 1046 & & 4 & A1 & 283 & 14 & 2 & 3.06 & 1 & & & 1 & & & & \\
\hline 12719 & 1046 & & 4 & A1 & 283 & 14 & 1 & 1.19 & 1 & & & 1 & & & & \\
\hline 12719 & 1047 & & 2 & $\mathrm{~A} 1$ & 281 & 4 & 4 & 43.74 & 1 & 1 & & 1 & & 1 & & \\
\hline 12719 & 1047 & & 2 & $\mathrm{~A} 1$ & 281 & 4 & 1 & 1.54 & 1 & & 1 & 1 & & 1 & & \\
\hline 12719 & 1049 & & 2 & $\mathrm{~A} 1$ & 281 & 4 & 2 & 8.62 & 3 & 3 & & 3 & & 2 & 1 & \\
\hline 12719 & \begin{tabular}{|l|}
1049 \\
\end{tabular} & & 2 & $\mathrm{~A} 1$ & 283 & 14 & 4 & 26.39 & 1 & & & 1 & & & & \\
\hline 12719 & 1049 & & 2 & $\mathrm{~A} 1$ & 281 & 4 & 5 & 119.15 & 2 & 2 & & 2 & & 2 & & \\
\hline 12719 & \begin{tabular}{|l|}
1049 \\
\end{tabular} & & 2 & $\mathrm{~A} 1$ & 281 & 4 & 3 & 14.25 & 2 & 2 & & 2 & & 2 & & \\
\hline 12719 & 1049 & & 2 & $\mathrm{~A} 1$ & 281 & 4 & 1 & 0.62 & 1 & 1 & & 1 & & & 1 & \\
\hline 12719 & 1049 & & 2 & $\mathrm{~A} 1$ & 283 & 14 & 1 & 6.27 & 8 & & & 8 & & & & \\
\hline 12719 & 1049 & & 2 & $\mathrm{~A} 1$ & 283 & 14 & 2 & 4.01 & 2 & & & 2 & & & & \\
\hline 12719 & 1050 & & 3 & $\mathrm{~A} 1$ & 281 & 4 & 2 & 9.82 & 3 & 3 & & 1 & 2 & & 3 & \\
\hline 12719 & 1050 & & 2 & $\mathrm{~A} 1$ & 283 & 14 & 2 & 9.63 & 5 & & & 5 & & & & \\
\hline 12719 & 1051 & & 3 & $\mathrm{~A} 1$ & 281 & 4 & 2 & 2.46 & 1 & 1 & & 1 & & 1 & & \\
\hline 12719 & 1051 & & 3 & $\mathrm{~A} 1$ & 281 & 4 & 3 & 15.08 & 1 & 1 & & 1 & & & 1 & \\
\hline 12719 & 1052 & & 2 & $\mathrm{~A} 1$ & 281 & 4 & 3 & 13.6 & 1 & 1 & & 1 & & & 1 & \\
\hline 12719 & 1052 & & 2 & $\mathrm{~A} 1$ & 281 & 4 & 4 & 90.21 & 1 & 1 & & 1 & & 1 & & \\
\hline 12719 & 1052 & & 2 & $\mathrm{~A} 1$ & 281 & 4 & 2 & 7.72 & 3 & 3 & & 3 & & & 3 & 2 flakes \\
\hline 12719 & 1053 & & 3 & $\mathrm{~A} 1$ & 283 & 14 & 2 & 9.48 & 1 & & & 1 & & & & \\
\hline 12719 & 1053 & & 3 & A1 & 281 & 4 & 3 & 2.03 & 1 & 1 & & 1 & & 1 & & \\
\hline 12719 & 1054 & & 3 & $\mathrm{~A} 1$ & 281 & 4 & 2 & 7.38 & 1 & & & 1 & & & & \\
\hline 12719 & 1055 & & 3 & A1 & 283 & 14 & 1 & 2.43 & 4 & & & 4 & & & & \\
\hline 12719 & 1055 & & 3 & A1 & 283 & 4 & 2 & 7.16 & 3 & & & 3 & & & & 2 flakes \\
\hline 12719 & 1056 & & 2 & $\mathrm{~A} 1$ & 283 & 14 & 1 & 4.19 & 5 & & & 5 & & & & \\
\hline 12719 & 1056 & & 2 & A1 & 283 & 14 & 3 & 28.37 & 2 & & & 2 & & & & \\
\hline 12719 & 1056 & & 2 & A1 & 283 & 14 & 2 & 33.18 & 12 & & & 12 & & & & \\
\hline 12719 & 1057 & & 3 & $\mathrm{~A} 1$ & 283 & 14 & 1 & 1.79 & 2 & & & 2 & & & & \\
\hline 12719 & 1057 & & 3 & $\mathrm{~A} 1$ & 283 & 14 & 2 & 6.91 & 1 & 1 & & 1 & & & & \\
\hline 12719 & 1057 & & 3 & $\mathrm{~A} 1$ & 281 & 4 & 3 & 11.72 & 1 & 1 & & 1 & & 1 & & \\
\hline 12719 & 1057 & & 3 & A1 & 283 & 14 & 3 & 36.38 & 2 & 2 & & 2 & & 2 & & \\
\hline 12719 & 1057 & & 3 & A1 & 281 & 4 & 1 & 7.06 & 9 & 6 & 3 & 9 & & 7 & 2 & \\
\hline 12719 & 1057 & & 3 & $\mathrm{~A} 1$ & 281 & 4 & 2 & 44.13 & 12 & 12 & & 12 & & 12 & & \\
\hline 12719 & 1057 & & 3 & A1 & 281 & 4 & 4 & 37.93 & 1 & 1 & & 1 & & 1 & & \\
\hline 12719 & 1058 & & 3 & $\mathrm{~A} 1$ & 283 & 14 & 2 & 2.84 & 1 & & 1 & 1 & & & & \\
\hline 12719 & 1059 & & 3 & $\mathrm{~A} 1$ & 281 & 4 & 2 & 5.86 & 1 & 1 & & 1 & & & 1 & \\
\hline 12719 & 1059 & & 3 & A1 & 281 & 4 & 3 & 6.6 & 1 & 1 & & 1 & & & 1 & \\
\hline 12719 & 1060 & & 3 & $\mathrm{~A} 1$ & 283 & 14 & 2 & 4.53 & 1 & & & 1 & & & & \\
\hline 12719 & 1062 & & 2 & A1 & 283 & 14 & 2 & 8.2 & 2 & & & 2 & & & & \\
\hline
\end{tabular}




\begin{tabular}{|c|c|c|c|c|c|c|c|c|c|c|c|c|c|c|c|c|}
\hline Site & Coll \# & Feature & Lev & Blk & $A C$ & Mat & $\mathrm{Sz}$ & Grams & Qty & Frac & $\mathrm{NF}$ & Disc $P$ & Disc A & Cort $\mathrm{P}$ & Cort A & Comments \\
\hline 12719 & 1062 & & 2 & $\mathrm{~A} 1$ & 283 & 14 & 1 & 0.69 & 2 & & & 2 & & & & \\
\hline 12719 & 1063 & & 2 & $\mathrm{~A} 1$ & 281 & 4 & 3 & 9.92 & 1 & 1 & & 1 & & & 1 & \\
\hline 12719 & 1064 & & 4 & A1 & 283 & 14 & 2 & 2.17 & 1 & & & 1 & & & & \\
\hline 12719 & 1066 & 32 & 4 & A1 & 281 & 4 & 3 & 24.97 & 4 & 4 & & 4 & & 3 & 1 & \\
\hline 12719 & 1066 & 32 & 4 & A1 & 281 & 4 & 4 & 123.57 & 3 & 3 & & 3 & & 2 & 1 & \\
\hline 12719 & 1066 & 32 & 4 & A1 & 283 & 14 & 3 & 18.46 & 2 & & & 2 & & & & \\
\hline 12719 & 1066 & 32 & 4 & A1 & 281 & 4 & 2 & 50.6 & 15 & 15 & & 15 & & 6 & 9 & \\
\hline \begin{tabular}{|l|l|}
12719 \\
\end{tabular} & 1066 & 32 & 4 & $\mathrm{~A} 1$ & 281 & 4 & 1 & 3.71 & 4 & 4 & & 4 & & 4 & & 1 flake \\
\hline 12719 & 1066 & 32 & 4 & A1 & 281 & 4 & 5 & 298.48 & 2 & 2 & & 2 & & 1 & 1 & \\
\hline 12719 & 1067 & 32 & 4 & A1 & 283 & 14 & 1 & 0.04 & 2 & & & 2 & & & & \\
\hline 12719 & 1068 & 32 & 4 & A1 & 283 & 14 & 1 & 0.9 & 1 & & & 2 & & & & \\
\hline 12719 & 1069 & 32 & 4 & A1 & 283 & 14 & 1 & 0.71 & 3 & & & 3 & & & & \\
\hline 12719 & 1070 & 32 & 4 & A1 & 283 & 14 & 1 & 0.8 & 1 & & & 3 & & & & \\
\hline 12719 & 1070 & 32 & 4 & A1 & 283 & 14 & 3 & 13.8 & 1 & & & 3 & & & & \\
\hline 12719 & 1070 & 32 & 4 & A1 & 281 & 4 & 2 & 1.38 & 1 & 1 & & 1 & & 1 & & \\
\hline 12719 & 1070 & 32 & 4 & $\overline{A 1}$ & 281 & 4 & 1 & 0.54 & 2 & 2 & & 2 & & & 2 & \\
\hline 12719 & 1070 & 32 & 4 & A1 & 283 & 14 & 2 & 2 & 2 & & & 1 & & & & \\
\hline 12719 & 1071 & 32 & 4 & $\mathrm{~A} 1$ & 283 & 14 & 2 & 7.02 & 2 & & & 2 & & & & \\
\hline 12719 & 1071 & 32 & 4 & A1 & 283 & 14 & 4 & 30.23 & 1 & & & 1 & & & & \\
\hline 12719 & 1071 & 32 & 4 & A1 & 283 & 14 & 3 & 16.89 & 1 & & & & 1 & & & \\
\hline 12719 & 1071 & 32 & 4 & A1 & 283 & 14 & 1 & 1.8 & 2 & & & 2 & & & & \\
\hline 12719 & 1073 & 32 & 4 & A1 & 281 & 4 & 1 & 0.67 & 1 & 1 & & 1 & & & 1 & \\
\hline 12719 & 1073 & 32 & 4 & A1 & 283 & 14 & 1 & 1.13 & 2 & & & 2 & & & & \\
\hline 12719 & 1073 & 32 & 4 & $\mathrm{~A} 1$ & 283 & 14 & 4 & 78.24 & 1 & & & 1 & & & & \\
\hline 12719 & 1073 & 32 & 4 & A1 & 283 & 14 & 2 & 2 & 1 & & & 1 & & & & \\
\hline 12719 & 1073 & 32 & 4 & A1 & 281 & 4 & 4 & 84.8 & 1 & 1 & & 1 & & 1 & & \\
\hline 12719 & 1076 & 32 & 4 & A1 & 283 & 14 & 1 & 2.26 & 2 & & & 2 & & & & \\
\hline 12719 & 1076 & 32 & 4 & A1 & 283 & 14 & 2 & 20.97 & 2 & & & 2 & & & & \\
\hline 12719 & 1079 & 32 & 4 & A1 & 283 & 14 & 2 & 1.76 & 1 & & & 1 & & & & \\
\hline 12719 & 1079 & 32 & 4 & A1 & 283 & 14 & 1 & 0.4 & 1 & & & 1 & & & & \\
\hline 12719 & 1080 & & 0 & A1 & 281 & 4 & 1 & 3.16 & 4 & 4 & & 4 & & 1 & 3 & \\
\hline 12719 & 1080 & & 0 & A1 & 283 & 14 & 1 & 2.98 & 3 & & & 3 & & & & \\
\hline 12719 & 1080 & & 0 & A1 & 283 & 14 & 3 & 28.3 & 1 & & & 1 & & & & \\
\hline 12719 & 1080 & & 0 & A1 & 281 & 4 & 4 & 17.35 & 1 & 1 & & 1 & & 1 & & \\
\hline 12719 & 1080 & & 0 & A1 & 281 & 4 & 2 & 24.11 & 6 & 6 & & 6 & & 1 & 5 & \\
\hline 12719 & 1080 & & 0 & A1 & 283 & 14 & 2 & 11.39 & 4 & & & 4 & & & & \\
\hline 12719 & 1081 & & 0 & A1 & 281 & 4 & 2 & 2.94 & 1 & 1 & & 1 & & 1 & & \\
\hline 12719 & 1081 & & 0 & A1 & 283 & 14 & 1 & 2.63 & 3 & & & 3 & & & & \\
\hline 12719 & 1081 & & 0 & A1 & 283 & 14 & 2 & 10.71 & 4 & & & 4 & & & & \\
\hline 12719 & 1081 & & 0 & A1 & 281 & 4 & 4 & 18.72 & 1 & 1 & & 1 & & & 1 & \\
\hline 12719 & 1081 & & 0 & A1 & 281 & 4 & 1 & 2.97 & 4 & 4 & & 4 & & 1 & 3 & 1 chert potlid \\
\hline 12719 & 1082 & & 2 & A1 & 283 & 14 & 4 & 41.36 & 1 & & & 1 & & & & \\
\hline 12719 & 1082 & & 2 & A1 & 283 & 14 & 2 & 5.6 & 6 & & & 7 & & & & \\
\hline 12719 & 1082 & & 2 & A1 & 281 & 4 & 4 & 62.73 & 2 & 2 & & 1 & 1 & 1 & 1 & \\
\hline 12719 & 1083 & & 2 & A1 & 283 & 14 & 1 & 4.87 & 6 & & & 6 & & & & \\
\hline 12719 & 1083 & & 2 & A1 & 281 & 4 & 3 & 12.58 & 1 & 1 & & 1 & & & 1 & \\
\hline 12719 & 1083 & & 2 & A1 & 283 & 14 & 3 & 23.67 & 1 & & & 1 & & & & \\
\hline 12719 & 1083 & & 2 & A1 & 281 & 4 & 2 & 7.49 & 3 & 3 & & 3 & & 2 & 1 & \\
\hline 12719 & 1083 & & 2 & A1 & 283 & 14 & 2 & 10.67 & 3 & & & 3 & & & & \\
\hline 12719 & 1083 & & 2 & A1 & 281 & 4 & 1 & 1.11 & 2 & 2 & & 2 & & & 2 & \\
\hline 12719 & 1084 & & 2 & A1 & 281 & 4 & 2 & 4.1 & 1 & 1 & & 1 & & & 1 & \\
\hline 12719 & 1084 & & 2 & A1 & 281 & 4 & 1 & 3.42 & 5 & 5 & & 5 & & 3 & 2 & \\
\hline 12719 & 1084 & & 2 & A1 & 283 & 14 & 2 & 7.83 & 4 & & & $\frac{\pi}{4}$ & & & & \\
\hline 12719 & 1084 & & 2 & A1 & 283 & 14 & 1 & 4.9 & 6 & & & 6 & & & & \\
\hline 12719 & 1085 & & 2 & A1 & 283 & 14 & 2 & 4.48 & 2 & & & 2 & & & & \\
\hline 12719 & 1085 & & 2 & A1 & 283 & 14 & 1 & 7.53 & 14 & & & 14 & & & & \\
\hline 12719 & \begin{tabular}{|l|}
1085 \\
\end{tabular} & & 2 & A1 & 281 & 4 & 1 & 0.73 & 3 & 3 & & 2 & 1 & & 3 & \\
\hline 12719 & 1085 & & 2 & A1 & 281 & 1 & 2 & 7.93 & 1 & 1 & & & 1 & & 1 & \\
\hline 12719 & 1085 & & 2 & A1 & 281 & 4 & 2 & 1.95 & 2 & 2 & & 2 & & 1 & 1 & \\
\hline 12719 & 1086 & & 2 & A1 & 281 & 4 & 4 & 17.87 & 1 & 1 & & 1 & & 1 & & \\
\hline 12719 & 1086 & & 2 & A1 & 281 & 6 & 2 & 2.04 & 1 & 1 & & & 1 & & 1 & \\
\hline 12719 & 1086 & & 2 & A1 & 281 & 6 & 2 & 2.36 & 1 & 1 & & & 1 & 1 & & \\
\hline 12719 & 1086 & & 2 & $\mathrm{~A} 1$ & 283 & 14 & 4 & 4.9 & 1 & & & 2 & & & & \\
\hline 12719 & 1086 & & 2 & A1 & 281 & 4 & 1 & 1.43 & 1 & 1 & & 1 & & & 1 & \\
\hline 12719 & 1086 & & 2 & A1 & 283 & 14 & 3 & 23.5 & 2 & & & 2 & & & & \\
\hline 12719 & 1086 & & 2 & A1 & 281 & 4 & 2 & 9.28 & 2 & 2 & & 1 & 1 & 1 & 1 & \\
\hline 12719 & 1086 & & 2 & A1 & 283 & 14 & 1 & 0.5 & 1 & & & 8 & & & & \\
\hline 12719 & 1086 & & 2 & A1 & 281 & 6 & 1 & 0.57 & 1 & 1 & & & 1 & & 1 & \\
\hline
\end{tabular}




\begin{tabular}{|c|c|c|c|c|c|c|c|c|c|c|c|c|c|c|c|c|}
\hline Site & Coll \# & Feature & Lev & Blk & $A C$ & Mat & $\mathrm{Sz}$ & Grams & Qty & Frac & $\mathrm{NF}$ & Disc $P$ & Disc A & \begin{tabular}{|l|} 
Cort $P$ \\
\end{tabular} & Cort A & Comments \\
\hline 12719 & 1086 & & 2 & $\mathrm{~A} 1$ & 281 & 6 & 1 & 0.43 & 1 & 1 & & & 1 & & 1 & \\
\hline 12719 & 1086 & & 2 & A1 & 283 & 14 & \begin{tabular}{|l|}
2 \\
\end{tabular} & 24.4 & 9 & & & 3 & & & & \\
\hline 12719 & 1087 & & 2 & A1 & 281 & 4 & 3 & 12.7 & 1 & 1 & & 1 & & & 1 & \\
\hline 12719 & 1087 & & 2 & A1 & 281 & 6 & 2 & 2.08 & 1 & 1 & & 1 & & & 1 & \\
\hline 12719 & 1087 & & 2 & $\mathrm{~A} 1$ & 283 & 14 & 1 & $\begin{array}{l}3.1 \\
\end{array}$ & 5 & & & 1 & & & & \\
\hline 12719 & 1087 & & 2 & A1 & 281 & 4 & 4 & 86.39 & 3 & 3 & & 3 & & 2 & 1 & \\
\hline 12719 & 1087 & & 2 & $\mathrm{~A} 1$ & 283 & 14 & 4 & 55.6 & 2 & 1 & 7 & 8 & & & & \\
\hline 12719 & 1087 & & 2 & $\mathrm{~A} 1$ & 283 & 14 & 2 & 8.9 & 5 & & & 4 & & & & \\
\hline 12719 & 1087 & & 2 & A1 & 281 & 4 & 5 & 85.52 & 1 & 1 & & 1 & & 1 & & \\
\hline 12719 & 1087 & & 2 & $\mathrm{~A} 1$ & 281 & 4 & 2 & 3.14 & 1 & 1 & & 1 & & & 1 & \\
\hline 12719 & 1087 & & 2 & A1 & 281 & 4 & 1 & 0.72 & 1 & 1 & & 1 & & & 1 & \\
\hline 12719 & 1088 & & 2 & $\mathrm{~A} 1$ & 283 & 14 & 1 & 6.09 & 11 & & & 11 & & & & \\
\hline 12719 & 1088 & & 2 & $\mathrm{~A} 1$ & 283 & 14 & 2 & 24.87 & 9 & & & 9 & & & & \\
\hline 12719 & 1088 & & 2 & $\mathrm{~A} 1$ & 281 & 4 & 4 & 10.25 & 1 & 1 & & 1 & & 1 & & \\
\hline 12719 & 1090 & & 2 & $\mathrm{~A} 1$ & 281 & 4 & 1 & 0.73 & 1 & 1 & & 1 & & 1 & & \\
\hline 12719 & 1090 & & 2 & A1 & 281 & 6 & 2 & 2.58 & 1 & 1 & & & 1 & & 1 & \\
\hline 12719 & 1090 & & 2 & $\mathrm{A1}$ & 283 & 14 & 4 & 20.72 & 1 & 1 & & 1 & & & & \\
\hline 12719 & 1090 & & 2 & $\mathrm{~A} 1$ & 281 & 6 & 1 & 1.31 & 1 & 1 & & & 1 & & 1 & \\
\hline 12719 & 1090 & & 2 & $\mathrm{~A} 1$ & 283 & 14 & 1 & \begin{tabular}{|l|}
8.5 \\
\end{tabular} & 7 & & & 7 & & & & \\
\hline 12719 & 1090 & & 2 & A1 & 281 & 4 & 4 & 41.28 & 2 & 2 & & 2 & & 2 & & \\
\hline 12719 & 1090 & & 2 & $\overline{A 1}$ & 283 & 14 & 3 & $\begin{array}{l}4.7 \\
\end{array}$ & 1 & 1 & & 1 & & & & \\
\hline 12719 & 1090 & & 2 & A1 & 283 & 14 & 2 & 4.21 & 2 & & & 2 & & & & \\
\hline 12719 & 1091 & & 2 & A1 & 283 & 14 & 1 & 2.91 & 4 & & & 4 & & & & \\
\hline 12719 & 1091 & & 2 & $\mathrm{~A} 1$ & 281 & 6 & 2 & 2.47 & 1 & 1 & & & 1 & & 1 & \\
\hline 12719 & 1091 & & 2 & A1 & 283 & 14 & 2 & 19.89 & 6 & 2 & 4 & 6 & & & & \\
\hline 12719 & 1091 & & 2 & A1 & 281 & 4 & 3 & 15.76 & 1 & 1 & & 1 & & 1 & & 1 flake \\
\hline 12719 & 1091 & & 2 & A1 & 281 & 6 & 1 & 0.48 & 1 & 1 & & 1 & & & 1 & \\
\hline 12719 & 1091 & & 2 & A1 & 281 & 4 & 1 & 1.36 & 3 & 3 & & 3 & & & 3 & \\
\hline 12719 & 1091 & & 2 & $\mathrm{~A} 1$ & 281 & 4 & 2 & 1.94 & 2 & 2 & & 2 & & & 2 & \\
\hline 12719 & 1092 & & 2 & A1 & 283 & 14 & 1 & 5.91 & 6 & & & 6 & & & & \\
\hline 12719 & 1092 & & 2 & A1 & 283 & 14 & 2 & 25.29 & 7 & & & 7 & & & & \\
\hline 12719 & 1092 & & 2 & A1 & 283 & 14 & 3 & 15.01 & 1 & & & 1 & & & & \\
\hline 12719 & 1093 & & 2 & A1 & 283 & 14 & 2 & 21.24 & 4 & & & 4 & & & & \\
\hline 12719 & 1093 & & 2 & A1 & 283 & 14 & 1 & 0.98 & 1 & & & 1 & & & & \\
\hline 12719 & 1094 & & 0 & A1 & 283 & 14 & 5 & 61.4 & 1 & & & 18 & & & & \\
\hline 12719 & 1094 & & 0 & A1 & 281 & 4 & 2 & 10.08 & 2 & 2 & & 2 & & 2 & & 2 flakes \\
\hline 12719 & 1094 & & 0 & $\mathrm{~A} 1$ & 281 & 4 & 5 & 329.77 & 2 & 2 & & 2 & & 1 & 1 & \\
\hline 12719 & 1094 & & 0 & $\mathrm{~A} 1$ & 283 & 14 & 1 & 8.8 & 11 & & & 1 & & & & \\
\hline 12719 & 1094 & & 0 & A1 & 283 & 14 & 3 & 33.6 & 4 & & & 6 & & & & \\
\hline 12719 & 1094 & & 0 & A1 & 283 & 14 & 2 & 29.8 & 14 & & & 1 & & & & \\
\hline 12719 & 1095 & & 4 & A1 & 281 & 4 & 3 & 36.42 & 2 & 2 & & 2 & & 1 & 1 & \\
\hline 12719 & 1095 & & 2 & $\overline{A 1}$ & 281 & 4 & 2 & 2.31 & 7 & 1 & & 1 & & & 1 & \\
\hline 12719 & 1095 & & 2 & $\mathrm{~A} 1$ & 283 & 14 & 3 & 15.7 & 1 & & & 1 & & & & \\
\hline 12719 & 1095 & & 2 & A1 & 283 & 14 & 1 & 7.59 & 5 & & & 5 & & & & \\
\hline 12719 & 1095 & & 2 & A1 & 283 & 14 & 2 & 13.55 & 5 & 1 & 4 & 5 & & & & \\
\hline 12719 & 1096 & & 4 & A1 & 281 & 4 & 3 & 18.18 & 1 & 1 & & 1 & & & 1 & \\
\hline 12719 & 1096 & & 4 & A1 & 283 & 14 & 2 & 11.56 & 3 & & & 3 & & & & \\
\hline 12719 & 1099 & 32 & 4 & A1 & 281 & 4 & 3 & 52.91 & 1 & & 1 & 1 & & 1 & & \\
\hline 12719 & 2000 & 32 & 4 & A1 & 281 & 4 & 1 & 2.78 & 9 & 9 & & 2 & $\overline{7}$ & 6 & 3 & \\
\hline 12719 & 2000 & 32 & 4 & A1 & 281 & 4 & 3 & 20.14 & 1 & 1 & & & 1 & & 1 & \\
\hline 12719 & 2004 & 32 & 4 & A1 & 283 & 14 & 1 & 0.9 & 3 & & & 1 & & & & \\
\hline 12719 & 2004 & 32 & 4 & A1 & 281 & 4 & 2 & 0.89 & 1 & 1 & & & 1 & & 1 & \\
\hline 12719 & 2005 & & 3 & A1 & 283 & 14 & 1 & 9.3 & 16 & & & 3 & & & & \\
\hline 12719 & 2005 & & 3 & A1 & 283 & 14 & 2 & 35.8 & 19 & & & 23 & & & & \\
\hline 12719 & 2005 & & 3 & A1 & 283 & 14 & 3 & 36 & 3 & & & 19 & & & & 1 flake \\
\hline 12719 & 2005 & & 3 & A1 & 281 & 6 & 2 & 2.2 & 1 & 1 & & 1 & & & 1 & \\
\hline 12719 & 2005 & & 3 & A1 & 281 & 6 & 4 & 8.76 & 1 & 1 & & 1 & & & 1 & \\
\hline 12719 & 2005 & & 3 & A1 & 281 & 4 & 1 & 1.95 & 3 & 3 & & 1 & 2 & & 3 & \\
\hline 12719 & 2005 & & 2 & A1 & 281 & 4 & 4 & 11.07 & 1 & 1 & & & 1 & & 1 & 2 flakes \\
\hline 12719 & 2005 & & 3 & A1 & 281 & 4 & 3 & 7.56 & 1 & 1 & & & 1 & 1 & & \\
\hline 12719 & 2005 & & 3 & A1 & 281 & 4 & 2 & 7.38 & 4 & 4 & & 4 & & & 4 & \\
\hline 12719 & 2006 & 33 & 3 & A1 & 283 & 14 & 1 & 0.47 & 3 & & & 3 & & & & 3 flakes \\
\hline 12719 & 2007 & 33 & 3 & A1 & 283 & 14 & 1 & 6.11 & 18 & & & 18 & & & & \\
\hline 12719 & 2007 & 33 & 3 & A1 & 283 & 14 & 2 & 11.71 & 9 & & & 9 & & & & \\
\hline 12719 & 2007 & 33 & 2 & A1 & 281 & 4 & 3 & 37.12 & 3 & 2 & 1 & 3 & & 2 & 1 & \\
\hline 12719 & 2007 & 33 & 3 & $\mathrm{~A} 1$ & 281 & 6 & 2 & 1.33 & 1 & 1 & & 1 & & & 1 & \\
\hline 12719 & 2007 & 33 & 3 & A1 & 281 & 6 & 1 & 0.26 & 1 & 1 & & 1 & & & 1 & \\
\hline 12719 & 2007 & 33 & 3 & A1 & 281 & 6 & 2 & 1.81 & 1 & 1 & & 1 & & & 1 & \\
\hline
\end{tabular}




\begin{tabular}{|c|c|c|c|c|c|c|c|c|c|c|c|c|c|c|c|c|}
\hline Site & Coll\# & Feature & Lev & Blk & $A C$ & Mat & $\mathrm{Sz}$ & Grams & Qty & Frac & $\mathrm{NF}$ & Disc $P$ & Disc A & Cort P & Cort A & Comments \\
\hline 12719 & 2007 & 33 & 3 & $\mathrm{~A} 1$ & 281 & 4 & 4 & 34.75 & 1 & 1 & & 1 & & 1 & & \\
\hline 12719 & 2007 & 33 & 3 & $\mathrm{~A} 1$ & 281 & 6 & 1 & 0.37 & 1 & 1 & & 1 & & & 1 & \\
\hline 12719 & 2007 & 33 & 2 & $\mathrm{~A} 1$ & 281 & 4 & 2 & 12.13 & 3 & 3 & & 3 & & 2 & 1 & \\
\hline 12719 & 2007 & 33 & 2 & $\mathrm{~A} 1$ & 281 & 4 & 1 & 0.33 & 1 & 1 & & 1 & & & 1 & \\
\hline 12719 & 2007 & 33 & 3 & $\mathrm{~A} 1$ & 281 & 6 & 3 & 15.47 & 1 & 1 & & 1 & & & 1 & \\
\hline 12719 & 2008 & 33 & 3 & A1 & 283 & 14 & 3 & 8.61 & 1 & & & 1 & & & & \\
\hline 12719 & 2008 & 33 & 3 & A1 & 283 & 14 & 2 & 6.32 & 5 & & & 5 & & & & \\
\hline 12719 & 2008 & 33 & 3 & A1 & 283 & 14 & 1 & 6.16 & 13 & & & 13 & & & & \\
\hline 12719 & 2008 & 33 & 3 & A1 & 281 & 4 & 2 & 3.77 & 1 & 1 & & 1 & & & 1 & \\
\hline 12719 & 2009 & 33 & 3 & A1 & 283 & 14 & 1 & 0.64 & 2 & & & 1 & 1 & & & \\
\hline 12719 & 2009 & 33 & 3 & A1 & 283 & 14 & 2 & 5 & 2 & & & 2 & & & & \\
\hline 12719 & 2009 & 33 & 3 & A1 & 283 & 14 & 4 & 37.55 & 2 & & & 2 & & & & \\
\hline 12719 & 2009 & 33 & 3 & A1 & 283 & 14 & 3 & 11.61 & 2 & & & 2 & & & & \\
\hline 12719 & 2010 & 33 & 2 & A1 & 281 & 4 & 1 & 0.44 & 1 & 1 & & 1 & & & 1 & \\
\hline 12719 & 2010 & 33 & 2 & A1 & 281 & 7 & 3 & 7.24 & 1 & 1 & & & 1 & 1 & & \\
\hline 12719 & 2010 & 33 & 2 & $\mathrm{A1}$ & 281 & 4 & 2 & 5.01 & 2 & 2 & & 1 & 1 & & 2 & \\
\hline 12719 & 2010 & 33 & 2 & $\mathrm{~A} 1$ & 283 & 14 & 3 & 13.5 & 1 & & & 14 & & & & \\
\hline 12719 & 2010 & 33 & 2 & A1 & 283 & 14 & 1 & 6.4 & 12 & & & 2 & & & & \\
\hline 12719 & 2010 & 33 & 2 & $\mathrm{~A} 1$ & 283 & 14 & 2 & 22.24 & 5 & & & 4 & 1 & 1 & & \\
\hline 12719 & 2011 & 33 & 3 & $\mathrm{~A} 1$ & 281 & 6 & 2 & 1.21 & 1 & 1 & & & 1 & & 1 & \\
\hline 12719 & \begin{tabular}{|l|}
2011 \\
\end{tabular} & 33 & 3 & $\mathrm{~A} 1$ & 281 & 4 & 1 & 0.38 & 1 & 1 & & & 1 & & 1 & \\
\hline 12719 & \begin{tabular}{|l|}
2011 \\
\end{tabular} & 33 & 3 & $\mathrm{~A} 1$ & 281 & 6 & 3 & 3.67 & 1 & 1 & & 1 & & 1 & & \\
\hline 12719 & 2011 & 33 & 3 & A1 & 281 & 4 & 3 & 10.08 & 2 & 2 & & 2 & & 1 & 1 & 3 flakes \\
\hline 12719 & 2011 & 33 & 3 & A1 & 281 & 4 & 2 & \begin{tabular}{|l|}
1.77 \\
\end{tabular} & 1 & 1 & & & 1 & & 1 & \\
\hline 12719 & 2011 & 33 & 3 & A1 & 283 & 14 & 2 & \begin{tabular}{|c|}
16.7 \\
\end{tabular} & 8 & & & 12 & & & & \\
\hline 12719 & 2011 & 33 & 3 & A1 & 283 & 14 & 1 & 3.3 & 7 & & & 56 & & & & \\
\hline 12719 & \begin{tabular}{|l|}
2011 \\
\end{tabular} & 33 & 3 & A1 & 283 & 14 & 3 & 14.8 & 2 & & & 61 & & & & \\
\hline 12719 & 2011 & 33 & 3 & A1 & 283 & 14 & 5 & 77.4 & 2 & & & 2 & & & & \\
\hline 12719 & 2011 & 33 & 3 & A1 & 283 & 14 & 4 & 73 & 2 & & & 4 & & & & \\
\hline 12719 & 2012 & & 2 & A1 & 281 & 7 & 2 & 5.2 & 1 & 1 & & 1 & & & 1 & \\
\hline 12719 & 2012 & & 2 & A1 & 281 & 7 & 1 & 0.52 & 1 & 1 & & 1 & & & 7 & \\
\hline 12719 & 2012 & & 2 & A1 & 281 & 7 & 1 & 0.68 & 1 & 1 & & 1 & & & 1 & \\
\hline 12719 & 2012 & & 2 & A1 & 281 & 6 & 2 & \begin{tabular}{|c|}
0.87 \\
\end{tabular} & 1 & 1 & & & 1 & & 1 & \\
\hline 12719 & 2012 & & 2 & A1 & 281 & 4 & 3 & 13.98 & 2 & 2 & & 2 & & 1 & 1 & \\
\hline 12719 & 2012 & & 2 & $\mathrm{~A} 1$ & 281 & 4 & 4 & 24.84 & 1 & 1 & & & 1 & & 1 & 1 lfake \\
\hline 12719 & 2012 & & 2 & A1 & 281 & 6 & 1 & 0.37 & 1 & 1 & & & 1 & & 1 & \\
\hline 12719 & 2012 & & 2 & $A 1$ & 283 & 14 & 2 & 4.1 & 1 & & & 2 & 1 & & & \\
\hline 12719 & 2012 & & 2 & A1 & 283 & 14 & 1 & 6.4 & 2 & & & 2 & & & & \\
\hline 12719 & 2012 & & 2 & A1 & 281 & 7 & 1 & \begin{tabular}{|l|l|}
0.83 \\
\end{tabular} & 1 & 1 & & 1 & & & 1 & \\
\hline 12719 & 2013 & & 2 & A1 & 283 & 14 & 2 & 6.67 & 3 & & & 3 & & & & \\
\hline 12719 & 2013 & & 2 & A1 & 281 & 4 & 4 & 10.14 & 1 & 1 & & 1 & & & 1 & \\
\hline 12719 & \begin{tabular}{|l|}
2013 \\
\end{tabular} & & 2 & A1 & 283 & 14 & 5 & 89.57 & 1 & & & 1 & & & & \\
\hline 12719 & 2013 & & 2 & A1 & 283 & 14 & 3 & 17.49 & 1 & & & 1 & & & & \\
\hline 12719 & 2013 & & 2 & A1 & 281 & 4 & 3 & 10.46 & 1 & 1 & & 1 & & & 1 & \\
\hline 12719 & 2013 & & 2 & $\mathrm{~A} 1$ & 283 & 14 & 4 & 41.54 & 1 & & & 1 & & & & \\
\hline 12719 & \begin{tabular}{|l|}
2014 \\
\end{tabular} & & 2 & $A 1$ & 281 & 7 & 1 & 0.83 & 1 & 1 & & 1 & & & 1 & \\
\hline 12719 & 2014 & & 2 & $\mathrm{~A} 1$ & 281 & 4 & 3 & 4.88 & 1 & 1 & & 1 & & 1 & & \\
\hline 12719 & 2014 & & 2 & A1 & 281 & 7 & 1 & 0.68 & 1 & 1 & & 1 & & & 1 & \\
\hline 12719 & 2014 & & 2 & A1 & 281 & 1 & 1 & 0.52 & 1 & 1 & & 1 & & & 1 & \\
\hline 12719 & 2014 & & 2 & $\mathrm{~A}_{1}$ & 281 & 7 & 1 & 5.2 & 1 & 1 & & 1 & & & 1 & \\
\hline 12719 & 2014 & & 2 & $\mathrm{~A} 1$ & 283 & 14 & 1 & \begin{tabular}{|l|}
3.7 \\
\end{tabular} & 11 & & & 5 & & & & \\
\hline 12719 & 2014 & & 2 & $\mathrm{~A} 1$ & 283 & 14 & 2 & 14.2 & 6 & & & 1 & & & & \\
\hline 12719 & 2015 & & 3 & A1 & 283 & 14 & 3 & 17.29 & 1 & & & 1 & & & & \\
\hline 12719 & 2015 & & 2 & A1 & 283 & 14 & 1 & 11.19 & 18 & & & 18 & & & & \\
\hline 12719 & 2015 & & 2 & A1 & 281 & 6 & 3 & 5.46 & 1 & 1 & & & 1 & 1 & & \\
\hline 12719 & 2015 & & 2 & $\mathrm{~A} 1$ & 281 & 4 & 2 & 1.39 & 1 & 7 & & 1 & & & 1 & \\
\hline 12719 & 2015 & & 2 & $\mathrm{~A} 1$ & 283 & 14 & 2 & 16.76 & 7 & & & 7 & & & & \\
\hline 12719 & \begin{tabular}{|l|}
2015 \\
\end{tabular} & & 2 & A1 & 281 & 6 & 1 & 0.34 & 1 & 1 & & & 1 & & 1 & \\
\hline 12719 & 2015 & & 2 & A1 & 281 & 6 & 2 & 0.94 & 1 & 1 & & 1 & & & 1 & \\
\hline 12719 & 2015 & & 2 & A1 & 281 & 6 & 1 & 0.51 & 1 & 1 & & & 1 & & 1 & \\
\hline 12719 & 2016 & & 3 & $\mathrm{~A} 1$ & 283 & 14 & 2 & 8.1 & 3 & & & 2 & & & & \\
\hline 12719 & 2016 & & 3 & A1 & 283 & 14 & 1 & 6.1 & 12 & & & 6 & & & & \\
\hline 12719 & \begin{tabular}{|c|}
2017 \\
\end{tabular} & & 3 & A1 & 281 & 4 & 2 & 2.22 & 1 & 1 & & 1 & & & 1 & \\
\hline 12719 & \begin{tabular}{|l|}
2017 \\
\end{tabular} & & 3 & A1 & 283 & 14 & 2 & 20.3 & 5 & & & 1 & 1 & & & \\
\hline 12719 & 2017 & & 3 & A1 & 281 & 4 & 2 & 16.34 & 6 & 6 & & 6 & & & 6 & \\
\hline 12719 & \begin{tabular}{|l|}
2017 \\
\end{tabular} & & 3 & A1 & 283 & 14 & 3 & 29.8 & 3 & & & 13 & & & & \\
\hline 12719 & 2017 & & 3 & $\mathrm{A1}$ & 281 & 4 & 4 & 60.7 & 2 & 2 & & 2 & & & 2 & \\
\hline 12719 & \begin{tabular}{|l|}
2017 \\
\end{tabular} & & 3 & $\mathrm{~A} 1$ & 281 & 4 & 6 & 754.6 & 2 & 2 & & 2 & & 1 & 1 & \\
\hline
\end{tabular}




\begin{tabular}{|c|c|c|c|c|c|c|c|c|c|c|c|c|c|c|c|c|}
\hline Site & Coll \# & Feature & Lev & Blk & $A C$ & Mat & $\mathrm{Sz}$ & Grams & Qty & Frac & $\mathrm{NF}$ & Disc $P$ & Disc A & Cort $P$ & Cort A & Comments \\
\hline 12719 & 2017 & & 3 & $\mathrm{~A} 1$ & 281 & 4 & 1 & 6.95 & 13 & 13 & & 13 & & 1 & 12 & \\
\hline 12719 & 2017 & & 3 & A1 & 283 & 14 & 1 & 4.2 & 4 & & & 28 & & & & \\
\hline 12719 & 2017 & & 3 & A1 & 281 & 4 & 3 & 35.27 & 3 & 3 & & 3 & & 1 & 2 & \\
\hline 12719 & 2018 & & 2 & $\mathrm{~A} 1$ & 283 & 14 & 2 & 10.51 & 4 & & & 4 & & & & \\
\hline 12719 & 2018 & & 2 & $\mathrm{~A} 1$ & 283 & 14 & 3 & 13.89 & 2 & 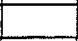 & & 2 & & & & \\
\hline 12719 & 2018 & & 2 & $\mathrm{~A} 1$ & 283 & 14 & 1 & 2.94 & 6 & & & 6 & & & & \\
\hline 12719 & 2018 & & 2 & $\mathrm{~A} 1$ & 281 & 4 & 5 & 61.53 & 1 & 1 & & & 1 & & 1 & \\
\hline 12719 & 2018 & & 2 & $\bar{A} 1$ & 281 & 4 & 4 & 24.92 & 1 & 1 & & 1 & & & 1 & \\
\hline 12719 & 2018 & & 2 & $\mathrm{~A} 1$ & 281 & 4 & 1 & 1.23 & 4 & 4 & & 2 & 2 & & 4 & \\
\hline 12719 & 2018 & & 2 & $\mathrm{~A} 1$ & 281 & 4 & 2 & 1.85 & 2 & 2 & & & 2 & & 2 & \\
\hline 12719 & 2018 & & 2 & $\mathrm{~A} 1$ & 281 & 6 & 3 & 4.74 & 1 & 1 & & & 1 & 1 & & \\
\hline 12719 & 2020 & & 3 & $\mathrm{~A} 1$ & 283 & 14 & 1 & 0.77 & 2 & & & 2 & & & & \\
\hline 12719 & 2020 & & 3 & $\mathrm{~A} 1$ & 283 & 14 & 2 & 12.12 & 2 & & & 2 & & & & \\
\hline 12719 & 2021 & & 1 & A1 & 283 & 14 & 2 & 12.35 & 2 & & & 2 & & & & \\
\hline 12719 & 2021 & & 1 & $\mathrm{~A} 1$ & 281 & 4 & 1 & 5.07 & 4 & 4 & & 3 & 1 & 1 & 3 & \\
\hline 12719 & 2021 & & 1 & $\mathrm{~A} 1$ & 283 & 14 & 1 & 5.53 & 7 & & & 7 & & & & \\
\hline 12719 & 2021 & & 1 & A1 & 281 & 6 & 2 & 1.97 & 1 & 1 & & & 1 & 1 & & \\
\hline 12719 & 2021 & & 1 & $\mathrm{~A} 1$ & 281 & 4 & 2 & 9.42 & 2 & 2 & & 1 & 1 & & 2 & \\
\hline 12719 & 2023 & & 3 & $\overline{A 1}$ & 281 & 4 & 2 & 1.62 & 1 & 1 & & & 1 & 1 & & \\
\hline 12719 & 2023 & & 3 & $\mathrm{~A} 1$ & 283 & 14 & 1 & 1.72 & 6 & & & 6 & & & 6 & 1 debitage \\
\hline 12719 & 2024 & & 1 & A1 & 281 & 4 & 2 & 2.33 & 1 & 1 & & 1 & & 1 & & \\
\hline 12719 & 2024 & & 1 & A1 & 281 & 4 & 3 & 7.71 & 1 & 1 & & & 1 & 1 & & \\
\hline 12719 & 2024 & & 1 & A1 & 281 & 4 & $\frac{4}{4}$ & 46.65 & 2 & 2 & & 2 & & $\frac{5}{2}$ & & \\
\hline 12719 & 2024 & & 1 & $\mathrm{~A} 1$ & 281 & 4 & 4 & 44.44 & 1 & 1 & & 1 & & 1 & & \\
\hline 12719 & 2024 & & 1 & A1 & 281 & 4 & 1 & 0.85 & 3 & 3 & & 3 & & & 3 & \\
\hline 12719 & 2024 & & 1 & $\mathrm{~A} 1$ & 281 & 4 & 1 & 0.85 & 1 & 1 & & & 1 & & 1 & \\
\hline 12719 & 2024 & & 1 & A1 & 283 & 14 & 2 & 28.54 & 8 & & & 8 & & & & \\
\hline 12719 & 2024 & & 1 & A1 & 283 & 14 & 1 & 17.6 & 29 & & & 29 & & & & \\
\hline 12719 & 2024 & & 1 & $\mathrm{~A} 1$ & 281 & 4 & 2 & 6.14 & 2 & 2 & & 2 & & & 2 & \\
\hline 12719 & 2025 & & 1 & A1 & 281 & 6 & 1 & 0.9 & 4 & 4 & & 4 & & & 4 & \\
\hline 12719 & 2025 & & 1 & $\mathrm{~A} 1$ & 281 & 4 & 2 & 23.95 & 2 & 2 & & 1 & 1 & & 2 & \\
\hline 12719 & 2025 & & 1 & $\mathrm{~A} 1$ & 281 & 4 & 4 & 29.6 & 1 & 1 & & & 1 & 1 & & \\
\hline 12719 & 2025 & & 1 & $\mathrm{~A} 1$ & 281 & 6 & 2 & 4.23 & 1 & 1 & & 1 & & & 1 & \\
\hline 12719 & 2025 & & 1 & $\mathrm{~A} 1$ & 283 & 14 & 1 & 8.64 & 21 & & & 21 & & & & \\
\hline 12719 & 2025 & & 1 & A1 & 283 & 14 & 2 & 33.25 & 10 & & & 10 & & & & \\
\hline 12719 & 2025 & & 1 & $\mathrm{~A} 1$ & 281 & 7 & 2 & 3.04 & 1 & 1 & & 1 & & & 1 & \\
\hline 12719 & 2025 & & 1 & A1 & 281 & 4 & 1 & 1.72 & 4 & 4 & & 4 & & 1 & 3 & \\
\hline 12719 & 2026 & & 1 & $\mathrm{~A} 1$ & 281 & 4 & 2 & 6.61 & 1 & & 1 & 1 & & 1 & & \\
\hline 12719 & 2026 & & 1 & A1 & 283 & 14 & 1 & 3.72 & 3 & & & 3 & & & & \\
\hline 12719 & 2026 & & 1 & $\mathrm{~A} 1$ & 281 & 6 & 2 & 2.55 & 1 & 1 & & & 1 & & 1 & \\
\hline 12719 & 2026 & & 1 & $\mathrm{A1}$ & 281 & 6 & 1 & 0.32 & 1 & 1 & & & 1 & & 1 & \\
\hline 12719 & 2026 & & 1 & A1 & 281 & 6 & 3 & 8.22 & 1 & 1 & & & 1 & 1 & & \\
\hline 12719 & 2026 & & 1 & A1 & 283 & 14 & 2 & 14.18 & 5 & 1 & 4 & 5 & & & & \\
\hline 12719 & 2026 & & 1 & A1 & 281 & 4 & 4 & 129.44 & 2 & 2 & & $\frac{5}{2}$ & & 2 & & \\
\hline 12719 & 2026 & & 1 & A1 & 281 & 6 & 3 & 7.86 & 1 & 1 & & & 1 & & 1 & \\
\hline 12719 & 2026 & & 1 & A1 & 281 & 6 & 2 & 1.44 & 1 & 1 & & & 1 & & 1 & \\
\hline 12719 & 2026 & & 1 & $\mathrm{A1}$ & 281 & 4 & 5 & 255.03 & 1 & 1 & & & 1 & 1 & & \\
\hline 12719 & 2027 & & 1 & $\mathrm{A1}$ & 281 & 4 & 1 & 1.16 & 1 & 1 & & & 1 & 1 & & 1 debitage \\
\hline 12719 & 2027 & & 1 & $\mathrm{~A} 1$ & 281 & 6 & 2 & 1.2 & 1 & 1 & & & 1 & & 1 & \\
\hline 12719 & 2027 & & 1 & A1 & 281 & 6 & 2 & 1.52 & 1 & 1 & & & 1 & & 1 & \\
\hline 12719 & 2027 & & 1 & A1 & 281 & 6 & 2 & 3.17 & 1 & 1 & & & 1 & & 1 & 1 flake \\
\hline 12719 & 2027 & & 1 & A1 & 283 & 14 & 2 & 36.02 & 9 & & & 9 & & & & \\
\hline 12719 & 2027 & & 1 & $\mathrm{~A} 1$ & 283 & 14 & 1 & 5.51 & 15 & & & 15 & & & & \\
\hline \begin{tabular}{|l|}
12719 \\
\end{tabular} & 2027 & & 1 & A1 & 283 & 14 & 4 & 26.59 & 1 & & & 1 & & & & \\
\hline 12719 & 2027 & & 1 & $\mathrm{~A} 1$ & 281 & 4 & 2 & 2.3 & 2 & 2 & & & 2 & & 2 & \\
\hline 12719 & 2028 & & 1 & A1 & 283 & 14 & 1 & \begin{tabular}{|l|}
14.47 \\
\end{tabular} & 16 & & & 16 & & & & \\
\hline 12719 & 2028 & & 1 & A1 & 281 & 4 & 2 & 1.03 & 1 & 1 & & 1 & & & 1 & \\
\hline 12719 & 2028 & & 1 & $\mathrm{A1}$ & 283 & 14 & 2 & 21.1 & 8 & 1 & 7 & 8 & & & 8 & \\
\hline 12719 & 2028 & & 3 & A1 & 283 & 14 & 3 & 33.76 & 3 & & & 3 & & & & \\
\hline 12719 & 2028 & & 1 & A1 & 281 & 4 & 3 & \begin{tabular}{l|l|}
7.89 \\
\end{tabular} & 1 & 1 & & 1 & & & 1 & \\
\hline 12719 & 2028 & & 1 & $\mathrm{A1}$ & 281 & 4 & 1 & 0.42 & 1 & 1 & & 1 & & & 1 & \\
\hline 12719 & 2028 & & 1 & A1 & 281 & 6 & 1 & 0.55 & 1 & 1 & & & 1 & & 1 & \\
\hline 12719 & 2028 & & 1 & $\mathrm{~A} 1$ & 281 & 6 & 2 & 3.28 & 1 & 1 & & & 1 & & 1 & \\
\hline 12719 & 2029 & & 3 & $\mathrm{~A} 1$ & 283 & 14 & 2 & 3.2 & 1 & & & 3 & & & & \\
\hline 12719 & 2029 & & 3 & $\mathrm{~A} 1$ & 283 & 14 & 1 & 1.4 & 2 & & & 4 & & & & \\
\hline 12719 & 2030 & & 3 & $\mathrm{~A} 1$ & 281 & 4 & 5 & 115.26 & 2 & 2 & & 2 & & 2 & & \\
\hline 12719 & 2030 & & 3 & $\mathrm{~A} 1$ & 281 & 4 & 2 & 6.74 & 3 & 3 & & 3 & & & 3 & \\
\hline 12719 & 2030 & & 3 & $\mathrm{~A} 1$ & 283 & 14 & 4 & 31.7 & 2 & & & 7 & & & & \\
\hline
\end{tabular}




\begin{tabular}{|c|c|c|c|c|c|c|c|c|c|c|c|c|c|c|c|c|}
\hline Site & Coll \# & Feature & Lev & Blk & $A C$ & Mat & $\mathrm{Sz}$ & Grams & Qty & Frac & $\mathrm{NF}$ & Disc $P$ & Disc A & Cort P & Cort A & Comments \\
\hline 12719 & 2030 & & 3 & A1 & 281 & 4 & 1 & 2.46 & 5 & 5 & & 5 & & & 5 & \\
\hline 12719 & 2030 & & 3 & A1 & 283 & 14 & 3 & 66 & 4 & & & 1 & & & & \\
\hline 12719 & 2030 & & 3 & $\mathrm{~A} 1$ & 283 & 14 & 2 & 50.1 & 22 & & & 3 & & & & \\
\hline 12719 & 2030 & & 3 & $\mathrm{~A} 1$ & 283 & 14 & 5 & 125.2 & 2 & & & 26 & & & & \\
\hline 12719 & 2030 & & 3 & $\mathrm{~A} 1$ & 281 & 4 & 3 & 13.52 & 2 & 2 & & 2 & & 1 & 1 & \\
\hline 12719 & 2030 & & 3 & $\mathrm{~A} 1$ & 283 & 14 & 1 & 14.8 & 22 & & & 2 & & & & \\
\hline 12719 & \begin{tabular}{|l|}
2030 \\
\end{tabular} & & 3 & $\mathrm{~A} 1$ & 283 & 14 & 6 & 237.9 & 1 & & & 36 & & & & \\
\hline 12719 & 2031 & & 3 & $\mathrm{~A} 1$ & 281 & 4 & 1 & 1.59 & 1 & 1 & & 1 & & & 1 & \\
\hline 12719 & 2031 & & 1 & $\mathrm{~A} 1$ & 281 & 4 & 4 & 73.64 & 1 & 1 & & 1 & & & 1 & \\
\hline 12719 & 2031 & & 3 & $\mathrm{~A} 1$ & 283 & 14 & 4 & 55.9 & 1 & & & 4 & & & & \\
\hline 12719 & 2031 & & 3 & $\mathrm{~A} 1$ & 283 & 14 & 1 & 0.6 & 2 & & & 8 & & & & \\
\hline 12719 & 2031 & & 3 & $\mathrm{~A} 1$ & 283 & 14 & 2 & 12.2 & 4 & & & 1 & & & & \\
\hline 12719 & 2031 & & 3 & A1 & 281 & 7 & 3 & 4.03 & 1 & 1 & & & 1 & & 1 & \\
\hline 12719 & 2031 & & 3 & $\mathrm{~A} 1$ & 281 & 4 & 2 & 7.47 & 3 & 3 & & 3 & & & 3 & \\
\hline 12719 & 2032 & & 1 & $\mathrm{~A} 1$ & 281 & 6 & 2 & 4.1 & 1 & 1 & & & 1 & & 1 & \\
\hline 12719 & 2032 & & 1 & A1 & 283 & 14 & 2 & 3.25 & 2 & & & 2 & & & & \\
\hline 12719 & 2032 & & 1 & A1 & 281 & 4 & 2 & 24.61 & 3 & 3 & & 3 & & 2 & 1 & \\
\hline 12719 & 2033 & & 3 & $\mathrm{~A} 1$ & 283 & 14 & 2 & 2.99 & 1 & & & 1 & & & & \\
\hline 12719 & 2033 & & 3 & $\mathrm{~A} 1$ & 283 & 14 & 1 & 0.17 & 1 & & & 1 & & & & \\
\hline 12719 & 2037 & & 3 & $\mathrm{~A} 1$ & 283 & 14 & 1 & 0.13 & 7 & & & 7 & & & & \\
\hline 12719 & 2038 & & 3 & $\mathrm{~A} 1$ & 283 & 14 & 2 & 5.2 & 2 & & & 1 & & & & \\
\hline 12719 & 2038 & & 3 & A1 & 283 & 14 & 1 & 2.2 & 7 & & & 11 & & & & \\
\hline 12719 & 2038 & & 3 & A1 & 281 & 7 & 1 & 0.27 & 1 & 1 & & & 1 & & 1 & \\
\hline 12719 & 2040 & & 3 & A1 & 281 & 6 & 2 & 0.81 & 1 & 1 & & & 1 & & 1 & \\
\hline 12719 & 2040 & & 3 & A1 & 281 & 6 & 2 & 3.2 & 1 & 1 & & & 1 & & 1 & \\
\hline 12719 & 2040 & & 3 & $\mathrm{~A} 1$ & 281 & 4 & 3 & 58.88 & 1 & & 1 & 1 & & 1 & & \\
\hline 12719 & 2040 & & 3 & A1 & 281 & 6 & 1 & 0.37 & 1 & 1 & & & 1 & & 1 & \\
\hline 12719 & \begin{tabular}{|l|}
2040 \\
\end{tabular} & & 3 & $\mathrm{~A} 1$ & 281 & 4 & 1 & 2.4 & 6 & 6 & & 6 & & & 6 & 3 flakes \\
\hline 12719 & 2040 & & 3 & A1 & 283 & 14 & 2 & 3.5 & 1 & & & 8 & & & & \\
\hline 12719 & 2041 & & 3 & A1 & 283 & 14 & 4 & 49 & 1 & & & 1 & & & & \\
\hline 12719 & 2041 & & 3 & $\mathrm{~A} 1$ & 283 & 14 & 2 & 23.2 & 9 & & & 14 & & & & \\
\hline 12719 & 2042 & & 3 & $\mathrm{~A} 1$ & 283 & 14 & 2 & 19.22 & 6 & & & 6 & & & & \\
\hline 12719 & 2042 & & 3 & A1 & 283 & 14 & 1 & 8.62 & & & & & & & & check 4QTY \\
\hline 12719 & \begin{tabular}{|l|}
2042 \\
\end{tabular} & & 3 & A1 & 283 & 14 & 3 & 11.54 & 1 & & & 1 & & & & \\
\hline 12719 & \begin{tabular}{|l|}
2043 \\
\end{tabular} & & 3 & A1 & 281 & 4 & 1 & 1.62 & 2 & 2 & & 1 & 1 & 1 & & 2 flakes \\
\hline 12719 & 2043 & & 3 & A1 & 281 & 4 & 4 & 26.64 & 1 & 1 & & & 1 & 1 & & \\
\hline 12719 & \begin{tabular}{|l|}
2043 \\
\end{tabular} & & 3 & A1 & 283 & 14 & 2 & 8.86 & 3 & 1 & 2 & 3 & & 3 & & \\
\hline 12719 & 2043 & & 3 & A1 & 281 & 4 & 2 & 7.52 & 2 & 2 & & 2 & & 2 & & \\
\hline 12719 & 2043 & & 3 & A1 & 283 & 14 & 1 & 0.68 & 2 & & & 2 & & & & \\
\hline 12719 & 2045 & & 3 & $\mathrm{~A} 1$ & 281 & 4 & 2 & 1.23 & 1 & 1 & & 1 & & 1 & & \\
\hline 12719 & 2045 & & 3 & $\mathrm{~A} 1$ & 283 & 14 & 1 & 0.35 & 1 & & & 1 & & & & \\
\hline 12719 & 2046 & & 3 & $\mathrm{~A} 1$ & 281 & 4 & 1 & 0.97 & 2 & 2 & & 1 & 1 & 1 & & \\
\hline 12719 & 2046 & & 3 & $\mathrm{~A} 1$ & 281 & 6 & 3 & 5.3 & 1 & 1 & & & 1 & & 1 & \\
\hline 12719 & 2046 & & 3 & A1 & 281 & 4 & 2 & 5.34 & 2 & 2 & & 2 & & 2 & & \\
\hline 12719 & 2046 & & 3 & $\mathrm{~A} 1$ & 281 & 6 & 2 & 1.1 & 1 & 1 & & & 1 & & 1 & \\
\hline 12719 & 2046 & & 3 & $\mathrm{~A} 1$ & 283 & 14 & 1 & 1.62 & 3 & & & 3 & & & & \\
\hline 12719 & 2046 & & 3 & A1 & 281 & 6 & 2 & 3.13 & 1 & 1 & & & 1 & & 1 & \\
\hline 12719 & 2047 & & 3 & A1 & 283 & 14 & 1 & 0.7 & 2 & & & 2 & & & & \\
\hline 12719 & 2048 & & 3 & A1 & 283 & 14 & 1 & 8.31 & 9 & & & 9 & & & & \\
\hline 12719 & 2048 & & 3 & $\mathrm{~A} 1$ & 283 & 14 & 3 & \begin{tabular}{|c|}
61.47 \\
\end{tabular} & 4 & & & 4 & & & & \\
\hline 12719 & 2048 & & 3 & A1 & 283 & 14 & 5 & 88.04 & 1 & & & 1 & & & & \\
\hline 12719 & 2048 & & 3 & A1 & 283 & 14 & 2 & 150.72 & 33 & & & 33 & & & & \\
\hline 12719 & 2048 & & 3 & A1 & 283 & 14 & 4 & 171.15 & 4 & & & 4 & & & & \\
\hline 12719 & 2048 & & 3 & A1 & 281 & 4 & 1 & 1.42 & 2 & 2 & & 2 & & & 2 & \\
\hline 12719 & 2048 & & 3 & $\mathrm{~A} 1$ & 281 & 4 & 3 & \begin{tabular}{|c|}
6.16 \\
\end{tabular} & 1 & 1 & & 1 & & & 1 & \\
\hline 12719 & 2048 & & 3 & A1 & 281 & 6 & 1 & \begin{tabular}{|l|l|}
0.73 \\
\end{tabular} & 1 & 1 & & & 1 & & 1 & \\
\hline 12719 & 2048 & & 3 & $\mathrm{~A} 1$ & 281 & 4 & 2 & 10.99 & 5 & 5 & & 5 & & 1 & 4 & \\
\hline 12719 & 2049 & & 3 & A1 & 283 & 14 & 2 & 26.49 & 8 & & & 8 & & & & \\
\hline 12719 & 2049 & & 3 & $\overline{A 1}$ & 283 & 14 & 1 & 3.76 & 3 & & & 3 & & & & \\
\hline 12719 & 2049 & & 3 & A1 & 283 & 14 & 3 & 8.88 & 1 & & & 1 & & & & \\
\hline 12719 & 2050 & & 3 & $\mathrm{~A} 1$ & 283 & 14 & 2 & 0.89 & 1 & & & 1 & & & & \\
\hline 12719 & 2050 & & 3 & $\mathrm{~A} 1$ & 281 & 6 & 2 & \begin{tabular}{|l|}
1.38 \\
\end{tabular} & 1 & 1 & & & 1 & & 1 & \\
\hline 12719 & 2050 & & 3 & $\mathrm{~A} 1$ & 283 & 14 & 1 & 4.3 & 6 & & & 6 & & & & \\
\hline 12719 & 2050 & & 3 & A1 & 283 & 14 & 3 & 12.62 & 2 & & & 2 & & & & \\
\hline 12719 & 2051 & & 2 & $\mathrm{~A} 1$ & 283 & 14 & 1 & 4 & 7 & & & 7 & & & & \\
\hline 12719 & 2051 & & 2 & A1 & 283 & 14 & 2 & 20.74 & 2 & & & 2 & & & & \\
\hline 12719 & 2051 & & 2 & $A 1$ & 283 & 14 & 2 & 20.46 & 9 & & & 9 & & & & \\
\hline 12719 & 2100 & 32 & 0 & A1 & 283 & 14 & 1 & 1.72 & 4 & & & 4 & & & & \\
\hline
\end{tabular}




\begin{tabular}{|c|c|c|c|c|c|c|c|c|c|c|c|c|c|c|c|c|}
\hline Site & Coll \# & Feature & Lev & Blk & $\overline{A C}$ & \begin{tabular}{|l|} 
Mat \\
\end{tabular} & $\mathrm{Sz}$ & Grams & Qty & \begin{tabular}{|l|} 
Frac \\
\end{tabular} & $\mathrm{NF}$ & DiscP & Disc A & Cort $\mathrm{P}$ & Cort A & Comments \\
\hline 12719 & 2100 & 32 & 0 & A1 & 281 & 4 & 4 & 44.64 & 1 & 1 & & & 1 & & $i$ & \\
\hline 12719 & 2100 & 32 & 0 & $\mathrm{~A} 1$ & 283 & 14 & 3 & 6.95 & 1 & & & 1 & & & & \\
\hline 12719 & 2100 & 32 & 0 & $\mathrm{~A} 1$ & 281 & 4 & 3 & 59 & 2 & 1 & 1 & & 2 & 1 & 1 & \\
\hline 12719 & 2100 & 32 & 0 & A1 & 283 & 14 & 2 & 1.79 & 2 & & & 2 & & & & \\
\hline 12719 & 2101 & 33 & 0 & $\bar{A} 1$ & 283 & 14 & 3 & 16 & 2 & & & 1 & & & & \\
\hline 12719 & 2101 & 33 & 0 & A1 & 283 & 14 & 1 & 26 & 69 & & & 71 & & & & \\
\hline 12719 & 2101 & 33 & 0 & A1 & 283 & 14 & 2 & 82.2 & 30 & & & 4 & & & & \\
\hline 12719 & 2102 & & 3 & $\overline{\mathrm{A} 1}$ & 283 & 14 & 1 & 0.65 & 2 & & & $\overline{2}$ & & & & \\
\hline 12719 & 2102 & & 3 & $\mathrm{~A} 1$ & 281 & 4 & 2 & 1.99 & 1 & 1 & & 1 & & 1 & & \\
\hline 12719 & 2102 & & 3 & A1 & 283 & 14 & 2 & 6.98 & 2 & & & 2 & & & & \\
\hline 12719 & 2102 & & 3 & A1 & 281 & 4 & 5 & 85.67 & 1 & 1 & & 1 & & 1 & & 1 flake \\
\hline 12719 & 2103 & & 3 & $\mathrm{A1}$ & 283 & 14 & 1 & 3.4 & 6 & & & 6 & & & & \\
\hline 12719 & 2103 & & 3 & A1 & 283 & 14 & 2 & 9.22 & 4 & & & 4 & & & & \\
\hline 12719 & \begin{tabular}{|l|}
2104 \\
\end{tabular} & & 3 & A1 & 281 & 4 & 3 & 7.16 & 1 & 1 & & 1 & & & 1 & \\
\hline 12719 & 2104 & & 3 & $\mathrm{~A} 1$ & 283 & 14 & 1 & 0.44 & 2 & & & 2 & & & & \\
\hline 12719 & \begin{tabular}{|l|}
2104 \\
\end{tabular} & & 3 & A1 & 281 & 4 & 2 & 2.14 & 1 & & 1 & & 1 & & 1 & \\
\hline 12719 & 2105 & & 3 & A1 & 283 & 14 & 1 & 1.63 & 1 & & & 1 & & & & \\
\hline 12719 & 2106 & & 3 & A1 & 283 & 14 & 1 & 0.61 & 1 & & & 1 & & & & \\
\hline 12719 & 2108 & 32 & 5 & $\mathrm{~A} 1$ & 283 & 14 & 3 & 5.91 & 1 & & & 1 & & & & \\
\hline 12719 & \begin{tabular}{|l|}
2108 \\
\end{tabular} & 32 & 5 & A1 & 281 & 6 & 1 & 0.38 & 1 & 1 & & & 1 & & 1 & \\
\hline 12719 & \begin{tabular}{|l|}
2108 \\
\end{tabular} & 32 & 5 & $\bar{A} 1$ & 283 & 14 & 2 & \begin{tabular}{ll|}
4.96 \\
\end{tabular} & 2 & & & 2 & & & & \\
\hline 12719 & \begin{tabular}{|l|}
2109 \\
\end{tabular} & 32 & 5 & A1 & 283 & 14 & 1 & 1.18 & 4 & & & 4 & & & & \\
\hline 12719 & 2110 & 32 & 5 & A1 & 283 & 14 & 1 & 0.6 & 1 & & & 4 & & & & \\
\hline 12719 & 2112 & & 3 & $\mathrm{~A} 1$ & 281 & 4 & 1 & 0.15 & 1 & 1 & & 1 & & & 1 & 1 flake \\
\hline 12719 & 2112 & & 5 & $\overline{A 1}$ & 281 & 6 & 4 & 20.9 & 1 & 1 & & 1 & & 1 & & \\
\hline 12719 & 2112 & & 3 & A1 & 281 & 4 & 2 & 3.09 & 1 & 1 & & 1 & & & 1 & \\
\hline 12719 & 2112 & & 3 & $\mathrm{~A} 1$ & 281 & 4 & 3 & 3.8 & 1 & 1 & & 1 & & & 1 & \\
\hline 12719 & 2112 & & 3 & $\mathrm{~A} 1$ & 283 & 14 & 1 & 1.76 & 4 & & & 4 & & & & \\
\hline 12719 & 2112 & & 3 & $\mathrm{~A} 1$ & 283 & 14 & 2 & 3.45 & 3 & & & 3 & & & & \\
\hline 12719 & 2112 & & 3 & $\mathrm{~A} 1$ & 283 & 14 & 3 & 3.89 & 1 & & & 1 & & & & \\
\hline 12719 & 2114 & & 3 & $\mathrm{~A} 1$ & 283 & 14 & 1 & 1.98 & 9 & & & 9 & & & & \\
\hline 12719 & 2114 & & 3 & $\mathrm{~A} 1$ & 281 & 4 & 2 & 13.88 & 3 & 3 & & 3 & & 1 & 2 & \\
\hline 12719 & 2114 & & 3 & $\mathrm{~A} 1$ & 281 & 4 & 1 & 1.79 & 6 & 6 & & 4 & 2 & & 6 & \\
\hline 12719 & 2114 & & 3 & A1 & 283 & 14 & 2 & 5.92 & 3 & & & 3 & & & & \\
\hline 12719 & 2114 & & 3 & A1 & 281 & 4 & 3 & 13.66 & 1 & 1 & & 1 & & 1 & & \\
\hline 12719 & 2116 & 32 & 5 & A1 & 283 & 14 & 1 & 0.47 & 5 & & & 5 & & & & \\
\hline 12719 & 2116 & 32 & 5 & A1 & 281 & 6 & 3 & 8.1 & 1 & 1 & & 1 & & & 1 & \\
\hline 12719 & 2119 & & 3 & $\mathrm{~A} 1$ & 281 & 4 & 3 & 4.31 & 1 & 1 & & 1 & & & 1 & \\
\hline 12719 & 2119 & & 3 & A1 & 281 & 4 & 2 & 0.97 & 1 & 1 & & 1 & & & 1 & \\
\hline 12719 & 2119 & & 3 & A1 & 281 & 4 & 4 & 31.05 & 2 & 2 & & 2 & & & 2 & \\
\hline 12719 & 2120 & & 3 & A1 & 283 & 14 & 1 & 2 & 7 & & & 7 & & & & \\
\hline 12719 & 2125 & 32 & 5 & A1 & 283 & 14 & 1 & 0.94 & 1 & & & 1 & & & & \\
\hline 12719 & 2126 & & 5 & A1 & 283 & 14 & 1 & 2.6 & 4 & & & 1 & & & & \\
\hline 12719 & 2126 & & 5 & A1 & 281 & 4 & 1 & 0.51 & 1 & 1 & & 1 & & & 1 & \\
\hline 12719 & 2127 & 32 & 5 & A1 & 283 & 14 & 3 & 6.5 & 1 & & & 3 & & & & \\
\hline 12719 & 2127 & 32 & 5 & A1 & 283 & 14 & 6 & \begin{tabular}{|l|l|}
261.3 \\
\end{tabular} & 1 & & & 49 & & & & \\
\hline 12719 & 2127 & 32 & 5 & A1 & 281 & 4 & 1 & 0.84 & 2 & 2 & & 2 & & & 2 & \\
\hline 12719 & 2127 & 32 & 5 & A1 & 281 & 4 & 3 & 8.86 & 1 & 1 & & 1 & & 1 & & 2 flakes \\
\hline 12719 & 2127 & 32 & 5 & A1 & 281 & 4 & 2 & 1.76 & 1 & 1 & & 1 & & & 1 & \\
\hline 12719 & 2128 & & 1 & A1 & 283 & 14 & 1 & 1.54 & 4 & & & 4 & & & & \\
\hline 12719 & 2128 & & 1 & A1 & 283 & 14 & 2 & 2.6 & 1 & & & 1 & & & & \\
\hline 12719 & 2129 & & 1 & A1 & 283 & 14 & $\frac{\pi}{1}$ & 0.57 & 3 & & & 2 & & & & \\
\hline 12719 & 2130 & & 1 & $\mathrm{~A} 1$ & 281 & 4 & 3 & 31.04 & 1 & 1 & & 1 & & & 1 & \\
\hline 12719 & 2130 & & 1 & $\mathrm{~A} 1$ & 283 & 14 & 1 & 1.42 & 4 & & & 4 & & & & \\
\hline 12719 & 2130 & & 1 & A1 & 281 & 4 & 6 & 433 & 1 & 1 & & 1 & & 1 & & \\
\hline 12719 & 2140 & & 1 & $\mathrm{A1}$ & 283 & 14 & 2 & \begin{tabular}{|l|l|}
3.89 \\
\end{tabular} & 3 & & & 3 & & & & \\
\hline 12719 & 2140 & & 1 & $\mathrm{~A} 1$ & 283 & 14 & 1 & 0.41 & 1 & & & 1 & & & & \\
\hline 12719 & 2140 & & 1 & $\mathrm{~A} 1$ & 283 & 14 & 3 & 25.18 & 3 & & & 3 & & & & \\
\hline 12719 & 2141 & & 1 & $\mathrm{~A} 1$ & 283 & 14 & 1 & 1.61 & 2 & & & 2 & & & & \\
\hline 12719 & 2141 & & 1 & $\mathrm{~A} 1$ & 283 & 14 & 2 & 5.43 & 2 & & & 2 & & & & \\
\hline 12719 & 2142 & & 1 & A1 & 283 & 14 & 1 & 1.09 & 4 & & & 4 & & & & \\
\hline 12719 & 2144 & & 1 & A1 & 281 & 4 & 2 & 2.33 & 1 & 1 & & 1 & & 1 & & \\
\hline 12719 & 2144 & & 1 & A1 & 283 & 14 & 2 & 5.13 & 1 & & & 1 & & & & \\
\hline 12719 & 2147 & & 1 & A1 & 283 & 14 & 1 & 1.14 & 3 & & & 3 & & & & \\
\hline 12719 & 2149 & & 1 & $\mathrm{~A} 1$ & 283 & 14 & 2 & 1.53 & 1 & & & 1 & & & & \\
\hline 12719 & 2152 & & 1 & A1 & 281 & 4 & 3 & 6.56 & 1 & 1 & & 1 & & 1 & & \\
\hline 12719 & 2153 & & 1 & A1 & 281 & 4 & 5 & 255.1 & 1 & 1 & & 1 & & & 1 & \\
\hline \begin{tabular}{|l|}
12719 \\
\end{tabular} & 2153 & & 1 & $\mathrm{~A} 1$ & 283 & 14 & 2 & 2.05 & 1 & & & 1 & & & & \\
\hline
\end{tabular}




\begin{tabular}{|c|c|c|c|c|c|c|c|c|c|c|c|c|c|c|c|c|}
\hline Site & Coll\# & Feature & Lev & Blk & $A C$ & Mat & $\mathrm{Sz}$ & Grams & Qty & Frac & $\mathrm{NF}$ & Disc $P$ & Disc A & Cort $P$ & Cort A & Comments \\
\hline 12719 & 2153 & & 1 & $A 1$ & 283 & 14 & \begin{tabular}{|l|}
1 \\
\end{tabular} & \begin{tabular}{|r|}
0.31 \\
\end{tabular} & 1 & & & 1 & & & & \\
\hline 12719 & 2154 & & 5 & A1 & 283 & 14 & 2 & 11.14 & 5 & & & 5 & & & & \\
\hline 12719 & 2154 & & 5 & A1 & 283 & 14 & 3 & 10.38 & 1 & & & 1 & & & & \\
\hline 12719 & 2154 & & 5 & A1 & 283 & 14 & \begin{tabular}{|l|}
1 \\
\end{tabular} & 6.96 & 14 & & & 14 & & & & \\
\hline 12719 & 2155 & 32 & $\frac{5}{5}$ & A1 & 283 & 14 & 2 & 5.2 & 2 & & & 43 & & & & \\
\hline 12719 & 2155 & 32 & 5 & $\mathrm{~A} 1$ & 283 & 14 & 1 & 2 & 3 & & & 72 & & & & \\
\hline 12719 & 2155 & 32 & 5 & A1 & 281 & 4 & 3 & 13.07 & 2 & 2 & & 2 & & & 2 & \\
\hline 12719 & \begin{tabular}{|l|}
2156 \\
\end{tabular} & & 2 & A1 & 281 & 4 & 3 & 9.63 & 1 & 1 & & 1 & & & 1 & \\
\hline 12719 & 2156 & & 2 & A1 & 281 & 4 & 1 & 0.87 & 1 & 1 & & 1 & & 1 & & \\
\hline 12719 & \begin{tabular}{|l|}
2156 \\
\end{tabular} & & $\frac{2}{2}$ & A1 & 283 & 14 & 2 & 16.5 & 4 & & & 1 & & & & \\
\hline 12719 & 2156 & & 2 & A1 & 283 & 14 & 1 & 5.2 & 8 & & & 4 & & & & \\
\hline 12719 & 2156 & & 2 & A1 & 281 & 4 & 5 & 88.81 & 1 & 1 & & & 1 & & 1 & \\
\hline 12719 & 2156 & & 2 & $\mathrm{A1}$ & 281 & 4 & 4 & 18.55 & 1 & 1 & & & 1 & & 1 & \\
\hline 12719 & 2156 & & $\frac{4}{2}$ & A1 & 281 & 4 & 3 & 11.21 & 1 & 1 & & & 1 & 1 & & \\
\hline 12719 & 2158 & & 1 & A1 & 283 & 14 & 2 & 19.07 & 5 & & & 5 & & & & \\
\hline 12719 & 2161 & & 1 & A1 & 281 & 4 & 1 & 1.23 & 1 & 1 & & 1 & & & 1 & \\
\hline 12719 & 2161 & & 1 & A1 & 281 & 4 & 6 & 14.86 & 1 & 1 & & & 1 & & 1 & \\
\hline 12719 & 2164 & & 1 & A1 & 283 & 14 & \begin{tabular}{l|l}
3 \\
\end{tabular} & 4.64 & 1 & & & 1 & & & & \\
\hline 12719 & 2166 & 33 & 3 & A1 & 283 & 14 & 1 & 3 & 5 & & & 2 & & & & \\
\hline 12719 & 2166 & 33 & $\frac{5}{3}$ & A1 & 283 & 14 & 2 & 4.1 & 1 & & & 5 & & & & \\
\hline 12719 & 2166 & 33 & 3 & $A 1$ & 281 & 4 & 3 & 5.53 & 1 & 1 & & 1 & & & 1 & \\
\hline 12719 & 2166 & 33 & 3 & $A 1$ & 281 & 4 & 2 & 1.4 & 1 & 1 & & 1 & & 1 & & \\
\hline 12719 & 2169 & & 4 & A1 & 283 & 14 & 1 & 6.78 & 15 & & & 15 & & & & \\
\hline 12719 & 2169 & & $\frac{7}{4}$ & A1 & 283 & 14 & 5 & 59.28 & 1 & & & 1 & & & & \\
\hline 12719 & 2169 & & 4 & $A 1$ & 281 & 4 & 4 & 24.44 & 1 & 1 & & 1 & & & 9 & \\
\hline 12719 & 2169 & & 4 & $A 1$ & 281 & 3 & 4 & 10.4 & 1 & 1 & & & 1 & 1 & & \\
\hline 12719 & 2169 & & 4 & A1 & 283 & 14 & 4 & 46.46 & 1 & & & 1 & & & & \\
\hline 12719 & 2169 & & 4 & $A 1$ & 283 & 14 & 2 & 16.11 & 5 & & & 5 & & & & \\
\hline 12719 & 2170 & 33 & 4 & A1 & 283 & 14 & 1 & 5.6 & 13 & & & 15 & & & & \\
\hline 12719 & 2171 & 32 & 5 & A1 & 281 & 6 & 4 & \begin{tabular}{|c|}
34.4 \\
\end{tabular} & 1 & 1 & & 1 & & 1 & & \\
\hline 12719 & 2172 & & 1 & $\mathrm{~A} 1$ & 283 & 14 & 2 & 62.7 & 21 & & & 22 & & & & \\
\hline 12719 & 2172 & & 1 & A1 & 283 & 14 & 3 & 27.7 & $\frac{1}{2}$ & & & 2 & & & & \\
\hline 12719 & 2172 & & 1 & $\mathrm{~A} 1$ & 283 & 14 & 1 & 25.9 & 42 & & & 52 & & & & \\
\hline 12719 & 2174 & & 1 & $\mathrm{~A} 1$ & 281 & 4 & 5 & 259.4 & 1 & 1 & & 1 & & & 1 & \\
\hline 12719 & 2178 & 32 & 5 & $\mathrm{~A} 1$ & 281 & 6 & 2 & 1.53 & 1 & 1 & & 1 & & & 1 & \\
\hline 12719 & 2178 & 32 & 5 & $\mathrm{~A} 1$ & 283 & 14 & 3 & 17.6 & 2 & & & 13 & & & & \\
\hline 12719 & 2178 & 32 & 5 & $\mathrm{A1}$ & 283 & 14 & 1 & 1.3 & 2 & & & 2 & & & & \\
\hline 12719 & 2178 & 32 & 5 & $\mathrm{~A} 1$ & 283 & 14 & 2 & 11.7 & 5 & & & 6 & & & & \\
\hline 12719 & 2178 & 32 & 5 & $\mathrm{~A} 1$ & 281 & 6 & 1 & 0.1 & 1 & 1 & & & 1 & & 1 & \\
\hline 12719 & 2179 & 32 & 5 & $\mathrm{~A} 1$ & 283 & 14 & 2 & 6.6 & 3 & & & 1 & & & & \\
\hline 12719 & 2179 & 32 & 5 & A1 & 283 & 14 & 1 & 5.5 & 9 & & & 24 & & & & \\
\hline 12719 & 2180 & 33 & 4 & $\mathrm{~A} 1$ & 281 & 4 & 6 & 706.2 & 2 & 2 & & 2 & & & 2 & \\
\hline 12719 & 2180 & 33 & 4 & A1 & 281 & 4 & 5 & 304.5 & 1 & 1 & & 1 & & & 1 & \\
\hline 12719 & 2180 & 33 & 4 & $\mathrm{~A} 1$ & 283 & 14 & 3 & 77.9 & 8 & & & 3 & & & & \\
\hline 12719 & 2180 & 33 & 4 & $\mathrm{~A} 1$ & 283 & 14 & 1 & 9.9 & 15 & & & 23 & & & & \\
\hline 12719 & 2180 & 33 & 4 & A1 & 283 & 14 & 2 & 43 & 17 & & & 25 & & & & \\
\hline 12719 & 2180 & 33 & 4 & A1 & 281 & 4 & 2 & 7.64 & 1 & 1 & & 1 & & & 1 & \\
\hline 12719 & 2180 & 33 & 4 & A1 & 283 & 14 & 4 & 61.4 & 2 & & & 10 & & & & \\
\hline 12719 & 2181 & 33 & 4 & A1 & 283 & 14 & 1 & 0.61 & 4 & & & 4 & & & & \\
\hline 12719 & 2183 & 33 & 3 & $\mathrm{~A} 1$ & 283 & 14 & 2 & 8.4 & 3 & & & 1 & & & & \\
\hline 12719 & 2183 & 33 & 3 & A1 & 281 & 4 & 3 & 45.55 & 1 & 1 & & 1 & & 1 & & \\
\hline 12719 & 2183 & 33 & 3 & A1 & 283 & 14 & 1 & 4.5 & 4 & & & 1 & & & & \\
\hline 12719 & 2183 & 33 & 3 & $\mathrm{~A} 1$ & 283 & 14 & 3 & \begin{tabular}{|l|}
8.8 \\
\end{tabular} & 1 & & & 5 & & & & \\
\hline 12719 & 2184 & 33 & 3 & A1 & 283 & 14 & 1 & 1.79 & 3 & & & 3 & & & & \\
\hline 12719 & 2184 & 33 & 3 & A1 & 281 & 6 & 4 & 12.4 & 1 & 1 & & 1 & & 1 & & \\
\hline 12719 & 2185 & & 1 & A1 & 283 & 14 & 2 & 31.38 & 17 & & & 17 & & & & \\
\hline 12719 & 2185 & & 1 & A1 & 283 & 14 & 3 & 7.31 & 1 & & & 1 & & & & \\
\hline 12719 & 2185 & & 1 & A1 & 281 & 4 & 2 & 1.6 & 1 & 1 & & 1 & & & 1 & \\
\hline 12719 & 2185 & & $\frac{1}{1}$ & A1 & 283 & 14 & 1 & 19.48 & 45 & & & 45 & & & & \\
\hline 12719 & 2186 & & 1 & A1 & 283 & 14 & 1 & 2.77 & 10 & & & 10 & & & & \\
\hline 12719 & 2186 & & 1 & A1 & 283 & 14 & 2 & 5.37 & 4 & & & 4 & & & & \\
\hline 12719 & 2191 & 32 & 5 & A1 & 283 & 14 & 9 & \begin{tabular}{|l|}
3.3 \\
\end{tabular} & 6 & & & 6 & & & & \\
\hline 12719 & 2191 & 32 & 5 & A1 & 283 & 14 & 2 & 25.42 & 8 & & & 8 & & & & \\
\hline 12719 & 2192 & & 1 & $\mathrm{~A} 1$ & 283 & 14 & 1 & 1.91 & 9 & & & 9 & & & & \\
\hline 12719 & 2194 & & 1 & $\mathrm{~A}_{1}$ & 283 & 14 & 1 & 0.44 & 5 & & & 5 & & & & \\
\hline 12719 & 2195 & & 1 & A1 & 283 & 14 & 1 & 0.4 & 2 & & & 2 & & & & \\
\hline 12719 & 2196 & & 1 & A1 & 283 & 14 & 1 & 2.23 & 2 & 1 & 1 & 2 & & & & \\
\hline 12719 & 2196 & & 1 & A1 & 283 & 14 & 2 & 1.74 & 1 & & & 1 & & & & \\
\hline
\end{tabular}




\begin{tabular}{|c|c|c|c|c|c|c|c|c|c|c|c|c|c|c|c|c|}
\hline Site & Coll \# & Feature & Lev & Blk & $A C$ & Mat & $\mathrm{Sz}$ & Grams & Qty & Frac & NF & Disc P & Disc A & Cort $P$ & Cort A & Comments \\
\hline 12719 & 2196 & & 1 & $\mathrm{~A} 1$ & 281 & 6 & 2 & 1.9 & 1 & 1 & & & 1 & & 1 & \\
\hline 12719 & 2197 & & 1 & $\mathrm{~A} 1$ & 283 & 14 & 1 & 0.13 & 1 & & & 1 & & & & \\
\hline 12719 & 2199 & & 1 & $\mathrm{A1}$ & 283 & 14 & 3 & 3.67 & 1 & 1 & & 1 & & & & \\
\hline 12719 & 2199 & & 1 & $\mathrm{~A} 1$ & 283 & 14 & 5 & 62.12 & 1 & & & 1 & & & & \\
\hline 12719 & 2199 & & 1 & $\mathrm{~A} 1$ & 283 & 14 & 1 & 0.6 & 1 & 1 & & 1 & & & & \\
\hline 12719 & 2199 & & 1 & $\mathrm{~A} 1$ & 281 & 4 & 3 & 22.03 & 1 & 1 & & 1 & & 1 & & \\
\hline 12719 & 2199 & & 1 & $A 1$ & 283 & 14 & 1 & 0.81 & 1 & 1 & & 1 & & & & \\
\hline 12719 & 2201 & 32 & 6 & A1 & 283 & 14 & 1 & 28.31 & 40 & & & 40 & & & & \\
\hline 12719 & 2201 & 32 & 6 & $\mathrm{A1}$ & 283 & 14 & 3 & 20.83 & 3 & & & 3 & & & & \\
\hline 12719 & 2201 & 32 & 6 & $\mathrm{A1}$ & 283 & 14 & 2 & 65.41 & 22 & & & 22 & & & & \\
\hline 12719 & 2201 & 32 & 6 & A1 & 281 & 4 & 11 & 1963.9 & 1 & 1 & & 1 & & 1 & & \\
\hline 12719 & 2201 & 32 & 6 & $\mathrm{~A} 1$ & 281 & 4 & 3 & 19.7 & 1 & 1 & & 1 & & & 1 & \\
\hline 12719 & 2201 & 32 & 6 & A1 & 281 & 4 & 4 & 43.87 & 1 & & 1 & 1 & & 1 & & \\
\hline 12719 & 2201 & 32 & 6 & A1 & 283 & 14 & 5 & 128.92 & 1 & & & 1 & & & & \\
\hline 12719 & 2202 & 32 & 6 & $\mathrm{~A} 1$ & 281 & 1 & 3 & 20.7 & 1 & & & 1 & & 1 & & \\
\hline 12719 & 2203 & & 1 & A1 & 281 & 4 & 5 & 126.99 & 1 & 1 & & 1 & & 1 & & \\
\hline 12719 & 2203 & & 1 & $\mathrm{~A} 1$ & 281 & 4 & 3 & 5.1 & 1 & 1 & & 1 & & & 1 & \\
\hline 12719 & 2203 & & 1 & A1 & 281 & 4 & 4 & 12.75 & 1 & 1 & & & 1 & & 1 & \\
\hline 12719 & 2203 & & 1 & A1 & 283 & 14 & 2 & 6.26 & 1 & & & 1 & & & & \\
\hline 12719 & 2205 & & 1 & A1 & 281 & 6 & 2 & 1.7 & 1 & 1 & & & 1 & & 1 & \\
\hline 12719 & 2205 & & 1 & A1 & 281 & 6 & 2 & 2.3 & 1 & 1 & & & 1 & & 1 & \\
\hline 12719 & 2206 & & 1 & $\mathrm{~A} 1$ & 283 & 14 & 1 & 1.16 & 2 & & & 2 & & & & \\
\hline 12719 & 2206 & & 1 & A1 & 283 & 14 & 2 & 1.49 & 1 & & & 1 & & & & \\
\hline 12719 & 2207 & & 1 & A1 & 283 & 14 & 1 & 0.62 & 1 & & & 1 & & & & \\
\hline 12719 & 2208 & & 1 & A1 & 283 & 14 & 1 & 0.32 & 2 & & & 2 & & & & \\
\hline 12719 & 2209 & & 1 & A1 & 283 & 14 & 1 & 17.03 & 56 & & & 56 & & & & \\
\hline 12719 & 2209 & & 1 & A1 & 283 & 14 & 2 & 18.03 & 9 & & & 9 & & & & \\
\hline 12719 & 2209 & & 1 & A1 & 283 & 14 & 3 & 13.92 & 2 & & & 2 & & & & \\
\hline 12719 & 2210 & & & A1 & 281 & 4 & 2 & 4.35 & 1 & 1 & & 1 & & & 1 & \\
\hline 12719 & 2210 & & 1 & $\mathrm{~A} 1$ & 281 & 4 & 3 & 5.76 & 1 & 1 & & & 1 & 1 & & 1 flake \\
\hline 12719 & 2210 & & 1 & A1 & 283 & 14 & 3 & 20.62 & 3 & & & 3 & & & & \\
\hline 12719 & 2210 & & 1 & $\mathrm{~A} 1$ & 283 & 14 & 2 & 47.31 & 18 & & & 18 & & & & \\
\hline 12719 & 2210 & & 1 & $\mathrm{~A} 1$ & 283 & 14 & 1 & 34.21 & 54 & & & 54 & & & & \\
\hline 12719 & 2214 & 32 & 6 & $\mathrm{~A} 1$ & 281 & 6 & 2 & 1.02 & 1 & 1 & & & 1 & & 1 & \\
\hline 12719 & 2214 & 32 & 6 & A1 & 283 & 14 & 1 & 7.5 & 12 & & & 3 & & & & \\
\hline 12719 & 2214 & 32 & 6 & A1 & 281 & 4 & 5 & 64.49 & 1 & 1 & & 1 & & 1 & & 2 flakes \\
\hline 12719 & 2214 & 32 & 6 & A1 & 283 & 14 & 2 & 4.6 & 2 & & & 42 & & & & \\
\hline 12719 & 2214 & 32 & 6 & A1 & 281 & 4 & 2 & 0.39 & 1 & 1 & & 1 & & & 1 & \\
\hline 12719 & 2215 & & 1 & A1 & 281 & 4 & 2 & 5.94 & 1 & 1 & & 1 & & 1 & & 1 flake \\
\hline 12719 & 2215 & & 1 & A1 & 281 & 4 & 1 & 0.76 & 1 & 1 & & 1 & & & 1 & \\
\hline 12719 & 2215 & & 1 & A1 & 283 & 14 & 2 & 17.7 & 8 & & & 8 & & & & \\
\hline 12719 & 2215 & & 1 & A1 & 283 & 14 & 1 & 9.8 & 28 & & & 28 & & & & \\
\hline 12719 & 2216 & & 1 & $\overline{A 1}$ & 283 & 14 & 2 & 4.95 & 2 & & & 2 & & & & \\
\hline 12719 & 2216 & & 1 & A1 & 283 & 14 & 1 & 2.38 & 10 & & & 10 & & & & \\
\hline 12719 & 2217 & & 1 & $\mathrm{~A} 1$ & 283 & 14 & 1 & 5.34 & 11 & & & 11 & & & & \\
\hline 12719 & 2220 & & 1 & A1 & 281 & 4 & 3 & 27.05 & 1 & & 1 & 1 & & 1 & & 1 debitage(core?) \\
\hline 12719 & 2220 & & 1 & $\mathrm{A1}$ & 283 & 14 & 2 & 2.04 & 1 & & & 1 & & & & \\
\hline 12719 & 2220 & & 1 & A1 & 281 & 4 & 1 & 1.07 & 1 & 1 & & 1 & & 1 & & \\
\hline 12719 & 2222 & & 1 & $\mathrm{A1}$ & 283 & 14 & 3 & 13.03 & 1 & & & 1 & & & & \\
\hline 12719 & 2223 & & 1 & $\mathrm{~A} 1$ & 281 & 4 & 2 & 2.27 & 1 & 1 & & 1 & & & 1 & \\
\hline 12719 & 2223 & & 1 & $\mathrm{~A} 1$ & 283 & 14 & 1 & 2.43 & 4 & & & 4 & & & & \\
\hline 12719 & 2224 & & 1 & $\mathrm{~A} 1$ & 283 & 14 & 1 & 0.58 & 2 & & & 2 & & & & \\
\hline 12719 & 2224 & & 1 & At & 283 & 14 & 2 & 4.24 & 1 & & & 1 & & & & \\
\hline 12719 & 2225 & & 1 & A1 & 283 & 14 & 1 & 7.38 & 18 & & & 18 & & & & \\
\hline 12719 & 2225 & & 1 & $\mathrm{~A} 1$ & 283 & 14 & 3 & 131.6 & 1 & & & 1 & & & & \\
\hline 12719 & 2225 & & 1 & $\mathrm{~A} 1$ & 283 & 14 & 2 & 17.12 & 6 & & & 6 & & & & \\
\hline 12719 & 2225 & & 1 & $\mathrm{~A} 1$ & 281 & 4 & 5 & 46.72 & 1 & 1 & & 1 & & 1 & & 1 flake \\
\hline 12719 & 2226 & & 1 & A1 & 283 & 14 & 1 & 4.97 & 14 & & & 14 & & & & \\
\hline 12719 & 2226 & & 1 & A1 & 281 & 4 & 8 & 70.7 & 1 & 1 & & 1 & & & 1 & \\
\hline 12719 & 2226 & & 1 & $\mathrm{~A} 1$ & 283 & 14 & 2 & 5.31 & 2 & & & 2 & & & & \\
\hline 12719 & 2227 & 32 & 6 & A1 & 283 & 14 & 5 & 98.3 & 1 & & & 3 & & & & \\
\hline 12719 & 2227 & 32 & 6 & $\mathrm{~A} 1$ & 281 & 4 & 3 & 9.74 & 1 & 1 & & 1 & & 1 & & \\
\hline 12719 & 2227 & 32 & 6 & A1 & 281 & 4 & 2 & 2.1 & 1 & 1 & & 1 & & & 1 & \\
\hline 12719 & 2228 & 33 & 3 & A1 & 281 & 4 & 2 & 9.81 & 1 & 1 & & 1 & & & 1 & \\
\hline 12719 & 2228 & 33 & 3 & $\mathrm{~A} 1$ & 283 & 14 & 1 & 4.21 & 8 & & & 8 & & & & \\
\hline 12719 & 2229 & 33 & 3 & A1 & 281 & 6 & 1 & 0.1 & 1 & 1 & & & 1 & & 1 & \\
\hline 12719 & 2229 & 33 & 3 & A1 & 283 & 14 & 1 & 0.44 & 3 & & & 3 & & & & \\
\hline 12719 & 2230 & 33 & 3 & A1 & 283 & 14 & 1 & 0.9 & 2 & & & 2 & & & & \\
\hline
\end{tabular}




\begin{tabular}{|c|c|c|c|c|c|c|c|c|c|c|c|c|c|c|c|c|}
\hline Site & Coll \# & Feature & Lev & Blk & $A C$ & Mat & $\mathrm{Sz}$ & Grams & Qty & Frac & \begin{tabular}{|l|}
$\mathrm{NF}$ \\
\end{tabular} & Disc $P$ & Disc A & Cort $\mathrm{P}$ & \begin{tabular}{|l|} 
Cort A \\
\end{tabular} & Comments \\
\hline \begin{tabular}{|l|}
12719 \\
\end{tabular} & 2230 & 33 & 3 & $\mathrm{~A} 1$ & 283 & 14 & 2 & 5.82 & 5 & & & 5 & & & & \\
\hline 12719 & 2230 & 33 & 3 & $\mathrm{~A} 1$ & 283 & 14 & 3 & 8.98 & 1 & & & 1 & & & & 1 flake \\
\hline 12719 & 2231 & 78 & 7 & $\mathrm{~A} 1$ & 283 & 14 & 2 & 10.74 & 2 & & & 2 & & & & \\
\hline 12719 & 2231 & 78 & 7 & $\mathrm{~A} 1$ & 283 & 14 & 1 & 1.01 & 5 & & & 5 & & & & \\
\hline 12719 & 2232 & 78 & 7 & A1 & 283 & 14 & 1 & 0.4 & 3 & & & 3 & & & & \\
\hline 12719 & 2237 & 32 & 6 & $\mathrm{A1}$ & 283 & 14 & 3 & 6.15 & 1 & & & 1 & & & & \\
\hline 12719 & 2237 & 32 & 6 & A1 & 283 & 14 & 1 & 3.27 & 8 & & & 8 & & & & \\
\hline 12719 & 2237 & 32 & 6 & $\mathrm{~A} 1$ & 283 & 14 & 2 & 8.18 & 6 & & & 6 & & & & \\
\hline 12719 & 2238 & & & $\mathrm{~A} 1$ & 283 & 14 & 2 & 2.93 & 3 & & & 3 & & & & \\
\hline 12719 & 2238 & & & A1 & 283 & 14 & 1 & 3.46 & 9 & & & 9 & & & & \\
\hline 12719 & 2238 & & & A1 & 283 & 14 & 3 & 8.89 & 7 & & & 1 & & & & \\
\hline 12719 & 2239 & & & A1 & 283 & 14 & 3 & 20.64 & 2 & & & 2 & & & & \\
\hline 12719 & 2239 & & & A1 & 283 & 14 & 1 & 0.63 & 2 & & & 2 & & & & \\
\hline 12719 & 2240 & & 1 & A1 & 283 & 14 & 2 & 7.99 & 5 & & & 5 & & & & \\
\hline 12719 & 2240 & & 1 & A1 & 283 & 14 & 1 & 1.06 & 6 & & & 6 & & & & \\
\hline 12719 & 2240 & & 1 & A1 & 281 & 6 & 1 & 0.1 & 1 & 1 & & & 1 & & 1 & \\
\hline 12719 & 2241 & & 1 & A1 & 283 & 14 & 1 & 5.03 & 6 & & & 6 & & & & \\
\hline 12719 & 2241 & & 1 & $\mathrm{A1}$ & 283 & 14 & 2 & 0.86 & 1 & & & 1 & & & & \\
\hline 12719 & 2242 & & 1 & $\mathrm{~A} 1$ & 283 & 14 & 3 & 25.38 & 1 & & & 1 & & & & \\
\hline 12719 & 2242 & & 1 & A1 & 283 & 14 & 1 & 3.4 & 2 & & & 2 & & & & \\
\hline 12719 & \begin{tabular}{|l|}
2242 \\
\end{tabular} & & 1 & $\mathrm{~A} 1$ & 283 & 14 & 2 & 12.61 & 4 & & & 4 & & & & \\
\hline 12719 & \begin{tabular}{|l|}
2242 \\
\end{tabular} & & 1 & A1 & 281 & 4 & 3 & 12.6 & 1 & 1 & & 1 & & 1 & & \\
\hline 12719 & 2242 & & 1 & A1 & 281 & 4 & 4 & 153.95 & 3 & 3 & & 2 & 1 & 2 & 1 & \\
\hline 12719 & 2242 & & 1 & A1 & 281 & 4 & 5 & 48.96 & 1 & 1 & & & 1 & 1 & & \\
\hline 12719 & 2242 & & 1 & A1 & 281 & 4 & 2 & 9.91 & 1 & 1 & & & 1 & 1 & & \\
\hline 12719 & \begin{tabular}{|l|}
2243 \\
\end{tabular} & & 1 & $\bar{A} 1$ & 283 & 14 & 2 & 11.55 & 4 & & & 4 & & & & \\
\hline 12719 & \begin{tabular}{|l|}
2245 \\
\end{tabular} & & 1 & A1 & 283 & 14 & 2 & 10.11 & 3 & & & 3 & & & & \\
\hline 12719 & 2245 & & 1 & A1 & 283 & 14 & 1 & 5.32 & 10 & & & 10 & & & & \\
\hline 12719 & \begin{tabular}{|l|}
2245 \\
\end{tabular} & & 1 & A1 & 281 & 4 & 4 & 35.57 & 1 & 1 & & 1 & & 1 & & \\
\hline 12719 & \begin{tabular}{|l|}
2246 \\
\end{tabular} & & 1 & A1 & 283 & $\frac{1}{14}$ & 2 & 3.84 & 1 & & & 1 & & & & \\
\hline 12719 & 2246 & & 1 & A1 & 283 & 14 & 1 & 1.57 & 2 & & & 2 & & & & \\
\hline 12719 & \begin{tabular}{|l|}
2247 \\
\end{tabular} & & 1 & A1 & 283 & 14 & 1 & 17.49 & 30 & & & 30 & & & & \\
\hline 12719 & 2247 & & 1 & A1 & 283 & 14 & 2 & 42.04 & 12 & & & 12 & & & & \\
\hline 12719 & 2248 & & 1 & A1 & 281 & 4 & 5 & 148.16 & 2 & 2 & & 1 & 1 & 1 & 1 & \\
\hline 12719 & 2248 & & 1 & A1 & 283 & 14 & 1 & 3.35 & 8 & & & 8 & & & & \\
\hline 12719 & 2248 & & 1 & A1 & 283 & 14 & 2 & 11.49 & 5 & & & 5 & & & & \\
\hline 12719 & 2248 & & 1 & A1 & 281 & 4 & 2 & 11.63 & 2 & 1 & 1 & 2 & & 2 & & \\
\hline 12719 & 2249 & & 1 & A1 & 283 & 14 & 3 & 59.9 & 4 & & & 4 & & & & \\
\hline 12719 & 2249 & & 1 & A1 & 283 & 14 & 4 & 51.91 & 1 & & & 1 & & & & \\
\hline 12719 & 2249 & & 1 & A1 & 281 & 4 & 4 & 39.97 & 1 & 1 & & 1 & & 1 & & \\
\hline 12719 & 2249 & & 1 & A1 & 283 & 14 & 2 & 8.44 & 2 & & & 2 & & & & \\
\hline 12719 & \begin{tabular}{|l|}
2249 \\
\end{tabular} & & 1 & A1 & 281 & 4 & 6 & 453.2 & 1 & 1 & & 1 & & 1 & & \\
\hline 12719 & 2249 & & 1 & A1 & 281 & 4 & 5 & 111.18 & 1 & 1 & & 1 & & 1 & & \\
\hline 12719 & 2249 & & 1 & A1 & 281 & 4 & 3 & 41.6 & 2 & & 2 & 2 & & 2 & & \\
\hline 12719 & 2250 & & 1 & $\mathrm{~A} 1$ & 283 & 14 & 1 & 0.99 & 4 & & & 4 & & & & \\
\hline 12719 & 2250 & & 1 & A1 & 283 & 14 & 2 & 3.99 & 1 & & & 1 & & & & \\
\hline 12719 & 2251 & & 1 & A1 & 281 & 4 & 3 & 19.89 & 1 & 1 & & 1 & & 1 & & \\
\hline 12719 & 2251 & & 1 & A1 & 283 & 14 & 2 & 14.72 & 5 & & & 5 & & & & \\
\hline 12719 & 2251 & & 1 & A.1 & 283 & 14 & 1 & 8.55 & 13 & & & 13 & & & & \\
\hline 12719 & 2251 & & 1 & A1 & 281 & 4 & 2 & 5.27 & 2 & 2 & & 2 & & 2 & & \\
\hline 12719 & 2252 & & 1 & A1 & 283 & 14 & 2 & 4.84 & 1 & & & 1 & & & & \\
\hline 12719 & 2252 & & 1 & A1 & 283 & 14 & 1 & 3.02 & 3 & & & 3 & & & & \\
\hline \begin{tabular}{|l|}
12719 \\
\end{tabular} & 2252 & & 1 & A1 & 281 & 4 & 3 & 111.69 & 1 & 1 & & 1 & & & 1 & \\
\hline 12719 & 2253 & 33 & 5 & A1 & 283 & 14 & 2 & 8.16 & 3 & & & 3 & & & & \\
\hline 12719 & 2253 & 33 & 5 & A1 & 283 & 14 & 3 & 26.38 & 2 & & & 2 & & & & \\
\hline 12719 & 2253 & 33 & 5 & A1 & 283 & 14 & 1 & 10.6 & 10 & & & 10 & & & & \\
\hline 12719 & 2254 & 33 & 5 & A1 & 283 & 14 & 2 & 5 & 2 & & & 2 & & & & \\
\hline 12719 & \begin{tabular}{|l|}
2254 \\
\end{tabular} & 33 & 5 & A1 & 283 & 14 & 5 & 164.9 & 1 & & & 1 & & & & \\
\hline 12719 & 2255 & 33 & 5 & A1 & 283 & 14 & 2 & 5.76 & 1 & 1 & & 1 & & & & \\
\hline 12719 & 2255 & 33 & 5 & A1 & 283 & 14 & 1 & 0.16 & 1 & & & 1 & & & & \\
\hline 12719 & \begin{tabular}{|l|}
2256 \\
\end{tabular} & 33 & 5 & A1 & 283 & 14 & 6 & 119.01 & 1 & & & 1 & & & & \\
\hline 12719 & \begin{tabular}{|l|}
2256 \\
\end{tabular} & 33 & 5 & A1 & 281 & 4 & 4 & 26.26 & 1 & 1 & & 1 & & & 1 & \\
\hline 12719 & \begin{tabular}{|l|}
2257 \\
\end{tabular} & 33 & 5 & A1 & 283 & 14 & 2 & 9.05 & 2 & & & 2 & & & & \\
\hline 12719 & 2257 & 33 & 5 & A1 & 283 & 14 & 1 & 5.39 & 7 & & & 7 & & & & \\
\hline 12719 & 2257 & 33 & 5 & A1 & 283 & 14 & 3 & 42.34 & 2 & & & 2 & & & & \\
\hline 12719 & 2257 & 33 & 5 & A1 & 281 & 4 & 1 & 0.12 & 1 & 1 & & 1 & & 1 & & \\
\hline 12719 & \begin{tabular}{|l|}
2257 \\
\end{tabular} & 33 & 5 & A1 & 281 & 4 & 2 & 1.04 & 1 & 1 & & 1 & & 1 & & \\
\hline 12719 & \begin{tabular}{|l|}
2258 \\
\end{tabular} & 33 & 5 & A1 & 283 & 14 & 1 & 3.2 & 5 & & & 4 & & & & \\
\hline
\end{tabular}




\begin{tabular}{|c|c|c|c|c|c|c|c|c|c|c|c|c|c|c|c|c|}
\hline Site & Coll \# & Feature & Lev & Blk & $A C$ & Mat & $\mathrm{Sz}$ & Grams & Qty & Frac & $\mathrm{NF}$ & Disc P & Disc A & Cort P & Cort $A$ & Comments \\
\hline 12719 & 2258 & 33 & 5 & $\mathrm{~A} 1$ & 283 & 14 & 4 & 14 & 1 & & & \begin{tabular}{|l|}
3 \\
\end{tabular} & & & & \\
\hline 12719 & 2259 & 33 & 5 & $\mathrm{A1}$ & 283 & 14 & 2 & 26.9 & 12 & & & 29 & & & & \\
\hline 12719 & 2259 & 33 & 5 & A1 & 283 & 14 & 1 & 16.2 & 22 & & & 17 & & & & \\
\hline 12719 & 2259 & 33 & 5 & $\mathrm{~A} 1$ & 281 & 6 & 2 & 2.3 & 4 & 4 & & & 4 & & 4 & \\
\hline 12719 & 2259 & 33 & 5 & $\mathrm{~A} 1$ & 283 & 14 & 3 & 33.4 & 3 & & & 3 & & & & \\
\hline 12719 & 2259 & 33 & 5 & A1 & 281 & 6 & 2 & 1.9 & 1 & 1 & & & 1 & & 1 & \\
\hline 12719 & \begin{tabular}{|l|}
2259 \\
\end{tabular} & 33 & 5 & $\mathrm{A1}$ & 281 & 4 & 2 & 3.2 & 1 & 1 & & 1 & & & 1 & \\
\hline 12719 & 2259 & 33 & 5 & $\mathrm{~A} 1$ & 281 & 4 & 1 & 2.82 & 6 & 6 & & 6 & & 2 & 4 & \\
\hline 12719 & \begin{tabular}{|l|}
2259 \\
\end{tabular} & 33 & 5 & A1 & 281 & 4 & 4 & 55.53 & 1 & 1 & & 1 & & 1 & & \\
\hline 12719 & \begin{tabular}{|l|}
2261 \\
\end{tabular} & & 1 & A1 & 281 & 4 & 2 & 4.55 & 3 & 2 & 1 & 2 & 1 & 3 & & \\
\hline 12719 & \begin{tabular}{|l|}
2261 \\
\end{tabular} & & 1 & $\mathrm{A1}$ & 283 & 14 & 2 & 4.4 & 2 & & & 3 & & & & \\
\hline 12719 & 2261 & & 1 & $\mathrm{~A} 1$ & 283 & 14 & 1 & 6 & 12 & & & 1 & & & & \\
\hline 12719 & 2261 & & 1 & $\mathrm{A1}$ & 281 & 4 & 3 & 7.99 & 1 & 1 & & 1 & & 1 & & 3 flakes \\
\hline 12719 & 2261 & & 1 & A1 & 281 & 4 & 1 & 0.96 & 2 & 2 & & 2 & & & 2 & \\
\hline 12719 & 2262 & & 1 & $\mathrm{A1}$ & 281 & 4 & 4 & 86.35 & 1 & 1 & & & 1 & 1 & & \\
\hline 12719 & \begin{tabular}{|l|}
2262 \\
\end{tabular} & & 1 & A1 & 281 & 4 & 2 & 4.85 & 1 & 1 & & 1 & & 1 & & \\
\hline 12719 & \begin{tabular}{|l|}
2262 \\
\end{tabular} & & 1 & A1 & 283 & 14 & 2 & 5.19 & 2 & & & 2 & & & & \\
\hline 12719 & \begin{tabular}{|l|}
2262 \\
\end{tabular} & & 1 & $\mathrm{~A} 1$ & 283 & 14 & 1 & 3.46 & 7 & & & 7 & & & & \\
\hline 12719 & 2263 & & 1 & A1 & 283 & 14 & 1 & 22.68 & 44 & & & 44 & & & & \\
\hline 12719 & 2263 & & 1 & A1 & 281 & 4 & 5 & 84.12 & 1 & 1 & & 1 & & 1 & & \\
\hline 12719 & 2263 & & 1 & A1 & 283 & 14 & 2 & 17.79 & 2 & & & 2 & & & & \\
\hline 12719 & 2263 & & 1 & A1 & 281 & 4 & 2 & 10.49 & 6 & 6 & & 6 & & 5 & 1 & \\
\hline 12719 & 2263 & & 1 & $\mathrm{A1}$ & 281 & 4 & 3 & 33.01 & 2 & 1 & 1 & 2 & & 2 & & \\
\hline 12719 & 2263 & & 1 & $\mathrm{~A} 1$ & 281 & 4 & 1 & 2.37 & 5 & 5 & & 5 & & 1 & 4 & \\
\hline 12719 & 2263 & & 1 & A1 & 283 & 14 & 2 & 22.52 & 10 & & & 10 & & & & \\
\hline 12719 & 2263 & & 1 & A1 & 281 & 4 & 4 & 32.12 & 1 & 1 & & 1 & & 1 & & \\
\hline 12719 & 2263 & & 1 & $\mathrm{A1}$ & 281 & 6 & 3 & 5.6 & 1 & 1 & & & 1 & 1 & & \\
\hline 12719 & 2265 & & 1 & A1 & 283 & 14 & 2 & 2.64 & 2 & & & 2 & & & & \\
\hline 12719 & 2265 & & 1 & $\mathrm{A1}$ & 283 & 14 & 1 & 2.25 & 4 & & & 4 & & & & \\
\hline 12719 & 2266 & & 1 & $\mathrm{~A} 1$ & 281 & 4 & 3 & 12.68 & 2 & 2 & & 2 & & 2 & & \\
\hline 12719 & 2266 & & 1 & A1 & 283 & 14 & 3 & 17.07 & 2 & & & 2 & & & & \\
\hline 12719 & 2266 & & 1 & A1 & 283 & 14 & 4 & 28.96 & 1 & & & 1 & & & & \\
\hline 12719 & 2266 & & 1 & $\mathrm{~A} 1$ & 283 & 14 & 2 & 7.73 & 4 & & & 4 & & & & \\
\hline 12719 & 2266 & & 1 & A1 & 281 & 4 & 2 & 56.26 & 1 & 1 & & 1 & & 1 & & \\
\hline 12719 & 2266 & & 1 & $\overline{A 1}$ & 281 & 4 & 2 & 1.24 & 1 & 1 & & 1 & & & 1 & \\
\hline 12719 & 2266 & & 1 & $\mathrm{~A} 1$ & 283 & 14 & 1 & 2.5 & 4 & & & 4 & & & & \\
\hline 12719 & 2267 & & 1 & A1 & 283 & 14 & 1 & 0.1 & 2 & & & 2 & & & & \\
\hline 12719 & 2268 & & 1 & A1 & 283 & 14 & 1 & 15.83 & 37 & & & 37 & & & & \\
\hline 12719 & 2268 & & 1 & A1 & 281 & 6 & 2 & 2.3 & 1 & 1 & & & 1 & 1 & & \\
\hline 12719 & 2268 & & 1 & A1 & 283 & 14 & 3 & 3.84 & 1 & & & 1 & & & & \\
\hline 12719 & 2268 & & 1 & A1 & 281 & 4 & 2 & 10.82 & 4 & 4 & & 4 & & 2 & 2 & \\
\hline 12719 & 2268 & & 1 & A1 & 281 & 4 & 1 & 0.9 & 2 & 2 & & 2 & & 2 & & \\
\hline 12719 & 2268 & & 1 & A1 & 281 & 4 & 5 & 88.72 & 1 & 1 & & 1 & & 1 & & \\
\hline 12719 & 2268 & & 1 & A1 & 281 & 4 & 3 & 21.44 & 2 & 2 & & 2 & & 1 & 1 & \\
\hline 12719 & 2268 & & 1 & A1 & 283 & 14 & 2 & 21.14 & 14 & & & 14 & & & & \\
\hline 12719 & 2269 & & 1 & A1 & 283 & 14 & 1 & 2.57 & 10 & & & 10 & & & & \\
\hline 12719 & 2269 & & 1 & A1 & 281 & 4 & 2 & 2.94 & 2 & 2 & & 2 & & & 2 & \\
\hline 12719 & 2269 & & 1 & A1 & 281 & 4 & 1 & 1.23 & 1 & & 1 & 1 & & 1 & & \\
\hline 12719 & 2269 & & 1 & A1 & 281 & 6 & 1 & $\begin{array}{ll}0.4 \\
\end{array}$ & 1 & 1 & & & 1 & & 1 & \\
\hline 12719 & 2269 & & 1 & A1 & 283 & 14 & 2 & 8.88 & 4 & & & 4 & & & & \\
\hline 12719 & 2270 & 33 & 5 & A1 & 281 & 4 & 4 & 66.86 & 2 & 2 & & 2 & & 1 & 1 & \\
\hline 12719 & 2270 & 33 & 5 & $\mathrm{~A} 1$ & 281 & 4 & 1 & 0.59 & 2 & 2 & & 2 & & & 2 & 3 flakes \\
\hline 12719 & 2270 & 33 & 5 & A1 & 283 & 14 & 1 & 3.2 & 4 & & & 13 & & & & \\
\hline 12719 & 2270 & 33 & 5 & $\mathrm{~A} 1$ & 283 & 14 & 4 & 16.5 & 1 & & & 1 & & & & \\
\hline 12719 & 2270 & 33 & 5 & $\mathrm{~A} 1$ & 283 & 14 & 2 & 20 & 4 & & & 1 & & & & \\
\hline 12719 & 2270 & 33 & 5 & $\mathrm{A1}$ & 283 & 14 & 3 & 20.4 & 2 & & & 32 & & & & \\
\hline 12719 & 2270 & 33 & 5 & A1 & 281 & 4 & 2 & 1.57 & 1 & 1 & & 1 & & & 1 & \\
\hline 12719 & 2271 & 33 & 5 & A1 & 281 & 4 & 4 & 16.4 & 1 & 1 & & 1 & & & 1 & \\
\hline 12719 & 2271 & 33 & 5 & $\mathrm{~A} 1$ & 283 & 14 & 1 & 1.38 & 4 & & & 4 & & & & \\
\hline 12719 & 2272 & 33 & 5 & A1 & 281 & 4 & 1 & 3.3 & 5 & 5 & & 5 & & 1 & 4 & \\
\hline 12719 & 2272 & 33 & 5 & A1 & 283 & 14 & 2 & 8.7 & 2 & & & 3 & & & & \\
\hline 12719 & 2272 & 33 & 5 & $\mathrm{~A} 1$ & 283 & 14 & 4 & 12 & 1 & & & 6 & & & & \\
\hline 12719 & 2272 & 33 & 5 & A1 & 281 & 4 & 4 & 150.75 & 2 & 1 & 1 & 2 & & 2 & & \\
\hline 12719 & 2272 & 33 & 5 & A1 & 281 & 4 & 2 & 10.47 & 4 & 4 & & 4 & & 2 & 2 & \\
\hline 12719 & 2272 & 33 & 5 & A1 & 283 & 14 & 1 & 6.1 & 8 & & & 1 & & & & \\
\hline 12719 & 2273 & 33 & 5 & A1 & 283 & 14 & 1 & 5.7 & 8 & & & 8 & & & & \\
\hline 12719 & 2274 & & 1 & A1 & 281 & 4 & 2 & 19.56 & 5 & 3 & 2 & 5 & & 3 & 2 & \\
\hline 12719 & 2274 & & 1 & $\mathrm{~A} 1$ & 281 & 4 & 4 & 155.99 & 1 & 1 & & 1 & & 1 & & \\
\hline
\end{tabular}




\begin{tabular}{|c|c|c|c|c|c|c|c|c|c|c|c|c|c|c|c|c|}
\hline Site & Coll \# & Feature & Lev & Blk & $\mathrm{AC}$ & Mat & $\mathrm{Sz}$ & Grams & Qty & Frac & $\mathrm{NF}$ & Disc P & Disc A & Cort $P$ & Cort A & Comments \\
\hline 12719 & \begin{tabular}{|l|}
2274 \\
\end{tabular} & & 1 & $\mathrm{~A} 1$ & 283 & 14 & 1 & 0.5 & 1 & & & 9 & & & & \\
\hline 12719 & \begin{tabular}{|l|}
2274 \\
\end{tabular} & & 1 & A1 & 283 & 14 & 2 & 2 & 1 & & & 15 & & & & \\
\hline 12719 & 2275 & & 1 & $\mathrm{~A} 1$ & 283 & 14 & 2 & 6.08 & 2 & & & 2 & & & & \\
\hline 12719 & 2276 & & 1 & $\mathrm{A1}$ & 283 & 14 & 2 & 1.66 & 1 & & & 1 & & & & \\
\hline 12719 & 2276 & & 1 & A1 & 283 & 14 & 1 & 4.49 & 4 & & & 4 & & & & \\
\hline 12719 & 2277 & & 1 & A1 & 283 & 14 & 2 & 20.28 & 7 & & & 7 & & & & \\
\hline 12719 & \begin{tabular}{|l|}
2277 \\
\end{tabular} & & 1 & A1 & 283 & 14 & 1 & 7.02 & 17 & & & 17 & & & & \\
\hline 12719 & 2277 & & 1 & A1 & 281 & 4 & 1 & 0.65 & 1 & 1 & & 1 & & & 1 & \\
\hline 12719 & 2278 & & 1 & A1 & 281 & 4 & 2 & 7.32 & 3 & & & 3 & & 2 & & \\
\hline 12719 & 2278 & & 1 & $\mathrm{A1}$ & 281 & 4 & 4 & 40.92 & 1 & & 1 & 1 & & 1 & & \\
\hline 12719 & 2278 & & 1 & $\mathrm{~A}_{1}$ & 283 & 14 & 2 & 24.02 & 8 & & & 8 & & & & \\
\hline 12719 & 2278 & & 1 & $\mathrm{~A} 1$ & 283 & 14 & 1 & 7.1 & 12 & & & 12 & & & & \\
\hline 12719 & 2278 & & 1 & $\mathrm{~A} 1$ & 281 & 4 & 5 & 22.25 & 1 & 1 & & 1 & & 1 & & \\
\hline 12719 & 2278 & & 1 & $\mathrm{~A} 1$ & 283 & 14 & 3 & 15.36 & 2 & & & 2 & & & & \\
\hline 12719 & 2279 & & 1 & A1 & 283 & 14 & 2 & 2.83 & 2 & & & 2 & & & & \\
\hline 12719 & 2279 & & 1 & A1 & 281 & 4 & 2 & 2.13 & 1 & 1 & & & 1 & & & \\
\hline 12719 & 2279 & & 1 & A1 & 281 & 4 & 3 & 4.68 & 2 & 2 & & & 2 & 1 & 1 & \\
\hline 12719 & 2280 & & 1 & A1 & 283 & 14 & 2 & 6.7 & 3 & & & 2 & & & & \\
\hline 12719 & 2280 & & 1 & $\mathrm{~A} 1$ & 283 & 14 & 1 & 2.76 & 8 & & & 8 & & & & \\
\hline 12719 & 2280 & & 1 & A1 & 283 & 14 & 3 & 7.3 & 1 & & & 1 & & & & \\
\hline 12719 & 2280 & & 1 & $\mathrm{~A} 1$ & 281 & 4 & 4 & 14.68 & 1 & 1 & & 1 & & & 1 & \\
\hline 12719 & 2283 & 33 & 6 & A1 & 283 & 14 & 2 & 9 & 3 & & & 1 & & & & \\
\hline 12719 & 2283 & 33 & 6 & $\mathrm{~A} 1$ & 283 & 14 & 1 & 3 & 3 & & & 2 & & & & \\
\hline 12719 & 2284 & 33 & 6 & A1 & 281 & 4 & 1 & 0.73 & 2 & 2 & & 2 & & & 2 & \\
\hline 12719 & 2287 & 33 & 6 & $\mathrm{~A} 1$ & 283 & 14 & 2 & 2.9 & 3 & & & 16 & & & & \\
\hline 12719 & 2287 & 33 & 6 & $\mathrm{~A} 1$ & 281 & 4 & 2 & 3.7 & 1 & 1 & & 1 & & 1 & & \\
\hline 12719 & 2287 & 33 & 6 & $\overline{A 1}$ & 283 & 14 & 4 & 20.8 & 1 & & & 2 & & & & \\
\hline 12719 & 2287 & 33 & 6 & $\mathrm{~A} 1$ & 283 & 14 & 3 & 8.6 & 1 & & & 3 & & & & \\
\hline 12719 & 2288 & & 1 & A1 & 281 & 4 & 2 & 4.2 & 1 & 1 & & & 1 & 1 & & 1 flake \\
\hline 12719 & 2288 & & 1 & $\mathrm{~A} 1$ & 283 & 14 & 1 & 6.12 & 12 & & & 12 & & & & \\
\hline 12719 & 2288 & & 1 & A1 & 283 & 14 & 2 & 13.92 & 4 & & & 4 & & & & \\
\hline 12719 & 2289 & & 1 & A1 & 283 & 14 & 1 & \begin{tabular}{|l|}
1.11 \\
\end{tabular} & 6 & & & 6 & & & & \\
\hline 12719 & 2289 & & 1 & $\mathrm{~A} 1$ & 283 & 14 & 2 & 0.99 & 1 & & & 1 & & & & \\
\hline 12719 & 2290 & & 1 & $\bar{A} 1$ & 281 & 4 & 2 & 2.08 & 1 & 1 & & 1 & & 1 & & \\
\hline 12719 & 2290 & & 1 & $\mathrm{~A} 1$ & 283 & 14 & 1 & 0.8 & 1 & & & 1 & & & & \\
\hline 12719 & 2291 & 34 & 3 & $\mathrm{~A} 1$ & 283 & 14 & 1 & 10.2 & 11 & & & 83 & & & & \\
\hline 12719 & 2291 & 34 & 3 & $\mathrm{~A} 1$ & 281 & 4 & 4 & 50.41 & 1 & 1 & & 1 & & 1 & & \\
\hline 12719 & 2291 & 34 & 3 & $\mathrm{~A} 1$ & 283 & 14 & 4 & 88.5 & 1 & & & 104 & & & & \\
\hline 12719 & 2291 & 34 & 3 & A1 & 283 & 14 & 3 & 18 & 3 & & & 29 & & & & \\
\hline 12719 & 2291 & 34 & 3 & A1 & 283 & 14 & 2 & 12 & 6 & & & 4 & & & & \\
\hline 12719 & 2291 & 34 & 3 & A1 & 281 & 4 & 3 & 10.69 & 1 & 1 & & 1 & & 1 & & \\
\hline 12719 & 2291 & 34 & 3 & $\mathrm{~A} 1$ & 281 & 4 & 2 & 15.43 & 2 & 2 & & 2 & & 2 & & \\
\hline 12719 & 2292 & 34 & 3 & A1 & 281 & 4 & 1 & 0.84 & 2 & 2 & & 2 & & & 2 & \\
\hline 12719 & 2293 & 34 & 3 & $\mathrm{~A} 1$ & 281 & 4 & 2 & 0.91 & 1 & & 1 & 1 & & 1 & & 1 flake \\
\hline 12719 & 2293 & 34 & 3 & A1 & 281 & 4 & 1 & 0.36 & 1 & 1 & & 1 & & 1 & & \\
\hline 12719 & 2294 & 34 & 3 & $\mathrm{~A} 1$ & 283 & 14 & 2 & 2.3 & 1 & & & 11 & & & & \\
\hline 12719 & 2294 & 34 & 3 & A1 & 283 & 14 & 1 & 1 & 1 & & & 20 & & & & \\
\hline 12719 & 2294 & 34 & 3 & $\mathrm{~A} 1$ & 281 & 4 & 5 & 229.1 & 1 & 1 & & 1 & & 1 & & \\
\hline 12719 & 2294 & 34 & 3 & $\mathrm{~A} 1$ & 281 & 4 & 2 & 10.84 & 3 & 3 & & 3 & & & 3 & \\
\hline 12719 & 2294 & 34 & 3 & $\mathrm{~A} 1$ & 281 & 4 & 3 & 19.66 & 2 & 2 & & 2 & & 1 & 1 & \\
\hline 12719 & 2294 & 34 & 3 & A1 & 281 & 4 & 1 & 1.07 & 1 & 1 & & 1 & & 1 & & \\
\hline 12719 & 2295 & 34 & 1 & A1 & 283 & 14 & 1 & 4.75 & 20 & & & 20 & & & & \\
\hline 12719 & 2295 & 34 & 1 & A1 & 283 & 14 & 4 & 36.32 & 1 & & & 1 & & & & \\
\hline 12719 & 2295 & 34 & 1 & A1 & 281 & 4 & 2 & 4.8 & 2 & 1 & 1 & 2 & & 2 & & \\
\hline 12719 & 2295 & 34 & 1 & A1 & 283 & 14 & 3 & 10.82 & 2 & & & 2 & & & & \\
\hline 12719 & 2295 & 34 & 1 & A1 & 283 & 14 & 2 & 10.97 & 4 & & & 4 & & & & \\
\hline 12719 & 2296 & 34 & 1 & A1 & 283 & 14 & 1 & 11.57 & 19 & & & 19 & & & & \\
\hline 12719 & 2296 & 34 & 1 & $\mathrm{~A} 1$ & 281 & 4 & 3 & 22.18 & 2 & 2 & & 2 & & 1 & 1 & \\
\hline 12719 & 2296 & 34 & 1 & $\mathrm{~A} 1$ & 281 & 4 & 4 & 31.88 & 1 & 1 & & 1 & & & 1 & \\
\hline 12719 & 2296 & 34 & 1 & A1 & 283 & 14 & 2 & 13.98 & 4 & & & 4 & & & & \\
\hline 12719 & 2297 & 34 & 1 & A1 & 283 & 14 & 2 & 11.8 & 4 & & & 4 & & & & \\
\hline 12719 & 2297 & 34 & 1 & A1 & 283 & 14 & 1 & 1.3 & 2 & & & 2 & & & & \\
\hline 12719 & 2297 & 34 & 1 & A1 & 283 & 14 & 4 & 35.1 & 2 & & & 4 & & & & \\
\hline 12719 & 2298 & 34 & 1 & A1 & 281 & 6 & 1 & 0.42 & 1 & 1 & & & 1 & & 1 & \\
\hline 12719 & 2298 & 34 & 1 & A1 & 283 & 14 & 1 & 3 & 4 & & & 67 & & & & \\
\hline 12719 & 2298 & 34 & 1 & $\mathrm{~A} 1$ & 281 & 6 & 1 & 0.6 & 1 & 1 & & & 1 & & 1 & \\
\hline 12719 & 2298 & 34 & 1 & A1 & 281 & 6 & 3 & 4.1 & 1 & 1 & & & 1 & & 1 & \\
\hline 12719 & 2298 & 34 & 1 & $A 1$ & 281 & 4 & 2 & 10.22 & 4 & 4 & & 4 & & 3 & 1 & \\
\hline
\end{tabular}




\begin{tabular}{|c|c|c|c|c|c|c|c|c|c|c|c|c|c|c|c|c|}
\hline Site & Coll \# & Feature & Lev & Blk & $A C$ & Mat & $\overline{S z}$ & Grams & Qty & Frac & $\mathrm{NF}$ & Disc $P$ & Disc A & Cort P & Cort A & Comments \\
\hline 12719 & 2298 & 34 & 1 & A1 & 281 & 7 & 1 & 0.05 & 1 & 1 & & & 1 & & 1 & \\
\hline 12719 & 2298 & 34 & 1 & $\mathrm{~A} 1$ & 283 & 14 & 2 & 15.2 & 4 & & & 16 & & & & \\
\hline 12719 & 2298 & 34 & 1 & $\mathrm{~A} 1$ & 283 & 14 & 4 & 21.9 & 1 & & & 4 & & & & \\
\hline 12719 & 2298 & 34 & 1 & $\mathrm{~A} 1$ & 281 & 4 & 4 & 33.58 & 2 & 2 & & 2 & & 1 & 1 & \\
\hline 12719 & 2298 & 34 & 1 & $\mathrm{~A} 1$ & 281 & 4 & 3 & 3.2 & 1 & 1 & & 1 & & 1 & & \\
\hline 12719 & 2298 & 34 & 1 & A1 & 281 & 4 & 3 & 14.49 & 1 & 1 & & 1 & & 1 & & \\
\hline 12719 & 2298 & 34 & 1 & $\mathrm{~A} 1$ & 281 & 4 & 1 & 0.14 & 1 & 1 & & 1 & & 1 & & \\
\hline 12719 & 2299 & 34 & 1 & A1 & 283 & 14 & 4 & 56.47 & 2 & & & 2 & & & & \\
\hline 12719 & 2299 & 34 & 1 & $\bar{A} 1$ & 283 & 14 & 1 & 8.7 & 8 & & & 9 & & & & \\
\hline 12719 & 2299 & 34 & 1 & $\mathrm{~A} 1$ & 281 & 4 & 3 & 49.64 & 3 & 3 & & 3 & & 2 & 1 & \\
\hline 12719 & 2299 & 34 & 1 & $\mathrm{~A} 1$ & 283 & 14 & 5 & 167.73 & 2 & & & 2 & & & & \\
\hline 12719 & 2299 & 34 & 1 & A1 & 283 & 14 & 1 & 32.91 & 60 & & & 60 & & & & \\
\hline 12719 & 2299 & 34 & 1 & A1 & 283 & 14 & 2 & 17.6 & 3 & & & 1 & & & & \\
\hline 12719 & 2299 & 34 & 1 & A1 & 281 & 4 & 4 & 38.16 & 1 & 1 & & 1 & & 1 & & \\
\hline 12719 & \begin{tabular}{|l|}
2299 \\
\end{tabular} & 34 & 1 & A1 & 281 & 4 & 2 & 12.76 & 3 & 3 & & 3 & & 3 & & \\
\hline 12719 & 2300 & & 1 & $\mathrm{~A} 1$ & 283 & 14 & 1 & 21.4 & 57 & & & 57 & & & & \\
\hline 12719 & 2300 & & 1 & A1 & 283 & 14 & 3 & 19 & 2 & & & 2 & & & & \\
\hline 12719 & 2300 & & 1 & $\mathrm{~A} 1$ & 283 & 14 & 4 & 55.12 & 2 & & & 2 & & & & \\
\hline 12719 & 2300 & & 1 & A1 & 283 & 14 & 2 & 27.1 & 12 & & & 12 & & & & \\
\hline 12719 & 2300 & & 1 & A1 & 281 & 4 & 2 & 5.13 & 1 & 1 & & 1 & & & 1 & \\
\hline 12719 & 2300 & & 1 & $\mathrm{A1}$ & 281 & 7 & 1 & 0.35 & 1 & 1 & & & 1 & & 1 & \\
\hline 12719 & 2301 & & 1 & A1 & 283 & 14 & 3 & 58.23 & 2 & 2 & & 2 & 1 & 1 & & \\
\hline 12719 & 2301 & & 1 & A1 & 283 & 14 & 2 & 45.26 & 20 & & & 20 & & & & \\
\hline 12719 & 2301 & & 1 & A1 & 283 & 14 & 4 & 32.68 & 1 & & & 1 & & & & \\
\hline 12719 & 2301 & & 1 & A1 & 283 & 14 & 1 & 44.39 & 93 & & & 93 & & & & \\
\hline 12719 & \begin{tabular}{|l|}
2301 \\
\end{tabular} & & 1 & $\mathrm{~A} 1$ & 283 & 14 & 5 & 131.38 & 2 & & & 2 & & & & \\
\hline 12719 & \begin{tabular}{|l|}
2301 \\
\end{tabular} & & 1 & $A 1$ & 281 & 6 & 2 & 2.1 & 1 & 1 & & & 1 & & 1 & \\
\hline 12719 & 2301 & & 1 & $\overline{A 1}$ & 281 & 6 & 1 & 0.5 & 1 & 1 & & 1 & & & 1 & \\
\hline 12719 & 2301 & & 1 & A1 & 281 & 4 & 6 & 184.45 & 1 & 1 & & 1 & & 1 & & \\
\hline 12719 & 2301 & & 1 & $A 1$ & 283 & 14 & 3 & 42.02 & 3 & & & 3 & & & & \\
\hline 12719 & 2302 & & 1 & A1 & 283 & 14 & 2 & 7.97 & 5 & & & 5 & & & & \\
\hline 12719 & 2302 & & 1 & $A 1$ & 283 & 14 & 4 & 16.14 & 1 & & & 1 & & & & \\
\hline 12719 & 2302 & & 1 & $\overline{A 1}$ & 281 & 4 & & & & & & & & & & 1 flake \\
\hline 12719 & 2302 & & 1 & A1 & 283 & 14 & 1 & 23.28 & 41 & & & 41 & & & & \\
\hline 12719 & 2302 & & 1 & A1 & 281 & 7 & 1 & 0.3 & 1 & 1 & & & 1 & & 1 & \\
\hline 12719 & 2303 & & 1 & $\mathrm{~A} 1$ & 283 & 14 & 2 & 13.97 & 3 & & & 3 & & & & \\
\hline 12719 & 2303 & & 1 & A1 & 283 & 14 & 1 & 1.21 & 3 & & & 3 & & & & \\
\hline 12719 & 2305 & & 1 & $\mathrm{~A} 1$ & 283 & 14 & 1 & 0.71 & 2 & & & 2 & & & & \\
\hline 12719 & 2306 & & 1 & A1 & 283 & 14 & 3 & 7.17 & 1 & & & 1 & & & & \\
\hline 12719 & 2306 & & 1 & A1 & 283 & 14 & 1 & 1.11 & 2 & & & 2 & & & & \\
\hline 12719 & 2306 & & 1 & $\overline{A 1}$ & 281 & 7 & 1 & 0.27 & 1 & 1 & & & 1 & & 1 & \\
\hline 12719 & 2307 & & 1 & A1 & 281 & 4 & 1 & 0.24 & 1 & 1 & & 1 & & & 1 & \\
\hline 12719 & 2307 & & 1 & A1 & 281 & 4 & 2 & 0.91 & 1 & 1 & & 1 & & & 1 & 1 flake \\
\hline 12719 & 2307 & & 1 & A1 & 281 & 6 & 2 & 5.58 & 1 & 1 & & & 1 & & 1 & \\
\hline 12719 & 2308 & & 1 & $\mathrm{~A} 1$ & 281 & 4 & 5 & 26.84 & 1 & 1 & & & 1 & & 1 & \\
\hline 12719 & 2308 & & 1 & $\mathrm{~A} 1$ & 281 & 4 & 3 & 6.67 & 1 & 1 & & 1 & & & 1 & \\
\hline 12719 & 2308 & & 1 & A1 & 281 & 4 & 2 & 6.19 & 2 & 2 & & 2 & & & 2 & \\
\hline 12719 & 2308 & & 1 & A1 & 281 & 6 & 1 & 1.1 & 1 & 1 & & & 1 & & 1 & \\
\hline 12719 & 2308 & & 1 & A1 & 281 & 4 & 7 & 282.1 & 1 & 1 & & 1 & & & 1 & \\
\hline 12719 & 2309 & & 1 & $\overline{A 1}$ & 281 & 6 & 2 & 2.1 & 1 & 1 & & & 1 & 1 & & \\
\hline 12719 & 2310 & & 1 & $\mathrm{A1}$ & 281 & 4 & 3 & 28.15 & 2 & 2 & & 2 & & 1 & 1 & \\
\hline 12719 & 2310 & & 1 & A1 & 281 & 4 & 2 & 6.58 & 1 & 1 & & 1 & & & 1 & \\
\hline 12719 & 2311 & & 1 & A1 & 281 & 4 & 2 & 2.49 & 1 & 1 & & 1 & & 1 & & \\
\hline 12719 & 2312 & & 1 & $\mathrm{~A} 1$ & 283 & 14 & 1 & 3.7 & 4 & & & 4 & & & & \\
\hline 12719 & 2312 & & 1 & $\mathrm{~A} 1$ & 283 & 14 & 2 & 4.04 & 2 & & & 2 & & & & \\
\hline 12719 & 2312 & & 1 & A1 & 281 & 4 & 1 & 0.75 & 2 & 2 & & 2 & & & 2 & 1 flake \\
\hline 12719 & 2313 & 33 & 5 & A1 & 283 & 14 & 1 & 0.63 & 3 & & & 3 & & & & 3 flakes \\
\hline 12719 & 2314 & 33 & 5 & A1 & 281 & 4 & 2 & 5.6 & 4 & 4 & & 4 & & 2 & 2 & \\
\hline 12719 & 2314 & 33 & 5 & $\mathrm{~A} 1$ & 283 & 14 & 4 & 47.32 & 2 & & & 2 & & & & \\
\hline 12719 & 2314 & 33 & 5 & $\mathrm{~A} 1$ & 283 & 14 & 1 & 59.98 & 63 & & & 63 & & 1 & 62 & \\
\hline 12719 & 2314 & 33 & 5 & A1 & 281 & 4 & 1 & 2.93 & 4 & 4 & & 4 & & & 4 & \\
\hline 12719 & 2314 & 33 & 5 & A1 & 283 & 14 & 3 & 98.27 & 12 & & & 12 & & & & \\
\hline 12719 & 2314 & 33 & 5 & $\mathrm{~A} 1$ & 283 & 14 & 2 & 92.81 & 30 & & & 30 & & & & \\
\hline 12719 & 2314 & 33 & 5 & A.1 & 283 & 14 & 5 & 65.52 & 1 & & & 1 & & & & \\
\hline 12719 & 2316 & 33 & 5 & $\mathrm{~A} 1$ & 283 & 14 & 1 & 42.46 & 44 & & & 44 & & & & \\
\hline 12719 & 2316 & 33 & 5 & A1 & 283 & 14 & 5 & 54.13 & 1 & & & 1 & & & & 1 flake \\
\hline 12719 & 2316 & 33 & 5 & A1 & 283 & 14 & 3 & 19.2 & 3 & & & 3 & & & & \\
\hline 12719 & 2316 & 33 & 5 & A1 & 283 & 14 & 4 & 41.06 & 2 & & & 2 & & & & \\
\hline
\end{tabular}




\begin{tabular}{|c|c|c|c|c|c|c|c|c|c|c|c|c|c|c|c|c|}
\hline Site & Coll \# & Feature & Lev & Blk & $A C$ & Mat & $\mathrm{Sz}$ & Grams & Qty & Frac & $\mathrm{NF}$ & Disc $P$ & $\operatorname{Disc} A$ & Cort $P$ & Cort A & Comments \\
\hline 12719 & 2316 & 33 & 5 & $\mathrm{~A} 1$ & 283 & 14 & \begin{tabular}{|l|}
2 \\
\end{tabular} & 78.71 & 21 & & & 21 & & & & \\
\hline 12719 & 2318 & 33 & 5 & A1 & 281 & 6 & 2 & 0.8 & 1 & 1 & & & 1 & & 1 & \\
\hline 12719 & 2320 & 33 & 5 & $\mathrm{~A} 1$ & 283 & 14 & 3 & 12.08 & 1 & & & 1 & & & & \\
\hline 12719 & 2320 & 33 & 5 & $\mathrm{A1}$ & 281 & 4 & 1 & 0.43 & 2 & 2 & & 2 & & & 2 & \\
\hline 12719 & 2320 & 33 & 5 & $\mathrm{~A} 1$ & 281 & 4 & \begin{tabular}{|l|}
2 \\
\end{tabular} & 0.72 & 1 & 1 & & 1 & & & 1 & \\
\hline 12719 & 2320 & 33 & 5 & A1 & 283 & 14 & 5 & 70.05 & 1 & & & 1 & & & & \\
\hline 12719 & 2320 & 33 & 5 & $\mathrm{~A} 1$ & 283 & 14 & \begin{tabular}{|l|}
6 \\
\end{tabular} & 68.93 & 1 & & & 1 & & & & \\
\hline 12719 & 2320 & 33 & 5 & $\mathrm{~A} 1$ & 283 & 14 & 4 & \begin{tabular}{|l|l|}
111.66 \\
\end{tabular} & 3 & & & 3 & & & & \\
\hline 12719 & 2320 & 33 & 5 & $\mathrm{~A} 1$ & 283 & 14 & 2 & 1.85 & 1 & & & 1 & & & & \\
\hline 12719 & 2321 & & 1 & $\mathrm{~A} 1$ & 283 & 14 & 1 & 4.7 & 8 & & & 8 & & & & \\
\hline 12719 & \begin{tabular}{|l|}
2321 \\
\end{tabular} & & 1 & $\mathrm{~A} 1$ & 281 & 4 & 4 & 72.82 & 1 & 1 & & 1 & & 1 & & \\
\hline 12719 & 2321 & & 1 & $\mathrm{~A} 1$ & 281 & 4 & 2 & 4.81 & 2 & 2 & & 1 & 1 & 1 & 1 & \\
\hline 12719 & 2321 & & 1 & $\mathrm{~A} 1$ & 283 & 14 & 3 & 15.65 & 2 & & & 2 & & & & \\
\hline 12719 & 2321 & & 1 & $\mathrm{~A} 1$ & 283 & 14 & 2 & 7.18 & 3 & & & 3 & & & & \\
\hline 12719 & 2321 & & 1 & $\mathrm{A1}$ & 283 & 14 & 4 & 51.52 & 1 & & & 1 & & & & \\
\hline 12719 & \begin{tabular}{|l|}
2321 \\
\end{tabular} & & 1 & $\mathrm{~A} 1$ & 281 & 4 & 1 & 1.5 & 2 & 2 & & 2 & & 1 & 1 & \\
\hline 12719 & 2322 & & 1 & $\mathrm{A1}$ & 283 & 14 & 2 & $\begin{array}{l}7.53 \\
\end{array}$ & 2 & & & 2 & & & & \\
\hline 12719 & 2322 & & 1 & $\mathrm{~A} 1$ & 281 & 4 & 6 & \begin{tabular}{|l|}
558.9 \\
\end{tabular} & 1 & 1 & & 1 & & 1 & & \\
\hline 12719 & 2322 & & 1 & A1 & 283 & 14 & 1 & 1.95 & 2 & & & 2 & & & & \\
\hline 12719 & 2323 & & 1 & $\mathrm{A1}$ & 281 & 4 & 4 & 39.41 & 1 & 1 & & 1 & & & 1 & \\
\hline 12719 & 2323 & & 1 & A1 & 283 & 14 & 4 & 13.38 & 1 & & & 1 & & & & \\
\hline 12719 & \begin{tabular}{|l|}
2323 \\
\end{tabular} & & 1 & $\mathrm{~A} 1$ & 281 & 4 & 2 & 1.16 & 1 & 1 & & & 1 & & 1 & \\
\hline 12719 & 2323 & & 1 & $\mathrm{A1}$ & 283 & 14 & 1 & 2.1 & 3 & & & 3 & & & & \\
\hline \begin{tabular}{l|l|}
12719 \\
\end{tabular} & 2323 & & 1 & $\mathrm{A1}$ & 283 & 14 & 2 & 9.18 & 3 & & & 3 & & & & \\
\hline 12719 & 2324 & & 1 & $\mathrm{~A} 1$ & 281 & 4 & 3 & 11.9 & 1 & & 1 & & 1 & 1 & & \\
\hline 12719 & 2324 & & 1 & $\mathrm{A1}$ & 283 & 14 & 2 & 1.74 & 1 & & & 1 & & & & \\
\hline 12719 & 2324 & & 1 & $\mathrm{A1}$ & 283 & 14 & 1 & 6.16 & 14 & & & 14 & & & & \\
\hline 12719 & 2324 & & 1 & $\mathrm{~A} 1$ & 281 & 4 & 1 & 1.88 & 2 & 1 & 1 & 2 & & & 2 & 2 flakes \\
\hline 12719 & 2324 & & 1 & $\mathrm{~A} 1$ & 281 & 4 & 4 & 63.16 & 1 & 1 & & 1 & & & 1 & \\
\hline 12719 & 2325 & & 1 & A1 & 283 & 14 & 1 & 24.22 & 45 & & & 45 & & & & \\
\hline 12719 & 2325 & & 1 & $\mathrm{~A} 1$ & 283 & 14 & 3 & 22.47 & 3 & & & 3 & & & & \\
\hline 12719 & 2325 & & 1 & $\bar{A} 1$ & 283 & 14 & 2 & 39.94 & 14 & & & 14 & & & & \\
\hline \begin{tabular}{|l|l|}
12719 \\
\end{tabular} & 2326 & & 1 & $\overline{A 1}$ & 281 & 4 & 2 & $\begin{array}{l}5.06 \\
\end{array}$ & 2 & 2 & & 2 & & 1 & 1 & \\
\hline 12719 & 2326 & & 1 & $\mathrm{~A} 1$ & 281 & 4 & 4 & 30.01 & 1 & 1 & & 1 & & & 1 & \\
\hline 12719 & 2326 & & 1 & $\mathrm{~A} 1$ & 281 & 6 & 2 & $\begin{array}{l}3.89 \\
\end{array}$ & 2 & 2 & & & 2 & 1 & 1 & \\
\hline 12719 & 2326 & & 1 & $\mathrm{~A} 1$ & 283 & 14 & 1 & 16.4 & 28 & & & 28 & & & & \\
\hline 12719 & 2326 & & 1 & $\mathrm{A1}$ & 283 & 14 & 2 & 34.82 & 14 & & & 14 & & & & \\
\hline 12719 & 2326 & & 1 & $\mathrm{~A} 1$ & 283 & 14 & 3 & 20.32 & 3 & & & 3 & & & & \\
\hline 12719 & 2326 & & 1 & $\mathrm{A1}$ & 281 & 6 & 3 & 10 & 1 & 1 & & & 1 & & 1 & \\
\hline 12719 & 2326 & & 1 & $\mathrm{~A} 1$ & 281 & 4 & 1 & 0.26 & 1 & 1 & & 1 & & & 1 & \\
\hline 12719 & 2327 & & 1 & $\mathrm{A1}$ & 281 & 4 & 2 & 3.9 & 1 & 1 & & 1 & & 1 & & \\
\hline 12719 & 2327 & & 1 & $\mathrm{~A} 1$ & 281 & 4 & 4 & 46.7 & 1 & 1 & & 1 & & & 1 & \\
\hline 12719 & 2327 & & 1 & $\overline{A 1}$ & 283 & 14 & 2 & 9.48 & 4 & & & 4 & & & & \\
\hline 12719 & 2327 & & 1 & A1 & 283 & 14 & 4 & 18.88 & 1 & & & 1 & & & & \\
\hline 12719 & 2327 & & 1 & $\mathrm{A1}$ & 281 & 4 & 6 & 79.99 & 1 & 1 & & 1 & & 1 & & \\
\hline 12719 & 2327 & & 1 & $\mathrm{~A} 1$ & 281 & 4 & 5 & 137.99 & 1 & 1 & & 1 & & & 1 & \\
\hline 12719 & 2327 & & 1 & A1 & 283 & 14 & 3 & 13.13 & 2 & & & 2 & & & & \\
\hline 12719 & 2327 & & 1 & $\mathrm{~A} 1$ & 283 & 14 & 1 & 3.24 & 6 & & & 6 & & & & \\
\hline \begin{tabular}{l|l}
12719 \\
\end{tabular} & 2328 & & 1 & $\mathrm{~A} 1$ & 283 & 14 & 2 & 16.16 & 7 & & & 7 & & & & \\
\hline 12719 & 2328 & & 1 & $\mathrm{~A} 1$ & 283 & 14 & 3 & 9.64 & 2 & & & 2 & & & & \\
\hline 12719 & 2328 & & 1 & $\mathrm{~A} 1$ & 283 & 14 & 1 & 5.42 & 9 & & & 9 & & & & \\
\hline 12719 & 2328 & & 1 & $\mathrm{~A} 1$ & 281 & 4 & 1 & 1.31 & 1 & 1 & & 1 & & & 1 & \\
\hline 12719 & 2328 & & 1 & $\mathrm{~A} 1$ & 283 & 14 & 4 & 35.53 & 1 & & & 1 & & & & \\
\hline 12719 & 2329 & & 1 & A1 & 283 & 14 & 3 & 5.47 & 1 & & & 1 & & & & \\
\hline 12719 & 2329 & & 1 & $\mathrm{~A} 1$ & 283 & 14 & 6 & 141.11 & 1 & & & 1 & & & & \\
\hline 12719 & 2329 & & 1 & $\mathrm{A1}$ & 283 & 14 & 1 & 10.74 & 17 & & & 17 & & & & \\
\hline 12719 & 2329 & & 1 & A1 & 283 & 14 & 2 & 14.39 & 7 & & & 7 & & & & \\
\hline 12719 & 2329 & & 1 & A1 & 281 & 4 & 3 & 21.87 & 2 & 2 & & 2 & & & 2 & \\
\hline 12719 & 2329 & & 1 & $\mathrm{~A} 1$ & 281 & 6 & 2 & 6.4 & 2 & 2 & & & 2 & & 2 & \\
\hline 12719 & 2329 & & 1 & A1 & 281 & 4 & 2 & 18.03 & 5 & 4 & 1 & 5 & & 1 & 4 & \\
\hline 12719 & 2329 & & 1 & A1 & 281 & 4 & 1 & 2.9 & 6 & 6 & & 6 & & & 6 & \\
\hline 12719 & 2330 & 34 & 3 & A1 & 281 & 4 & 2 & 2.84 & 1 & 1 & & 1 & & & 1 & \\
\hline 12719 & 2331 & 34 & 3 & A1 & 283 & 14 & 2 & 229.41 & 59 & & & 59 & & & & \\
\hline 12719 & 2331 & 34 & 3 & A1 & 283 & 14 & \begin{tabular}{l|l}
3 \\
\end{tabular} & 115.67 & 12 & & & 12 & & & & \\
\hline 12719 & 2331 & 34 & 3 & $\mathrm{~A} 1$ & 281 & 4 & 2 & 13.94 & 5 & 5 & & 5 & & 5 & & \\
\hline 12719 & 2331 & 34 & 3 & A1 & 283 & 14 & 5 & \begin{tabular}{|l|l|}
319.94 \\
\end{tabular} & 3 & & & 3 & & & & \\
\hline 12719 & 2331 & 34 & 3 & A1 & 283 & 14 & 4 & 51.61 & 2 & & & 2 & & & & \\
\hline 12719 & 2331 & 34 & 3 & $\mathrm{~A} 1$ & 281 & 4 & 11 & $\begin{array}{l}7.85 \\
\end{array}$ & 7 & 7 & & 7 & & 1 & 6 & \\
\hline
\end{tabular}




\begin{tabular}{|c|c|c|c|c|c|c|c|c|c|c|c|c|c|c|c|c|}
\hline Site & Coll \# & Feature & Lev & Blk & $A C$ & Mat & $\mathrm{Sz}$ & Grams & Qty & Frac & $\mathrm{NF}$ & Disc P & Disc A & Cort P & Cort A & Comments \\
\hline 12719 & 2331 & 34 & 3 & $\mathrm{A1}$ & 283 & 14 & \begin{tabular}{|l|}
7 \\
\end{tabular} & 544.2 & 1 & & & 1 & & & & \\
\hline 12719 & 2331 & 34 & 3 & $\mathrm{~A} 1$ & 283 & 14 & 1 & 87.39 & 94 & & & 94 & & & & \\
\hline 12719 & 2333 & 34 & 3 & $\mathrm{A1}$ & 283 & 14 & 3 & 26.8 & 2 & & & 2 & & & & \\
\hline 12719 & 2333 & 34 & 3 & A1 & 283 & 14 & 4 & 54.33 & 1 & & & 1 & & & & \\
\hline 12719 & 2333 & 34 & 3 & $\mathrm{~A} 1$ & 283 & 14 & 1 & 4.48 & 4 & & & 4 & & & & \\
\hline 12719 & 2333 & 34 & 3 & A1 & 283 & 14 & 2 & 39.83 & 11 & & & 11 & & & & \\
\hline 12719 & 2333 & 34 & 3 & $\overline{\mathrm{A} 1}$ & 283 & 14 & 5 & 178.43 & 2 & & & 2 & & & & \\
\hline 12719 & 2334 & 34 & 3 & $A 1$ & 281 & 4 & 1 & 0.36 & 1 & 1 & & 1 & & & 1 & \\
\hline 12719 & 2334 & 34 & 3 & $\overline{A 1}$ & 283 & 14 & 1 & 0.87 & 1 & & & 1 & & & & \\
\hline 12719 & 2335 & 34 & 3 & $\mathrm{~A} 1$ & 281 & 4 & 2 & 2.04 & 1 & 1 & & 1 & & & 1 & \\
\hline 12719 & 2335 & 34 & 3 & $A 1$ & 281 & 4 & 1 & 0.4 & 1 & & 1 & 1 & & 1 & & \\
\hline 12719 & 2335 & 34 & 3 & $\mathrm{~A} 1$ & 283 & 14 & 1 & 10.45 & 10 & & & 10 & & & & \\
\hline 12719 & 2335 & 34 & 3 & $\mathrm{~A} 1$ & 283 & 14 & 2 & 34.71 & 10 & & & 10 & & & & \\
\hline 12719 & 2335 & 34 & 3 & $\mathrm{~A}_{1}$ & 283 & 14 & 4 & 86.71 & 2 & & & 2 & & & & \\
\hline 12719 & 2340 & 34 & 3 & $\mathrm{~A} 1$ & 283 & 14 & 2 & 171.46 & 35 & & & 35 & & & & \\
\hline 12719 & 2340 & 34 & 3 & $\mathrm{~A} 1$ & 283 & 14 & 1 & 38.92 & 30 & & & 30 & & & & \\
\hline 12719 & 2340 & 34 & 3 & $\mathrm{~A} 1$ & 281 & 4 & 1 & 3.85 & 3 & 2 & 1 & 3 & & 1 & 2 & \\
\hline 12719 & 2340 & 34 & 3 & $\mathrm{~A} 1$ & 281 & 4 & 5 & 133.25 & 1 & & 1 & 1 & & 1 & & \\
\hline 12719 & 2340 & 34 & 3 & $\mathrm{A1}$ & 281 & 4 & 3 & 19.5 & 3 & 3 & & 3 & & 1 & 2 & \\
\hline 12719 & 2340 & 34 & 3 & $\mathrm{~A} 1$ & 281 & 4 & 4 & 15.6 & 1 & 1 & & 1 & & 1 & & \\
\hline 12719 & 2340 & 34 & 3 & $\mathrm{A1}$ & 283 & 14 & 3 & 178.75 & 11 & & & 11 & & & & \\
\hline 12719 & 2340 & 34 & 3 & $\mathrm{~A} 1$ & 283 & 14 & 4 & 105.47 & 4 & & & 4 & & & & \\
\hline 12719 & 2340 & 34 & 3 & $\mathrm{~A} 1$ & 281 & 4 & 2 & 20.09 & 7 & 6 & 1 & 7 & & 6 & 1 & \\
\hline 12719 & 2341 & & 2 & $\mathrm{~A} 1$ & 283 & 14 & 1 & 2.89 & 9 & & & 9 & & & & \\
\hline 12719 & 2341 & & 2 & A1 & 283 & 14 & 2 & 3.48 & 2 & & & 2 & & & & \\
\hline 12719 & 2341 & & 2 & $\mathrm{~A} 1$ & 281 & 4 & 3 & $\begin{array}{ll}14.06 \\
\end{array}$ & 1 & 1 & & & 1 & 1 & & \\
\hline 12719 & 2342 & & 2 & $\mathrm{~A} 1$ & 283 & 14 & 2 & 3.76 & 2 & & & 2 & & & & \\
\hline 12719 & 2342 & & 2 & $\mathrm{~A} 1$ & 283 & 14 & 1 & 1.14 & 2 & & & 2 & & & & \\
\hline 12719 & 2343 & & 3 & $\overline{A 1}$ & 283 & 14 & 1 & 1.51 & 2 & & & 2 & & & & \\
\hline 12719 & 2345 & & 3 & $\overline{\mathrm{A} 1}$ & 283 & 14 & 1 & 3.23 & 5 & & & 5 & & & & \\
\hline 12719 & 2345 & & 3 & A1 & 281 & 4 & 1 & $\begin{array}{l}0.78 \\
0.0\end{array}$ & 1 & 1 & & & 1 & & 1 & \\
\hline 12719 & 2346 & & 3 & $\mathrm{~A} 1$ & 283 & 14 & 3 & 11.13 & 1 & & & 1 & & & & \\
\hline 12719 & 2346 & & 3 & $\mathrm{~A} 1$ & 281 & 4 & 2 & 3.95 & 1 & 1 & & & 1 & 1 & & \\
\hline 12719 & 2346 & & 3 & A1 & 283 & 14 & 1 & 2.8 & 20 & & & 20 & & & & \\
\hline 12719 & 2346 & & 3 & $\overline{A 1}$ & 283 & 14 & 2 & 7.85 & 3 & & & 3 & & & & \\
\hline 12719 & 2347 & & 4 & $\mathrm{~A} 1$ & 283 & 14 & 2 & 1.99 & 2 & & & 2 & & & & \\
\hline 12719 & 2347 & & 4 & $A 1$ & 283 & 14 & 1 & 4.59 & 12 & & & 12 & & & & \\
\hline 12719 & 2348 & & 5 & A1 & 283 & 14 & 1 & \begin{tabular}{|l|l}
0.74 \\
\end{tabular} & 3 & & & & 3 & & & \\
\hline 12719 & 2349 & & 4 & A1 & 281 & 4 & 2 & 1.08 & 1 & 1 & & 1 & & & 1 & \\
\hline 12719 & \begin{tabular}{|l|}
2349 \\
\end{tabular} & & 3 & $\bar{A} 1$ & 283 & 14 & 2 & 7.53 & 3 & & & 3 & & & & \\
\hline 12719 & 2349 & & 3 & $\mathrm{~A} 1$ & 281 & 4 & 1 & $\begin{array}{l}0.48 \\
\end{array}$ & 1 & 1 & & 1 & & & 1 & \\
\hline 12719 & 2349 & & 3 & $\overline{A 1}$ & 283 & 14 & 1 & 6.17 & 17 & & & 17 & & & & \\
\hline 12719 & 2350 & & 3 & A1 & 281 & 7 & 2 & 0.85 & 1 & 1 & & 1 & & & 1 & \\
\hline 12719 & 2350 & & 4 & $\mathrm{~A}_{1}$ & 283 & 14 & 1 & 3.47 & 11 & & & 11 & & & & \\
\hline 12719 & 2350 & & 4 & $\bar{A} 1$ & 283 & 14 & 2 & 1.03 & 1 & & & 1 & & & & \\
\hline 12719 & 2350 & & 3 & $\mathrm{~A} 1$ & 281 & 7 & 1 & 0.97 & 2 & 1 & 1 & 2 & & & 2 & \\
\hline 12719 & 2351 & 34 & 3 & A1 & 281 & 4 & 2 & 1.06 & 1 & 1 & & 1 & & & 1 & \\
\hline 12719 & 2352 & 34 & 4 & A1 & 281 & 4 & 2 & 5.4 & 1 & & 1 & 1 & & 1 & & \\
\hline 12719 & 2352 & 34 & 4 & $\mathrm{~A} 1$ & 283 & 14 & 4 & 48.37 & 2 & & & 2 & & & & \\
\hline 12719 & 2352 & 34 & 4 & A1 & 283 & 14 & 1 & 22.9 & 32 & & & 32 & & & & \\
\hline 12719 & 2352 & 34 & 4 & A1 & \begin{tabular}{|l|}
283 \\
\end{tabular} & 14 & 2 & 112.85 & 37 & & & 37 & & & & \\
\hline 12719 & 2352 & 34 & 4 & $\mathrm{~A} 1$ & \begin{tabular}{|l|}
283 \\
\end{tabular} & 14 & 3 & 76.52 & 9 & & & 9 & & & & \\
\hline 12719 & 2352 & 34 & 4 & $\mathrm{A1}$ & \begin{tabular}{|l|}
283 \\
\end{tabular} & 14 & 5 & 161.24 & 2 & & & 2 & & & & \\
\hline 12719 & 2352 & 34 & 4 & A1 & \begin{tabular}{l|}
281 \\
\end{tabular} & 4 & 3 & 25.26 & 1 & 1 & & 1 & & 1 & & \\
\hline 12719 & 2352 & 34 & 4 & $\mathrm{A1}$ & 281 & 4 & 2 & 14.79 & 5 & 3 & 2 & 5 & & 4 & 1 & \\
\hline 12719 & 2352 & 34 & 4 & A1 & 281 & 4 & 1 & 0.43 & 1 & 1 & & 1 & & & 1 & \\
\hline 12719 & 2353 & 34 & 3 & $\mathrm{~A} 1$ & \begin{tabular}{|l|}
283 \\
\end{tabular} & 14 & 1 & 2.31 & 4 & & & 4 & & & & \\
\hline 12719 & 2353 & 34 & 3 & $\mathrm{~A} 1$ & \begin{tabular}{|l|}
283 \\
\end{tabular} & 14 & 2 & 0.84 & 1 & & & 1 & & & & \\
\hline 12719 & 2353 & 34 & 3 & A1 & 283 & 14 & 3 & 40.9 & 3 & & & 3 & & & & \\
\hline 12719 & 2354 & 80 & 4 & $\overline{\mathrm{A} 1}$ & 281 & 4 & 1 & 0.51 & 2 & 2 & & 2 & & & 2 & \\
\hline 12719 & 2358 & 33 & 4 & A1 & 283 & 14 & 2 & 4.88 & 2 & & & 2 & & & & \\
\hline 12719 & 2358 & 33 & 4 & A1 & \begin{tabular}{|l|}
283 \\
\end{tabular} & 14 & 1 & 3.01 & 8 & & & 8 & & & & \\
\hline 12719 & 2358 & 33 & 4 & A1 & \begin{tabular}{|l|}
281 \\
\end{tabular} & 4 & 1 & 0.27 & 3 & 3 & & 3 & & & 3 & other \\
\hline 12719 & 2358 & 33 & 4 & $\mathrm{A1}$ & 281 & 4 & 2 & \begin{tabular}{|l|l|}
3.74 \\
\end{tabular} & 1 & 1 & & 1 & & 1 & & \\
\hline 12719 & 2359 & 33 & 4 & A1 & 283 & 14 & 2 & 35.36 & 10 & & & 10 & & & & \\
\hline 12719 & 2359 & 33 & 4 & $\mathrm{~A} 1$ & 283 & 14 & 3 & 72.08 & 4 & & & 4 & & & & \\
\hline 12719 & 2359 & 33 & 4 & $\mathrm{A1}$ & 283 & 14 & 1 & 12.78 & 22 & & & 22 & & & & \\
\hline 12719 & 2359 & 33 & 4 & $\overline{A 1}$ & \begin{tabular}{|l|}
283 \\
\end{tabular} & 14 & 6 & \begin{tabular}{|l|}
353.7 \\
\end{tabular} & 2 & & & 2 & & & & \\
\hline
\end{tabular}




\begin{tabular}{|c|c|c|c|c|c|c|c|c|c|c|c|c|c|c|c|c|}
\hline Site & Coll \# & Feature & Lev & Blk & $A C$ & Mat & $\mathrm{Sz}$ & Grams & Qty & Frac & NF & Disc $P$ & Disc A & Cort $P$ & Cort A & Comments \\
\hline 12719 & 2359 & 33 & 4 & $\mathrm{~A} 1$ & 281 & 6 & 2 & 0.6 & 1 & 1 & & 1 & & 1 & & \\
\hline 12719 & 2359 & 33 & 4 & $\mathrm{~A} 1$ & 281 & 4 & 4 & 55.75 & 1 & 1 & & 1 & & & 1 & \\
\hline 12719 & 2359 & 33 & 4 & $\mathrm{~A} 1$ & 283 & 14 & 4 & 56.2 & 2 & & & 2 & & & & \\
\hline 12719 & 2359 & 33 & 4 & A1 & 283 & 14 & 5 & 244.5 & 3 & & & 3 & & & & \\
\hline 12719 & 2361 & 33 & 4 & $\mathrm{~A} 1$ & 283 & 14 & 5 & 430.46 & 3 & & & 3 & & & & \\
\hline 12719 & 2361 & 33 & 4 & A1 & 281 & 4 & 2 & 1.17 & 1 & 1 & & 1 & & & 1 & \\
\hline 12719 & 2361 & 33 & 4 & A1 & 283 & 14 & 1 & 7.44 & 14 & & & 14 & & & & \\
\hline 12719 & 2361 & 33 & 4 & $\mathrm{~A} 1$ & 283 & 14 & 2 & 38.8 & 9 & & & 9 & & & & \\
\hline 12719 & 2361 & 33 & 4 & A1 & 283 & 14 & 6 & 198.3 & 1 & & & 1 & & & & \\
\hline 12719 & 2361 & 33 & 4 & $\mathrm{~A} 1$ & 281 & 4 & 3 & 9.86 & 1 & 1 & & 1 & & 1 & & \\
\hline 12719 & 2361 & 33 & 4 & $\mathrm{~A}_{1}$ & 283 & 14 & 3 & 125.55 & 8 & & & 8 & & & & \\
\hline 12719 & 2361 & 33 & 4 & $\mathrm{~A} 1$ & 283 & 14 & 4 & 167.59 & 4 & & & 4 & & & & \\
\hline 12719 & 2362 & 33 & 4 & $\mathrm{~A} 1$ & 283 & 14 & 2 & 1.06 & 1 & & & 1 & & & & \\
\hline 12719 & 2362 & 33 & 4 & A1 & 283 & 14 & 1 & 1.51 & 3 & & & 3 & & & & \\
\hline 12719 & 2362 & 33 & 4 & $\mathrm{~A} 1$ & 281 & 4 & 1 & 0.03 & 1 & 1 & & 1 & & & 1 & \\
\hline 12719 & 2362 & 33 & 4 & $A 1$ & 283 & 14 & 3 & 10.54 & 1 & & & 1 & & & & \\
\hline 12719 & 2363 & 33 & 4 & A1 & 281 & 7 & 1 & 0.27 & 1 & 1 & & & 1 & & 1 & \\
\hline 12719 & 2363 & 33 & 4 & A1 & 283 & 14 & 4 & 19.81 & 1 & & & 1 & & & & \\
\hline 12719 & 2363 & 33 & 4 & $\overline{A 1}$ & 283 & 14 & 2 & 29.23 & 10 & & & 10 & & & & \\
\hline 12719 & 2363 & 33 & 4 & A1 & 283 & 14 & 1 & \begin{tabular}{|l|}
7.66 \\
\end{tabular} & 14 & & & 14 & & & & \\
\hline 12719 & 2364 & 33 & 4 & A1 & 283 & 14 & 1 & 0.74 & 2 & & & 2 & & & & \\
\hline 12719 & 2364 & 33 & 4 & A1 & 281 & 4 & 1 & 0.68 & 1 & 1 & & 1 & & & 1 & \\
\hline 12719 & 2365 & 33 & 4 & A1 & 283 & 14 & 1 & 6.26 & 9 & & & 9 & & & & \\
\hline 12719 & 2365 & 33 & 4 & A1 & 283 & 14 & 2 & 19.56 & 8 & & & 8 & & & & \\
\hline 12719 & 2365 & 33 & 4 & $\mathrm{~A} 1$ & 283 & 14 & 3 & 16.37 & 2 & & & 2 & & & & \\
\hline 12719 & 2366 & & 1 & A1 & 283 & 14 & 6 & 10.88 & 1 & & & 1 & & & & \\
\hline 12719 & 2366 & & 1 & A1 & 283 & 14 & 1 & 17.46 & 22 & & & 22 & & & & \\
\hline 12719 & 2366 & & 1 & A1 & 281 & 4 & 2 & 4.12 & 2 & 2 & & 2 & & 2 & & \\
\hline 12719 & 2366 & & 1 & $\mathrm{~A} 1$ & 281 & 4 & 1 & 2.8 & 5 & 5 & & 5 & & 3 & 2 & \\
\hline 12719 & 2366 & & 1 & A1 & 281 & 4 & 3 & 26.12 & 1 & 1 & & 1 & & 1 & & \\
\hline 12719 & 2366 & & 1 & $\mathrm{~A} 1$ & 283 & 14 & 2 & 50.66 & 13 & & & 13 & & & & \\
\hline 12719 & 2367 & & 1 & $\mathrm{~A} 1$ & 281 & 4 & 4 & 37.84 & 1 & 1 & & 1 & & 1 & & \\
\hline 12719 & 2367 & & 1 & A1 & 283 & 14 & 1 & 5.62 & 12 & & & 12 & & & & \\
\hline 12719 & 2367 & & 1 & A1 & 283 & 14 & 2 & 5.84 & 1 & & & 1 & & & & \\
\hline 12719 & 2367 & & 1 & $\mathrm{~A} 1$ & 281 & 4 & 3 & 35.53 & 1 & 1 & & 1 & & & 1 & \\
\hline 12719 & 2368 & & 1 & $\mathrm{~A} 1$ & 283 & 14 & 3 & 6.06 & 1 & & & 1 & & & & \\
\hline 12719 & 2368 & & 1 & $\mathrm{~A} 1$ & 283 & 14 & 2 & \begin{tabular}{|l|}
7.86 \\
\end{tabular} & 4 & & & 4 & & & & \\
\hline 12719 & 2368 & & 1 & A1 & 283 & 14 & 1 & 3.96 & 9 & & & 9 & & & & \\
\hline 12719 & 2368 & & 1 & A1 & 283 & 14 & 4 & 25.16 & 1 & & & 1 & & & & \\
\hline 12719 & 2369 & & 1 & A1 & 283 & 14 & 1 & 7.46 & 14 & & & 14 & & & & \\
\hline 12719 & 2369 & & 1 & $\mathrm{~A} 1$ & 283 & 14 & 2 & 19.99 & 5 & & & 5 & & & & \\
\hline 12719 & 2369 & & 1 & $\mathrm{~A} 1$ & 283 & 14 & 3 & 14.15 & 1 & & & 1 & & & & \\
\hline 12719 & 2370 & & 1 & $\mathrm{A1}$ & 283 & 14 & 3 & 11.77 & 1 & & & 1 & & & & \\
\hline 12719 & 2370 & & 1 & $\mathrm{~A} 1$ & 281 & 4 & 2 & \begin{tabular}{|l|}
3.84 \\
\end{tabular} & 1 & 1 & & 1 & & & 1 & \\
\hline 12719 & 2370 & & 1 & A1 & 283 & 14 & 1 & \begin{tabular}{|l|}
7.04 \\
\end{tabular} & 16 & & & 16 & & & & \\
\hline 12719 & 2370 & & 1 & $\mathrm{~A} 1$ & 281 & 4 & 2 & 85.35 & 1 & 1 & & 1 & & & 1 & \\
\hline 12719 & 2370 & & 1 & $\mathrm{~A} 1$ & 283 & 14 & 2 & 4.39 & 2 & & & 2 & & & & \\
\hline 12719 & 2370 & & 1 & $\mathrm{~A} 1$ & 281 & 7 & 5 & 168.82 & 1 & 1 & & 1 & & 1 & & \\
\hline 12719 & 2371 & & 1 & $\mathrm{~A} 1$ & 283 & 14 & 4 & 16.85 & 1 & & & 1 & & & & \\
\hline 12719 & 2371 & & 1 & $\mathrm{~A} 1$ & 283 & 14 & 1 & 2.72 & 4 & & & 4 & & & & \\
\hline 12719 & 2371 & & 1 & A1 & 283 & 14 & 3 & 14.09 & 1 & & & 1 & & & & \\
\hline 12719 & 2371 & & 1 & A1 & 281 & 4 & 2 & 1.9 & 1 & 1 & & 1 & & & 1 & \\
\hline 12719 & 2371 & & 1 & $\mathrm{~A} 1$ & 281 & 6 & 1 & \begin{tabular}{|l|}
0.87 \\
\end{tabular} & 1 & 1 & & & 1 & & 1 & \\
\hline 12719 & 2372 & & 1 & A1 & 281 & 4 & 5 & 85.18 & 1 & 1 & & 1 & & & 1 & \\
\hline 12719 & 2372 & & 1 & A1 & 281 & 4 & 3 & 6.22 & 1 & 1 & & 1 & & 1 & & \\
\hline 12719 & 2372 & & 1 & $\mathrm{~A} 1$ & 283 & 14 & 2 & 27.65 & 15 & & & 15 & & & & 2 flakes \\
\hline 12719 & 2372 & & 1 & A1 & 283 & 14 & 1 & 19.96 & 43 & & & 43 & & & & \\
\hline 12719 & 2373 & & 1 & $\mathrm{~A} 1$ & 281 & 4 & 2 & 7.6 & 2 & 2 & & 2 & & 1 & 1 & \\
\hline 12719 & 2373 & & 1 & $\mathrm{~A} 1$ & 281 & 4 & 1 & 3.24 & 4 & 4 & & 4 & & & 4 & \\
\hline 12719 & 2373 & & 1 & A1 & 283 & 14 & 2 & 16.72 & 6 & & & 6 & & & & \\
\hline 12719 & 2374 & & 1 & $\mathrm{~A} 1$ & 283 & 14 & 1 & 6.51 & 10 & & & 10 & & & & \\
\hline 12719 & 2374 & & 1 & A1 & 283 & 14 & 3 & 13.83 & 1 & & & 1 & & & & \\
\hline 12719 & 2374 & & 1 & A1 & 283 & 14 & 1 & 20.68 & 52 & & & 52 & & & & \\
\hline 12719 & 2374 & & 1 & $\mathrm{~A} 1$ & 281 & 6 & 3 & 3.5 & 1 & 1 & & & 1 & 1 & & \\
\hline 12719 & 2374 & & 1 & $A 1$ & 283 & 14 & 2 & 12.41 & 5 & & & 5 & & & & \\
\hline 12719 & 2375 & & 1 & A1 & 281 & 4 & 2 & 6.32 & 1 & 1 & & 1 & & 1 & & \\
\hline 12719 & 2375 & & 1 & A1 & 283 & 14 & 1 & 6.64 & 14 & & & 14 & & & & \\
\hline 12719 & 2375 & & 1 & $\mathrm{~A} 1$ & 283 & 14 & 2 & 8.46 & 5 & & & 5 & & & & \\
\hline
\end{tabular}




\begin{tabular}{|c|c|c|c|c|c|c|c|c|c|c|c|c|c|c|c|c|}
\hline Site & Coll \# & Feature & Lev & Blk & $\overline{A C}$ & Mat & $\mathrm{Sz}$ & Grams & Qty & Frac & $\mathrm{NF}$ & Disc $P$ & Disc A & Cort $P$ & Cort A & Comments \\
\hline 12719 & 2376 & & 1 & $\mathrm{~A} 1$ & 281 & 4 & \begin{tabular}{|l|}
4 \\
\end{tabular} & 33.68 & 1 & 1 & & 1 & & 1 & & \\
\hline 12719 & 2376 & & 1 & $\mathrm{~A} 1$ & 283 & 14 & 1 & 22.01 & 42 & & & 42 & & & & \\
\hline 12719 & 2376 & & 1 & A1 & 283 & 14 & \begin{tabular}{|l|}
2 \\
\end{tabular} & $\begin{array}{l}15.2 \\
\end{array}$ & 7 & & & 7 & & & & \\
\hline 12719 & 2377 & & 1 & $\mathrm{~A} 1$ & 283 & 14 & 2 & 38.61 & 18 & & & 18 & & & & \\
\hline 12719 & 2377 & & 1 & $\mathrm{~A} 1$ & 281 & 4 & 1 & 1.35 & 3 & 3 & & 3 & & & 3 & \\
\hline \begin{tabular}{|l|l|}
12719 \\
\end{tabular} & 2377 & & 1 & $\mathrm{~A} 1$ & 283 & 14 & 3 & 15.86 & 2 & & & 2 & & & & \\
\hline 12719 & 2377 & & 1 & $A 1$ & 281 & 4 & 3 & 23.97 & 2 & 2 & & 2 & & 1 & 1 & \\
\hline 12719 & 2377 & & 1 & $\mathrm{~A} 1$ & 283 & 14 & 1 & 51.14 & 102 & & & 102 & & & & \\
\hline 12719 & 2377 & & 1 & $\mathrm{~A} 1$ & 281 & 4 & \begin{tabular}{|l|}
2 \\
\end{tabular} & 20.85 & 6 & 6 & & 6 & & 1 & 5 & \\
\hline 12719 & 2378 & & 1 & $\mathrm{~A} 1$ & 283 & 14 & \begin{tabular}{|l|}
2 \\
\end{tabular} & 34.84 & 11 & & & 11 & & & & \\
\hline 12719 & \begin{tabular}{|l|}
2378 \\
\end{tabular} & & 1 & A1 & 283 & 14 & \begin{tabular}{|l|}
3 \\
\end{tabular} & 10.82 & 1 & & & 1 & & & & \\
\hline 12719 & 2378 & & 1 & $\mathrm{~A} 1$ & 283 & 14 & 1 & 13.97 & 22 & & & 22 & & & & \\
\hline 12719 & \begin{tabular}{|l|}
2378 \\
\end{tabular} & & 1 & $\mathrm{~A} 1$ & 281 & 4 & 2 & 8.62 & 1 & 1 & & 1 & & 1 & & \\
\hline 12719 & 2378 & & 1 & $\mathrm{~A} 1$ & 281 & 4 & 1 & 2.72 & 1 & 1 & & 1 & & 1 & & \\
\hline 12719 & 2379 & & 1 & $\mathrm{~A} 1$ & 281 & 4 & 4 & 53.88 & 1 & 1 & & 1 & & 1 & & \\
\hline 12719 & 2379 & & 1 & $\mathrm{~A} 1$ & 283 & 14 & 1 & 2.91 & 7 & & & 7 & & & & \\
\hline 12719 & 2379 & & 1 & $\mathrm{~A} 1$ & 283 & 14 & 2 & 4.62 & 2 & & & 2 & & & & \\
\hline 12719 & 2379 & & 1 & $\mathrm{~A} 1$ & 281 & 4 & 2 & 8.29 & 1 & 1 & & 1 & & & 1 & \\
\hline 12719 & 2380 & & 1 & $\mathrm{A1}$ & 283 & 14 & 1 & 29.53 & 35 & & & 35 & & & & \\
\hline 12719 & 2380 & & 1 & A1 & 283 & 14 & 2 & 45.09 & 22 & & & 22 & & & & \\
\hline 12719 & 2380 & & 1 & $\bar{A} 1$ & 283 & 14 & 3 & 30.34 & 3 & & & 3 & & & & \\
\hline 12719 & 2381 & & 1 & $\mathrm{~A} 1$ & 283 & 14 & 1 & 4.64 & 8 & & & 8 & & & & \\
\hline 12719 & \begin{tabular}{|l|}
2381 \\
\end{tabular} & & 1 & $\overline{A 1}$ & 283 & 14 & 2 & 6.35 & 3 & & & 3 & & & & \\
\hline 12719 & 2381 & & 1 & A1 & 281 & 4 & 3 & 8.24 & 1 & 1 & & 1 & & & 1 & \\
\hline 12719 & 2381 & & 1 & $\mathrm{~A} 1$ & 281 & 4 & 1 & 1.02 & 1 & 1 & & 1 & & 1 & & \\
\hline 12719 & 2382 & & 1 & A1 & 283 & 14 & 1 & 6.65 & 8 & & & 8 & & & & \\
\hline 12719 & 2382 & & 1 & A1 & 283 & 14 & 2 & $\begin{array}{l}10.66 \\
\end{array}$ & 5 & & & 5 & & & & \\
\hline 12719 & 2382 & & 1 & A1 & 281 & 4 & 2 & \begin{tabular}{|l|}
7.21 \\
\end{tabular} & 2 & 2 & & 2 & & 2 & & \\
\hline 12719 & \begin{tabular}{|l|}
2383 \\
\end{tabular} & & 1 & A1 & 283 & 14 & 3 & 11.73 & 2 & & & 2 & & & & \\
\hline 12719 & \begin{tabular}{|l|}
2383 \\
\end{tabular} & & 1 & A1 & 283 & 14 & 1 & $\begin{array}{l}5.85 \\
\end{array}$ & 16 & & & 16 & & & & \\
\hline 12719 & 2383 & & 1 & A1 & 281 & 4 & 2 & 3 & 1 & 1 & & 1 & & & 1 & \\
\hline 12719 & 2383 & & 1 & A1 & 283 & 14 & 2 & 5.2 & 2 & & & 2 & & & & \\
\hline 12719 & 2384 & & 1 & $\overline{A 1}$ & 281 & 4 & 5 & 108.78 & 1 & 1 & & 1 & & & 1 & \\
\hline 12719 & 2384 & & 1 & A1 & 281 & 4 & \begin{tabular}{l|l}
3 \\
\end{tabular} & \begin{tabular}{|l|l|}
4.16 \\
\end{tabular} & 1 & 1 & & 1 & & & 1 & \\
\hline 12719 & 2384 & & 1 & $\mathrm{~A} 1$ & 283 & 14 & 1 & 3.38 & 4 & & & 4 & & & & \\
\hline 12719 & 2385 & & 1 & $\mathrm{~A} 1$ & 283 & 14 & 2 & $\begin{array}{l}8.86 \\
\end{array}$ & 2 & & & 2 & & & & \\
\hline 12719 & 2386 & & 1 & $\mathrm{~A} 1$ & 283 & 14 & 2 & 7.44 & 3 & & & 3 & & & & \\
\hline 12719 & 2386 & & 1 & $\mathrm{~A} 1$ & 283 & 14 & 1 & \begin{tabular}{|l|}
3.72 \\
\end{tabular} & 7 & & & 7 & & & & \\
\hline 12719 & 2386 & & 1 & $\mathrm{~A} 1$ & 283 & 14 & 3 & $\begin{array}{l}6.79 \\
\end{array}$ & 1 & & & 1 & & & & \\
\hline 12719 & 2388 & & 1 & $\overline{A 1}$ & 283 & 14 & 2 & 2.08 & 1 & & & 1 & & & & \\
\hline 12719 & 2389 & & 1 & $\mathrm{~A} 1$ & 283 & 14 & 1 & 1.4 & 3 & & & 3 & & & & \\
\hline 12719 & 2390 & & 1 & $\mathrm{~A} 1$ & 283 & 14 & 1 & 1.38 & 4 & & & 4 & & & & \\
\hline 12719 & 2391 & 34 & 3 & $\overline{A 1}$ & 283 & 14 & 1 & $\begin{array}{l}0.59 \\
\end{array}$ & 1 & & & 1 & & & & \\
\hline 12719 & 2391 & 34 & 3 & $\mathrm{~A} 1$ & 283 & 14 & 2 & $\begin{array}{l}1.62 \\
\end{array}$ & 1 & & & 1 & & & & \\
\hline 12719 & 2392 & 34 & 3 & $\mathrm{~A} 1$ & 283 & 14 & 1 & 83.5 & 88 & & & 88 & & & & \\
\hline 12719 & 2392 & 34 & 3 & A1 & 283 & 14 & 7 & 261.1 & 1 & & & 1 & & & & \\
\hline 12719 & 2392 & 34 & 3 & $\mathrm{A1}$ & 283 & 14 & 4 & 183.8 & 7 & & & 7 & & & & \\
\hline 12719 & 2392 & 34 & 3 & A1 & 283 & 14 & 6 & 172.4 & 1 & & & 1 & & & & \\
\hline 12719 & 2392 & 34 & 3 & $\mathrm{A1}$ & 283 & 14 & 5 & \begin{tabular}{|l|l|}
718.4 \\
\end{tabular} & 9 & & & 9 & & & & \\
\hline 12719 & 2392 & 34 & 3 & A1 & 283 & 14 & 2 & 271.3 & 85 & & & 85 & & & & \\
\hline 12719 & 2392 & 34 & 3 & $\mathrm{~A} 1$ & 281 & 4 & 5 & 90.42 & 1 & 1 & & 1 & & & 1 & \\
\hline 12719 & 2392 & 34 & 3 & $\mathrm{~A} 1$ & 281 & 4 & 6 & 1.96 & 1 & 1 & & 1 & & & 1 & \\
\hline 12719 & 2392 & 34 & 3 & $\mathrm{A1}$ & 281 & 4 & 2 & $\begin{array}{l}3.86 \\
\end{array}$ & 2 & 2 & & 2 & & & 2 & \\
\hline 12719 & 2392 & 34 & 3 & A1 & 281 & 4 & 4 & 100.44 & 2 & 2 & & 2 & & 1 & 1 & \\
\hline 12719 & 2392 & 34 & 3 & $\mathrm{A1}$ & 281 & 4 & 3 & 20.33 & 3 & 3 & & 2 & 1 & 2 & 1 & \\
\hline 12719 & 2392 & 34 & 3 & A1 & 283 & 14 & 3 & 183.6 & 17 & & & 17 & & & & \\
\hline \begin{tabular}{|l|l|}
12719 \\
\end{tabular} & 2393 & 34 & 3 & A1 & 283 & 14 & 1 & \begin{tabular}{|l|}
2.22 \\
\end{tabular} & 5 & & & 5 & & & & \\
\hline 12719 & 2394 & 34 & 3 & $\mathrm{~A} 1$ & 281 & 4 & 1 & 1.1 & 2 & 2 & & 2 & & & 2 & \\
\hline 12719 & 2394 & 34 & 3 & A1 & 283 & 14 & 1 & 14.4 & 19 & & & 19 & & & & \\
\hline 12719 & 2394 & 34 & 3 & A1 & 283 & 14 & 8 & 665.5 & 1 & & & 1 & & & & \\
\hline 12719 & 2394 & 34 & 3 & A1 & 283 & 14 & 5 & $\begin{array}{ll}148.6 \\
\end{array}$ & 1 & & & 1 & & & & \\
\hline 12719 & 2394 & 34 & 3 & A1 & 283 & 14 & 4 & 139 & 4 & & & 4 & & & & \\
\hline 12719 & 2394 & 34 & 3 & $\mathrm{~A} 1$ & 281 & 4 & 2 & 2.02 & 1 & 1 & & 1 & & & 1 & in same bag as 28 \\
\hline 12719 & 2394 & 34 & 3 & A1 & 283 & 14 & 3 & 112.8 & 7 & & & 7 & & & & \\
\hline 12719 & 2394 & 34 & 3 & A1 & 283 & 14 & 6 & 332.3 & 1 & & & 1 & & & & \\
\hline 12719 & 2394 & 34 & 3 & $\mathrm{~A} 1$ & 283 & 14 & 2 & 58.5 & 17 & & & 17 & & & & \\
\hline 12719 & 2395 & 34 & 3 & A1 & 281 & 4 & 2 & 4.48 & 2 & 2 & & 2 & & & 2 & \\
\hline 12719 & 2395 & 34 & 3 & A1 & 281 & 4 & 4 & \begin{tabular}{|l|l|}
58.4 \\
\end{tabular} & 1 & 1 & & 1 & & & 1 & \\
\hline
\end{tabular}




\begin{tabular}{|c|c|c|c|c|c|c|c|c|c|c|c|c|c|c|c|c|}
\hline Site & Coll \# & Feature & \begin{tabular}{|l|} 
Lev \\
\end{tabular} & Blk & $A C$ & Mat & Sz & Grams & Qty & Frac & $\mathrm{NF}$ & Disc $P$ & Disc A & Cort $P$ & Cort A & Comments \\
\hline 12719 & 2395 & 34 & 3 & $\mathrm{~A} 1$ & 281 & 4 & 3 & 11.9 & 1 & 1 & & 1 & & & 1 & \\
\hline 12719 & 2395 & 34 & 3 & A1 & 283 & 14 & 5 & 401.7 & 3 & & & 3 & & & & \\
\hline 12719 & 2395 & 34 & 3 & A1 & 283 & 14 & 3 & 166.5 & 14 & & & 14 & & & & \\
\hline 12719 & 2395 & 34 & 3 & A1 & 283 & 14 & 2 & 118 & 32 & & & 32 & & & & \\
\hline 12719 & 2395 & 34 & 3 & $\mathrm{~A} 1$ & 283 & 14 & 1 & 27.6 & 27 & & & 27 & & & & \\
\hline 12719 & 2395 & 34 & 3 & A1 & 283 & 14 & 6 & 189.6 & 1 & & & 1 & & & & \\
\hline 12719 & 2395 & 34 & 3 & A1 & 283 & 14 & 4 & 269.2 & 10 & & & 10 & & & & \\
\hline 12719 & 2395 & 34 & 3 & $\mathrm{~A} 1$ & 281 & 4 & 5 & 64.35 & 1 & 1 & & 1 & & 1 & & \\
\hline 12719 & 2396 & 34 & 3 & $\mathrm{~A} 1$ & 283 & 14 & 1 & 0.34 & 2 & & & 2 & & & & \\
\hline 12719 & 2397 & 34 & 3 & A1 & 281 & 4 & 2 & 3.01 & 1 & 1 & & 1 & & & 1 & \\
\hline 12719 & 2397 & 34 & 3 & $\overline{A 1}$ & 281 & 4 & 4 & 18.84 & 1 & 1 & & 1 & & & 1 & \\
\hline 12719 & 2397 & 34 & 3 & A1 & 281 & 4 & 3 & 16.4 & 2 & 2 & & 2 & & 2 & & \\
\hline 12719 & 2397 & 34 & 3 & A1 & 281 & 4 & 1 & 0.38 & 2 & 2 & & 2 & & & 2 & \\
\hline 12719 & 2397 & 34 & 3 & $\mathrm{~A} 1$ & 283 & 14 & 2 & 75.98 & 20 & & & 20 & & & & \\
\hline 12719 & 2397 & 34 & 3 & $A 1$ & 283 & 14 & 1 & 21.7 & 31 & & & 31 & & & & \\
\hline 12719 & 2397 & 34 & 3 & A1 & 283 & 14 & 6 & 196.2 & 1 & & & 1 & & & & \\
\hline 12719 & 2397 & 34 & 3 & $\overline{A 1}$ & 283 & 14 & 3 & 90.4 & 6 & & & 6 & & & & \\
\hline 12719 & 2397 & 34 & 3 & A1 & 283 & 14 & 5 & 146.1 & 2 & & & 2 & & & & \\
\hline 12719 & 2397 & 34 & 3 & $A \hat{\imath}$ & 283 & 14 & 4 & 175.7 & 4 & & & 4 & & & & \\
\hline 12719 & 2398 & 34 & 3 & At & 283 & 14 & 3 & 18.57 & 1 & & & 1 & & & & \\
\hline 12719 & 2398 & 34 & 3 & $\mathrm{~A} 1$ & 283 & 14 & 4 & 28.58 & 1 & & & 1 & & & & \\
\hline 12719 & 2398 & 34 & 3 & A1 & 283 & 14 & 2 & 1.09 & 1 & & & 1 & & & & \\
\hline 12719 & 2398 & 34 & 3 & $\mathrm{A1}$ & 283 & 14 & 1 & 5.53 & 8 & & & 8 & & & & \\
\hline 12719 & 2400 & 34 & 3 & A1 & 281 & 3 & 2 & 1.06 & 1 & 1 & & 1 & & 1 & & \\
\hline 12719 & 2400 & 34 & 3 & $\mathrm{~A} 1$ & 281 & 4 & 2 & \begin{tabular}{|c|}
10.06 \\
\end{tabular} & 3 & 3 & & 3 & & & 3 & \\
\hline 12719 & 2400 & 34 & 3 & $\mathrm{~A} 1$ & 281 & 4 & 4 & 35.12 & 2 & 2 & & 2 & & 1 & 1 & \\
\hline 12719 & 2400 & 34 & 3 & $\mathrm{~A} 1$ & 283 & 14 & 4 & 130.5 & 4 & & & 4 & & & & \\
\hline 12719 & 2400 & 34 & 3 & A1 & 283 & 14 & 1 & 29.62 & 41 & & & 41 & & & & \\
\hline 12719 & 2400 & 34 & 3 & A1 & 283 & 14 & 2 & 82.09 & 24 & & & 24 & & & & \\
\hline 12719 & 2400 & 34 & 3 & $\mathrm{~A} 1$ & 283 & 14 & 3 & 69.19 & 4 & & & 4 & & & & \\
\hline 12719 & 2400 & 34 & 3 & $\mathrm{~A} 1$ & 281 & 4 & 3 & 11.33 & 1 & 1 & & 1 & & & 1 & \\
\hline 12719 & 2400 & 34 & 3 & A1 & 281 & 4 & 3 & 57.84 & 2 & 2 & & 2 & & & 2 & \\
\hline 12719 & 2400 & 34 & 3 & $\mathrm{~A}_{1}$ & 283 & 14 & 5 & 514 & 4 & & & 4 & & & & \\
\hline 12719 & 2401 & 34 & 3 & $\mathrm{~A} 1$ & 283 & 14 & 1 & 1.25 & 3 & & & 3 & & & & \\
\hline 12719 & 2402 & 34 & 3 & $\mathrm{~A} 1$ & 281 & 6 & 2 & 2.46 & 1 & 1 & & 1 & & & 1 & \\
\hline 12719 & 2402 & 34 & 3 & $A 1$ & 283 & 14 & 9 & 613.2 & 1 & & & & 1 & & & \\
\hline 12719 & 2402 & 34 & 3 & A1 & 283 & 14 & 5 & 550 & 5 & & & 2 & 3 & & & \\
\hline 12719 & 2402 & 34 & 3 & A1 & 283 & 14 & 6 & \begin{tabular}{|l|}
438.5 \\
\end{tabular} & 3 & & & 2 & 1 & & & \\
\hline 12719 & 2402 & 34 & 3 & $\mathrm{~A} 1$ & 283 & 14 & 1 & 17.35 & 16 & & & 16 & & & & \\
\hline 12719 & 2402 & 34 & 3 & $\mathrm{~A} 1$ & 283 & 14 & 3 & 98.31 & 10 & & & 2 & 8 & & & \\
\hline 12719 & 2402 & 34 & 3 & $\mathrm{~A} 1$ & 283 & 14 & 2 & 44.33 & 13 & & & 8 & 5 & & & \\
\hline 12719 & 2402 & 34 & 3 & $\mathrm{~A} 1$ & 281 & 4 & 5 & 144.44 & 1 & 1 & & 1 & & & 1 & \\
\hline 12719 & 2402 & 34 & 3 & A1 & 283 & 14 & 4 & 36.85 & 2 & & & 1 & 1 & & & \\
\hline 12719 & 2402 & 34 & 3 & $\mathrm{~A} 1$ & 283 & 14 & 7 & \begin{tabular}{|l|}
705.7 \\
\end{tabular} & 2 & & & 2 & & & & \\
\hline 12719 & 2403 & 34 & 3 & $\mathrm{~A} 1$ & 281 & 4 & 4 & 55.11 & 1 & 1 & & 1 & & 1 & & \\
\hline 12719 & 2403 & 34 & 3 & $\mathrm{~A} 1$ & 283 & 14 & 3 & 14.87 & 1 & & & & 1 & & & \\
\hline 12719 & 2403 & 34 & 3 & $\mathrm{~A} 1$ & 283 & 14 & 1 & 6.42 & 7 & & & 7 & & & & \\
\hline 12719 & 2405 & 34 & 3 & $\mathrm{~A} 1$ & 283 & 14 & 1 & 4.48 & 6 & & & 6 & & & & \\
\hline 12719 & 2405 & 34 & 3 & A1 & 283 & 14 & 5 & 56.78 & 1 & & & 1 & & & & \\
\hline 12719 & 2405 & 34 & 3 & $\mathrm{~A} 1$ & 281 & 4 & 2 & 2.72 & 1 & 1 & & 1 & & & 1 & \\
\hline 12719 & 2405 & 34 & 3 & A1 & 281 & 6 & 1 & 0.47 & 1 & 1 & & 1 & & 1 & & \\
\hline 12719 & 2405 & 34 & 3 & A1 & 283 & 14 & 2 & 52.46 & 11 & & & 8 & 3 & & & \\
\hline 12719 & 2406 & 33 & 5 & A1 & 283 & 14 & 2 & 18.32 & 4 & & & 4 & & & & \\
\hline 12719 & 2406 & 33 & 5 & A1 & 283 & 14 & 1 & 1.44 & 2 & & & 2 & & & & \\
\hline 12719 & 2408 & 33 & 5 & A1 & 283 & 14 & 2 & 22.04 & 5 & & & 5 & & & & \\
\hline 12719 & 2408 & 33 & 5 & $\mathrm{~A} 1$ & 283 & 14 & 1 & 17.51 & 33 & & & 33 & & & & \\
\hline 12719 & 2408 & 33 & 5 & A1 & 283 & 14 & 3 & 31.33 & 3 & & & 3 & & & & \\
\hline 12719 & 2408 & 33 & 5 & A1 & 283 & 14 & 4 & 18.37 & 1 & & & 1 & & & & \\
\hline 12719 & 2408 & 33 & 5 & A1 & 281 & 6 & 3 & 9.55 & 1 & 1 & & 1 & & 1 & & \\
\hline 12719 & 2408 & 33 & 5 & A1 & 281 & 6 & 2 & 16.1 & 1 & 1 & & 1 & & & 1 & \\
\hline 12719 & 2408 & 33 & 5 & $\mathrm{~A} 1$ & 283 & 14 & 5 & 110.91 & 2 & & & 2 & & & & 1 flake \\
\hline 12719 & 2409 & 33 & 5 & $\mathrm{~A} 1$ & 283 & 14 & 1 & 0.47 & 2 & & & 2 & & & & \\
\hline 12719 & 2409 & 33 & 5 & $\mathrm{~A}_{1}$ & 283 & 14 & 2 & 2.44 & 2 & & & 2 & & & & \\
\hline 12719 & 2410 & 33 & 5 & $\mathrm{~A} 1$ & 283 & 14 & 3 & 24.19 & 3 & & & 3 & & & & \\
\hline 12719 & 2410 & 33 & 5 & A1 & 283 & 14 & 5 & 236.9 & 3 & & & 3 & & & & \\
\hline 12719 & 2410 & 33 & 5 & $\mathrm{~A} 1$ & 283 & 14 & 2 & 38.89 & 14 & & & 14 & & & & \\
\hline 12719 & 2410 & 33 & 5 & $\mathrm{~A} 1$ & 281 & 6 & 1 & 0.26 & 4 & 4 & & 4 & & & 4 & \\
\hline 12719 & 2410 & 33 & 5 & $\mathrm{~A}_{1}$ & 283 & 14 & 4 & 32.7 & 1 & & & 1 & & & & \\
\hline
\end{tabular}




\begin{tabular}{|c|c|c|c|c|c|c|c|c|c|c|c|c|c|c|c|c|}
\hline Site & Coll \# & Feature & Lev & Blk & $A C$ & Mat & $\mathrm{Sz}$ & Grams & Qty & Frac & $\mathrm{NF}$ & Disc P & Disc $A$ & Cort P & $\operatorname{Cort} A$ & Comments \\
\hline 12719 & 2410 & 33 & 5 & A1 & 283 & 14 & 1 & 15.53 & 25 & & & 25 & & & & \\
\hline 12719 & 2411 & 33 & 5 & $\mathrm{~A} 1$ & 283 & 14 & 1 & 3.33 & 4 & & & 4 & & & & \\
\hline 12719 & 2412 & 33 & 5 & $\mathrm{~A} 1$ & 283 & 14 & 1 & 26.56 & 33 & & & 33 & & & & \\
\hline 12719 & 2412 & 33 & 5 & A1 & 281 & 4 & 1 & 0.73 & 1 & 1 & & 1 & & & 1 & \\
\hline 12719 & 2412 & 33 & 5 & $\mathrm{~A} 1$ & 281 & 4 & 4 & 59.63 & 1 & 1 & & 1 & & 1 & & \\
\hline 12719 & 2412 & 33 & 5 & $\mathrm{~A} 1$ & 283 & 14 & 4 & 84.35 & 2 & & & 2 & & & & \\
\hline 12719 & 2412 & 33 & 5 & $\mathrm{~A} 1$ & 283 & 14 & 6 & 259.2 & 1 & & & 1 & & & & \\
\hline 12719 & \begin{tabular}{|l|}
2412 \\
\end{tabular} & 33 & 5 & $\mathrm{~A} 1$ & 283 & 14 & 3 & 59.33 & 6 & & & 6 & & & & \\
\hline 12719 & 2412 & 33 & 5 & $\mathrm{~A} 1$ & 283 & 14 & 2 & 20.08 & 8 & & & 8 & & & & \\
\hline 12719 & \begin{tabular}{|l|}
2414 \\
\end{tabular} & & 1 & $\mathrm{~A} 1$ & 281 & 4 & 5 & 127.82 & 4 & 4 & & 4 & & & 4 & \\
\hline 12719 & \begin{tabular}{|l|}
2414 \\
\end{tabular} & & 1 & $\mathrm{~A} 1$ & 283 & 14 & 1 & 2.18 & 4 & & & 4 & & & & \\
\hline 12719 & 2415 & & 1 & A1 & 283 & 14 & 2 & 2.39 & 1 & & & 1 & & & & \\
\hline 12719 & 2415 & & 1 & A1 & 283 & 14 & 1 & 0.6 & 3 & & & 3 & & & & \\
\hline 12719 & 2416 & & 1 & A1 & 283 & 14 & 1 & 0.61 & 2 & & & 2 & & & & \\
\hline 12719 & 2416 & & 1 & A1 & 283 & 14 & 2 & 4.22 & 1 & & & 1 & & & & \\
\hline 12719 & \begin{tabular}{|l|}
2417 \\
\end{tabular} & & 1 & A1 & 283 & 14 & 1 & 2.16 & 4 & & & 4 & & & & \\
\hline 12719 & 2418 & & 1 & $A 1$ & 281 & 4 & 2 & 2.94 & 1 & 1 & & 1 & & & 1 & \\
\hline 12719 & 2418 & & 1 & $\mathrm{~A} 1$ & 281 & 4 & 4 & 14.67 & 1 & 1 & & 1 & & & 1 & \\
\hline 12719 & 2418 & & 1 & $\mathrm{~A} 1$ & 283 & 14 & 1 & 1.83 & 4 & & & 4 & & & & \\
\hline 12719 & 2418 & & 1 & $\mathrm{~A} 1$ & 281 & 4 & 3 & 11.35 & 1 & 1 & & 1 & & & 1 & \\
\hline 12719 & \begin{tabular}{|l|}
2418 \\
\end{tabular} & & 1 & $\bar{A} 1$ & 283 & 14 & 2 & 17.91 & 4 & & & 4 & & & & \\
\hline 12719 & 2419 & & 1 & A1 & 283 & 14 & 1 & 5.74 & 5 & & & 5 & & & & \\
\hline 12719 & \begin{tabular}{|l|}
2419 \\
\end{tabular} & & 1 & $\bar{A} 1$ & 283 & 14 & 2 & 3.46 & 2 & & & 2 & & & & \\
\hline 12719 & 2420 & & 1 & $\mathrm{~A} 1$ & 283 & 14 & 1 & 0.23 & 1 & & & 1 & & & & \\
\hline 12719 & 2420 & & 1 & $\mathrm{~A} 1$ & 283 & 14 & 2 & 3.4 & 1 & & & 1 & & & & \\
\hline 12719 & 2421 & & 1 & $\mathrm{~A} 1$ & 283 & 14 & 1 & 1.86 & 2 & & & 2 & & & & \\
\hline 12719 & 2421 & & 1 & $\mathrm{~A} 1$ & 283 & 14 & 2 & 8.59 & 3 & & & 3 & & & & \\
\hline 12719 & \begin{tabular}{|l|}
2422 \\
\end{tabular} & & 1 & A1 & 283 & 14 & 1 & 0.34 & 1 & & & 1 & & & & \\
\hline 12719 & 2422 & & 1 & $\mathrm{~A} 1$ & 283 & 14 & 2 & 3.9 & 2 & & & 2 & & & & \\
\hline 12719 & 2423 & & 1 & $\mathrm{~A} 1$ & 281 & 4 & 2 & 3.94 & 2 & 2 & & 2 & & 2 & & \\
\hline 12719 & 2423 & & 1 & $\mathrm{~A} 1$ & 281 & 4 & 1 & 2.38 & 2 & & 2 & 2 & & 2 & & \\
\hline 12719 & 2423 & & 1 & $\mathrm{~A} 1$ & 281 & 4 & 3 & 38.89 & 2 & 1 & 1 & 2 & & 2 & & \\
\hline 12719 & \begin{tabular}{|l|}
2424 \\
\end{tabular} & & 1 & $\mathrm{~A} 1$ & 281 & 4 & 2 & 6.03 & 1 & 1 & & 1 & & 1 & & \\
\hline 12719 & \begin{tabular}{|l|}
2424 \\
\end{tabular} & & 1 & $\mathrm{A1}$ & 283 & \begin{tabular}{|l|}
14 \\
\end{tabular} & 1 & 0.77 & 6 & & & 6 & & & & \\
\hline 12719 & \begin{tabular}{|l|}
2424 \\
\end{tabular} & & 1 & $\mathrm{~A} 1$ & 283 & 14 & 2 & 3.79 & 2 & & & 2 & & & & \\
\hline 12719 & 2426 & & 1 & A1 & 283 & 14 & 2 & 5.95 & 1 & & & 1 & & & & \\
\hline 12719 & \begin{tabular}{|l|}
2426 \\
\end{tabular} & & 1 & $\mathrm{A1}$ & 281 & 4 & 4 & 84.99 & 2 & 2 & & 2 & & 1 & 1 & \\
\hline 12719 & \begin{tabular}{|l|}
2426 \\
\end{tabular} & & 1 & $\mathrm{~A} 1$ & 283 & 14 & 1 & 4.29 & 9 & & & 9 & & & & \\
\hline 12719 & \begin{tabular}{|l|}
2427 \\
\end{tabular} & & 1 & A1 & 283 & 14 & 1 & \begin{tabular}{l|l}
0.56 \\
\end{tabular} & 3 & & & 3 & & & & \\
\hline 12719 & \begin{tabular}{|l|}
2428 \\
\end{tabular} & & 1 & A1 & 281 & 4 & 1 & 1.05 & 1 & 1 & & 1 & & 1 & & \\
\hline 12719 & \begin{tabular}{|l|}
2428 \\
\end{tabular} & & 1 & A1 & 283 & 14 & 2 & 1.89 & 1 & & & 1 & & & & \\
\hline 12719 & \begin{tabular}{|l|}
2428 \\
\end{tabular} & & 1 & $\mathrm{~A} 1$ & 283 & 14 & 1 & 4.67 & 25 & & & 25 & & & & \\
\hline 12719 & \begin{tabular}{|l|}
2428 \\
\end{tabular} & & 1 & A1 & 281 & 4 & 5 & 98.77 & 1 & 1 & & 1 & & 1 & & \\
\hline 12719 & \begin{tabular}{|l|}
2429 \\
\end{tabular} & & 1 & $\bar{A} 1$ & 283 & 14 & 1 & 0.35 & 2 & & & 2 & & & & \\
\hline 12719 & 2430 & & 1 & $\mathrm{~A} 1$ & 283 & 14 & 4 & 10.72 & 1 & & & 1 & & & & \\
\hline 12719 & \begin{tabular}{|l|}
2430 \\
\end{tabular} & & 1 & $\mathrm{~A} 1$ & 283 & 14 & 1 & 5.77 & 28 & & & 28 & & & & \\
\hline 12719 & \begin{tabular}{|l|}
2431 \\
\end{tabular} & & 1 & $\mathrm{~A} 1$ & 283 & 14 & 2 & 2.16 & 2 & & & 2 & & & & \\
\hline 12719 & \begin{tabular}{|l|}
2431 \\
\end{tabular} & & 1 & $\mathrm{~A} 1$ & 281 & 4 & 2 & \begin{tabular}{|l|}
4.29 \\
\end{tabular} & 1 & 1 & & 1 & & 1 & & \\
\hline 12719 & 2431 & & 1 & $\mathrm{A1}$ & 283 & 14 & 3 & 31.98 & 2 & & & 2 & & & & \\
\hline 12719 & 2431 & & 1 & $\mathrm{~A} 1$ & 283 & 14 & 1 & 2.02 & 4 & & & 4 & & & & \\
\hline 12719 & \begin{tabular}{|l|}
2431 \\
\end{tabular} & & 1 & $\overline{A 1}$ & 281 & 4 & 4 & 85.85 & 1 & 1 & & 1 & & 1 & & \\
\hline 12719 & 2432 & & 1 & $\mathrm{~A} 1$ & 283 & 14 & 1 & \begin{tabular}{l|l}
0.98 \\
\end{tabular} & 1 & & & 1 & & & & \\
\hline 12719 & \begin{tabular}{|l|}
2432 \\
\end{tabular} & & 1 & A1 & 283 & 14 & 3 & \begin{tabular}{l|l|}
5.08 \\
\end{tabular} & 1 & & & 1 & & & & \\
\hline 12719 & 2432 & & 1 & $\bar{A} 1$ & 281 & 4 & 2 & $\begin{array}{l}1.62 \\
\end{array}$ & 1 & 1 & & & 1 & 1 & & \\
\hline 12719 & 2432 & & 1 & A1 & 281 & 4 & 1 & 2.35 & 5 & 4 & 1 & 5 & & 3 & 2 & \\
\hline 12719 & 2432 & & 1 & A1 & 281 & 4 & 4 & $\begin{array}{l}14.66 \\
\end{array}$ & 1 & 1 & & 1 & & 1 & & \\
\hline 12719 & 2433 & & 1 & A1 & 283 & 14 & 2 & $\begin{array}{ll}1.96 \\
\end{array}$ & 1 & & & 1 & & & & \\
\hline 12719 & 2433 & & 1 & $\mathrm{~A} 1$ & 283 & 14 & 1 & 0.98 & 2 & & & 2 & & & & \\
\hline 12719 & 2434 & & 1 & $\mathrm{~A} 1$ & 283 & 14 & 2 & 2.87 & 2 & & & 2 & & & & \\
\hline 12719 & 2435 & & 1 & $\mathrm{~A} 1$ & 283 & 14 & 1 & $\begin{array}{ll}0.28 \\
\end{array}$ & 1 & & & 1 & & & & \\
\hline 12719 & 2435 & & 1 & $\mathrm{~A} 1$ & 283 & 14 & 3 & 9.22 & 1 & & & 1 & & & & \\
\hline 12719 & 2436 & & 1 & $\mathrm{A1}$ & 283 & 14 & 1 & \begin{tabular}{|l|l}
4.08 \\
\end{tabular} & 13 & & & 13 & & & & \\
\hline 12719 & 2436 & & 1 & $\mathrm{A1}$ & 283 & 14 & 3 & 23.45 & 2 & & & 2 & & & & \\
\hline 12719 & 2436 & & 1 & $\mathrm{~A} 1$ & 283 & 14 & 2 & 20.75 & 5 & & & 5 & & & & \\
\hline \begin{tabular}{|c|}
12719 \\
\end{tabular} & 2438 & & 1 & $\mathrm{~A} 1$ & 283 & 14 & 1 & \begin{tabular}{|c|}
0.85 \\
\end{tabular} & 1 & & & 1 & & & & \\
\hline 12719 & 2438 & & 1 & $\mathrm{A1}$ & 283 & 14 & 2 & 3.84 & 1 & & & 1 & & & & \\
\hline 12719 & 2439 & & 1 & $\mathrm{A1}$ & 283 & 14 & 2 & 4.47 & 1 & & & 1 & & & & \\
\hline 12719 & 2439 & & 1 & $\mathrm{~A} 1$ & 283 & 14 & 1 & \begin{tabular}{|l|l|}
0.76 \\
\end{tabular} & 1 & & & 1 & & & & \\
\hline
\end{tabular}




\begin{tabular}{|c|c|c|c|c|c|c|c|c|c|c|c|c|c|c|c|c|}
\hline Site & Coll \# & Feature & Lev & Blk & $A C$ & Mat & $\mathrm{Sz}$ & Grams & Qty & Frac & NF & Disc P & Disc A & Cort $P$ & Cort A & Comments \\
\hline 12719 & 2440 & & 1 & A1 & 283 & 14 & 1 & 1.47 & 1 & & & 1 & & & & \\
\hline 12719 & 2441 & & 1 & $\mathrm{A1}$ & 283 & 14 & 2 & 1.9 & 1 & & & 1 & & & & \\
\hline 12719 & 2441 & & 1 & $\mathrm{A1}$ & 281 & 4 & 3 & 2.86 & 1 & 1 & & 1 & & & 1 & \\
\hline 12719 & 2441 & & 1 & A1 & 283 & 14 & 1 & 1.3 & 3 & & & 3 & & & & \\
\hline 12719 & 2441 & & 1 & $\mathrm{A1}$ & 283 & 14 & 3 & 9.05 & 1 & & & 1 & & & & \\
\hline 12719 & 2442 & & 1 & A1 & 283 & 14 & 1 & 2.98 & 7 & & & 7 & & & & \\
\hline 12719 & 2442 & & 1 & $\mathrm{A1}$ & 283 & 14 & 2 & 11.94 & 4 & & & 4 & & & & \\
\hline 12719 & 2443 & & 1 & $\mathrm{A1}$ & 283 & 14 & 3 & 9.62 & 1 & & & 1 & & & & \\
\hline 12719 & 2443 & & 1 & A1 & 283 & 14 & 4 & 29.5 & 1 & & & 1 & & & & \\
\hline 12719 & 2443 & & 1 & $\mathrm{A1}$ & 283 & 14 & 2 & 5.32 & 1 & & & 1 & & & & \\
\hline 12719 & 2443 & & 1 & A1 & 283 & 14 & 1 & 1.06 & 1 & & & 1 & & & & \\
\hline 12719 & 2445 & & 1 & $\mathrm{A1}$ & 283 & 14 & 1 & 0.29 & 1 & & & 1 & & & & \\
\hline 12719 & 2445 & & 1 & A1 & 281 & 4 & 3 & 49.75 & 2 & 2 & & 2 & & 2 & & \\
\hline 12719 & 2445 & & 1 & $\mathrm{A1}$ & 281 & 4 & 1 & 1.24 & 1 & 1 & & 1 & & 1 & & \\
\hline 12719 & 2446 & & 1 & A1 & 283 & 14 & 2 & 1.09 & 1 & & & 1 & & & & \\
\hline 12719 & 2447 & & 1 & $\mathrm{~A} 1$ & 283 & 14 & 2 & 1.63 & 1 & & & 1 & & & & \\
\hline 12719 & 2447 & & 1 & $\mathrm{A1}$ & 281 & 4 & 4 & 37.53 & 1 & 1 & & 1 & & 1 & & \\
\hline 12719 & 2447 & & 1 & A1 & 281 & 4 & 5 & 143.41 & 1 & 1 & & 1 & & 1 & & \\
\hline 12719 & 2449 & & 1 & A1 & 283 & 14 & 1 & 1.01 & 3 & & & 3 & & & & \\
\hline 12719 & 2449 & & 1 & $\mathrm{A1}$ & 283 & 14 & 2 & 6.31 & 1 & & & 1 & & & & \\
\hline 12719 & 2449 & & 1 & A1 & 281 & 4 & 2 & 2.14 & 2 & & & 2 & & & & \\
\hline 12719 & 2450 & & 1 & A1 & 281 & 4 & 3 & 20.28 & 2 & 2 & & 2 & & 1 & 1 & \\
\hline 12719 & 2450 & & 1 & A1 & 281 & 4 & 2 & 12.88 & 3 & 3 & & & 3 & 2 & 1 & \\
\hline 12719 & 2450 & & 1 & $\mathrm{A1}$ & 281 & 4 & 1 & 0.15 & 2 & 2 & & 2 & & 1 & 1 & \\
\hline 12719 & 2450 & & 1 & $\mathrm{A1}$ & 283 & 14 & 1 & 0.73 & 4 & & & 4 & & & & \\
\hline 12719 & 2451 & & 1 & $\mathrm{A1}$ & 281 & 4 & 3 & 39.87 & 1 & & 1 & 1 & & 1 & & \\
\hline 12719 & 2451 & & 1 & $\mathrm{A1}$ & 283 & 14 & 5 & 43.35 & 1 & & & 1 & & & & \\
\hline 12719 & 2452 & & 1 & $A 1$ & 283 & 14 & 1 & 0.9 & 3 & & & 3 & & & & \\
\hline 12719 & 2452 & & 1 & $\overline{A 1}$ & 283 & 14 & 2 & 3.71 & 2 & & & 2 & & & & \\
\hline 12719 & 2453 & & 1 & A1 & 283 & 14 & 2 & 5.61 & 2 & & & 2 & & & & \\
\hline 12719 & 2453 & & 1 & $\mathrm{A1}$ & 281 & 4 & 2 & 4.42 & 3 & 3 & & 3 & & 1 & 2 & \\
\hline 12719 & 2453 & & 1 & $\mathrm{A1}$ & 283 & 14 & 1 & 1.23 & 2 & & & 2 & & & & \\
\hline 12719 & 2453 & & 1 & $A 1$ & 283 & 14 & 3 & 22.5 & 1 & & & 1 & & & & \\
\hline 12719 & 2453 & & 1 & $\mathrm{~A} 1$ & 281 & 4 & 3 & 7.13 & 1 & 1 & & 1 & & & 1 & \\
\hline 12719 & 2454 & & 1 & A1 & 281 & 4 & 4 & 104.09 & 1 & & 1 & 1 & & 1 & & \\
\hline 12719 & 2454 & & 1 & A1 & 283 & 14 & 1 & 2.39 & 2 & & & 2 & & & & \\
\hline 12719 & 2455 & & 1 & $\mathrm{A1}$ & 281 & 4 & 3 & 15.49 & 1 & 1 & & 1 & & 1 & & \\
\hline 12719 & 2456 & & 1 & $\mathrm{~A} 1$ & 283 & 14 & 1 & 4.78 & 8 & & & 8 & & & & \\
\hline 12719 & 2456 & & 1 & $\mathrm{A1}$ & 283 & 14 & 2 & 5.01 & 1 & & & 1 & & & & \\
\hline 12719 & 2456 & & 1 & $\overline{A 1}$ & 281 & 4 & 1 & 1.8 & 1 & 1 & & & 1 & 1 & & \\
\hline 12719 & 2457 & & 1 & $\mathrm{A1}$ & 283 & 14 & 2 & 2.94 & 1 & & & 1 & & & & \\
\hline 12719 & 2459 & & 1 & $\mathrm{A1}$ & 283 & 14 & 2 & 5.98 & 1 & & & 1 & & & & \\
\hline 12719 & 2459 & & 1 & $\mathrm{~A} 1$ & 281 & 4 & 2 & 2.49 & 1 & 1 & & 1 & & 1 & & \\
\hline 12719 & 2459 & & 1 & $\mathrm{~A} 1$ & 281 & 4 & 5 & 93.03 & 1 & 1 & & 1 & & 1 & & \\
\hline 12719 & 2460 & & 1 & A1 & 283 & 14 & 1 & 1.2 & 3 & & & 3 & & & & \\
\hline 12719 & 2461 & & 1 & $\mathrm{~A} 1$ & 283 & 14 & 1 & \begin{tabular}{l|l|}
0.49 \\
\end{tabular} & 1 & & & 1 & & & & \\
\hline 12719 & 2461 & & 1 & $\overline{A 1}$ & 281 & 4 & 3 & 15.05 & 1 & 1 & & 1 & & 1 & & \\
\hline 12719 & 2461 & & 1 & $\mathrm{~A} 1$ & 281 & 4 & 2 & 5.64 & 2 & 2 & & 2 & & 1 & 1 & \\
\hline 12719 & 2462 & & & $\mathrm{~A} 1$ & 283 & 14 & 2 & 14.3 & 3 & & & 3 & & & & \\
\hline 12719 & 2462 & & & $\mathrm{~A} 1$ & 283 & 14 & 1 & 5.51 & 26 & & & 26 & & & & \\
\hline 12719 & 2463 & & 4 & $\mathrm{~A} 1$ & 281 & 4 & 4 & 33.39 & 1 & 1 & & 1 & & 1 & & \\
\hline 12719 & 2463 & & 4 & $\mathrm{A1}$ & 283 & 14 & 3 & 83.33 & 7 & & & 7 & & & & \\
\hline 12719 & 2463 & & 4 & $\mathrm{~A} 1$ & 281 & 4 & 2 & \begin{tabular}{l|}
0.62 \\
\end{tabular} & 1 & 1 & & 1 & & & 1 & \\
\hline 12719 & 2463 & & 4 & $\mathrm{A1}$ & 283 & 14 & 1 & 18.06 & 30 & & & 30 & & & & \\
\hline 12719 & 2463 & & 4 & A1 & 283 & 14 & 4 & 280.2 & 5 & & & 5 & & & & \\
\hline 12719 & 2463 & & 4 & $\overline{\mathrm{A} 1}$ & 283 & 14 & 2 & 150.91 & 42 & & & 42 & & & & \\
\hline 12719 & 2463 & & 4 & $\mathrm{~A} 1$ & 283 & 14 & 2 & 14.3 & 3 & & & 3 & & & & \\
\hline 12719 & 2463 & & 4 & A1 & 283 & 14 & 6 & 426.7 & 2 & & & 2 & & & & \\
\hline 12719 & 2463 & & 4 & A1 & 283 & 14 & 5 & 376.9 & 6 & & & 6 & & & & \\
\hline 12719 & 2464 & & 4 & $\mathrm{~A} 1$ & 283 & 14 & 1 & 3.28 & 12 & & & 12 & & & & \\
\hline 12719 & 2464 & & 4 & A1 & 283 & 14 & 2 & 3.96 & 2 & & & 2 & & & & \\
\hline 12719 & 2465 & & 5 & $\overline{\mathrm{A} 1}$ & 283 & 14 & 1 & 1.41 & 4 & & & 4 & & & & \\
\hline 12719 & 2466 & 89 & 4 & $\mathrm{A1}$ & 283 & 14 & 2 & 18.2 & 4 & & & 4 & & & & \\
\hline 12719 & 2466 & 89 & 4 & A1 & 283 & 14 & 1 & 9.66 & 16 & & & 16 & & & & \\
\hline 12719 & 2466 & 89 & 4 & A1 & 283 & 14 & 3 & \begin{tabular}{|l|}
7.87 \\
\end{tabular} & 1 & & & 1 & & & & \\
\hline 12719 & 2466 & 89 & 4 & A1 & 283 & 14 & 4 & 18.13 & 1 & & & 1 & & & & \\
\hline 12719 & 2467 & 89 & 4 & $\overline{A 1}$ & 283 & 14 & 3 & 8.09 & 1 & & & 1 & & & & \\
\hline 12719 & 2467 & 89 & 4 & $\mathrm{~A} 1$ & 283 & 14 & 1 & \begin{tabular}{|l|}
6.94 \\
\end{tabular} & 10 & & & 10 & & & & \\
\hline
\end{tabular}




\begin{tabular}{|c|c|c|c|c|c|c|c|c|c|c|c|c|c|c|c|c|}
\hline Site & Coll \# & Feature & Lev & Blk & $A C$ & Mat & $\mathrm{Sz}$ & Grams & Qty & Frac & $\mathrm{NF}$ & Disc $P$ & \begin{tabular}{|l}
$\operatorname{Disc} A$ \\
\end{tabular} & Cort P & Cort A & Comments \\
\hline 12719 & 2471 & & 1 & $\mathrm{~A} 1$ & 283 & 14 & \begin{tabular}{|l|}
2 \\
\end{tabular} & 3.91 & 1 & & & 1 & & & & \\
\hline 12719 & 2471 & & 1 & $\mathrm{~A} 1$ & 283 & 14 & 1 & 0.39 & 1 & & & 1 & & & & \\
\hline 12719 & 2475 & & 1 & $\mathrm{~A} 1$ & 283 & 14 & 1 & 0.94 & 4 & & & 4 & & & & \\
\hline 12719 & 2475 & & 1 & $\mathrm{~A} 1$ & 281 & 6 & 1 & 0.39 & 1 & 1 & & 1 & & & 1 & \\
\hline 12719 & 2476 & & 1 & $\mathrm{~A} 1$ & 283 & 14 & 1 & 2.4 & 2 & & & 2 & & & & \\
\hline 12719 & 2477 & & 1 & $\overline{\mathrm{A} 1}$ & 281 & 4 & 3 & 8.53 & 1 & 1 & & 1 & & & 1 & \\
\hline 12719 & 2477 & & 1 & $A 1$ & 281 & 4 & 2 & 6.15 & 3 & 3 & & 3 & & & 3 & \\
\hline 12719 & 2477 & & 1 & $\mathrm{~A} 1$ & 283 & 14 & 1 & 2.99 & 9 & & & 9 & & & & \\
\hline 12719 & 2477 & & 1 & $\mathrm{~A} 1$ & 283 & 14 & 2 & 4.51 & 3 & & & 3 & & & & \\
\hline 12719 & 2477 & & 1 & $\mathrm{~A} 1$ & 281 & 4 & 4 & \begin{tabular}{|l|}
47.71 \\
\end{tabular} & 1 & 1 & & 1 & & & 1 & \\
\hline 12719 & 2478 & & 1 & $\mathrm{~A} 1$ & 281 & 4 & 4 & 45.68 & 2 & 2 & & 2 & & & 2 & \\
\hline 12719 & 2478 & & 1 & A1 & 283 & 14 & 1 & $\begin{array}{l}6.53 \\
\end{array}$ & 10 & & & 10 & & & & \\
\hline 12719 & 2478 & & 1 & A1 & 283 & 14 & 2 & 10.12 & 3 & & & 3 & & & & \\
\hline 12719 & 2478 & & 1 & A1 & 283 & 14 & 3 & 9.76 & 1 & & & 1 & & & & \\
\hline 12719 & 2479 & & 1 & A1 & 281 & 4 & \begin{tabular}{|l|}
3 \\
\end{tabular} & 4.27 & 1 & 1 & & 1 & & & 1 & \\
\hline 12719 & 2479 & & 1 & A1 & 283 & 14 & 1 & 8.02 & 26 & & & 26 & & & & \\
\hline 12719 & 2479 & & 1 & A1 & 283 & 14 & 2 & 2.7 & 3 & & & 3 & & & & \\
\hline 12719 & 2480 & & 1 & A1 & 281 & 7 & 1 & 0.69 & 1 & 1 & & & 1 & & 1 & \\
\hline 12719 & 2480 & & 1 & A1 & 281 & 7 & 2 & 2.85 & 1 & 1 & & & 1 & & 1 & \\
\hline 12719 & 2480 & & 1 & A1 & 281 & 4 & 2 & 5.09 & 2 & 2 & & 2 & & 1 & 1 & \\
\hline 12719 & 2480 & & 1 & $\mathrm{~A} 1$ & 281 & 4 & 1 & 0.51 & 1 & 1 & & 1 & & & 1 & \\
\hline 12719 & 2480 & & 1 & A1 & 281 & 4 & 3 & 15.14 & 1 & 1 & & 1 & & & 1 & \\
\hline 12719 & 2480 & & 1 & A1 & 281 & 4 & 4 & 79.14 & 2 & 2 & & 2 & & 1 & 1 & \\
\hline 12719 & 2480 & & 1 & A1 & 281 & 4 & 5 & 70.04 & 1 & 1 & & 1 & & & 1 & \\
\hline 12719 & 2480 & & 1 & A1 & 283 & 14 & 6 & 157.4 & 1 & & & 1 & & & & \\
\hline 12719 & 2480 & & 1 & A1 & 283 & 14 & 2 & 7.88 & 1 & & & 1 & & & & \\
\hline 12719 & 2480 & & 1 & A1 & 283 & 14 & 1 & 6.33 & 18 & & & 18 & & & & \\
\hline 12719 & 2481 & & 1 & A1 & 281 & 4 & 2 & 1.24 & 1 & 1 & & 1 & & 1 & & \\
\hline 12719 & 2481 & & 1 & A1 & 283 & 14 & 2 & 33.49 & 8 & & & 8 & & & & \\
\hline 12719 & 2481 & & 1 & A1 & 283 & 14 & 1 & 10.02 & 14 & & & 14 & & & & \\
\hline 12719 & 2481 & & 1 & A1 & 283 & 14 & 3 & 29.45 & 1 & & & 1 & & & & \\
\hline 12719 & 2481 & & 1 & A1 & 281 & 4 & 2 & \begin{tabular}{l|}
0.63 \\
\end{tabular} & 1 & 1 & & & 1 & & 1 & \\
\hline 12719 & 2481 & & 1 & A1 & 281 & 4 & 4 & $\begin{array}{l}81.93 \\
\end{array}$ & 2 & 2 & & 2 & & & 2 & \\
\hline 12719 & 2481 & & 1 & A1 & 281 & 4 & 3 & 20.65 & 3 & 3 & & 3 & & 1 & 2 & \\
\hline 12719 & 2481 & & 1 & $\mathrm{~A} 1$ & 281 & 4 & 1 & \begin{tabular}{|l|}
3.03 \\
\end{tabular} & 4 & 4 & & 4 & & 1 & 3 & \\
\hline 12719 & 2482 & & 1 & A1 & 283 & 14 & 2 & 27.12 & 11 & & & 11 & & & & \\
\hline 12719 & 2482 & & 1 & $\mathrm{~A} 1$ & 283 & 14 & 1 & 16.77 & 32 & & & 32 & & & & \\
\hline 12719 & 2482 & & 1 & $\mathrm{A1}$ & 281 & 6 & 1 & 0.99 & 2 & 2 & & 2 & & & 2 & \\
\hline 12719 & 2482 & & 1 & $\mathrm{~A} 1$ & 281 & 4 & 2 & 5.01 & 3 & 3 & & 3 & & & 3 & \\
\hline 12719 & 2483 & & 1 & $\mathrm{~A} 1$ & 283 & 14 & 2 & \begin{tabular}{l|l}
6.82 \\
\end{tabular} & 2 & & & 2 & & & & \\
\hline 12719 & 2483 & & 1 & A1 & 281 & 4 & 5 & 128.41 & 1 & 1 & & 1 & & & 1 & \\
\hline 12719 & 2483 & & 1 & $\mathrm{~A} 1$ & 283 & 14 & 1 & 1.8 & 4 & & & 4 & & & & \\
\hline 12719 & 2483 & & 1 & $\mathrm{~A} 1$ & 283 & 14 & 3 & 14.71 & 1 & & & 1 & & & & \\
\hline 12719 & 2483 & & 1 & A1 & 283 & 14 & 4 & 37.69 & 1 & & & 1 & & & & \\
\hline 12719 & 2484 & & 1 & $\mathrm{A1}$ & 281 & 4 & 3 & 23.15 & 2 & 2 & & 2 & & & 2 & \\
\hline 12719 & 2484 & & 1 & $\mathrm{~A} 1$ & 283 & 14 & 1 & \begin{tabular}{l|l|}
6.48 \\
\end{tabular} & 9 & & & 9 & & & & \\
\hline 12719 & 2484 & & 1 & $\mathrm{~A} 1$ & 281 & 4 & 4 & $\begin{array}{l}89.24 \\
\end{array}$ & 1 & 1 & & 1 & & & 1 & \\
\hline 12719 & 2484 & & 1 & A1 & 283 & 14 & 2 & 17.44 & 4 & & & 4 & & & & \\
\hline 12719 & 2484 & & 1 & $\mathrm{~A} 1$ & 281 & 4 & 2 & \begin{tabular}{|l|l|}
2.38 \\
\end{tabular} & 1 & 1 & & 1 & & & 1 & \\
\hline 12719 & 2484 & & 1 & $\mathrm{A1}$ & 283 & 14 & 3 & 34.77 & 3 & & & 3 & & & & \\
\hline 12719 & 2485 & & 1 & $\mathrm{~A} 1$ & 281 & 4 & 3 & 14.12 & 1 & 1 & & 1 & & & 1 & \\
\hline 12719 & 2485 & & 1 & $\mathrm{A1}$ & 283 & 14 & 1 & $\begin{array}{l}5.32 \\
\end{array}$ & 12 & & & 12 & & & & \\
\hline 12719 & 2485 & & 1 & A1 & 283 & 14 & 2 & \begin{tabular}{l|l|}
2.86 \\
\end{tabular} & 2 & & & 2 & & & & \\
\hline 12719 & 2485 & & 1 & $\mathrm{~A} 1$ & 281 & 4 & 7 & 7.12 & 1 & 1 & & 1 & & & 1 & \\
\hline 12719 & 2485 & & 1 & $\mathrm{~A} 1$ & 281 & 4 & 2 & 5.54 & 1 & 1 & & 1 & & & 1 & \\
\hline 12719 & 2486 & & 1 & $\mathrm{A1}$ & 281 & 4 & 2 & 8.8 & 3 & 3 & & 3 & & 1 & 2 & \\
\hline 12719 & 2486 & & 1 & $\mathrm{~A} 1$ & 283 & 14 & 2 & 4.9 & 2 & & & 2 & & & & \\
\hline 12719 & 2486 & & 1 & $\mathrm{~A} 1$ & 281 & 4 & 3 & \begin{tabular}{|l|}
54.37 \\
\end{tabular} & 2 & 2 & & 2 & & & 2 & \\
\hline 12719 & 2486 & & 1 & A1 & 281 & 6 & 5 & \begin{tabular}{|l|}
4.97 \\
\end{tabular} & 1 & 1 & & & 1 & 1 & & \\
\hline 12719 & 2486 & & 1 & A1 & 283 & 14 & 1 & \begin{tabular}{|l|}
6.54 \\
\end{tabular} & 9 & & & 9 & & & & \\
\hline 12719 & 2487 & & 1 & $\mathrm{~A} 1$ & 281 & 4 & 1 & 1.21 & 1 & 1 & & 1 & & & 1 & \\
\hline 12719 & \begin{tabular}{|l|}
2487 \\
\end{tabular} & & 1 & A1 & 281 & 6 & 2 & $\begin{array}{ll}0.82 \\
\end{array}$ & 1 & 1 & & 1 & & 1 & & \\
\hline 12719 & 2487 & & 1 & $\mathrm{A1}$ & 283 & 14 & 2 & 14.15 & 6 & & & 6 & & & & \\
\hline 12719 & \begin{tabular}{|l|}
2487 \\
\end{tabular} & & 1 & $\mathrm{~A} 1$ & 283 & 14 & 1 & 14.26 & 31 & & & 31 & & & & \\
\hline 12719 & 2487 & & 1 & $\mathrm{A1}$ & 281 & 4 & 2 & \begin{tabular}{|l|}
8.87 \\
\end{tabular} & 3 & 3 & & 3 & & & 3 & 1 flake \\
\hline 12719 & \begin{tabular}{|l|}
2487 \\
\end{tabular} & & 1 & A1 & 281 & 6 & 1 & \begin{tabular}{|l|l|}
0.15 \\
\end{tabular} & 1 & 1 & & 1 & & & 1 & \\
\hline 12719 & 2488 & & 1 & $\overline{\mathrm{A} 1}$ & 283 & 14 & 3 & 11.41 & 1 & & & 1 & & & & \\
\hline 12719 & \begin{tabular}{|l|}
2488 \\
\end{tabular} & & 1 & A1 & 283 & 14 & 2 & 7.62 & 4 & & & 4 & & & & \\
\hline
\end{tabular}




\begin{tabular}{|c|c|c|c|c|c|c|c|c|c|c|c|c|c|c|c|c|}
\hline Site & Coll\# & Feature & Lev & Blk & $A C$ & Mat & $\mathrm{Sz}$ & Grams & Qty & Frac & $\mathrm{NF}$ & Disc $P$ & Disc A & Cort P & Cort A & Comments \\
\hline 12719 & 2488 & & 1 & A1 & 283 & 14 & 1 & 15.45 & 21 & & & 21 & & & & \\
\hline 12719 & 2488 & & 1 & $\mathrm{A1}$ & 281 & 4 & 3 & 20.43 & 2 & 2 & & 2 & & & 2 & \\
\hline 12719 & 2488 & & 1 & $\mathrm{A1}$ & 281 & 4 & 4 & 54.9 & 1 & 1 & & 1 & & 1 & & \\
\hline 12719 & 2488 & & 1 & A1 & 281 & 6 & 3 & 6.35 & 1 & 1 & & 1 & & 1 & & \\
\hline 12719 & 2490 & & 1 & $\mathrm{~A} 1$ & 283 & 14 & 2 & 5.3 & 1 & & & 1 & & & & \\
\hline 12719 & 2490 & & 1 & $\mathrm{~A} 1$ & 281 & 4 & 1 & 1.12 & 1 & 1 & & 1 & & & 1 & \\
\hline 12719 & 2490 & & 1 & $\mathrm{~A} 1$ & 281 & 6 & 2 & 3.77 & 1 & 1 & & 1 & & 1 & & \\
\hline 12719 & 2490 & & 1 & $\mathrm{~A} 1$ & 281 & 4 & 2 & 6.21 & 3 & 3 & & 3 & & & 3 & \\
\hline 12719 & 2491 & & 1 & $\overline{\mathrm{A} 1}$ & 283 & 14 & 2 & $\begin{array}{ll}7.03 \\
\end{array}$ & 3 & & & 3 & & & & \\
\hline 12719 & 2491 & & 1 & $\bar{A} 1$ & 281 & 4 & 3 & 16.05 & 1 & 1 & & 1 & & & 1 & \\
\hline 12719 & 2491 & & 1 & $\mathrm{~A} 1$ & 281 & 4 & 1 & 0.81 & 1 & 1 & & 1 & & & 1 & \\
\hline 12719 & 2491 & & 1 & A1 & 283 & 14 & 1 & 2.79 & 6 & & & 6 & & & & \\
\hline 12719 & 2492 & & 2 & $\mathrm{~A} 1$ & 821 & 4 & 2 & 2.08 & 1 & 1 & & 1 & & & 1 & \\
\hline 12719 & 2492 & & 2 & $\mathrm{~A} 1$ & 281 & 4 & 1 & 1.11 & 2 & 2 & & 2 & & 1 & 1 & \\
\hline 12719 & 2492 & & 2 & $\mathrm{~A} 1$ & 283 & 14 & 1 & 3.57 & 5 & & & 5 & & & & \\
\hline 12719 & 2493 & & 2 & $\mathrm{~A} 1$ & 283 & 14 & 1 & 4.44 & 5 & & & 5 & & & & \\
\hline 12719 & 2493 & & 2 & $\mathrm{~A} 1$ & 281 & 4 & 3 & 15.44 & 1 & 1 & & 1 & & 1 & & \\
\hline 12719 & 2493 & & 2 & $\mathrm{~A} 1$ & 281 & 4 & 4 & 11.54 & 1 & 1 & & 1 & & & 1 & \\
\hline 12719 & 2493 & & 2 & A1 & 283 & 14 & 2 & 1.11 & 1 & & & 1 & & & & \\
\hline 12719 & 2493 & & 2 & $\mathrm{~A} 1$ & 283 & 14 & 3 & 14.87 & 1 & & & 1 & & & & \\
\hline 12719 & 2494 & & 2 & $\mathrm{~A} 1$ & 281 & 4 & 1 & 0.21 & 1 & 1 & & 1 & & & 1 & \\
\hline 12719 & 2494 & & 2 & $\mathrm{~A} 1$ & 283 & 14 & 3 & 9.58 & 1 & & & 1 & & & & \\
\hline 12719 & 2494 & & 2 & $\mathrm{~A} 1$ & 283 & 14 & 1 & 2.82 & 3 & & & 3 & & & & \\
\hline 12719 & 2494 & & 2 & $\mathrm{~A} 1$ & 281 & 4 & 2 & 3.57 & 2 & 2 & & 2 & & & 2 & \\
\hline 12719 & 2495 & & 2 & $\mathrm{~A} 1$ & 283 & 14 & 1 & 5.21 & 12 & & & 12 & & & & \\
\hline 12719 & 2495 & & 2 & $\mathrm{~A} 1$ & 281 & 4 & 1 & 1.4 & 1 & 1 & & 1 & & & 1 & \\
\hline 12719 & 2496 & & 1 & $\mathrm{~A} 1$ & 283 & 14 & 1 & 3.98 & 10 & & & 10 & & & & \\
\hline 12719 & 2496 & & 1 & $\mathrm{~A} 1$ & 283 & 14 & 2 & 12.96 & 6 & & & 6 & & & & \\
\hline 12719 & 2496 & & 1 & $\bar{A} 1$ & 281 & 4 & 4 & \begin{tabular}{|l|}
50.16 \\
\end{tabular} & 1 & 1 & & 1 & & 1 & & \\
\hline 12719 & 2496 & & 1 & $\mathrm{~A} 1$ & 281 & 4 & 2 & \begin{tabular}{|l|l|}
4.28 \\
\end{tabular} & 2 & 2 & & 2 & & 1 & 1 & \\
\hline 12719 & 2496 & & 1 & $\mathrm{~A} 1$ & 281 & 4 & 1 & 1.38 & 3 & 3 & & 3 & & & 3 & \\
\hline 12719 & 2497 & & 2 & $\mathrm{~A} 1$ & 281 & 4 & 1 & 1.13 & 3 & 3 & & 3 & & & 3 & \\
\hline 12719 & 2497 & & 2 & $\mathrm{~A} 1$ & 283 & 14 & 2 & 14.24 & 2 & & & 2 & & & & \\
\hline 12719 & 2497 & & 2 & $\mathrm{~A} 1$ & 283 & 14 & 1 & 6.1 & 10 & & & 10 & & & & \\
\hline 12719 & 2498 & & 2 & $\mathrm{~A} 1$ & 281 & 4 & 2 & 8.45 & 3 & 3 & & 3 & & 1 & 2 & \\
\hline 12719 & \begin{tabular}{|l|}
2498 \\
\end{tabular} & & 2 & $\mathrm{~A} 1$ & 281 & 4 & 1 & \begin{tabular}{l|}
2.59 \\
\end{tabular} & 2 & 2 & & 2 & & 1 & 1 & \\
\hline 12719 & \begin{tabular}{|l|}
2498 \\
\end{tabular} & & 2 & $\mathrm{~A} 1$ & 283 & 14 & 1 & 2.86 & 10 & & & 10 & & & & \\
\hline 12719 & 2498 & & 2 & $\overline{\mathrm{A} 1}$ & 283 & 14 & 2 & 3.99 & 2 & & & 2 & & & & \\
\hline 12719 & 2499 & & & $\mathrm{~A} 1$ & 281 & 6 & 1 & 0.91 & 1 & 1 & & 1 & & & 1 & \\
\hline 12719 & 2499 & & & A1 & 283 & 14 & 1 & $\begin{array}{l}5.84 \\
\end{array}$ & 9 & & & 9 & & & & \\
\hline 12719 & 2499 & & & A1 & 281 & 4 & 1 & 0.54 & 3 & 3 & & 3 & & & 3 & \\
\hline 12719 & 2500 & 85 & 7 & A1 & 281 & 6 & 1 & 0.21 & 2 & 2 & & 2 & & & 2 & \\
\hline 12719 & 2500 & 85 & 7 & $\overline{A 1}$ & 283 & 14 & 1 & 4.9 & 9 & & & 9 & & & & \\
\hline 12719 & 2500 & 85 & 7 & A1 & 283 & 14 & 2 & 2.72 & 2 & & & 2 & & & & \\
\hline 12719 & 2501 & 85 & 7 & A1 & 283 & 14 & 2 & 5.94 & 3 & & & 3 & & & & \\
\hline 12719 & 2501 & 85 & 7 & $\mathrm{~A} 1$ & 283 & 14 & 1 & 4.88 & 4 & & & 4 & & & & \\
\hline 12719 & 2503 & 32 & 5 & $\mathrm{~A} 1$ & 281 & 4 & 2 & 2.21 & 2 & 2 & & 2 & & & 2 & \\
\hline 12719 & 2503 & 32 & 5 & $A 1$ & 283 & 14 & 1 & \begin{tabular}{|l|}
3.15 \\
\end{tabular} & 4 & & & 4 & & & & \\
\hline 12719 & 2504 & 32 & 6 & $\mathrm{~A} 1$ & 281 & 4 & 1 & $\begin{array}{l}0.07 \\
\end{array}$ & 1 & 1 & & 1 & & & 1 & \\
\hline 12719 & 2504 & 32 & 6 & A1 & 283 & 14 & 1 & 1.14 & 4 & & & 4 & & & & \\
\hline 12719 & 2505 & 32 & 6 & A1 & 283 & 14 & 2 & 1.32 & 1 & & & 1 & & & & \\
\hline 12719 & \begin{tabular}{|l|}
2506 \\
\end{tabular} & 32 & 5 & $\mathrm{A1}$ & 281 & 4 & 1 & 0.55 & 1 & 1 & & 1 & & & 1 & \\
\hline 12719 & 2506 & 32 & 7 & $\mathrm{~A} 1$ & 281 & 4 & 2 & 3.08 & 1 & 1 & & 1 & & 1 & & \\
\hline 12719 & 2506 & 32 & 7 & $\mathrm{~A} 1$ & 283 & 14 & 1 & 3.26 & 6 & & & 6 & & & & \\
\hline 12719 & 2508 & 32 & 5 & $\mathrm{~A} 1$ & 281 & 4 & 1 & \begin{tabular}{l|l|}
0.92 \\
\end{tabular} & 1 & 1 & & 1 & & & 1 & \\
\hline 12719 & \begin{tabular}{|l|}
2508 \\
\end{tabular} & 32 & 5 & $\mathrm{~A} 1$ & 281 & 4 & 4 & 26.11 & 1 & 1 & & 1 & & 1 & & \\
\hline 12719 & \begin{tabular}{|l|}
2508 \\
\end{tabular} & 32 & 5 & $\mathrm{A1}$ & 283 & 14 & 2 & 12.69 & 5 & & & 5 & & & & \\
\hline 12719 & 2508 & 32 & 5 & $\mathrm{~A} 1$ & 283 & 14 & 4 & 43.26 & 1 & & & 1 & & & & \\
\hline 12719 & 2508 & 32 & 5 & $\mathrm{~A} 1$ & 283 & 14 & 1 & \begin{tabular}{|l|}
5.91 \\
\end{tabular} & 9 & & & 9 & & & & \\
\hline 12719 & \begin{tabular}{|l|}
2508 \\
\end{tabular} & 32 & 5 & $\mathrm{~A} 1$ & 283 & 14 & 3 & 8.53 & 1 & & & 1 & & & & \\
\hline 12719 & 2510 & 32 & 6 & $\mathrm{~A} 1$ & 283 & 14 & 8 & 832 & 1 & & & 1 & & & & \\
\hline 12719 & 2510 & 32 & 6 & $\mathrm{~A} 1$ & 283 & 14 & 4 & 31.48 & 1 & & & 1 & & & & \\
\hline 12719 & 2510 & 32 & 6 & $\mathrm{~A} 1$ & 283 & 14 & 4 & 45.67 & 3 & & & 3 & & & & \\
\hline 12719 & 2510 & 32 & 6 & $\mathrm{~A} 1$ & 283 & 14 & 1 & 18.01 & 26 & & & 26 & & & & \\
\hline 12719 & 2510 & 32 & 6 & $\mathrm{~A} 1$ & 283 & 14 & 2 & $\begin{array}{l}11.8 \\
\end{array}$ & 5 & & & 5 & & & & \\
\hline 12719 & 2510 & 32 & 6 & $\mathrm{~A} 1$ & 283 & 14 & 3 & 8.56 & 2 & & & 2 & & & & \\
\hline 12719 & 2512 & 32 & 7 & $\mathrm{~A} 1$ & 283 & 14 & 3 & 5.55 & 1 & & & & 1 & & & \\
\hline 12719 & 2512 & 32 & 7 & $\mathrm{~A} 1$ & 283 & 14 & 1 & 3.29 & 5 & & & 5 & & & & \\
\hline
\end{tabular}




\begin{tabular}{|c|c|c|c|c|c|c|c|c|c|c|c|c|c|c|c|c|}
\hline Site & Coll \# & Feature & Lev & Blk & $A C$ & Mat & $\mathrm{Sz}$ & Grams & Qty & Frac & $\mathrm{NF}$ & Disc P & Disc A & Cort $P$ & Cort A & Comments \\
\hline 12719 & 2512 & 32 & 7 & A1 & 283 & 14 & 2 & 13.32 & 3 & & & 3 & & & & \\
\hline 12719 & 2513 & 32 & 5 & $\mathrm{~A} 1$ & 281 & 4 & 1 & 1.16 & 1 & 1 & & 1 & & & 1 & \\
\hline 12719 & 2513 & 32 & 5 & A1 & 281 & 4 & 3 & 14.21 & 1 & 1 & & 1 & & & & \\
\hline 12719 & 2513 & 32 & 5 & $\mathrm{~A} 1$ & 283 & 14 & 2 & 6.45 & 2 & & & 2 & & & & \\
\hline 12719 & 2513 & 32 & 5 & A1 & 283 & 14 & 3 & 4.32 & 1 & & & 1 & & & & \\
\hline 12719 & 2513 & 32 & 5 & A1 & 283 & \begin{tabular}{|l|}
14 \\
\end{tabular} & 1 & 1.38 & 1 & & & 1 & & & & \\
\hline 12719 & 2516 & 32 & 5 & A1 & 283 & 14 & 1 & 16.1 & 15 & & & 15 & & & & \\
\hline 12719 & 2516 & 32 & 5 & $\mathrm{~A} 1$ & 283 & 14 & 2 & 24.98 & 9 & & & 9 & & & & \\
\hline 12719 & \begin{tabular}{|l|}
2516 \\
\end{tabular} & 32 & 5 & A1 & 281 & 4 & 1 & 0.68 & 2 & 2 & & 2 & & & 2 & \\
\hline 12719 & 2516 & 32 & 5 & A1 & 281 & 4 & 2 & 2.58 & 2 & 2 & & 2 & & & 2 & \\
\hline 12719 & 2516 & 32 & 5 & $\mathrm{~A} 1$ & 283 & 14 & 3 & 35.15 & 2 & & & 2 & & & & \\
\hline 12719 & 2517 & & 2 & A1 & 281 & 4 & 2 & 3.03 & 1 & 1 & & 1 & & 1 & & \\
\hline 12719 & 2517 & & 2 & A1 & 283 & 14 & 3 & 4.2 & 1 & & & 1 & & & & \\
\hline 12719 & 2517 & & 2 & A1 & 281 & 4 & 5 & 115.46 & 1 & 1 & & 1 & & & 1 & 1 flake \\
\hline 12719 & 2517 & & 2 & A1 & 283 & 14 & 2 & 3.6 & 2 & & & 2 & & & & \\
\hline 12719 & 2517 & & 2 & $\mathrm{~A} 1$ & 283 & 14 & 1 & 2.41 & 3 & & & 3 & & & & \\
\hline 12719 & 2518 & & 2 & $\mathrm{~A} 1$ & 283 & 14 & 1 & 2.66 & 4 & & & 4 & & & & \\
\hline 12719 & 2518 & & 2 & A1 & 281 & 6 & 4 & \begin{tabular}{|c|}
19.1 \\
\end{tabular} & 1 & 1 & & 1 & & 1 & & \\
\hline 12719 & 2518 & & 2 & A1 & 281 & 4 & 1 & 0.53 & 1 & 1 & & 1 & & & 1 & \\
\hline 12719 & 2518 & & 2 & $\mathrm{~A} 1$ & 283 & 14 & 2 & 1.54 & 1 & & & 1 & & & & \\
\hline 12719 & \begin{tabular}{|l|}
2519 \\
\end{tabular} & 32 & 6 & A1 & 283 & 14 & 3 & 23.6 & 2 & & & 2 & & & & \\
\hline 12719 & \begin{tabular}{|l|}
2519 \\
\end{tabular} & 32 & 6 & A1 & 281 & 4 & 2 & 9.86 & 2 & 2 & & 2 & & 1 & 1 & \\
\hline 12719 & \begin{tabular}{|l|}
2519 \\
\end{tabular} & 32 & 6 & $\mathrm{~A} 1$ & 283 & 14 & 2 & 26.85 & 7 & & & 7 & & & & \\
\hline 12719 & \begin{tabular}{|l|}
2519 \\
\end{tabular} & 32 & 6 & A1 & 283 & 14 & 1 & 30.33 & 33 & & & 33 & & & & \\
\hline 12719 & 2519 & 32 & 6 & $\mathrm{A1}$ & 281 & 4 & 1 & 0.84 & 2 & 2 & & 2 & & & 2 & \\
\hline 12719 & \begin{tabular}{|l|}
2519 \\
\end{tabular} & 32 & 6 & $\mathrm{~A} 1$ & 281 & 4 & 7 & 643.2 & 1 & 1 & & 1 & & & 1 & \\
\hline 12719 & 2520 & 32 & 7 & A1 & 283 & 14 & 2 & 4.66 & 2 & & & 2 & & & & \\
\hline 12719 & \begin{tabular}{|l|}
2520 \\
\end{tabular} & 32 & 7 & $\mathrm{~A} 1$ & 281 & 7 & 2 & 2.1 & 1 & 1 & & 1 & & & 1 & \\
\hline 12719 & 2520 & 32 & 7 & $\bar{A} 1$ & 283 & 14 & 3 & 17.19 & 1 & & & 1 & & & & \\
\hline 12719 & \begin{tabular}{|l|}
2520 \\
\end{tabular} & 32 & 7 & A1 & 283 & 14 & 1 & 5.58 & 7 & & & 7 & & & & \\
\hline 12719 & \begin{tabular}{|l|}
2521 \\
\end{tabular} & & 1 & $\mathrm{~A} 1$ & 283 & 14 & 4 & 29.2 & 1 & & & 1 & & & & \\
\hline 12719 & \begin{tabular}{|l|}
2521 \\
\end{tabular} & & 1 & $\mathrm{~A} 1$ & 281 & 4 & 4 & 17.18 & 1 & 1 & & 1 & & & 1 & \\
\hline 12719 & \begin{tabular}{|l|}
2521 \\
\end{tabular} & & 1 & $\mathrm{~A} 1$ & 283 & 14 & 2 & 11.04 & 3 & & & 3 & & & & \\
\hline 12719 & \begin{tabular}{|l|}
2521 \\
\end{tabular} & & 1 & $\mathrm{~A} 1$ & 283 & 14 & 1 & 1.05 & 3 & & & 3 & & & & \\
\hline 12719 & 2522 & & 1 & A1 & 281 & 4 & 2 & 124.36 & 1 & 1 & & 1 & & 1 & & \\
\hline 12719 & \begin{tabular}{|l|}
2522 \\
\end{tabular} & & 1 & $\mathrm{~A} 1$ & 283 & 14 & 2 & 1025 & 4 & & & 4 & & & & \\
\hline 12719 & 2522 & & 1 & A1 & 283 & 14 & 1 & 6.31 & 9 & & & 9 & & & & \\
\hline 12719 & 2523 & & 2 & $\mathrm{A1}$ & 283 & 14 & 3 & $\begin{array}{l}19.36 \\
\end{array}$ & 2 & & & 2 & & & & \\
\hline 12719 & \begin{tabular}{|l|}
2523 \\
\end{tabular} & & 2 & $\mathrm{~A} 1$ & 283 & 14 & 1 & 22.59 & 31 & & & 31 & & & & \\
\hline 12719 & 2523 & & 2 & $\mathrm{A1}$ & 283 & 14 & 2 & 26.59 & 7 & & & 7 & & & & \\
\hline 12719 & \begin{tabular}{|l|}
2523 \\
\end{tabular} & & 2 & A1 & 281 & 4 & 2 & 2.48 & 1 & 1 & & 1 & & & 1 & \\
\hline 12719 & 2523 & & 2 & $\mathrm{~A} 1$ & 281 & 4 & 4 & $81.18 \mid$ & 1 & 1 & & 1 & & 1 & & \\
\hline 12719 & \begin{tabular}{|l|}
2523 \\
\end{tabular} & & 2 & $\mathrm{A1}$ & 281 & 4 & 1 & \begin{tabular}{|l|}
1.27 \\
\end{tabular} & 3 & 3 & & 3 & & 1 & 2 & \\
\hline 12719 & 2524 & & 2 & A1 & 283 & 14 & 1 & \begin{tabular}{l|l}
6.06 \\
\end{tabular} & 6 & & & 6 & & & & \\
\hline 12719 & 2524 & & 2 & A1 & 281 & 4 & 1 & \begin{tabular}{|l|}
1.37 \\
\end{tabular} & 1 & 1 & & 1 & & & 1 & \\
\hline 12719 & 2524 & & 2 & $\mathrm{~A} 1$ & 281 & 4 & 2 & 4.19 & 1 & 1 & & 1 & & & 1 & \\
\hline 12719 & 2524 & & 2 & A1 & 283 & 14 & 2 & \begin{tabular}{|l|}
15.6 \\
\end{tabular} & 6 & & & 6 & & & & \\
\hline 12719 & 2524 & & 2 & A1 & 281 & 6 & 2 & \begin{tabular}{|l|l|}
2.43 \\
\end{tabular} & 1 & 1 & & 1 & & 1 & & \\
\hline 12719 & 2524 & & 2 & $\overline{\mathrm{A} 1}$ & 283 & 14 & 3 & \begin{tabular}{|c|}
30.13 \\
\end{tabular} & 3 & & & 3 & & & & \\
\hline 12719 & 2525 & & 2 & $\overline{A 1}$ & 281 & 4 & 3 & 4.72 & 1 & 1 & & 1 & & & 1 & \\
\hline 12719 & 2525 & & 2 & $\mathrm{~A} 1$ & 281 & 6 & 2 & 1.95 & 1 & 1 & & & 1 & 1 & & \\
\hline 12719 & 2525 & & 2 & $A 1$ & 283 & 14 & 2 & $\begin{array}{l}14.63 \\
\end{array}$ & 7 & & & 7 & & & & \\
\hline 12719 & 2525 & & 2 & $\mathrm{~A} 1$ & 283 & 14 & 4 & 51.99 & 1 & & & 1 & & & & \\
\hline 12719 & 2525 & & 2 & $\mathrm{~A} 1$ & 283 & 14 & 1 & 19.58 & 30 & & & 30 & & & & \\
\hline 12719 & 2525 & & 2 & A1 & 281 & 4 & 2 & 1.1 & 1 & 1 & & 1 & & & 1 & \\
\hline 12719 & 2526 & & 2 & A1 & 281 & 4 & 2 & $\begin{array}{l}0.87 \\
\end{array}$ & 1 & 1 & & 1 & & & 1 & \\
\hline 12719 & 2526 & & 2 & $\mathrm{~A} 1$ & 281 & 4 & 5 & 27.56 & 1 & 1 & & 1 & & & 1 & \\
\hline \begin{tabular}{|l|l|}
2719 \\
\end{tabular} & 2526 & & 2 & $\mathrm{~A} 1$ & 283 & 14 & 4 & \begin{tabular}{l|l|}
45.55 \\
\end{tabular} & 2 & & & 2 & & & & \\
\hline 12719 & 2526 & & 2 & A1 & 283 & 14 & 1 & $\begin{array}{l}12.86 \\
\end{array}$ & 15 & & & 15 & & & & \\
\hline 12719 & 2526 & & 2 & $\mathrm{~A} 1$ & 283 & 14 & 5 & 155.22 & 2 & & & 2 & & & & \\
\hline 12719 & 2526 & & 2 & $\mathrm{A1}$ & 283 & 14 & 2 & 13.57 & 4 & & & 4 & & & & \\
\hline 12719 & 2526 & & 2 & A1 & 281 & 4 & 3 & 39.35 & 2 & 2 & & 2 & & 1 & 1 & \\
\hline 12719 & 2527 & & 3 & $\mathrm{~A} 1$ & 283 & 14 & 3 & 28.03 & 1 & & & 1 & & & & \\
\hline 12719 & 2527 & & 3 & $\mathrm{A1}$ & 283 & 14 & 2 & 42.59 & 4 & & & 4 & & & & \\
\hline \begin{tabular}{|c|}
2719 \\
\end{tabular} & 2527 & & 3 & $\overline{A 1}$ & 281 & 4 & 4 & 52.67 & 1 & 1 & & 1 & & 1 & & \\
\hline 12719 & 2527 & & 3 & $\mathrm{A1}$ & 281 & 4 & 2 & 3.33 & 2 & 2 & & 2 & & & 2 & \\
\hline 12719 & 2527 & & 3 & $\mathrm{~A} 1$ & 283 & 14 & 1 & 12.17 & 15 & & & 15 & & & & \\
\hline 12719 & 2528 & & 4 & $\mathrm{A1}$ & 283 & 14 & 3 & 16.52 & 2 & & & 2 & & & & \\
\hline
\end{tabular}




\begin{tabular}{|c|c|c|c|c|c|c|c|c|c|c|c|c|c|c|c|c|}
\hline Site & Coll \# & \begin{tabular}{|l|} 
Feature \\
\end{tabular} & Lev & Blk & $\mathrm{AC}$ & Mat & $\mathrm{Sz}$ & Grams & Qty & Frac & $\mathrm{NF}$ & Disc $P$ & Disc A & \begin{tabular}{|l|} 
Cort $\mathrm{P}$ \\
\end{tabular} & Cort A & Comments \\
\hline 12719 & 2528 & & 4 & A1 & 281 & 7 & \begin{tabular}{|l|}
1 \\
\end{tabular} & 1.01 & 2 & 2 & & 2 & & & 2 & \\
\hline 12719 & 2528 & & 4 & A1 & 281 & 4 & 3 & 8.45 & 1 & 1 & & 1 & & & 1 & \\
\hline 12719 & 2528 & & 4 & $\mathrm{~A} 1$ & 283 & 14 & \begin{tabular}{|l|}
2 \\
\end{tabular} & 9.57 & 4 & & & 4 & & & & \\
\hline 12719 & 2528 & & 4 & A1 & 283 & 14 & 1 & 6.47 & 14 & & & 14 & & & & \\
\hline 12719 & 2529 & & 3 & $\overline{A 1}$ & 283 & 14 & 5 & 76.1 & 1 & & & 1 & & & & \\
\hline 12719 & 2529 & & 3 & $\mathrm{~A} 1$ & 281 & 4 & 2 & 4.04 & 1 & 1 & & 1 & & & 1 & \\
\hline 12719 & 2529 & & 3 & $\mathrm{~A} 1$ & 281 & 4 & 3 & 14.2 & 2 & 2 & & 2 & & & 2 & \\
\hline 12719 & 2529 & & 3 & $\mathrm{~A} 1$ & 283 & 14 & 4 & 44.08 & 2 & & & 2 & & & & \\
\hline 12719 & 2529 & & 3 & $\mathrm{~A} 1$ & 283 & 14 & 1 & 4.99 & 8 & & & 8 & & & & \\
\hline 12719 & 2529 & & 3 & $\mathrm{~A} 1$ & 283 & 14 & 2 & 5.77 & 4 & & & 4 & & & & \\
\hline 12719 & 2530 & & 2 & $\mathrm{~A} 1$ & 283 & 14 & 3 & 27.83 & 2 & & & 2 & & & & \\
\hline 12719 & 2530 & & 2 & $\mathrm{~A} 1$ & 283 & 14 & 1 & 12.66 & 12 & & & 12 & & & & \\
\hline 12719 & 2530 & & 2 & A1 & 281 & 4 & 4 & 52 & 2 & 2 & & 2 & & 1 & 1 & \\
\hline 12719 & 2530 & & 2 & $\mathrm{~A} 1$ & 281 & 4 & 2 & 2.68 & 1 & 1 & & 1 & & 1 & & \\
\hline 12719 & 2530 & & 2 & $\mathrm{~A} 1$ & 281 & 4 & 5 & 55.27 & 1 & 1 & & 1 & & 1 & & \\
\hline 12719 & 2530 & & 2 & $\mathrm{~A} 1$ & 283 & 14 & 2 & 32.79 & 11 & & & 11 & & & & \\
\hline 12719 & 2530 & & 2 & $\mathrm{~A} 1$ & 281 & 6 & 3 & 2.65 & 1 & 1 & & & 1 & 1 & & \\
\hline 12719 & 2530 & & 2 & $\mathrm{~A} 1$ & 281 & 4 & 3 & 28.82 & 1 & 1 & & 1 & & 1 & & \\
\hline 12719 & 2530 & & 2 & A1 & 283 & 14 & 5 & 30.01 & 1 & & & 1 & & & & \\
\hline 12719 & 2531 & & 2 & $\mathrm{~A} 1$ & 283 & 14 & 5 & 109.58 & 1 & & & 1 & & & & \\
\hline 12719 & 2531 & & 2 & $\mathrm{A1}$ & 283 & 14 & 2 & 27.24 & 6 & & & 6 & & & & \\
\hline 12719 & 2531 & & 2 & $\bar{A} 1$ & 283 & 14 & 1 & 17.36 & 28 & & & 28 & & & & \\
\hline 12719 & 2531 & & 2 & $\mathrm{~A} 1$ & 281 & 4 & 1 & 1.78 & 1 & 1 & & 1 & & & 1 & \\
\hline 12719 & 2531 & & 2 & $\mathrm{~A} 1$ & 281 & 6 & 2 & 2.56 & 1 & 1 & & & 1 & 1 & & \\
\hline 12719 & 2531 & & 2 & $\mathrm{~A} 1$ & 281 & 4 & 5 & 58.67 & 1 & 1 & & 1 & & & 1 & \\
\hline 12719 & 2531 & & 2 & $\mathrm{A1}$ & 281 & 4 & 2 & 6.88 & 2 & 2 & & 2 & & & 2 & \\
\hline 12719 & 2531 & & 2 & $\mathrm{~A} 1$ & 283 & 14 & 4 & 28.32 & 1 & & & 1 & & & & \\
\hline 12719 & 2532 & & 2 & $\mathrm{A1}$ & 281 & 4 & 2 & 8.76 & 2 & 2 & & 2 & & & 2 & 1 flake \\
\hline 12719 & 2532 & & 2 & $\overline{A 1}$ & 281 & 4 & 1 & 0.99 & 3 & 3 & & 1 & 2 & & 3 & \\
\hline 12719 & 2532 & & 2 & $\mathrm{~A} 1$ & 283 & 14 & 2 & 9.51 & 4 & & & 4 & & & & \\
\hline 12719 & 2532 & & 2 & A1 & 283 & 14 & 3 & 16.02 & 1 & & & 1 & & & & \\
\hline 12719 & 2532 & & 2 & A1 & 283 & 14 & 1 & 10.32 & 21 & & & 21 & & & & \\
\hline 12719 & 2533 & & 2 & A1 & 281 & 4 & 5 & 67.46 & 1 & 1 & & 1 & & 1 & & \\
\hline 12719 & 2533 & & 2 & $\overline{A 1}$ & 281 & 4 & 3 & 22.52 & 1 & 1 & & 1 & & & 1 & \\
\hline 12719 & 2533 & & 1 & A1 & 283 & 14 & 3 & 4.92 & 1 & & & 1 & & & & \\
\hline 12719 & 2533 & & 2 & A1 & 281 & 4 & 1 & 1.06 & 2 & 2 & & 2 & & & 2 & \\
\hline 12719 & 2533 & & 2 & A1 & 283 & 14 & 4 & 46.8 & 2 & & & 2 & & & & \\
\hline 12719 & 2533 & & 1 & $\mathrm{~A} 1$ & 283 & 14 & 2 & 22.49 & 10 & & & 10 & & & & \\
\hline 12719 & 2533 & & 1 & $\mathrm{A1}$ & 283 & 14 & 1 & 36.44 & 66 & & & 66 & & & & \\
\hline 12719 & 2533 & & 2 & $\mathrm{~A} 1$ & 281 & 6 & 1 & $\begin{array}{l}0.46 \\
\end{array}$ & 1 & 1 & & & 1 & & 1 & \\
\hline 12719 & 2533 & & 2 & A1 & 281 & 6 & 1 & 0.37 & 1 & 1 & & & 1 & & 1 & \\
\hline 12719 & 2534 & & 1 & A1 & 283 & 14 & 2 & 14.75 & 5 & & & 5 & & & & \\
\hline 12719 & 2534 & & 1 & $\mathrm{A1}$ & 281 & 4 & 2 & 4.11 & 1 & 1 & & 1 & & & 1 & \\
\hline 12719 & 2534 & & 1 & $\mathrm{~A} 1$ & 281 & 4 & 1 & 0.6 & 1 & 1 & & 1 & & & 1 & \\
\hline 12719 & 2534 & & 1 & A1 & 281 & 4 & 5 & \begin{tabular}{|l|l|}
42.97 \\
\end{tabular} & 1 & 1 & & 1 & & & 1 & \\
\hline 12719 & 2534 & & 1 & A1 & 283 & 14 & 1 & 15.87 & 16 & & & 16 & & & & \\
\hline 12719 & 2534 & & 1 & $\mathrm{~A} 1$ & 281 & 6 & 2 & 6.45 & 1 & 1 & & & 1 & 1 & & \\
\hline 12719 & 2535 & & 2 & $\mathrm{~A} 1$ & 281 & 6 & 1 & 0.35 & 1 & 1 & & & 1 & & 1 & \\
\hline 12719 & 2535 & & 2 & $\mathrm{~A} 1$ & 281 & 6 & 2 & 4.16 & 1 & 1 & & & 1 & & 1 & \\
\hline 12719 & 2535 & & 2 & $\mathrm{~A} 1$ & 281 & 6 & 2 & 2.6 & 1 & 1 & & & 1 & & 1 & \\
\hline 12719 & 2535 & & 2 & $\mathrm{~A} 1$ & 281 & 4 & 1 & 2.57 & 3 & 3 & & 3 & & & 3 & \\
\hline 12719 & 2535 & & 2 & $\mathrm{A1}$ & 281 & 7 & 2 & 1.3 & 1 & 1 & & & 1 & & 1 & \\
\hline 12719 & 2535 & & 2 & $\mathrm{~A} 1$ & 283 & 14 & 1 & 18.17 & 29 & & & 29 & & & & \\
\hline 12719 & 2535 & & 2 & $\mathrm{~A} 1$ & 281 & 4 & 2 & $\begin{array}{l}3.83 \\
\end{array}$ & 1 & 1 & & 1 & & 1 & & \\
\hline 12719 & 2535 & & 2 & $\mathrm{~A} 1$ & 283 & 14 & 2 & 11.49 & 5 & & & 5 & & & & \\
\hline 12719 & 2536 & & 1 & $\mathrm{A1}$ & 281 & 4 & 1 & 2.62 & 2 & 2 & & 2 & & 1 & 1 & \\
\hline 12719 & 2536 & & 1 & $\mathrm{~A} 1$ & 281 & 4 & 2 & 4.64 & 2 & 2 & & 2 & & 1 & 1 & \\
\hline 12719 & 2536 & & 1 & $\mathrm{~A} 1$ & 283 & 14 & 2 & 24.25 & 9 & & & 9 & & & & \\
\hline 12719 & 2536 & & 1 & $\mathrm{~A} 1$ & 283 & 14 & 1 & 29.68 & 57 & & & 57 & & & & \\
\hline 12719 & 3000 & & 3 & B1 & 281 & 4 & 1 & 0.68 & 2 & & 2 & 2 & & 2 & & \\
\hline 12719 & 3000 & & 3 & B1 & 283 & 14 & 1 & 1.08 & 6 & & & 6 & & & & \\
\hline 12719 & 3000 & & 3 & B1 & 283 & 14 & 2 & 5.32 & 2 & & & 2 & & & & \\
\hline 12719 & 3001 & & 3 & B1 & 283 & 14 & 2 & 4.39 & 1 & & & 1 & & & & \\
\hline 12719 & 3001 & & 3 & B1 & 283 & 14 & 3 & 30.18 & 3 & & & 3 & & & & \\
\hline 12719 & 3001 & & 3 & $\mathrm{~B} 1$ & 281 & 4 & 1 & 3.33 & 7 & 7 & & 7 & & 7 & & \\
\hline 12719 & 3001 & & 3 & $\mathrm{B1}$ & 281 & 4 & 2 & 4.38 & 2 & 2 & & 2 & & 1 & 1 & \\
\hline 12719 & 3001 & & 3 & $\mathrm{~B} 1$ & 281 & 4 & 3 & 15.88 & 2 & 2 & & 2 & & 2 & & \\
\hline 12719 & 3001 & & 3 & B1 & 283 & 14 & 1 & 4.16 & 19 & & & 19 & & & & \\
\hline
\end{tabular}




\begin{tabular}{|c|c|c|c|c|c|c|c|c|c|c|c|c|c|c|c|c|}
\hline Site & \begin{tabular}{|l|l|} 
Coll \# \\
\end{tabular} & \begin{tabular}{|l|} 
Feature \\
\end{tabular} & Lev & Bik & $\mathrm{AC}$ & Mat & $\mathrm{Sz}$ & Grams & Qty & Frac & $\mathrm{NF}$ & Disc P & Disc A & Cort P & Cort A & Comments \\
\hline 12719 & 3002 & & 3 & B1 & 283 & 14 & 2 & 21.2 & 7 & & & 7 & & & & \\
\hline 12719 & 3002 & & 3 & B1 & 283 & 14 & 3 & 8.32 & 1 & & & 1 & & & & \\
\hline 12719 & 3002 & & 3 & B1 & 283 & 14 & 1 & 9.05 & 25 & & & 25 & & & & \\
\hline 12719 & 3002 & & 3 & $\mathrm{B1}$ & 281 & 4 & 1 & 4.76 & 8 & & 8 & 8 & & 8 & & \\
\hline 12719 & 3002 & & 3 & B1 & 281 & 4 & 2 & 4.28 & 1 & & 1 & 1 & & 1 & & \\
\hline 12719 & 3003 & & 3 & $\mathrm{~B} 1$ & 283 & 14 & 2 & 17.3 & 5 & & & 5 & & & & \\
\hline 12719 & 3003 & & 3 & $\mathrm{B1}$ & 283 & 14 & 3 & 28.17 & 3 & & & 3 & & & & \\
\hline 12719 & 3003 & & 3 & $B 1$ & 283 & 14 & 1 & 9.03 & 18 & & & 18 & & & & \\
\hline 12719 & 3004 & & 3 & $\mathrm{~B} 1$ & 283 & 14 & 1 & 5.52 & 6 & & & 6 & & & & \\
\hline 12719 & 3004 & & 3 & $\mathrm{~B} 1$ & 283 & 14 & 3 & 8.62 & 2 & & & 2 & & & & \\
\hline 12719 & 3004 & & 3 & $\mathrm{B1}$ & 283 & 14 & 2 & 27.57 & 8 & & & 8 & & & & \\
\hline 12719 & 3005 & & 4 & B1 & 283 & 14 & 2 & 18.95 & 10 & & & 10 & & & & \\
\hline 12719 & 3005 & & 4 & $B 1$ & 283 & 14 & 3 & 5.36 & 1 & & & 1 & & & & \\
\hline 12719 & 3005 & & 4 & $\mathrm{~B} 1$ & 281 & 4 & 3 & 9.72 & 1 & & 1 & 1 & & 1 & & \\
\hline 12719 & 3005 & & 4 & B1 & 281 & 4 & 1 & 2.58 & 9 & 8 & 1 & 9 & & 8 & 1 & \\
\hline 12719 & 3005 & & 4 & $B 1$ & 283 & 14 & 1 & 6.84 & 21 & & & 21 & & & & \\
\hline 12719 & 3006 & & 4 & B1 & 283 & 14 & 1 & 8.49 & 23 & & & 23 & & & & \\
\hline 12719 & 3006 & & 4 & $B 1$ & 281 & 4 & 5 & 817.7 & 4 & 4 & & 4 & & 4 & & from same rock \\
\hline 12719 & 3006 & & 4 & $\mathrm{B1}$ & 281 & 4 & 4 & 51.41 & 2 & 2 & & 2 & & 2 & & \\
\hline 12719 & 3006 & & 4 & $B 1$ & 281 & 4 & 1 & 9.69 & 22 & 22 & & 22 & & 7 & 15 & \\
\hline 12719 & 3006 & & 4 & $\mathrm{B1}$ & 283 & 14 & 2 & 12.61 & 7 & & & 7 & & & & \\
\hline 12719 & 3006 & & 4 & $\mathrm{~B} 1$ & 281 & 4 & 3 & 7.94 & 1 & 1 & & 1 & & 1 & & \\
\hline 12719 & 3006 & & 4 & $\mathrm{~B} 1$ & 281 & 4 & 2 & 36.39 & 6 & 6 & & 6 & & 4 & 2 & \\
\hline 12719 & 3007 & & 4 & B1 & 281 & 4 & 1 & 6.71 & 15 & 15 & & 15 & & 9 & 6 & \\
\hline 12719 & 3007 & & 4 & $\mathrm{B1}$ & 281 & 4 & 2 & 6.78 & 2 & 2 & & 2 & & 2 & & \\
\hline 12719 & 3007 & & 4 & $\mathrm{B1}$ & 283 & 14 & 1 & 9.85 & 18 & & & 18 & & & & \\
\hline 12719 & 3007 & & 4 & $\mathrm{B1}$ & 281 & 4 & 4 & 162.98 & 2 & 2 & & 2 & & 2 & & \\
\hline 12719 & 3007 & & 4 & $\mathrm{~B} 1$ & 281 & 4 & 3 & 7.65 & 2 & 2 & & 2 & & 1 & 1 & \\
\hline 12719 & 3007 & & 4 & B1 & 283 & 14 & 2 & 35.21 & 13 & & & 13 & & & & \\
\hline 12719 & 3008 & & 4 & $\mathrm{~B} 1$ & 281 & 4 & 3 & 15.83 & 2 & 2 & & 2 & & 2 & & \\
\hline 12719 & 3008 & & 4 & B1 & 281 & 4 & 1 & 2 & 6 & 6 & & 6 & & 4 & 2 & \\
\hline 12719 & 3008 & & 4 & $\mathrm{~B} 1$ & 281 & 4 & 2 & 10.65 & 2 & 2 & & 2 & & 2 & & \\
\hline 12719 & 3008 & & 4 & B1 & 281 & 4 & 6 & 187.42 & 1 & 1 & & 1 & & 1 & & \\
\hline 12719 & 3008 & & 4 & B1 & 283 & 14 & 2 & 19.55 & 8 & & & 8 & & & & \\
\hline 12719 & 3008 & & 4 & $\mathrm{~B} 1$ & 283 & 14 & 1 & 5.66 & 14 & & & 14 & & & & \\
\hline 12719 & 3009 & & 4 & $\mathrm{~B} 1$ & 283 & 14 & 2 & 18.29 & 4 & & & 4 & & & & \\
\hline 12719 & 3009 & & 4 & $\mathrm{~B} 1$ & 283 & 14 & 3 & 12.02 & 1 & & & 1 & & & & \\
\hline 12719 & 3009 & & 4 & $\mathrm{~B} 1$ & 281 & 4 & 2 & 7.83 & 1 & 1 & & 1 & & & 1 & \\
\hline 12719 & 3009 & & 4 & $\mathrm{~B} 1$ & 283 & 14 & 1 & 7.4 & 17 & & & 17 & & & & \\
\hline 12719 & 3009 & & 4 & B1 & 283 & 14 & 4 & 30.3 & 1 & & & 1 & & & & \\
\hline 12719 & 3010 & & 3 & $\mathrm{~B} 1$ & 281 & 4 & 1 & 5.62 & 16 & 14 & 2 & 16 & & 4 & 12 & \\
\hline 12719 & 3010 & & 3 & B1 & 283 & 14 & 2 & 22.56 & 10 & & & 10 & & & & \\
\hline 12719 & 3010 & & 3 & $\mathrm{B1}$ & 281 & 4 & 2 & $\begin{array}{l}4.78 \\
\end{array}$ & 6 & 2 & 4 & 6 & & 6 & & \\
\hline 12719 & 3010 & & 3 & B1 & 283 & 14 & 1 & 2.51 & 16 & & & 16 & & & & \\
\hline 12719 & 3011 & & 3 & B1 & 281 & 4 & 1 & 5.23 & 12 & 9 & 3 & 12 & & 7 & 5 & \\
\hline 12719 & 3011 & & 3 & $\mathrm{~B} 1$ & 283 & 14 & 3 & 7.07 & 1 & & & 1 & & & & \\
\hline 12719 & 3011 & & 3 & B1 & 283 & 14 & 2 & 14.25 & 5 & & & 5 & & & & \\
\hline 12719 & 3011 & & 3 & B1 & 283 & 14 & 1 & 5.65 & 23 & & & 23 & & & & \\
\hline 12719 & 3012 & & 4 & $\mathrm{B1}$ & 281 & 4 & 2 & 3.26 & 1 & & & & & & & \\
\hline 12719 & 3012 & & 4 & $\mathrm{B1}$ & 283 & 14 & 1 & 8.14 & 17 & & & 17 & & & & \\
\hline 12719 & 3012 & & 4 & B1 & 283 & 14 & 2 & 12.34 & 4 & & & 4 & & & & \\
\hline 12719 & 3012 & & 4 & B1 & 283 & 14 & 4 & 14.53 & 1 & & & 1 & & & & \\
\hline 12719 & 3012 & & 4 & B1 & 281 & 4 & 1 & 1.31 & 3 & 3 & & 3 & & 1 & $\overline{2}$ & \\
\hline 12719 & $\begin{array}{l}3012 \\
\end{array}$ & & 4 & B1 & 283 & 14 & 3 & 20.7 & 2 & & & 2 & & & & \\
\hline 12719 & 3013 & & 4 & $\mathrm{~B} 1$ & 281 & 4 & 2 & 5.38 & 3 & 2 & 1 & 3 & & 2 & 1 & \\
\hline 12719 & 3013 & & 4 & $\mathrm{Bt}$ & 281 & 4 & 1 & 1.53 & 10 & 9 & 1 & 8 & 2 & 2 & 8 & \\
\hline 12719 & 3013 & & 4 & B1 & 283 & 14 & 1 & \begin{tabular}{|l|l|}
4.16 \\
\end{tabular} & 12 & & & 12 & & & & \\
\hline 12719 & $\begin{array}{l}3013 \\
\end{array}$ & & 4 & B1 & 283 & 14 & 2 & 14.74 & 5 & & & 5 & & & & \\
\hline 12719 & 3014 & & 3 & B1 & 281 & 4 & 1 & 26.2 & 71 & 71 & & 71 & & 71 & & \\
\hline 12719 & 3014 & & 3 & B1 & 283 & 14 & 1 & \begin{tabular}{|l|}
2.95 \\
\end{tabular} & 5 & & & 5 & & & & \\
\hline 12719 & 3014 & & 4 & $\mathrm{~B} 1$ & 281 & 4 & 6 & 258.3 & 1 & 1 & & 1 & & 1 & & \\
\hline 12719 & 3014 & & 3 & B1 & 283 & 14 & 4 & 32.49 & 1 & & & 1 & & & & \\
\hline 12719 & 3014 & & 3 & B1 & 283 & 14 & 2 & \begin{tabular}{|l|l|}
8.45 \\
\end{tabular} & 3 & & & 3 & & & & \\
\hline 12719 & 3014 & & 3 & $B 1$ & 281 & 4 & 2 & $\begin{array}{l}21.13 \\
\end{array}$ & 6 & 6 & & 6 & & 6 & & \\
\hline 12719 & 3014 & & 3 & B1 & 281 & 4 & 4 & 35.95 & 4 & 4 & & 4 & & 4 & & \\
\hline 12719 & 3014 & & 4 & $\mathrm{B1}$ & 281 & 4 & 5 & 131.96 & 1 & 1 & & 1 & & 1 & & \\
\hline 12719 & 3014 & & 3 & $\mathrm{B1}$ & 281 & 4 & 3 & 14.47 & 1 & 1 & & 1 & & 1 & & \\
\hline 12719 & 3015 & & 4 & $\mathrm{~B} 1$ & 283 & 14 & 2 & 10.05 & 7 & & & 7 & & & & \\
\hline
\end{tabular}




\begin{tabular}{|c|c|c|c|c|c|c|c|c|c|c|c|c|c|c|c|c|}
\hline Site & Coll \# & Feature & Lev & Blk & $A C$ & Mat & $\mathrm{Sz}$ & Grams & Qty & Frac & NF & Disc $P$ & Disc A & Cort $P$ & Cort A & Comments \\
\hline 12719 & 3015 & & 4 & $\mathrm{B1}$ & 281 & 4 & 5 & 58.9 & 1 & 1 & & 1 & & 1 & & \\
\hline 12719 & 3015 & & 4 & B1 & 281 & 4 & 2 & 53.46 & 15 & 15 & & 15 & & 15 & & \\
\hline 12719 & 3015 & & 4 & B1 & 283 & 14 & 1 & 4.33 & 15 & & & 15 & & & & \\
\hline 12719 & 3015 & & 4 & $\mathrm{B1}$ & 283 & 14 & 3 & 14.99 & 2 & & & 2 & & & & \\
\hline 12719 & 3015 & & 4 & $\mathrm{~B} 1$ & 281 & 4 & 1 & 32.04 & 87 & 87 & & 87 & & 87 & & \\
\hline 12719 & 3015 & & 4 & $\mathrm{~B} 1$ & 281 & 4 & 4 & 64.28 & 2 & 2 & & 2 & & 2 & & \\
\hline 12719 & 3015 & & 4 & B1 & 281 & 4 & 3 & 30.84 & 4 & 4 & & 4 & & 4 & & \\
\hline 12719 & 3016 & & 4 & $\mathrm{~B} 1$ & 283 & 14 & 1 & 5.3 & 20 & & & 20 & & & & \\
\hline 12719 & 3016 & & 4 & $\mathrm{B1}$ & 281 & 4 & 6 & 158.57 & 1 & 1 & & 1 & & 1 & & \\
\hline 12719 & 3016 & & 4 & $\mathrm{~B} 1$ & 281 & 4 & 5 & 16.72 & 1 & 1 & & 1 & & & 1 & \\
\hline 12719 & 3016 & & 4 & $\mathrm{~B} 1$ & 283 & 14 & 2 & 3.44 & 2 & & & 2 & & & & \\
\hline 12719 & 3016 & & 4 & B1 & 281 & 4 & 2 & 4.82 & 1 & 1 & & & 1 & 1 & & \\
\hline 12719 & 3016 & & 4 & B1 & 281 & 4 & 1 & 5.57 & 11 & 11 & & 11 & & 11 & & \\
\hline 12719 & 3017 & & 4 & $\mathrm{~B} 1$ & 281 & 4 & 1 & 7.44 & 10 & 10 & & 10 & & 10 & & \\
\hline 12719 & 3017 & & 4 & B1 & 281 & 4 & 2 & 4.01 & 1 & 1 & & 1 & & 1 & & \\
\hline 12719 & 3017 & & 4 & B1 & 281 & 4 & 3 & 40.73 & 2 & 2 & & 2 & & 2 & & \\
\hline 12719 & 3017 & & 4 & B1 & 283 & 14 & 2 & 6.72 & 4 & & & 4 & & & & \\
\hline 12719 & 3017 & & 4 & $\mathrm{~B} 1$ & 283 & 14 & 1 & 4.43 & 12 & & & 12 & & & & \\
\hline 12719 & 3018 & & 5 & B1 & 283 & 14 & 1 & 1.34 & 6 & & & 6 & & & & \\
\hline 12719 & 3018 & & 5 & B1 & 283 & 14 & 2 & 1.68 & 2 & & & 2 & & & & \\
\hline 12719 & 3018 & & 5 & $\mathrm{B1}$ & 281 & 4 & 2 & 0.46 & 1 & 1 & & 1 & & 1 & & \\
\hline 12719 & 3018 & & 5 & B1 & 281 & 4 & 3 & 18.95 & 2 & 2 & & 2 & & 2 & & \\
\hline 12719 & 3018 & & 5 & $\mathrm{~B} 1$ & 281 & 4 & 1 & 2.43 & 9 & 9 & & 9 & & 3 & 6 & \\
\hline 12719 & 3019 & & 5 & B1 & 283 & 14 & 1 & 2.24 & 6 & & & 6 & & & & \\
\hline 12719 & 3019 & & 5 & $B 1$ & 281 & 4 & & & & & & & & & & \\
\hline 12719 & 3019 & & 5 & $\mathrm{B1}$ & 283 & 14 & 2 & 2.63 & 1 & & & 1 & & & & \\
\hline 12719 & 3019 & & 5 & $\mathrm{B1}$ & 283 & 14 & 3 & 6.14 & 1 & & & 1 & & & & \\
\hline 12719 & 3020 & & 5 & $\mathrm{B1}$ & 281 & 4 & 1 & 4.19 & 3 & 3 & & 3 & & 2 & 1 & \\
\hline 12719 & 3020 & & 5 & $\mathrm{B1}$ & 283 & 14 & 2 & 8.79 & 2 & & & 2 & & & & \\
\hline 12719 & 3020 & & 5 & B1 & 283 & 14 & 1 & 1.98 & 6 & & & 6 & & & & \\
\hline 12719 & 3021 & & 5 & B1 & 281 & 4 & 1 & 0.61 & 3 & 3 & & 3 & & & 3 & \\
\hline 12719 & 3021 & & 5 & B1 & 283 & 14 & 1 & 3.2 & 5 & & & 5 & & & & \\
\hline 12719 & 3022 & & 5 & $\mathrm{~B} 1$ & 281 & 4 & 1 & 0.99 & 1 & 1 & & 1 & & & 1 & \\
\hline 12719 & 3022 & & 5 & B1 & 283 & 14 & 2 & 1.57 & 1 & 1 & & 1 & & & 1 & \\
\hline 12719 & 3022 & & 5 & $\mathrm{~B} 1$ & 281 & 4 & 2 & 1.81 & 1 & 1 & & 1 & & & 1 & \\
\hline 12719 & 3022 & & 5 & B1 & 283 & 14 & 1 & 1.31 & 5 & 5 & & 5 & & & 5 & \\
\hline 12719 & 3023 & & 5 & B1 & 283 & 14 & 2 & 1.41 & 1 & & & 1 & & & & \\
\hline 12719 & 3023 & & 5 & $\mathrm{B1}$ & 281 & 4 & 1 & 2.76 & 4 & 4 & & 4 & & & 4 & \\
\hline 12719 & 3023 & & 5 & B1 & 281 & 6 & 2 & 2.7 & 1 & 1 & & & 1 & 1 & & \\
\hline 12719 & 3023 & & 5 & B1 & 281 & 4 & 2 & 17.7 & 3 & 3 & & 3 & & 1 & 2 & \\
\hline 12719 & 3023 & & 5 & B1 & 283 & 14 & 1 & 0.92 & 3 & & & 3 & & & & \\
\hline 12719 & 3023 & & 5 & B1 & 281 & 4 & 3 & 20.1 & 1 & & 1 & 1 & & 1 & & \\
\hline 12719 & 3024 & & 5 & $\mathrm{~B} 1$ & 283 & 14 & 1 & 3.48 & 6 & & & 6 & & & & \\
\hline 12719 & 3024 & & 5 & B1 & 281 & 4 & 1 & 2.71 & 3 & 3 & & 3 & & & 3 & \\
\hline 12719 & 3025 & & 5 & B1 & 281 & 4 & 2 & 13.28 & 4 & 4 & & 4 & & 2 & 2 & \\
\hline 12719 & 3025 & & 5 & B1 & 283 & 14 & 2 & 8.03 & 5 & & & 5 & & & & \\
\hline 12719 & 3025 & & 5 & B1 & 281 & 6 & 1 & 0.91 & 2 & 2 & & 2 & & & 2 & \\
\hline 12719 & 3025 & & 5 & B1 & 283 & 14 & 1 & 6.94 & 20 & & & 20 & & & & \\
\hline 12719 & 3025 & & 5 & B1 & 281 & 4 & 1 & 3.28 & 6 & 6 & & 6 & & & 6 & \\
\hline 12719 & 3025 & & 5 & B1 & 281 & 4 & 5 & 114.62 & 1 & 1 & & 1 & & 1 & & \\
\hline 12719 & 3026 & & 5 & B1 & 281 & 4 & 1 & 3.52 & 6 & 6 & & 6 & & & 6 & \\
\hline 12719 & 3026 & & 5 & B1 & 281 & 4 & 2 & 5.48 & 2 & 2 & & 2 & & 1 & 1 & \\
\hline 12719 & 3026 & & 5 & B1 & 281 & 6 & 2 & 1.23 & 1 & 1 & & 1 & & & 1 & \\
\hline 12719 & 3026 & & 5 & B1 & 283 & 14 & 2 & 5.49 & 3 & & & 3 & & & & \\
\hline 12719 & 3026 & & 5 & B1 & 281 & 4 & 2 & 10.96 & 1 & 1 & & 1 & & 1 & & \\
\hline 12719 & 3026 & & 5 & B1 & 283 & 14 & 1 & 10.78 & 32 & & & 32 & & & & \\
\hline 12719 & 3027 & & 5 & $\mathrm{~B} 1$ & 281 & 4 & 4 & 76.81 & 1 & 1 & & 1 & & 1 & & \\
\hline 12719 & 3027 & & 5 & $\mathrm{~B} 1$ & 281 & 4 & 2 & 6.82 & 3 & 3 & & 3 & & 1 & 2 & \\
\hline 12719 & 3027 & & 5 & $\mathrm{~B} 1$ & 283 & 14 & 2 & 15 & 5 & & & 5 & & & & \\
\hline 12719 & 3027 & & 5 & B1 & 283 & 14 & 1 & 6.11 & 13 & & & 13 & & & & \\
\hline 12719 & 3027 & & 5 & B1 & 283 & 14 & 3 & 6.1 & 1 & & & 1 & & & & \\
\hline 12719 & 3027 & & 5 & B1 & 281 & 4 & 3 & 16.58 & 1 & 1 & & 1 & & 1 & & \\
\hline 12719 & 3027 & & 5 & B1 & 281 & 4 & 1 & 3.6 & 8 & 8 & & 8 & & & 8 & \\
\hline 12719 & 3028 & & 4 & B1 & 283 & 14 & 1 & 5.02 & 8 & & & 8 & & & & \\
\hline 12719 & 3028 & & 4 & B1 & 281 & 4 & 1 & 8.18 & 11 & 11 & & 11 & & 1 & 10 & \\
\hline 12719 & 3028 & & 4 & $\mathrm{~B} 1$ & 283 & 14 & 2 & 24.39 & 6 & & & 6 & & & & \\
\hline 12719 & 3029 & & 5 & B1 & 283 & 14 & 1 & 5.68 & 17 & & & 17 & & & & \\
\hline 12719 & 3029 & & 5 & B1 & 283 & 14 & 3 & 11.46 & 1 & & & 1 & & & & \\
\hline
\end{tabular}




\begin{tabular}{|c|c|c|c|c|c|c|c|c|c|c|c|c|c|c|c|c|}
\hline Site & Coll \# & Feature & Lev & Blk & $A C$ & Mat & $S z$ & Grams & Qty & Frac & $\mathrm{NF}$ & Disc $\mathrm{P}$ & Disc A & Cort $\mathrm{P}$ & Cort A & Comments \\
\hline 12719 & 3029 & & 5 & B1 & 281 & 4 & 2 & \begin{tabular}{|l|}
4.08 \\
\end{tabular} & 2 & 2 & & 2 & & & 2 & \\
\hline 12719 & 3029 & & 5 & B1 & 283 & 14 & 2 & 9.59 & 6 & & & 6 & & & & \\
\hline 12719 & 3029 & & 5 & B1 & 281 & 4 & 1 & 0.84 & 4 & 4 & & 4 & & & 4 & \\
\hline 12719 & 3029 & & 5 & B1 & 281 & 4 & 4 & 32.2 & 1 & 1 & & 1 & & 1 & & \\
\hline 12719 & 3030 & & 5 & B1 & 283 & 14 & 1 & 6.7 & 19 & & & 19 & & & & \\
\hline 12719 & 3030 & & 5 & B1 & 281 & 4 & 3 & 27.21 & 2 & 2 & & 2 & & 2 & & \\
\hline 12719 & 3030 & & 5 & B1 & 283 & 14 & 2 & 13.63 & 7 & & & 7 & & & & \\
\hline 12719 & 3030 & & 5 & $\mathrm{~B} 1$ & 281 & 4 & 2 & 4.05 & 2 & 2 & & 2 & & & 2 & \\
\hline 12719 & 3030 & & 5 & B1 & 281 & 4 & 1 & 2.95 & 9 & 9 & & 9 & & & 9 & \\
\hline 12719 & 3030 & & 5 & $\mathrm{~B} 1$ & 281 & 4 & 4 & 36.17 & 1 & 1 & & 1 & & 1 & & \\
\hline 12719 & 3031 & & 5 & B1 & 281 & 4 & 1 & 2.84 & 9 & 9 & & 9 & & & 9 & \\
\hline 12719 & 3032 & & 4 & $\mathrm{~B} 1$ & 283 & 14 & 1 & 5.29 & 11 & & & 11 & & & & \\
\hline 12719 & 3032 & & 4 & $\mathrm{~B} 1$ & 283 & 14 & 2 & 9 & 3 & & & 3 & & & & \\
\hline 12719 & 3032 & & 4 & $\mathrm{~B} 1$ & 283 & 14 & 3 & 9.43 & 1 & & & 1 & & & & \\
\hline 12719 & 3032 & & 4 & B1 & 281 & 4 & 1 & 3.77 & 6 & 6 & & 6 & & 1 & 5 & \\
\hline 12719 & 3033 & & 6 & $\mathrm{~B} 1$ & 281 & 4 & 2 & 1.45 & 1 & 1 & & 1 & & 1 & & \\
\hline 12719 & 3033 & & 6 & $\mathrm{~B} 1$ & 281 & 4 & 3 & 14.45 & 1 & 1 & & 1 & & 1 & & 1 flake \\
\hline 12719 & 3033 & & 6 & B1 & 281 & 4 & 1 & 0.53 & 3 & 3 & & 3 & & & 3 & \\
\hline 12719 & 3034 & & 5 & B1 & 283 & 14 & 2 & 13.02 & 6 & & & 6 & & & & \\
\hline 12719 & 3034 & & 5 & $\mathrm{B1}$ & 281 & 4 & 1 & 1.82 & 9 & 9 & & 9 & & & 9 & \\
\hline 12719 & 3034 & & 5 & $B 1$ & 283 & 14 & 1 & 5.67 & 14 & & & 14 & & & & \\
\hline 12719 & 3034 & & 5 & $\mathrm{~B} 1$ & 281 & 4 & 2 & 3.15 & 2 & 2 & & 2 & & & 2 & \\
\hline 12719 & 3035 & & 6 & $\mathrm{B1}$ & 281 & 4 & 1 & 0.33 & 2 & 2 & & 2 & & & 2 & \\
\hline 12719 & 3035 & & 6 & $\mathrm{~B} 1$ & 281 & .4 & 2 & 4.98 & 1 & 1 & & 1 & & 1 & & \\
\hline 12719 & 3036 & & 5 & $\mathrm{B1}$ & 283 & 14 & 1 & 3.05 & 11 & & & 11 & & & & \\
\hline 12719 & 3036 & & 5 & $\mathrm{B1}$ & 281 & 4 & 3 & 20.54 & 1 & 1 & & 1 & & 1 & & \\
\hline 12719 & 3036 & & 5 & $\mathrm{B1}$ & 281 & 4 & 1 & 4.29 & 10 & 10 & & 10 & & & 10 & \\
\hline 12719 & 3036 & & 5 & B1 & 281 & 4 & 2 & 5.76 & 5 & 5 & & 5 & & & 5 & \\
\hline 12719 & 3036 & & 5 & $\mathrm{~B} 1$ & 283 & 14 & 2 & 6.12 & 1 & & & 1 & & & & \\
\hline 12719 & 3038 & & 4 & B1 & 281 & 4 & 2 & 1.97 & 2 & 2 & & 2 & & 1 & 1 & \\
\hline 12719 & 3038 & & 4 & $\mathrm{~B} 1$ & 283 & 14 & 2 & 5.13 & 3 & & & 3 & & & & \\
\hline 12719 & 3038 & & 4 & $\mathrm{B1}$ & 281 & 4 & 1 & 1.21 & 4 & 4 & & 4 & & & 4 & \\
\hline 12719 & 3038 & & 4 & $\mathrm{~B} 1$ & 283 & 14 & 1 & 5.85 & 10 & & & 10 & & & & \\
\hline 12719 & 3039 & & 5 & $\mathrm{B1}$ & 283 & 14 & 2 & 11.91 & 3 & & & 3 & & & & \\
\hline 12719 & 3039 & & 5 & $\mathrm{~B} 1$ & 283 & 14 & 4 & 18.89 & 1 & & & 1 & & & & \\
\hline 12719 & 3039 & & 5 & $\mathrm{B1}$ & 281 & 4 & 1 & 2.05 & 5 & 5 & & 5 & & 1 & 4 & \\
\hline 12719 & 3039 & & 5 & $\mathrm{B1}$ & 281 & 6 & 1 & 0.22 & 1 & 1 & & 1 & & & 1 & \\
\hline 12719 & 3039 & & 5 & $\mathrm{B1}$ & 283 & 14 & 1 & 1.59 & 7 & & & $\overline{7}$ & & & & \\
\hline 12719 & 3040 & & 5 & $\mathrm{B1}$ & 283 & 14 & 2 & 11.23 & 3 & & & 3 & & & & \\
\hline 12719 & 3040 & & 5 & B1 & 281 & 4 & 1 & 2.53 & 6 & 6 & & 6 & & & 6 & \\
\hline 12719 & 3040 & & 5 & $\mathrm{~B} 1$ & 283 & 14 & 1 & 2.62 & 10 & & & 10 & & & & \\
\hline 12719 & 3040 & & 5 & $\mathrm{B1}$ & 281 & 4 & 2 & 0.88 & 1 & 1 & & 1 & & & 1 & \\
\hline 12719 & 3041 & & 5 & $\mathrm{B1}$ & 281 & 4 & 4 & 35.05 & 1 & 1 & & 1 & & 1 & & \\
\hline 12719 & 3041 & & 5 & $\mathrm{~B} 1$ & 281 & 4 & 1 & 1.68 & 4 & 4 & & 4 & & & 4 & \\
\hline 12719 & 3041 & & 5 & $\mathrm{~B} 1$ & 281 & 4 & 2 & 5.48 & 4 & 4 & & 4 & & & 4 & \\
\hline 12719 & 3042 & & 5 & $\mathrm{B1}$ & 283 & 14 & 1 & 6.06 & 13 & & & 13 & & & & \\
\hline 12719 & 3042 & & 5 & $\mathrm{~B} 1$ & 281 & 6 & 5 & 25.04 & 1 & 1 & & 1 & & & 1 & \\
\hline 12719 & 3042 & & 5 & $\mathrm{~B} 1$ & 283 & 14 & 2 & 8.61 & 3 & & & 3 & & & & \\
\hline 12719 & 3042 & & 5 & $\mathrm{B1}$ & 283 & 14 & 4 & 15.92 & 1 & & & 1 & & & & \\
\hline 12719 & 3043 & & 5 & $\mathrm{~B} 1$ & 281 & 4 & 3 & 16.35 & 5 & 5 & & 5 & & 5 & & \\
\hline 12719 & 3043 & & 5 & $\mathrm{~B} 1$ & 281 & 6 & 2 & 1.85 & 1 & 1 & & 1 & & & 1 & \\
\hline 12719 & 3043 & & 5 & B1 & 283 & 14 & 1 & 0.83 & 5 & & & 5 & & & & \\
\hline 12719 & 3043 & & 5 & $\mathrm{B1}$ & \begin{tabular}{|l|}
281 \\
\end{tabular} & 4 & 2 & 5.5 & 1 & 1 & & 1 & & 1 & & \\
\hline 12719 & 3043 & & 5 & $\mathrm{B1}$ & 283 & 14 & 2 & 1.08 & 1 & & & 1 & & & & \\
\hline 12719 & 3043 & & 5 & $B 1$ & 281 & 4 & 1 & 5.21 & 7 & 7 & & 7 & & & 7 & \\
\hline 12719 & 3044 & & 5 & $\mathrm{~B} 1$ & 281 & 4 & 1 & 4.64 & 12 & 12 & & 12 & & & 12 & \\
\hline 12719 & 3044 & & 5 & B1 & 283 & 14 & 1 & 10.33 & 30 & & & 30 & & & & \\
\hline 12719 & 3044 & & 5 & $B 1$ & 283 & 14 & 3 & 11.76 & 1 & & & 1 & & & & \\
\hline 12719 & 3044 & & 5 & B1 & \begin{tabular}{|l|}
283 \\
\end{tabular} & 14 & 2 & 4.64 & 2 & & & 2 & & & & \\
\hline 12719 & 3044 & & 5 & $\mathrm{B1}$ & \begin{tabular}{|l|}
281 \\
\end{tabular} & 4 & 2 & $\begin{array}{ll}7.26 \\
\end{array}$ & 4 & 4 & & 4 & & & 4 & \\
\hline 12719 & 3045 & & 5 & $\mathrm{B1}$ & \begin{tabular}{|l|}
283 \\
\end{tabular} & 14 & 3 & $\begin{array}{l}18.82 \\
\end{array}$ & 1 & & & 1 & & & & \\
\hline 12719 & 3045 & & 5 & B1 & 283 & 14 & 2 & \begin{tabular}{|l|}
9.5 \\
\end{tabular} & 3 & & & 3 & & & & \\
\hline 12719 & 3045 & & 5 & $\mathrm{B1}$ & \begin{tabular}{|l|}
283 \\
\end{tabular} & 14 & 1 & 3.62 & 7 & & & 7 & & & & \\
\hline 12719 & 3045 & & 5 & $\mathrm{B1}$ & 281 & 6 & 2 & 1.2 & 1 & 1 & & & 1 & 1 & & \\
\hline 12719 & 3045 & & 6 & $\mathrm{B1}$ & 281 & 4 & 1 & 1.38 & 4 & 4 & & 4 & & & 4 & \\
\hline 12719 & 3045 & & 5 & $B 1$ & \begin{tabular}{|l|}
281 \\
\end{tabular} & 4 & 2 & 3.41 & 2 & 2 & & 2 & & & 2 & \\
\hline 12719 & 3046 & & 6 & B1 & 281 & 4 & 1 & 9.09 & 18 & 18 & & 18 & & & 18 & \\
\hline 12719 & 3046 & & 6 & $\mathrm{~B} 1$ & 281 & 4 & 5 & \begin{tabular}{|l|}
126.45 \\
\end{tabular} & 1 & 1 & & 1 & & 1 & & \\
\hline
\end{tabular}




\begin{tabular}{|c|c|c|c|c|c|c|c|c|c|c|c|c|c|c|c|c|}
\hline Site & Coll \# & Feature & Lev & Blk & $A C$ & Mat & $\mathrm{Sz}$ & Grams & Qty & Frac & $\mathrm{NF}$ & Disc $P$ & Disc A & Cort $P$ & Cort A & Comments \\
\hline 12719 & 3046 & & 6 & B1 & 281 & 4 & 3 & 8.57 & 1 & 1 & & 1 & & 1 & & \\
\hline 12719 & 3046 & & 6 & B1 & 281 & 4 & 2 & 25.01 & 6 & 6 & & 6 & & & 6 & \\
\hline 12719 & 3046 & & 6 & $\mathrm{~B} 1$ & 283 & 14 & 1 & 16.4 & 45 & & & 45 & & & & \\
\hline 12719 & 3046 & & 6 & $\mathrm{~B} 1$ & 283 & 14 & 3 & 34.68 & 3 & & & 3 & & & & \\
\hline 12719 & 3046 & & 6 & B1 & 283 & 14 & 2 & 12.52 & 4 & & & 4 & & & & \\
\hline 12719 & 3047 & & 6 & B1 & 283 & 14 & 1 & 6.08 & 22 & & & 22 & & & & \\
\hline 12719 & 3047 & & 6 & B1 & 283 & 14 & 2 & 10.31 & 4 & & & 4 & & & & \\
\hline 12719 & 3047 & & 6 & B1 & 281 & 4 & 2 & 7.63 & 1 & 1 & & 1 & & & 1 & \\
\hline 12719 & 3047 & & 6 & B1 & 281 & 4 & 3 & \begin{tabular}{|l|}
30.42 \\
\end{tabular} & 1 & 1 & & 1 & & & 1 & \\
\hline 12719 & 3047 & & 6 & B1 & 281 & 4 & 4 & 82.36 & 2 & 2 & & 2 & & 1 & 1 & \\
\hline 12719 & 3047 & & 6 & B1 & 281 & 4 & 1 & 6.76 & 10 & 10 & & 10 & & & 10 & \\
\hline 12719 & 3048 & & 6 & B1 & 281 & 4 & 2 & 7.78 & 2 & 2 & & 2 & & 1 & 1 & \\
\hline 12719 & 3048 & & 6 & $\mathrm{~B} 1$ & 283 & 14 & 1 & 5.22 & 14 & & & 14 & & & & \\
\hline 12719 & 3048 & & 6 & B1 & 281 & 4 & 1 & 3.38 & 6 & 6 & & 6 & & & 6 & \\
\hline 12719 & 3048 & & 6 & $\mathrm{~B} 1$ & 281 & 4 & 4 & 26.77 & 1 & 1 & & 1 & & 1 & & \\
\hline 12719 & 3049 & & 6 & B1 & 283 & 14 & 2 & 11.82 & 6 & & & 6 & & & & \\
\hline 12719 & 3049 & & 6 & B1 & 281 & 4 & 1 & 2.44 & 2 & 2 & & 2 & & & 2 & \\
\hline 12719 & 3049 & & 6 & $\mathrm{~B} 1$ & 281 & 4 & 5 & 140.84 & 1 & 1 & & 1 & & 1 & & \\
\hline 12719 & 3049 & & 6 & B1 & 283 & 14 & 1 & 7.39 & 22 & & & 22 & & & & \\
\hline 12719 & 3050 & & 6 & $B 1$ & 281 & 4 & 1 & 0.91 & 1 & 1 & & 1 & & & 1 & \\
\hline 12719 & 3050 & & 6 & B1 & 283 & 14 & 3 & 11.88 & 1 & & & 1 & & & & \\
\hline 12719 & 3050 & & 6 & B1 & 281 & 4 & 4 & 42.61 & 2 & 2 & & 2 & & & 2 & \\
\hline 12719 & 3050 & & 6 & B1 & 283 & 14 & 1 & 4.44 & 11 & & & 11 & & & & \\
\hline 12719 & 3050 & & 6 & $\mathrm{B1}$ & 283 & 14 & 2 & 7.76 & 2 & & & 2 & & & & \\
\hline 12719 & 3051 & & 6 & $\mathrm{~B} 1$ & 281 & 4 & 1 & 0.52 & 1 & 1 & & 1 & & & 1 & \\
\hline 12719 & 3051 & & 6 & B1 & 283 & 14 & 2 & 4.81 & 4 & & & 4 & & & & \\
\hline 12719 & 3051 & & 6 & $\mathrm{B1}$ & 283 & 14 & 1 & 2.97 & 9 & & & 9 & & & & \\
\hline 12719 & 3051 & & 6 & $\mathrm{~B} 1$ & 281 & 4 & 3 & 6.93 & 1 & 1 & & 1 & & & 1 & \\
\hline 12719 & 3051 & & 6 & B1 & 281 & 4 & 2 & 4.83 & 1 & 1 & & 1 & & & 1 & \\
\hline 12719 & 3052 & & 6 & B1 & 283 & 14 & 2 & 4.22 & 1 & & & 1 & & & & \\
\hline 12719 & 3052 & & 6 & B1 & 281 & 4 & 5 & 45.25 & 1 & 1 & & 1 & & & 1 & \\
\hline 12719 & 3052 & & 6 & $\mathrm{B1}$ & 283 & 14 & 1 & 1.07 & 3 & & & 3 & & & & \\
\hline 12719 & 3052 & & 6 & $\mathrm{B1}$ & 281 & 6 & 1 & 1.74 & 2 & 2 & & 2 & & & 2 & \\
\hline 12719 & 3053 & & 6 & B1 & 283 & 14 & 1 & 1.53 & 2 & & & 2 & & & & \\
\hline 12719 & 3053 & & 6 & B1 & 281 & 4 & 2 & 4.05 & 1 & 1 & & 1 & & 1 & & \\
\hline 12719 & 3054 & & 6 & B1 & 281 & 4 & 1 & 0.23 & 1 & 1 & & 1 & & & 1 & \\
\hline 12719 & 3054 & & 6 & $\mathrm{BI}$ & 283 & 14 & 2 & 7 & 2 & & & 2 & & & & \\
\hline 12719 & 3055 & & 6 & $\mathrm{~B} 1$ & 283 & 14 & 1 & 1.43 & 3 & & & 3 & & & & \\
\hline 12719 & 3058 & & 6 & $\mathrm{~B} 1$ & 281 & 4 & 4 & 12.28 & 1 & 1 & & 1 & & 1 & & \\
\hline 12719 & 3058 & & 6 & $\mathrm{~B} 1$ & 283 & 14 & 1 & 2.87 & 4 & & & 4 & & & & \\
\hline 12719 & 3060 & & 6 & $\mathrm{B1}$ & 283 & 14 & 1 & 0.44 & 4 & & & 4 & & & & \\
\hline 12719 & 3063 & & 6 & $\overline{B 1}$ & 283 & 14 & 1 & 1.61 & 5 & & & 5 & & & & \\
\hline 12719 & 3063 & & 6 & B1 & 281 & 4 & 1 & 3.11 & 4 & 4 & & 4 & & & 4 & \\
\hline 12719 & 3064 & & 6 & $\mathrm{~B} 1$ & 281 & 4 & 2 & 12.11 & 2 & 2 & & 2 & & & 2 & \\
\hline 12719 & 3064 & & 6 & $\mathrm{~B} 1$ & 283 & 14 & 1 & 0.53 & 2 & & & 2 & & & & \\
\hline 12719 & 3064 & & 6 & $\mathrm{~B} 1$ & 281 & 4 & 1 & 1.04 & 1 & 1 & & 1 & & & 1 & \\
\hline 12719 & 3065 & & 6 & B1 & 283 & 14 & 1 & 1.82 & 7 & & & 7 & & & & \\
\hline 12719 & 3066 & & 6 & B1 & 283 & 14 & 1 & 1.38 & 1 & & & 1 & & & & \\
\hline 12719 & 3066 & & 6 & $\mathrm{~B} 1$ & 283 & 14 & 3 & 8.63 & 1 & & & 1 & & & & \\
\hline 12719 & 3066 & & 6 & B1 & 283 & 14 & 2 & 2.41 & 2 & & & 2 & & & & \\
\hline 12719 & 3067 & & 5 & B1 & 283 & 14 & 1 & 1.6 & 10 & & & 10 & & & & \\
\hline 12719 & 3067 & & 5 & B1 & 283 & 14 & 3 & 13.46 & 1 & & & 1 & & & & \\
\hline 12719 & 3068 & & 6 & B1 & 283 & 14 & 2 & 4.87 & 1 & & & 1 & & & & \\
\hline 12719 & 3068 & & 6 & $\mathrm{B1}$ & 283 & 14 & 1 & 3.38 & 7 & & & 7 & & & & \\
\hline 12719 & 3069 & & 5 & B1 & 283 & 14 & 1 & 2.81 & 3 & & & 3 & & & & \\
\hline 12719 & 3070 & & 5 & B1 & 283 & 14 & 1 & 2.69 & 7 & & & 7 & & & & \\
\hline 12719 & 3070 & & 5 & B1 & 283 & 14 & 2 & 5.36 & 2 & & & 2 & & & & \\
\hline 12719 & 3071 & & 6 & B1 & 283 & 14 & 4 & 36.63 & 1 & & & 1 & & & & \\
\hline 12719 & 3071 & & 6 & $\mathrm{B1}$ & 283 & 14 & 2 & 3.17 & 1 & & & 1 & & & & \\
\hline 12719 & 3071 & & 6 & $\mathrm{B1}$ & 283 & 14 & 3 & 13.19 & 2 & & & 2 & & & & \\
\hline 12719 & 3071 & & 6 & $\mathrm{~B} 1$ & 283 & 14 & 1 & 1.95 & 5 & & & 5 & & & & \\
\hline 12719 & 3072 & & 5 & $\mathrm{~B} 1$ & 281 & 4 & 2 & 4.17 & 1 & 1 & & 1 & & & 1 & \\
\hline 12719 & 3072 & & 5 & $\mathrm{~B} 1$ & 281 & 4 & 1 & 1.95 & 2 & 2 & & 2 & & & 2 & \\
\hline 12719 & 3072 & & 5 & B1 & 283 & 14 & 2 & 5.83 & 2 & & & 2 & & & & \\
\hline 12719 & 3072 & & 5 & B1 & 283 & 14 & 1 & 0.26 & 1 & & & 1 & & & & \\
\hline 12719 & 3072 & & 5 & B1 & 281 & 4 & 3 & 15.17 & 1 & 1 & & 1 & & 1 & & \\
\hline 12719 & 3074 & 30 & 6 & B1 & 281 & 4 & 1 & \begin{tabular}{|c|}
6.03 \\
\end{tabular} & 9 & 9 & & 9 & & & 9 & \\
\hline 12719 & 3074 & 30 & 6 & B1 & 281 & 4 & 5 & 142.59 & 1 & 1 & & 1 & & 1 & & \\
\hline
\end{tabular}




\begin{tabular}{|c|c|c|c|c|c|c|c|c|c|c|c|c|c|c|c|c|}
\hline Site & Coll \# & Feature & Lev & Blk & $A C$ & Mat & $\mathrm{Sz}$ & Grams & Qty & Frac & $\mathrm{NF}$ & Disc $\mathrm{P}$ & Disc A & Cort P & Cort A & Comments \\
\hline 12719 & 3074 & 30 & 6 & $\mathrm{~B} 1$ & 281 & 4 & 2 & 41.94 & 7 & 7 & & 7 & & 2 & 5 & \\
\hline 12719 & 3074 & 30 & 6 & B1 & 283 & 14 & 2 & 14.18 & 4 & & & 4 & & & & \\
\hline 12719 & 3074 & 30 & 6 & B1 & 283 & 14 & 1 & 9.61 & 20 & & & 20 & & & & \\
\hline 12719 & 3074 & 30 & 6 & B1 & 281 & 4 & 6 & 141.08 & 1 & 1 & & 7 & & & 1 & \\
\hline 12719 & 3075 & 30 & 6 & $\mathrm{~B} 1$ & 281 & 4 & 4 & 144.8 & 5 & 5 & & 5 & & 2 & 3 & \\
\hline 12719 & 3075 & 30 & 6 & B1 & 281 & 4 & 3 & 79.16 & 7 & 7 & & 7 & & 2 & 5 & \\
\hline 12719 & 3075 & 30 & 6 & $\mathrm{~B} 1$ & 281 & 4 & 5 & 363.4 & 3 & 3 & & 3 & & 2 & 1 & \\
\hline 12719 & 3075 & 30 & 6 & $\mathrm{~B} 1$ & 281 & 4 & 2 & 37.72 & 13 & 13 & & 13 & & & 13 & \\
\hline 12719 & 3075 & 30 & 6 & $\mathrm{~B} 1$ & 283 & 14 & 4 & 38.21 & 1 & & & 1 & & & & \\
\hline 12719 & 3075 & 30 & 6 & $\mathrm{B1}$ & 283 & 14 & 3 & 19.4 & 1 & & & 1 & & & & \\
\hline 12719 & 3075 & 30 & 6 & $\mathrm{B1}$ & 283 & 14 & 5 & 212.8 & 1 & & & 1 & & & & \\
\hline 12719 & 3075 & 30 & 6 & B1 & 283 & 14 & 2 & 27.33 & 12 & & & 12 & & & & \\
\hline 12719 & 3075 & 30 & 6 & B1 & 283 & 14 & 1 & 21.02 & 45 & & & 45 & & & & \\
\hline 12719 & 3075 & 30 & 6 & B1 & 281 & 4 & 1 & 11.02 & 12 & 12 & & 12 & & & 12 & \\
\hline 12719 & 3076 & 30 & 6 & B1 & 281 & 4 & 3 & 52.94 & 4 & 4 & & 4 & & 2 & 2 & \\
\hline 12719 & 3076 & 30 & 6 & B1 & 281 & 4 & 5 & 49.14 & 1 & 1 & & 1 & & 1 & & \\
\hline 12719 & 3076 & 30 & 6 & B1 & 281 & 4 & 4 & 21.46 & 1 & 1 & & 1 & & 1 & & \\
\hline 12719 & 3076 & 30 & 6 & B1 & 281 & 4 & 2 & 21.38 & 5 & 5 & & 5 & & & 5 & \\
\hline 12719 & 3076 & 30 & 6 & B1 & 283 & 14 & 5 & 154.37 & 2 & & & 2 & & & & \\
\hline 12719 & 3076 & 30 & 6 & $\mathrm{B1}$ & 283 & 14 & 1 & 22.9 & 51 & & & 51 & & & & \\
\hline 12719 & 3076 & 30 & 6 & B1 & 283 & 14 & 2 & 7.55 & 4 & & & 4 & & & & \\
\hline 12719 & 3076 & 30 & 6 & $\mathrm{B1}$ & 281 & 4 & 1 & 11.55 & 14 & 14 & & 14 & & & 14 & \\
\hline 12719 & 3077 & 30 & 6 & $\mathrm{B1}$ & 281 & 4 & 4 & 34.24 & 1 & 1 & & 1 & & 1 & & \\
\hline 12719 & 3078 & 30 & 6 & B1 & 281 & 4 & 4 & 34.12 & 1 & 1 & & 1 & & 1 & & \\
\hline 12719 & 3079 & 30 & 5 & $\mathrm{B1}$ & 281 & 4 & 1 & 12.45 & 20 & 20 & & 20 & & 2 & 18 & \\
\hline 12719 & 3079 & 30 & 5 & $\mathrm{~B} 1$ & 281 & 4 & 5 & 55.89 & 1 & 1 & & 1 & & & 1 & \\
\hline 12719 & 3079 & 30 & 5 & $\mathrm{B1}$ & 283 & 14 & 2 & 10.17 & 5 & & & 5 & & & & \\
\hline 12719 & 3079 & 30 & 5 & $\mathrm{~B} 1$ & 283 & 14 & 5 & 120.06 & 1 & & & 1 & & & & \\
\hline 12719 & 3079 & 30 & 5 & $\mathrm{B1}$ & 283 & 14 & 1 & 25.01 & 60 & & & 60 & & & & \\
\hline 12719 & 3079 & 30 & 5 & $\mathrm{B1}$ & 283 & 14 & 3 & 32.65 & 4 & & & 4 & & & & \\
\hline 12719 & 3079 & 30 & 5 & $\mathrm{~B} 1$ & 281 & 4 & 2 & 24.69 & 8 & 8 & & 8 & & & 8 & \\
\hline 12719 & 3088 & & 6 & $\mathrm{~B} 1$ & 283 & 14 & 1 & 2.93 & 2 & & & 2 & & & & \\
\hline 12719 & 3089 & & 6 & B1 & 283 & 14 & 1 & 2.98 & 2 & & & 2 & & & & \\
\hline 12719 & 3090 & & 7 & B1 & 283 & 14 & 3 & 7.07 & 1 & & & 1 & & & & \\
\hline 12719 & 3090 & & 7 & $\mathrm{~B} 1$ & 283 & 14 & 2 & 1.19 & 1 & & & 1 & & & & \\
\hline 12719 & 3090 & & 7 & B1 & 283 & 14 & 1 & 1.1 & 3 & & & 3 & & & & \\
\hline 12719 & 3095 & 77 & 5 & B1 & 283 & 14 & 2 & 9.23 & 2 & & & 2 & & & & \\
\hline 12719 & 3095 & 77 & 5 & B1 & 283 & 14 & 3 & 8.31 & 1 & & & 1 & & & & \\
\hline 12719 & 3096 & & 4 & B1 & 281 & 4 & 2 & 2.87 & 1 & 1 & & 1 & & & 1 & \\
\hline 12719 & 3096 & & 4 & B1 & 283 & 14 & 1 & 0.72 & 2 & & & 2 & & & & \\
\hline 12719 & 3097 & & 5 & $\mathrm{~B} 1$ & 283 & 14 & 3 & 16.49 & 1 & & & 1 & & & & \\
\hline 12719 & 3097 & & 5 & B1 & 281 & 4 & 2 & 8.88 & 1 & 1 & & 1 & & & 1 & \\
\hline 12719 & 3097 & & 5 & $\mathrm{B1}$ & 283 & 14 & 1 & 0.24 & 1 & & & 1 & & & & \\
\hline 12719 & 3097 & & 5 & $\mathrm{B1}$ & 283 & 14 & 2 & 6.89 & 1 & & & 1 & & & & \\
\hline 12719 & 3098 & 32 & 6 & $\mathrm{~A} 1$ & 283 & 14 & 1 & 0.1 & 1 & & & 1 & & & & \\
\hline 12719 & 3099 & & 1 & $\mathrm{~A} 1$ & 283 & 14 & 1 & 1.78 & 1 & & & 1 & & & & \\
\hline 12719 & 3099 & & 1 & $\mathrm{~A} 1$ & 283 & 14 & 2 & 9.79 & 2 & & & 2 & & & & \\
\hline 12719 & 3099 & & 1 & B1 & 281 & 4 & 2 & 2.43 & 1 & 1 & & & 1 & 1 & & \\
\hline 12719 & 3099 & & 1 & $\overline{A 1}$ & 281 & 4 & 2 & 5.77 & 1 & 1 & & 1 & & & 1 & \\
\hline 12719 & 3099 & & 1 & $\mathrm{~A} 1$ & 283 & 14 & 5 & 93.15 & 1 & & & 1 & & & & \\
\hline 12719 & 3099 & & 1 & $\mathrm{~A} 1$ & 281 & 4 & 3 & 14.71 & 1 & 1 & & 1 & & & 1 & \\
\hline 12719 & 4001 & & 1 & $\mathrm{~A} 1$ & 283 & 14 & 4 & 10.02 & 1 & & & 1 & & & & \\
\hline 12719 & 4001 & & 1 & $\mathrm{~A} 1$ & 283 & 14 & 2 & 17.57 & 5 & & & 5 & & & & \\
\hline 12719 & 4001 & & 1 & $\mathrm{~A} 1$ & 281 & 4 & 1 & 0.83 & 1 & 1 & & 7 & & & 1 & \\
\hline 12719 & 4001 & & 1 & A1 & 283 & 14 & 1 & 9.79 & 22 & & & 22 & & & & \\
\hline 12719 & 4001 & & 1 & $\mathrm{~A} 1$ & 281 & 6 & 3 & 5.88 & 1 & 1 & & & 1 & 1 & & \\
\hline 12719 & 4001 & & 1 & $\overline{\mathrm{A} 1}$ & 281 & 4 & 2 & 6.59 & 1 & 1 & & 1 & & 1 & & \\
\hline 12719 & 4001 & & 1 & $\overline{A 1}$ & 281 & 4 & 3 & 23.99 & 1 & 1 & & 1 & & 1 & & \\
\hline 12719 & 4002 & & 1 & $\bar{A} 1$ & 281 & 4 & 2 & 5.19 & 3 & 3 & & 3 & & & 3 & \\
\hline 12719 & 4002 & & 1 & A1 & 283 & 14 & 3 & 129.58 & 12 & & & 12 & & & & \\
\hline 12719 & 4002 & & 1 & $\mathrm{~A} 1$ & 281 & 6 & 3 & 2.87 & 1 & 1 & & 1 & & 1 & & \\
\hline 12719 & 4002 & & 1 & A1 & 281 & 4 & 2 & 23.02 & 8 & 8 & & 8 & & & 8 & \\
\hline 12719 & 4002 & & 1 & A1 & 281 & 4 & 1 & 2.43 & 7 & 7 & & 7 & & & 7 & \\
\hline 12719 & 4002 & & 1 & A1 & 281 & 4 & 3 & 10.36 & 1 & 1 & & 1 & & 1 & & \\
\hline 12719 & 4002 & & 1 & $\mathrm{~A} 1$ & 283 & 14 & 4 & 219.9 & 9 & & & 9 & & & & \\
\hline 12719 & 4002 & & 1 & $\mathrm{~A} 1$ & 283 & 14 & 2 & 166.83 & 52 & & & 52 & & & & \\
\hline 12719 & 4002 & & 1 & $\mathrm{~A} 1$ & 283 & 14 & 1 & 78.94 & 89 & & & 89 & & & & \\
\hline 12719 & 4002 & & 1 & A1 & 281 & 4 & 4 & \begin{tabular}{l|l}
64.37 \\
\end{tabular} & 3 & 3 & & 3 & & & & \\
\hline
\end{tabular}




\begin{tabular}{|c|c|c|c|c|c|c|c|c|c|c|c|c|c|c|c|c|}
\hline Site & Coll \# & Feature & Lev & BIk & $A C$ & Mat & $\mathrm{Sz}$ & Grams & Qty & Frac & NF & Disc P & Disc A & Cort P & Cort $A$ & Comments \\
\hline 12719 & 4002 & & 1 & A1 & 283 & 14 & 5 & 144.77 & 2 & & & 2 & & & & \\
\hline 12719 & 4003 & & 1 & A1 & 281 & 4 & 1 & 0.65 & 1 & 1 & & 1 & & & 1 & \\
\hline 12719 & 4003 & & 1 & $\overline{A 1}$ & 281 & 6 & 1 & 0.87 & 1 & 1 & & 1 & & & 1 & \\
\hline 12719 & 4004 & & 1 & $\mathrm{~A} 1$ & 283 & 14 & 2 & 5.86 & 3 & & & 3 & & & & \\
\hline 12719 & 4004 & & 1 & $\mathrm{~A} 1$ & 281 & 4 & 2 & 5 & 2 & 2 & & 2 & & & 2 & \\
\hline 12719 & 4004 & & 1 & A1 & 281 & 4 & 1 & 0.2 & 2 & 2 & & 2 & & & 2 & \\
\hline 12719 & 4004 & & 1 & A1 & 283 & 14 & 3 & 13.08 & 1 & & & 1 & & & & \\
\hline 12719 & 4004 & & 1 & A1 & 283 & 14 & 1 & 1.5 & 4 & & & 4 & & & & \\
\hline 12719 & 4004 & & 1 & $\mathrm{A1}$ & 281 & 4 & 4 & 72.61 & 2 & 2 & & 2 & & & 2 & \\
\hline 12719 & 4005 & & 1 & $\mathrm{A1}$ & 283 & 14 & 1 & 3.46 & 4 & & & 4 & & & & \\
\hline 12719 & 4005 & & 1 & $\mathrm{~A} 1$ & 283 & 14 & 2 & 4.36 & 2 & & & 2 & & & & \\
\hline 12719 & 4006 & & 1 & A1 & 283 & 14 & 1 & 96.61 & 92 & & & 92 & & & & \\
\hline 12719 & 4006 & & 1 & A1 & 283 & 14 & 6 & 237.8 & 1 & & & 1 & & & & \\
\hline 12719 & 4006 & & 1 & A1 & 283 & 14 & 5 & 105.94 & 2 & & & 2 & & & & \\
\hline 12719 & 4006 & & 1 & $\mathrm{~A} 1$ & 283 & 14 & 2 & 81.78 & 29 & & & 29 & & & & \\
\hline 12719 & 4006 & & 1 & A1 & 283 & 14 & 3 & 84.94 & 10 & & & 10 & & & & \\
\hline 12719 & 4006 & & 1 & A1 & 281 & 6 & 2 & 2.39 & 1 & 1 & & 1 & & & 1 & \\
\hline 12719 & 4006 & & 1 & A1 & 281 & 4 & 2 & 21.96 & 7 & 7 & & 7 & & & 7 & \\
\hline 12719 & 4006 & & 1 & A1 & 281 & 4 & 5 & 178.84 & 1 & 1 & & 1 & & & & \\
\hline 12719 & 4006 & & 1 & $\overline{\mathrm{A} 1}$ & 281 & 4 & 4 & 81.14 & 2 & 2 & & 1 & 1 & 1 & 1 & \\
\hline 12719 & 4006 & & 1 & $\mathrm{~A} 1$ & 281 & 4 & 1 & 9.51 & 14 & 14 & & 14 & & & 14 & \\
\hline 12719 & 4006 & & 1 & A1 & 281 & 4 & 3 & 56.04 & 4 & 4 & & 4 & & & 4 & \\
\hline 12719 & 4010 & & 2 & $\overline{\mathrm{A} 1}$ & 283 & 14 & 1 & 6.99 & 12 & & & 12 & & & & \\
\hline 12719 & 4010 & & 2 & $\mathrm{A1}$ & 283 & 14 & 2 & 2.56 & 2 & & & 2 & & & & \\
\hline 12719 & 4010 & & 2 & A1 & 281 & 4 & 2 & 8.63 & 3 & 3 & & 3 & & & 3 & \\
\hline 12719 & 4010 & & 2 & A1 & 281 & 4 & 4 & 63.49 & 2 & 2 & & 2 & & & 2 & \\
\hline \begin{tabular}{|c|}
12719 \\
\end{tabular} & 4014 & & 3 & A1 & 283 & 14 & 1 & 6.98 & 7 & & & 7 & & & & \\
\hline
\end{tabular}




\begin{tabular}{|c|c|c|c|c|c|c|c|c|c|c|c|c|c|c|c|c|}
\hline Site & Coll \# & Feature & Lv & Blk & $A C$ & Mat & $\mathrm{Sz}$ & Grams & Qty & $\mathrm{Fr}$ & $\mathrm{NF}$ & Disc P & Disc A & Cort P & Cort A & Comm \\
\hline 13237 & 123 & & & & 281 & 4 & 4 & 974.8 & 31 & 16 & 15 & 31 & & 31 & & \\
\hline 13237 & 123 & & & & 281 & 4 & 5 & 314.8 & 5 & 5 & & 5 & & 5 & & \\
\hline 13237 & 123 & & & & 281 & 4 & 1 & 18.37 & 21 & 15 & 6 & 21 & & 11 & 10 & \\
\hline 13237 & 123 & & & & 281 & 4 & 2 & 356.3 & 80 & 18 & 62 & 80 & & 80 & & \\
\hline 13237 & 123 & & & & \begin{tabular}{|l|}
281 \\
\end{tabular} & 4 & 3 & 890.4 & 77 & 30 & 47 & 77 & & 77 & & \\
\hline 13237 & 190 & 45 & & & 281 & 6 & 3 & 9.82 & 1 & 1 & & 1 & & 1 & & \\
\hline 13237 & 500 & & 2 & B1 & 281 & 4 & 4 & 177.4 & 4 & 4 & & 4 & & 4 & & \\
\hline 13237 & 500 & & 2 & B1 & 281 & 4 & 3 & 212.3 & 21 & 11 & 10 & 21 & & 12 & 9 & \\
\hline 13237 & 500 & & 2 & B1 & 281 & 4 & 2 & 117.8 & 38 & 38 & & 38 & & 13 & 25 & \\
\hline 13237 & 501 & & 2 & B1 & 281 & 4 & 3 & 154.85 & 15 & 13 & 2 & 15 & & 8 & 7 & \\
\hline 13237 & 501 & & 2 & B1 & 281 & 4 & 1 & 20.98 & 34 & 25 & 9 & 34 & & 11 & 14 & \\
\hline 13237 & 501 & & 2 & $B 1$ & 281 & 4 & 2 & 100.19 & 35 & 15 & 20 & 35 & & 25 & 10 & \\
\hline 13237 & 502 & & 2 & C1 & 281 & 4 & 4 & 69.3 & 1 & 1 & & 1 & & 1 & & \\
\hline 13237 & 502 & & 2 & $\mathrm{C1}$ & 281 & 4 & 2 & 67.7 & 21 & 16 & 5 & 21 & & 7 & 14 & \\
\hline 13237 & 502 & & 2 & C1 & 281 & 4 & 3 & 95.5 & 10 & 7 & 3 & 7 & & 6 & 4 & \\
\hline 13237 & 503 & & 2 & B1 & 281 & 4 & 5 & 901.4 & 11 & 5 & 6 & 11 & & 9 & 2 & \\
\hline 13237 & 503 & & 2 & B1 & 281 & 4 & 4 & 207.7 & 6 & 2 & 4 & 6 & & 4 & 2 & \\
\hline 13237 & 503 & & 2 & B1 & 281 & 4 & 1 & 30.92 & 29 & 29 & & 29 & & 5 & 24 & \\
\hline 13237 & 503 & & 2 & B1 & 281 & 4 & 2 & 226 & 49 & 31 & 18 & 49 & & 31 & 18 & \\
\hline 13237 & 503 & & 2 & B1 & 281 & 4 & 3 & 458 & 37 & 25 & 12 & 37 & & 19 & 18 & \\
\hline 13237 & 507 & & 2 & B1 & 281 & 4 & 6 & 253.1 & 1 & 1 & & & 1 & 1 & & \\
\hline 13237 & 507 & & 2 & B1 & \begin{tabular}{|l|}
281 \\
\end{tabular} & 4 & 5 & 482.7 & 2 & 2 & & 1 & 1 & 1 & 1 & \\
\hline 13237 & 507 & & 2 & $\mathrm{~B} 1$ & 281 & 4 & 2 & 71.54 & 18 & & 18 & 18 & & 18 & & \\
\hline 13237 & 507 & & 2 & B1 & 281 & 4 & 3 & 66.05 & 4 & 2 & 2 & 4 & & 3 & 1 & \\
\hline 13237 & 507 & & 2 & B1 & 281 & 4 & 4 & 231.1 & 7 & 7 & & 7 & & & 7 & \\
\hline 13237 & 510 & & 2 & B1 & 281 & 4 & 6 & 622.6 & 1 & & 1 & 1 & & 1 & & \\
\hline 13237 & 510 & & 2 & B1 & 281 & 4 & 4 & 222.7 & 9 & 2 & 7 & 9 & & 4 & 5 & \\
\hline 13237 & 510 & & 2 & B1 & 281 & 1 & 4 & 100.7 & 1 & 1 & & 1 & & 1 & & \\
\hline 13237 & 510 & & 2 & B1 & 281 & 4 & 2 & 79.42 & 25 & 13 & 12 & 25 & & & 25 & \\
\hline 13237 & 510 & & 2 & B1 & 281 & 4 & 3 & 93.95 & 9 & 2 & 7 & 9 & & 1 & 8 & \\
\hline 13237 & 511 & & 2 & $\mathrm{B1}$ & 281 & 4 & 6 & 402.1 & 2 & 1 & 1 & 2 & & 2 & & \\
\hline 13237 & 511 & & 2 & B1 & 281 & 4 & 7 & 418.4 & 1 & & 1 & 1 & & 1 & & \\
\hline 13237 & 511 & & 2 & $\mathrm{~B} 1$ & 281 & 4 & 5 & 866.7 & 8 & 5 & 3 & 6 & 2 & 6 & 2 & \\
\hline 13237 & 511 & & 2 & B1 & 281 & 4 & 1 & 12.16 & 19 & 19 & & 19 & & & 19 & \\
\hline 13237 & 511 & & 2 & B1 & 281 & 4 & 2 & 186.5 & 54 & 43 & 11 & 54 & & 15 & 39 & \\
\hline 13237 & 511 & & 2 & B1 & 281 & 4 & 4 & 660.3 & 21 & 15 & 6 & 21 & & 12 & 9 & \\
\hline 13237 & 511 & & 2 & B1 & 281 & 4 & 3 & 370.58 & 37 & 25 & 12 & 36 & 1 & 22 & 15 & \\
\hline 13237 & 512 & & 2 & B1 & 281 & 4 & 5 & 277.8 & 5 & 2 & 3 & 3 & 2 & 5 & & \\
\hline 13237 & 512 & & 2 & B1 & 281 & 4 & 4 & 535.5 & 16 & 6 & 10 & 16 & & 16 & & \\
\hline 13237 & 512 & & 2 & B1 & 281 & 4 & 1 & 1.05 & 1 & 1 & & 1 & & & 1 & \\
\hline 13237 & 512 & & 2 & B1 & 281 & 4 & 2 & 77.51 & 15 & 7 & 8 & 13 & 2 & 7 & 8 & \\
\hline 13237 & 512 & & 2 & B1 & 281 & 4 & 3 & 433.8 & 28 & 19 & 9 & 16 & 12 & 25 & 3 & \\
\hline 13237 & 515 & & 2 & $\mathrm{B1}$ & 281 & 4 & 4 & 143.14 & 5 & 4 & 1 & 2 & 3 & 2 & 3 & \\
\hline 13237 & 515 & & 2 & B1 & 281 & 4 & 2 & 87.3 & 19 & 13 & 6 & 10 & 9 & 1 & 18 & \\
\hline 13237 & 515 & & 2 & $B 1$ & 281 & 4 & 1 & 4.45 & 3 & 2 & 1 & 2 & 1 & & 3 & \\
\hline 13237 & 515 & & 2 & B1 & 281 & 4 & 3 & 74.9 & 7 & 5 & 2 & 7 & & 1 & 6 & \\
\hline 13237 & 516 & & 2 & B1 & 281 & 4 & 5 & 59.11 & 1 & 1 & & 1 & & 1 & & \\
\hline 13237 & 516 & & 2 & B1 & 281 & 4 & 6 & 272.9 & 1 & 1 & & 1 & & 1 & & \\
\hline 13237 & 516 & & 2 & B1 & 281 & 4 & 4 & 196.4 & 8 & 8 & & 3 & 5 & 3 & 5 & \\
\hline 13237 & 516 & & 2 & $\mathrm{B1}$ & 281 & 4 & 1 & 2.45 & 5 & 5 & & 5 & & 1 & 4 & \\
\hline 13237 & 516 & & 2 & B1 & 281 & 1 & 2 & 3.97 & 1 & 1 & & 1 & & 1 & & \\
\hline 13237 & 516 & & 2 & B1 & 281 & 4 & 3 & 102.51 & 13 & 13 & & 8 & 5 & 2 & 11 & \\
\hline 13237 & 516 & & 2 & $\mathrm{B1}$ & 281 & 4 & 2 & 83.48 & 31 & 31 & & 25 & 6 & 1 & 30 & \\
\hline 13237 & 517 & & 2 & 81 & 281 & 4 & 5 & 230.4 & 5 & 5 & & 3 & 2 & 3 & 2 & \\
\hline 13237 & 517 & & 2 & B1 & 281 & 4 & 6 & 533.3 & 2 & 2 & & & 2 & 2 & & \\
\hline 13237 & 517 & & 2 & B1 & 281 & 4 & 2 & 89.36 & 27 & 27 & & 25 & 2 & 4 & 23 & \\
\hline 13237 & 517 & & 2 & $\mathrm{B1}$ & 281 & 4 & 1 & 9.79 & 11 & 11 & & 3 & 8 & 3 & 8 & \\
\hline 13237 & 517 & & 2 & B1 & 281 & 4 & 4 & 231.8 & 11 & 11 & & 4 & 7 & 1 & 10 & \\
\hline 13237 & 517 & & 2 & B1 & 281 & 4 & 3 & 134.08 & 14 & 14 & & 13 & 1 & 4 & 10 & \\
\hline 13237 & 518 & & 2 & B1 & 281 & 4 & 5 & 484.1 & 7 & 7 & & 3 & 4 & 3 & 4 & \\
\hline 13237 & 518 & & 2 & B1 & 283 & 14 & 2 & 4.04 & 1 & & & 1 & & & & \\
\hline 13237 & 518 & & 2 & B1 & 281 & 4 & 2 & 251.5 & 63 & 61 & 2 & 38 & 23 & 7 & 56 & \\
\hline 13237 & 518 & & 2 & $\mathrm{~B} 1$ & 281 & 4 & 1 & 43.43 & 41 & 40 & 1 & 31 & 10 & 2 & 39 & \\
\hline 13237 & 518 & & 2 & B1 & 281 & 4 & 4 & 592.6 & 21 & 21 & & 8 & 13 & 3 & 18 & \\
\hline 13237 & 518 & & 2 & B1 & 281 & 4 & 3 & 309.9 & 28 & 28 & & 15 & 9 & 3 & 25 & \\
\hline 13237 & 519 & & 2 & B1 & 281 & 4 & 4 & 100.3 & 27 & 25 & 2 & 15 & 12 & 6 & 21 & \\
\hline 13237 & 519 & & 2 & B1 & 281 & 4 & 5 & 639.6 & 8 & 7 & 1 & 4 & 4 & 1 & 7 & \\
\hline 13237 & 519 & & 2 & B1 & 281 & 4 & 1 & 19.04 & 18 & 18 & & 15 & 3 & 2 & 16 & \\
\hline 13237 & 519 & & 2 & B1 & 281 & 1 & 2 & 2.72 & 1 & 1 & & 1 & & 1 & & \\
\hline
\end{tabular}




\begin{tabular}{|c|c|c|c|c|c|c|c|c|c|c|c|c|c|c|c|c|}
\hline Site & Coll \# & Feature & LV & Blk & $\overline{A C}$ & Mat & $\mathrm{Sz}$ & Grams & Qty & $\overline{F r}$ & NF & Disc P & Disc A & Cort $P$ & Cort A & Comm \\
\hline 13237 & 519 & & 2 & B1 & 281 & 4 & 3 & 523.1 & 43 & 41 & 2 & 18 & 25 & 2 & 41 & \\
\hline 13237 & 519 & & 2 & $\mathrm{~B} 1$ & 281 & 4 & 2 & 268.7 & 63 & 62 & 1 & 46 & 17 & 3 & 60 & \\
\hline 13237 & 520 & & 3 & $B 1$ & 281 & 4 & 5 & 333 & 3 & 3 & & 1 & 2 & 2 & 1 & \\
\hline 13237 & 520 & & 3 & B1 & 281 & 4 & 4 & 676.6 & 18 & 18 & & 16 & 2 & 4 & 14 & \\
\hline \begin{tabular}{|l|}
13237 \\
\end{tabular} & 520 & & 3 & $\mathrm{~B} 1$ & 281 & 4 & 2 & 334.4 & 70 & 68 & 2 & 57 & 13 & 6 & 64 & \\
\hline 13237 & 520 & & 3 & B1 & 281 & 4 & 1 & 22.48 & 18 & 18 & & 18 & & 1 & 17 & \\
\hline 13237 & 520 & & 3 & $\mathrm{~B} 1$ & 281 & 4 & 3 & 420.2 & 31 & 31 & & 23 & 8 & 7 & 24 & \\
\hline 13237 & 521 & & 3 & $\mathrm{~B} 1$ & 281 & 4 & 5 & 162 & 3 & 3 & & 2 & 1 & 2 & 1 & \\
\hline 13237 & 521 & & 3 & $\mathrm{~B} 1$ & 281 & 4 & 7 & 780.5 & 1 & & 1 & 1 & & 1 & & \\
\hline 13237 & 521 & & 3 & B1 & 281 & 4 & 4 & 47.22 & 3 & 3 & & 3 & & & 3 & \\
\hline 13237 & 521 & & 3 & $\mathrm{B1}$ & 281 & 4 & 1 & 22.16 & 20 & 20 & & 19 & 1 & 1 & 19 & \\
\hline 13237 & 521 & & 3 & B1 & 281 & 1 & 4 & 25.52 & 1 & 1 & & 1 & & 1 & & \\
\hline 13237 & 521 & & 3 & B1 & 281 & 4 & 3 & 209.6 & 23 & 22 & 1 & 21 & 2 & 4 & 19 & \\
\hline 13237 & 521 & & 3 & B1 & 281 & 4 & 2 & 123.62 & 36 & 36 & & 34 & 2 & 5 & 31 & \\
\hline 13237 & 522 & & 3 & $\mathrm{~B} 1$ & 281 & 4 & 6 & 508.1 & 1 & 1 & & 1 & & 1 & & \\
\hline 13237 & \begin{tabular}{l|}
522 \\
\end{tabular} & & 3 & B1 & 281 & 4 & 7 & 488.4 & 1 & 1 & & 1 & & 1 & & \\
\hline 13237 & \begin{tabular}{|l|}
522 \\
\end{tabular} & & 3 & B1 & 281 & 4 & 5 & 1503.9 & 14 & 14 & & 14 & & 14 & & \\
\hline 13237 & 522 & & 3 & B1 & 281 & 4 & 2 & 192 & 48 & 26 & 22 & 48 & & 11 & 37 & \\
\hline 13237 & 522 & & 3 & B1 & 281 & 4 & 1 & 15.48 & 27 & 25 & 2 & 27 & & 3 & 24 & \\
\hline 13237 & 522 & & 3 & B1 & 281 & 4 & 4 & 774 & 22 & 19 & 3 & 22 & & 22 & & \\
\hline 13237 & 522 & & 3 & B1 & 281 & 4 & 3 & 445.9 & 35 & 24 & 11 & 35 & & 7 & 28 & \\
\hline 13237 & 523 & & 3 & $\mathrm{~B} 1$ & 281 & 4 & 6 & 165 & 1 & 1 & & 1 & & 1 & & \\
\hline 13237 & \begin{tabular}{l|}
523 \\
\end{tabular} & & 3 & 81 & 281 & 4 & 7 & 1208.4 & 3 & 2 & 1 & 3 & & 3 & & \\
\hline 13237 & \begin{tabular}{|l|}
523 \\
\end{tabular} & & 3 & B1 & 281 & 4 & 5 & 400.5 & 7 & 3 & 4 & 7 & & 7 & & \\
\hline 13237 & 523 & & 3 & B1 & 281 & 4 & 2 & 159.07 & 47 & 21 & 26 & 47 & & 33 & 14 & \\
\hline 13237 & 523 & & 3 & B1 & 281 & 4 & 1 & 14.33 & 11 & 2 & 9 & 11 & & 10 & 1 & \\
\hline 13237 & 523 & & $\overline{3}$ & B1 & 281 & 4 & 4 & 618.5 & 14 & 9 & 5 & 14 & & 10 & 4 & \\
\hline 13237 & 523 & & 3 & B1 & 281 & 4 & 3 & 323.2 & 30 & 15 & 15 & 38 & 2 & 28 & 2 & \\
\hline 13237 & 524 & & 3 & $\mathrm{~B} 1$ & 281 & 4 & 5 & 49.45 & 1 & 1 & & 1 & & 1 & & \\
\hline 13237 & 524 & & 3 & B1 & 281 & 4 & 4 & 110.16 & 4 & & 4 & 4 & & 4 & & \\
\hline 13237 & 524 & & 3 & B1 & 281 & 4 & 2 & 106.3 & 36 & 7 & 29 & 36 & & 36 & & \\
\hline 13237 & 524 & & 3 & B1 & 281 & 4 & 1 & 16.55 & 19 & 3 & 16 & 19 & & 19 & & \\
\hline 13237 & 524 & & 3 & $\mathrm{B1}$ & 281 & 4 & 3 & 177.8 & 23 & 6 & 17 & 23 & & 20 & 3 & \\
\hline 13237 & 525 & & 3 & B1 & 281 & 4 & 6 & 1165 & 3 & 1 & 2 & 3 & & 3 & & \\
\hline 13237 & 525 & & 3 & $\mathrm{B1}$ & 281 & 4 & 7 & 536.8 & 1 & & 1 & 1 & & 1 & & \\
\hline 13237 & 525 & & 3 & $\mathrm{B1}$ & 281 & 4 & 5 & 612.5 & 6 & 2 & 4 & 6 & & 5 & 1 & \\
\hline 13237 & 525 & & 3 & B1 & 281 & 4 & 2 & 128.3 & 26 & 15 & 11 & 26 & & 17 & 9 & \\
\hline 13237 & 525 & & 3 & B1 & 281 & 4 & 1 & 1.57 & 1 & 1 & & 1 & & & 1 & \\
\hline 13237 & 525 & & 3 & B1 & 281 & 4 & 4 & 750.5 & 18 & 5 & 13 & 18 & & 16 & 2 & \\
\hline 13237 & 525 & & 3 & B1 & 281 & 4 & 3 & 501.5 & 29 & 6 & 23 & 29 & & 24 & 5 & \\
\hline 13237 & 526 & & 3 & B1 & 281 & 4 & 5 & 484.7 & 5 & 5 & & 4 & 1 & 4 & 1 & \\
\hline 13237 & 526 & & 3 & $\mathrm{B1}$ & 281 & 4 & 4 & 375.9 & 15 & 12 & 3 & 12 & 3 & 5 & 10 & \\
\hline 13237 & 526 & & 3 & B1 & 281 & 4 & 7 & 433.7 & 1 & 1 & & 1 & & 1 & & \\
\hline 13237 & 526 & & 3 & B1 & 281 & 4 & 6 & 187.7 & 1 & 1 & & 1 & & 1 & & \\
\hline 13237 & \begin{tabular}{|l|}
526 \\
\end{tabular} & & 3 & B1 & 281 & 1 & 5 & 87.84 & 1 & 1 & & & 1 & 1 & & \\
\hline 13237 & 526 & & 3 & B1 & 281 & 1 & 4 & 80.65 & 1 & 1 & & 1 & & 1 & & \\
\hline 13237 & $\begin{array}{l}526 \\
\end{array}$ & & 3 & $\mathrm{B1}$ & 281 & 1 & 3 & 30.05 & 2 & 2 & & 2 & & 2 & & \\
\hline 13237 & 526 & & 3 & B1 & 281 & 4 & 3 & 422.4 & 42 & 40 & 2 & 38 & 4 & 10 & 32 & \\
\hline 13237 & 526 & & 3 & B1 & 281 & 4 & 2 & 176.57 & 47 & 45 & 2 & 47 & & 8 & 39 & \\
\hline 13237 & 526 & & 3 & B1 & 281 & 4 & 1 & 21.86 & 20 & 20 & & 20 & & 1 & 19 & \\
\hline 13237 & 527 & & 3 & B1 & 281 & 4 & 5 & 171.1 & 3 & 2 & 1 & 3 & & 2 & 1 & \\
\hline 13237 & (527 & & 3 & B1 & 281 & 4 & 6 & 551.3 & 3 & 3 & & 2 & 1 & 2 & 1 & 2 FLKS \\
\hline 13237 & 527 & & 3 & B1 & 281 & 4 & 5 & 1025.9 & 14 & 14 & & 10 & 4 & 6 & 8 & \\
\hline 13237 & 527 & & 3 & B1 & 281 & 4 & 2 & 958.6 & 277 & 275 & 2 & 274 & 3 & 42 & 235 & \\
\hline 13237 & 527 & & 3 & B1 & 281 & 4 & 1 & 185.64 & 221 & 220 & 1 & 218 & 3 & 14 & 207 & \\
\hline 13237 & 527 & & 3 & B1 & 281 & 4 & 4 & 668.2 & 27 & 27 & & 24 & 3 & 9 & 18 & \\
\hline 13237 & 527 & & 3 & B1 & 281 & 4 & 3 & 1002.8 & 90 & 85 & 5 & 85 & 5 & 27 & 63 & \\
\hline 13237 & 528 & & 3 & B1 & 281 & 4 & 5 & 3098 & 4 & 2 & 2 & 4 & & 4 & & \\
\hline 13237 & \begin{tabular}{l|l}
528 \\
\end{tabular} & & 3 & B1 & 281 & 4 & 6 & 346.1 & 2 & 1 & 1 & 2 & & 2 & & \\
\hline 13237 & 528 & & 3 & B1 & 281 & 4 & 2 & 886.6 & 219 & 171 & 48 & 219 & & 85 & 134 & \\
\hline 13237 & 528 & & 3 & B1 & 281 & 4 & 1 & 167 & 191 & 191 & & 191 & & & 191 & \\
\hline 13237 & 528 & & 3 & B1 & 281 & 4 & 4 & 879 & 27 & 11 & 16 & 27 & & 22 & 5 & \\
\hline 13237 & 古28 & & 3 & B1 & 281 & 4 & 3 & 816.2 & 65 & 24 & 41 & 65 & & 46 & 19 & \\
\hline 13237 & 529 & & 3 & B1 & 281 & 4 & 5 & 223.5 & 2 & 1 & 1 & 2 & & 2 & & \\
\hline 13237 & 529 & & 3 & B1 & 281 & 4 & 4 & 384.1 & 14 & 8 & 6 & 14 & & 6 & 8 & \\
\hline 13237 & 529 & & 3 & B1 & 281 & 4 & 1 & 7.63 & 14 & 14 & & 14 & & & 14 & \\
\hline 13237 & 529 & & 3 & B1 & 281 & 4 & 2 & 707.8 & 292 & 292 & & 292 & & & 292 & \\
\hline 13237 & 529 & & 3 & B1 & 281 & 4 & 3 & 642.5 & 58 & 19 & 39 & 58 & & 41 & 17 & \\
\hline 13237 & \begin{tabular}{l|l}
538 \\
\end{tabular} & & 4 & $\mathrm{B1}$ & 281 & 1 & 5 & 278.7 & 1 & 1 & & 1 & & 1 & & \\
\hline
\end{tabular}




\begin{tabular}{|c|c|c|c|c|c|c|c|c|c|c|c|c|c|c|c|c|}
\hline Site & Coll \# & Feature & Lv & Blk & $A C$ & Mat & $\mathrm{Sz}$ & Grams & Qty & $\mathrm{Fr}$ & NF & Disc P & $\operatorname{Disc} A$ & Cort $P$ & Cort A & Comm \\
\hline 13237 & 543 & & 4 & B1 & 281 & 4 & 1 & 127.26 & 145 & 145 & & 145 & & & 145 & \\
\hline 13237 & 543 & & 4 & B1 & 281 & 4 & 4 & 112.6 & 4 & 4 & & 4 & & 4 & & \\
\hline 13237 & 543 & & 4 & B1 & 281 & 4 & 2 & 402.6 & 102 & 9 & 93 & 102 & & 95 & 7 & \\
\hline 13237 & 543 & & 4 & B1 & 281 & 4 & 3 & 287.4 & 24 & 4 & 20 & 24 & & 21 & 3 & \\
\hline 13237 & 544 & & 4 & B1 & 281 & 4 & 6 & 544.4 & 2 & 2 & & 2 & & 2 & & \\
\hline 13237 & 544 & & 4 & B1 & 281 & 4 & 5 & 133.2 & 2 & 2 & & 2 & & 2 & & \\
\hline 13237 & 544 & & 4 & $\mathrm{~B} 1$ & 281 & 4 & 3 & 218.7 & 20 & 8 & 12 & 20 & & .20 & & \\
\hline 13237 & 544 & & 4 & $\mathrm{~B} 1$ & 281 & 4 & 2 & 133.4 & 44 & 3 & 41 & 44 & & 44 & & \\
\hline 13237 & 544 & & 4 & B1 & 281 & 4 & 4 & 126.4 & 6 & 4 & 2 & 6 & & 2 & 4 & \\
\hline 13237 & 545 & & 4 & B1 & 281 & 4 & 5 & 90.5 & 2 & 1 & 1 & 2 & & 2 & & \\
\hline 13237 & 545 & & 4 & $\mathrm{~B} 1$ & 281 & 4 & 6 & 109.3 & 1 & 1 & & 1 & & 1 & & \\
\hline 13237 & 545 & & 4 & B1 & 281 & 4 & 2 & 187.6 & 50 & 16 & 34 & 50 & & 11 & 39 & \\
\hline 13237 & 545 & & 4 & B1 & 281 & 4 & 1 & 19.4 & 21 & 21 & & 21 & & 3 & 18 & \\
\hline 13237 & 545 & & 4 & B1 & 281 & 4 & 4 & 177.9 & 8 & 1 & 7 & 8 & & 5 & 3 & \\
\hline 13237 & 545 & & 4 & $\mathrm{~B} 1$ & 281 & 4 & 3 & 281.9 & 21 & 7 & 17 & 21 & & 7 & 14 & \\
\hline 13237 & 546 & & 4 & B1 & 281 & 4 & 5 & 55.1 & 2 & 1 & 1 & 2 & & 1 & 1 & \\
\hline 13237 & 546 & & 4 & $\mathrm{B1}$ & 281 & 4 & 6 & 498.8 & 2 & 1 & 1 & 2 & & 2 & & \\
\hline 13237 & 546 & & 4 & B1 & 281 & 4 & 2 & 326.5 & 79 & 15 & 64 & 79 & & 13 & 66 & \\
\hline 13237 & 546 & & 4 & $\mathrm{B1}$ & 281 & 4 & 1 & 81 & 86 & 77 & 9 & 86 & & 20 & 66 & \\
\hline 13237 & 546 & & 4 & $\mathrm{B1}$ & 281 & 4 & 4 & 93.7 & 4 & 3 & 1 & 4 & & 2 & 2 & \\
\hline 13237 & 546 & & 4 & $\mathrm{~B} 1$ & 281 & 4 & 3 & 340.8 & 28 & 3 & 25 & 28 & & 9 & 19 & \\
\hline 13237 & 547 & & 4 & B1 & 281 & 4 & 4 & 207.2 & 8 & 4 & 4 & 8 & & 5 & 3 & \\
\hline 13237 & 547 & & 4 & B1 & 281 & 4 & 2 & 147.1 & 40 & 12 & 28 & 40 & & 7 & 33 & \\
\hline 13237 & 547 & & 4 & $\mathrm{~B} 1$ & 281 & 4 & 1 & 32.98 & 34 & 34 & & 34 & & 4 & 30 & \\
\hline 13237 & 547 & & 4 & B1 & 281 & 4 & 3 & 187.4 & 15 & 4 & 11 & 15 & & 3 & 12 & \\
\hline 13237 & 548 & & 4 & B1 & 281 & 4 & 5 & 19.87 & 1 & 1 & & 1 & & & 1 & \\
\hline 13237 & 548 & & 4 & B1 & 281 & 4 & 6 & 486 & 3 & 3 & & 3 & & 3 & & \\
\hline 13237 & 548 & & 4 & B1 & 281 & 4 & 4 & 32.79 & 1 & 1 & & 1 & & 1 & & \\
\hline 13237 & 548 & & 4 & B1 & 281 & 4 & 2 & 330.1 & 95 & 91 & 4 & 90 & 5 & 18 & 77 & \\
\hline 13237 & 548 & & 4 & $B 1$ & 281 & 4 & 1 & 65.59 & 90 & 64 & 26 & 90 & & 6 & 84 & \\
\hline 13237 & 548 & & 4 & $\mathrm{B1}$ & 281 & 4 & 3 & 397.4 & 45 & 7 & 38 & 45 & & 10 & 35 & \\
\hline 13237 & 548 & & 4 & $\mathrm{~B} 1$ & 281 & 4 & 2 & 370.2 & 124 & 14 & 110 & 124 & & 18 & 106 & \\
\hline 13237 & 549 & & 4 & B1 & 281 & 4 & 5 & 171.1 & 3 & 2 & 1 & 3 & & 2 & 1 & \\
\hline 13237 & 549 & & 4 & $\mathrm{B1}$ & 281 & 4 & 9 & 762.9 & 1 & 1 & & 1 & & 1 & & \\
\hline 13237 & 549 & & 4 & $\mathrm{~B} 1$ & 281 & 4 & 2 & 330.1 & 95 & 91 & 4 & 90 & 5 & 18 & 77 & \\
\hline 13237 & 549 & & 4 & B1 & 281 & 4 & 1 & 176.3 & 64 & 59 & 5 & 64 & & 13 & 51 & \\
\hline 13237 & 549 & & 4 & B1 & 281 & 4 & 3 & 406.1 & 34 & 32 & 2 & 32 & 2 & 14 & 20 & \\
\hline 13237 & 549 & & 4 & B1 & 281 & 4 & 4 & 286.9 & 10 & 8 & 2 & 10 & & 6 & 4 & \\
\hline 13237 & 550 & & 4 & B1 & 281 & 4 & 5 & 197.3 & 3 & 2 & 1 & 3 & & 1 & 2 & \\
\hline 13237 & 550 & & 4 & B1 & 281 & 4 & 4 & 415.7 & 14 & 3 & 11 & 14 & & 6 & 8 & \\
\hline 13237 & 550 & & 4 & B1 & 281 & 4 & 1 & 134.72 & 159 & 132 & 27 & 159 & & 6 & 153 & \\
\hline 13237 & 550 & & 4 & $\mathrm{B1}$ & 281 & 4 & 2 & 579.7 & 131 & 33 & 98 & 131 & & 13 & 118 & \\
\hline 13237 & 550 & & 4 & B1 & 281 & 4 & 3 & 561.6 & 50 & 9 & 41 & 50 & & 12 & 38 & \\
\hline 13237 & 554 & & 4 & B1 & 281 & 4 & 5 & 175.5 & 3 & 3 & & 3 & & 3 & & \\
\hline 13237 & 554 & & 4 & $\mathrm{~B} 1$ & 281 & 4 & 4 & 232.8 & 11 & 9 & 2 & 11 & & 7 & 4 & \\
\hline 13237 & 554 & & 4 & B1 & 281 & 4 & 2 & 644 & 211 & 208 & 3 & 207 & 4 & 50 & 161 & \\
\hline 13237 & 554 & & 4 & B1 & 281 & 4 & 1 & 278.7 & 80 & 76 & 4 & 80 & & 31 & 49 & \\
\hline 13237 & 554 & & 4 & $\mathrm{~B} 1$ & 281 & 4 & 3 & 363.6 & 39 & 33 & 6 & 38 & 1 & 12 & 27 & \\
\hline 13237 & 555 & 46 & 3 & B1 & 281 & 4 & 2 & 6.23 & 3 & 3 & & 3 & & & 3 & \\
\hline 13237 & 555 & 46 & 3 & $\mathrm{B1}$ & 281 & 4 & 1 & 0.24 & 1 & 1 & & 1 & & & 1 & \\
\hline 13237 & 555 & 46 & 3 & B1 & 281 & 4 & 1 & 1.16 & 1 & 1 & & 1 & & & 1 & \\
\hline 13237 & 556 & 46 & 3 & B1 & 281 & 4 & 7 & 2698.4 & 3 & 1 & 2 & 3 & & 3 & & \\
\hline 13237 & 556 & 46 & 3 & $\mathrm{~B} 1$ & 281 & 4 & 6 & 2398.6 & 6 & 3 & 3 & 6 & & 6 & & \\
\hline 13237 & \begin{tabular}{l|l|}
556 \\
\end{tabular} & 46 & 3 & B1 & 281 & 4 & 5 & 243.8 & 2 & 2 & & 2 & & 1 & 1 & \\
\hline 13237 & \begin{tabular}{l|}
556 \\
\end{tabular} & 46 & 3 & B1 & 281 & 4 & 4 & 143.75 & 5 & 3 & 2 & 5 & & 3 & 2 & \\
\hline 13237 & \begin{tabular}{l|}
556 \\
\end{tabular} & 46 & 3 & $\mathrm{~B} 1$ & 281 & 4 & 3 & 77.77 & 8 & 2 & 6 & 8 & & 3 & 5 & \\
\hline 13237 & \begin{tabular}{l|l}
556 \\
\end{tabular} & 46 & 3 & B1 & 281 & 4 & 2 & 15.44 & 5 & 3 & 2 & 5 & & 1 & 4 & \\
\hline 13237 & 557 & 46 & 3 & B1 & 281 & 4 & 3 & 33.67 & 4 & 3 & 1 & 4 & & & 4 & \\
\hline 13237 & 557 & 46 & 3 & B1 & 281 & 4 & 2 & 44.1 & 16 & 2 & 14 & 16 & & 2 & 14 & \\
\hline 13237 & 557 & 46 & 3 & $\mathrm{B1}$ & 281 & 4 & 1 & 1.62 & 2 & 2 & & 2 & & 1 & 1 & \\
\hline 13237 & $\begin{array}{l}558 \\
\end{array}$ & 46 & 3 & B1 & 281 & 4 & 7 & 2455.1 & 5 & 3 & 2 & 5 & & 5 & & \\
\hline 13237 & 558 & 46 & 3 & $\mathrm{~B} 1$ & 281 & 4 & 6 & 474.5 & 2 & 1 & 1 & 2 & & 2 & & \\
\hline 13237 & 558 & 46 & 3 & B1 & 281 & 4 & 5 & 845 & 7 & 6 & 1 & 7 & & 3 & 4 & \\
\hline 13237 & \begin{tabular}{|l|}
558 \\
\end{tabular} & 46 & 3 & B1 & 281 & 4 & 4 & 329.7 & 14 & 11 & 3 & 14 & & 8 & 6 & \\
\hline 13237 & 558 & 46 & 3 & $\mathrm{B1}$ & 281 & 4 & 3 & 350.8 & 27 & 23 & 4 & 27 & & 13 & 14 & \\
\hline 13237 & 558 & 46 & 3 & B1 & 281 & 4 & 2 & 3.27 & 1 & 1 & & 1 & & & 1 & \\
\hline 13237 & 558 & 46 & 3 & B1 & 281 & 4 & 2 & 78.57 & 12 & 11 & 1 & 11 & 1 & 4 & 7 & \\
\hline 13237 & 558 & 46 & 3 & B1 & 281 & 4 & 1 & 4.79 & 5 & 5 & & 5 & & & 5 & \\
\hline 13237 & 560 & & 3 & 81 & 281 & 4 & 1 & 117.39 & 150 & 96 & 54 & 150 & & 6 & 144 & \\
\hline
\end{tabular}




\begin{tabular}{|c|c|c|c|c|c|c|c|c|c|c|c|c|c|c|c|c|}
\hline Site & Coll \# & Feature & LV & Blk & $A C$ & Mat & $\mathrm{Sz}$ & Grams & Qty & $\mathrm{Fr}$ & $\mathrm{NF}$ & Disc P & Disc A & Cort P & Cort A & Comm \\
\hline 13237 & 560 & & 3 & $\mathrm{B1}$ & 281 & 4 & 2 & 702.2 & 209 & 9 & 200 & 209 & & 14 & 185 & \\
\hline 13237 & 560 & & 3 & $\mathrm{~B} 1$ & 281 & 4 & 3 & 557.3 & 50 & 4 & 46 & 50 & & 14 & 36 & \\
\hline 13237 & 560 & & 3 & $\mathrm{~B} 1$ & 281 & 4 & 6 & 106.5 & 1 & & 1 & 1 & & 1 & & \\
\hline 13237 & 560 & & 3 & $\overline{B 1}$ & 281 & 4 & 4 & 458 & 15 & 4 & 11 & 15 & & 7 & 8 & \\
\hline 13237 & 560 & & 3 & B1 & 281 & 4 & 5 & 125.6 & 2 & 2 & & 2 & & 2 & & \\
\hline 13237 & 562 & 98 & 3 & B1 & 281 & 4 & 2 & 5.2 & 2 & & 2 & 2 & & & 2 & \\
\hline 13237 & 562 & 98 & 3 & $\mathrm{~B} 1$ & 281 & 4 & 4 & 30.66 & 2 & & 2 & & & 2 & & \\
\hline 13237 & 563 & 46 & 3 & B1 & 281 & 4 & 5 & 64.8 & 1 & 1 & & 1 & & 1 & & \\
\hline 13237 & 563 & 46 & 3 & B1 & 281 & 4 & 1 & 154.2 & 59 & 59 & & 57 & 2 & 4 & 55 & \\
\hline 13237 & 563 & 46 & 3 & B1 & 281 & 4 & 7 & 326.4 & 1 & 1 & & 1 & & 1 & & \\
\hline 13237 & 563 & 46 & 3 & $\mathrm{~B} 1$ & 281 & 4 & 2 & 629.7 & 62 & 59 & 3 & 60 & 2 & 26 & 36 & \\
\hline 13237 & 563 & 46 & 3 & B1 & 281 & 4 & 4 & 31.81 & 13 & 11 & 2 & 11 & 2 & 8 & 5 & \\
\hline 13237 & 563 & 46 & 3 & $\mathrm{B1}$ & 281 & 4 & 3 & 559.2 & 54 & 52 & 2 & 53 & 1 & 16 & 38 & \\
\hline 13237 & 566 & 98 & 3 & B1 & 281 & 4 & 2 & 6.26 & 2 & & 2 & 2 & & 1 & 1 & \\
\hline 13237 & 566 & 98 & 3 & B1 & 281 & 4 & 3 & 14.46 & 2 & 1 & 1 & 2 & & 2 & & \\
\hline 13237 & 566 & 98 & 3 & $\mathrm{B1}$ & 281 & 4 & 4 & 53.02 & 2 & & 2 & 2 & & 2 & & \\
\hline 13237 & 566 & 98 & 3 & $\mathrm{~B} 1$ & 281 & 4 & 5 & 28.49 & 1 & & 1 & 1 & & 1 & & \\
\hline 13237 & 567 & & 3 & $\mathrm{~B} 1$ & 281 & 4 & 4 & 490.8 & 21 & 21 & & 18 & 3 & 13 & 8 & \\
\hline 13237 & 567 & & 3 & $\mathrm{~B} 1$ & 281 & 4 & 3 & 734.2 & 65 & 65 & & 62 & 3 & 20 & 45 & \\
\hline 13237 & 567 & & 3 & B1 & 281 & 4 & 2 & 857 & 222 & 219 & 3 & 218 & 4 & 36 & 186 & \\
\hline 13237 & 567 & & 3 & $\mathrm{~B} 1$ & 281 & 4 & 7 & 476 & 1 & 1 & & 1 & & $\overline{1}$ & & \\
\hline 13237 & 567 & & 3 & $\mathrm{~B} 1$ & 281 & 4 & 6 & 1007 & 4 & 4 & & 4 & & 4 & & \\
\hline 13237 & 567 & & 3 & B1 & 281 & 4 & 5 & 790.6 & 8 & 6 & 2 & 8 & & 4 & 4 & \\
\hline 13237 & 567 & & 3 & B1 & 281 & 4 & 1 & 146.9 & 143 & 142 & 1 & 143 & & 6 & 137 & \\
\hline 13237 & 568 & & 4 & $\mathrm{~B} 1$ & 281 & 1 & 1 & 0.4 & 1 & 1 & & 1 & & 1 & & \\
\hline 13237 & 568 & & 4 & B1 & 281 & 4 & 1 & 137.8 & 122 & 46 & 76 & 47 & 75 & 7 & 115 & \\
\hline 13237 & 568 & & 4 & B1 & 281 & 4 & 2 & 208.1 & 68 & 38 & 30 & 65 & 3 & 14 & 54 & \\
\hline 13237 & 568 & & 4 & B1 & 281 & 4 & 6 & 221.5 & 1 & 1 & & 1 & & & 1 & \\
\hline 13237 & 568 & & 4 & B1 & 281 & 4 & 4 & 375.1 & 12 & 12 & & 5 & 7 & 4 & 8 & \\
\hline 13237 & 568 & & 4 & B1 & 281 & 4 & 3 & 156.1 & 18 & 18 & & 10 & 8 & 3 & 15 & \\
\hline 13237 & 568 & & 4 & B1 & 281 & 4 & 5 & 91 & 1 & 1 & & 1 & & & 1 & $1 \mathrm{FLK}$ \\
\hline 13237 & 569 & & 4 & B1 & 281 & 4 & 4 & 716.2 & 23 & 4 & 19 & 23 & & 10 & 13 & \\
\hline 13237 & 569 & & 4 & $\mathrm{~B} 1$ & 281 & 4 & 3 & 587.8 & 60 & 9 & 51 & 60 & & 12 & 48 & \\
\hline 13237 & 569 & & 4 & B1 & 281 & 4 & 2 & 822.9 & 241 & 22 & 219 & 241 & & 29 & 190 & \\
\hline 13237 & 569 & & 4 & B1 & 281 & 4 & 1 & 148.8 & 167 & 23 & 144 & 167 & & 6 & 138 & \\
\hline 13237 & 569 & & 4 & $\mathrm{B1}$ & 281 & 1 & 2 & 4.19 & 1 & & 1 & 1 & & & 1 & \\
\hline 13237 & 569 & & 4 & $\mathrm{B1}$ & 281 & 4 & 5 & 130.7 & 2 & & 2 & 2 & & 2 & & \\
\hline 13237 & 570 & & 4 & B1 & 281 & 4 & 6 & 219.4 & 1 & 1 & & 1 & & & 1 & \\
\hline 13237 & 570 & & 4 & B1 & 281 & 4 & 2 & 309.4 & 92 & 89 & 3 & 90 & 2 & 14 & 78 & \\
\hline 13237 & 570 & & 4 & B1 & 281 & 4 & 1 & 62.6 & 68 & 67 & 1 & 67 & 1 & 4 & 63 & \\
\hline 13237 & 570 & & 4 & B1 & 281 & 4 & 3 & 451.7 & 35 & 1 & 34 & 35 & & 5 & 30 & \\
\hline 13237 & 570 & & 4 & B1 & 281 & 4 & 4 & 476.9 & 14 & 12 & 2 & 13 & 1 & 6 & 8 & \\
\hline 13237 & 570 & & 4 & $\mathrm{~B} 1$ & 281 & 4 & 5 & 140.9 & 2 & 2 & & 2 & & 1 & 1 & \\
\hline 13237 & 571 & 46 & 4 & B1 & 281 & 4 & 1 & 0.9 & 2 & 2 & & 2 & & 1 & 1 & \\
\hline 13237 & 571 & 46 & 4 & B1 & 281 & 4 & 2 & 4.7 & 3 & 3 & & 3 & & & 3 & \\
\hline 13237 & 571 & 46 & 4 & B1 & 281 & 4 & 4 & 31.3 & 1 & $t$ & & 1 & & 1 & & \\
\hline 13237 & 572 & 46 & 4 & B1 & 281 & 4 & 1 & 7.3 & 9 & 6 & 3 & 9 & & 2 & 7 & \\
\hline 13237 & 572 & 46 & 4 & B1 & 281 & 4 & 2 & 8.6 & 3 & 3 & & 3 & & 2 & 1 & \\
\hline 13237 & 572 & 46 & 4 & B1 & 281 & 4 & 3 & 33 & 3 & 3 & & 3 & & 1 & 2 & \\
\hline 13237 & 572 & 46 & 4 & $\mathrm{~B} 1$ & 281 & 4 & 4 & 17.6 & 1 & 1 & & 1 & & 1 & & \\
\hline 13237 & 572 & 46 & 4 & B1 & 281 & 4 & 6 & 1262.2 & 2 & 2 & & 2 & & 2 & & \\
\hline 13237 & 572 & 46 & 4 & B1 & 281 & 4 & 7 & 4222.3 & 7 & 3 & 4 & 7 & & 7 & & \\
\hline 13237 & 573 & 46 & 4 & $\mathrm{~B} 1$ & 281 & 4 & 1 & 2.1 & 3 & 3 & & 3 & & & 3 & \\
\hline 13237 & 573 & 46 & 4 & B1 & 281 & 4 & 2 & 33.3 & 9 & 8 & 1 & 9 & & 3 & 6 & \\
\hline 13237 & 573 & 46 & 4 & $\mathrm{~B} 1$ & 281 & 4 & 3 & 24.1 & 3 & 3 & & 3 & & 1 & 2 & \\
\hline 13237 & 574 & & 4 & B1 & 281 & 4 & 5 & 3828.5 & 26 & 23 & 3 & 26 & & 26 & & \\
\hline 13237 & 574 & & 4 & B1 & 281 & 4 & 6 & 11409.3 & 24 & 12 & 12 & & 24 & 24 & & \\
\hline 13237 & 574 & & 4 & $\mathrm{~B} 1$ & 281 & 4 & 7 & 10114.4 & 13 & 9 & 4 & 13 & & 13 & & \\
\hline 13237 & 574 & & 4 & $\mathrm{~B} 1$ & 281 & 4 & 4 & 959 & 27 & 24 & 3 & 27 & & 12 & 15 & \\
\hline 13237 & 574 & & 4 & $\mathrm{B1}$ & 281 & 4 & 3 & 347 & 24 & 10 & 14 & 24 & & 9 & 15 & \\
\hline 13237 & 574 & & 4 & $\mathrm{~B} 1$ & 281 & 4 & 2 & 74.5 & 29 & 26 & 3 & 29 & & 3 & 26 & \\
\hline 13237 & 600 & & 3 & C1 & 281 & 4 & 4 & 476.7 & 10 & 5 & 5 & 10 & & 8 & 2 & \\
\hline 13237 & 600 & & 3 & $\mathrm{C1}$ & 281 & 4 & 5 & 719.4 & 6 & 5 & 1 & 6 & & 6 & & \\
\hline 13237 & 600 & & 3 & $\mathrm{C1}$ & 281 & 4 & 3 & 133.5 & 7 & 4 & 3 & 7 & & 4 & 3 & \\
\hline 13237 & 600 & & 3 & $\mathrm{C} 1$ & 281 & 4 & 1 & 11.58 & 12 & 12 & & 12 & & & 12 & \\
\hline 13237 & 600 & & 3 & C1 & 281 & 4 & 2 & 7 & 4 & 4 & & 4 & & 1 & 3 & \\
\hline 13237 & 601 & & 3 & $\mathrm{C1}$ & 281 & 4 & 4 & 405.2 & 13 & 13 & & 12 & 1 & 1 & 12 & \\
\hline 13237 & 601 & & 3 & $\mathrm{C} 1$ & 281 & 4 & 5 & 443.1 & 5 & 5 & & 5 & & 3 & 2 & \\
\hline 13237 & 601 & & 3 & $\mathrm{C} 1$ & 281 & 4 & 7 & 530 & 1 & 1 & & 1 & & 1 & & \\
\hline
\end{tabular}




\begin{tabular}{|c|c|c|c|c|c|c|c|c|c|c|c|c|c|c|c|c|}
\hline Site & Coll \# & Feature & Lv & Blk & $A C$ & Mat & $\mathrm{Sz}$ & Grams & Qty & $\mathrm{Fr}$ & $\mathrm{NF}$ & Disc P & Disc A & Cort P & Cort A & Comm \\
\hline 13237 & 601 & & 3 & $\mathrm{Cl}$ & 281 & 4 & 3 & 170.4 & 13 & 13 & & 10 & 3 & 2 & 11 & \\
\hline 13237 & 601 & & 3 & $\mathrm{C1}$ & 281 & 1 & 2 & 4.1 & 1 & 1 & & 1 & & 1 & & \\
\hline 13237 & 601 & & 3 & $\mathrm{C1}$ & 281 & 4 & 1 & 16.3 & 16 & 15 & 1 & 15 & 1 & 1 & 15 & \\
\hline 13237 & 601 & & 3 & $\mathrm{C1}$ & 281 & 4 & 2 & 177.2 & 47 & 47 & & 36 & 11 & 3 & 44 & \\
\hline 13237 & 602 & & 3 & $\mathrm{C} 1$ & 281 & 4 & 4 & 249.9 & 7 & 4 & 3 & 7 & & 6 & 1 & \\
\hline 13237 & 602 & & 3 & $\mathrm{C} 1$ & 281 & 4 & 5 & 152.7 & 2 & 2 & & 2 & & 1 & 1 & \\
\hline 13237 & 602 & & 3 & C1 & 281 & 4 & 1 & 1.8 & 1 & 1 & & 1 & & & 1 & \\
\hline 13237 & 602 & & 3 & $\mathrm{C1}$ & 281 & 4 & 3 & 53.7 & 3 & 3 & & 3 & & 1 & 2 & \\
\hline 13237 & 603 & & 3 & $\mathrm{C1}$ & 281 & 4 & 4 & 615 & 15 & 14 & 1 & 15 & & 3 & 12 & \\
\hline 13237 & 603 & & 3 & C1 & 281 & 4 & 5 & 750.5 & 7 & 4 & 3 & 6 & 1 & 5 & 2 & \\
\hline 13237 & 603 & & 3 & $\mathrm{C1}$ & 281 & 4 & 7 & 445.1 & 1 & 1 & & 1 & & & 1 & \\
\hline 13237 & 603 & & 3 & $\mathrm{C1}$ & 281 & 4 & 3 & 411 & 27 & 24 & 3 & 27 & & 5 & 22 & \\
\hline 13237 & 603 & & 3 & $\mathrm{C1}$ & 281 & 1 & 2 & 3.1 & 1 & 1 & & 1 & & & 1 & \\
\hline 13237 & 603 & & 3 & $\mathrm{C1}$ & 281 & 4 & 1 & 11 & 13 & 12 & 1 & 13 & & & 13 & \\
\hline 13237 & 603 & & 3 & $\mathrm{C1}$ & 281 & 4 & 2 & 108.6 & 29 & 27 & 2 & 29 & & 2 & 27 & \\
\hline 13237 & 604 & & 3 & $\mathrm{C1}$ & 281 & 4 & 1 & 22.7 & 33 & 33 & & 33 & & 1 & 32 & \\
\hline 13237 & 604 & & 3 & $\mathrm{C1}$ & 281 & 4 & 6 & 542.5 & 2 & 2 & & 2 & & 1 & 1 & \\
\hline 13237 & 604 & & 3 & C1 & 281 & 4 & 7 & 1433.6 & 2 & 2 & & 2 & & 2 & & \\
\hline 13237 & 604 & & 3 & $\mathrm{C1}$ & 281 & 4 & 8 & 1041.2 & 1 & 1 & & 1 & & & 1 & \\
\hline 13237 & 604 & & 3 & $\mathrm{C} 1$ & 281 & 4 & 5 & 1143.7 & 8 & 7 & 1 & 8 & & 5 & 3 & \\
\hline 13237 & 604 & & 3 & $\mathrm{C1}$ & 281 & 4 & 2 & 199.1 & 44 & 43 & 1 & 44 & & 4 & 40 & \\
\hline 13237 & 604 & & 3 & $\mathrm{C1}$ & 281 & 4 & 3 & 371.5 & 30 & 28 & 2 & 30 & & 4 & 26 & \\
\hline 13237 & 604 & & 3 & C1 & 281 & 4 & 4 & 1061.6 & 28 & 27 & 1 & 27 & 1 & 7 & 21 & \\
\hline 13237 & 605 & & 3 & C1 & 281 & 4 & 3 & 232.9 & 17 & 15 & 2 & 15 & 2 & 4 & 13 & \\
\hline 13237 & 605 & & 3 & $\mathrm{C} 1$ & 281 & 4 & 2 & 143.8 & 30 & 27 & 3 & 29 & 1 & 3 & 27 & \\
\hline 13237 & 605 & & 3 & $\mathrm{C1}$ & 281 & 4 & 1 & 33.7 & 33 & 33 & & 33 & & & 33 & \\
\hline 13237 & 605 & & 3 & $\mathrm{C1}$ & 281 & 4 & 7 & 644.9 & 1 & & 1 & 1 & & 1 & & \\
\hline 13237 & 605 & & 3 & C1 & 281 & 4 & 5 & 1760.5 & 13 & 9 & 4 & 12 & 1 & 8 & 5 & \\
\hline 13237 & 605 & & 3 & $\mathrm{C} 1$ & 281 & 4 & 4 & 402.1 & 12 & 11 & 1 & 7 & 5 & 4 & 8 & \\
\hline 13237 & 606 & & 3 & C1 & 281 & 4 & 6 & 1132.5 & 5 & 5 & & 5 & & 3 & 2 & \\
\hline 13237 & 606 & & 3 & C1 & 281 & 4 & 5 & 1746.7 & 19 & 18 & 1 & 17 & 2 & 5 & 14 & \\
\hline 13237 & \begin{tabular}{l|l|}
606 \\
\end{tabular} & & 3 & $\mathrm{C1}$ & 281 & 4 & 8 & 1025.8 & 1 & 1 & & 1 & & 1 & & \\
\hline 13237 & 606 & & 3 & C1 & 281 & 4 & 7 & 388.3 & 1 & 1 & & 1 & & 1 & & \\
\hline 13237 & 606 & & 3 & $\mathrm{C} 1$ & 281 & 4 & 2 & 103.7 & 23 & 23 & & 22 & 1 & 1 & 22 & \\
\hline 13237 & 606 & & 3 & C1 & 281 & 4 & 1 & 20.2 & 18 & 18 & & 17 & 1 & 1 & 17 & \\
\hline 13237 & 606 & & 3 & C1 & 281 & 4 & 4 & 685.7 & 20 & 20 & & 19 & 1 & 4 & 16 & \\
\hline 13237 & 606 & & 3 & C1 & 281 & 4 & 3 & 470.4 & 31 & 31 & & 29 & 2 & 4 & 27 & \\
\hline 13237 & 607 & & 4 & C1 & 281 & 4 & 6 & 2727.6 & 9 & 5 & 4 & 9 & & 7 & 2 & \\
\hline 13237 & 607 & & 4 & $\mathrm{C1}$ & 281 & 4 & 5 & 2165.6 & 19 & 12 & 7 & 17 & 2 & 14 & 5 & \\
\hline 13237 & 607 & & 4 & $\mathrm{C1}$ & 281 & 4 & 9 & 955.8 & 1 & & 1 & 1 & & 1 & & \\
\hline 13237 & 607 & & 4 & $\mathrm{C} 1$ & 281 & 4 & 7 & 1036.2 & 2 & 1 & 1 & 2 & & 2 & & \\
\hline 13237 & 607 & & 4 & $\mathrm{C} 1$ & 281 & 4 & 2 & 198.5 & 44 & 42 & 2 & 43 & 1 & 3 & 41 & \\
\hline 13237 & 607 & & 4 & $\mathrm{C1}$ & 281 & 4 & 1 & 26.5 & 17 & 14 & 3 & 17 & & 3 & 14 & \\
\hline 13237 & 607 & & 4 & $\mathrm{C1}$ & 281 & 4 & 4 & 1274.7 & 28 & 26 & 2 & 25 & 3 & 8 & 20 & \\
\hline 13237 & 607 & & 4 & $\mathrm{C1}$ & 281 & 4 & 3 & 373.8 & 29 & 29 & & 28 & 1 & 4 & 25 & \\
\hline 13237 & 608 & & 4 & $\mathrm{C} 1$ & 281 & 4 & 4 & 653.7 & 18 & 16 & 2 & 16 & 2 & 9 & 9 & \\
\hline 13237 & 608 & & 4 & C1 & 281 & 4 & 5 & 375.3 & 5 & 5 & & 5 & & 2 & 3 & \\
\hline 13237 & 608 & & 4 & C1 & 281 & 4 & 6 & 1256.8 & 5 & 3 & 2 & 5 & & 3 & 2 & \\
\hline 13237 & 608 & & 4 & C1 & 281 & 4 & 3 & 211.5 & 13 & 13 & & 13 & & 7 & 6 & \\
\hline 13237 & 608 & & 4 & C1 & 281 & 4 & 1 & 10.3 & 8 & 8 & & 8 & & & 8 & \\
\hline 13237 & 608 & & 4 & $\mathrm{C} 1$ & 281 & 4 & 2 & 9.6 & 1 & 1 & & 1 & & 1 & & \\
\hline 13237 & 608 & & 4 & $\mathrm{C1}$ & 281 & 4 & 2 & 61.1 & 13 & 13 & & 13 & & 2 & 11 & \\
\hline 13237 & 609 & & 4 & $\mathrm{C1}$ & 281 & 4 & 6 & 1850.1 & 7 & 5 & 2 & 7 & & 6 & 1 & \\
\hline 13237 & 609 & & 4 & $\mathrm{C} 1$ & 281 & 4 & 5 & 1617.6 & 10 & 8 & 2 & 10 & & 7 & 1 & \\
\hline 13237 & 609 & & 4 & $\mathrm{C1}$ & 281 & 4 & 10 & 1083.1 & 1 & 1 & & 1 & & 1 & & \\
\hline 13237 & 609 & & 4 & $\mathrm{C} 1$ & 281 & 4 & 7 & 2601.3 & 4 & 2 & 2 & 4 & & 4 & & \\
\hline 13237 & 609 & & 4 & $\mathrm{C1}$ & 281 & 4 & 2 & 245.3 & 63 & 59 & 4 & 62 & 1 & 9 & 54 & \\
\hline 13237 & 609 & & 4 & C1 & 281 & 4 & 1 & 61.6 & 78 & 78 & & 78 & & 4 & 74 & \\
\hline 13237 & 609 & & 4 & C1 & 281 & 4 & 4 & 841.4 & 26 & 26 & & 26 & & 6 & 20 & \\
\hline 13237 & 609 & & 4 & $\mathrm{C1}$ & 281 & 4 & 3 & 512.7 & 40 & 40 & & 38 & 2 & 6 & 34 & \\
\hline 13237 & 610 & & 4 & $\mathrm{C} 1$ & 281 & 4 & 7 & 609.9 & 1 & 1 & & 1 & & 1 & & \\
\hline 13237 & 610 & & 4 & C1 & 281 & 4 & 6 & 2201.5 & 8 & 3 & 5 & 8 & & 6 & 2 & \\
\hline 13237 & 610 & & 4 & $\mathrm{C} 1$ & 283 & 14 & 2 & 7.9 & 2 & & & 2 & & & & \\
\hline 13237 & 610 & & 4 & C1 & 283 & 14 & 5 & 116.1 & 1 & & & 1 & & & & \\
\hline 13237 & 610 & & 4 & $\mathrm{C} 1$ & 283 & 14 & 4 & 75.6 & 2 & & & 2 & & & & \\
\hline 13237 & 610 & & 4 & C1 & 281 & 4 & 2 & 119.3 & 25 & 9 & 16 & 25 & & 5 & 20 & \\
\hline 13237 & 610 & & 4 & $\mathrm{C1}$ & 281 & 4 & 1 & 5.1 & 6 & 6 & & 6 & & & 6 & \\
\hline 13237 & \begin{tabular}{|l|}
610 \\
\end{tabular} & & 4 & C1 & 281 & 4 & 3 & 386.3 & 26 & 20 & 6 & 26 & & 9 & 17 & \\
\hline 13237 & 610 & & 4 & $\mathrm{C} 1$ & 281 & 4 & 5 & 2826.1 & 21 & 12 & 9 & 21 & & 12 & 9 & \\
\hline
\end{tabular}




\begin{tabular}{|c|c|c|c|c|c|c|c|c|c|c|c|c|c|c|c|c|}
\hline Site & Coll \# & Feature & LV & Blk & $A C$ & Mat & $\mathrm{Sz}$ & Grams & Qty & $\mathrm{Fr}$ & NF & DiscP & Disc A & Cort P & $\operatorname{Cort} A$ & Comm \\
\hline \begin{tabular}{|l|}
13237 \\
\end{tabular} & 610 & & 4 & $\mathrm{C1}$ & \begin{tabular}{|l|}
281 \\
\end{tabular} & 4 & 4 & 890.3 & 17 & 11 & 6 & 17 & & 13 & 4 & \\
\hline \begin{tabular}{|l|}
13237 \\
\end{tabular} & 611 & & 4 & $\mathrm{C} 1$ & 281 & 4 & 4 & 1243 & 20 & 14 & 6 & 20 & & 10 & 10 & \\
\hline \begin{tabular}{|l|}
13237 \\
\end{tabular} & 611 & & 4 & C1 & \begin{tabular}{|l|}
281 \\
\end{tabular} & 4 & 5 & 1708.4 & 14 & 12 & 2 & 14 & & 7 & 7 & \\
\hline 13237 & 611 & & 4 & $\mathrm{C1}$ & \begin{tabular}{|l|}
281 \\
\end{tabular} & 4 & 3 & 502 & 30 & 12 & 18 & 30 & & 9 & 21 & \\
\hline \begin{tabular}{|l|}
13237 \\
\end{tabular} & 611 & & 4 & C1 & 281 & 4 & 1 & 45.4 & 49 & 24 & 25 & 49 & & 4 & 45 & \\
\hline 13237 & 611 & & 4 & $\mathrm{C1}$ & 281 & 4 & 2 & 293.6 & 67 & 30 & 37 & 67 & & 6 & 63 & \\
\hline 13237 & 612 & & 4 & $\mathrm{C1}$ & 281 & 4 & 5 & 1127.1 & 12 & 12 & & 12 & & 5 & 7 & \\
\hline 13237 & 612 & & 4 & $\mathrm{C1}$ & 281 & 4 & 6 & 347.2 & 2 & 2 & & 2 & & 1 & 1 & \\
\hline 13237 & 612 & & 4 & $\mathrm{C1}$ & \begin{tabular}{|l|}
281 \\
\end{tabular} & 4 & 7 & 801.2 & 2 & 2 & & 2 & & 2 & & \\
\hline 13237 & 612 & & 4 & $\mathrm{C1}$ & \begin{tabular}{|l|}
281 \\
\end{tabular} & 4 & 4 & 766.9 & 18 & 18 & & 18 & & 9 & 9 & \\
\hline 13237 & 612 & & 4 & $\mathrm{C} 1$ & 281 & 4 & 1 & 21.2 & 14 & 14 & & 14 & & 1 & 13 & \\
\hline 13237 & 612 & & 4 & $\mathrm{C1}$ & 281 & 4 & 2 & 103.5 & 21 & 20 & 7 & 21 & & 5 & 16 & \\
\hline 13237 & 612 & & 4 & $\mathrm{C1}$ & 281 & 4 & 3 & 452.2 & 26 & 25 & 1 & 26 & & 5 & 21 & \\
\hline 13237 & 613 & & 4 & $\mathrm{C} 1$ & 281 & 4 & 7 & 1410.2 & 2 & 2 & & 2 & & 2 & & \\
\hline 13237 & 613 & & 4 & C1 & 281 & 4 & 6 & 1387.1 & 3 & & 3 & 3 & & 3 & & \\
\hline 13237 & 613 & & 4 & C1 & \begin{tabular}{|l|}
281 \\
\end{tabular} & 4 & 11 & 7779.1 & 2 & & 2 & 2 & & 2 & & \\
\hline 13237 & 613 & & 4 & $\mathrm{C} 1$ & 281 & 4 & 8 & 2671.1 & 2 & 1 & 1 & 2 & & 2 & & \\
\hline 13237 & 613 & & 4 & $\mathrm{C} 1$ & \begin{tabular}{|l|}
281 \\
\end{tabular} & 4 & 5 & 519.5 & 3 & 2 & 1 & 3 & & 3 & & \\
\hline 13237 & 613 & & 4 & C1 & \begin{tabular}{|l|}
281 \\
\end{tabular} & 4 & 2 & $\begin{array}{l}78.4 \\
\end{array}$ & 27 & 17 & 10 & 25 & 2 & 8 & 19 & \\
\hline 13237 & 613 & & 4 & $\mathrm{C} 1$ & \begin{tabular}{|l|}
281 \\
\end{tabular} & 4 & 1 & 11.7 & 17 & 12 & 5 & 17 & & & 17 & \\
\hline 13237 & 613 & & 4 & $\mathrm{C1}$ & \begin{tabular}{|l|}
281 \\
\end{tabular} & 4 & 4 & \begin{tabular}{l|l|}
159.6 \\
\end{tabular} & 5 & 3 & 2 & 5 & & 4 & 1 & \\
\hline 13237 & 613 & & 4 & C1 & 281 & 4 & 3 & 72.3 & 7 & 4 & 3 & 7 & & 1 & 6 & \\
\hline 13237 & 614 & & 4 & $\mathrm{C1}$ & 281 & 4 & 4 & 155.3 & 5 & 4 & 1 & 5 & & 4 & 1 & \\
\hline 13237 & 614 & & 4 & C1 & 281 & 4 & 5 & 323.5 & 2 & 1 & 1 & 2 & & 2 & & \\
\hline 13237 & 614 & & 4 & $\mathrm{C} 1$ & 281 & 4 & 6 & \begin{tabular}{|l|}
220.3 \\
\end{tabular} & 1 & & 1 & 7 & & 1 & & \\
\hline 13237 & 614 & & 4 & $\mathrm{C} 1$ & \begin{tabular}{|l|}
281 \\
\end{tabular} & 4 & 1 & 3.3 & 5 & 4 & 1 & 5 & & 1 & 4 & \\
\hline 13237 & 614 & & 4 & $\mathrm{C} 1$ & 281 & 4 & 2 & 91.3 & 22 & 8 & 14 & 22 & & 6 & 16 & \\
\hline 13237 & 614 & & 4 & C1 & \begin{tabular}{|l|}
281 \\
\end{tabular} & 4 & 3 & 219.3 & 11 & 4 & 7 & 11 & & 6 & 5 & \\
\hline 13237 & 615 & & 4 & $\mathrm{C1}$ & 281 & 4 & 3 & 24.5 & 2 & 2 & & 2 & & 1 & 1 & \\
\hline 13237 & 615 & & 4 & $\mathrm{C} 1$ & 281 & 4 & 4 & 180 & 5 & 3 & 2 & 5 & & 4 & 1 & \\
\hline 13237 & 615 & & 4 & $\mathrm{C1}$ & 281 & 4 & 1 & 9.8 & 14 & 13 & 1 & 14 & & 2 & 12 & \\
\hline 13237 & 615 & & 4 & $\mathrm{C1}$ & 281 & 4 & 2 & \begin{tabular}{|c|}
30.6 \\
\end{tabular} & 13 & 12 & 1 & 13 & & 4 & 9 & \\
\hline 13237 & 615 & & 4 & $\mathrm{C} 1$ & 281 & 4 & 5 & 98.1 & 2 & 2 & & 1 & 1 & 1 & 1 & \\
\hline 13237 & 616 & & 4 & $\mathrm{C} 1$ & 281 & 4 & 4 & 90 & 5 & 3 & 2 & 5 & & 1 & 4 & \\
\hline 13237 & 616 & & 4 & $\mathrm{C} 1$ & 281 & 4 & 5 & 351.2 & 1 & & 1 & 1 & & 1 & & \\
\hline 13237 & 616 & & 4 & $\mathrm{C1}$ & 281 & 4 & 6 & 445.3 & 1 & 1 & & 1 & & 1 & & \\
\hline 13237 & 616 & & 4 & $\mathrm{C1}$ & 281 & 4 & $\frac{1}{1}$ & 14.9 & 8 & 5 & 3 & 8 & & & 8 & \\
\hline 13237 & 616 & & 4 & $\mathrm{C1}$ & 281 & 4 & 2 & 80.4 & 16 & 12 & 4 & 16 & & 14 & 2 & \\
\hline 13237 & 616 & & 4 & $\mathrm{C} 1$ & 281 & 4 & 3 & \begin{tabular}{|l|}
88.6 \\
\end{tabular} & 7 & 4 & 3 & 7 & & 3 & 4 & \\
\hline 13237 & 617 & & 4 & $\mathrm{C1}$ & 281 & 4 & 4 & 119.8 & 5 & 5 & & 5 & & 2 & 3 & \\
\hline 13237 & 617 & & 4 & $\mathrm{C1}$ & 281 & 4 & 5 & 237.7 & 2 & 2 & & 2 & & 1 & 1 & \\
\hline 13237 & 617 & & 4 & $\mathrm{C} 1$ & 281 & 4 & 3 & 36.9 & 3 & 3 & & 3 & & 1 & 2 & \\
\hline 13237 & 617 & & 4 & $\mathrm{C} 1$ & 281 & 4 & 1 & \begin{tabular}{|l|}
8.9 \\
\end{tabular} & 10 & 10 & & 10 & & 2 & 8 & \\
\hline 13237 & 617 & & 4 & $\mathrm{C1}$ & 281 & 4 & 2 & \begin{tabular}{|c|}
44.5 \\
\end{tabular} & 11 & 10 & 1 & 11 & & 3 & 8 & \\
\hline 13237 & 618 & & 4 & $\mathrm{C} 1$ & 281 & 4 & 4 & 14.5 & 1 & 1 & & 1 & & 1 & & \\
\hline 13237 & 618 & & 4 & $\mathrm{C1}$ & 281 & 4 & 3 & $\begin{array}{ll}64.2 \\
\end{array}$ & 8 & 8 & & 8 & & 3 & 5 & \\
\hline 13237 & 618 & & 4 & C1 & 281 & 4 & 2 & 57.1 & 16 & 16 & & 16 & & 3 & 13 & \\
\hline 13237 & 618 & & 4 & $\mathrm{C1}$ & 281 & 4 & 1 & 5.3 & 11 & 11 & & 11 & & & 11 & \\
\hline 13237 & 619 & & 4 & C1 & 281 & 4 & 3 & 169.9 & 11 & 8 & 3 & 11 & & 5 & 6 & \\
\hline 13237 & 619 & & 4 & $\mathrm{C} 1$ & 281 & 4 & 4 & 48.5 & 2 & & 2 & 2 & & 1 & 1 & \\
\hline 13237 & 619 & & 4 & $\mathrm{C} 1$ & 281 & 4 & 1 & 2 & 2 & 2 & & 2 & & & 2 & \\
\hline 13237 & 619 & & 4 & $\mathrm{C} 1$ & 281 & 4 & 2 & 53.7 & 10 & 4 & 6 & 10 & & 4 & 6 & \\
\hline 13237 & 619 & & 4 & $\mathrm{C1}$ & 281 & 4 & 5 & 103.5 & 1 & 1 & & 1 & & & 1 & \\
\hline 13237 & 620 & & 4 & $\mathrm{C} 1$ & \begin{tabular}{|l|}
281 \\
\end{tabular} & 4 & 4 & 1229.5 & 31 & 30 & 1 & 31 & & 9 & 22 & \\
\hline 13237 & 620 & & 4 & C1 & 281 & 4 & 5 & 596.9 & 6 & 6 & & 6 & & 4 & 2 & \\
\hline 13237 & 620 & & 4 & $\mathrm{C} 1$ & 281 & 4 & 6 & 248.3 & 2 & 2 & & 2 & & 2 & & \\
\hline 13237 & 620 & & 4 & $\mathrm{C1}$ & \begin{tabular}{|l|}
281 \\
\end{tabular} & 4 & 1 & 23.1 & 27 & 26 & 1 & 27 & & 3 & 24 & \\
\hline 13237 & 620 & & 4 & $\mathrm{C1}$ & 281 & 4 & 2 & 110 & 25 & 25 & & 25 & & 6 & 19 & \\
\hline 13237 & 620 & & 4 & $\mathrm{C} 1$ & 281 & 4 & 3 & 314.2 & 22 & 19 & 3 & 21 & 1 & 9 & 13 & \\
\hline 13237 & 623 & & 4 & C1 & \begin{tabular}{|l|}
281 \\
\end{tabular} & 4 & 3 & 164.7 & 14 & 3 & 11 & 14 & & 4 & 10 & \\
\hline 13237 & 623 & & 4 & $\mathrm{C} 1$ & \begin{tabular}{|l|}
281 \\
\end{tabular} & 4 & 4 & 128.7 & 3 & 3 & & 3 & & & 3 & \\
\hline 13237 & 623 & & 4 & $\mathrm{C} 1$ & \begin{tabular}{|l|}
281 \\
\end{tabular} & 4 & 1 & 1.8 & 1 & 1 & & 1 & & & 1 & \\
\hline 13237 & 623 & & 4 & C1 & 281 & 4 & 2 & 50.1 & 14 & 7 & 7 & 14 & & 1 & 13 & \\
\hline 13237 & 624 & & 4 & $\mathrm{C1}$ & 281 & 4 & 1 & 5.9 & 4 & 4 & & 4 & & & 4 & \\
\hline 13237 & 624 & & 4 & $\mathrm{C} 1$ & 281 & 4 & 5 & 592.5 & 5 & 5 & & 5 & & 4 & 1 & \\
\hline 13237 & 624 & & 4 & $\mathrm{C1}$ & \begin{tabular}{|l|}
281 \\
\end{tabular} & 4 & 6 & 395.3 & 2 & 2 & & 2 & & 2 & & \\
\hline 13237 & 624 & & 4 & C1 & 281 & 4 & 4 & 99.2 & 5 & 5 & & 5 & & 2 & 3 & \\
\hline 13237 & 624 & & 4 & C1 & 281 & 4 & 3 & 117.6 & 8 & 8 & & 8 & & 3 & 5 & \\
\hline 13237 & 624 & & 4 & $\mathrm{C1}$ & \begin{tabular}{|l|}
281 \\
\end{tabular} & 4 & 2 & 23.7 & 7 & 7 & & 6 & 1 & 3 & 4 & \\
\hline
\end{tabular}




\begin{tabular}{|c|c|c|c|c|c|c|c|c|c|c|c|c|c|c|c|c|}
\hline Site & Coll \# & Feature & LV & Blk & $\mathrm{AC}$ & Mat & $\overline{\mathrm{Sz}}$ & Grams & Qty & $\mathrm{Fr}$ & $\mathrm{NF}$ & Disc $P$ & $\operatorname{Disc} A$ & Cort P & Cort A & Comm \\
\hline \begin{tabular}{|l|}
13237 \\
\end{tabular} & 625 & & 4 & C1 & 281 & 4 & 4 & 929.1 & 28 & 28 & & 28 & & 11 & 17 & \\
\hline 13237 & 625 & & 4 & $\mathrm{C1}$ & 281 & 4 & 5 & 1044.6 & 11 & 11 & & 11 & & 7 & 4 & \\
\hline 13237 & 625 & & 4 & C1 & \begin{tabular}{|l|}
281 \\
\end{tabular} & 4 & 2 & 283.8 & 61 & 59 & 2 & 61 & & 11 & 50 & \\
\hline 13237 & 625 & & 4 & $\mathrm{C} 1$ & 281 & 4 & 3 & 606 & 42 & 42 & & 42 & & 10 & 32 & \\
\hline 13237 & 625 & & 4 & $\mathrm{C1}$ & 281 & 4 & 1 & 26.1 & 23 & 23 & & 23 & & 3 & 20 & \\
\hline 13237 & 625 & & 4 & C1 & \begin{tabular}{|l}
281 \\
\end{tabular} & 1 & 1 & 1.3 & 1 & 1 & & 1 & & & 1 & \\
\hline 13237 & 625 & & 4 & $\mathrm{C1}$ & 281 & 4 & 6 & 306.2 & 2 & 2 & & 2 & & 2 & & \\
\hline 13237 & 625 & & 4 & $\mathrm{C1}$ & 281 & 4 & 7 & 673.6 & 1 & & 1 & 1 & & 1 & & \\
\hline 13237 & 635 & & 4 & C1 & 281 & 4 & 6 & 375 & 2 & & 2 & 2 & & 2 & & \\
\hline 13237 & 635 & & 4 & C1 & 281 & 4 & 7 & 807.9 & 1 & 1 & & 1 & & 1 & & \\
\hline 13237 & 635 & & 4 & $\mathrm{C1}$ & 281 & 4 & 1 & 47.6 & 75 & 26 & 39 & 75 & & & 75 & \\
\hline 13237 & 635 & & 4 & $\mathrm{C} 1$ & 281 & 4 & 5 & 2021.3 & 17 & 10 & 7 & 17 & & 8 & 9 & \\
\hline 13237 & 635 & & 4 & $\mathrm{C1}$ & 281 & 4 & 2 & 558.8 & 147 & 38 & 109 & 147 & & 10 & 137 & \\
\hline 13237 & 635 & & 4 & $\mathrm{C} 1$ & 281 & 4 & 3 & 742.1 & 41 & 18 & 33 & 41 & & 10 & 31 & \\
\hline 13237 & 635 & & 4 & $\mathrm{C1}$ & 281 & 4 & 4 & 1141.4 & 33 & 21 & 12 & 33 & & 13 & 20 & \\
\hline 13237 & 636 & & 5 & $\mathrm{C1}$ & 281 & 4 & 6 & 136.9 & 1 & 1 & & 1 & & 1 & & \\
\hline 13237 & 636 & & 5 & $\mathrm{C} 1$ & 281 & 4 & 3 & 83.1 & 6 & 5 & 1 & 6 & & 3 & 3 & \\
\hline 13237 & 636 & & 5 & $\mathrm{C1}$ & 281 & 4 & 1 & 8.5 & 9 & 9 & & 9 & & 2 & 7 & \\
\hline 13237 & 636 & & 5 & C1 & 281 & 4 & 2 & 29.4 & 7 & 7 & & 7 & & 3 & 4 & \\
\hline 13237 & 638 & & 5 & C1 & 281 & 4 & 5 & 379.3 & 4 & 4 & & 4 & & 3 & 1 & \\
\hline 13237 & 638 & & 5 & C1 & 281 & 4 & 6 & 148.5 & 1 & & 1 & 1 & & 1 & & \\
\hline 13237 & 638 & & 5 & $\mathrm{C1}$ & 281 & 4 & $\frac{7}{7}$ & 239.1 & 1 & 1 & & 1 & & 1 & & \\
\hline 13237 & 638 & & 5 & $\mathrm{C1}$ & 281 & 4 & 4 & 299.4 & 9 & 8 & 1 & 7 & 2 & 1 & 6 & \\
\hline 13237 & 638 & & 5 & $\mathrm{C1}$ & 281 & 4 & 1 & 9.4 & 12 & 12 & & 12 & & 2 & 10 & \\
\hline 13237 & 638 & & 5 & C1 & 281 & 1 & 2 & 3.9 & 1 & 1 & & 1 & & 1 & & \\
\hline 13237 & 638 & & 5 & $\mathrm{C} 1$ & 281 & 4 & 3 & 188.3 & 13 & 13 & & 13 & & 7 & 6 & \\
\hline 13237 & 638 & & 5 & $\mathrm{C1}$ & 281 & 4 & 2 & 18.9 & 9 & 9 & & 9 & & 3 & 6 & \\
\hline 13237 & 639 & & 5 & $\mathrm{C1}$ & 281 & 4 & 4 & 90.1 & 3 & 3 & & 3 & & 1 & 2 & \\
\hline 13237 & 639 & & 5 & C1 & 281 & 4 & 5 & \begin{tabular}{|c|}
99.7 \\
\end{tabular} & 1 & 1 & & 1 & & 1 & & \\
\hline 13237 & 639 & & 5 & $\mathrm{C1}$ & 281 & 4 & 7 & 867.1 & 1 & 1 & & 1 & & 1 & & \\
\hline 13237 & 639 & & 5 & C1 & 281 & 4 & 3 & 71.1 & 9 & 8 & 1 & 9 & & 4 & 5 & \\
\hline 13237 & 639 & & 5 & C1 & 281 & 1 & 4 & 57.5 & 2 & 2 & & 2 & & 1 & 1 & \\
\hline 13237 & 639 & & 5 & C1 & 281 & 1 & 2 & 2.1 & 1 & 1 & & 1 & & 1 & & \\
\hline 13237 & 639 & & 5 & $\mathrm{C} 1$ & 281 & 4 & 2 & 64.4 & 14 & 13 & 1 & 14 & & 5 & 9 & \\
\hline 13237 & \begin{tabular}{l|l}
639 \\
\end{tabular} & & 5 & $\overline{\mathrm{C} 1}$ & 281 & 4 & 1 & 6.3 & 6 & 6 & & 6 & & & 6 & \\
\hline 13237 & 640 & & 5 & C1 & 281 & 4 & 6 & 882.5 & 2 & 2 & & 2 & & 2 & & \\
\hline 13237 & 640 & & 5 & $\mathrm{C} 1$ & 281 & 4 & 10 & 5443.2 & 1 & & 1 & 1 & & 1 & & \\
\hline 13237 & 640 & & 5 & C1 & 281 & 4 & 4 & 397.3 & 9 & 6 & 3 & 9 & & 4 & 5 & \\
\hline 13237 & 640 & & 5 & $\mathrm{C1}$ & 281 & 4 & 1 & 9 & 9 & 6 & 3 & 9 & & & 9 & \\
\hline 13237 & 640 & & 5 & C1 & 281 & 4 & 2 & 87.7 & 19 & 11 & 8 & 19 & & 3 & 16 & \\
\hline 13237 & 640 & & 5 & $\mathrm{C} 1$ & 281 & 4 & 3 & 253.3 & 20 & 10 & 10 & 20 & & 3 & 17 & \\
\hline 13237 & 641 & & 5 & $\mathrm{C1}$ & 281 & 4 & 4 & 185.4 & 5 & 3 & 2 & 5 & & 4 & 1 & \\
\hline 13237 & 641 & & 5 & C1 & 281 & 4 & 5 & 551.5 & 5 & 4 & 1 & 5 & & 5 & & \\
\hline 13237 & 641 & & 5 & $\mathrm{C} 1$ & 281 & 4 & 6 & 1697.1 & 3 & 1 & 2 & 3 & & 3 & & \\
\hline 13237 & 641 & & 5 & $\mathrm{C} 1$ & 281 & 4 & 1 & 6.2 & 7 & 6 & 1 & 7 & & 2 & 5 & \\
\hline 13237 & 641 & & 5 & $\mathrm{C} 1$ & 281 & 4 & 2 & 78.4 & 19 & 16 & 3 & 19 & & 6 & 13 & \\
\hline 13237 & 641 & & 5 & C1 & 281 & 4 & 3 & 43 & 2 & 2 & & 2 & & 2 & & \\
\hline 13237 & 642 & & 5 & $\mathrm{C} 1$ & 281 & 4 & 4 & 263.3 & 10 & 4 & 6 & 10 & & 3 & 7 & \\
\hline 13237 & 642 & & 5 & $\mathrm{C} 1$ & 281 & 4 & 5 & 458 & 5 & 3 & 2 & 5 & & 1 & 4 & \\
\hline 13237 & 642 & & 5 & $\mathrm{C} 1$ & 281 & 4 & 2 & 95.6 & 18 & 13 & 5 & 18 & & 3 & 15 & \\
\hline 13237 & 642 & & 5 & $\mathrm{C} 1$ & 281 & 4 & 3 & 298.9 & 16 & 8 & 8 & 16 & & 6 & 10 & \\
\hline 13237 & \begin{tabular}{|l|}
643 \\
\end{tabular} & & 5 & $\mathrm{C} 1$ & 281 & 4 & 2 & 370.7 & 57 & 16 & 41 & 57 & & 12 & 45 & \\
\hline 13237 & 643 & & 5 & C1 & 281 & 4 & 1 & 60.5 & 47 & 21 & 26 & 47 & & 5 & 42 & \\
\hline 13237 & 643 & & 5 & $\mathrm{C1}$ & 281 & 4 & 6 & 3042.5 & 7 & 5 & 2 & 7 & & 6 & 1 & \\
\hline 13237 & 643 & & 5 & C1 & 281 & 4 & 7 & 1813.8 & 3 & 2 & 1 & 3 & & 3 & & \\
\hline 13237 & \begin{tabular}{|l|}
643 \\
\end{tabular} & & 5 & $\mathrm{C1}$ & 281 & 4 & 5 & 2862.7 & 17 & 11 & 8 & 17 & & 9 & 8 & \\
\hline 13237 & 643 & & 5 & C1 & 281 & 4 & 3 & 794 & 41 & 24 & 17 & 41 & & 19 & 22 & \\
\hline 13237 & \begin{tabular}{l|l|}
643 \\
\end{tabular} & & 5 & C1 & 281 & 4 & 4 & 1226.4 & 25 & 21 & 4 & 25 & & 13 & 12 & \\
\hline 13237 & 64 & & 5 & C1 & 281 & 4 & 8 & 3359.3 & 3 & & 3 & 3 & & 3 & & \\
\hline 13237 & 644 & & 5 & C1 & 281 & 4 & 7 & 5686.2 & 9 & 3 & 6 & 9 & & 9 & & \\
\hline 13237 & 644 & & 5 & $\mathrm{C} 1$ & 281 & 4 & 10 & 2183.6 & 1 & & 1 & 1 & & 1 & & \\
\hline 13237 & 644 & & 5 & $\mathrm{C1}$ & 281 & 4 & 9 & 3475.2 & 2 & & 2 & 2 & & 2 & & \\
\hline 13237 & 644 & & 5 & C1 & 281 & 4 & 6 & 4160.1 & 12 & 4 & 8 & 12 & & 12 & & \\
\hline 13237 & 644 & & 5 & C1 & 281 & 4 & 3 & 209.2 & 14 & 11 & 3 & 14 & & 10 & 4 & \\
\hline 13237 & 644 & & 5 & $\mathrm{C} 1$ & 281 & 4 & 2 & 41.4 & 13 & 13 & & 13 & & 3 & 10 & \\
\hline 13237 & 644 & & 5 & $\mathrm{C1}$ & 281 & 4 & 5 & 1964.4 & 16 & 8 & 8 & 15 & 1 & 14 & 2 & \\
\hline 13237 & 644 & & 5 & C1 & 281 & 4 & 4 & 743.7 & 19 & 8 & 11 & 19 & & 16 & 3 & \\
\hline 13237 & 64 & & 5 & C1 & 281 & 4 & 1 & 8.2 & 8 & 8 & & 8 & & & 8 & \\
\hline 13237 & \begin{tabular}{l|l|}
650 \\
\end{tabular} & & 5 & C1 & 281 & 4 & 5 & 1677.7 & 18 & 14 & 4 & 18 & & 11 & 7 & \\
\hline
\end{tabular}




\begin{tabular}{|c|c|c|c|c|c|c|c|c|c|c|c|c|c|c|c|c|}
\hline Site & Coll \# & Feature & LV & Blk & $A C$ & Mat & $\mathrm{Sz}$ & Grams & Qty & $\mathrm{Fr}$ & $\mathrm{NF}$ & Disc $P$ & Disc A & Cort P & Cort A & Comm \\
\hline 13237 & 650 & & 5 & $\mathrm{C1}$ & 281 & 4 & 6 & 90.2 & 1 & 1 & & 1 & & 1 & & \\
\hline 13237 & 650 & & 5 & $\mathrm{C1}$ & 281 & 1 & 3 & 14.8 & 1 & 1 & & 1 & & 1 & & \\
\hline 13237 & 650 & & 5 & $\mathrm{C1}$ & 281 & 4 & 4 & 1138.8 & 27 & 21 & 6 & 27 & & 18 & 9 & \\
\hline 13237 & 650 & & 5 & $\mathrm{C1}$ & 281 & 4 & 2 & 86.8 & 20 & 20 & & 20 & & 6 & 14 & \\
\hline 13237 & 650 & & 5 & $\mathrm{C1}$ & 281 & 4 & 1 & 10 & 7 & 7 & & 7 & & 2 & 5 & \\
\hline 13237 & 650 & & 5 & $\mathrm{C1}$ & 281 & 4 & 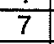 & 345.5 & 1 & 1 & & 1 & & 1 & & \\
\hline 13237 & 650 & & 5 & $\mathrm{C1}$ & 281 & 4 & 3 & 184.1 & 12 & 10 & 2 & 12 & & 6 & 6 & \\
\hline 13237 & 652 & & 5 & $\mathrm{C} 1$ & 281 & 4 & 4 & 1206.7 & 26 & 7 & 19 & 26 & & 26 & & \\
\hline 13237 & 652 & & 5 & $\mathrm{C1}$ & 281 & 4 & 5 & 3817.8 & 24 & 15 & 9 & 24 & & 20 & 4 & \\
\hline 13237 & 652 & & 5 & $\mathrm{C}_{1}$ & 281 & 4 & 2 & 244.1 & 60 & 23 & 37 & 60 & & 9 & 51 & \\
\hline 13237 & 652 & & 5 & $\mathrm{C} 1$ & 281 & 4 & 3 & 680.3 & 43 & 7 & 36 & 43 & & 21 & 22 & \\
\hline 13237 & 652 & & 5 & $\mathrm{C1}$ & 281 & 4 & 7 & 859.6 & 1 & & 1 & 1 & & 1 & & \\
\hline 13237 & 652 & & 5 & $\mathrm{C} 1$ & \begin{tabular}{|l|}
281 \\
\end{tabular} & 4 & 8 & 569.7 & 1 & 1 & & 1 & & 1 & & \\
\hline 13237 & 652 & & 5 & $\mathrm{C1}$ & \begin{tabular}{|l|}
281 \\
\end{tabular} & 4 & 6 & 2888.4 & 8 & 6 & 2 & 8 & & 8 & & \\
\hline 13237 & 652 & & 6 & $\mathrm{C1}$ & 281 & 4 & 1 & 38.7 & 38 & 15 & 23 & 38 & & & 38 & \\
\hline 13237 & 653 & & 5 & $\mathrm{C1}$ & 281 & 4 & 2 & 107 & 20 & 19 & 1 & 20 & & 3 & 17 & \\
\hline 13237 & 653 & & 5 & $\mathrm{C1}$ & 281 & 4 & 1 & 9.7 & 12 & 12 & & 12 & & & 12 & \\
\hline 13237 & 653 & & 5 & $\mathrm{C} 1$ & 281 & 4 & 6 & 127 & 1 & 1 & & 1 & & 1 & & \\
\hline 13237 & 653 & & 5 & C1 & 281 & 4 & 5 & 461.1 & 7 & 3 & 4 & 7 & & 1 & 6 & \\
\hline 13237 & 653 & & 5 & C1 & 281 & 4 & 4 & 635.8 & 17 & 15 & 2 & 17 & & 6 & 11 & \\
\hline 13237 & 653 & & 5 & $\mathrm{C} 1$ & 281 & 4 & 3 & 120.3 & 11 & 9 & 2 & 11 & & 2 & 9 & \\
\hline 13237 & 654 & & 5 & $\mathrm{C1}$ & 281 & 1 & 1 & \begin{tabular}{l|l}
0.8 \\
\end{tabular} & 1 & 1 & & 1 & & 1 & & \\
\hline 13237 & 654 & & 5 & C1 & 281 & 4 & 2 & 2.7 & 1 & 1 & & 1 & & & 1 & \\
\hline 13237 & 654 & & 5 & $\mathrm{C1}$ & 281 & 4 & 1 & 0.6 & 3 & 3 & & 3 & & & 3 & \\
\hline 13237 & 654 & & 5 & C1 & 281 & 4 & 4 & 10.7 & 1 & 1 & & 1 & & 1 & & \\
\hline 13237 & 654 & & 5 & $\mathrm{C1}$ & 281 & 4 & 3 & 13.1 & 1 & 1 & & 1 & & 1 & & \\
\hline 13237 & 659 & & 6 & $\mathrm{C1}$ & 281 & 1 & 1 & 0.05 & 1 & 1 & & 1 & & & 1 & \\
\hline 13237 & 659 & & 6 & $\mathrm{C} 1$ & 281 & 4 & 1 & 0.54 & 5 & 5 & & 5 & & & 5 & \\
\hline 13237 & 659 & & 6 & $\mathrm{Cl}$ & 281 & 4 & 2 & 0.66 & 1 & 1 & & 1 & & & 1 & \\
\hline 13237 & 660 & 40 & 6 & $\mathrm{Cl}$ & 281 & 4 & 3 & 15.3 & 1 & 1 & & 1 & & & 1 & \\
\hline 13237 & 660 & 40 & 6 & $\mathrm{C} 1$ & 281 & 4 & 2 & 5.3 & 2 & 2 & & 2 & & & 2 & \\
\hline 13237 & 660 & 40 & 6 & C1 & 281 & 4 & 1 & 0.6 & 3 & 3 & & 3 & & & 3 & \\
\hline 13237 & 660 & 40 & 6 & $\mathrm{C1}$ & 281 & 4 & 5 & \begin{tabular}{|l|}
87.4 \\
\end{tabular} & 1 & 1 & & 1 & & 1 & & $1 \mathrm{FLK}$ \\
\hline 13237 & 661 & 40 & 5 & $\mathrm{C1}$ & 281 & 4 & 1 & 1.2 & 2 & 2 & & 2 & & & 2 & \\
\hline 13237 & 661 & 40 & 6 & $\mathrm{C1}$ & 281 & 4 & 2 & 36 & 10 & 10 & & 10 & & & 10 & \\
\hline 13237 & 661 & 40 & 6 & $\mathrm{C} 1$ & 281 & 4 & 3 & 160.5 & 13 & 10 & 3 & 13 & & 9 & 4 & \\
\hline 13237 & 661 & 40 & 6 & C1 & 281 & 4 & 4 & 170.6 & 7 & 7 & & 7 & & 6 & 1 & \\
\hline 13237 & 661 & 40 & 6 & $\mathrm{CI}$ & 281 & 4 & 5 & 1551.5 & 10 & 8 & 2 & 10 & & 10 & & \\
\hline 13237 & 661 & 40 & 6 & $\mathrm{C} 1$ & 281 & 4 & 6 & 2374.8 & 7 & 6 & 1 & 7 & & 7 & & \\
\hline 13237 & 661 & 40 & 6 & $\mathrm{C} 1$ & 281 & 4 & 7 & 467.1 & 1 & 1 & & 1 & & 1 & & \\
\hline 13237 & 661 & 40 & 6 & C1 & 281 & 4 & 8 & 3156.2 & 3 & 2 & 1 & 3 & & 3 & & \\
\hline 13237 & 661 & 40 & 6 & $\mathrm{C1}$ & 281 & 4 & 9 & 7270.2 & 5 & 3 & 2 & 5 & & 5 & & \\
\hline 13237 & 661 & 40 & 6 & $\mathrm{C} 1$ & 281 & 4 & 10 & 3513.1 & 1 & & 1 & 1 & & 1 & & \\
\hline 13237 & 663 & 102 & 5 & C1 & 281 & 4 & 5 & 550 & 7 & 3 & 4 & 7 & & 6 & 1 & \\
\hline 13237 & 663 & 102 & 5 & C1 & 281 & 4 & 3 & 17.3 & 2 & 2 & & 2 & & & 2 & \\
\hline 13237 & 663 & 102 & 5 & $\mathrm{C} 1$ & 281 & 4 & 4 & 76.2 & 2 & 2 & & 2 & & 2 & & \\
\hline 13237 & 666 & 102 & 5 & $\mathrm{C1}$ & 281 & 4 & 1 & 0.4 & 1 & 1 & & 1 & & & 1 & \\
\hline 13237 & 666 & 102 & 5 & C1 & 281 & 4 & 2 & \begin{tabular}{|c|}
9.6 \\
\end{tabular} & 4 & 4 & & 4 & & 1 & 3 & \\
\hline 13237 & 666 & 102 & 5 & $\mathrm{Cl}$ & 281 & 4 & 3 & 59.8 & 3 & 2 & 1 & 3 & & 2 & 1 & \\
\hline 13237 & 666 & 102 & 5 & $\mathrm{C} 1$ & 281 & 4 & 4 & 217.4 & 3 & 2 & 1 & 3 & & 3 & & \\
\hline 13237 & 666 & 102 & 5 & $\mathrm{C1}$ & 281 & 4 & 5 & 637 & 7 & 5 & 2 & 7 & & 5 & 2 & \\
\hline 13237 & 666 & 102 & 5 & $\mathrm{C} 1$ & 281 & 4 & 6 & 1621.8 & 7 & 5 & 2 & 7 & & 5 & 2 & \\
\hline 13237 & 666 & 102 & 5 & C1 & 281 & 4 & 7 & 602.6 & 2 & 1 & 1 & 2 & & 2 & & \\
\hline 13237 & 666 & 102 & 5 & $\mathrm{C1}$ & 281 & 4 & 8 & 2211.3 & 2 & 1 & 1 & 2 & & 2 & & \\
\hline 13237 & 666 & 102 & 5 & C1 & 281 & 4 & 9 & 5077.4 & 3 & & 3 & 3 & & 3 & & \\
\hline 13237 & 668 & 102 & 5 & $\mathrm{C1}$ & 281 & 4 & 6 & 483.7 & 2 & 1 & 1 & 2 & & 2 & & \\
\hline 13237 & 668 & 102 & 5 & C1 & 281 & 4 & 5 & 405.9 & 5 & 5 & & 5 & & 5 & & \\
\hline 13237 & 668 & 102 & 5 & C1 & 281 & 4 & 1 & 4.2 & 7 & 7 & & 7 & & 2 & 5 & \\
\hline 13237 & 668 & 102 & 5 & $\mathrm{C1}$ & 281 & 4 & 3 & 68.8 & 5 & 4 & 1 & 4 & 1 & 3 & 2 & \\
\hline 13237 & 668 & 102 & 5 & $\mathrm{C} 1$ & \begin{tabular}{|l|}
281 \\
\end{tabular} & 4 & 2 & 5.3 & 2 & 2 & & 2 & & & 2 & \\
\hline 13237 & 668 & 102 & 5 & $\mathrm{C1}$ & \begin{tabular}{|l|}
281 \\
\end{tabular} & 4 & 4 & 551.7 & 14 & 9 & 5 & 14 & & 7 & 7 & \\
\hline 13237 & 669 & 103 & 5 & C1 & 281 & 4 & 5 & 2657.4 & 14 & 3 & 11 & 14 & & 14 & & \\
\hline 13237 & 669 & 103 & 5 & C1 & 281 & 4 & 1 & 6.3 & 5 & & 5 & 5 & & 5 & & \\
\hline 13237 & 669 & 103 & 5 & C1 & 281 & 4 & 2 & \begin{tabular}{c|}
12.7 \\
\end{tabular} & 4 & 1 & 3 & 4 & & 4 & & \\
\hline 13237 & 669 & 103 & 5 & $\mathrm{C1}$ & 281 & 4 & 6 & 3460.7 & 10 & 2 & 8 & 10 & & 10 & & \\
\hline 13237 & 669 & 103 & 5 & $\mathrm{C1}$ & 281 & 4 & 3 & 15.5 & 1 & 1 & & 1 & & 1 & & \\
\hline 13237 & 669 & 103 & 5 & $\mathrm{C1}$ & 281 & 4 & 4 & 169.6 & 3 & 2 & 1 & 3 & & 2 & 1 & \\
\hline 13237 & 669 & 103 & 5 & C1 & 281 & 4 & 7 & 6273.2 & 8 & 5 & 3 & 8 & & 8 & & \\
\hline 13237 & 669 & 103 & 5 & C1 & \begin{tabular}{|l|}
281 \\
\end{tabular} & 4 & 3 & 95.5 & 10 & 7 & 3 & 10 & & 6 & 4 & \\
\hline
\end{tabular}




\begin{tabular}{|c|c|c|c|c|c|c|c|c|c|c|c|c|c|c|c|c|}
\hline Site & Coll \# & \begin{tabular}{|l|} 
Feature \\
\end{tabular} & LV & Blk & $A C$ & Mat & $\mathrm{Sz}$ & Grams & Qty & $\mathrm{Fr}$ & $\mathrm{NF}$ & Disc $P$ & $\operatorname{Disc} A$ & Cort P & Cort A & Comm \\
\hline 13237 & 672 & & 5 & C1 & 281 & 1 & 1 & 1.1 & 1 & 1 & & 1 & & & 1 & \\
\hline 13237 & 672 & & 5 & $\mathrm{C1}$ & 281 & 4 & 9 & 4914.1 & 3 & 1 & 2 & 3 & & 3 & & \\
\hline 13237 & 672 & & 5 & $\mathrm{C1}$ & 281 & 4 & 2 & 94.9 & 20 & 20 & & 17 & 3 & 8 & 12 & \\
\hline 13237 & 672 & & 5 & $\mathrm{C} 1$ & 281 & 4 & 1 & 9.9 & 10 & 10 & & 10 & & 1 & 9 & \\
\hline 13237 & 672 & & 5 & $\mathrm{C1}$ & 281 & 4 & 8 & 5241.1 & 5 & 1 & 4 & 5 & & 5 & & \\
\hline 13237 & 672 & & 5 & $\mathrm{C} 1$ & 281 & 4 & 5 & 3989.9 & 31 & 12 & 19 & 30 & 1 & 28 & 3 & \\
\hline 13237 & 672 & & 5 & $\mathrm{C} 1$ & 281 & 4 & 4 & 776.5 & 17 & 8 & 9 & 17 & & 12 & 5 & \\
\hline 13237 & 672 & & 5 & $\mathrm{C1}$ & 281 & 4 & 7 & 5289.8 & 8 & 6 & 2 & 8 & & 8 & & \\
\hline \begin{tabular}{|l|}
13237 \\
\end{tabular} & 672 & & 5 & $\mathrm{C1}$ & 281 & 4 & 6 & 4165.6 & 14 & 5 & 9 & 14 & & 14 & & \\
\hline 13237 & 672 & & 5 & $\mathrm{C1}$ & 281 & 4 & 3 & 268.6 & 18 & 17 & 1 & 15 & 3 & 7 & 11 & \\
\hline 13237 & 673 & 40 & 5 & C1 & 281 & 4 & 5 & 109.6 & 1 & & 1 & 1 & & 1 & & \\
\hline 13237 & 673 & 40 & 5 & $\mathrm{C} 1$ & 281 & 4 & 4 & 30.1 & 2 & & 2 & 2 & & & 2 & \\
\hline 13237 & 673 & 40 & 5 & $\mathrm{C1}$ & 281 & 4 & 3 & 13.8 & 2 & & 2 & 2 & & & 2 & \\
\hline 13237 & 673 & 40 & 5 & $\mathrm{C1}$ & 281 & 4 & 2 & 44.3 & 12 & 6 & 6 & 12 & & 2 & 10 & \\
\hline 13237 & 673 & 40 & 5 & $\mathrm{C} 1$ & 281 & 4 & 1 & 7.7 & 8 & 8 & & 8 & & & 8 & \\
\hline 13237 & 674 & 40 & 5 & $\mathrm{C1}$ & 281 & 4 & 10 & 3252.1 & 1 & & 1 & 1 & & 1 & & \\
\hline \begin{tabular}{|l|}
13237 \\
\end{tabular} & 674 & 40 & 5 & $\mathrm{C} 1$ & 281 & 4 & 9 & 4471.2 & 2 & & 2 & 2 & & 2 & & \\
\hline 13237 & 674 & 40 & 5 & $\mathrm{C} 1$ & 281 & 4 & 8 & 5793 & 3 & & 3 & 3 & & 3 & & \\
\hline 13237 & 674 & 40 & 5 & $\mathrm{C1}$ & 281 & 4 & 7 & 3830.6 & 6 & 4 & 2 & 6 & & 6 & & \\
\hline 13237 & 674 & 40 & 5 & $\mathrm{C1}$ & 281 & 4 & 6 & 3064.2 & 10 & 5 & 5 & 10 & & 10 & & \\
\hline 13237 & 674 & 40 & 5 & $\mathrm{C1}$ & 281 & 4 & 5 & 1428.5 & 12 & 9 & 3 & 12 & & 9 & 3 & \\
\hline 13237 & 674 & 40 & 5 & C1 & 281 & 4 & 4 & 200 & 3 & 2 & 1 & 3 & & 2 & 1 & \\
\hline 13237 & 674 & 40 & 5 & $\mathrm{C1}$ & 281 & 4 & 3 & 55.3 & 5 & 5 & & 5 & & 3 & 2 & \\
\hline 13237 & 674 & 40 & 5 & $\mathrm{C1}$ & 281 & 4 & 2 & 20.14 & 10 & 7 & 3 & 10 & & 3 & 7 & \\
\hline 13237 & 674 & 40 & 5 & $\mathrm{C1}$ & 281 & 4 & 1 & 13.8 & 16 & 7 & 9 & 16 & & 4 & 12 & \\
\hline 13237 & 676 & & 5 & $\mathrm{C} 1$ & 281 & 4 & 3 & 203.7 & 16 & 15 & 1 & 16 & & 5 & 11 & \\
\hline 13237 & 676 & & 5 & $\mathrm{C} 1$ & 281 & 4 & 6 & 1740.4 & 7 & 4 & 3 & 7 & & 7 & & \\
\hline 13237 & 676 & & 5 & $\mathrm{C} 1$ & 281 & 4 & 5 & 1449.2 & 12 & 8 & 4 & 12 & & 9 & 3 & \\
\hline 13237 & 676 & & 5 & $\mathrm{C1}$ & 281 & 4 & 7 & 2084.8 & 3 & $T$ & 2 & 3 & & 3 & & \\
\hline \begin{tabular}{|l|}
13237 \\
\end{tabular} & 676 & & 5 & $\mathrm{C} 1$ & 281 & 4 & 9 & 4051.8 & 3 & 1 & 2 & 3 & & 3 & & \\
\hline 13237 & 676 & & 5 & $\mathrm{C} 1$ & 281 & 4 & 8 & 407.6 & 1 & & 1 & 1 & & 1 & & \\
\hline 13237 & 676 & & 5 & $\mathrm{C1}$ & 281 & 4 & 2 & 148.1 & 38 & 36 & 2 & 38 & & 10 & 28 & \\
\hline 13237 & 676 & & 5 & $\mathrm{C1}$ & 281 & 4 & 11 & 3310.9 & 1 & & 1 & 1 & & 1 & & \\
\hline 13237 & 676 & & 5 & $\mathrm{C}_{1}$ & 281 & 4 & 4 & 298.3 & 10 & 10 & & 10 & & 4 & 6 & \\
\hline 13237 & 676 & & 5 & $\mathrm{C} 1$ & 281 & 4 & 1 & 40.2 & 35 & 35 & & 35 & & 4 & 31 & \\
\hline 13237 & 677 & & 5 & $\mathrm{C1}$ & 281 & 4 & 1 & 21.2 & 33 & 22 & 11 & 33 & & 9 & 24 & \\
\hline 13237 & 677 & 40 & 5 & $\mathrm{C} 1$ & 281 & 4 & 7 & 9603 & 14 & 10 & 4 & & 14 & 14 & & \\
\hline 13237 & 677 & 40 & 5 & $\mathrm{C1}$ & 281 & 4 & 4 & 739.7 & 15 & 11 & 4 & 15 & & 10 & 5 & \\
\hline 13237 & 677 & 40 & 5 & C1 & 281 & 4 & 5 & 2286.5 & 13 & 10 & 3 & 13 & & 12 & 1 & \\
\hline 13237 & 677 & 40 & 5 & $\mathrm{C} 1$ & 281 & 4 & 2 & 40 & 11 & 8 & 3 & 11 & & 6 & 5 & \\
\hline 13237 & 677 & 40 & 5 & $\mathrm{C1}$ & 281 & 4 & 3 & 103.5 & 7 & 6 & 1 & 7 & & 3 & 4 & \\
\hline 13237 & 677 & 40 & 5 & C1 & 281 & 4 & 8 & 13747.2 & 11 & 7 & 4 & 11 & & 11 & & \\
\hline 13237 & 677 & 40 & 5 & $\mathrm{C} 1$ & 281 & 4 & 9 & 6775.2 & 3 & 2 & 1 & 3 & & 3 & & \\
\hline 13237 & 677 & 40 & 5 & $\mathrm{C} 1$ & 281 & 4 & 6 & 11967.8 & 31 & 20 & 11 & 31 & & 31 & & \\
\hline 13237 & 679 & 102 & 5 & C1 & 281 & 4 & 2 & 1 & 1 & & 1 & 1 & & 1 & & \\
\hline 13237 & 679 & 102 & 5 & $\mathrm{C1}$ & 281 & 4 & 4 & 178.5 & 6 & 2 & 4 & 6 & & 5 & 1 & \\
\hline 13237 & 679 & 102 & 5 & $\mathrm{C} 1$ & 281 & 4 & 5 & 1714.9 & 11 & 5 & 6 & 11 & & 11 & & \\
\hline 13237 & 679 & 102 & 5 & $\mathrm{C1}$ & 281 & 4 & 9 & 1281.5 & 2 & 1 & 1 & 2 & & 2 & & \\
\hline 13237 & 679 & 102 & 5 & $\mathrm{C1}$ & 281 & 4 & 7 & 6284.1 & 10 & 4 & 6 & 10 & & 10 & & \\
\hline 13237 & 679 & 102 & 5 & $\mathrm{C1}$ & 281 & 4 & 6 & \begin{tabular}{l|}
3651.2 \\
\end{tabular} & 11 & 6 & 5 & 11 & & 11 & & \\
\hline 13237 & 679 & 102 & 5 & C1 & 281 & 4 & 10 & 3038.2 & 2 & & 2 & 2 & & 2 & & \\
\hline 13237 & 681 & 102 & 5 & C1 & 281 & 4 & 1 & 1.3 & 1 & 1 & & 1 & & 1 & & \\
\hline 13237 & 681 & 102 & 5 & $\mathrm{C} 1$ & 281 & 4 & 5 & 1127 & 9 & 4 & 5 & 9 & & 8 & 1 & \\
\hline 13237 & 681 & 102 & 5 & $\mathrm{C1}$ & 281 & 4 & 3 & 29.6 & 3 & 3 & & 3 & & 3 & & \\
\hline 13237 & 681 & 102 & 5 & $\mathrm{C1}$ & 281 & 4 & 2 & 13.9 & 4 & 2 & 2 & 4 & & 4 & & \\
\hline 13237 & 681 & 102 & 5 & $\mathrm{C} 1$ & 281 & 4 & 6 & 5399.6 & 15 & 5 & 10 & 15 & 1 & 15 & & \\
\hline 13237 & 681 & 102 & 5 & $\mathrm{C}_{1}$ & 281 & 4 & 7 & 3560.6 & 6 & & 6 & 6 & & 6 & & \\
\hline 13237 & 681 & 102 & 5 & $\mathrm{C1}$ & 281 & 4 & 8 & 3538 & 3 & 2 & 1 & 3 & & 3 & & \\
\hline 13237 & 681 & 102 & 5 & $\mathrm{C} 1$ & 281 & 4 & 10 & 6786.7 & 3 & & 3 & 3 & & 3 & & \\
\hline 13237 & 705 & 48 & 2 & A1 & 281 & 4 & 4 & 191.2 & 6 & 4 & 2 & 6 & & 6 & & \\
\hline 13237 & 705 & 48 & 2 & $\overline{\mathrm{A} 1}$ & 281 & 4 & 5 & 278 & 3 & 2 & 1 & 3 & & 3 & & \\
\hline 13237 & 705 & 48 & 2 & $\mathrm{~A} 1$ & 281 & 4 & 6 & 469.4 & 1 & 1 & & 1 & & 1 & & \\
\hline 13237 & \begin{tabular}{ll|}
705 \\
\end{tabular} & 48 & 2 & $\mathrm{A1}$ & 281 & 4 & 1 & 23 & 25 & 13 & 12 & 25 & & 8 & 17 & \\
\hline 13237 & 705 & 48 & 2 & $\mathrm{~A} 1$ & 281 & 4 & 2 & 150.3 & 40 & 11 & 29 & 40 & & 35 & 5 & \\
\hline 13237 & 705 & 48 & 2 & $\overline{\mathrm{A} 1}$ & 281 & 4 & 3 & 211.5 & 16 & 4 & 12 & 16 & & 8 & 8 & \\
\hline 13237 & 706 & 48 & 1 & $\mathrm{~A} 1$ & 281 & 4 & 3 & 38.9 & 3 & & 3 & 3 & & 3 & & \\
\hline 13237 & 706 & 48 & 1 & $\mathrm{~A} 1$ & 281 & 4 & 4 & 14 & 1 & 1 & & 1 & & 1 & & \\
\hline 13237 & 706 & 48 & 1 & $\mathrm{~A} 1$ & 281 & 4 & 1 & 1.8 & 2 & 2 & & 2 & & & 2 & \\
\hline 13237 & 706 & 48 & 1 & $\mathrm{~A} 1$ & 281 & 4 & 2 & 12.5 & 2 & 1 & 1 & 2 & & 1 & 1 & \\
\hline
\end{tabular}




\begin{tabular}{|c|c|c|c|c|c|c|c|c|c|c|c|c|c|c|c|c|}
\hline Site & Coll \# & Feature & LV & Blk & $\overline{A C}$ & Mat & $\mathrm{Sz}$ & Grams & Qty & $\mathrm{Fr}$ & $\mathrm{NF}$ & Disc P & Disc A & Cort P & Cort A & Comm \\
\hline 13237 & 707 & 48 & 1 & A1 & 281 & 4 & 4 & 134.5 & 6 & 5 & 1 & 6 & & 6 & & \\
\hline 13237 & 707 & 48 & 1 & A1 & 281 & 4 & 5 & 144.9 & 3 & 3 & & 3 & & 3 & & \\
\hline 13237 & 707 & 48 & 1 & A1 & 281 & 4 & 3 & 4.5 & 1 & & 1 & 1 & & 1 & & \\
\hline 13237 & 707 & 48 & 1 & A1 & 281 & 4 & 1 & 1.12 & 3 & 3 & & 3 & & 3 & & \\
\hline 13237 & 707 & 48 & 1 & $\mathrm{A1}$ & 281 & 4 & 2 & 22.2 & 5 & 4 & 1 & 5 & & 3 & 2 & \\
\hline 13237 & 708 & 48 & 2 & A1 & 281 & 4 & 4 & 239.5 & 9 & 2 & 7 & 9 & & 9 & & \\
\hline 13237 & 708 & 48 & 2 & A1 & 281 & 4 & 5 & 55.3 & 1 & & 1 & 1 & & 1 & & \\
\hline 13237 & 708 & 48 & 2 & A1 & 281 & 4 & 2 & 61.2 & 14 & 4 & 10 & 14 & & 14 & & \\
\hline 13237 & 708 & 48 & 2 & $\bar{A} 1$ & 281 & 4 & 3 & 183.1 & 15 & 3 & 12 & 15 & & 15 & & \\
\hline \begin{tabular}{|l}
13237 \\
\end{tabular} & 709 & 48 & 1 & A1 & 281 & 4 & 3 & 37.6 & 3 & 2 & 1 & 3 & & 3 & & \\
\hline 13237 & 709 & 48 & 1 & A1 & 281 & 4 & 2 & 25.4 & 4 & 2 & 2 & 4 & & 4 & & \\
\hline 13237 & 709 & 48 & 1 & A1 & 281 & 4 & 1 & 0.37 & 1 & 1 & & 1 & & 1 & & \\
\hline 13237 & 710 & 48 & 1 & A1 & 281 & 4 & 4 & 40.3 & 3 & & 3 & 3 & & 3 & & \\
\hline 13237 & 710 & 48 & 1 & A1 & 281 & 4 & 5 & 444.1 & 3 & 3 & & 3 & & 3 & & \\
\hline 13237 & 710 & 48 & 1 & $\mathrm{A1}$ & 281 & 4 & 3 & 54.8 & 6 & 3 & 3 & 6 & & 2 & 4 & \\
\hline 13237 & 710 & 48 & 1 & $\mathrm{~A} 1$ & 281 & 4 & 1 & 5.1 & 12 & 9 & 3 & 12 & & 4 & 8 & \\
\hline 13237 & 710 & 48 & 1 & A1 & 281 & 4 & 2 & 116.7 & 31 & 8 & 23 & 31 & & 6 & 25 & \\
\hline 13237 & 711 & 48 & 1 & A1 & 281 & 4 & 3 & 102.1 & 8 & 1 & 7 & 8 & & 5 & 3 & \\
\hline 13237 & 711 & 48 & 1 & $\overline{A 1}$ & 281 & 4 & 2 & 48.2 & 10 & 3 & 7 & 10 & & 1 & 9 & \\
\hline 13237 & 711 & 48 & 1 & $\mathrm{~A} 1$ & 281 & 4 & 1 & 4.5 & 6 & 3 & 3 & 6 & & 3 & 3 & \\
\hline 13237 & 711 & 48 & 1 & A1 & 281 & 4 & 4 & 126.2 & 2 & & 2 & 2 & & 2 & & \\
\hline 13237 & 711 & 48 & 1 & A1 & 281 & 4 & 7 & 664.6 & 1 & & 1 & 1 & & 1 & & \\
\hline 13237 & 711 & 48 & 1 & A1 & \begin{tabular}{|l|}
281 \\
\end{tabular} & 4 & 6 & 477.4 & 1 & 1 & & 1 & & 1 & & \\
\hline 13237 & 711 & 48 & 1 & $\mathrm{~A} 1$ & 281 & 4 & 5 & 102.8 & 1 & 1 & & 1 & & 1 & & \\
\hline \begin{tabular}{|l|}
13237 \\
\end{tabular} & 712 & 48 & 1 & $\mathrm{~A} 1$ & 281 & 4 & 5 & 309.9 & 6 & 4 & 2 & 6 & & 5 & 1 & \\
\hline 13237 & 712 & 48 & 1 & A1 & 281 & 4 & 6 & 190.7 & 1 & 1 & & 1 & & 1 & & \\
\hline 13237 & 712 & 48 & 1 & A1 & 281 & 6 & 2 & 7.3 & 1 & 1 & & 1 & & & 1 & \\
\hline 13237 & 712 & 48 & 1 & $A 1$ & 281 & 4 & 4 & 493.9 & 19 & 15 & 4 & 17 & 2 & 11 & 8 & \\
\hline 13237 & 712 & 48 & 1 & $\mathrm{A1}$ & 281 & 4 & 1 & 9 & 9 & 9 & & 9 & & & 9 & \\
\hline 13237 & 712 & 48 & 1 & A1 & 281 & 4 & 2 & 126.6 & 29 & 26 & 3 & 29 & & 6 & 23 & \\
\hline 13237 & 712 & 48 & 1 & A1 & 281 & 4 & 3 & 277.5 & 25 & 19 & 6 & 25 & & 12 & 13 & \\
\hline 13237 & 713 & 48 & 1 & $\mathrm{~A} 1$ & 281 & 4 & 5 & 677.7 & 4 & 4 & & 4 & & 3 & 1 & \\
\hline 13237 & 713 & 48 & 1 & $\mathrm{~A}_{1}$ & 281 & 4 & 6 & 75.6 & 1 & 1 & & 1 & & 1 & & \\
\hline 13237 & 713 & 48 & 1 & $\mathrm{~A} 1$ & 281 & 4 & 7 & 974.1 & 1 & 1 & & 1 & & 1 & & \\
\hline 13237 & 713 & 48 & 1 & $\mathrm{~A} 1$ & \begin{tabular}{|l|}
281 \\
\end{tabular} & 4 & 4 & 86.1 & 4 & 3 & 1 & 4 & & 2 & 2 & \\
\hline 13237 & 713 & 48 & 1 & $\mathrm{~A} 1$ & 281 & 4 & 1 & 26 & 22 & 22 & & 22 & & & 22 & \\
\hline 13237 & 713 & 48 & 1 & $\mathrm{~A} 1$ & 281 & 4 & 2 & 58.1 & 16 & 16 & & 16 & & 4 & 12 & \\
\hline 13237 & 713 & 48 & 1 & A1 & 281 & 4 & 3 & 94.5 & 10 & 9 & 1 & 10 & & 3 & 7 & \\
\hline 13237 & 714 & 48 & 1 & A1 & 281 & 4 & 4 & 211.8 & 10 & 7 & 3 & 10 & & 5 & 5 & \\
\hline 13237 & 714 & 48 & 1 & $\mathrm{A1}$ & 281 & 4 & 5 & 134.8 & 1 & 1 & & 1 & & 7 & & \\
\hline 13237 & 714 & 48 & 1 & $\mathrm{A1}$ & 281 & 4 & 7 & 806.6 & 1 & 1 & & 1 & & 1 & & \\
\hline 13237 & 714 & 48 & 1 & A1 & 281 & 4 & 1 & 10.3 & 8 & 7 & 1 & 8 & & 2 & 6 & \\
\hline \begin{tabular}{|l|}
3237 \\
\end{tabular} & 714 & 48 & 1 & A1 & 281 & 4 & 2 & 92 & 26 & 21 & 5 & 26 & & 9 & 12 & \\
\hline 13237 & 714 & 48 & 1 & $\mathrm{~A} 1$ & 281 & 4 & 3 & 278 & 22 & 15 & 7 & 22 & & 15 & 7 & \\
\hline 13237 & 715 & 48 & 2 & $\mathrm{~A} 1$ & 281 & 4 & 3 & 819.5 & 63 & 12 & 51 & 63 & & 63 & & \\
\hline 13237 & 715 & 48 & 2 & A1 & 281 & 4 & 4 & 518.3 & 18 & 5 & 13 & 18 & & 18 & & \\
\hline 13237 & 715 & 48 & 2 & A1 & 281 & 4 & 1 & 68 & 79 & & 79 & 79 & & 79 & & \\
\hline 13237 & 715 & 48 & 2 & $\mathrm{A1}$ & 281 & 4 & 2 & 627.7 & 156 & 13 & 143 & 156 & & 156 & & \\
\hline 13237 & 716 & 48 & 2 & A1 & 281 & 4 & 3 & 763.8 & 64 & 50 & 14 & 64 & & 28 & 36 & \\
\hline 13237 & 716 & 48 & 2 & $\mathrm{~A} 1$ & 281 & 4 & 2 & 704.4 & 174 & 162 & 12 & 174 & & 34 & 140 & \\
\hline 13237 & 716 & 48 & 2 & A1 & 281 & 4 & 1 & 200.7 & 181 & 178 & 3 & 180 & 1 & 13 & 168 & \\
\hline \begin{tabular}{|l|}
13237 \\
\end{tabular} & 716 & 48 & 2 & A1 & 281 & 4 & 6 & 141.1 & 1 & & 1 & 1 & & 1 & & \\
\hline \begin{tabular}{|l|}
13237 \\
\end{tabular} & 716 & 48 & 2 & A1 & 281 & 4 & 5 & 191.9 & 2 & 1 & 1 & 2 & & 2 & & \\
\hline 13237 & 716 & 48 & 2 & $\mathrm{~A} 1$ & 281 & 4 & 4 & 585.7 & 23 & 15 & 8 & 23 & & 16 & 7 & \\
\hline 13237 & 717 & 48 & 2 & $\mathrm{~A} 1$ & 281 & 4 & 4 & 447.9 & 16 & 6 & 10 & 16 & & 4 & 12 & \\
\hline 13237 & 717 & 48 & 2 & A1 & 281 & 4 & 5 & 215.3 & 4 & 4 & & 4 & & 4 & & \\
\hline 13237 & 717 & 48 & 2 & A1 & 281 & 4 & 3 & 580.5 & 45 & 17 & 28 & 45 & & 9 & 36 & \\
\hline 13237 & 717 & 48 & 2 & $\mathrm{~A} 1$ & 281 & 4 & 1 & 66.9 & 71 & 16 & 55 & 71 & & 8 & 63 & \\
\hline 13237 & 717 & 48 & 2 & $\mathrm{A1}$ & 281 & 4 & 2 & 363.2 & 83 & 10 & 73 & 83 & & 10 & 73 & \\
\hline 13237 & 718 & 48 & 2 & $\mathrm{~A} 1$ & 281 & 4 & 4 & 889.8 & 26 & 14 & 12 & 26 & & 2 & 24 & \\
\hline 13237 & 718 & 48 & 2 & $\mathrm{A1}$ & 281 & 4 & 5 & 231.6 & 4 & 3 & 1 & 4 & & 4 & & \\
\hline 13237 & 718 & 48 & 2 & A1 & 281 & 4 & 3 & 619.8 & 41 & 25 & 16 & 41 & & 38 & 3 & \\
\hline 13237 & 718 & 48 & 2 & $\mathrm{A1}$ & 281 & 4 & 1 & 82.7 & 58 & 48 & 10 & 58 & & 17 & 41 & \\
\hline 13237 & 718 & 48 & 2 & $\overline{A 1}$ & 281 & 4 & 2 & 406.7 & 76 & 63 & 13 & 76 & & 21 & 55 & \\
\hline 13237 & 719 & 48 & 2 & $\mathrm{~A} 1$ & \begin{tabular}{|l|}
281 \\
\end{tabular} & 4 & 4 & 275.3 & 8 & 1 & 7 & 8 & & 4 & 4 & \\
\hline \begin{tabular}{|l|l|}
13237 \\
\end{tabular} & 719 & 48 & 2 & A1 & \begin{tabular}{|l|}
281 \\
\end{tabular} & 4 & 5 & 400.7 & 5 & 5 & & 5 & & 3 & 2 & \\
\hline 13237 & 719 & 48 & 2 & A1 & \begin{tabular}{|l|}
281 \\
\end{tabular} & 4 & 6 & 570.1 & 2 & 2 & & 2 & & 2 & & \\
\hline 13237 & 719 & 48 & 2 & A1 & \begin{tabular}{|l|}
281 \\
\end{tabular} & 4 & 1 & 9.5 & 9 & 5 & 4 & 9 & & 2 & 7 & \\
\hline \begin{tabular}{|l|}
13237 \\
\end{tabular} & 719 & 48 & 2 & $\mathrm{~A} 1$ & 281 & 4 & 2 & 57.4 & 15 & 6 & 9 & 15 & & 8 & 7 & \\
\hline
\end{tabular}




\begin{tabular}{|c|c|c|c|c|c|c|c|c|c|c|c|c|c|c|c|c|}
\hline Site & Coll \# & Feature & LV & Blk & $\overline{A C}$ & Mat & $\mathrm{Sz}$ & Grams & Qty & $\mathrm{Fr}$ & NF & Disc P & Disc A & Cort $P$ & Cort A & Comm \\
\hline 13237 & 719 & 48 & 2 & $\overline{A 1}$ & 281 & 4 & 3 & 211.7 & 16 & 6 & 10 & 16 & & 3 & 13 & \\
\hline 13237 & 720 & 48 & 2 & A1 & 281 & 4 & 4 & 369.3 & 9 & 5 & 4 & 9 & & 6 & 3 & \\
\hline 13237 & 720 & 48 & 2 & A1 & 281 & 4 & 5 & 333.2 & 3 & 2 & 1 & 3 & & 2 & 1 & \\
\hline 13237 & 720 & 48 & 2 & A1 & 281 & 4 & 7 & 743.2 & 1 & 1 & & 1 & & 1 & & \\
\hline 13237 & 720 & 48 & 2 & A1 & 281 & 4 & 1 & 6.1 & 5 & 5 & & 5 & & 2 & 4 & \\
\hline 13237 & 720 & 48 & 2 & $\overline{A 1}$ & 281 & 4 & 2 & 22.7 & 4 & 4 & & 4 & & 4 & & \\
\hline 13237 & 720 & 48 & 2 & $\overline{\mathrm{A} 1}$ & 281 & 4 & 3 & 87.6 & 6 & 5 & 1 & 6 & & 6 & & \\
\hline 13237 & 721 & 48 & 2 & $\mathrm{~A} 1$ & 281 & 4 & 4 & 884.5 & 27 & 7 & 20 & 27 & & 9 & 18 & \\
\hline 13237 & 721 & 48 & 2 & A1 & 281 & 4 & 5 & 569.5 & 8 & 4 & 4 & 8 & & 3 & 5 & \\
\hline 13237 & $721 \mid$ & 48 & 2 & A1 & 281 & 4 & 3 & 633.9 & 47 & 12 & 35 & 47 & & 8 & 39 & \\
\hline 13237 & 721 & 48 & 2 & A1 & 281 & 4 & 1 & 93.4 & 79 & 22 & 557 & 79 & & $\sqrt{11}$ & 68 & \\
\hline 13237 & 721 & 48 & 2 & A1 & 281 & 4 & 2 & 549.3 & 123 & 21 & 102 & 123 & & 10 & 113 & \\
\hline 13237 & 722 & 48 & 2 & $\mathrm{~A} 1$ & 281 & 4 & 4 & 859.1 & 28 & 5 & 23 & 28 & & 10 & 18 & \\
\hline 13237 & 722 & 48 & 2 & $\mathrm{~A} 1$ & 281 & 4 & 5 & 957.3 & 13 & 5 & 18 & 18 & & 8 & 5 & \\
\hline 13237 & 722 & 48 & 2 & A1 & 281 & 4 & 3 & 757.5 & 68 & 12 & 56 & 68 & & 14 & 54 & \\
\hline 13237 & 722 & 48 & 2 & A1 & 281 & 4 & 1 & 33.5 & 31 & 8 & 23 & 31 & & 5 & 26 & \\
\hline 13237 & 722 & 48 & 2 & $\overline{A 1}$ & 281 & 4 & 2 & 383.9 & 82 & 18 & 64 & 82 & & 14 & 54 & \\
\hline 13237 & 723 & 48 & 2 & $\mathrm{~A} 1$ & 281 & 4 & 4 & 276.1 & 7 & 1 & 6 & 7 & & 7 & & \\
\hline 13237 & 723 & 48 & 2 & A1 & 281 & 4 & 3 & 46.9 & 3 & 1 & 2 & 3 & & 2 & 1 & \\
\hline 13237 & 723 & 48 & 2 & A1 & 281 & 4 & 2 & 18.8 & 7 & 6 & 1 & 7 & & 3 & 4 & \\
\hline 13237 & 723 & 48 & 2 & $\overline{\mathrm{A} 1}$ & 281 & 4 & 9 & 573.7 & 1 & & 1 & 1 & & 1 & & \\
\hline 13237 & 723 & 48 & 2 & $\overline{\mathrm{A} 1}$ & \begin{tabular}{|l|}
281 \\
\end{tabular} & 4 & 7 & 1209.4 & 2 & 2 & & 2 & & 2 & & \\
\hline 13237 & 723 & 48 & 2 & A1 & 281 & 4 & 5 & 483 & 6 & 5 & 1 & 6 & & 5 & 1 & \\
\hline 13237 & 724 & 48 & 2 & $\mathrm{~A} 1$ & 281 & 4 & 4 & 872.8 & 30 & 20 & 10 & 30 & & 14 & 16 & \\
\hline 13237 & 724 & 48 & 2 & $\mathrm{~A} 1$ & 281 & 4 & 5 & 247.5 & 5 & 2 & 3 & 4 & 1 & 4 & 1 & \\
\hline 13237 & 724 & 48 & 2 & $\mathrm{~A} 1$ & 281 & 4 & 3 & 1059.2 & 92 & 74 & 18 & 92 & & 31 & 61 & \\
\hline 13237 & 724 & 48 & 2 & A1 & 281 & 4 & 1 & 46 & 42 & 39 & 3 & 41 & 1 & 3 & 36 & \\
\hline 13237 & 724 & 48 & 2 & $\mathrm{~A} 1$ & 281 & 4 & 2 & 450.6 & 119 & 110 & 9 & 119 & & 28 & 82 & \\
\hline 13237 & 725 & 48 & 2 & $\mathrm{~A} 1$ & 281 & 4 & 4 & 728.4 & 22 & 4 & 18 & 22 & & 15 & 7 & \\
\hline 13237 & 725 & 48 & 2 & A1 & 281 & 4 & 5 & 702.6 & 6 & 1 & 5 & 6 & & 6 & & \\
\hline 13237 & 725 & 48 & 2 & $\mathrm{~A} 1$ & 281 & 4 & 7 & 1241.2 & 2 & 1 & 1 & 2 & & 2 & & \\
\hline 13237 & 725 & 48 & 2 & $A 1$ & 281 & 4 & 1 & 55.2 & 74 & 16 & 58 & 74 & & 8 & 66 & \\
\hline 13237 & 725 & 48 & 2 & $\overline{A 1}$ & 281 & 4 & 2 & 758.2 & 109 & 21 & 88 & 109 & & 19 & 90 & \\
\hline 13237 & 725 & 48 & 2 & $\mathrm{~A} 1$ & 281 & 4 & 3 & 879.4 & 64 & 6 & 58 & 64 & & 23 & 41 & \\
\hline 13237 & 726 & 48 & 2 & $\mathrm{~A} 1$ & 281 & 4 & 4 & 491.9 & 21 & 4 & 17 & 21 & & 7 & 14 & \\
\hline 13237 & 726 & 48 & 2 & A1 & 281 & 4 & 5 & 235.56 & 6 & 1 & 5 & 6 & & 6 & & \\
\hline 13237 & 726 & 48 & 2 & A1 & \begin{tabular}{|l|}
281 \\
\end{tabular} & 4 & 3 & 566.9 & 53 & 4 & 49 & 53 & & 10 & 43 & \\
\hline 13237 & 726 & 48 & 2 & A1 & 281 & 4 & 1 & 75.5 & 74 & 6 & 68 & 74 & & 6 & 68 & \\
\hline 13237 & 726 & 48 & 2 & A1 & 281 & 4 & 2 & 377.4 & 88 & 3 & 85 & 88 & & 4 & 84 & \\
\hline 13237 & \begin{tabular}{|l|}
727 \\
\end{tabular} & 48 & 2 & $\mathrm{~A} 1$ & 281 & 4 & 4 & 440.5 & 18 & 2 & 16 & 18 & & 7 & 11 & \\
\hline 13237 & 727 & 48 & 2 & $\mathrm{~A} 1$ & 281 & 4 & 5 & 249.5 & 5 & 3 & 2 & 5 & & 4 & 1 & \\
\hline 13237 & 727 & 48 & 2 & $A 1$ & 281 & 4 & 6 & $\begin{array}{l}146.7 \\
\end{array}$ & 2 & 2 & & 2 & & & 2 & \\
\hline 13237 & 727 & 48 & 2 & $\mathrm{~A} 1$ & 281 & 4 & 1 & 21.2 & 19 & 1 & 18 & 19 & & 4 & 15 & \\
\hline 13237 & 727 & 48 & 2 & $\mathrm{~A} 1$ & 281 & 4 & 2 & 235.9 & 49 & 5 & 44 & 49 & & 18 & 37 & \\
\hline 13237 & 727 & 48 & 2 & $\mathrm{~A} 1$ & 281 & 4 & 3 & 607.4 & 45 & 2 & 43 & 45 & & 16 & 29 & \\
\hline & & & & & & & & & & & & & & & & \\
\hline
\end{tabular}




\section{Appendix B: Archaeomagnetic Analysis of Burned Rocks from Fort Bliss}

Wulf Gose Department of Geological Sciences, The University of Texas at Austin

\section{Methods}

Twenty-four cores (one-inch diameter) were drilled for archaeomagnetic analysis from rock samples collected at Fort Bliss (Table B1). Two preliminary samples were assigned laboratory numbers (1 and 2 ), the others were given letter designations (A-T).

All samples were thermally demagnetized in $50^{\circ}$ increments from $150^{\circ} \mathrm{C}$ to $550^{\circ} \mathrm{C}$. The magnetic remanence was measured after each heating step with a superconducting magnetometer. When plotted in a vector component diagram, discrete components of magnetization are indicated by three or more co-linear points. For the samples used in this study, a change in trend usually corresponds to the maximum heating temperature which the rock attained during cultural use. Data for all tested samples are given in the addendum.

\section{Results}

Because the rock samples were not oriented when collected, archaeomagnetic measurements cannot yield any information concerning past rock orientations such as whether a rock has remained undisturbed since the last heating and was part of a fireplace. The information that can be obtained is an estimate of the maximum temperature the rock experienced during its heating in a fire place.
The data for rock $\mathrm{M}$ are depicted in Figure B-1. ${ }^{1}$ The distinct change in trend after thermal demagnetization to $400^{\circ} \mathrm{C}$ is interpreted to indicate the temperature of heating in a fire place. Rock $\mathrm{K}$ suggests heating to $350^{\circ} \mathrm{C}$ (Figure B2). Rock A contains only one component of magnetization (Figure B3) which implies that this rock experienced temperatures in excess of $550^{\circ} \mathrm{C}$. Three components of magnetization can be identified in rock $\mathrm{T}$ (Figure B4). Component 1 is revealed between NRM (natural remanent magnetization) and $200^{\circ} \mathrm{C}$. component 2 is present in the $200^{\circ} \mathrm{C}$ to $300^{\circ} \mathrm{C}$ interval, and component 3 is identified between $300^{\circ} \mathrm{C}$ and $550^{\circ} \mathrm{C}$. Component 1 is interpreted as magnetic contamination, i.e. a magnetization acquired after the sample had been collected. Component 2 is interpreted as being due to cultural heating, and the high temperature component is the original geological magnetization.

Figure B-5 shows a histogram of the approximate temperatures to which these rocks were heated.

${ }^{1}$ For all vector component diagrams, the crosses are the projection onto the N-E-S-W plane, the open squares the projection onto the Up-Down-Horizontal plane. The intensity of the NRM is given in units of Ampere/meter. The numbers along the trajectories indicate the demagnetization temperatures in ${ }^{\circ} \mathrm{C}$. A linear trend of three or more data points defines a stable component of magnetization. 
Table B1. Fire-cracked Rock from Fort Bliss

\begin{tabular}{|c|c|c|c|c|c|c|}
\hline Site & Block & Feature & $\begin{array}{c}\text { Collection } \\
\text { No. }\end{array}$ & $\begin{array}{c}\text { Lab } \\
\text { Designation }\end{array}$ & $\begin{array}{c}\text { Max. } \\
\text { Temp (C) }\end{array}$ & $\begin{array}{c}\text { Magnetic } \\
\text { Vector }\end{array}$ \\
\hline \multirow{4}{*}{ FB12412 } & \multirow{2}{*}{$\mathrm{A} 2$} & & 203 & A & $>550^{\circ}$ & single \\
\hline & & & 203 & $\mathrm{~K}$ & $350^{\circ}$ & single \\
\hline & \multirow{2}{*}{ B1 } & & 256 & $\bar{Q}$ & - & multiple \\
\hline & & & 256 & Shattered & & \\
\hline \multirow{6}{*}{ FB12719 } & \multirow{6}{*}{$\mathrm{A} 1$} & 32 & 2201 & $E$ & $350^{\circ}$ & single \\
\hline & & \multirow{5}{*}{33} & 2180 & $I$ & $300^{\circ}$ & single \\
\hline & & & 2180 & $\mathrm{~L}$ & $375^{\circ}$ & single \\
\hline & & & 2322 & $\mathrm{~T}$ & $300^{\circ}$ & single \\
\hline & & & 3006 & Shattered & & \\
\hline & & & 2017 & Shattered & & \\
\hline \multirow{14}{*}{ FB13237 } & \multirow{8}{*}{$\mathrm{C} 1$} & \multirow{4}{*}{40} & 661 & B & $325^{\circ}$ & single \\
\hline & & & 677 & $\mathrm{C}$ & $350^{\circ}$ & single \\
\hline & & & 660 & 1 & $500^{\circ}$ & single \\
\hline & & & 674 & 2 & $250^{\circ}-450^{\circ}$ & multiple \\
\hline & & 102 & 681 & $\bar{F}$ & $450^{\circ}$ & single \\
\hline & & 103 & 669 & $\mathrm{~J}$ & $350^{\circ}$ & single \\
\hline & & & 613 & $\bar{D}$ & $500^{\circ}$ & single \\
\hline & & & 604 & $\overline{\mathrm{H}}$ & $450^{\circ}$ & single \\
\hline & \multirow{3}{*}{ B1 } & \multirow{2}{*}{46} & 572 & $\mathrm{M}$ & $450^{\circ}$ & single \\
\hline & & & 556 & $\mathrm{~N}$ & $>500^{\circ}$ & multiple \\
\hline & & & 511 & $S$ & $350^{\circ}$ & multiple \\
\hline & \multirow{3}{*}{$\mathrm{A} 1$} & \multirow{3}{*}{48} & 713 & $G$ & $450^{\circ}$ & single \\
\hline & & & 723 & $\mathrm{O}$ & $450^{\circ}$ & multiple \\
\hline & & & 725 & $P$ & $350^{\circ}$ & single \\
\hline
\end{tabular}

About half the samples $(n=10)$ experienced temperatures of $350^{\circ} \mathrm{C}$ or less while the rest $(n=11)$ were heated to $450^{\circ} \mathrm{C}$ or higher. Samples from the Camp Pearl Wheat site (41KR243) exhibited a similar dual temperature distribution (Gose 1990). Chemical analysis of those samples indicated that the cooler rocks were used for plant processing, whereas the hotter rocks yielded clear evidence of meat cooking. Whether such an interpretation may apply to the rocks from Fort Bliss cannot be ascertained without the proper organic geochemical analysis.

\section{Reference}

Gose, W.

1990 Data from Archeomagnetic Analysis. In Excavations at the Camp Pearl Wheat Site (41KR243), edited by M. B. Collins, B. Ellis, and C. Dodt-Ellis, pp. 115-124. Studies in Archeology 6. Texas Archeological Research Laboratory, The University of Texas at Austin. 


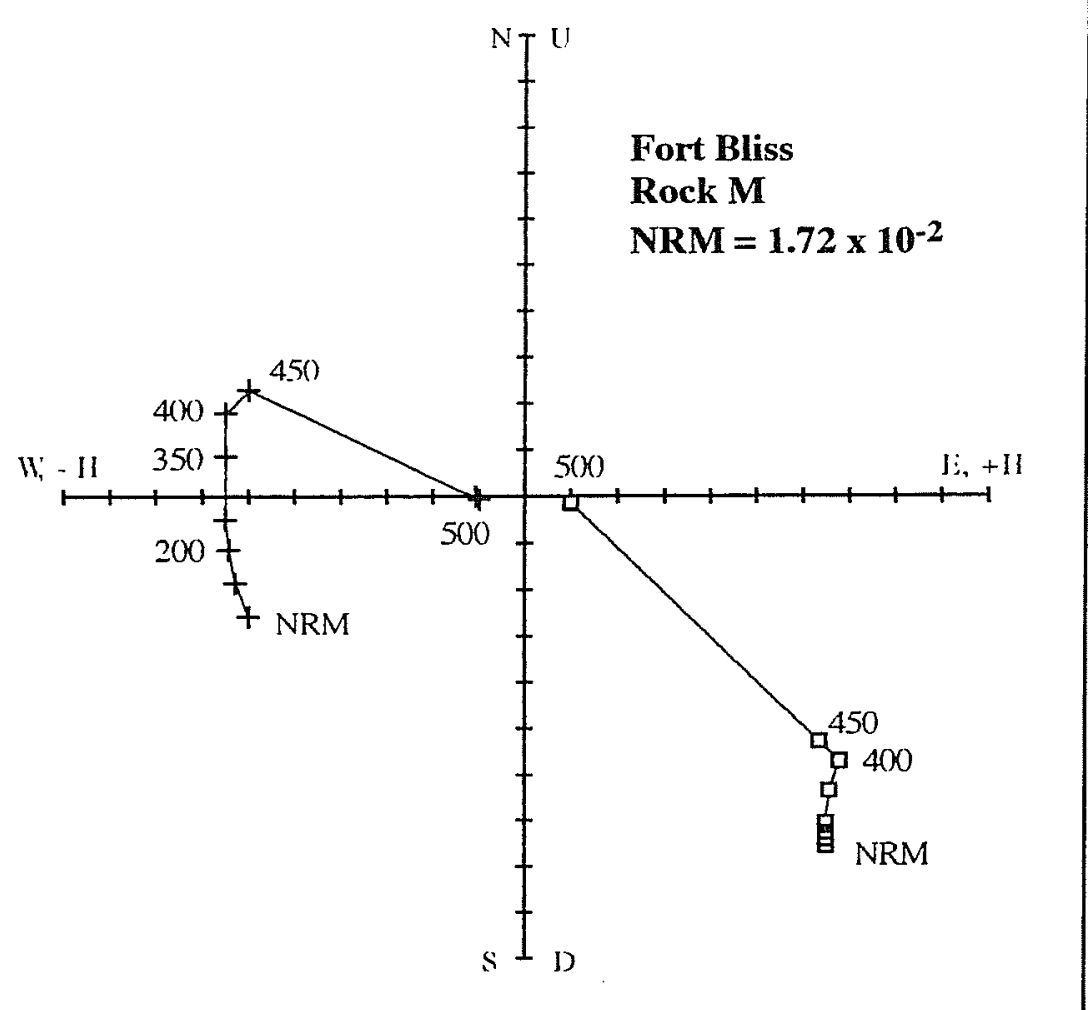

Figure B1. Vector component diagram for rock $M$.

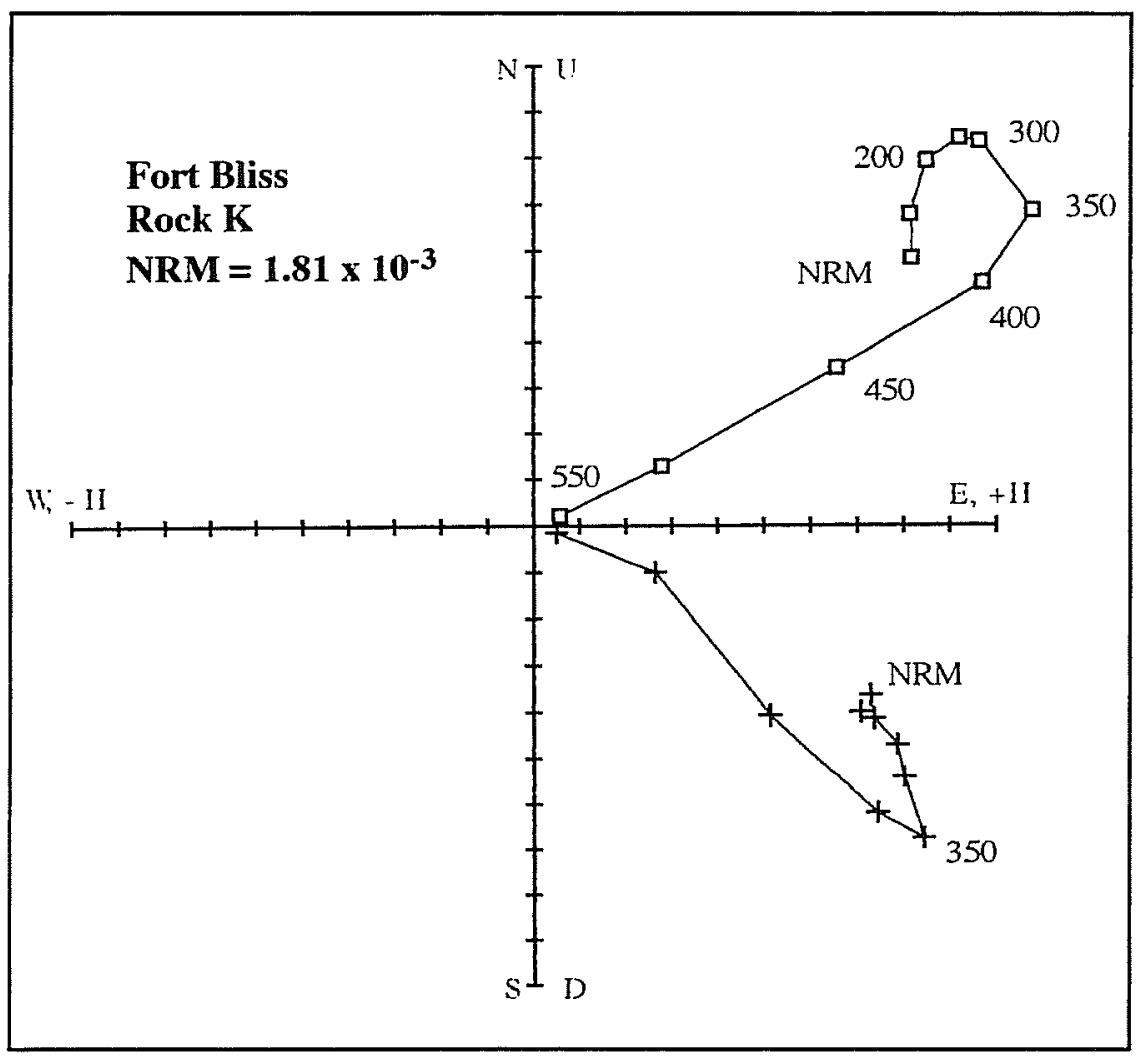

Figure B2. Vector component diagram for rock $K$. 


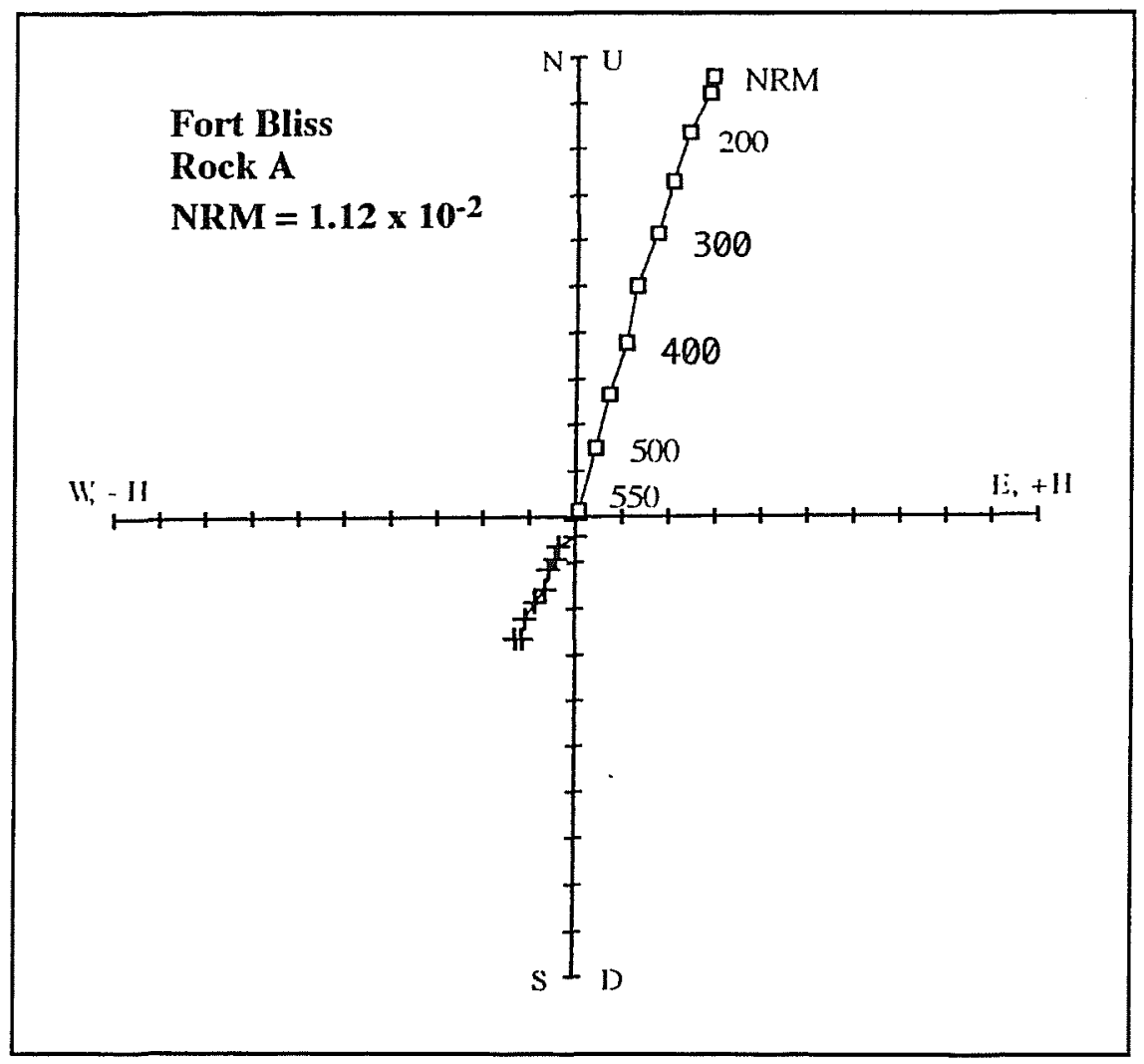

Figure B3. Vector component diagram for rock $A$.

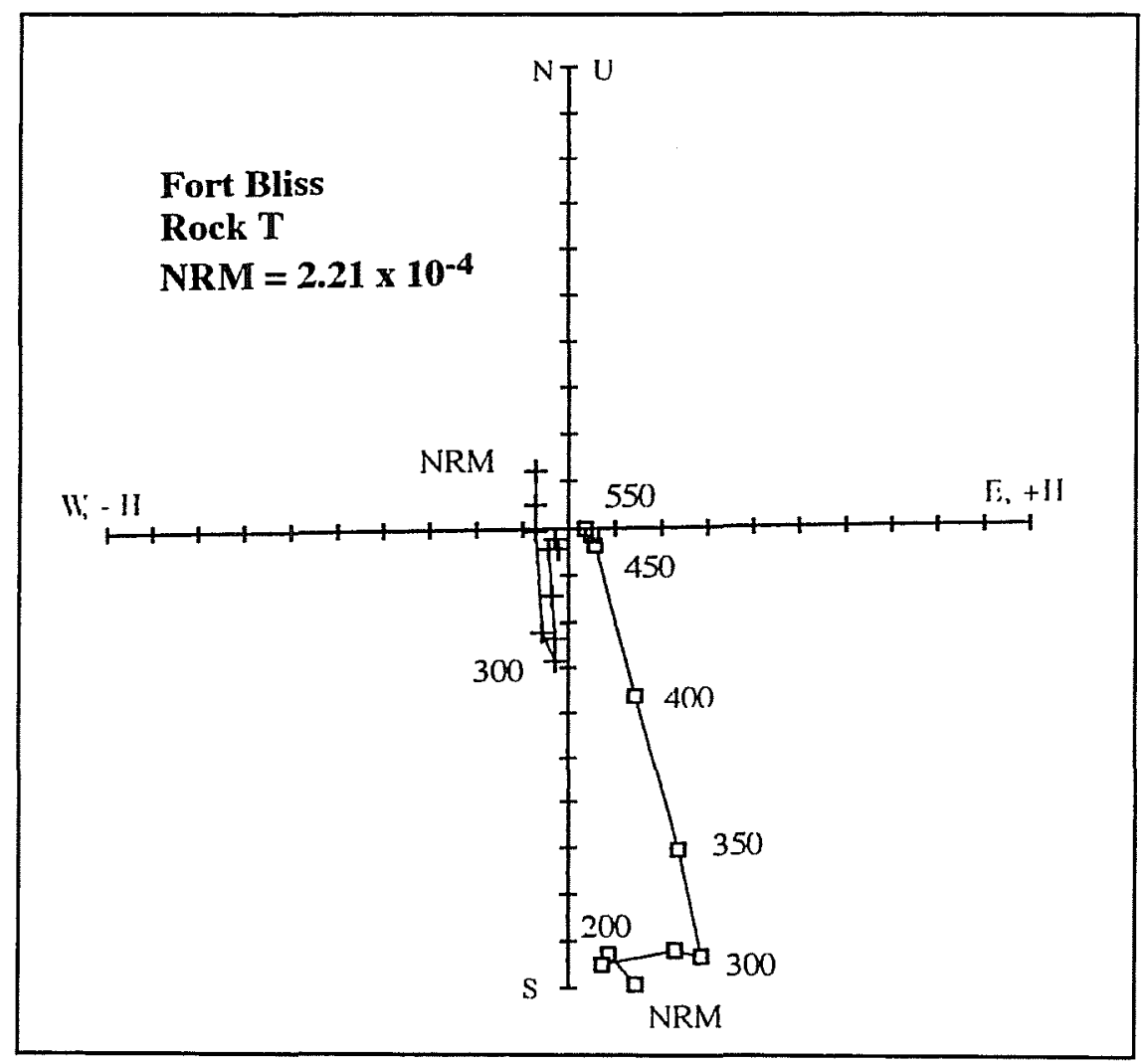

Figure B4. Vector component diagram for rock $T$. 


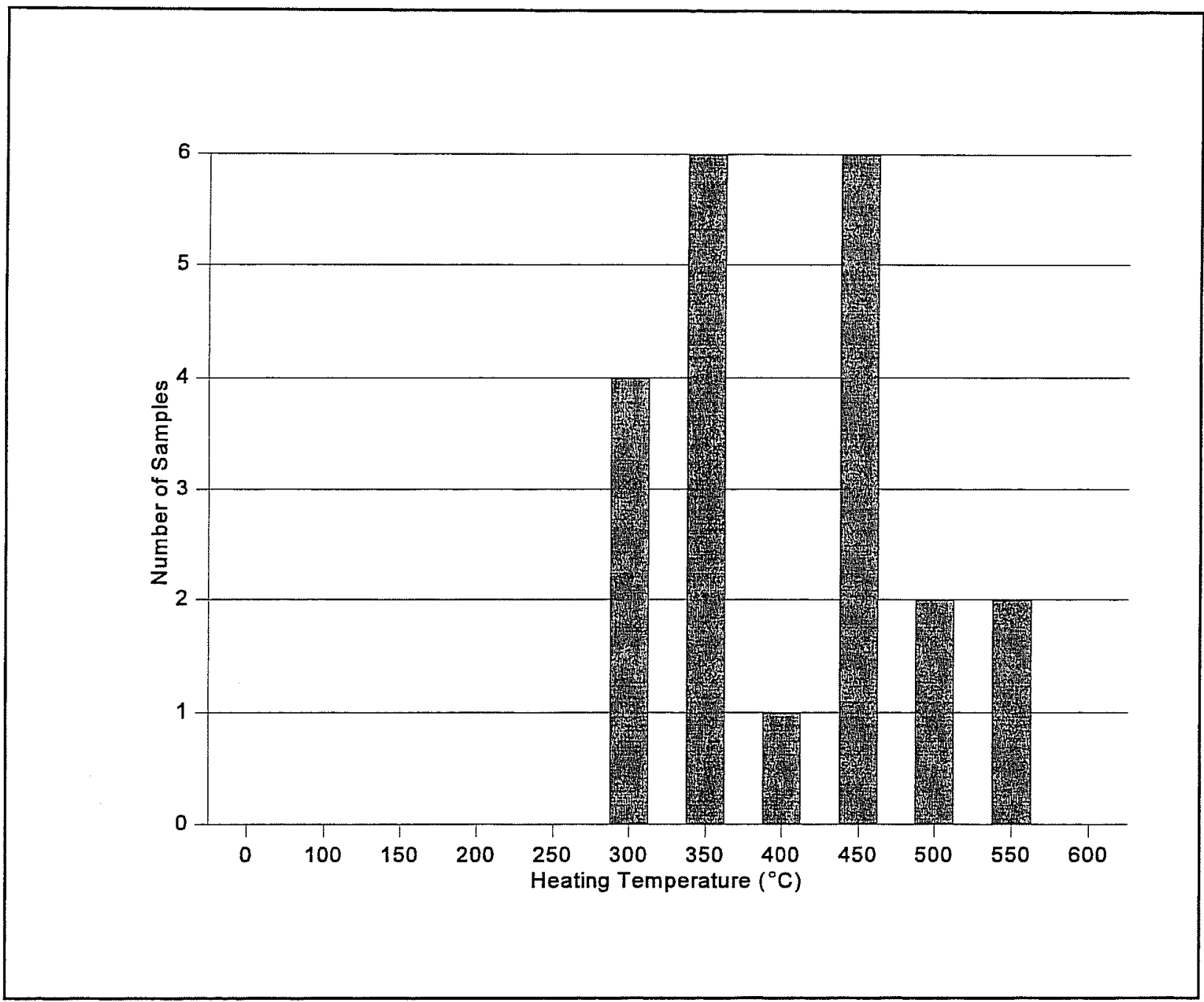

Figure B5. Histogram of magnetically estimated temperatures of heating of burned rocks from Fort Bliss. The bimodal distribution may indicate different usage. 
Addendum: Sample Data 

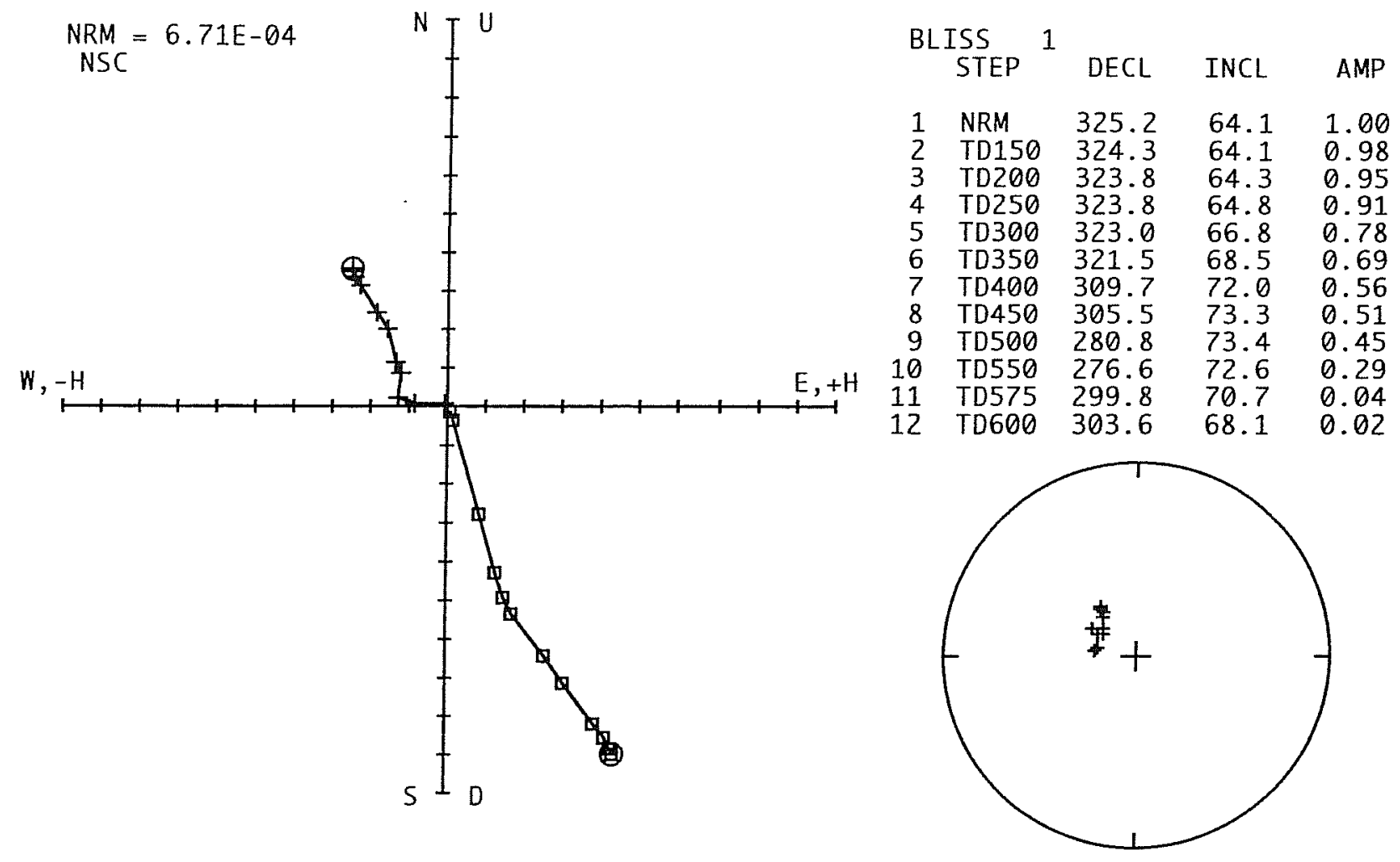

INTENSITY VS. DEMA GNETIZATION

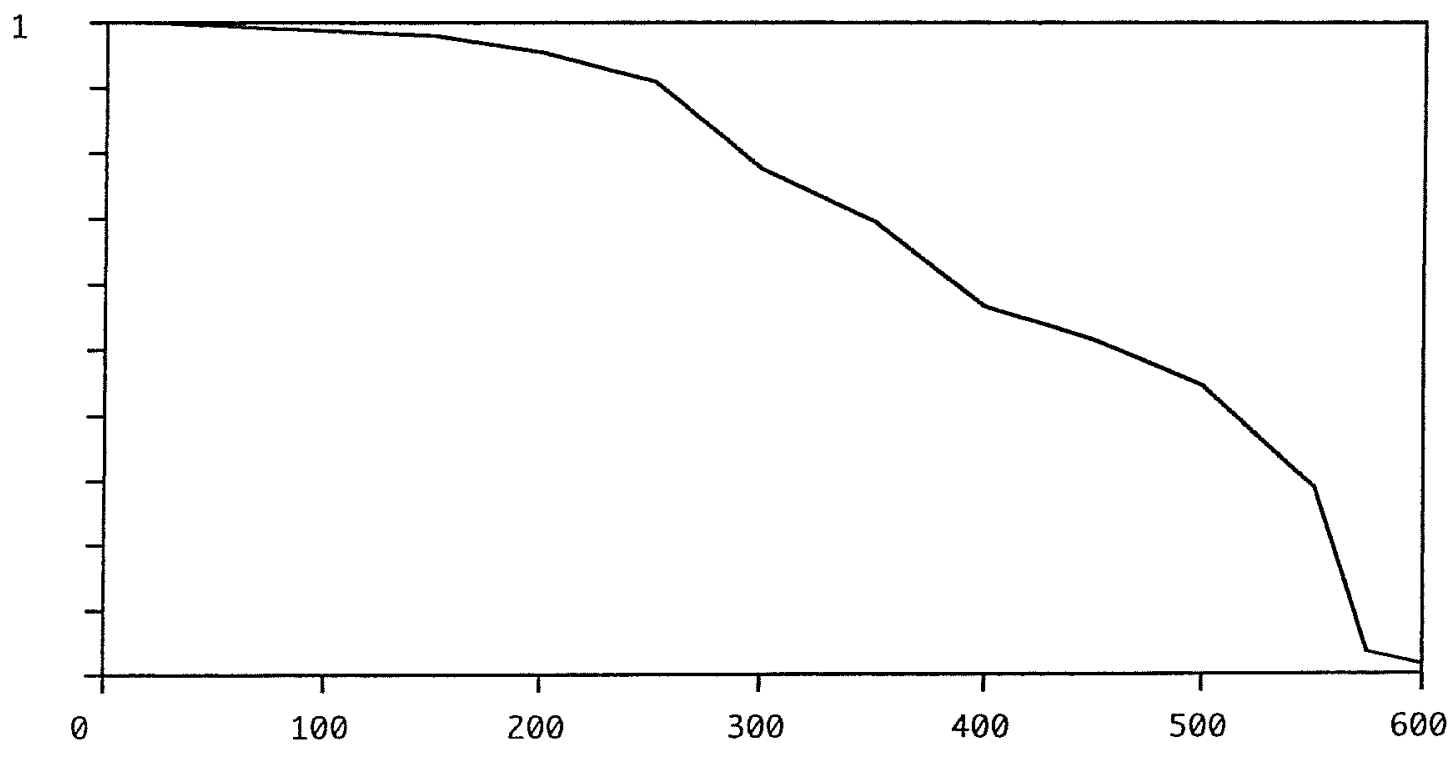




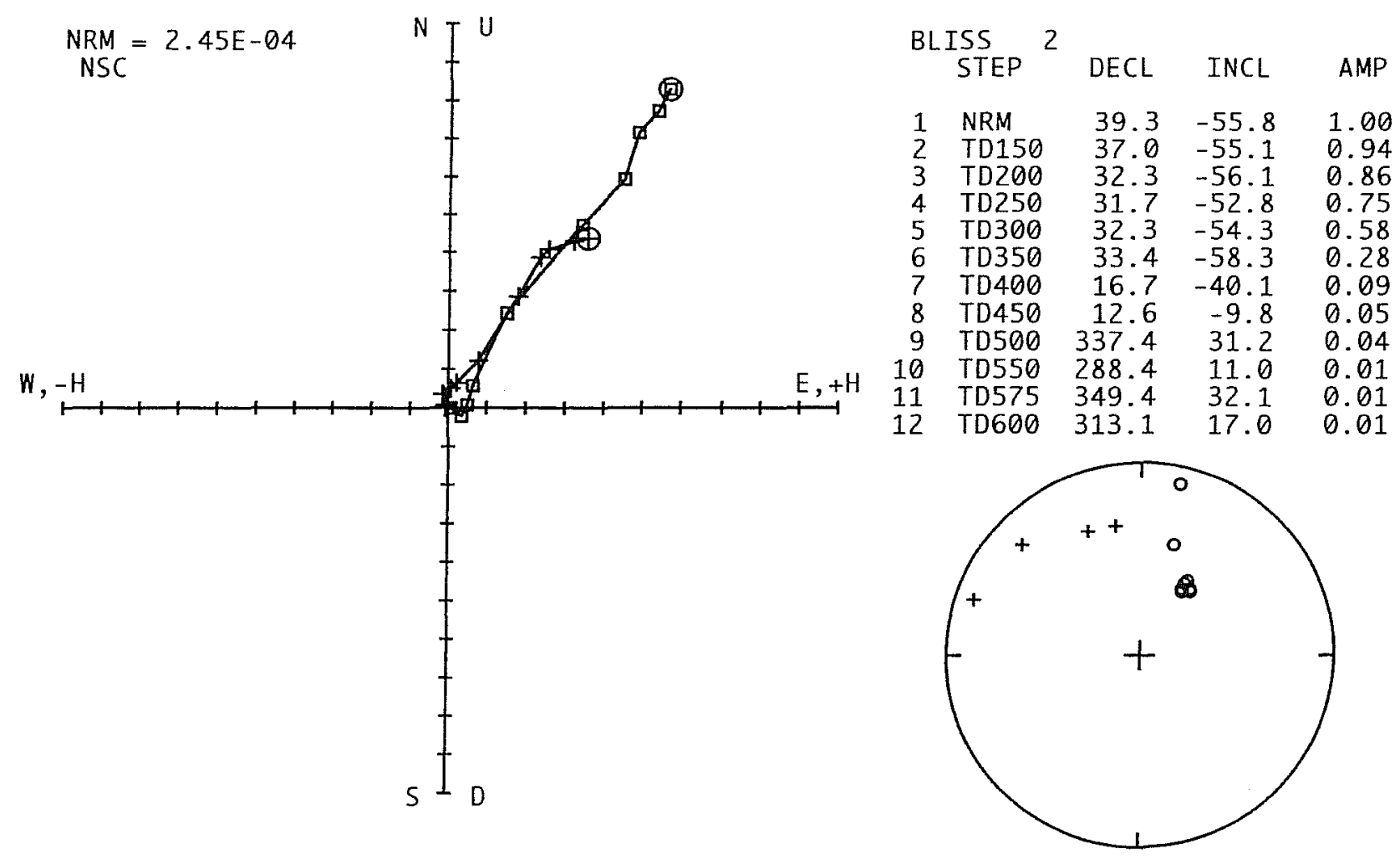

INTENSITY VS. DEMAGNETIZATION

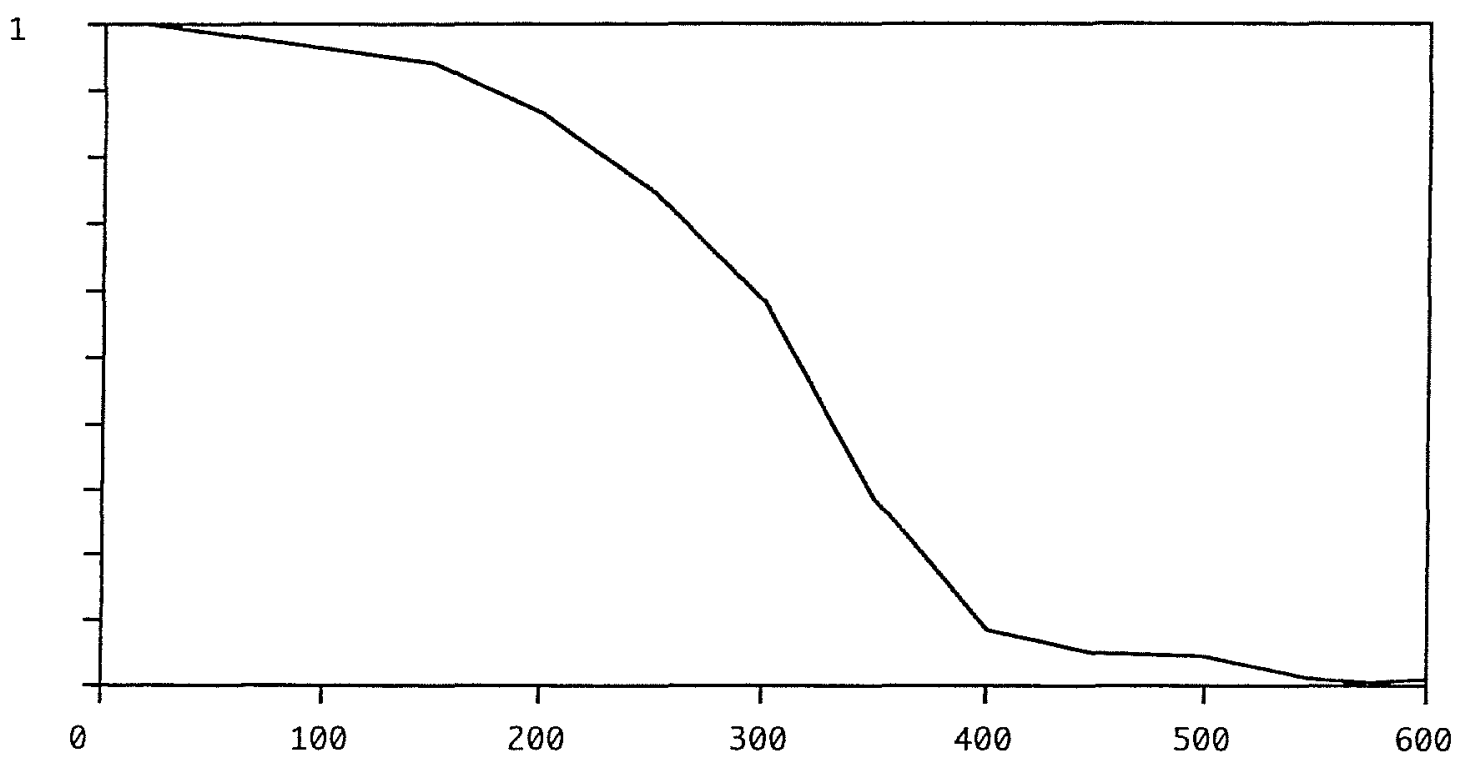




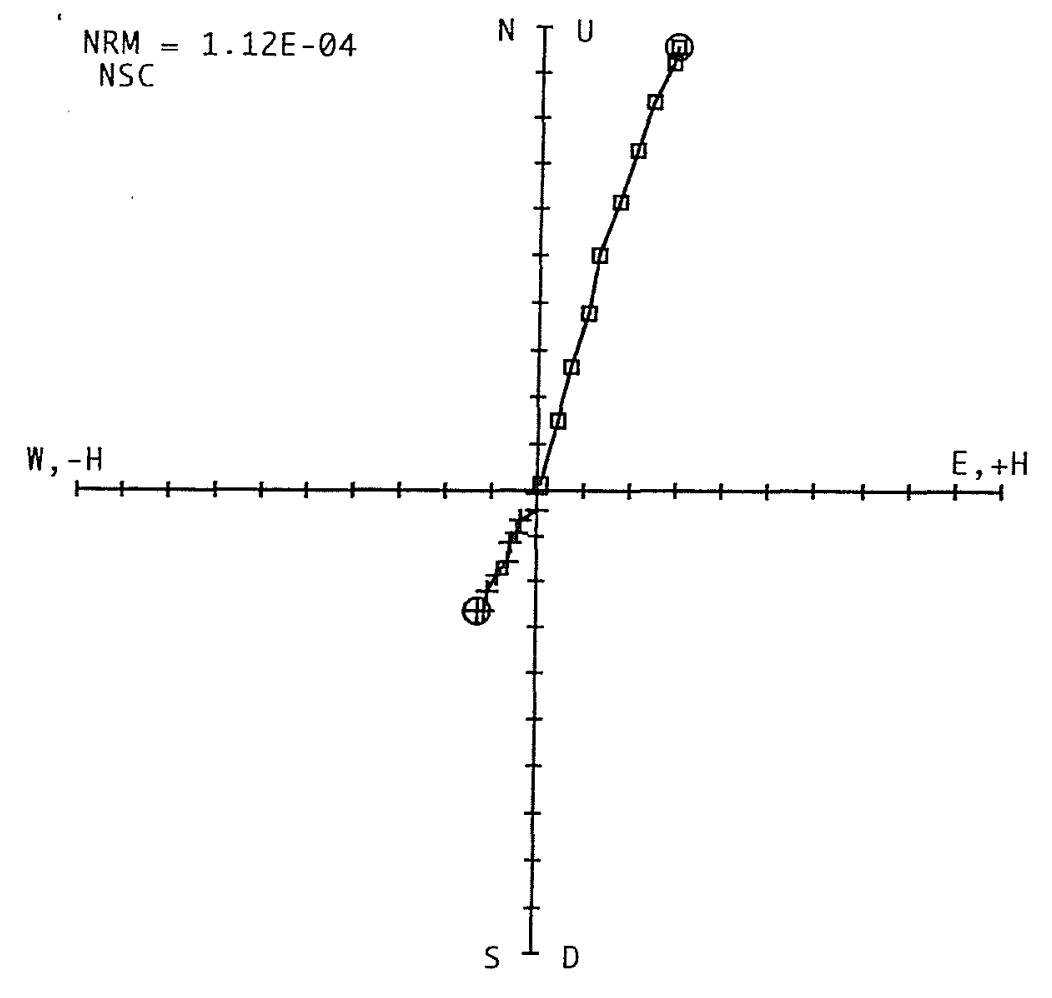

\begin{tabular}{rlrrc}
\multicolumn{2}{c}{ BLISS } & A & & \\
& STEP & DECL & INCL & AMP \\
1 & NRM & 205.5 & -72.8 & 1.00 \\
2 & TD150 & 203.4 & -72.8 & 0.97 \\
3 & TD200 & 205.4 & -73.8 & 0.87 \\
4 & TD250 & 204.3 & -74.3 & 0.76 \\
5 & TD300 & 203.1 & -74.5 & 0.64 \\
6 & TD350 & 207.6 & -75.7 & 0.52 \\
7 & TD400 & 204.2 & -74.6 & 0.39 \\
8 & TD450 & 208.4 & -75.1 & 0.27 \\
9 & TD500 & 184.2 & -73.5 & 0.16 \\
10 & TD550 & 204.6 & -69.1 & 0.02 \\
& & & &
\end{tabular}

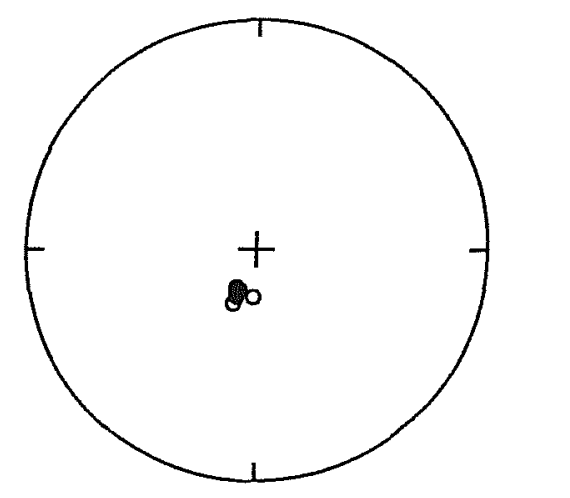

INTENSITY VS. DEMA GNETIZATION

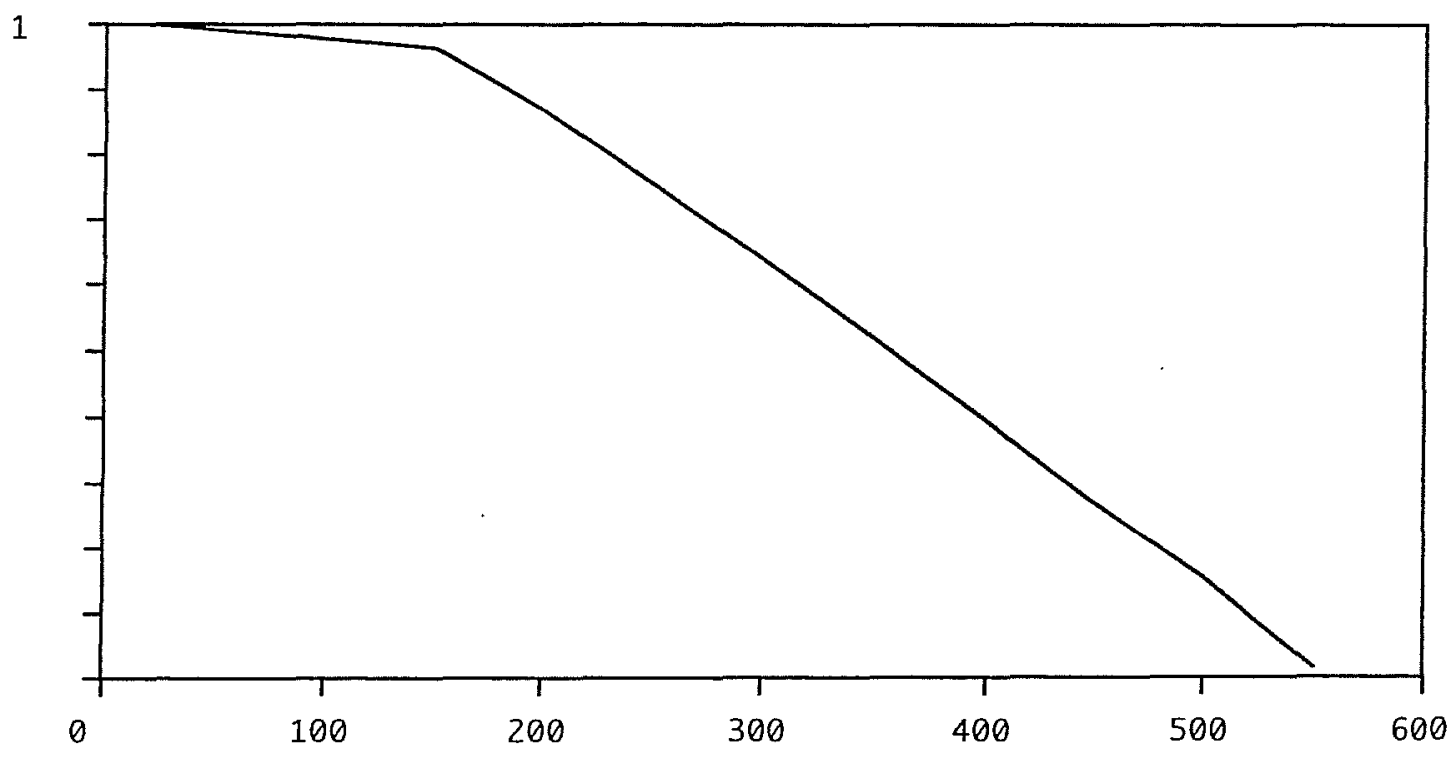




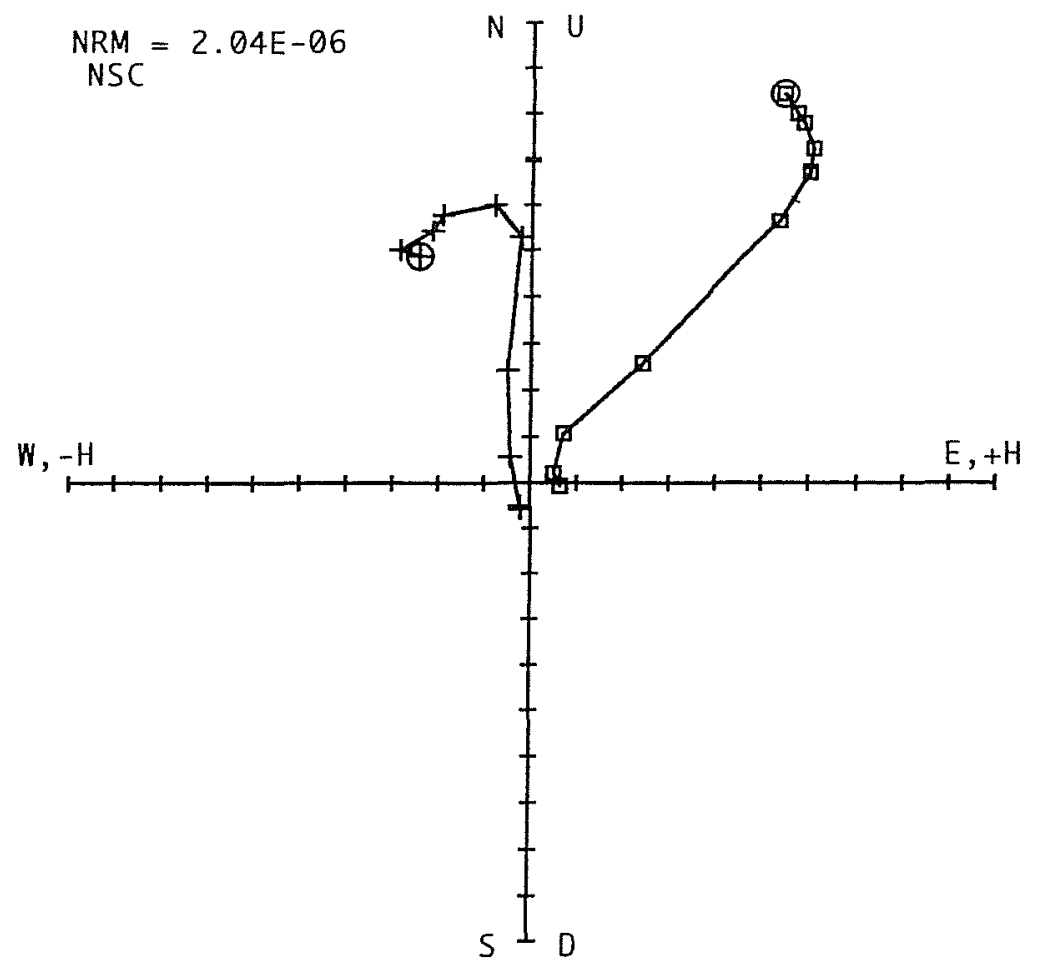

BLISS
STEP $\quad$ DECL INCL AMP

$\begin{array}{rlrrr}1 & \text { NRM } & 333.7 & -57.1 & 1.00 \\ 2 & \text { TD150 } & 330.2 & -54.3 & 0.99 \\ 3 & \text { TD200 } & 338.6 & -53.1 & 0.97 \\ 4 & \text { TD250 } & 341.3 & -49.8 & 0.94 \\ 5 & \text { TD300 } & 352.4 & -48.1 & 0.90 \\ 6 & \text { TD350 } & 357.7 & -46.5 & 0.77 \\ 7 & \text { TD400 } & 348.5 & -46.1 & 0.35 \\ 8 & \text { TD450 } & 321.1 & -54.6 & 0.13 \\ 9 & \text { TD500 } & 200.7 & -21.1 & 0.06 \\ 10 & \text { TD550 } & 200.7 & 3.9 & 0.06\end{array}$

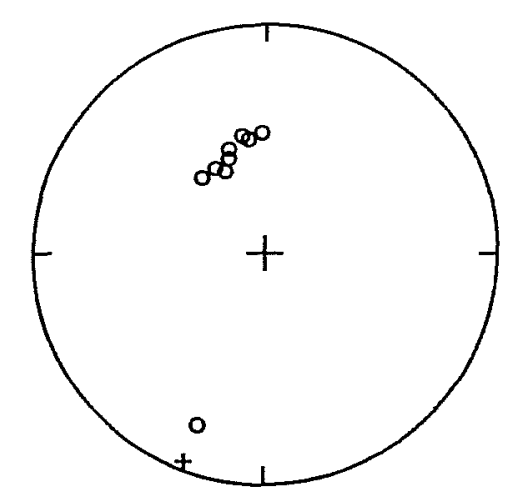

INTENSITY VS. DEMA GNETIZATION

1

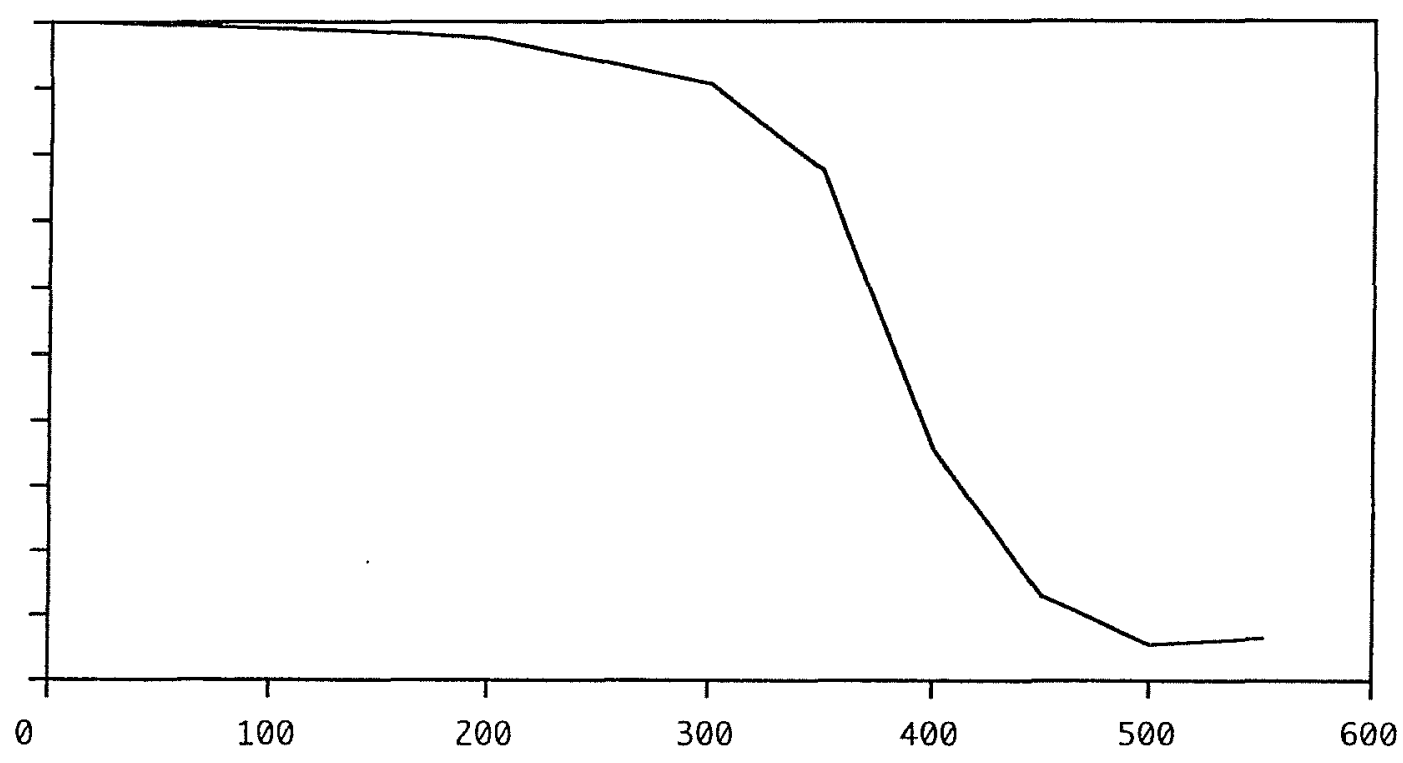




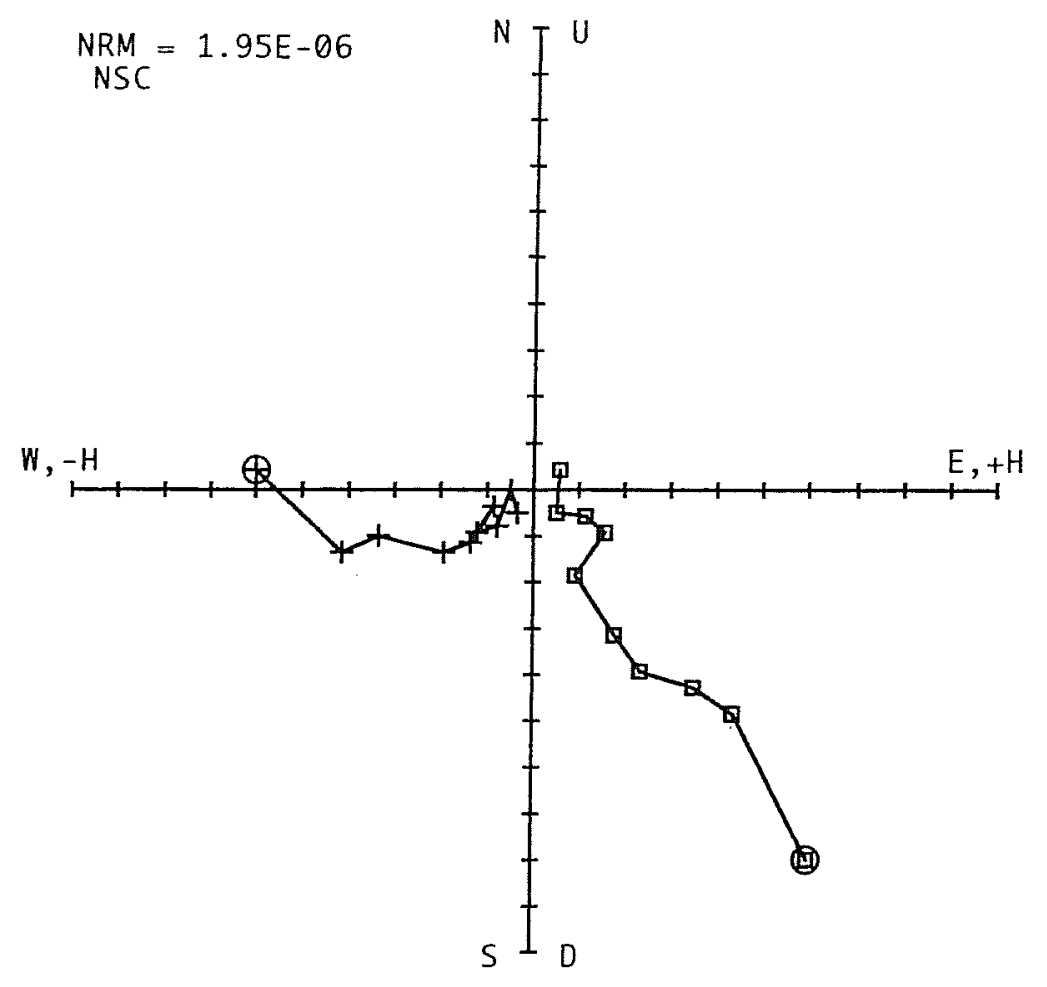

$$
\begin{array}{rlrrr}
\begin{array}{r}
\text { BLISS } \\
\text { STEP }
\end{array} & \text { DECL } & \text { INCL } & \text { AMP } \\
& \text { NRM } & 274.3 & 53.0 & 1.00 \\
2 & \text { TD150 } & 251.5 & 48.4 & 0.65 \\
3 & \text { TD200 } & 253.1 & 50.8 & 0.56 \\
4 & \text { TD250 } & 233.8 & 59.1 & 0.46 \\
5 & \text { TD300 } & 229.9 & 60.4 & 0.36 \\
6 & \text { TD350 } & 249.1 & 62.7 & 0.20 \\
7 & \text { TD400 } & 233.1 & 30.3 & 0.18 \\
8 & \text { TD450 } & 224.2 & 27.0 & 0.12 \\
9 & \text { TD500 } & 266.8 & 44.8 & 0.07 \\
10 & \text { TD550 } & 218.4 & -35.1 & 0.07
\end{array}
$$

INTENSITY VS. DEMAGNETIZATION

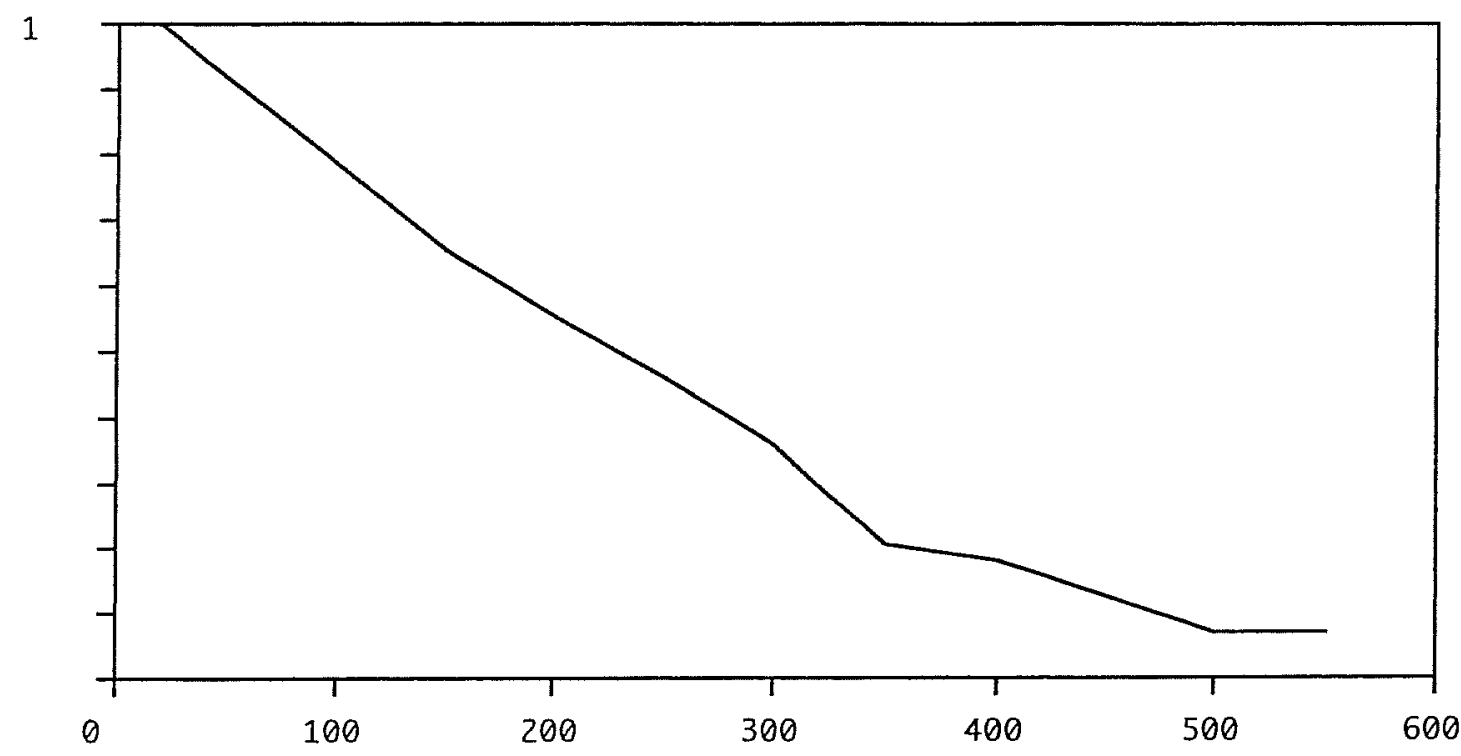




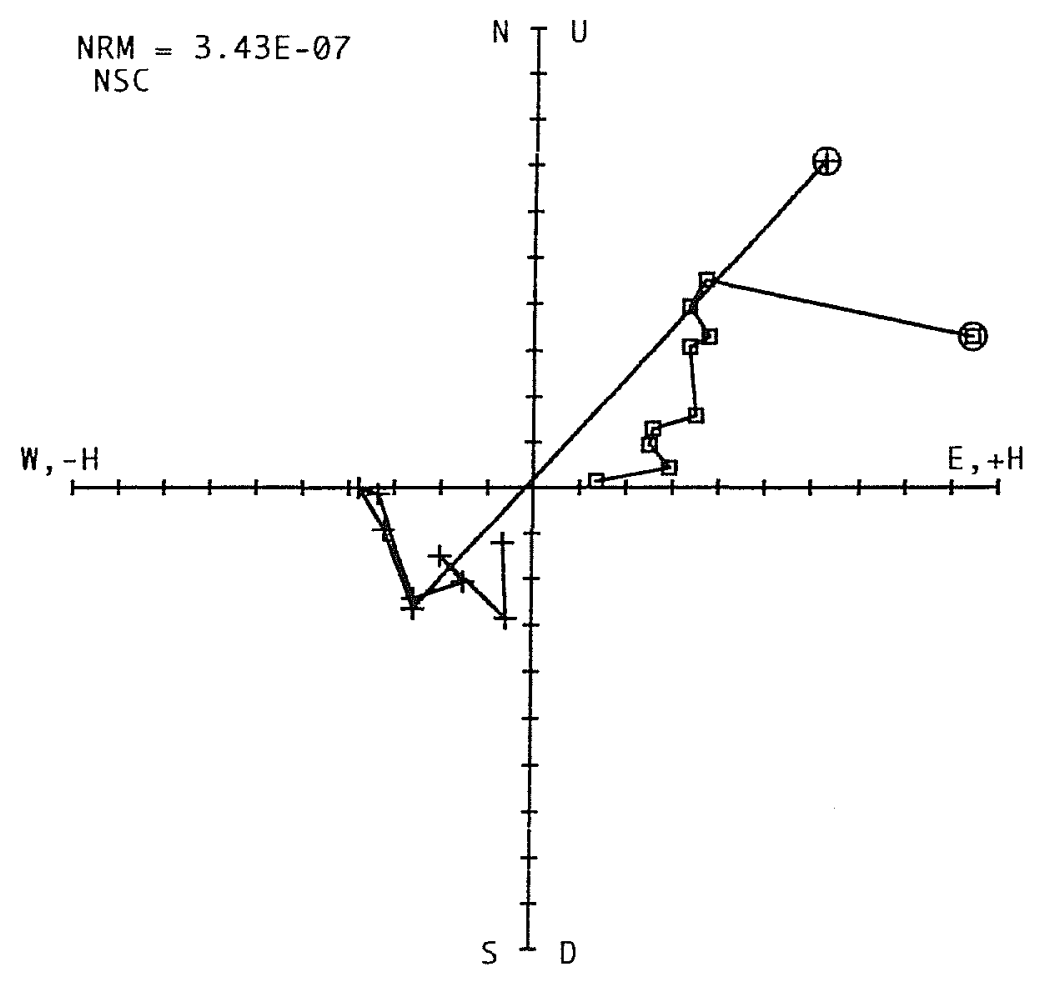

$\underset{\text { STEP }}{\text { BLISS DECL INCL AMP }}$

$\begin{array}{rlrrr}1 & \text { NRM } & 41.5 & -19.2 & 1.00 \\ 2 & \text { TD150 } & 224.1 & -50.9 & 0.58 \\ 3 & \text { TD200 } & 253.8 & -49.6 & 0.52 \\ 4 & \text { TD250 } & 270.2 & -41.1 & 0.50 \\ 5 & \text { TD300 } & 267.5 & -42.7 & 0.45 \\ 6 & \text { TD350 } & 226.4 & -23.7 & 0.38 \\ 7 & \text { TD400 } & 216.2 & -26.8 & 0.29 \\ 8 & \text { TD450 } & 233.0 & -20.7 & 0.27 \\ 9 & \text { TD500 } & 191.0 & -8.1 & 0.29 \\ 10 & \text { TD550 } & 208.6 & -6.8 & 0.14\end{array}$

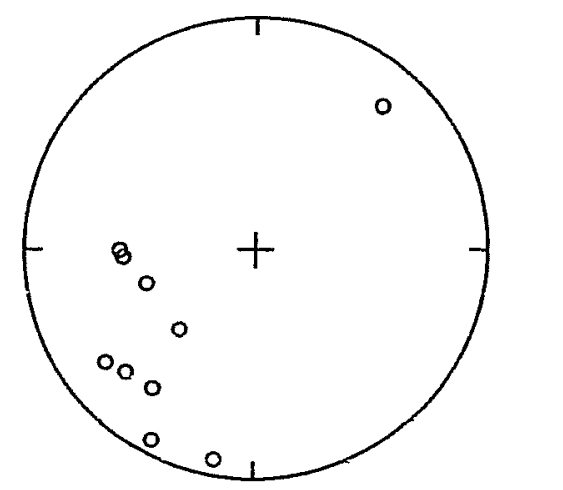

INTENSITY VS. DEMA GNETIZATION

\section{1}

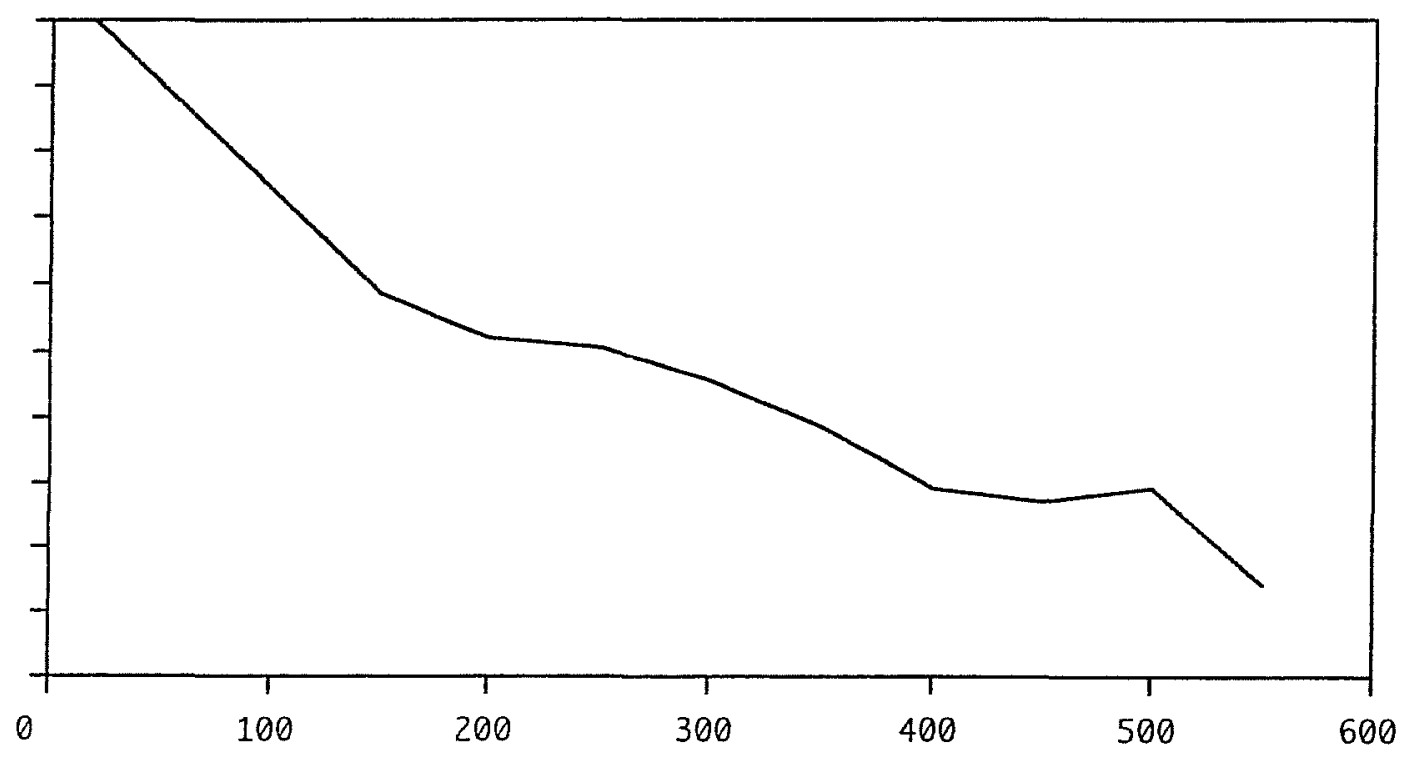




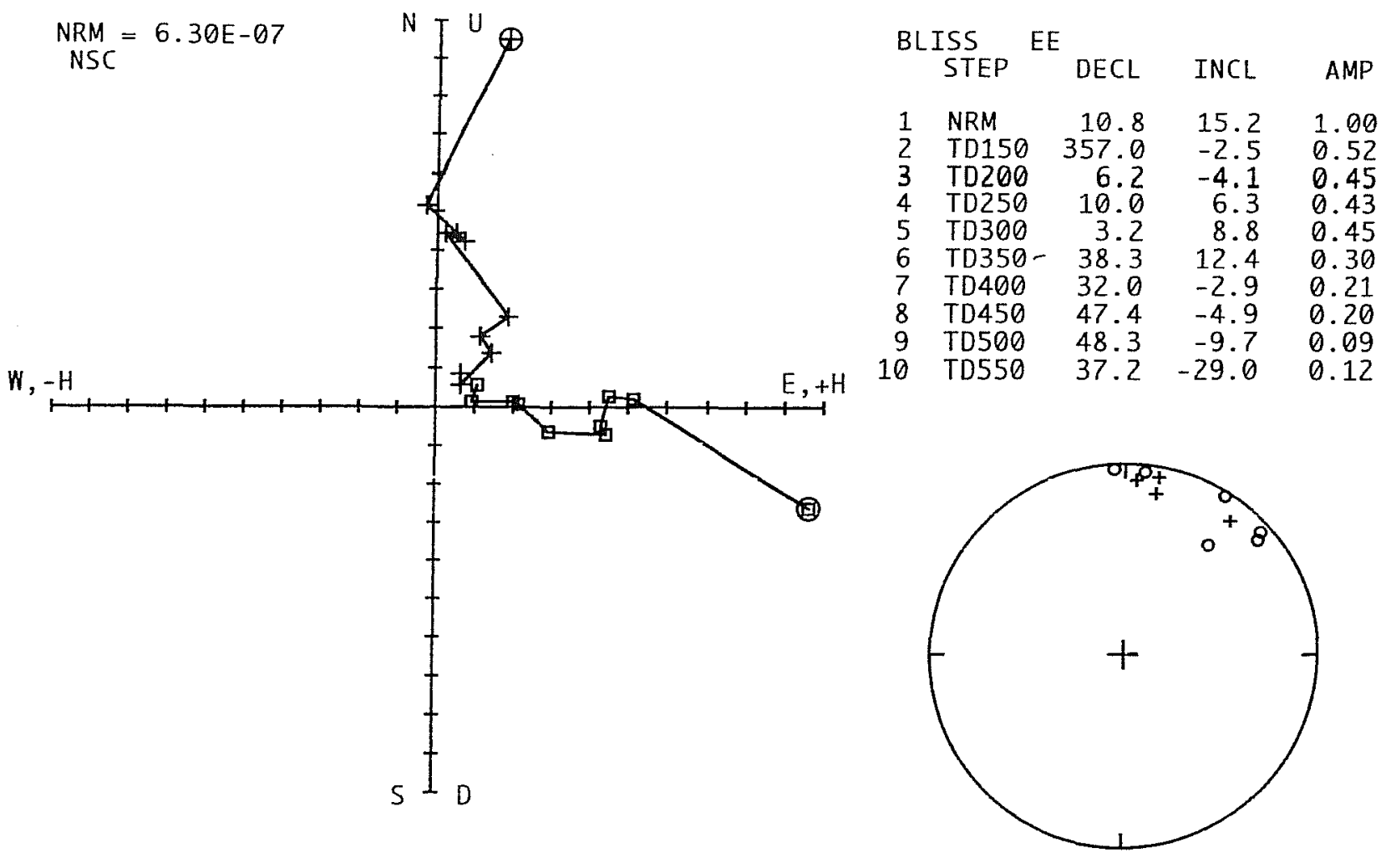

INTENSITY VS. DEMA GNETIZATION

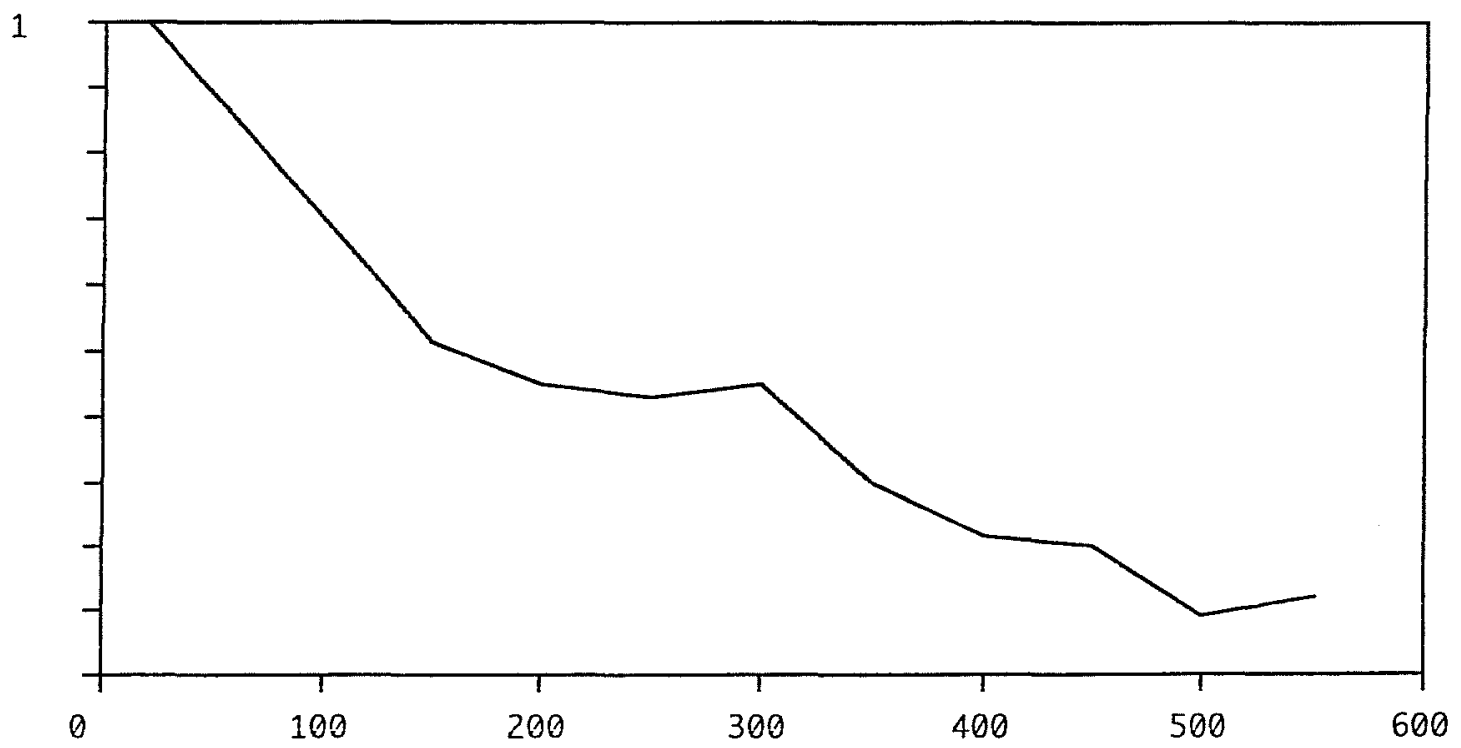



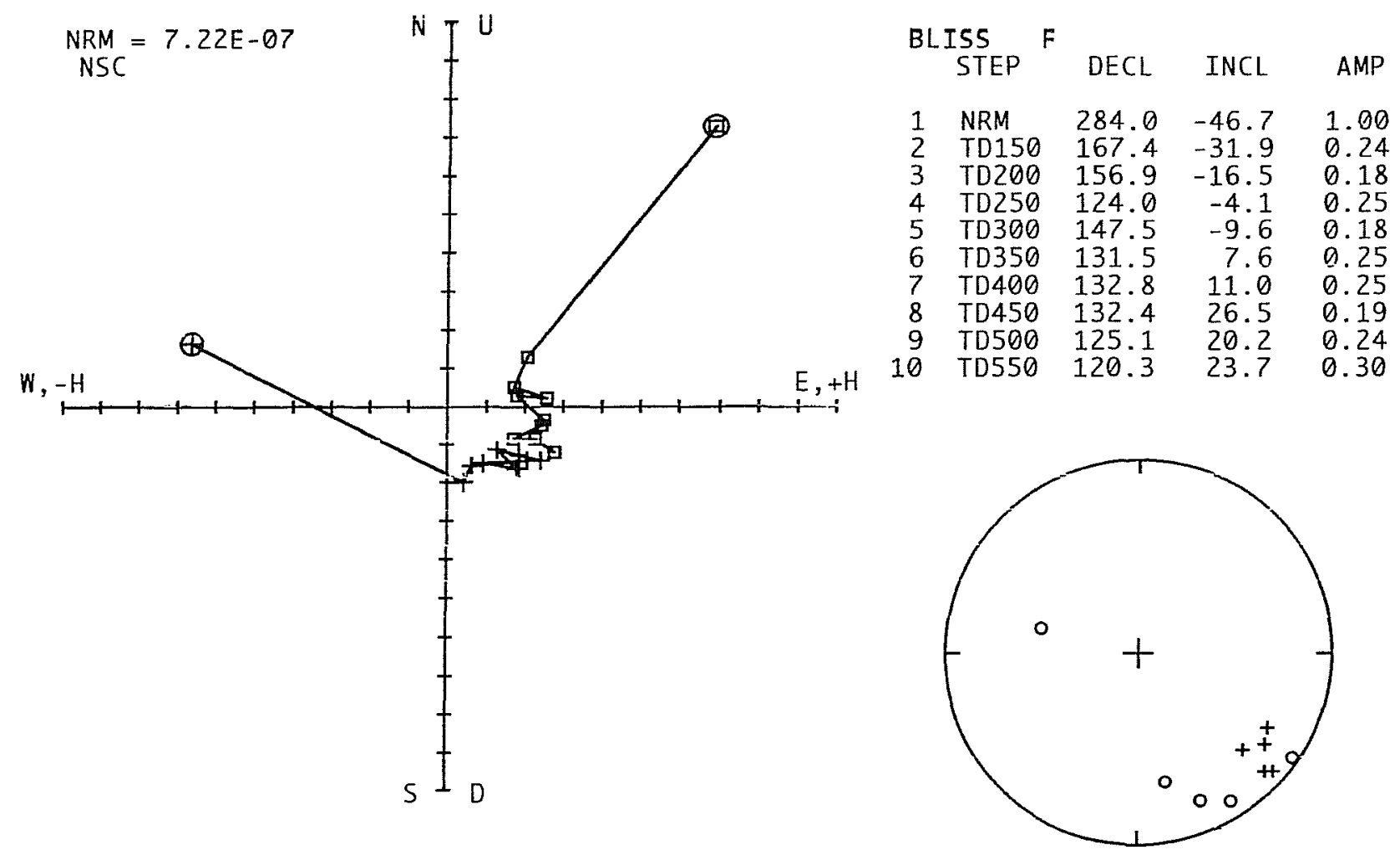

INTENSITY VS. DEMA GNETIZATION

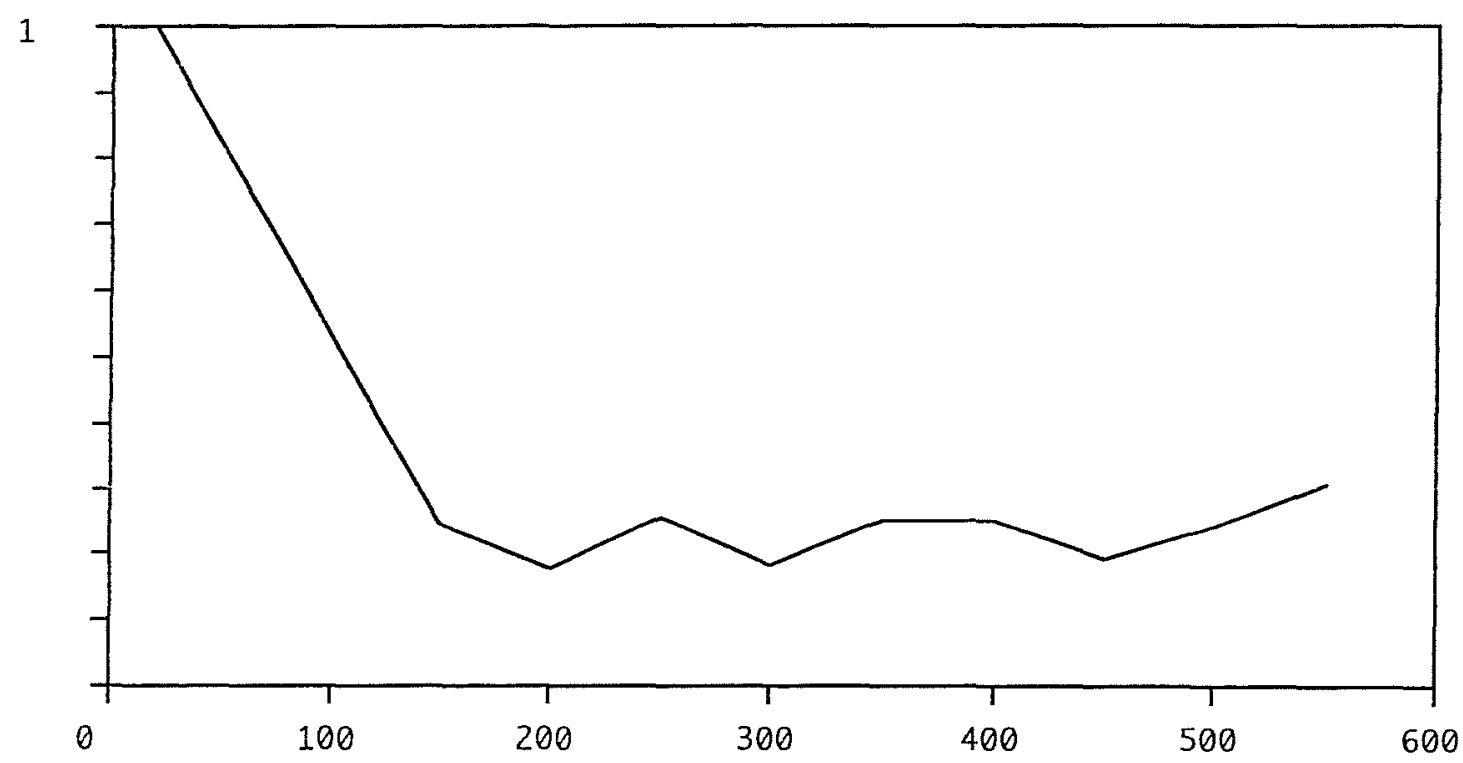




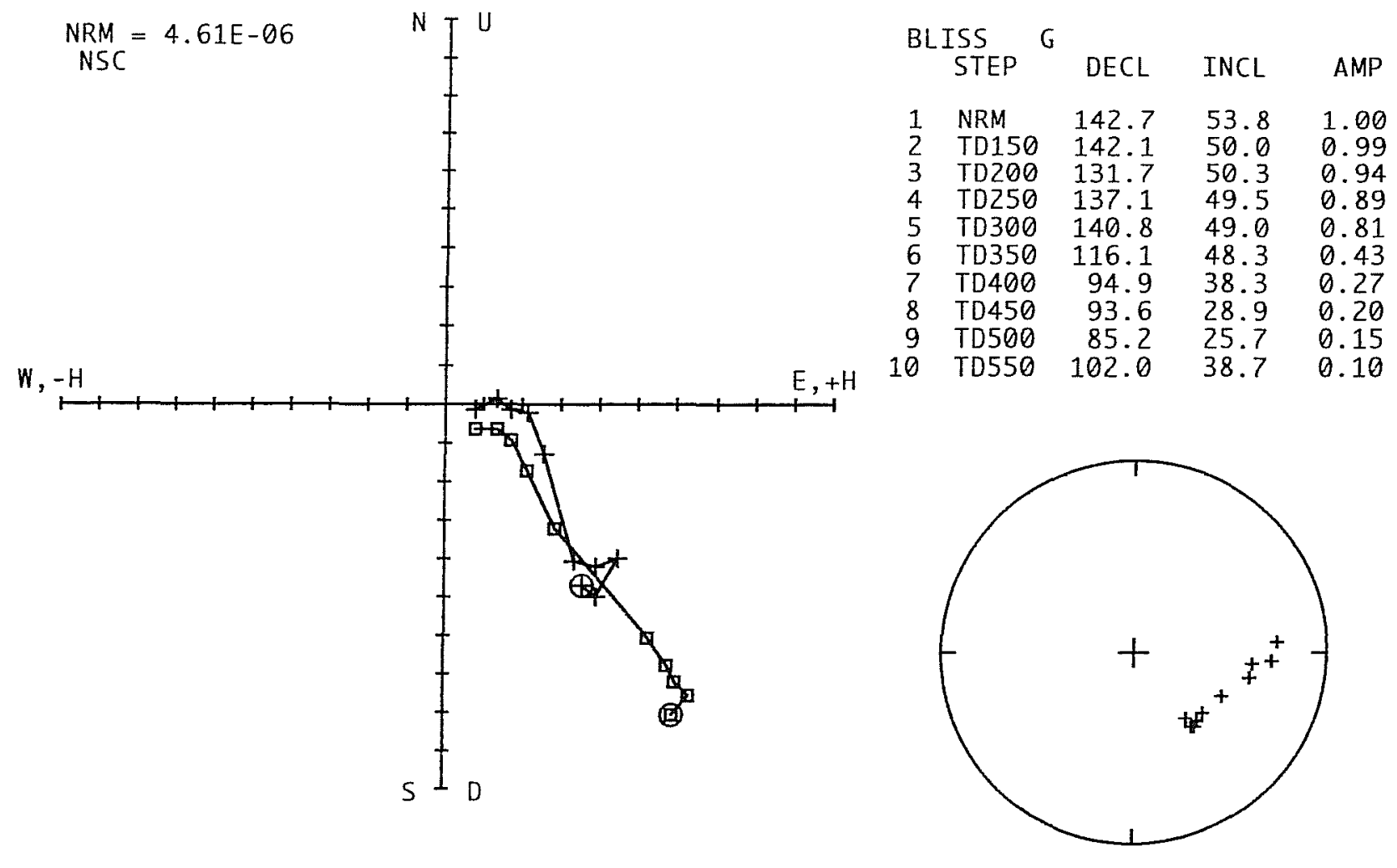

INTENSITY VS. DEMA GNETIZATION

1

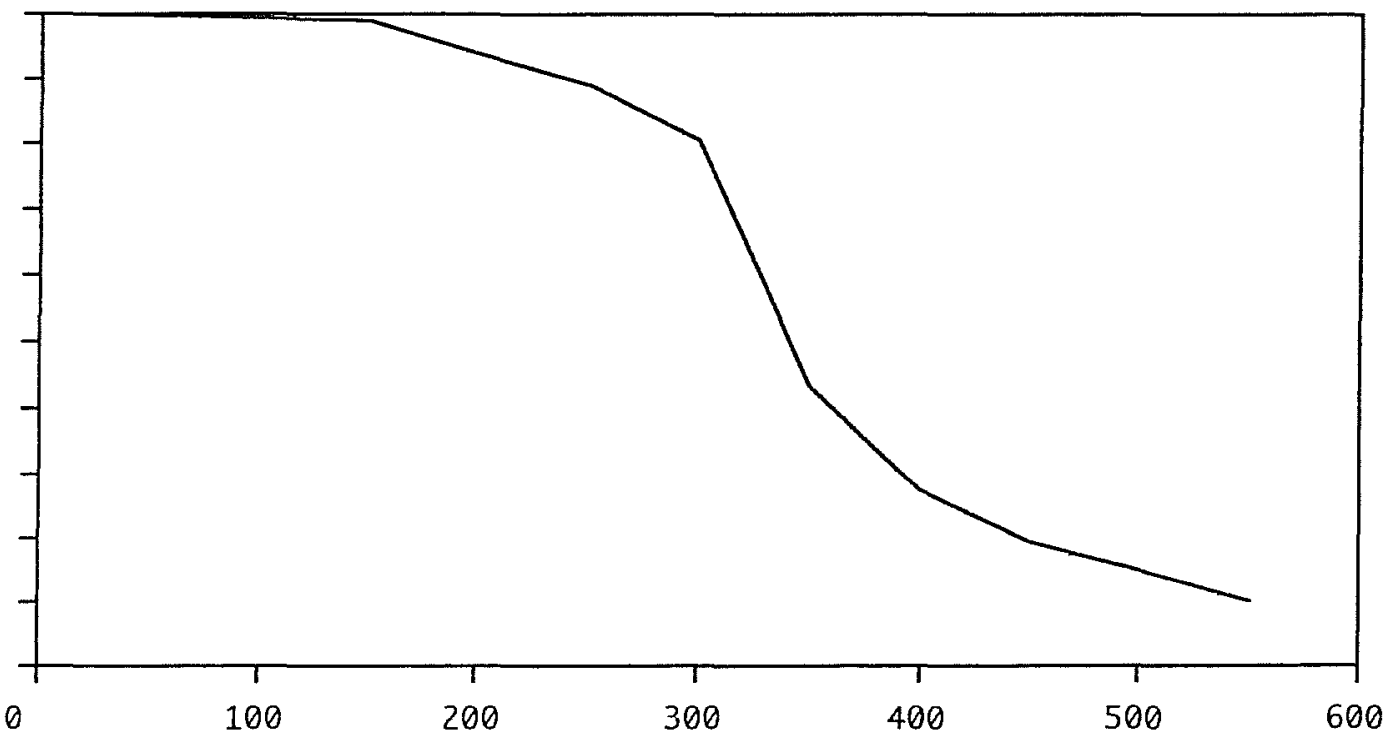



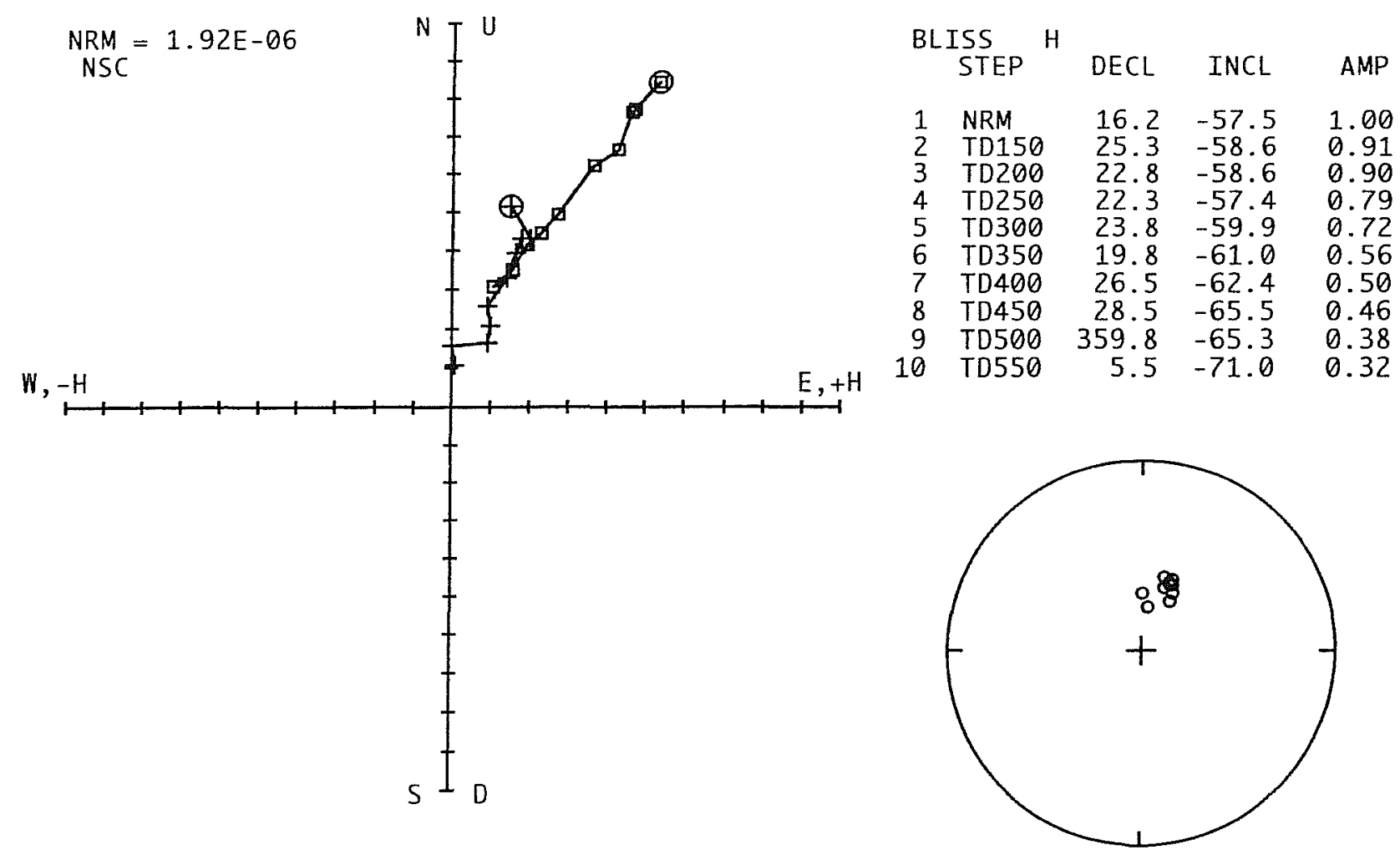

INTENSITY VS. DEMAGNETIZATION

1

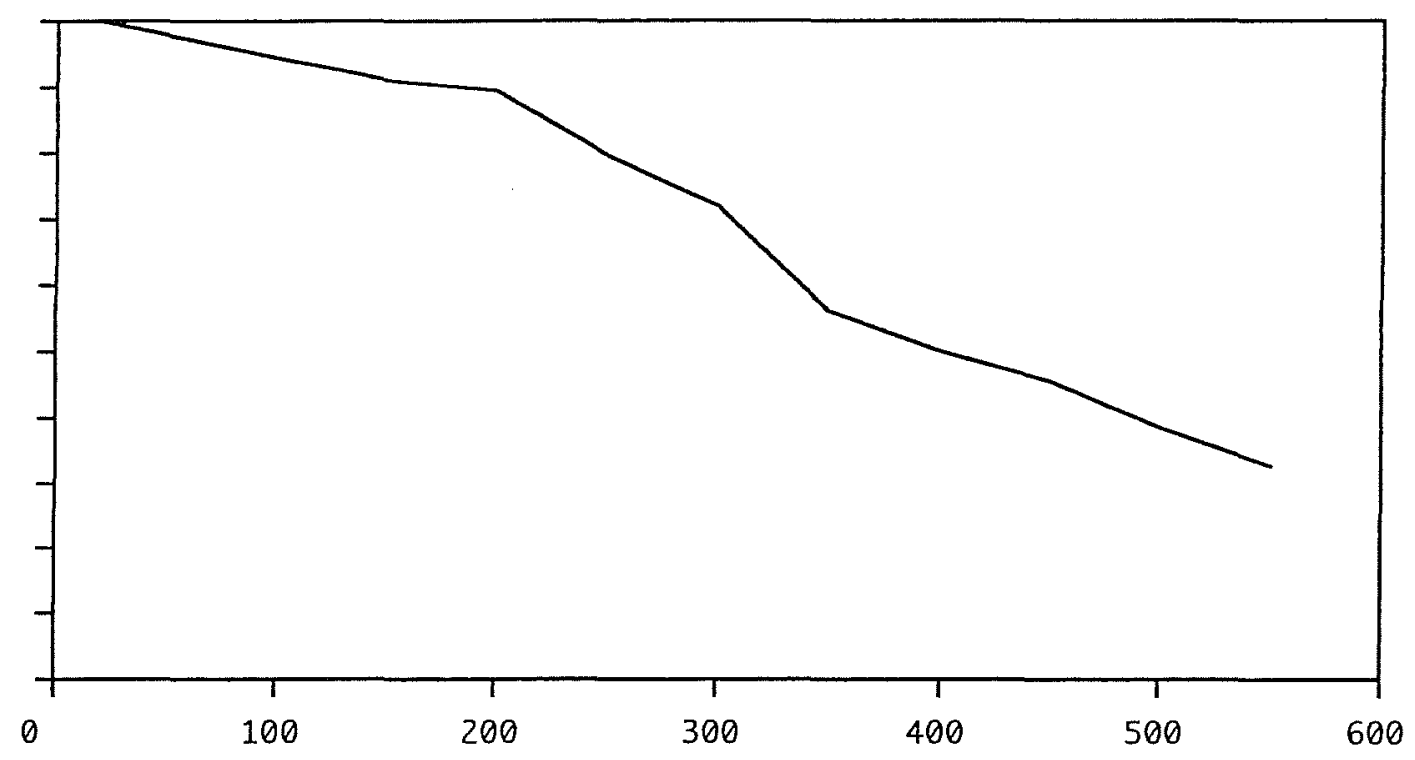




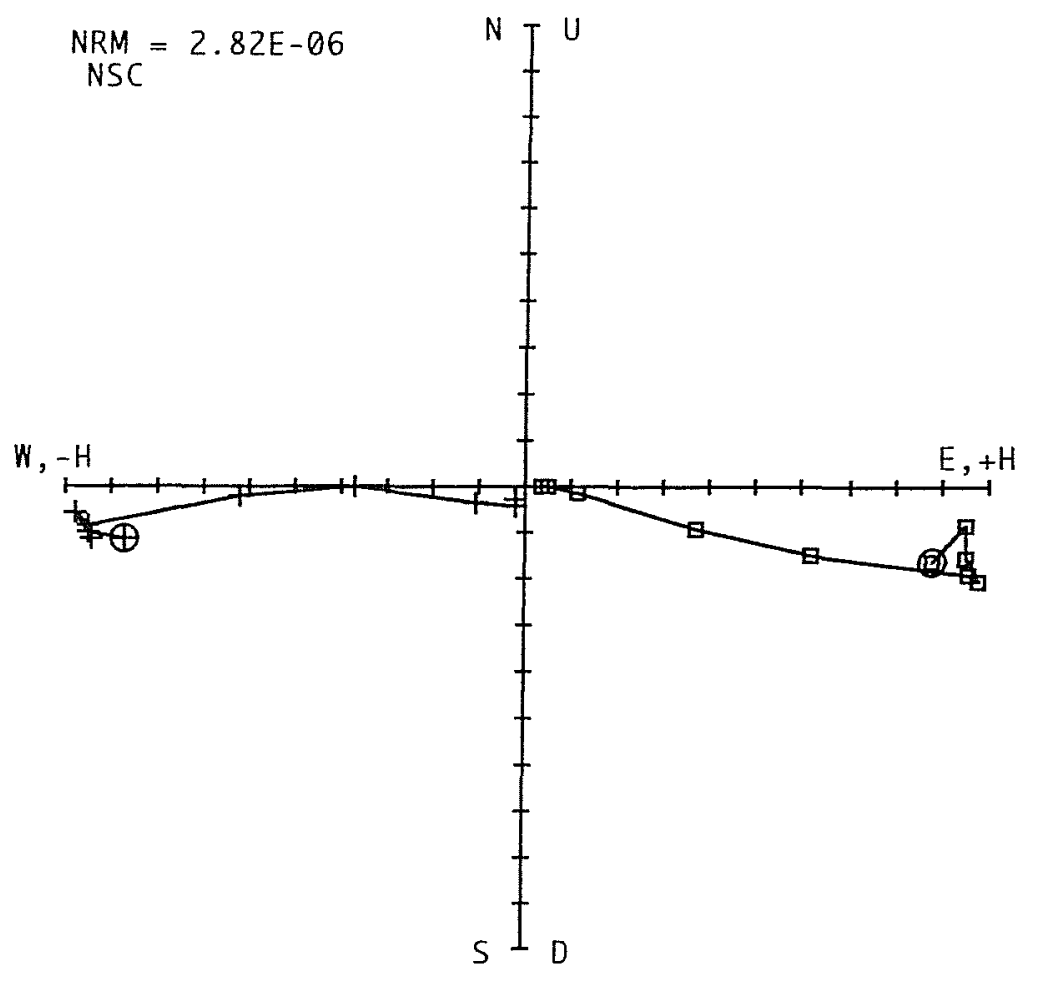

\begin{tabular}{rlrrr}
\multicolumn{2}{c}{ BLISS I } & & & \\
& STEP & DECL & INCL & AMP \\
1 & NRM & 262.4 & 10.5 & 0.90 \\
2 & TD150 & 263.8 & 5.1 & 0.96 \\
3 & TD200 & 263.3 & 9.4 & 0.96 \\
4 & TD250 & 266.6 & 12.0 & 1.00 \\
5 & TD300 & 264.9 & 11.2 & 0.97 \\
6 & TD350 & 268.3 & 13.4 & 0.64 \\
7 & TD400 & 269.7 & 13.7 & 0.38 \\
8 & TD450 & 252.9 & 8.5 & 0.12 \\
9 & TD500 & 208.7 & 0.1 & 0.05 \\
10 & TD550 & 219.1 & 1.3 & 0.03
\end{tabular}

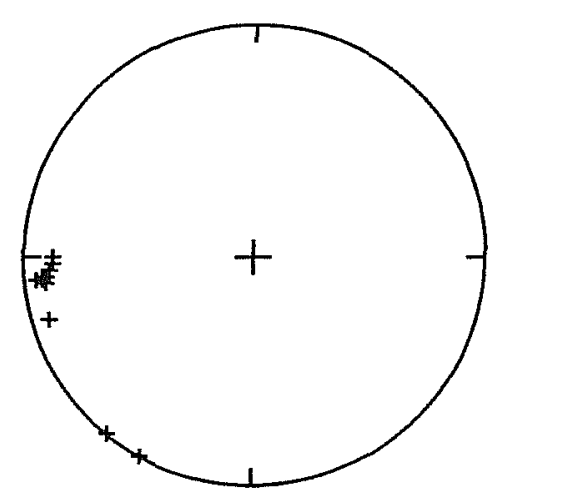

INTENSITY VS. DEMAGNETIZATION

1

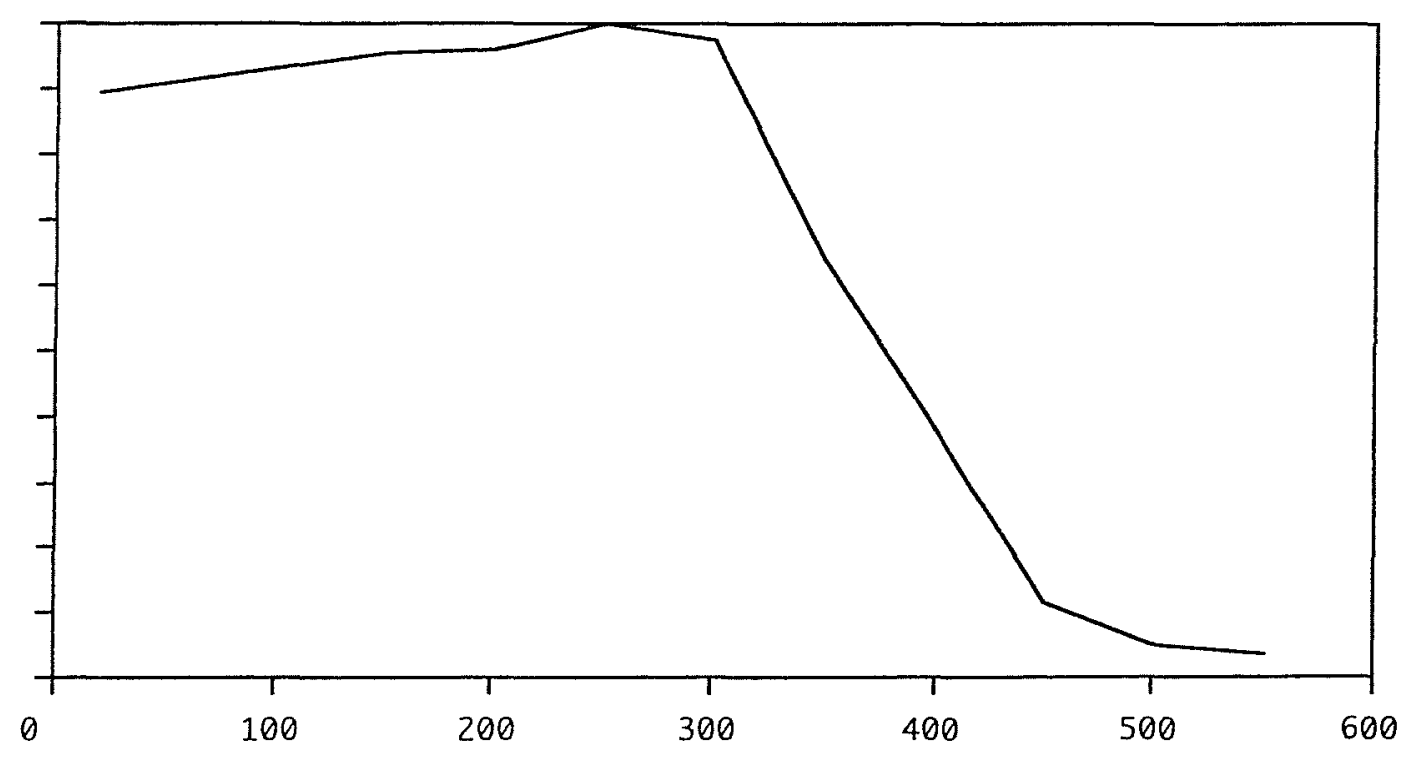




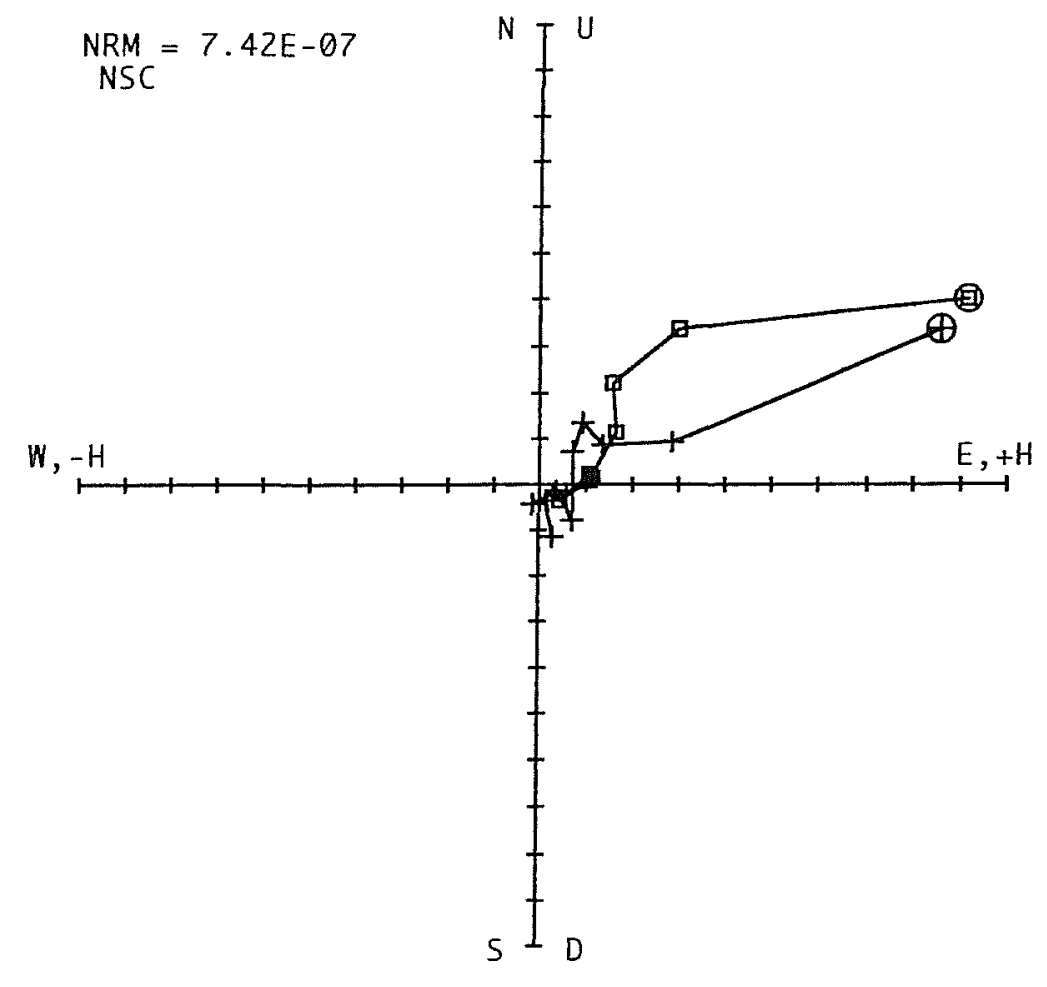

\begin{tabular}{rlrrr}
\multicolumn{2}{c}{ BLISS J J } & & & \\
& STEP & DECL & INCL & AMP \\
& & & & \\
2 & NRM & 68.7 & -23.5 & 1.00 \\
2 & TD150 & 71.5 & -48.2 & 0.45 \\
3 & TD200 & 56.7 & -53.9 & 0.27 \\
4 & TD250 & 35.2 & -34.2 & 0.20 \\
5 & TD300 & 45.1 & -4.3 & 0.10 \\
6 & TD350 & 136.3 & -10.7 & 0.11 \\
7 & TD400 & 116.1 & 39.1 & 0.05 \\
8 & TD450 & 201.6 & 15.2 & 0.05 \\
9 & TD500 & 162.6 & 41.1 & 0.05 \\
10 & TD550 & 166.5 & -6.7 & 0.12 \\
& & & &
\end{tabular}

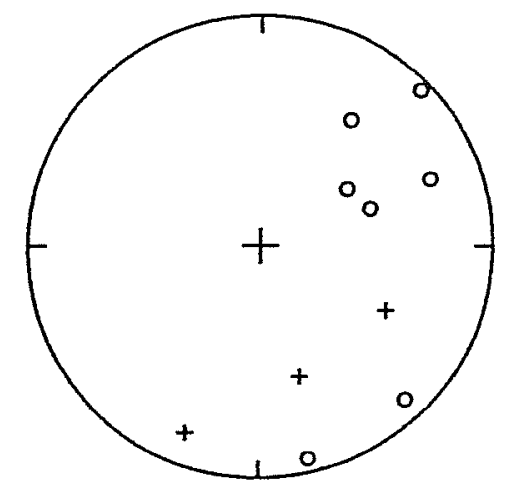

INTENSITY VS. DEMAGNETIZATION

1

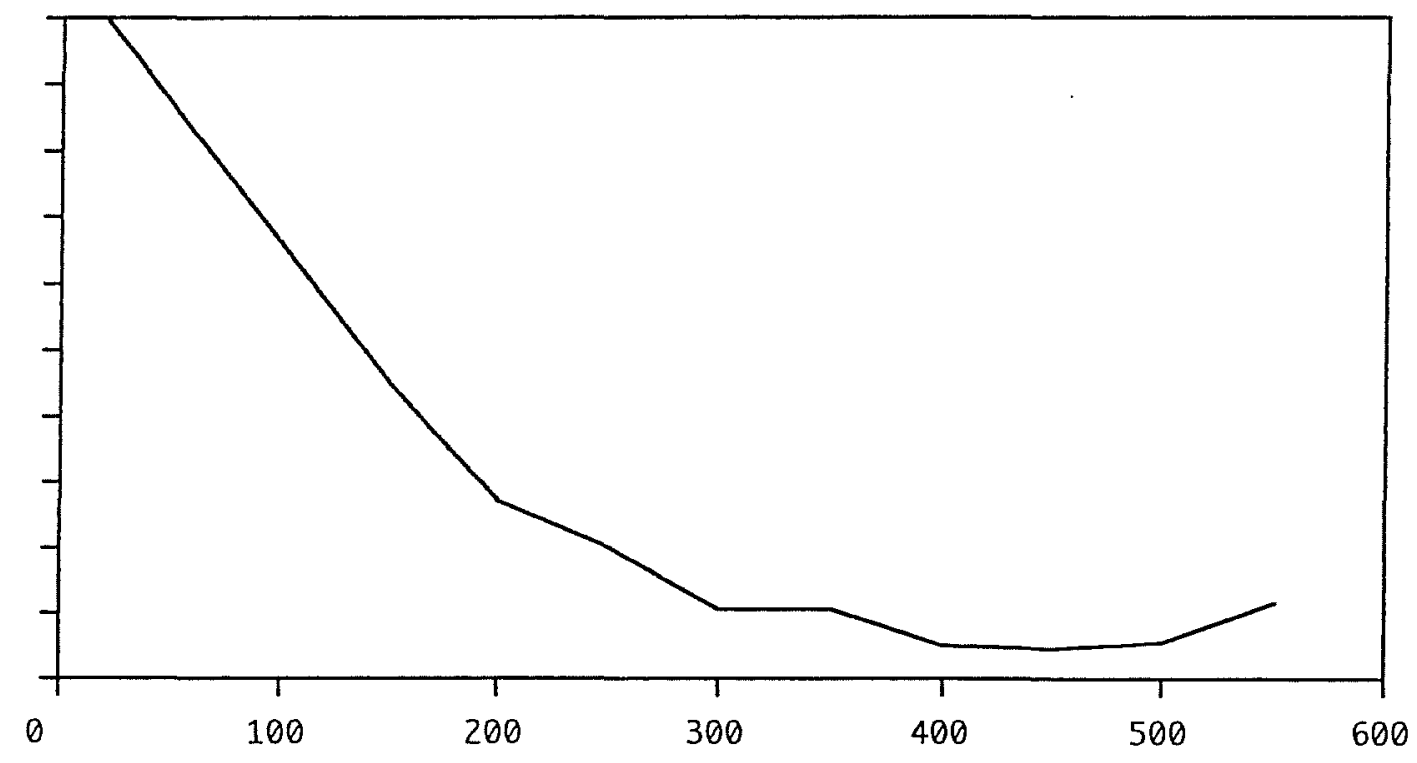




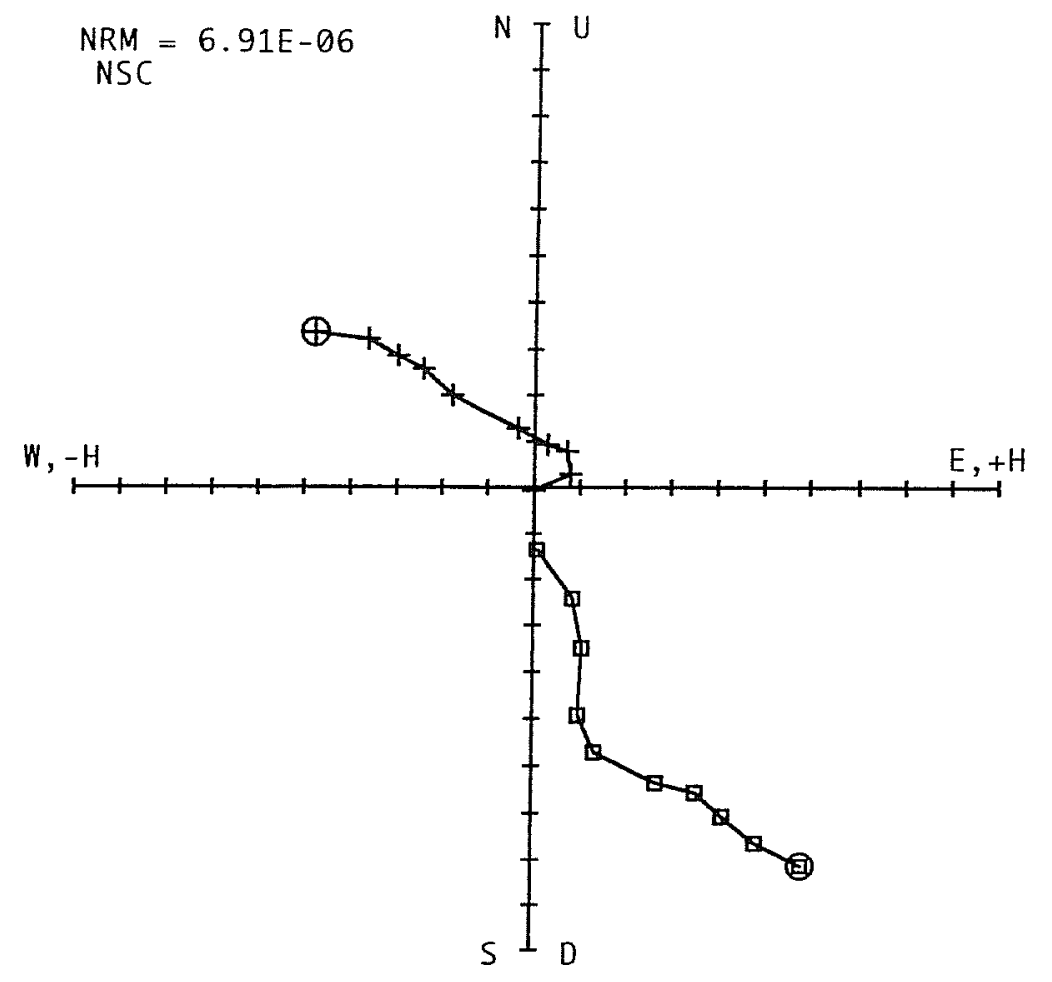

\begin{tabular}{rlrrc}
\multicolumn{2}{c}{ BLISS L L } & & & \\
& STEP & DECL & INCL & AMP \\
1 & NRM & 304.9 & 54.2 & 1.00 \\
2 & TD150 & 311.5 & 57.6 & 0.91 \\
3 & TD200 & 313.5 & 59.8 & 0.82 \\
4 & TD250 & 316.1 & 61.5 & 0.75 \\
5 & TD300 & 318.7 & 67.1 & 0.69 \\
6 & TD350 & 343.5 & 76.7 & 0.59 \\
7 & TD400 & 16.7 & 78.9 & 0.50 \\
8 & TD450 & 41.6 & 72.7 & 0.37 \\
9 & TD500 & 68.4 & 70.4 & 0.26 \\
10 & TD550 & 177.1 & 87.5 & 0.14 \\
& & & &
\end{tabular}

INTENSITY VS. DEMA GNETIZATION

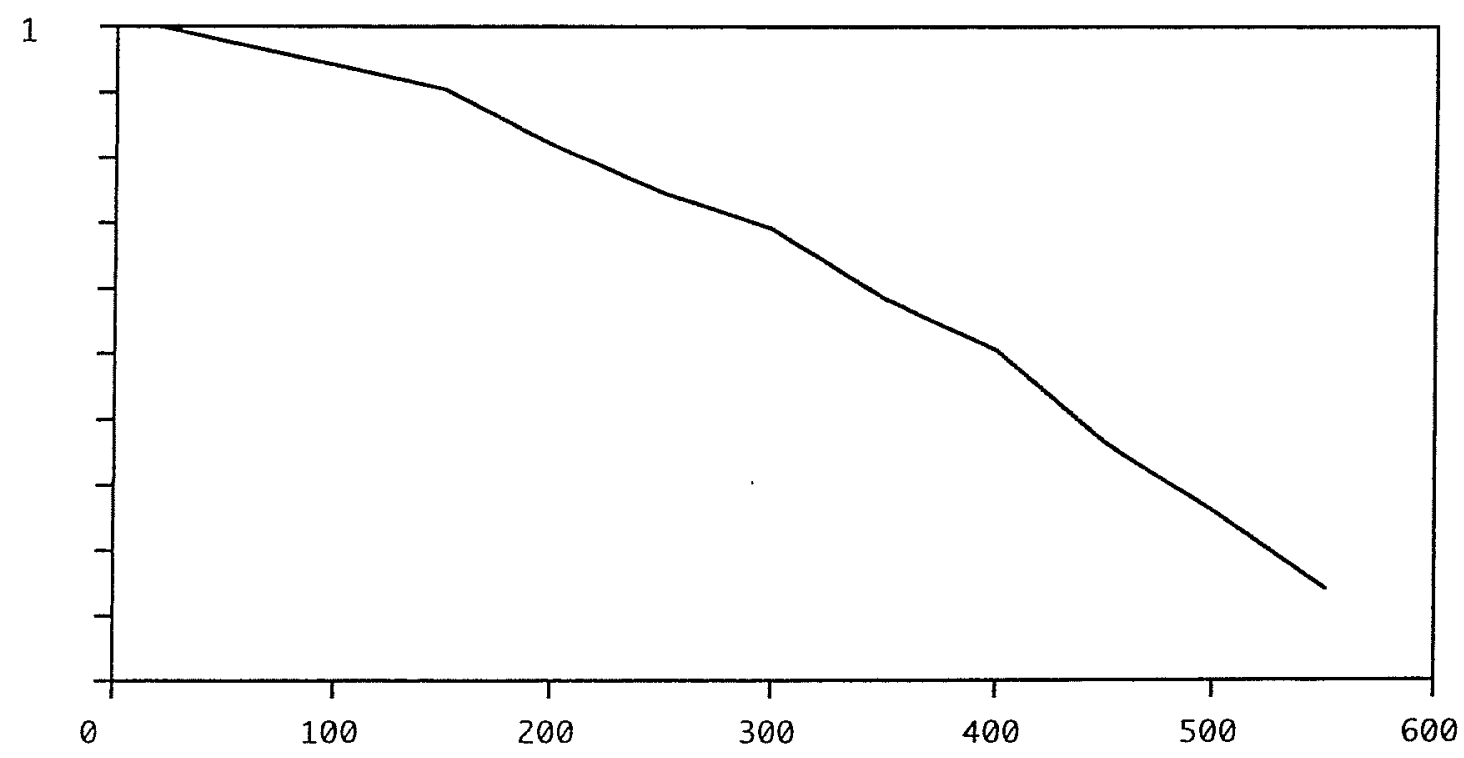



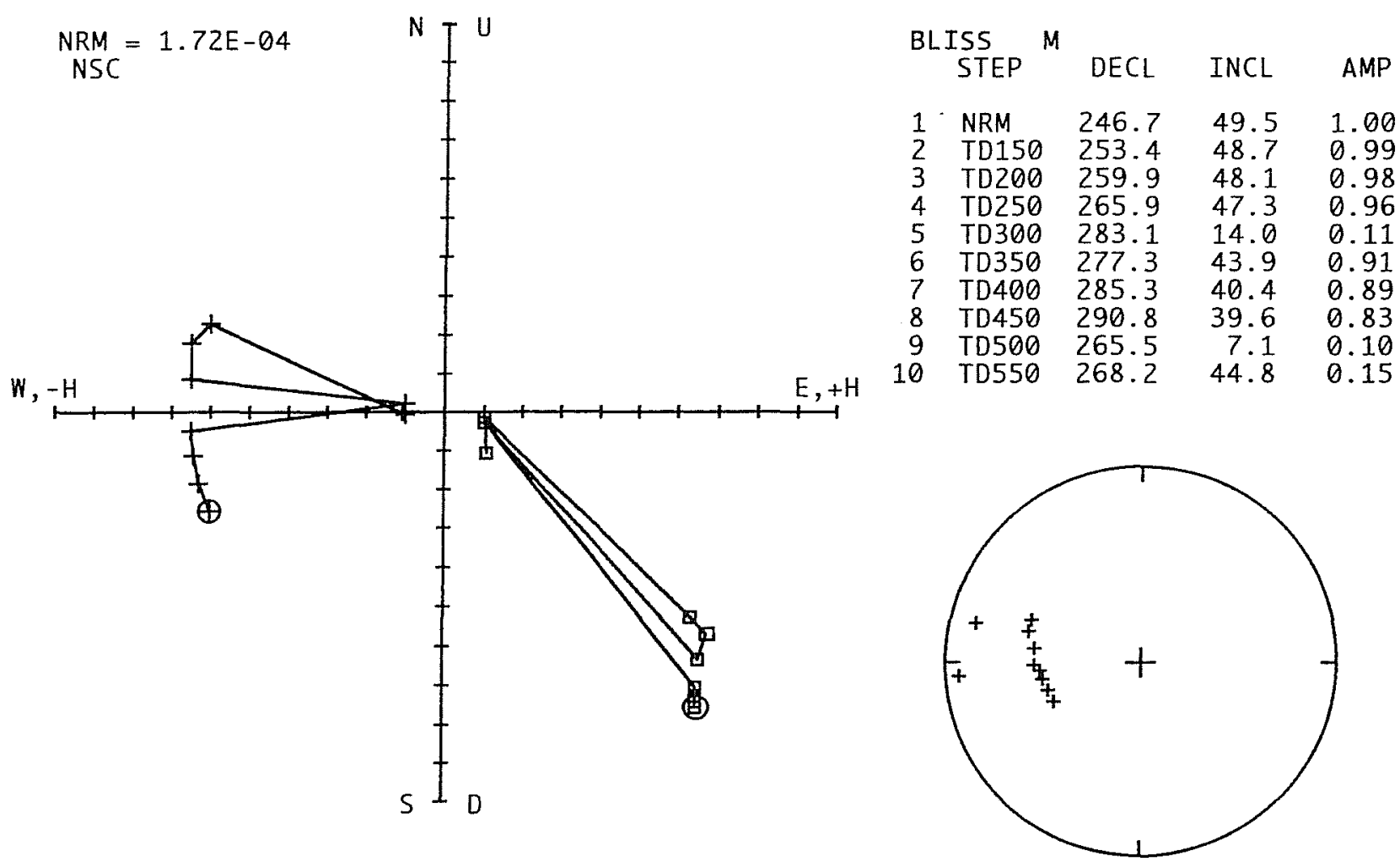

INTENSITY VS. DEMA GNETIZATION

1

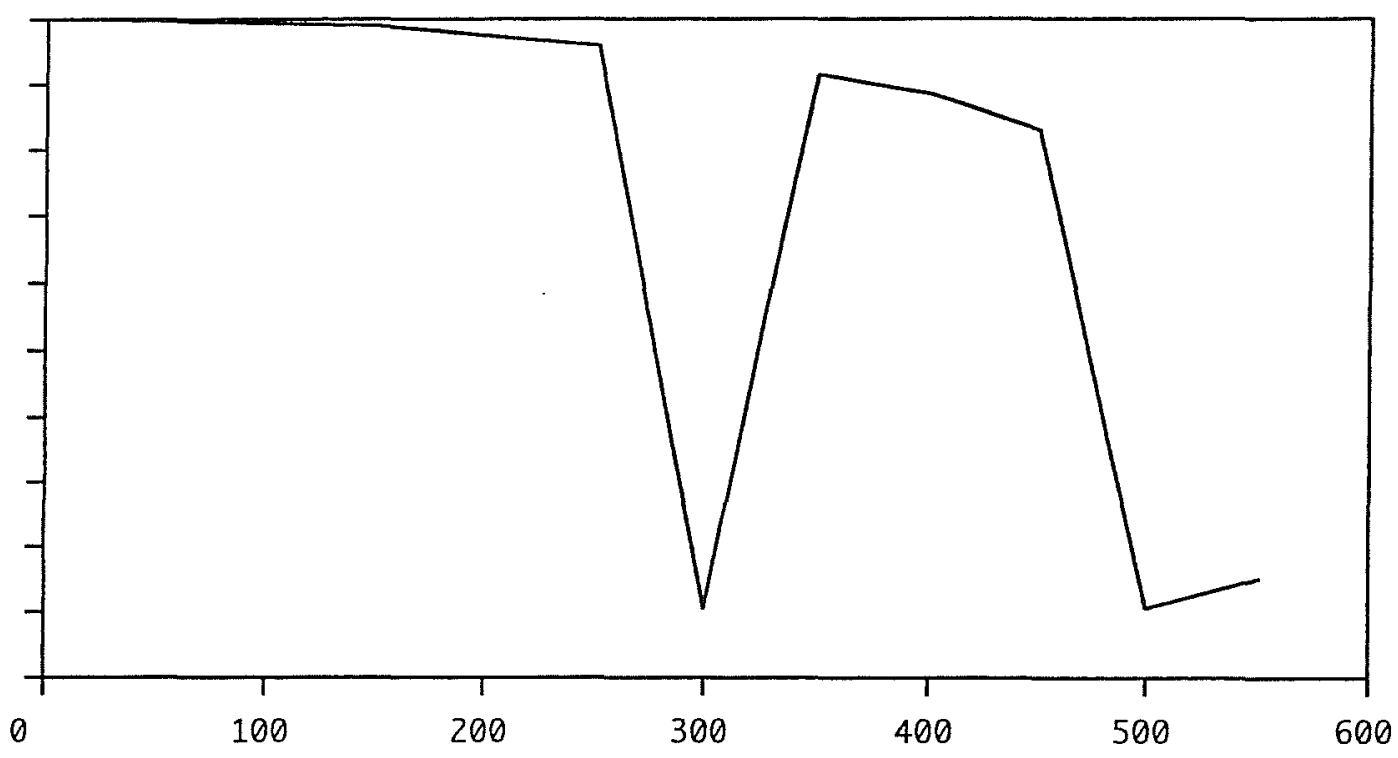



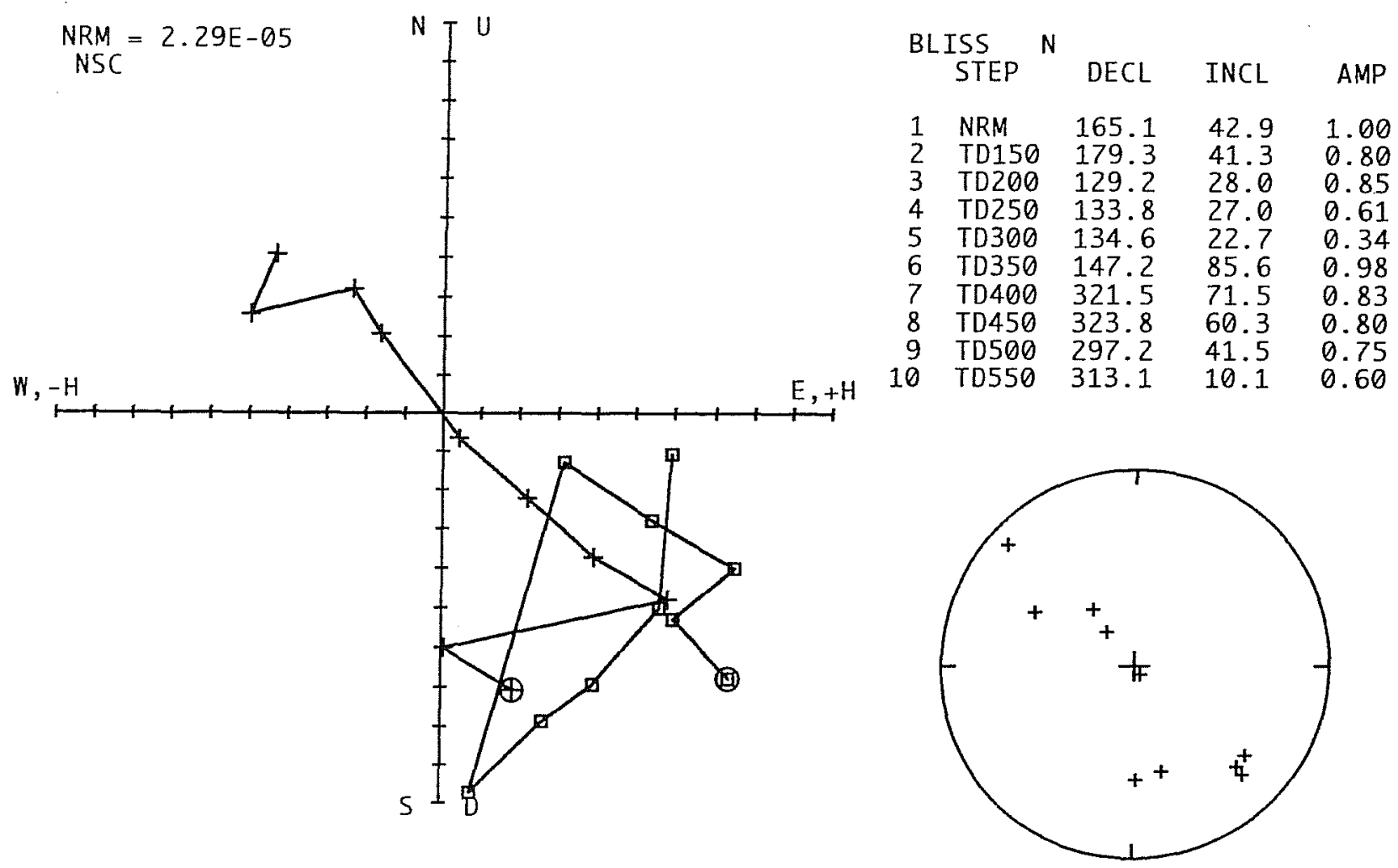

INTENSITY VS. DEMA GNETIZATION

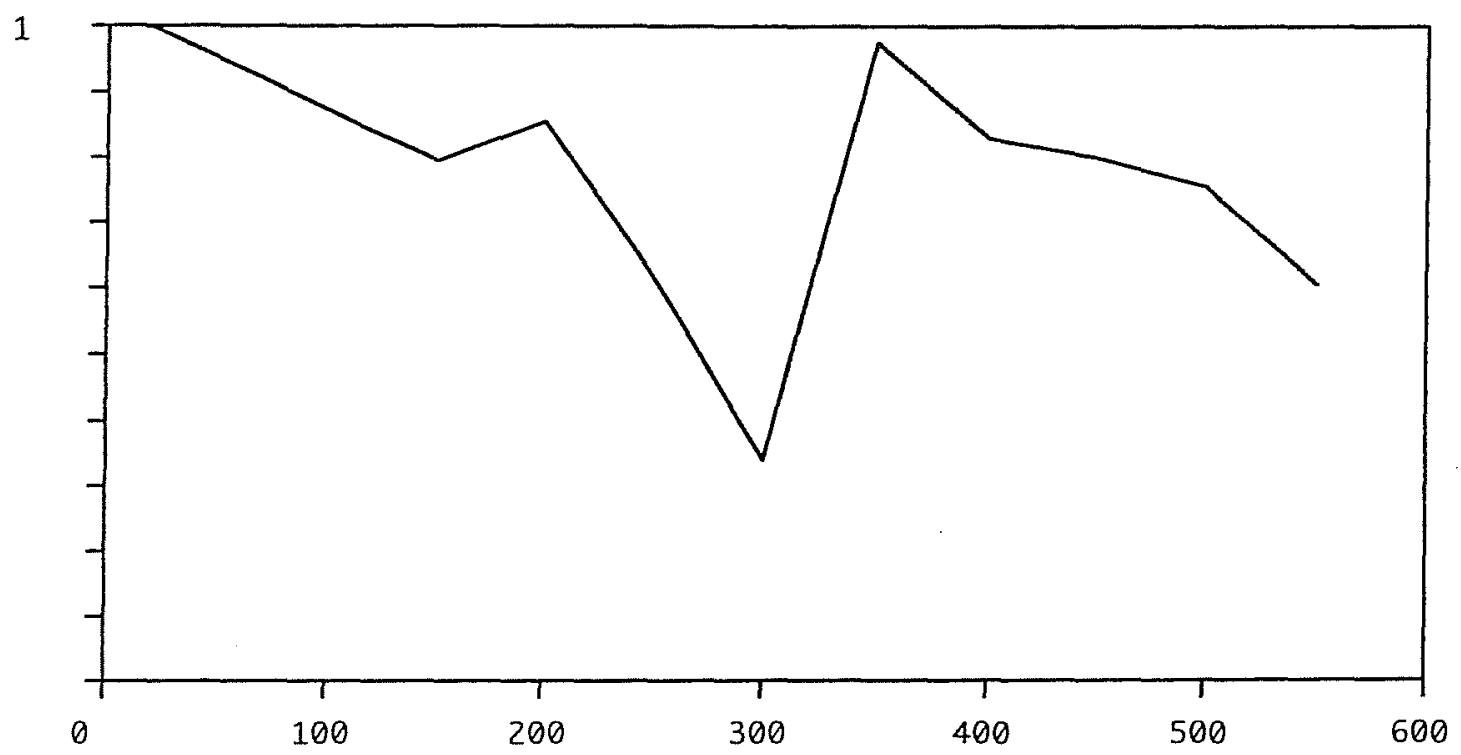




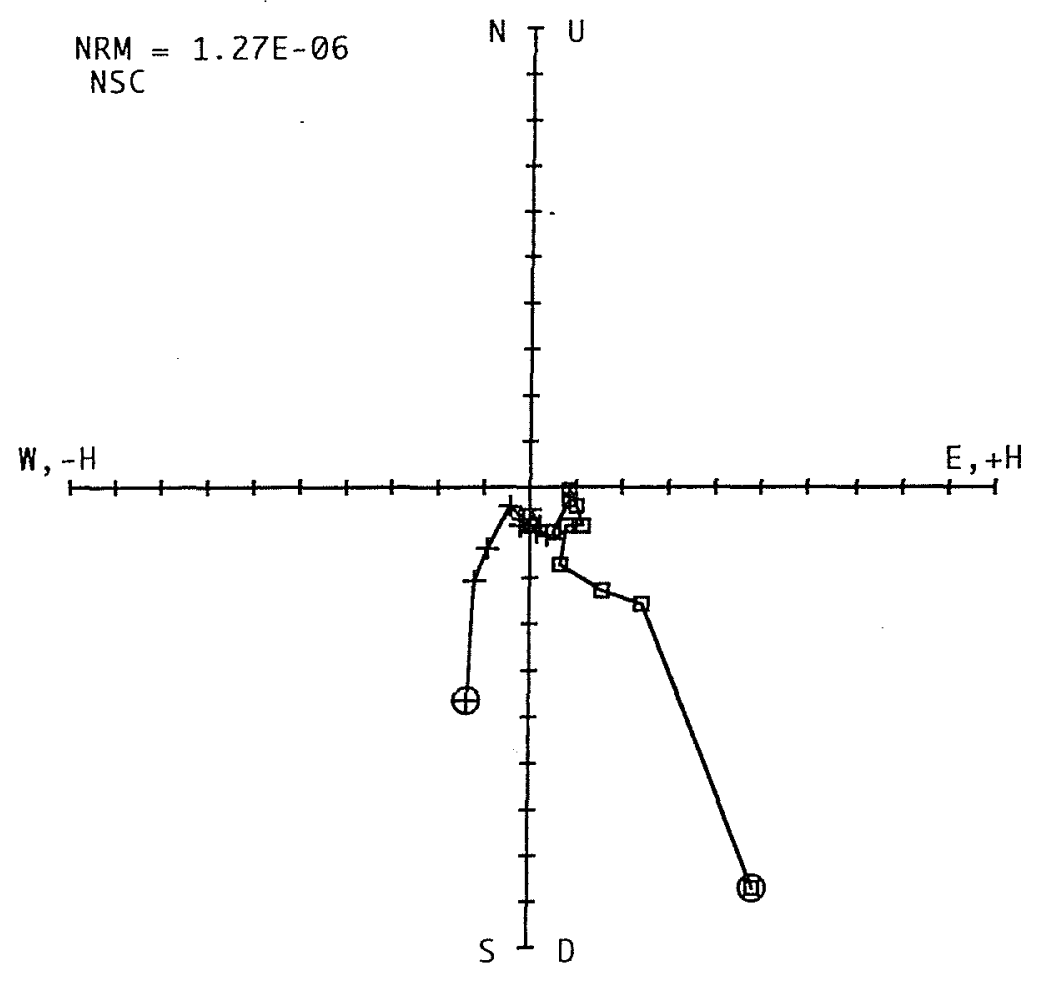

$\begin{array}{rlccc}\begin{array}{r}\text { BLISS } \\ \text { STEP }\end{array} & \text { DECL } & \text { INCL } & \text { AMP } \\ & & & & \\ 1 & \text { NRM } & 196.3 & 60.9 & 1.00 \\ 2 & \text { TD150 } & 209.7 & 46.9 & 0.35 \\ 3 & \text { TD200 } & 213.9 & 55.0 & 0.28 \\ 4 & \text { TD250 } & 226.8 & 69.7 & 0.18 \\ 5 & \text { TD300 } & 191.7 & 49.5 & 0.12 \\ 6 & \text { TD350 } & 162.4 & 36.5 & 0.14 \\ 7 & \text { TD400 } & 170.8 & 24.5 & 0.11 \\ 8 & \text { TD450 } & 195.6 & 4.5 & 0.09 \\ 9 & \text { TD500 } & 163.3 & 20.2 & 0.09 \\ 10 & \text { TD550 } & 177.8 & 61.6 & 0.11\end{array}$

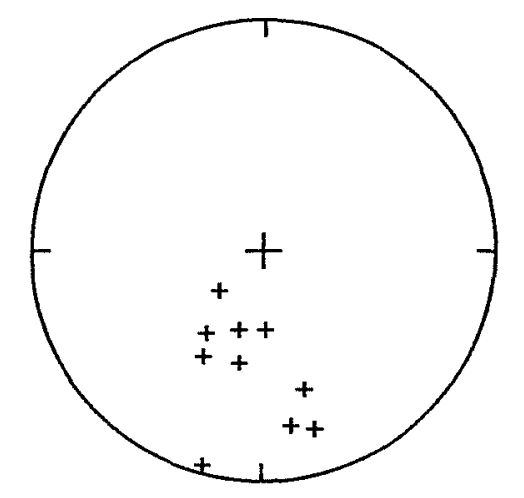

INTENSITY VS, DEMAGNETIZATION

1

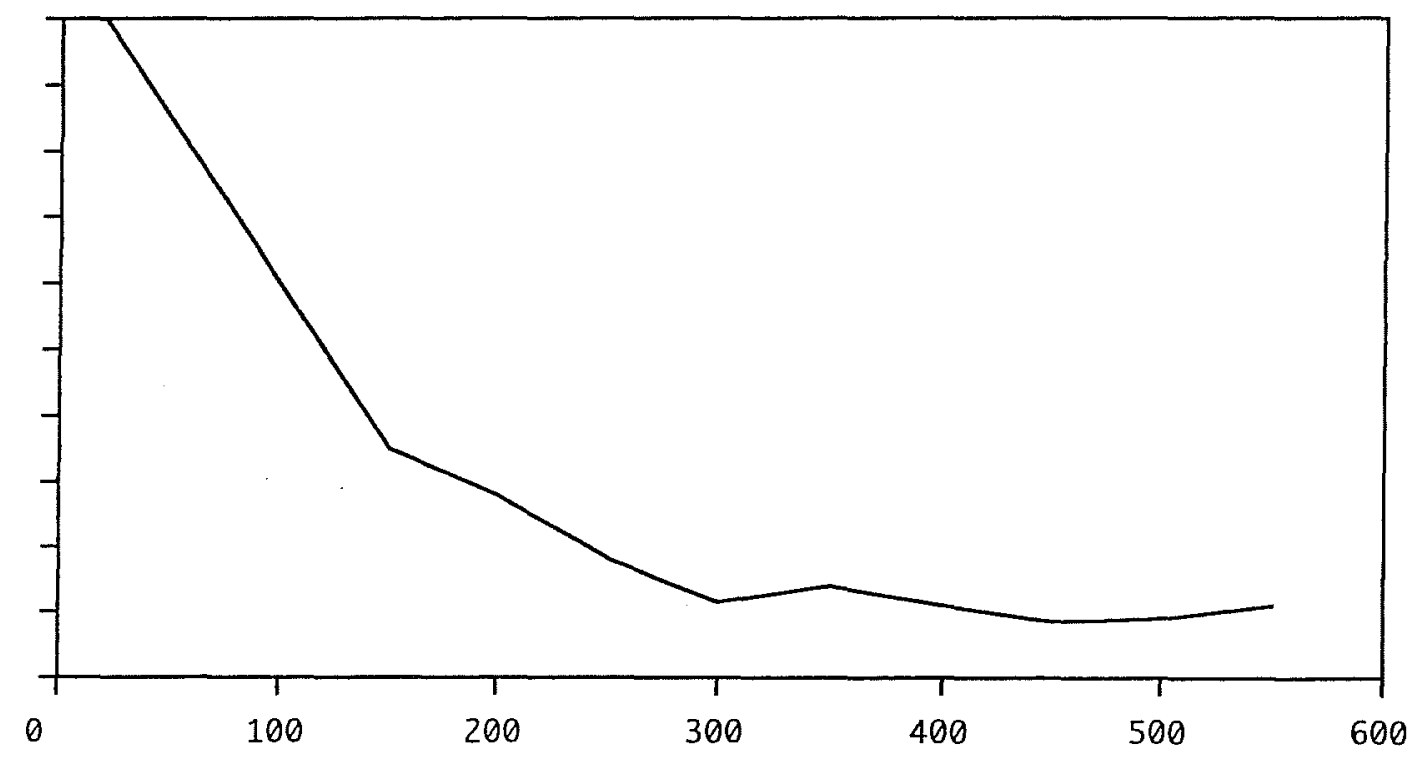



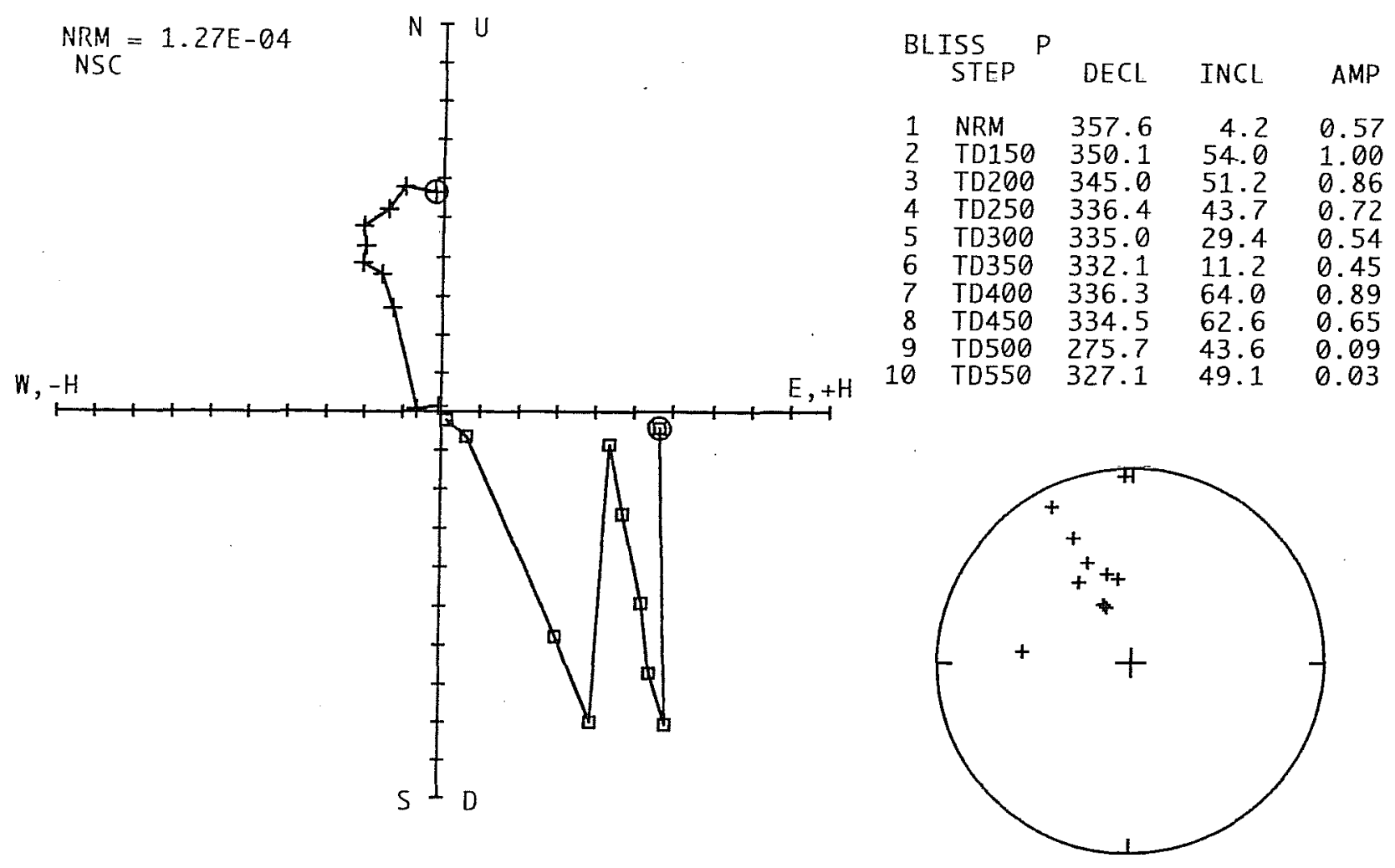

INTENSITY VS. DEMA GNETIZATION

1

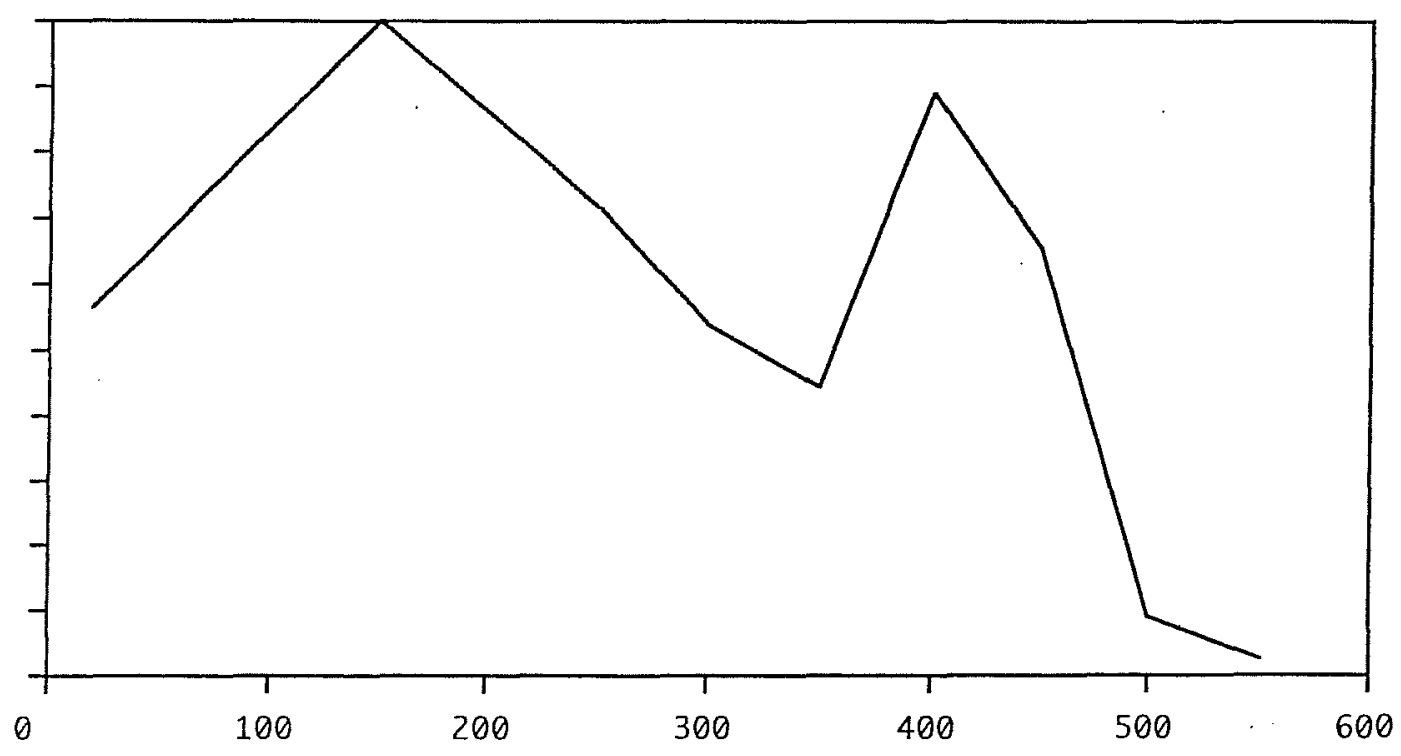



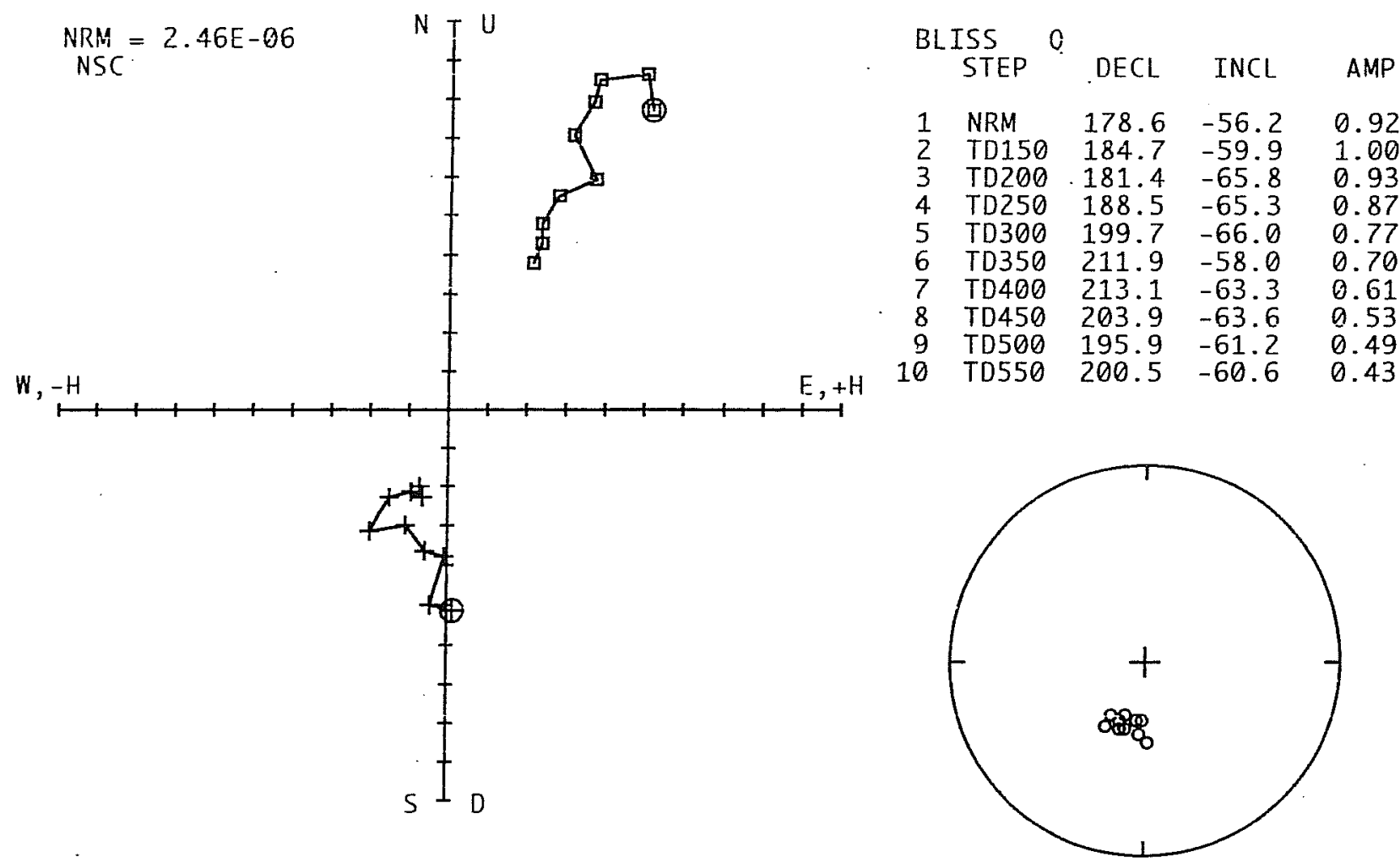

INTENSITY VS. DEMA GNETIZATION

1

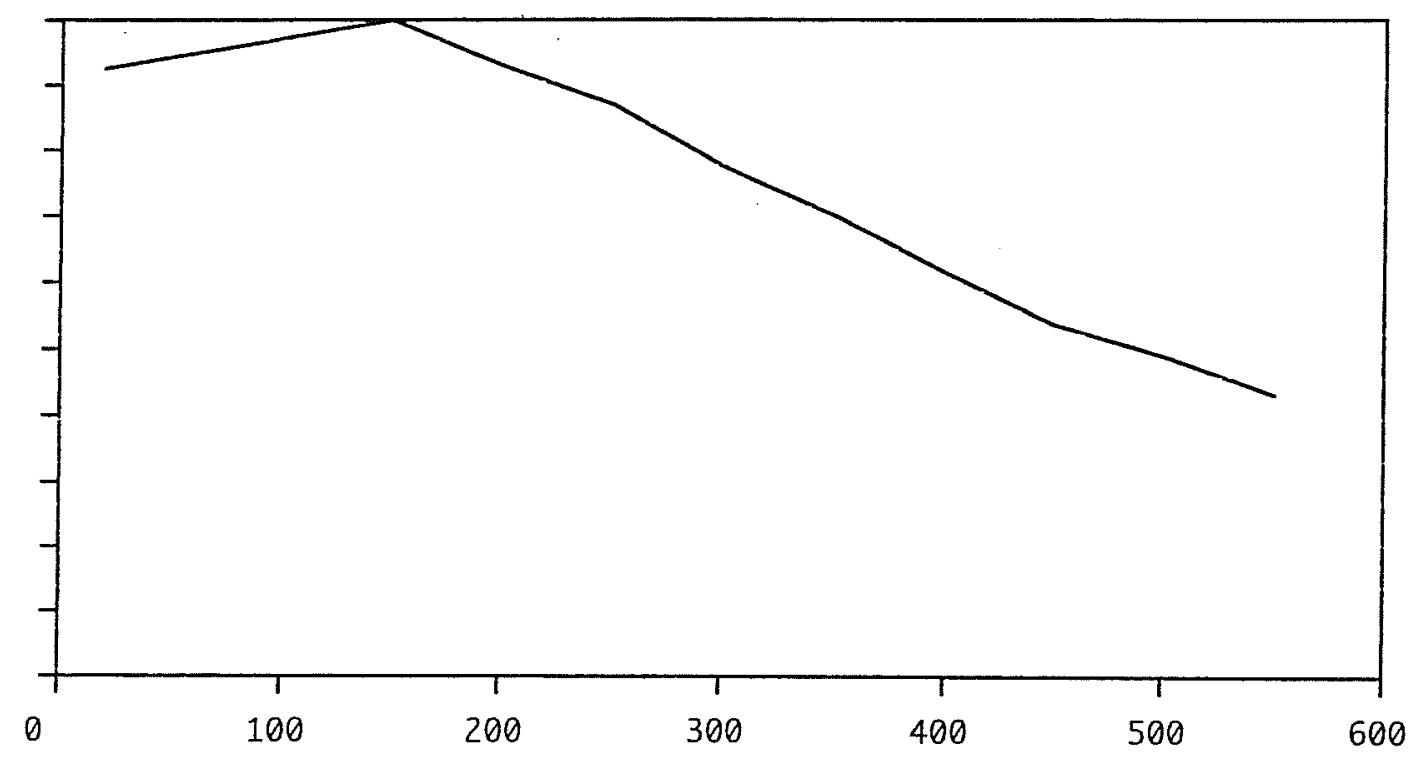




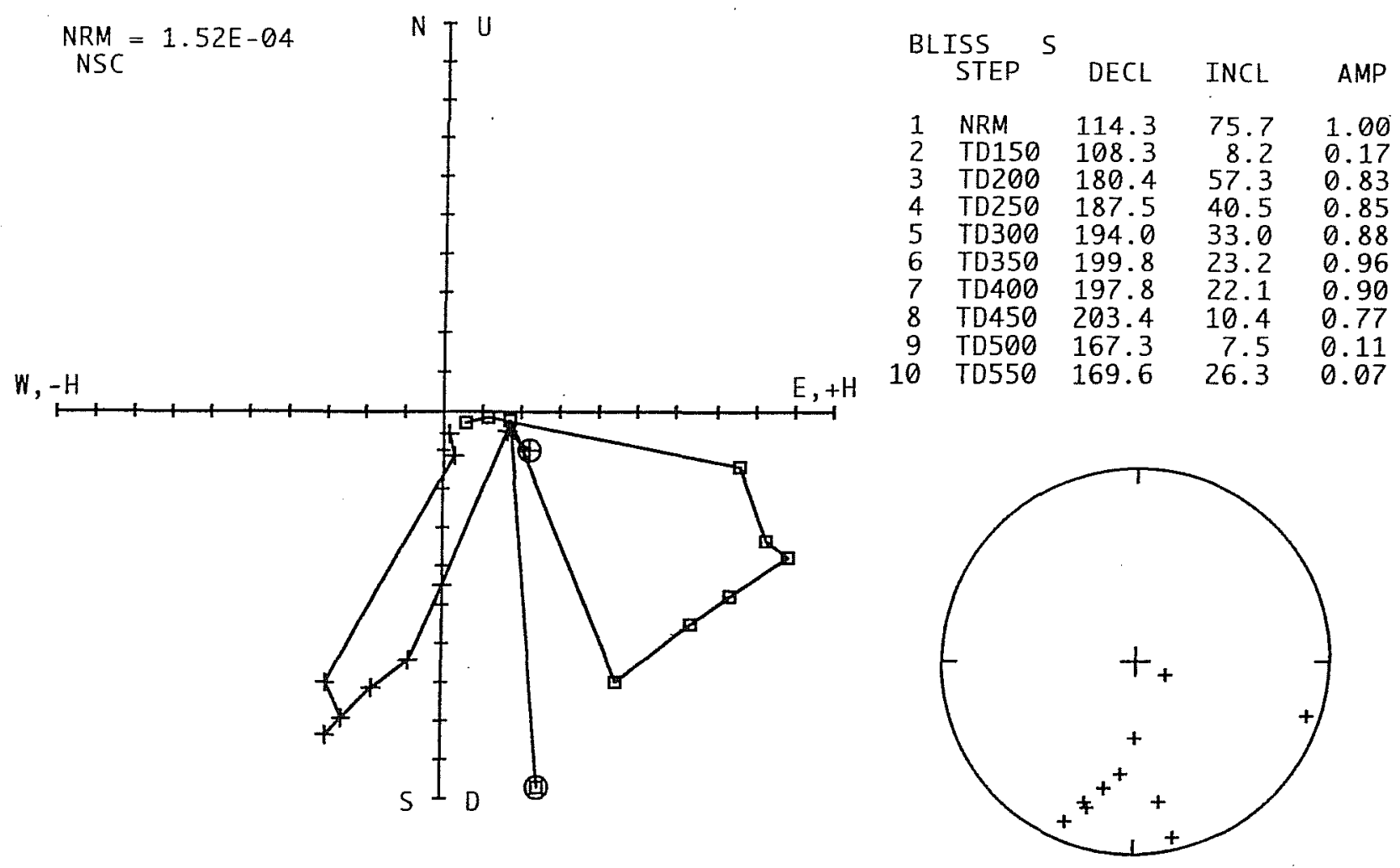

INTENSITY VS. DEMA GNETIZATION

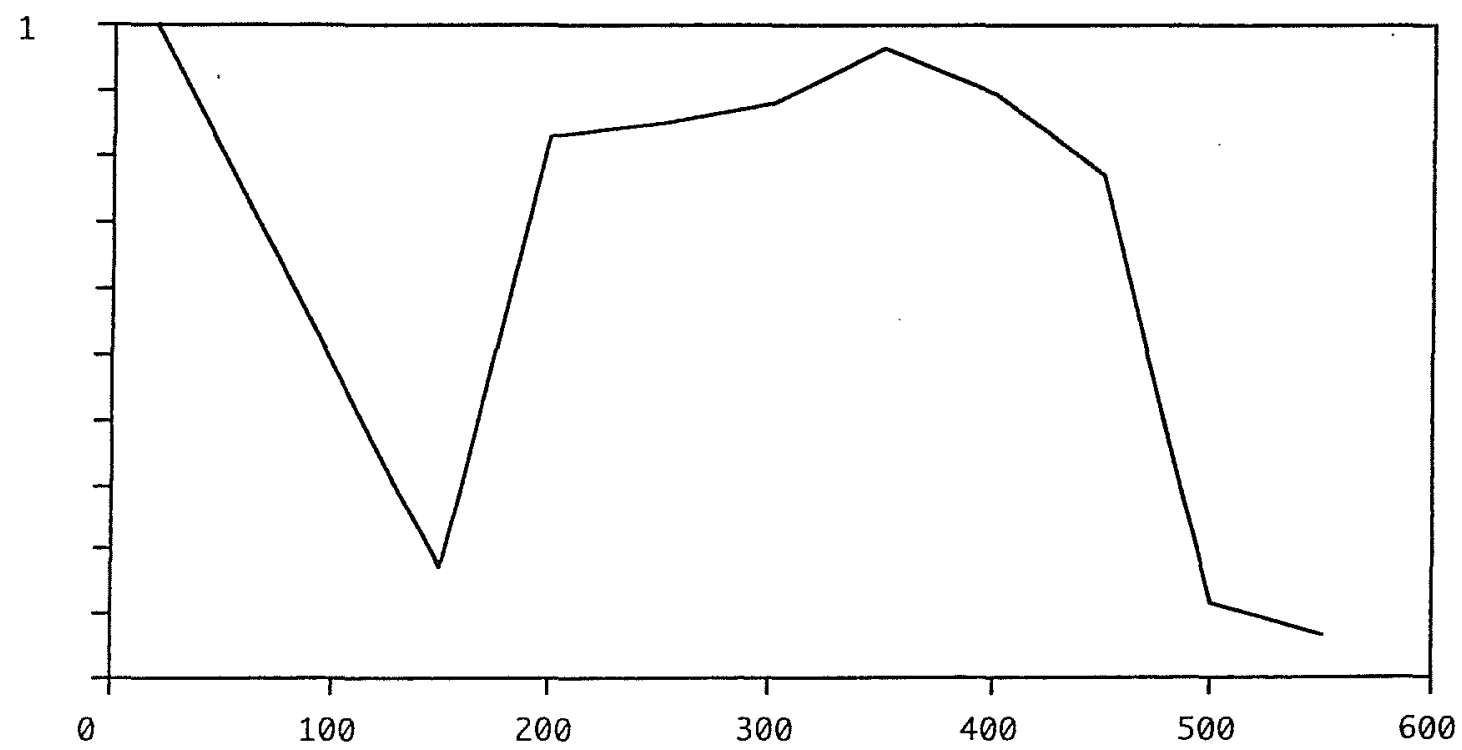




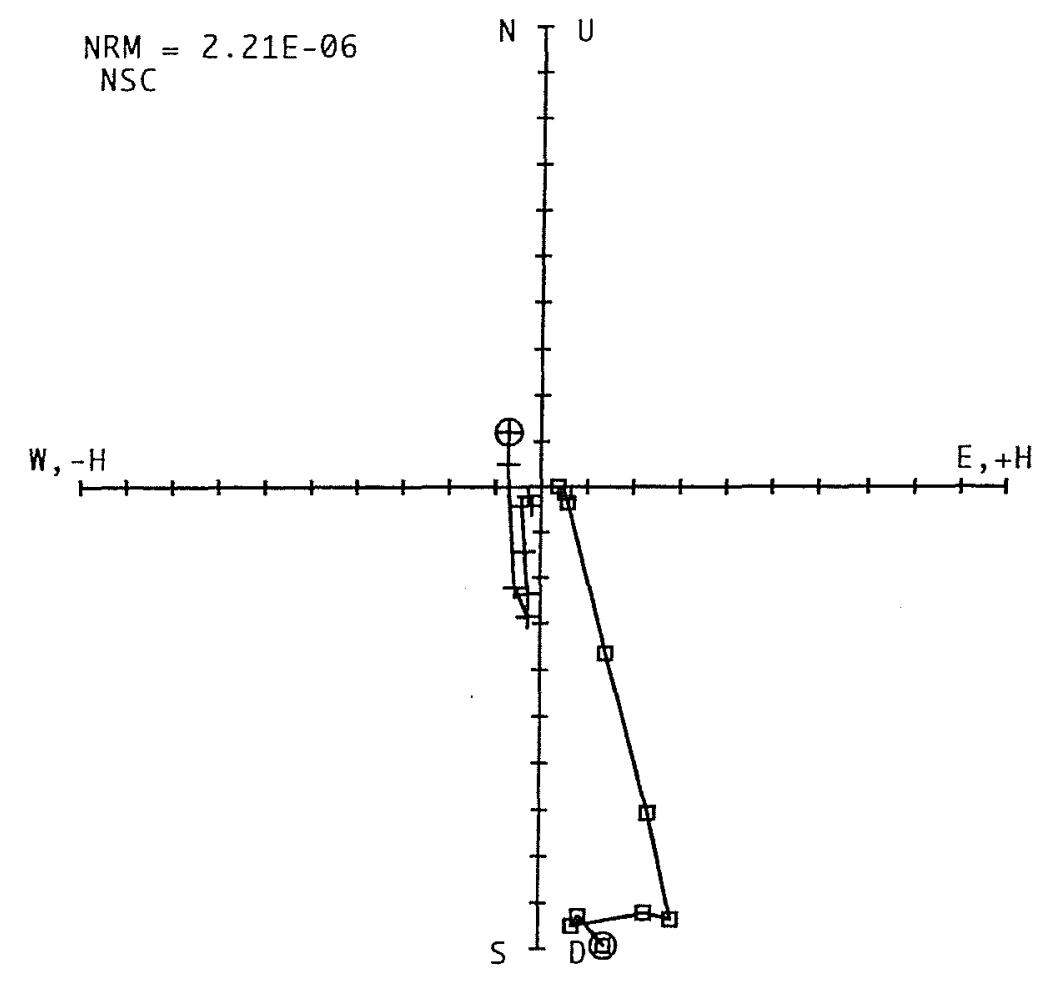

\begin{tabular}{rllll}
\multicolumn{2}{c}{ BLISS } & T & & \\
& STEP & DECL & INCL & AMP \\
1 & NRM & 328.6 & 82.0 & 1.00 \\
2 & TD150 & 304.0 & 84.8 & 0.93 \\
3 & TD200 & 269.7 & 85.7 & 0.95 \\
4 & TD250 & 195.1 & 76.2 & 0.95 \\
5 & TD300 & 185.2 & 72.9 & 0.98 \\
6 & TD350 & 186.7 & 71.5 & 0.75 \\
7 & TD400 & 194.2 & 68.3 & 0.39 \\
8 & TD450 & 224.5 & 32.6 & 0.07 \\
9 & TD500 & 206.4 & 14.9 & 0.05 \\
10 & TD550 & 229.4 & -0.3 & 0.03 \\
& & & &
\end{tabular}

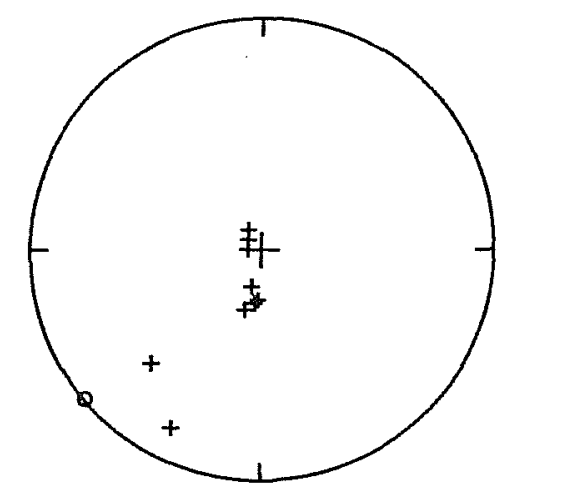

INTENSITY VS. DEMAGNETIZATION

1

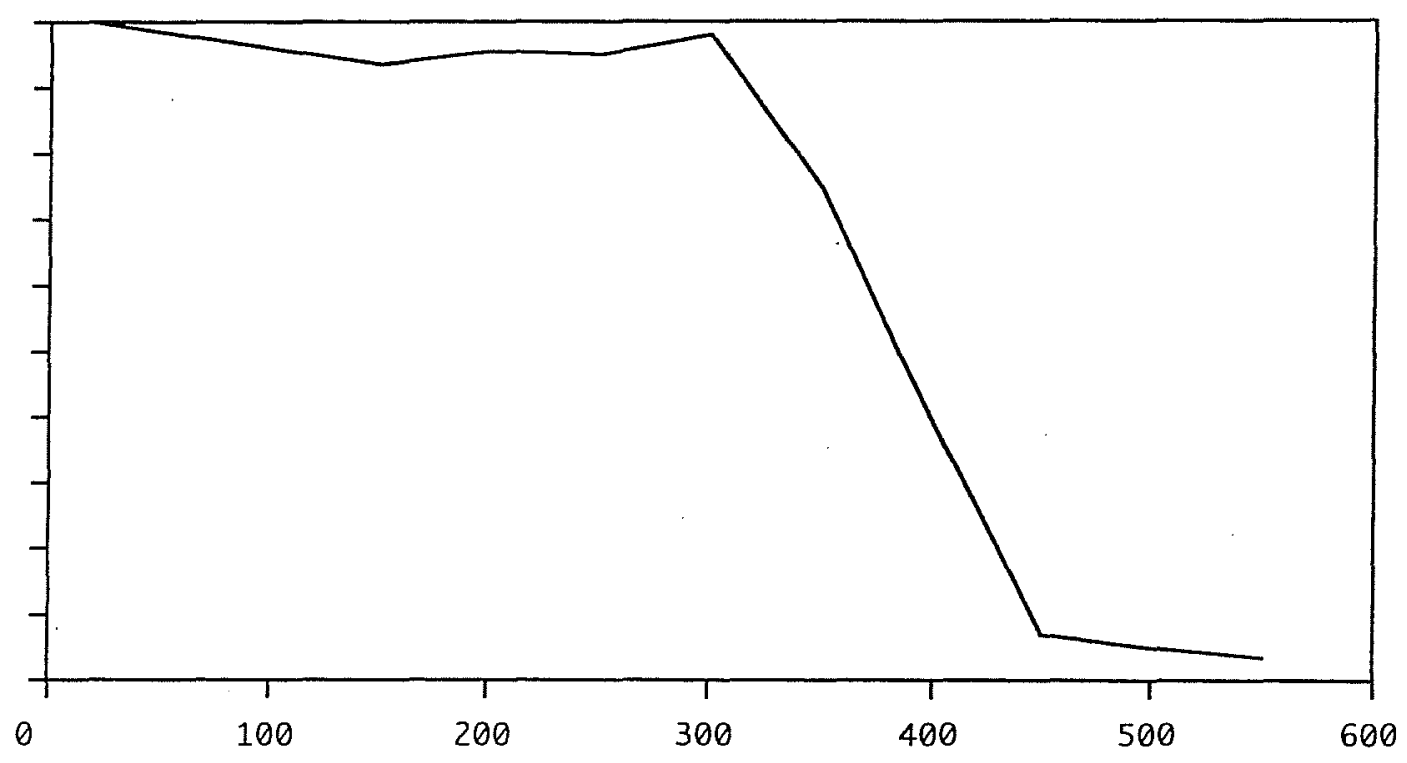

